MARCELO MENDES VIEIRA

\title{
ESTUDO EXPERIMENTAL DA EVAPORAÇÃO DE JATOS DE ISO-OCTANO SUPERAQUECIDO
}

Tese apresentada à Escola Politécnica da Universidade de São Paulo para obtenção do Título de Doutor em Engenharia.

VOLUME 1 E 2

SÃO PAULO

2005 


\section{ESTUDO EXPERIMENTAL DA EVAPORAÇÃO DE JATOS DE ISO-OCTANO SUPERAQUECIDO}

Tese apresentada à Escola Politécnica da Universidade de São Paulo para obtenção do Título de Doutor em Engenharia.

Área de Concentração:

Engenharia Mecânica

Orientador:

Prof. Dr. José Roberto Simões Moreira

VOLUME 1 E 2

SÃO PAULO

2005 
FICHA CATALOGRÁFICA

Vieira, Marcelo Mendes

Estudo experimental da evaporação de jatos de iso-octano superaquecido / M. M. Vieira -- São Paulo, 2005.

2 v.

Tese (Doutorado) - Escola Politécnica da Universidade de São Paulo. Departamento de Engenharia Mecânica.

1.Jatos evaporativos 2.Metaestável 3.Onda de choque 4.Onda de evaporação 5.Schlieren I. II. Universidade de São Paulo. Escola Politécnica. II.t. 
À minha esposa,

Marimar da Silva Barros Vieira. 


\section{AGRADECIMENTOS}

Agradeço à Fapesp pela bolsa de doutorado cujo processo está intitulado “Estudo Experimental de Jatos Evaporativos” de n 2000/06243-2. A esta entidade também agradeço o apoio financeiro oferecido ao projeto intitulado “Estudo Teórico Experimental de Jatos Evaporativos” de n ${ }^{\circ}$ 2000/08302-6.

Meus agradecimentos a todos do Laboratório SISEA, destacando os amigos Marcelo da Silva Rocha, Edvaldo Angelo, Ricardo Brás e Shigeharu Nakaba que me ajudaram neste projeto.

Em especial, ao Prof. Dr. José Roberto Simões Moreira, coordenador deste laboratório e meu orientador, agradeço pelo apoio e pela confiança em mim depositados para a realização deste projeto.

Ofereço minha estima e gratidão aos amigos, parentes e companheiros de trabalho que torceram por mim ou auxiliaram-me de forma direta ou indireta.

Aos meus irmãos, pelos quais tenho um sentimento especial, Sérgio, Edna, Fátima, Marcio, e respectivos cônjuges, aos meus sobrinhos, à querida Esmeralda, aos meus padrinhos Antônio e Celeste (in memoriam). São pesssoas que me apoiaram e incentivaram para realização deste trabalho.

Dedico o meu profundo respeito, carinho e gratidão a esta minha esposa e companheira, Marimar, pelo seu apoio e encorajamento a mim oferecidos e, a nossa filha, Fabiana, que proporcionou um significado maior em nossas vidas, no âmbito familiar.

E dedico a minha eterna gratidão aos meus pais, Abel e Izalina (in memoriam) que sempre buscaram ensinar a sabedoria de vida na simplicidade, dedicação e dignidade de suas ações e, com isso, me proporcionaram a formação acadêmica e, principalmente, a formação para a vida.

Finalmente, eu agradeço à Deus, que me permitiu ser testemunha de tantas realizações que acontecem em minha vida.

São Paulo, junho de 2005. 


\section{RESUMO}

Este trabalho experimental tem por objetivo apresentar os estudos experimentais realizados com jatos de líquidos evaporativos ("flash boiling") de isooctano. Nos estudos, o jato emergia de um diminuto bocal que descarrega em uma grande câmara de baixa pressão. O líquido ao passar pelo bocal sofria uma expansão interna alcançando elevados graus de superaquecimento ou de metaestabilidade, já que se mantinha na fase líquida. Nos experimentos, eram controladas as condições de pressão e temperatura de injeção durante um período de alguns poucos segundos suficientes para que as condições de regime permanente fossem estabelecidas. Um dos métodos para a visualização do escoamento do jato evaporativo foi o "Schlieren", o qual permitia visualizar elevados gradientes de densidade como normalmente ocorrem com ondas de choque, presentes nesta investigação. Também foi empregada a técnica de visualização de “iluminação por detrás” para que fossem comparadas as imagens obtidas por este método com o do "Schlieren", bem como mostrar detalhes do fenômeno em estudo. Com isso, foi possível estudar a estrutura do processo evaporativo do jato e, com o auxílio de ferramentas de filtragem matemática e manipulação das imagens obtidas, os fenômenos compressíveis envolvidos. Os perfis dos jatos observados foram: (1) filete contínuo de líquido sem evaporação, (2) jato com fragmentações ou atomizado e (3) abrupta evaporação seguida por expansão com formação de ondas de choque. Neste último caso, a inspeção das fotografias indicou que a evaporação do líquido se dava externamente ao bocal, a partir de um núcleo metaestável de líquido, o qual apresentava o formato aproximado de um cone. Também foi aplicada a teoria de ondas oblíquas de evaporação para estudar o comportamento deste cone líquido. Os ensaios foram conduzidos com três bocais cônico-convergentes de dimensões e materiais diferentes, quais sejam: bocal de aço com diâmetro de saída de 0,3 mm, bocal de aço com 0,8 mm e bocal de vidro com 0,35 mm. 


\begin{abstract}
The main goal of this thesis is to present results of experiments with flashing liquid jets of iso-octane. The experiments were carried out with a liquid jet issuing from a small nozzle into a low-pressure chamber. High degrees of metastability were obtained as the liquid jet expanded within the nozzle. Injection pressure and temperature were controlled to the desired testing values for a few seconds, which were found long enough to reach and keep the steady state regime. The photographic documentation of the phenomenon was obtained from a "Schlieren" set up using CCD camera. The "back-lightening” visualization technique was also used in order to compare both image techniques and to unveil some flashing phenomenon details. Analyses of these images with the help of mathematical filters as well as other image manipulating techniques enabled a qualitative visualization of the flashing liquid jet structure and geometry leaving the nozzle. Three liquid jet regimes were observed: (1) continuous liquid jet (2) partially atomized, and (3) evaporation with the presence of shock waves. In this latter case, we speculate that the evaporation took part on the liquid jet surface, which had the approximate shape of a cone. Also it was employed the oblique evaporation wave theory to explain some of the behavior of the overall evaporation process. The tests were carried out using three conical-converging nozzles made of different materials: a $0.3 \mathrm{~mm}$ exit diameter steel nozzle, a $0.8 \mathrm{~mm}$ exit diameter steel nozzle, and a $0.35 \mathrm{~mm}$ exit diameter glass nozzle.
\end{abstract}




\section{SUMÁRIO}

\section{LISTA DE FIGURAS}

\section{LISTA DE TABELAS}

\section{LISTA DE SÍMBOLOS}

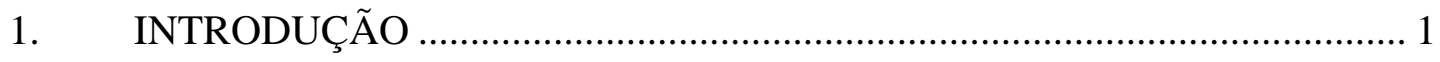

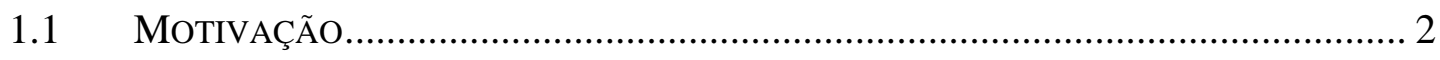

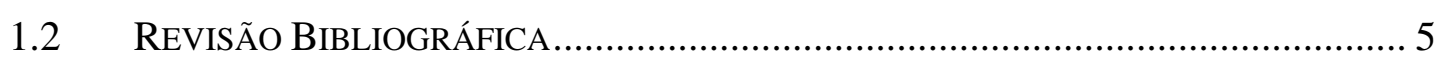

1.2.1 A Presença do Núcleo de Líquido................................................................. 5

1.2.2 A Condição de Líquido Metaestável........................................................... 11

1.2.3 A Formação da Onda de Evaporação.......................................................... 12

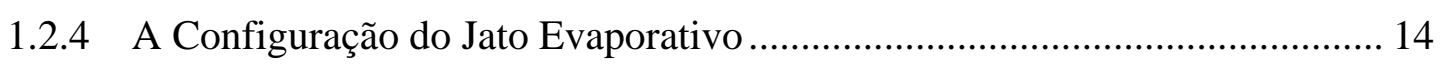

1.2.5 O Escoamento à Jusante da Onda de Evaporação......................................... 19

1.2.6 Considerações sobre o Efeito Transitório e o Comportamento do Jato em Regime Permanente................................................................................ 28

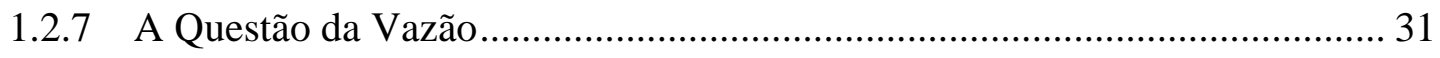

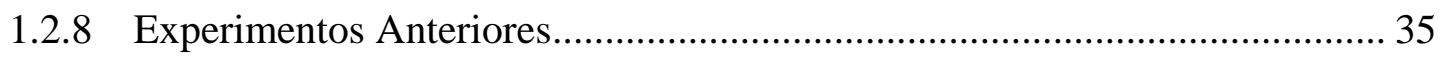

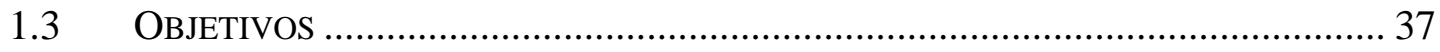

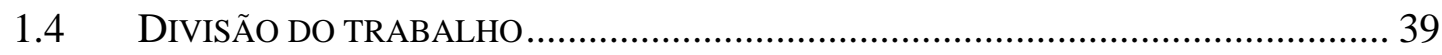

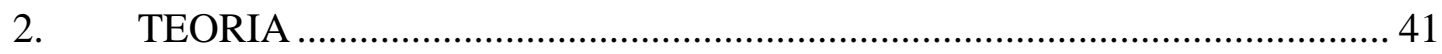

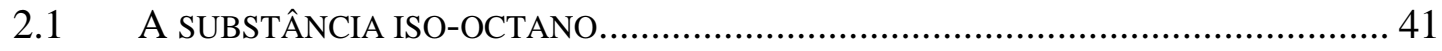

2.1.1 Comportamento da Substância SCME........................................................ 42

2.1.2 O Limite de Metaestabilidade do Líquido ................................................... 44

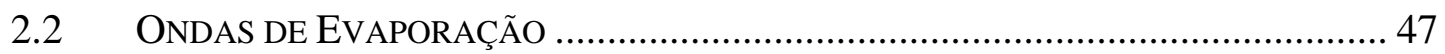

2.3 SOlUÇÃo ANALítica Proposta Para DETERMinAÇão DA Pressão À JUSANTE EM FUNÇÃO DO GRAU DE METAESTABILIDADE ................................. 52

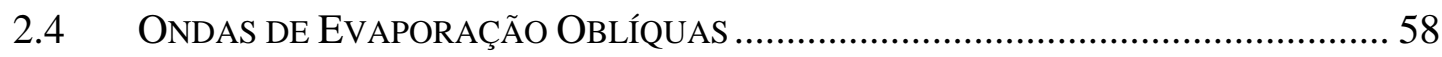

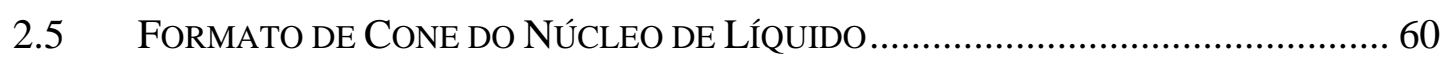

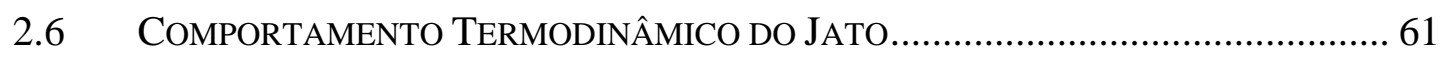

3. ARRANJO E PROCEDIMENTO EXPERIMENTAL ................................... 65

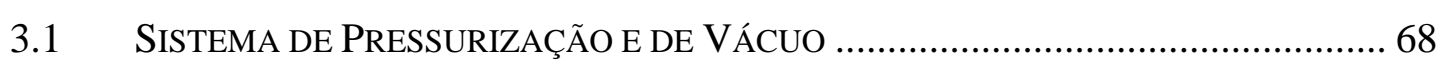

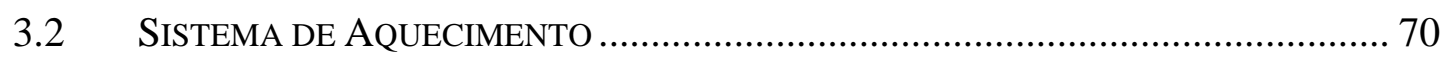

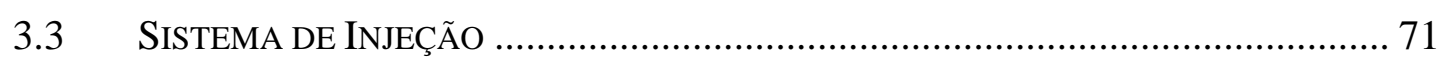

3.4 SiSTEMA ÓPTICO - MÉTODO “SCHLIEREN” ..................................................... 76 


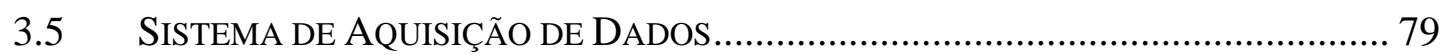

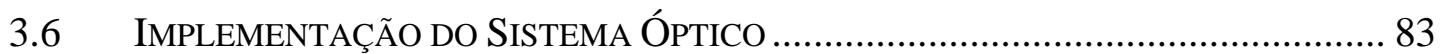

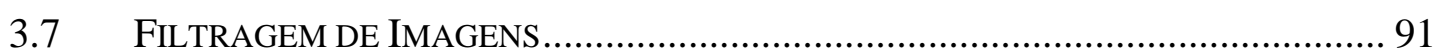

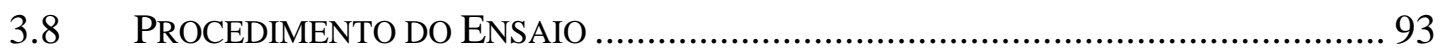

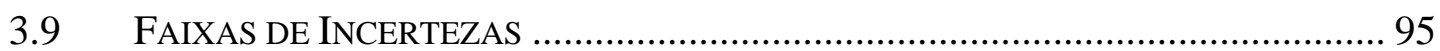

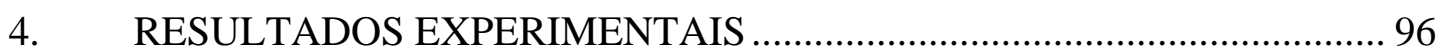

4.1 RESUltAdOS EXPERIMENTAIS: BOCAL DE AÇO COM 0,3 MM DE DIÂMETRO (SÉRIES: RUN1, RUN2 E RUN3) ….............................................. 96

4.1.1 Resultados das Medidas das Vazões Mássicas ............................................ 99

4.1.2 Comprimento de Extinção do Núcleo Líquido ............................................ 101

4.1.3 Dimensões Características da Estrutura da Onda de Choque ....................... 102

4.1.3.1 Influência da Pressão da Câmara sobre as Dimensões da Onda de

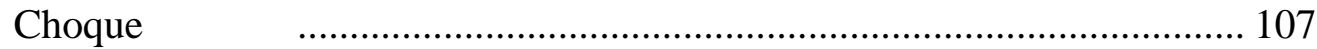

4.2 Ensaios com o Bocal Rugoso de 0,8 Mm de DiÂMetro na SAÍDA -

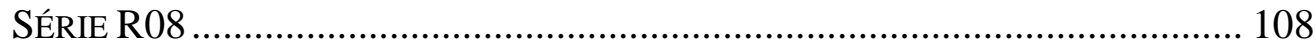

4.2.1 Resultados das Medidas das Vazões Mássicas - Série R08 .......................... 109

4.2.2 Comprimento de Extinção do Núcleo Líquido - Série R08 ......................... 109

4.2.3 Dimensões Características da Estrutura da Onda de Choque - Série

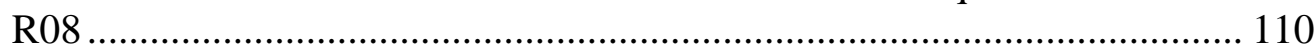

4.2.4 Considerações sobre o Regime Permanente da Série R08........................... 112

4.3 ENSAIOS COM o BoCAL DE VIDRO DE 0,35 MM DE DiÂMETRO NA SAÍDA

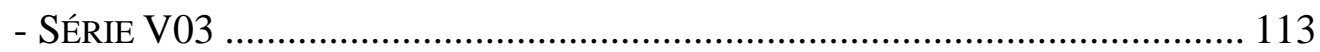

4.3.1 Resultados das Medidas das Vazões Mássicas - Série V03......................... 114

4.3.2 Comprimento de Extinção do Núcleo Líquido - Série V03 .......................... 116

4.3.3 Dimensões Características da Estrutura da Onda de Choque - Série

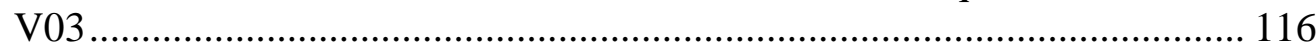

5. ANÁLISE E DISCUSSÃO DOS RESULTADOS EXPERIMENTAIS ..... 120

5.1 ANÁlise E DisCuSSÃo do BOCAL DE AÇO COM 0,3 MM DE DiÂMETRO ......... 120

5.1.1 A Condição de Máxima Vazão ................................................................. 124

5.1.2 Jatos com pressão de saturação abaixo ou próxima da pressão da câmara

5.1.3 Jatos no limiar da condição de blocagem................................................. 134

5.1.4 Jatos com vazão blocada sem a visualização da onda de choque ................. 137

5.1.5 Jatos blocados com a visualização da onda de choque ............................... 141

5.1.6 Análise de Comprimento de Extinção do Líquido...................................... 150

5.1.7 Comportamento da Onda de Choque ........................................................... 158 
5.2 COMPARAÇÃo dos JATOS EVAPORATIVOS DO BOCAL DE AÇO DE 0,3 MM DE DIÂMETRO COM BOCAIS DE AÇO DE 0,8 MM E DE VIDRO DE 0,35 $\mathrm{MM}$

5.2.1 Comparação da Condição de Máxima Vazão ............................................. 165

5.2.2 Comparação do Comprimento de Extinção do Líquido................................ 168

5.2.3 Comparação do Comportamento da Onda de Choque .................................. 172

5.2.4 A Influência das Condições de Injeção e do Comprimento do Núcleo Líquido nas Dimensões da Onda de Choque 174

5.2.5 Considerações Sobre a Dimensão da Onda de Choque do Bocal de Vidro 176

6. APLICAÇÃO DA TEORIA DA ONDA DE EVAPORAÇÃO NOS JATOS 180

6.1 CÁLCULO DO NÚCLEO DE LÍQUIDO ............................................................. 180

6.2 O ATRASO DA ONDA DE EVAPORAÇÃO ........................................................ 186

6.2.1 Condição do Líquido Metaestável no Atraso ................................................ 188

6.2.2 Considerações sobre a Onda de Choque Formada em Jatos com Atraso da Onda Evaporativa ................................................................... 188

7. CONCLUSÕES E CONTINUIDADE DO TRABALHO ........................... 190

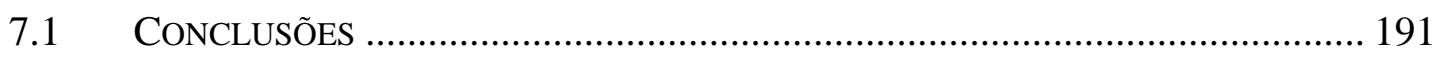

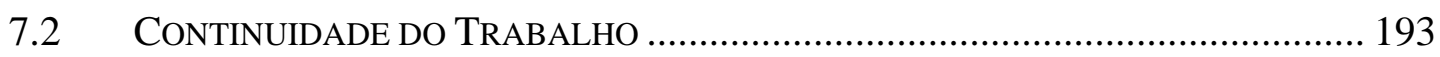

ANEXO A - PROPRIEDADES DE SATURAÇÃO DO ISO-OCTANO ................. 195

ANEXO B - RESULTADOS EXPERIMENTAIS DO BOCAL DE AÇO COM 0,3 MM DE DIÂMETRO (R03).................................................... 197

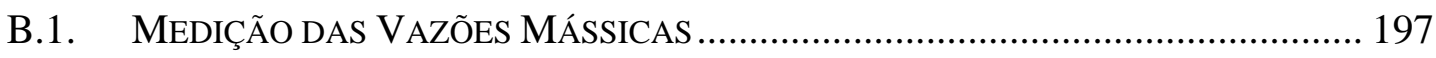

B.2. MEDIÇÃO DO COMPRIMENTO DE EXTINÇÃO DO NÚCLEO LÍQUIDO.................. 201

B.3. MediçÃo das Dimensões da Estrutura da Onda DE CHOQue ................ 204

B.4. IMAGENS DOS ENSAIOS REALIZADOS COM ISO-OCTANO .............................. 210

ANEXO C - RESULTADOS EXPERIMENTAIS DO BOCAL DE AÇO COM 0,8 MM DE DIÂMETRO (R08) E DO BOCAL DE VIDRO COM DIAMETRO DE 0,35 MM (V03).................................................. 268

C.1. MEdiÇÃO DAS VAZÕES MÁSSICAS - SÉRIE R08 ............................................ 268

C.2. MEDIÇÃO DO COMPRIMENTO DE EXTINÇÃO DO NÚCLEO LÍQUIDO -

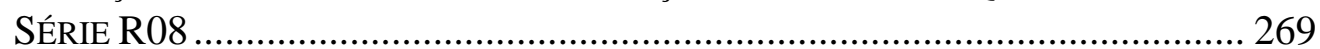

C.3. Medição das Dimensões da Estrutura da Onda de CHOQUe -

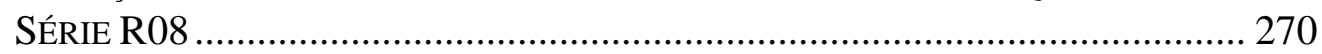

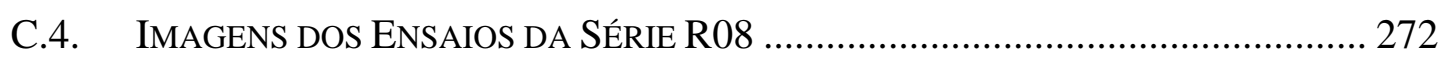

C.5. MEDIÇÃO DAS VAZÕES MÁSSICAS - SÉRIE V03 ........................................... 280 
C.6. MEDIÇÃO DO COMPRIMENTO DE EXTINÇÃO DO NÚCLEO LÍQUIDO -

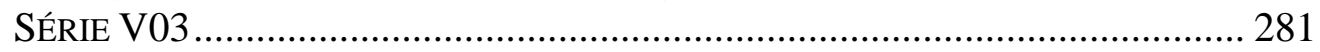

C.7. Medição das Dimensões da Estrutura da Onda de CHOQUe -

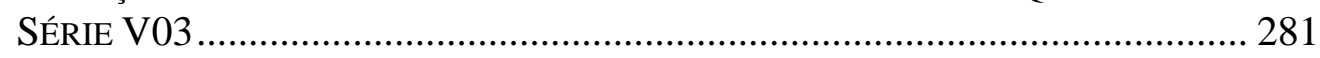

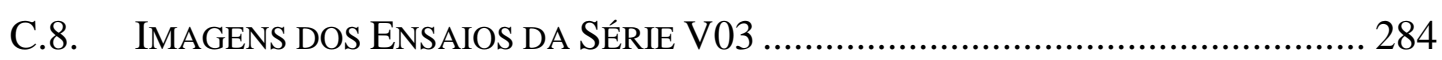

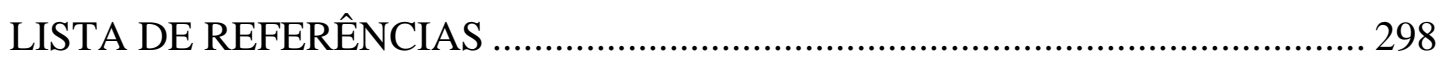
APÊNDICES 


\section{LISTA DE FIGURAS}

Figura 1.1 - A imagem à esquerda se refere a um jato de iso-octano com pressão $\left(P_{0}\right)$ e temperatura de injeção $\left(T_{0}\right)$ de $250 \mathrm{kPa}$ e $56^{\circ} \mathrm{C}$, respectivamente. A pressão de saturação é 300 vezes maior que a pressão da câmara $\left(P_{\infty}\right)$ que é de $0,09 \mathrm{kPa}$.

Figura 1.2 - Seqüência de imagens de jatos evaporativos de querosene com pressão de injeção de $600 \mathrm{kPa}$, e pressão da câmara igual a 1,6 kPa. A temperatura de injeção é de 38, 95, 120 e $260{ }^{\circ} \mathrm{C}$, respectivamente (Vieira, 1999).

Figura 1.3 - Exemplo de jato líquido que sofre uma desintegração, tomando um formato cônico. Nesta representação $D_{\mathrm{b}}$ é o diâmetro do bocal, $L_{\mathrm{d}}$ é o atraso que ocorre na fragmentação do núcleo líquido e $L_{\mathrm{E}}$ é o comprimento do núcleo líquido (Ramamurthi e Nandakumar, 1994).

Figura 1.4 - Imagem de jato de iso-octano com temperatura e pressão de injeção de $223{ }^{\circ} \mathrm{C}$ e $2068 \mathrm{kPa}$, respectivamente, obtidas pelo método de "laser sheet” (Athans, 1994).

Figura 1.5 - As fotografias representam as imagens de uma única injeção de querosene com pressão inicial de $500 \mathrm{kPa}$ e pressão da câmara de 0,6 $\mathrm{kPa}$ e temperatura de injeção de $150{ }^{\circ} \mathrm{C}$, obtidas pelo método "Schlieren". A primeira foi obtida $1 \mathrm{~s}$ após a abertura do injetor e, depois de $1 s$, a segunda foi adquirida (Vieira, 1999).

Figura 1.6 - Imagens obtidas por Kitamura e outros (1986) que ilustram uma seqüência de jatos de água que foram submetidos a uma pressão da câmara menor que a pressão de vapor, de forma progressiva. Isto proporcionou o aumento da evaporação, por conseqüência, da pulverização. A velocidade do inicial do jato, a pressão de injeção, e diferença entre a temperatura de injeção do fluido e a temperatura de saturação em função da pressão da câmara, são respectivamente: a) 8,5 $\mathrm{m} / \mathrm{s}, 760 \mathrm{mmHg}$, valor negativo ; b) $8,65 \mathrm{~m} / \mathrm{s}, 22 \mathrm{mmHg}, 28,5^{\circ} \mathrm{C}$; c) $8,22 \mathrm{~m} / \mathrm{s}, 23 \mathrm{mmHg}, 45,4{ }^{\circ} \mathrm{C}$; d) 8,22 m/s, $20 \mathrm{mmHg}, 48^{\circ} \mathrm{C}$

Figura 1.7 - Tipos de evaporação do jato de água descarregado na atmosfera emergente de um bocal com diâmetro de $0,5 \mathrm{~mm}$. Suas características estão em função da pressão e temperatura de injeção. Na região "a” não existe nucleação. Na região "b”, a nucleação está na superfície do jato. Na região “c”, o jato é totalmente pulverizado com a presença do núcleo de líquido. Nucleações provenientes da parede interna do bocal ou pela presença de partículas estão na região inferior do gráfico e tem a mesma configuração de jato (em destaque).

Figura 1.8- Através da correlação feita por Kitamura e outros (1986), foi verificado que sofrem "flashing" aqueles ensaios que se encontram acima da linha sólida. No gráfico, a abcissa é o número de Weber, $W e=\rho_{V} \cdot D_{b} \cdot u^{2} / \sigma$ e, na coordenada o número de Jacob, 
$J a=\rho_{L} \cdot C p_{L} \cdot \Delta T /\left(\rho_{V} \cdot \Delta h_{L V}\right)$, sendo $\rho$ a massa específica do fluido, $u$ a velocidade do jato, $\sigma$ a tensão superficial do líquido, $C p_{\mathrm{L}}$ o calor específico do líquido, $\Delta h_{\mathrm{LV}}$ a entalpia de vaporização e, $\Delta T$ é a diferença entre a temperatura do líquido e a temperatura de saturação à pressão ambiente onde é descarregado o jato. Os subscritos "L" e "V" se referem às fases líquida e vapor

Figura 1.9 - Onda de evaporação em n-dodecano metaestável.

Condições: A temperatura do líquido é de $230^{\circ} \mathrm{C}$, a pressão abaixo da onda é de $59 \mathrm{kPa}$, a pressão acima da onda de evaporação é de $37 \mathrm{kPa}$ e velocidade da onda sob o líquido estacionário é de 47,2 cm/s (Simões Moreira, 1994).

Figura 1.10 - Imagem do núcleo de líquido de um jato (Kurschat, 1992).

Figura 1.11 - Perfis de jatos de água (Peter e outros, 1994). O primeiro jato tem uma baixa taxa de evaporação no filete do jato. O segundo tipo, com um pequeno acréscimo da razão entre pressão de saturação e da câmara, já possui uma dispersão de gotículas devido à evaporação na periferia do núcleo líquido. Na seqüência, o terceiro jato tem um núcleo de líquido mais definido que o anterior com uma acentuada taxa de evaporação. No último caso, por causa da elevada razão entre a pressão de saturação e da câmara, o jato possui uma elevada taxa de evaporação proporcionando a dispersão imediata das gotículas logo na saída do bocal.

Figura 1.12 - Jatos de diferentes tipos dependentes do parâmetro $R_{\mathrm{P}}$ (Kurschat e outros, 1992). Imagens obtidas pela técnica de interferometria. O primeiro jato não possui evaporação. No segundo, existem nucleações esporádicas quebrando a continuidade do jato. O jato apresentado em "c" pulveriza-se totalmente, com o acréscimo da razão da pressão de vapor e da câmara, $R_{\mathrm{P}}$. A imagem seguinte, com um elevado valor de $R_{\mathrm{P}}$, apresenta a formação da onda de choque. A penúltima imagem ("e") mostra um jato semelhante ao anterior, porém destaca a presença do núcleo de líquido, além da onda de choque. Por último, um jato contendo um núcleo de líquido menor que o anterior e, uma onda de choque menor, embora a pressão da câmara seja a mesma comparada ao anterior, porém a temperatura de injeção é maior.

Figura 1.13 - Imagens de um jato com elevada taxa de evaporação. A primeira é a fotografia original e as outras correspondem às imagens filtradas e processadas matematicamente (Vieira, 1999).

Figura 1.14 - Esquema de uma onda de evaporação com a formação de uma estrutura de onda de choque.

Figura 1.15 - Gráficos que ilustram o comportamento da temperatura de estagnação das gotículas durante a expansão do jato de água com temperatura e pressão de injeção de $30,3{ }^{\circ} \mathrm{C}, 100 \mathrm{kPa}$, respectivamente e, pressão da câmara de $0,63 \mathrm{kPa}$. O primeiro corresponde à temperatura em função da distância axial destacando o ponto onde 
ocorreu a interrupção da continuidade do filete líquido e, o ponto "C" seria o início da estabilização da temperatura das gotículas com 0 ambiente. O segundo indica as temperaturas em função da distância radial apenas para o jato Tipo 3 (Peter e outros, 1994).

Figura 1.16 - Simulação numérica feita para o ensaio 2349100, cujas condições de injeção eram de $250 \mathrm{kPa}$ e $76{ }^{\circ} \mathrm{C}$. A linha contínua indica o comportamento da pressão, a linha tracejada corresponde o título da mistura e a linha traço-ponto indica o número de Mach. São indicadas as posições da onda de evaporação e da onda de choque (SimõesMoreira e outros, 2002).

Figura 1.17 - A mesma simulação numérica da Fig. 1.16 acrescentando o comportamento da temperatura com ênfase para regiões à montante e à jusante da onda de choque. Outra informação importante deste gráfico pode ser feita na observação do salto de propriedades na posição da onda de choque, considerando a hipótese de modelo homogêneo

Figura 1.18 - (a) Fotografia do jato de R134a descarregado no ambiente proveniente de um bocal de $1 \mathrm{~mm}$. As torres verticais são os termopares dispostos a uma distância de $50 \mathrm{~mm}$ entre eles. (b) Fotografia termográfica do jato do bocal de $1 \mathrm{~mm}$. (c) Gráfico da temperatura em função da posição axial de afastamento do bocal. Foram testados 3 bocais com diâmetros, $D_{\text {b }}$, de 1, 2 e 4mm.

Figura 1.19 - Fotografias obtidas pelo método "Schlieren” com jatos de gás Hélio em uma câmara contendo gás nitrogênio. As fotografias acima se referem a um jato descarregado em uma câmara cuja pressão é 10 vezes menor que a pressão de injeção, enquanto a segunda fileira, esta relação é de 3 vezes (Lacerda, 1986).

Figura 1.20 - Evolução de um jato de gás subexpandido com a formação do disco de Mach. Segundo Lacerda (1986), a frente de onda já não aparece porque ela assumiu uma dimensão maior que o quadro da fotografia.

Figura 1.21 - Evolução de um jato supersônico de óleo diesel emergente de um bocal de $1 \mathrm{~mm}$. O intervalo de tempo entre cada fotografia foi de $22 \mu \mathrm{s}$, $41 \mu$ s e $64 \mu$ s, respectivamente.

Figura 1.22 - Esquema do escoamento de um jato de gás subexpandido.

Figura 1.23 - Gráfico que compara a vazão superficial mássica teórica em função da pressão a jusante com aquela obtida experimental de uma placa de orifício. Refere-se a um escoamento de água saturada com pressão à montante de 145 psia $(1000 \mathrm{kPa})$. O cálculo teórico, que Benjamin e Miller (1941) se embasaram, assume que a mínima pressão é de 135 psia, ou 930,8 kPa.

Figura 1.25 - Gráfico que ilustra a vazão em função da diferença de pressão entre a jusante e à montante, $\Delta P=P_{1}-P_{2}$, sendo $P_{1}$ igual a 100 psia, $C_{\mathrm{v}}$, o coeficiente da válvula igual $6,6, C_{\mathrm{f}}$, o coeficiente para a condição de blocagem da válvula globo igual a 0,74 (Baumann, 1963). Entre a 
região de transição, que corresponde um escoamento suscetível à cavitação da válvula globo (em destaque), à esquerda existe a curva que respeita o regime hidráulico, e à direita, assume um regime de vazão crítica.

Figura 1.25 - Medições do fluxo mássico: - - - -, cálculo para incompressível (através da equação de Bernoulli); — modelo de cálculo; *, resultados experimentais. $P_{0}=15$ bar e $P_{\infty}=10$ mbar (Kurschat e outros, 1992).

Figura 1.26 - Fotografia com (a) tempo de exposição de 1/250 s com iluminação lateral e, (b) tempo de 20 ns com iluminação por detrás de um jato de água a uma temperatura de $146{ }^{\circ} \mathrm{C}$ e pressão de injeção de $697 \mathrm{kPa}$ descarregado em ambiente atmosférico (Reitz, 1990).

Figura 2.1 - Gráficos com dados relevantes do líquido saturado iso-octano em função da temperatura. Os dados são: volume específico, viscosidade dinâmica e pressão de vapor (Vargaftik, 1996).

Figura 2.2 - Diagrama T-s de uma substância SCME (n-dodecano e iso-octano) e uma substância simples (água).

Figura 2.3 - Representação da região metaestável de um fluido em diagrama temperatura - volume específico (Simões-Moreira, 1994).

Figura 2.4 - Taxa de densidade de nucleações, $J_{n}$, em função do grau de metaestabilidade, $\Pi$, do iso-octano.

Figura 2.5 - Volume de controle englobando uma onda de evaporação. Estado

“1” é o líquido metaestável e o estado “2” é a mistura bifásica

Figura 2.6 - Representação das curvas de Rankine-Hugoniot $(R-H)$ e de Rayleigh $(R)$ em uma evaporação. O ponto " $C$ " corresponde à condição de Chapman-Jouguet referente ao estado “ 1 ”.

Figura 2.7 - Representação do comportamento da razão de pressões à jusante e à montante da onda de evaporação em função do grau de metaestabilidade do iso-octano.

Figura 2.8 - Representação das curvas de $P_{2} / P_{1}$ em função de $\Pi$, para diversos fluidos apresentados na legenda. A linha contínua é a solução analítica proposta e os símbolos vêm da solução numérica da Tab. 2.4.

Figura 2.9 - Representação do comportamento da razão de pressões à jusante e à montante da onda de evaporação em função do grau de metaestabilidade do líquido para a iso-octano com temperatura inicial de $56{ }^{\circ} \mathrm{C}$ com pressão inicial de $750 \mathrm{kPa}$.

Figura 2.10 - Representação esquemática do jato à esquerda e, à direita, está em destaque a geometria da onda de evaporação com suas componentes de velocidade, em um plano coincidente ao eixo central.

Figura 2.11 - Ângulo de giro como função do ângulo de onda parametrizado pela razão entre os volumes específicos à jusante e à montante relativos à onda de evaporação (Simões-Moreira, 1999). 
Figura 2.12 - Explicação para o comportamento termodinâmico do jato evaporativo.

Figura 3.1 - Esquema geral da bancada experimental.

Figura 3.2 - Fotografia da câmara de baixa pressão, painel de controle e mesas ópticas com lentes, espelhos parabólicos e filtro espacial.

Figura 3.3 - Fotografia da bomba de vácuo e do painel com mano-vacuômetro de mercúrio e vacuômetro analógico de precisão.

Figura 3.4 - Esquema do sistema de vácuo.

Figura 3.5 - Esquema do sistema de aquecimento.

Figura 3.6 - Esquema da linha de injeção.

Figura 3.7 - Esquema do corpo de injeção mediante acionamento pneumático da haste, o líquido é subitamente expandido para fora do bocal. A temperatura inicial é obtida através da circulação de óleo aquecido no espaço anular.

Figura 3.8 - A primeira figura é um esquema das dimensões gerais de um bocal. A segunda figura mostra os dois bocais usinados com diâmetro de saída de 0,3 e 0,8 mm, respectivamente. Ao lado está a vista do orifício de saída do jato de um bocal. A quarta fotografia mostra o inserto de vidro utilizado, cujo diâmetro de saída é de $0,35 \mathrm{~mm}$. Seu comprimento é de $12 \mathrm{~mm}$, diferente dos outros dois que possuem uma cota de $8 \mathrm{~mm}$, como na imagem "a”.

Figura 3.9 - Arranjo de medição instantânea da vazão através do nível de líquido no tubo de vidro graduado.

Figura 3.10 - Sinais típicos adquiridos no ensaio. É possível observar os sinais de pressão e temperatura de injeção, com um ruído representado por um desvio padrão de $2,9 \mathrm{kPa}$ e $0,3{ }^{\circ} \mathrm{C}$. Estão representados também os sinais da pressão da câmara, do sensor de posição da haste do injetor que indica o tempo de duração da injeção e do sensor de nível de líquido que indica os intervalos de deslocamento do volume a cada $1,90 \mathrm{ml}$, representado por $t_{\mathrm{a}}, t_{\mathrm{b}}$ e $t_{\mathrm{c}}$

Figura 3.11 - Geometria do aparato óptico. 78

Figura 3.12 - Equipamentos: espelhos, lâmpada, lente convergente e filtro espacial.

Figura 3.13 - Equipamento: espelhos, filtro espacial e câmara CCD. 79

Figura 3.14 - Sistema de aquisição de dados, onde o canal "0" dispara o injetor e o canal "1" dispara a aquisição das imagens.

Figura 3.15 - Esquema dos sinais de saída. A linha vermelha corresponde ao sinal do acionamento do injetor, ou canal " 0 ”, e a linha azul corresponde ao sinal de disparo para a aquisição das imagens, canal “ 1 ”.

Figura 3.16 - Comparação dos tempos dos sinais de saída e de entrada. O 
primeiro sinal representa o sinal para a câmara CCD habilitar a aquisição das imagens na rampa de descida, indicada pelas setas. $\mathrm{O}$ segundo sinal apenas apresenta o tempo em que o computador habilitou a abertura do injetor. Estes dois sinais não possuem a representação da voltagem em sua amplitude. O terceiro e o quarto sinal são as representações típicas de um sinal adquirido da pressão de injeção e do sinal de posição da haste, respectivamente. Neles constam as coincidências dos transitórios devido à abertura e fechamento da injeção.

Figura 3.17 - A primeira fotografia, corresponde à imagem original obtida na câmara CCD. As duas imagens seguintes, b) e c), correspondem ao campo das linhas ímpares e pares da original, respectivamente. Com esta decomposição, é possível notar as descontinuidades no jato devido à evaporação.

Figura 3.18 - Seqüência de fotografias obtidas em um único ensaio conforme os intervalos de 0,10 , 0,50 , 2,50 e 4,50 segundos, após a abertura do injetor.

Figura 3.19 - Fotografia da mesa óptica que possui a fonte de luz. No caso, esta imagem mostra o "flash" empregado que possui um tempo de exposição de $2 \mu \mathrm{s}$.

Figura 3.20 - Interface do programa computacional “Aqjatos” projetado e programado para adquirir as imagens dos jatos desta bancada. Nele se regula o tempo de exposição da câmara CCD (Sync Master), quantidade de imagens adquiridas no ensaio, duração do ensaio e, utilização de uma segunda câmara.

Figura 3.21 - Esquema dos sinais que fazem o sincronismo entre a lâmpada de "flash" e a câmara CCD.

Figura 3.22 - Exemplo de seqüência de imagens adquiridas em um único ensaio. Observa-se que as imagens do lado esquerdo possuem os dois campos, enquanto as outras estão com um único campo, e por isso estão mais escurecidas.

Figura 3.23 - Planta esquemática da disposição das câmaras CCDs.

Figura 3.24 - Comparação de duas imagens de um mesmo ensaio. a) A primeira foi obtida pelo método "Schlieren" que destaca bastante a movimentação e evaporação do fluido em volta do jato e b) a outra foi adquirida pela segunda câmara CCD que destaca a trajetória das gotículas. A primeira imagem possui um tempo de exposição de $2 \mu \mathrm{s}$ e a segunda de $1000 \mu$ s. O líquido foi injetado a uma pressão de injeção de $750 \mathrm{kPa}$, temperatura de injeção de $56^{\circ} \mathrm{C}$ e pressão do reservatório é a metade da pressão de saturação da substância, iso-octano, que é de $25 \mathrm{kPa}$

Figura 3.25 - A primeira é a fotografia sem o jato e a seguinte contém o jato. A subtração da segunda fotografia pela fotografia sem o jato resulta na última imagem com um jato visualmente mais evidente. 
Figura 4.1 - Representação gráfica das condições de injeção e a pressão da câmara onde é descarregado o jato pelo bocal de 0,3 mm, rugoso.

Figura 4.2 - Representação dos parâmetros geométricos relevantes de um experimento típico.

Figura 4.3 -Vazão mássica em função da razão da pressão da câmara e a pressão de injeção. A pressão de injeção é de $125 \mathrm{kPa}$.

Figura 4.4 -Vazão mássica em função da razão da pressão da câmara e a pressão de injeção. A pressão de injeção é de $250 \mathrm{kPa}$.

Figura 4.5 -Vazão mássica em função da razão da pressão da câmara e a pressão de injeção. A pressão de injeção é de $500 \mathrm{kPa}$.

Figura 4.6 -Vazão mássica em função da razão da pressão da câmara e a pressão de injeção. A pressão de injeção é de $750 \mathrm{kPa}$.

Figura 4.7 - Comportamento do comprimento de extinção do núcleo líquido, $L_{\mathrm{E}}$, em função da temperatura de injeção. São diferenciados os ensaios com pressão de injeção de $125 \mathrm{kPa}, 250 \mathrm{kPa}, 500 \mathrm{kPa}$ e $750 \mathrm{kPa}$ (bocal rugoso com 0,3 mm de diâmetro).

Figura 4.8 - Representação das dimensões medidas na estrutura da onda de choque.

Figura 4.9 - O comprimento representativo, $r_{1}$ (no primeiro gráfico) e $r_{2}$ são indicados em função da pressão da câmara para os ensaios cuja pressão de injeção é $125 \mathrm{kPa}$ (bocal rugoso com 0,3 mm de diâmetro)... 103

Figura 4.10 - O comprimento representativo, $r_{1}$ (no primeiro gráfico) e $r_{2}$ são indicados em função da pressão da câmara para os ensaios cuja pressão de injeção é $250 \mathrm{kPa}$ (bocal rugoso com 0,3 mm de diâmetro)... 104

Figura 4.11 - O comprimento representativo, $r_{1}$ (no primeiro gráfico) e $r_{2}$ são indicados em função da pressão da câmara para os ensaios cuja pressão de injeção é $500 \mathrm{kPa}$ (bocal rugoso com 0,3 mm de diâmetro)... 105

Figura 4.12 - O comprimento representativo, $r_{1}$ (no primeiro gráfico) e $r_{2}$ são indicados em função da pressão da câmara para os ensaios cuja pressão de injeção é $750 \mathrm{kPa}$ (bocal rugoso com 0,3 mm de diâmetro)... 106

Figura 4.13 - Seqüência de duas imagens de um mesmo ensaio onde a pressão e temperatura de injeção é de $500 \mathrm{kPa}$ e $76{ }^{\circ} \mathrm{C}$ e, o $R_{\mathrm{P}}$ é de 50 , praticamente, pois a pressão da câmara variou de 0,90 a $0,99 \mathrm{kPa}$, respectivamente, em um intervalo de $1 \mathrm{~s}$.

Figura 4.14 - Seqüência de imagens de um mesmo ensaio onde a pressão de injeção é de $250 \mathrm{kPa}$ e temperatura de $56{ }^{\circ} \mathrm{C}$ e o $R_{\mathrm{P}}$ é de 500 , praticamente. No entanto, a pressão da câmara, desde a primeira imagem elevou de 0,05, 0,09 e, por último, 0,14 kPa em um intervalo de tempo de $1 s$ entre cada imagem obtida.

Figura 4.15 - Representação gráfica das condições de injeção e a pressão da câmara onde é descarregado o jato pelo bocal rugoso de $0,8 \mathrm{~mm}$ Série R08. Um desenho do bocal é visto no detalhe da figura... 
Figura 4.16 -Vazão mássica em função da razão da pressão da câmara e a pressão de injeção obtida dos ensaios com o bocal de aço de diâmetro $0,8 \mathrm{~mm}$

Figura 4.17 - Comportamento do comprimento de extinção do núcleo líquido em função da temperatura de injeção. São diferenciados os ensaios com pressão de injeção de $125 \mathrm{kPa}$ e $250 \mathrm{kPa}$ (bocal rugoso com 0,8 mm de diâmetro).

Figura 4.18 - Os comprimentos, $r_{1}$ (no primeiro gráfico) e $r_{2}$ são representados nos gráficos acima que contêm todos os ensaios da série R08 (bocal rugoso com $0,8 \mathrm{~mm}$ de diâmetro).

Figura 4.19 - Gráfico dos dados coletados do ensaio com pressão de injeção de $125 \mathrm{kPa}$ e temperatura de $56{ }^{\circ} \mathrm{C}$ (ensaio R08\1056500). A duração do regime permanente é indicada para o intervalo com temperatura de injeção constante.

Figura 4.20 - Representação gráfica das condições de injeção e a pressão da câmara onde é descarregado o jato pelo bocal de vidro de $0,35 \mathrm{~mm}$ Série V03. Um desenho do inserto de vidro é visto no detalhe da figura.

Figura 4.21 -Vazão mássica em função da razão da pressão da câmara e a pressão de injeção obtida dos ensaios com pressão de injeção de 125 $\mathrm{kPa}$ e bocal de vidro de diâmetro 0,35 mm.

Figura 4.22 -Vazão mássica em função da razão da pressão da câmara e a pressão de injeção obtida dos ensaios com pressão de injeção de 250 $\mathrm{kPa}$ e bocal de vidro de diâmetro 0,35 mm.

Figura 4.23 -Vazão mássica em função da razão da pressão da câmara e a pressão de injeção obtida dos ensaios com pressão de injeção de 500 $\mathrm{kPa}$ e bocal de vidro de diâmetro 0,35 mm.

Figura 4.24 - Comportamento do comprimento de extinção do núcleo líquido em função da temperatura de injeção. São diferenciados os ensaios com pressão de injeção de 125, 250 e 500 kPa (bocal de vidro com 0,35 mm de diâmetro).

Figura 4.25 - Os comprimentos, $r_{1}$ (no primeiro gráfico) e $r_{2}$ são representados nos gráficos acima que contêm os ensaios da série V03 (bocal rugoso com 0,35 mm de diâmetro) com pressão de injeção de $125 \mathrm{kPa}$.

Figura 4.26 - Os comprimentos, $r_{1}$ (no primeiro gráfico) e $r_{2}$ são representados nos gráficos acima que contêm os ensaios da série V03 (bocal rugoso com 0,35 mm de diâmetro) com pressão de injeção de $250 \mathrm{kPa}$.

Figura 4.27 - Os comprimentos, $r_{1}$ (no primeiro gráfico) e $r_{2}$ são representados nos gráficos acima que contêm os ensaios da série V03 (bocal rugoso com 0,35 mm de diâmetro) com pressão de injeção de $500 \mathrm{kPa}$.

Figura 5.1 - Alguns ensaios de valores de injeção nominais $P_{0}=250 \mathrm{kPa}$ e $T_{0}=76^{\circ} \mathrm{C}\left(P_{\text {sat }}=54 \mathrm{kPa}\right)$ 
Figura 5.2 - Alguns ensaios de valores de injeção nominais $P_{0}=250 \mathrm{kPa}$ e $T_{0}=130{ }^{\circ} \mathrm{C}\left(P_{\text {sat }}=220 \mathrm{kPa}\right)$

Figura 5.3 - Alguns ensaios de valores de injeção nominais $P_{0}=500 \mathrm{kPa}$ e $T_{0}$ $=130{ }^{\circ} \mathrm{C}\left(P_{\text {sat }}=220 \mathrm{kPa}\right)$.

Figura 5.4 - Alguns ensaios de valores de injeção nominais $P_{0}=500 \mathrm{kPa}$ e $T_{0}=$ $162{ }^{\circ} \mathrm{C}\left(P_{\text {sat }}=440 \mathrm{kPa}\right)$.

Figura 5.5 - Caso típico de um comportamento da vazão. Os pontos correspondem aos ensaios realizados a uma pressão e temperatura de injeção de $250 \mathrm{kPa}$ e $95^{\circ} \mathrm{C}$, respectivamente. A linha vertical contínua se refere à pressão de vapor de $90 \mathrm{kPa}$ a outra linha contínua corresponde à vazão mássica estimada através da Eq. 4.3.

Figura 5.6 - Gráfico que mostra as condições de injeção dos ensaios feitos para o bocal de aço com 0,3 mm de diâmetro (R03) e a pressão metaestável alcançada pelo ensaio.

Figura 5.7 - Gráfico que mostra o grau de metaestabilidade em função da pressão de injeção.

Figura 5.8 - Gráfico que mostra a razão de pressões $\left(R_{\mathrm{p}}\right)$ em função da razão entre a pressão de saturação e de injeção. Dependendo da pressão de injeção, ensaios acima da curva possuem a condição de máxima vazão.. 129

Figura 5.9 - Jato com pressão e temperatura de injeção de $250 \mathrm{kPa}$ e $95{ }^{\circ} \mathrm{C}$. A pressão da câmara é de $174 \mathrm{kPa}$ e a razão entre as pressões de saturação e câmara é de 0,5 (método “Schlieren”).

Figura 5.10 - Jato com pressão e temperatura de injeção de $250 \mathrm{kPa}$ e $95{ }^{\circ} \mathrm{C}$. A pressão da câmara é de $90 \mathrm{kPa}$ e a razão entre as pressões de saturação e câmara é igual a 1. A primeira imagem foi adquirida pela câmara CCD que utiliza o recurso de "iluminação por detrás" e a segunda imagem, referente ao mesmo jato, foi obtida pelo método "Schlieren”. .. 131

Figura 5.11 - Jato com pressão e temperatura de injeção de $124 \mathrm{kPa}$ e $93{ }^{\circ} \mathrm{C}$. A pressão da câmara é de $44 \mathrm{kPa}\left(R_{\mathrm{P}}=1,9\right)$. A primeira imagem foi adquirida pela câmara CCD que utiliza o recurso de "iluminação por detrás” e a segunda imagem, referente ao mesmo jato, foi obtida pelo método "Schlieren". O detalhe da primeira imagem comprova a continuidade do filete do jato.

Figura 5.12 - Ensaio 2368002: Jato com pressão e temperatura de injeção de $250,3 \mathrm{kPa}$ e $95,3{ }^{\circ} \mathrm{C}$. A pressão da câmara é de $45 \mathrm{kPa}\left(R_{\mathrm{P}}=2,0\right)$. Imagem obtida pelo método "Schlieren".

Figura 5.13 - Ensaio 7368001: jato com pressão e temperatura de injeção de 750 $\mathrm{kPa}$ e $95^{\circ} \mathrm{C}$. A pressão da câmara é de $93,3 \mathrm{kPa}$ e a razão entre as pressões de saturação e câmara é igual a 1. A primeira imagem foi adquirida pela câmara CCD que utiliza o recurso de "iluminação por detrás” e a segunda imagem, referente ao mesmo jato, foi obtida pelo método "Schlieren". 
Figura 5.14 - Ensaio 2393002: jato com pressão e temperatura de injeção de 250 $\mathrm{kPa}$ e $120{ }^{\circ} \mathrm{C}$. A pressão da câmara é de $89,9 \mathrm{kPa}$ e a razão entre as pressões de saturação e câmara é igual a 1,9. Imagem obtida pelo método "Schlieren".

Figura 5.15 - Ensaio 7349002: jato com pressão e temperatura de injeção de 750 $\mathrm{kPa}$ e $76^{\circ} \mathrm{C}$. A pressão da câmara é de $24,9 \mathrm{kPa}$ e a razão entre as pressões de saturação e câmara é igual a 2,0. Imagem obtida pelo método "Schlieren". No canto superior esquerdo, na mesma escala de tamanho, a imagem obtida pelo método de “iluminação por detrás". Este retrata uma grande dispersão de gotículas.

Figura 5.16 - Ensaio 2349005: jato com pressão e temperatura de injeção de 250 $\mathrm{kPa}$ e $76{ }^{\circ} \mathrm{C}$. A pressão da câmara é de $10,1 \mathrm{kPa}$ e a razão entre as pressões de saturação e câmara é igual a 5,1. Imagem obtida pelo método "Schlieren".

Figura 5.17 - Ensaio 2404005: jato com pressão e temperatura de injeção de 250 $\mathrm{kPa}$ e $131{ }^{\circ} \mathrm{C}$. A pressão da câmara é de $43,7 \mathrm{kPa}$ e a razão entre as pressões de saturação e câmara é igual a 5,1. Imagem obtida pelo método "Schlieren". O destaque foi obtido em 0,5 $s$ após adquirir a fotografia principal

Figura 5.18 - Ensaio 2404010: jato com pressão e temperatura de injeção de 250 $\mathrm{kPa}$ e $131{ }^{\circ} \mathrm{C}$. A pressão da câmara é de $24,0 \mathrm{kPa}$ e a razão entre as pressões de saturação e câmara é igual a 9,5. Imagem obtida pelo método "Schlieren". A imagem menor no detalhe foi obtida em 0,5 $\mathrm{s}$ após esta fotografia principal.

Figura 5.19 - Ensaio 7349050: jato com pressão e temperatura de injeção de $749,2 \mathrm{kPa}$ e $76,8^{\circ} \mathrm{C}$. A pressão da câmara é de $1,0 \mathrm{kPa}$ e a razão entre as pressões de saturação e câmara é igual a 51,3. Imagem obtida pelo método "Schlieren". O destaque se refere à imagem obtida pelo outro método, na mesma escala.

Figura 5.20 - Ensaio 7435100: jato com pressão e temperatura de injeção de $749,3 \mathrm{kPa}$ e $161,8^{\circ} \mathrm{C}$. A pressão da câmara é de 4,6 kPa e a razão entre as pressões de saturação e câmara é igual a 96,8. Imagem obtida pelo método "Schlieren". O destaque se refere a imagem obtida pelo outro método, na mesma escala.

Figura 5.21 - Jato com pressão e temperatura de injeção de $744 \mathrm{kPa}$ e 132,1 ${ }^{\circ} \mathrm{C}$. A pressão da câmara é de $0,10 \mathrm{kPa}$. A primeira imagem foi uma filtragem da imagem original obtida pelo método "Schlieren” que está no canto superior esquerdo dela, assim como, a fotografia obtida pela iluminação por detrás está no outro canto. Neste pequeno quadro a lâmina está projetada atrás do jato e por isso não é visível. A segunda imagem também é outra filtragem do original com um mapa de cores diferente ("prism”).

Figura 5.22 - A primeira corresponde à imagem original do jato do ensaio 5435m10c. Em seguida, são imagens filtradas e processadas 
matematicamente da original onde as imagens $b$ e $c$ foram submetidas a um filtro subtrativo que realça o campo de densidade do escoamento enquanto que, a quarta, foi processada para destacar o núcleo líquido e as ondas de choque. A última imagem se refere à fotografia obtida pelo método de iluminação por detrás.

Figura 5.23 - Imagens originais do jato do ensaio 5349500, com condições de injeção de $497,6 \mathrm{kPa}, 76,9{ }^{\circ} \mathrm{C}$ e a pressão da câmara de 0,09 kPa. A primeira obtida pelo método "Schlieren" e a outra pela "Iluminação por detrás".

Figura 5.24 - Imagens filtradas do jato do ensaio 5349500 da Fig. 5.23a.

Figura 5.25 - Imagens originais do jato do ensaio 5329050, com condições de injeção de $501,6 \mathrm{kPa}, 56,6{ }^{\circ} \mathrm{C}$ e a pressão da câmara de $0,50 \mathrm{kPa}$. A primeira obtida pelo método "Schlieren" e a outra pela "Iluminação por detrás"

Figura 5.26 - Imagens originais do jato do ensaio 5329100, com condições de injeção de 501,6 kPa, 56,6 ${ }^{\circ} \mathrm{C}$ e a pressão da câmara de 0,31 kPa. A primeira obtida pelo método "Schlieren" e a outra pela "Iluminação por detrás”.

Figura 5.27 - Imagens originais do jato do ensaio 5329500, com condições de injeção de $504,1 \mathrm{kPa}, 57,1{ }^{\circ} \mathrm{C}$ e a pressão da câmara de $0,12 \mathrm{kPa}$. A primeira obtida pelo método "Schlieren" e a outra pela "Iluminação por detrás”.

Figura 5.28 - Comparação do comprimento de extinção do núcleo líquido, $L_{\mathrm{E}}$, em função da razão da pressão de saturação e de injeção. Uma curva de ajuste para estes dados pode ser escrita através da seguinte equação: $L_{E}=2,04 .\left(P_{\text {sat }} / P_{0}\right)^{-0,6}$. O destaque no gráfico se refere à diferença de comprimento esperada nestes ensaios.

Figura 5.29 - Imagens originais do jato do ensaio 1329050, com condições de injeção de $122,1 \mathrm{kPa}, 56,4{ }^{\circ} \mathrm{C}$ e a pressão da câmara de $0,49 \mathrm{kPa}$. A primeira obtida pelo método "Schlieren" e a outra, que indica o atraso da onda de evaporação, pela "Iluminação por detrás".

Figura 5.30 - Imagens originais do jato do ensaio 1329500, com condições de injeção de $123,0 \mathrm{kPa}, 56,5{ }^{\circ} \mathrm{C}$ e a pressão da câmara de $0,10 \mathrm{kPa}$. A primeira obtida pelo método "Schlieren” e a outra, que indica o atraso da onda de evaporação, pela "Iluminação por detrás”.

Figura 5.31 - Os comprimentos representativos $r_{1}$ (em “a”) e $r_{2}$ em função da pressão da câmara. Aqui, todos com os ensaios possuem a pressão de injeção de $125 \mathrm{kPa}$ (bocal rugoso com 0,3 mm de diâmetro).

Figura 5.32 - Os comprimentos representativos $r_{1}$ (em "a”) e $r_{2}$ em função da pressão da câmara. Aqui, todos com os ensaios possuem a pressão de injeção de $750 \mathrm{kPa}$ (bocal rugoso com 0,3 mm de diâmetro).

Figura 5.33 - Os comprimentos representativos $r_{1}$ (em “a”) e $r_{2}$ em função da 
pressão da câmara. Aqui, todos com os ensaios possuem a temperatura de injeção de $56{ }^{\circ} \mathrm{C}$ (bocal rugoso com 0,3 mm de diâmetro).

Figura 5.34 - Os comprimentos representativos $r_{1}$ (em “a”) e $r_{2}$ em função da pressão da câmara. Aqui, todos com os ensaios possuem a temperatura de injeção de $95{ }^{\circ} \mathrm{C}$ (bocal rugoso com 0,3 mm de diâmetro).

Figura 5.35 - Gráfico que mostra a influência do comprimento do núcleo líquido na distância axial da onda de choque. Nele, a razão do comprimento característico $r_{2}$ pelo raio do bocal $r_{\mathrm{b}}$ está em função da pressão da câmara corrigido pelo fator de proporcionalidade do comprimento do núcleo líquido. As linhas tracejadas são os limites de erro encontrados em função da incerteza na medição desta razão $(+/-3,3)$ e da pressão da câmara (+/- 0,07).

Figura 5.36 - Jatos com pressão e temperatura de injeção de $250 \mathrm{kPa}$ e $22{ }^{\circ} \mathrm{C}$. A pressão da câmara é a atmosférica e a razão entre as pressões de saturação e câmara é igual a 0,05. A primeira é um jato do bocal R08 e a outra do bocal de vidro V03. Os destaques nos cantos superiores das imagens são imagens adquiridas pela câmara CCD que utiliza o recurso de “iluminação por detrás”. As imagens principais foram obtidas pelo método "Schlieren" (ensaios feitos na calibração do $C_{\mathrm{D}}$ ). ... 163

Figura 5.37 - Ensaios com as condições de injeção de $P_{0}=125 \mathrm{kPa}, T_{0}=56{ }^{\circ} \mathrm{C}$ e $P_{\infty}=0,150,07 \mathrm{kPa}$. Cada imagem se refere aos bocais R03, R08 e $\mathrm{V} 03$, respectivamente.

Figura 5.38 - Ensaios com as condições de injeção de $P_{0}=125 \mathrm{kPa}, T_{0}=56{ }^{\circ} \mathrm{C}$ e $P_{\infty}=0,450,07 \mathrm{kPa}$. Cada imagem se refere aos bocais R03, R08 e V03, respectivamente.

Figura 5.39 - Ensaios com as condições de injeção de $P_{0}=125 \mathrm{kPa}, T_{0}=95{ }^{\circ} \mathrm{C}$ e $P_{\infty}=0,240,07 \mathrm{kPa}$. Cada imagem se refere aos bocais R03, R08 e V03, respectivamente.

Figura 5.40 - Ensaios com as condições de injeção de $P_{0}=250 \mathrm{kPa}, T_{0}=120^{\circ} \mathrm{C}$ e $P_{\infty}=0,420,07 \mathrm{kPa}$. Cada imagem se refere aos bocais R03, R08 e V03, respectivamente.

Figura 5.41 - Comparativo das máximas vazões superficiais alcançadas pelos bocais com relação à seção de saída. Os símbolos da legenda representam a pressão de injeção e a cor do símbolo se refere ao bocal experimentado.

Figura 5.42 - Comparativo das máximas razões de pressão de saturação e da câmara $\left(R_{\mathrm{P}}\right)$ para alcançar a máxima vazão. Os símbolos da legenda representam a pressão de injeção e a cor do símbolo se refere ao bocal experimentado.

Figura 5.43 - Comparativo do grau de metaestabilidade em função da pressão de injeção. Os símbolos da legenda representam a pressão de injeção e a cor do símbolo se refere ao bocal experimentado.

Figura 5.44 - Comparativo do comprimento de extinção do núcleo líquido 
normalizado em função da razão da pressão de saturação e de injeção. Uma curva de ajuste para estes dados pode ser escrita através da seguinte equação: $L_{E} / D_{b}=13,643 .\left(P_{\text {sat }} / P_{0}\right)^{-0,607}$. O tracejado se refere ao limite inferior e superior de erro desta curva em função da precisão na medição deste comprimento que é de 3,3 para o bocal de $0,30 \mathrm{~mm}$ $\left(\Delta L_{E} / D_{b}= \pm 1,0 / D_{b}\right)$

Figura 5.45 - Imagens do jato do ensaio V03\1329m10, com condições de injeção de $121,7 \mathrm{kPa}, 56,5{ }^{\circ} \mathrm{C}$, pressão da câmara de 0,35 kPa e velocidade de $17,2 \mathrm{~m} / \mathrm{s}$. Nela existe a indicação do atraso da onda de evaporação, pela "Iluminação por detrás”.

Figura 5.46 - Imagens do jato do ensaio V03\1349500, com condições de injeção de $249,9 \mathrm{kPa}, 74,8{ }^{\circ} \mathrm{C}$, pressão da câmara de $1,70 \mathrm{kPa}$ e velocidade de $24,9 \mathrm{~m} / \mathrm{s}$. Nela existe a indicação do atraso da onda de evaporação, pela "Iluminação por detrás".

Figura 5.47 - Imagens do jato do ensaio V03 $2393 \mathrm{~m} 10$, com condições de injeção de $250,4 \mathrm{kPa}, 120,1{ }^{\circ} \mathrm{C}$, pressão da câmara de $0,60 \mathrm{kPa}$ e velocidade de $23,8 \mathrm{~m} / \mathrm{s}$. Nela não existe um atraso da onda de evaporação perceptível.

Figura 5.48 - O comprimento representativo, $r_{1}$ (a primeira imagem) e $r_{2}$ dos bocais estudados são comparados com os ensaios cuja pressão e temperatura de injeção são de $125 \mathrm{kPa}$ e $56^{\circ} \mathrm{C}$.

Figura 5.49 - O comprimento representativo, $r_{1}$ (a primeira imagem) e $r_{2}$ dos bocais estudados são comparados com os ensaios cuja pressão e temperatura de injeção são de $125 \mathrm{kPa}$ e $95^{\circ} \mathrm{C}$.

Figura 5.50 - O comprimento representativo, $r_{1}$ (a primeira imagem) e $r_{2}$ dos bocais estudados são comparados com os ensaios cuja pressão e temperatura de injeção são de $250 \mathrm{kPa}$ e $95^{\circ} \mathrm{C}$.

Figura 5.51 - O comprimento representativo, $r_{1}$ (a primeira imagem) e $r_{2}$ dos bocais estudados são comparados com os ensaios cuja pressão e temperatura de injeção são de $250 \mathrm{kPa}$ e $120^{\circ} \mathrm{C}$.

Figura 5.52 - A razão do comprimento característico $r_{1}$ pelo raio do bocal $r_{\mathrm{b}} \mathrm{em}$ função da razão da pressão de saturação e da câmara corrigido pelo fator de proporcionalidade do comprimento do núcleo líquido. As linhas tracejadas são os limites da correlação $\left(r_{1} / r_{\mathrm{b}} \quad 50 \%\right)$. No trabalho de Crist e outros (1966), para um escoamento de compressíveis de diversos gases foi obtida a correlação de $r_{1} / r_{b} \cong 0,373 *\left(P_{0} / P_{\infty}\right)^{0,523}$ enquanto a curva que melhor se ajusta para estes resultados é igual a $r_{1} / r_{b} \cong 2,152 *\left[\left(P_{\text {sat }} / P_{\infty}\right) \cdot\left(P_{0} / P_{s a t}\right)^{0,6}\right]^{0,521}$

Figura 5.53 - Imagens do jato do ensaio V03\1329500 com pressão e temperatura de injeção de $123,5 \mathrm{kPa}$ e $56,7^{\circ} \mathrm{C}$ e, pressão da câmara de $0,27 \mathrm{kPa}$. A primeira é a imagem original obtida pelo "Schlieren" e a segunda foi obtida pela "iluminação pro detrás”. A última imagem é 
filtrada matematicamente da primeira e mostra a onda de choque a distância de $0,8 \mathrm{~mm}$ da saída do bocal.

Figura 5.54 - Imagens do jato do ensaio V03\2368500 com pressão e temperatura de injeção de $250,8 \mathrm{kPa}$ e $94,4{ }^{\circ} \mathrm{C}$ e, pressão da câmara de $0,34 \mathrm{kPa}$. A primeira é a imagem original obtida pelo “Schlieren”, a segunda e a terceira foram filtradas desta original. A última imagem foi obtida pela "iluminação pro detrás".

Figura 5.55 - Imagens do jato do ensaio V03\2393m10 com pressão e temperatura de injeção de 255,4 kPa e $120,6{ }^{\circ} \mathrm{C}$ e, pressão da câmara de $0,53 \mathrm{kPa}$. A primeira é a imagem original obtida pelo "Schlieren” e tanto a segunda como a terceira foram filtradas desta original. A última imagem foi obtida pela "iluminação pro detrás".

Figura 5.56 - Imagens dos jatos dos ensaios V03\1368100 e V03\1368500, respectivamente. Suas pressões de injeção eram de 123,2 e 123,7 kPa, temperatura de $94,4{ }^{\circ} \mathrm{C}$ e $95,0^{\circ} \mathrm{C}$ e, pressões da câmara de 0,86 e 0,23 $\mathrm{kPa}$. As pressões metaestáveis calculadas eram de 23,2 e 22,5 kPa e a incerteza associada é de $5 \mathrm{kPa}$.

Figura 6.1 - Comparação do comprimento do núcleo de líquido experimental e o calculado do bocal R03.

Figura 6.2 - Comparação do ângulo de giro experimental e o calculado do bocal R03.

Figura 6.3 - Exemplo de medição do ângulo de giro do jato do ensaio 7349500. Este ângulo corresponde à tangente da trajetória do fluido quando parte da onda de evaporação. Devido à técnica de "iluminação por detrás”, este procedimento envolve um erro demasiado.

Figura 6.4 - Comparação do comprimento do núcleo de líquido experimental e o calculado do bocal R08.

Figura 6.5 - Comparação do comprimento do núcleo de líquido experimental e o calculado do bocal V03.

Figura 6.6 - Gráfico que mostra as condições de injeção dos ensaios feitos para o bocal de aço com 0,3 mm de diâmetro (R03) e a pressão metaestável alcançada pelo ensaio. Nele são indicados os ensaios com atraso da onda de evaporação.

Figura 6.7 - Ilustração esquemática da geometria das ondas de choque que ocorrem próxima da saída do bocal. A parte escurecida da expansão do esquema, entre a onda de choque oblíqua e o núcleo de líquido, pode apresentar ondas de choque reflexivas e oblíquas, internamente a esta região. O diâmetro do núcleo de líquido também pode aumentar após a saída do bocal.

Figura 6.8 - Ilustração esquemática da geometria das ondas de choque que ocorrem próxima da saída para o bocal de vidro, semelhante ao explicado na Fig 6.7. 


\section{LISTA DE TABELAS}

Tabela 2.1 - Tabela comparativa das propriedades termodinâmicas de alguns líquidos.

Tabela 2.2 - Valores da tensão superficial em função da temperatura. Os valores para as temperaturas de 20 e $90{ }^{\circ} \mathrm{C}$ são obtidos por Vargaftik (1996), e para temperaturas acima, são estimados através de polinômio.

Tabela 2.3 - Propriedades termodinâmicas dos fluidos para temperatura inicial de $40{ }^{\circ} \mathrm{C}$ e para determinação da constante B a $20{ }^{\circ} \mathrm{C}$ através da Eq. (2.14).

Tabela 2.4 - Comparação dos resultados obtidos através de uma solução numérica e analítica para a razão das pressões de uma onda de evaporação em função do grau de metaestabilidade, $\Pi$.

Tabela 3.1 - Incertezas relativas às medições realizadas.

Tabela 5.1 - Em função das categorias das condições de injeção, Pinj e Tinj, respectivamente, são mostrados a média da pressão de saturação, a pressão metaestável média das categorias de ensaio e seu desvio, vazão superficial mássica e as razões entre a pressão de saturação e a pressão de injeção, assim como, a pressão de saturação e a pressão metaestável do líquido. Finalmente, é apresentado o grau de metaestabilidade médio alcançado em cada série de experimentos. $\mathrm{O}$ desvio de $2 \sigma_{\mathrm{P} 1 \mathrm{~m}}$ é duas vezes o desvio padrão da amostra coletada de cada categoria de ensaio.

Tabela 5.2 - Determinação dos dados médios obtidos, sob a condição de máxima vazão, exemplificada para a categoria com $\mathrm{P}_{\text {inj }}=750 \mathrm{kPa}$ e $\mathrm{T}_{\text {inj }}=162^{\circ} \mathrm{C}$.

Tabela 5.3 - Em função das categorias das condições de injeção, Pinj e Tinj, estão os valores do desvio da amostra e das incertezas de P1m (UP1). Esta última incerteza depende da vazão medida e é calculada conforme deduzida no Apêndice I.

Tabela 5.4 - Representação do comprimento do núcleo líquido, LE , para a série de ensaios com pressão e temperatura de injeção de $500 \mathrm{kPa}$ e $56{ }^{\circ} \mathrm{C}$, respectivamente.

Tabela 5.5 - Alguns ensaios de Athans (1995) com um bocal de 0,864 mm de diâmetro utilizando iso-octano.

Tabela 5.6 - Ensaios de Athans (1995) com dimensões da onda de choque para o bocal de 0,864 mm de diâmetro utilizando iso-octano.

Tabela 6.1 - Resultados experimentais médios obtidos pelas séries de ensaios do bocal R03.

Tabela 6.2 - Resultados calculados das séries de ensaios do bocal R03 a jusante da onda de evaporação. 
Tabela 6.3 - Resultados experimentais médios obtidos pelas séries de ensaios do bocal R08 (de aço com 0,8 mm de diâmetro) e bocal V03 (de vidro com diâmetro de 0,35 mm).

Tabela 6.4 - Resultados calculados, a jusante da onda de evaporação, das séries de ensaios do bocal R08 (de aço com 0,8 mm de diâmetro) e bocal V03 (de vidro com diâmetro de 0,35 mm).

Tabela B.1 - Tabela com os ensaios da série "RUN1" (bocal rugoso com 0,3 mm de diâmetro).

Tabela B.2 - Tabela com os ensaios da série "RUN2" (bocal rugoso com 0,3 mm de diâmetro).

Tabela B.3 - Tabela com os ensaios da série "RUN3" (bocal rugoso com 0,3 mm de diâmetro).

Tabela B.4 - Relação do comprimento do núcleo líquido de cada ensaio (bocal rugoso com 0,3 mm de diâmetro).

Tabela B.5 - Relação das dimensões da onda de choque formada como o raio, r1 e a distancia axial, r2 (bocal rugoso com 0,3 mm de diâmetro).

Tabela C.1 - Tabela com os ensaios da série "R08” (bocal rugoso com 0,8 mm de diâmetro).

Tabela C.2 - Relação do comprimento do núcleo líquido de cada ensaio - Série R08 (bocal rugoso com 0,8 mm de diâmetro).

Tabela C.3 - Relação das dimensões da onda de choque formada como o raio, r1 e a distancia axial, r2 (bocal rugoso com 0,8 mm de diâmetro).

Tabela C.4 - Tabela com os ensaios da série "V03" (bocal de vidro com 0,35 mm de diâmetro).

Tabela C.5 - Relação do comprimento do núcleo líquido de cada ensaio - Série V03 (bocal de vidro com 0,35 mm de diâmetro).

Tabela C.6 - Relação das dimensões da onda de choque formada como o raio, r1 e a distancia axial, r2 (bocal de vidro com 0,35 mm de diâmetro). 


\section{LISTA DE SÍMBOLOS}

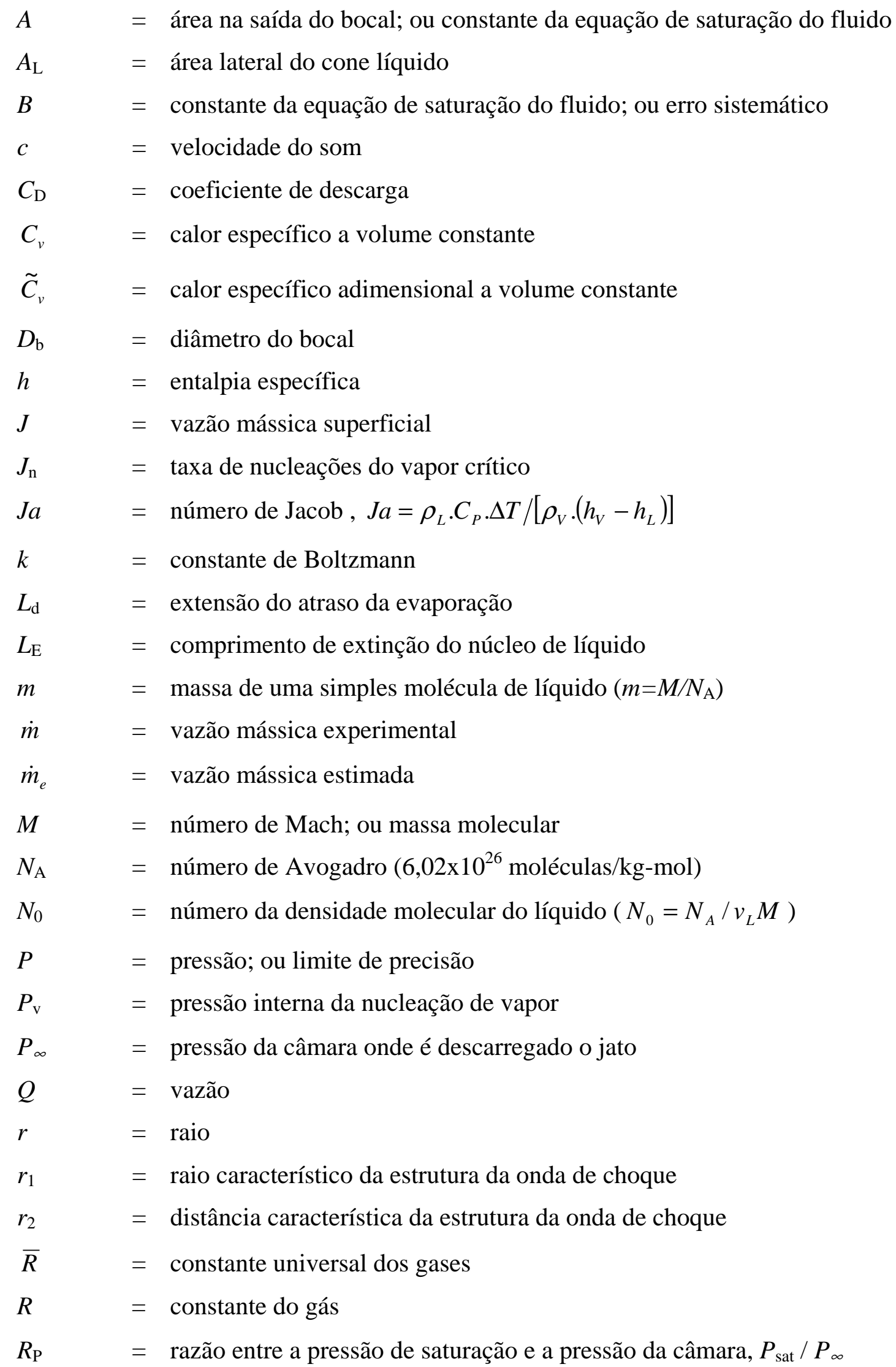




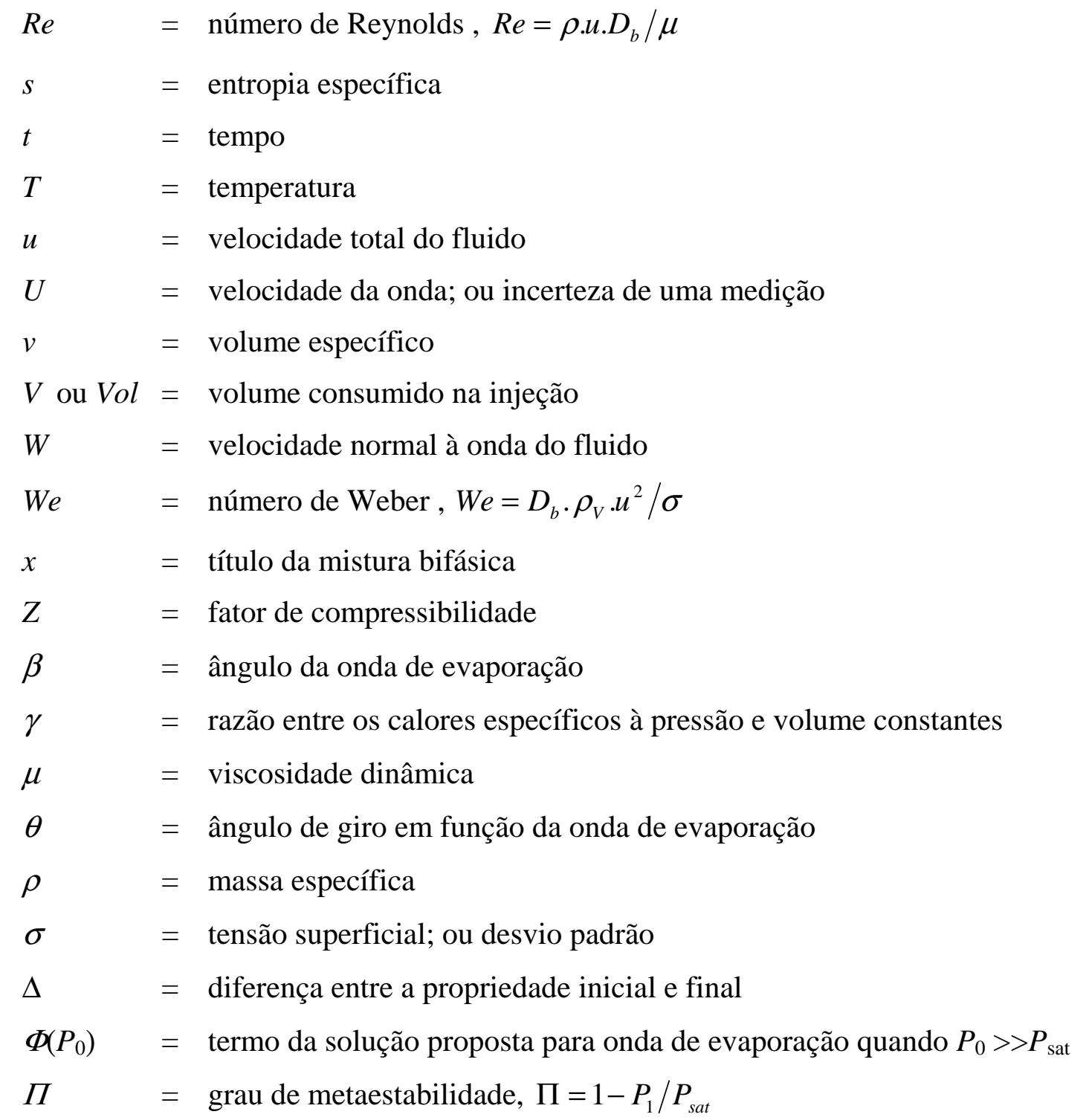

\section{Subscritos:}

$0=$ estado inicial ou de injeção

1 = à montante da onda de evaporação

2 = à jusante da onda de evaporação

3 = à montante da onda de choque

4 = à jusante da onda de choque

$\mathrm{b}=$ bocal

$\mathrm{C}=$ ponto crítico

CJ = condição de Chapman-Jouguet

$\mathrm{L}=$ líquido 
$\mathrm{m}=$ média

$\mathrm{LV}=$ diferença entre os valores da propriedade no estado vapor e no líquido

sat $=$ estado de saturação 


\section{INTRODUÇÃo}

A motivação principal dos estudos de jatos evaporativos foi a análise dos fenômenos de mudança de fase que ocorrem sob determinadas circunstâncias em dispositivos e equipamentos térmicos ainda não completamente elucidados. Para isso, utilizou-se nos experimentos o hidrocarboneto iso-octano $\left(\mathrm{C}_{8} \mathrm{H}_{18}\right)$, também chamado de 2,2,4 tri-metil-pentano. Um experimento típico consistia em injetar uma amostra de líquido através de um bocal cilíndrico-convergente em uma câmara de baixa pressão cujo valor era menor que a pressão de saturação do líquido à temperatura de injeção. Como conseqüência, se estabelece uma condição de mudança de fase baseada no rebaixamento da pressão, o que é conhecido na literatura inglesa como "flashing".

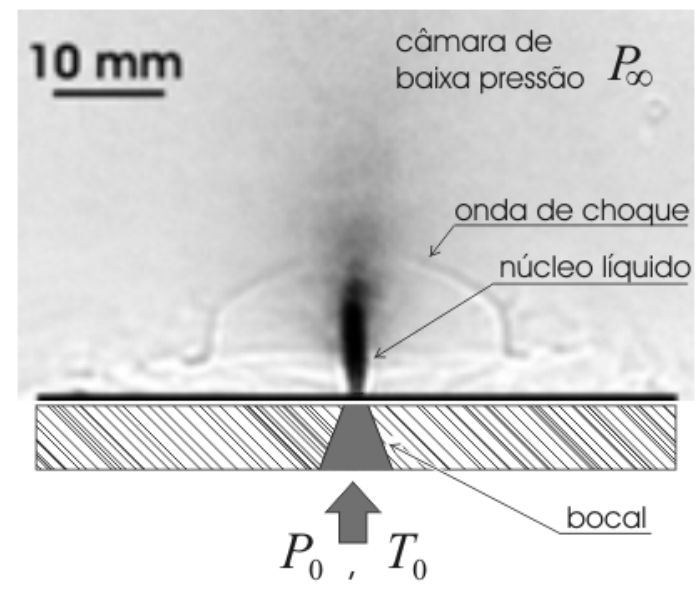

Figura 1.1 - A imagem se refere a um jato de iso-octano com pressão $\left(P_{0}\right)$ e temperatura de injeção $\left(T_{0}\right)$ de $250 \mathrm{kPa}$ e $56^{\circ} \mathrm{C}$, respectivamente. A pressão de saturação é 300 vezes maior que a pressão da câmara $\left(P_{\infty}\right)$ que é de $0,09 \mathrm{kPa}$.

Os experimentos foram documentados através de técnicas fotográficas especiais descritas adiante que permitiram registrar a presença de ondas de choque. A Fig. 1.1 ilustra a imagem típica de um jato inicialmente a uma pressão de injeção $\left(P_{0}\right)$ e temperatura de injeção $\left(T_{0}\right)$. Nesta figura são ilustradas as principais características dos jatos, como a formação de um núcleo de líquido junto à saída do bocal e uma estrutura de choque envolvendo aquele núcleo de líquido. Nela, estão ainda indicadas 
as condições de injeção, isto é a pressão $\left(P_{0}\right)$ e a temperatura $\left(T_{0}\right)$, e a pressão da câmara onde é descarregado o jato $\left(P_{\infty}\right)$ cujo valor é menor que a pressão de saturação do líquido $\left(P_{\text {sat }}\right)$ à temperatura de injeção. Essa primeira análise do fenômeno indica a complexidade do mesmo. A presença de ondas de choque indica que fenômenos compressíveis e supersônicos se fazem presentes. Interessante, também é notar que esses fenômenos estão localizados junto à saída do bocal onde existe uma grande quantidade de gotículas de líquido escoando em alta velocidade. Isto dificulta sobremaneira o registro fotográfico do fenômeno, o que fez com que esse comportamento bifásico-compressível passasse desapercebido por muito tempo, exceto para um ou outro pesquisador.

\subsection{Motivação}

A evaporação de jatos está ligada às aplicações de combustão de líquido em motores de combustão interna, sistemas de propulsão de aeronaves, motores de propulsão de foguetes e incineradores de fornos (Ramamurthi e Nandakumar, 1994, Faeth e outros, 1995, Lin e Rietz, 1998 e Lasheras e Hopfinger, 2000). Nestes equipamentos, comumente o fluido absorve o calor da câmara de combustão tornando a pressão de saturação maior que a pressão da câmara onde são descarregados. Isto pode ser vantajoso quando a injeção seguida da atomização, em virtude da evaporação, melhora a mistura combustível-comburente trazendo vantagens na eficiência da queima e, muitas vezes, proporcionando uma diminuição na emissão de poluentes. Com este mesmo objetivo, Oza e Sinnamon (1983) e Oza (1984) realizaram estudos sobre o pré-aquecimento do combustível empregando os mesmos injetores eletromagnéticos que são utilizados em motores de combustão interna. Eles verificaram que elevadas temperaturas de injeção promoviam um maior espalhamento do jato por causa da evaporação, conforme os seus registros fotográficos

Conhecido como crioterapia, na medicina, jatos de nitrogênio líquido, do tipo "spray", são empregados no tratamento de câncer de pele entre outras lesões. O nitrogênio líquido oferece a vantagem de poder ser estocado e, quando aplicado, permite uma elevada taxa de transferência de calor em regiões bem definidas, além 
de não reagir quimicamente na grande maioria dos casos. Na área biofarmacêutica, a estabilidade física e química de compostos orgânicos é um problema e, como solução, técnicas criogênicas são empregadas para o congelamento e conservação destas substâncias. Conhecer o comportamento da evaporação do nitrogênio líquido nestas aplicações criogênicas pode melhorar a eficiência do procedimento. Como exemplo, Yu e outros (2004) estudaram o congelamento de micropartículas nanoestruturadas de proteínas em nitrogênio líquido. Eles utilizaram micro-bocais para injetar a proteína no próprio nitrogênio líquido.

Micro-bocais são empregados em impressoras do tipo jato de tinta. $\mathrm{Na}$ pesquisa destes micro-dispositivos, são feitos estudos sobre a formação da bolha na câmara térmica que expulsa a quantidade desejada de líquido no jato. Este tipo de mecanismo produz uma ebulição controlada em um intervalo de $10 \mu$ s permitindo uma freqüência de injeção de $20 \mathrm{kHz}$ (Okuyama e outros, 2004). Dentro desta linha de micro-dispositivos, existem micro-bombas que também possuem um princípio de funcionamento semelhante (Khoo e outros, 2005). São dispositivos que realizam uma evaporação quase instantânea, semelhante à rápida evaporação que é observada nos jatos aqui estudados.

$\mathrm{Na}$ industria petroquímica, sistemas de injeção de petróleo pré-aquecido são empregados para separar os diferentes compostos em tanques. Gases nobres misturados são separados e as substâncias líquidas mais voláteis tendem a evaporar (Pinti e Marty, 1998). Os outros compostos decantam, pois a pressão de saturação é superior à pressão do tanque. Neste caso, o entendimento da evaporação dos compostos mais leves pode melhorar o rendimento deste sistema. Seguindo este mesmo princípio de funcionamento, o óleo cru proveniente do petróleo, é aquecido e injetado em tanques, porém sob a intensa temperatura do meio onde foi injetado, moléculas mais complexas de hidrocarbonetos se "quebram", formando hidrocarbonetos com menor número de átomos de carbono, ou seja, mais voláteis que podem ser separados na parte superior do tanque onde ocorre este processo. Segundo Wang e outros (2004), a eficiência deste processo, conhecido como craqueamento cujo objetivo é obter gasolina entre outros derivados, depende da atomização e mistura do jato evaporativo do óleo aquecido, entre outros fatores.

Catastróficos desastres, conhecidos como BLEVE ("Boiling Liquid 
Expanding Vapour Explosion", ou explosão decorrente da expansão do vapor evaporado do líquido) podem ocorrer tanto no armazenamento de GLP (van den Berg e outros, 2004), quanto em outros processos industriais (Ogle e outros, 2004). O surgimento de uma onda de choque que se propaga, aumentando drasticamente a pressão, está relacionada à evaporação repentina de grande quantidade de líquido. Isto se deve ao fato de que a evaporação do líquido multiplica o volume do fluido na ordem de dezenas e até centenas de vezes, de forma quase instantânea. Comenta Ogle e outros (2004) sobre um acidente que ocorreu em uma planta de produção de PVC (policloreto de vinila). Um dos tanques continha resíduo líquido do cloreto de vinila não polimerizado que evaporou rapidamente na operação de descarga do reator. Isto provocou a ruptura do tanque, seguida de um incêndio. Estudos de BLEVE não envolvem apenas a evaporação por causa da despressurização, neste campo existem fatos sobre a explosão de tanque de armazenamento em virtude do aquecimento imprevisto do mesmo (Stawczyk, 2003). No empenho de evitar ou minimizar os prejuízos, estudos sobre o escoamento do fluido que evapora em válvulas de segurança e discos de ruptura são dedicados com a finalidade de melhor dimensionar o tamanho destes dispositivos para uma ocasião de pressão de trabalho além da projetada (Lenzing e outros, 1998, Attou e outros, 2000, Darby, 2004 e Leung, 2004).

Quando é necessário medir a vazão de líquidos na condição de saturação, pode haver imprecisão da medida. Tomando o exemplo de uma placa de orifício, o líquido pode passar pela restrição do dispositivo com uma pressão bem abaixo da pressão de saturação sem sofrer a mudança de fase, limitando a confiabilidade do procedimento (Benjamin e Miller, 1941). O contrário também ocorre, o líquido evapora na passagem do dispositivo não permitindo utilizar a hipótese de fluido incompressível. No caso da evaporação acontecer, quando tal consideração não foi feita no projeto, o fluxo através da placa de orifício poderá ser menor do que aquele dimensionado. Para estas ocasiões sujeitas à evaporação na passagem do fluido, a norma ISA-S75.01 (1995) recomenda a utilização de fatores de correção empíricos para o cálculo de dimensionamento das principais válvulas empregadas na indústria. Quando ocorre evaporação na válvula, freqüentemente o fenômeno de cavitação é encontrado, comprometendo a vida útil do dispositivo. A norma ISA-S75.01 (1995) 
cita que a cavitação acontece quando a pressão a jusante está próxima da saturação do líquido. Em virtude da dificuldade de visualizar a evaporação nestes dispositivos, obter o conhecimento sobre o mecanismo da evaporação nos jatos pode trazer conclusões sobre a decorrência destes fenômenos nestes dispositivos e determinar com melhor precisão a pressão de evaporação, abaixo da saturação. Complementando, a cavitação não é um mero fato no escoamento de líquido saturado em dispositivos. Estudos são feitos com injetores de diesel, cuja pressão de injeção é bem maior que a pressão média de saturação, porém o transitório da abertura destes dispositivos proporcionam evaporação localizada nos dispositivos, promovendo a cavitação (Badock e outros, 1999 e Arcoumanis e outros, 2001).

Os jatos evaporativos aqui estudados simulam bem a evaporação em dispositivos de expansão empregados em ciclos de refrigeração. O refrigerante subresfriado passa pela válvula de expansão, ou pelo tubo de orifício, expandindo a jusante do mecanismo. Um estudo do escoamento na expansão do fluido pode beneficiar no projeto destes dispositivos, principalmente na questão do ruído que estes mecanismos geram em seu funcionamento (Simões-Moreira e Bullard, 2003).

Finalmente, o estudo do jato pode beneficiar no processo de dessalinização de água. O processo conhecido como, "Multi-stage flash", utilizado em plantas industriais com esta finalidade, possui bocais que injetam a água salgada quente em câmaras de baixa pressão dispostas seqüencialmente, proporcionando a evaporação e separação do vapor dessalinizado da água decantada com alta concentração de sal em cada estágio, ou câmara. Estudos deste processo são dedicados por Ferro e outros (2002) e Jernqvist e outros (2001), por exemplo.

\subsection{Revisão Bibliográfica}

\subsubsection{A Presença do Núcleo de Líquido}

Vieira (1999) testou jatos de querosene líquido. Os experimentos foram conduzidos com um jato de líquido produzido em bocais cônico-convergentes. A pressão do ambiente onde o líquido era descarregado estava abaixo de sua pressão de vapor da mistura, permitindo a mudança de fase líquido-vapor. A Fig. 1.2 mostra 
uma seqüência de imagens de jatos evaporativos que aqui serão discutidos. Em todos os casos, os jatos a uma pressão de injeção de $600 \mathrm{kPa}$ eram descarregados em uma câmara de baixa pressão, da ordem de 1,5 kPa. Quatro diferentes testes com diversas temperaturas de injeção foram testadas, proporcionando um aumento sucessivo da pressão média de saturação do líquido, dando origem à seqüência (a-d) de imagens da Fig. 1.2. Na primeira imagem, a evaporação não é perceptível, resultando em uma configuração contínua e retilínea do jato e, depois, com o aumento de temperatura, se verifica que a taxa de evaporação aumenta significativamente, diminuindo a porção líquida do jato, podendo, com isto, haver o surgimento de uma estrutura de onda de choque, como pode ser visto na Figs. 1.2c e 1.2d.

a)

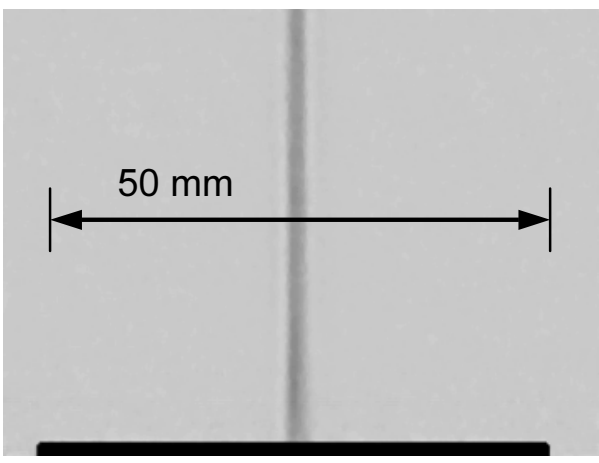

b)

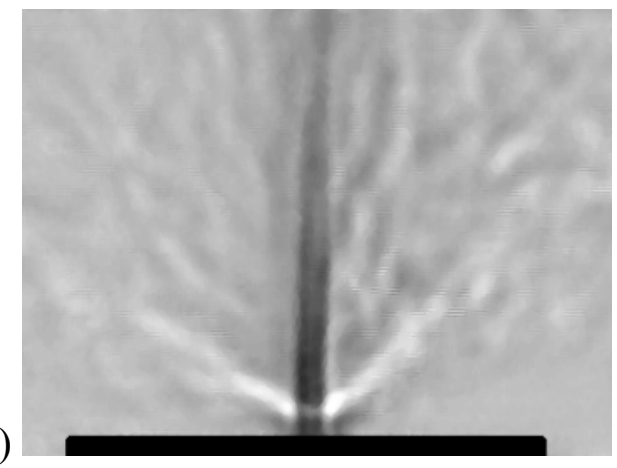

c)

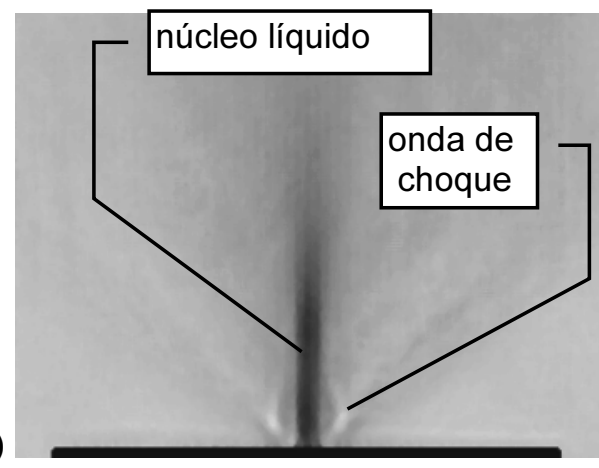

d)

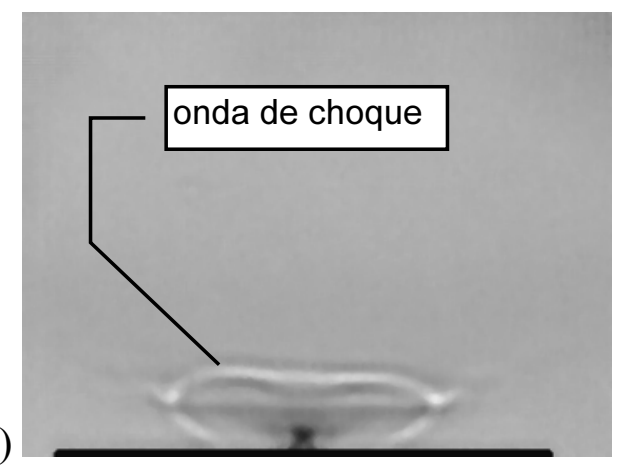

Figura 1.2 - Seqüência de imagens de jatos evaporativos de querosene com pressão de injeção de $600 \mathrm{kPa}$, e pressão da câmara igual a $1,5 \mathrm{kPa}$. A temperatura de injeção é de $38,95,120$ e $260^{\circ} \mathrm{C}$, respectivamente (Vieira, 1999).

O trabalho de Ramamurthi e Nandakumar (1994) ilustra o fenômeno de evaporação do jato pelo mero esquema da Fig. 1.3. Em conformidade, este esquema em muito se assemelha com as imagens das Figs. 1.2b e 1.2c. A motivação deles era associada ao processo de atomização na injeção de propelente líquido em câmaras de combustão de foguetes. Outros autores que também tinham o mesmo objetivo são 
Faeth e outros (1995), Lin e Rietz (1998) e Lasheras e Hopfinger (2000). Todos eles realizaram ensaios com água, sendo que, Faeth e outros ilustram a evolução da formação do núcleo de líquido com as etapas da atomização em função da velocidade do jato. É interessante que todos demonstram que o mecanismo de fragmentação do jato se inicia na periferia da porção líquida, originando um formato cônico.

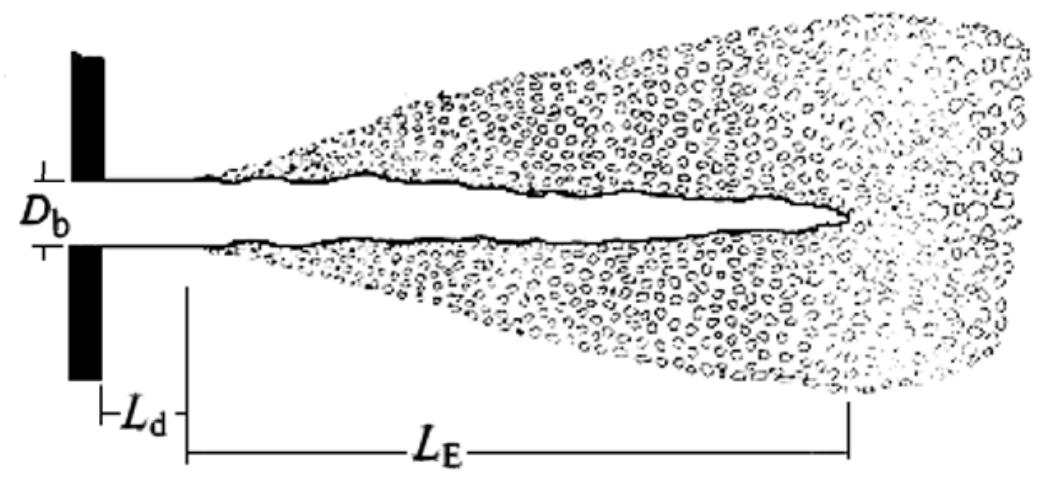

Figura 1.3 - Exemplo de jato líquido que sofre uma desintegração, tomando um formato cônico. Nesta representação $D_{\mathrm{b}}$ é o diâmetro do bocal, $L_{\mathrm{d}}$ é o atraso que ocorre na fragmentação do núcleo líquido e $L_{\mathrm{E}}$ é o comprimento do núcleo líquido (Ramamurthi e Nandakumar, 1994).

Nos ensaios de Athans (1994), realizados com iso-octano, é mostrado um núcleo de líquido que se estende na linha axial do jato. Uma das técnicas foi a iluminação por "laser sheet", ou seja, uma lâmina de laser que traspassa pela seção central do jato lateralmente, tomando o observador como referência. Uma fotografia típica está indicada na Fig. 1.4. Mesmo com uma temperatura de injeção próxima ao ponto crítico, é possível ver esta estrutura bem definida com boa qualidade. Ao redor desta estrutura, devido à evaporação, as gotículas desprendidas assumem um escoamento quase perpendicular em relação ao eixo axial do jato. 


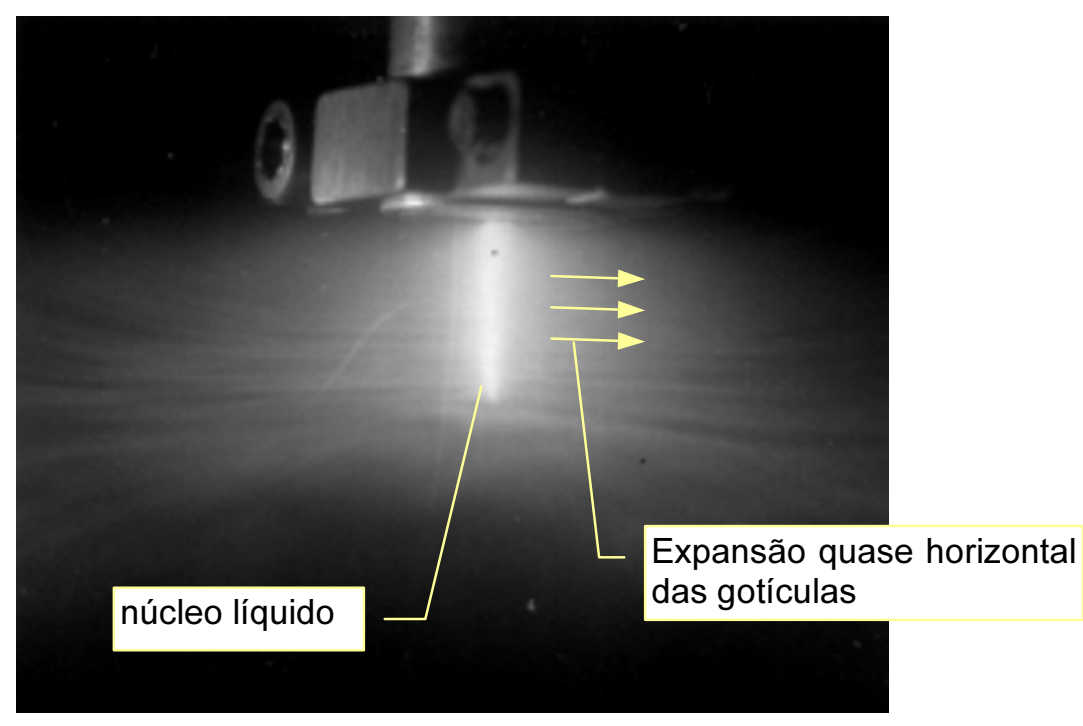

Figura 1.4 - Imagem de jato de iso-octano com temperatura e pressão de injeção de $223{ }^{\circ} \mathrm{C}$ e $2068 \mathrm{kPa}$, respectivamente, obtidas pelo método de "laser sheet" (Athans, 1994).

É importante também saber se existe repetibilidade nesta estrutura líquida, verificando se não existem variações do comprimento axial do núcleo de líquido ou do perfil axissimétrico, durante um ensaio que se mantém em regime permanente. Vieira (1999) observou esta regularidade, repetindo vários experimentos de mesmas condições iniciais. Um ensaio típico que possui duas imagens adquiridas em um intervalo de $1 s$ de um único jato está indicado na Fig. 1.5. Juntamente com a análise dos outros ensaios, foi comprovado que o núcleo de líquido assumiu uma regularidade dimensional durante toda a injeção.

a)

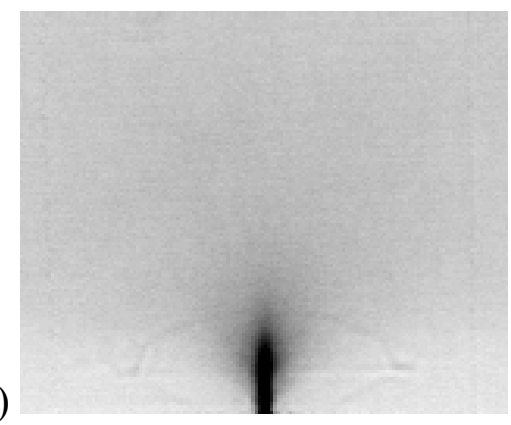

b)

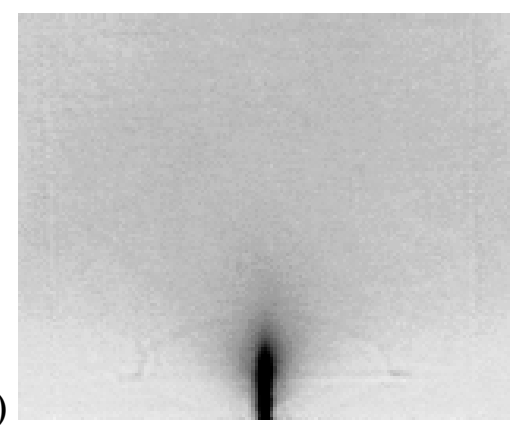

Figura 1.5 - As fotografias representam as imagens de uma única injeção de querosene com pressão inicial de $500 \mathrm{kPa}$ e pressão da câmara de $0,6 \mathrm{kPa}$ e temperatura de injeção de $150{ }^{\circ} \mathrm{C}$, obtidas pelo método "Schlieren". A primeira foi obtida $1 s$ após a abertura do injetor e, depois de $1 s$, a segunda foi adquirida (Vieira, 1999). 
A questão da extensão dimensional da porção líquida foi o principal tema abordado por Lienhard e Day (1970) que realizaram ensaios com água e nitrogênio líquido. Eles verificaram que este parâmetro está relacionado com o número de Reynolds e o número de Weber. As imagens de Kitamura e outros (1986) muito se assemelham com as imagens de Lienhard e Day (1970), mostradas na Fig. 1.6. Os autores (Kitamura e outros, 1986) versam que o fenômeno está associado ao número de Jacob, ao número de Weber e a razão entre os volumes específicos fluido do ambiente e do líquido.

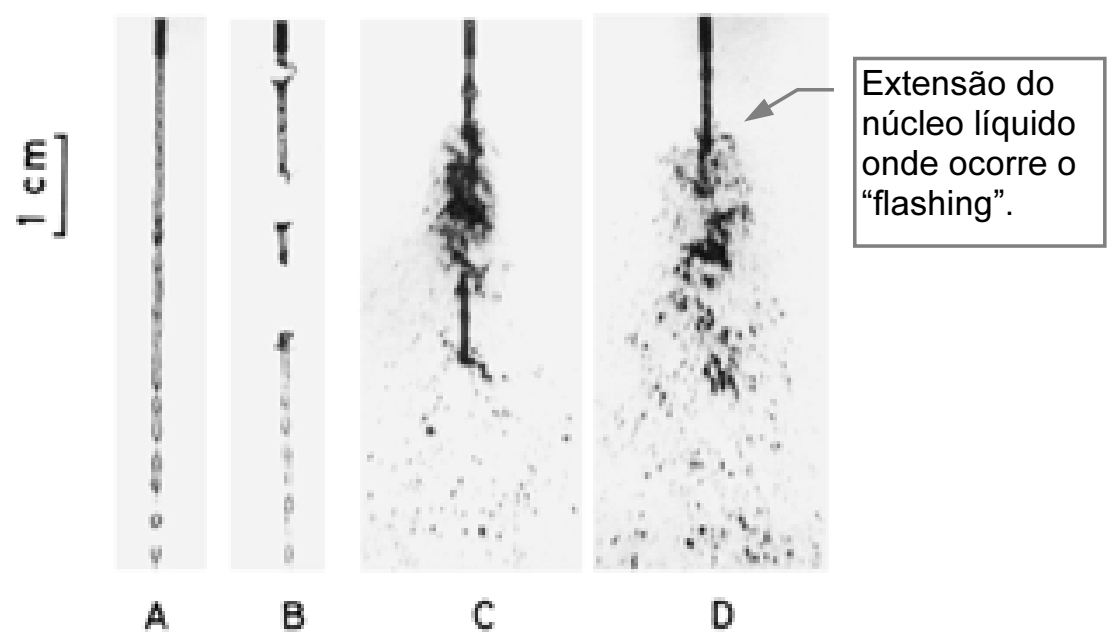

Figura 1.6 - Imagens obtidas por Kitamura e outros (1986) que ilustram uma seqüência de jatos de água que foram submetidos a uma pressão da câmara menor que a pressão de vapor, de forma progressiva. Isto proporcionou o aumento da evaporação, por conseqüência, da pulverização. A velocidade do inicial do jato, a pressão de injeção, e diferença entre a temperatura de injeção do fluido e a temperatura de saturação em função da pressão da câmara, são respectivamente: a) $8,5 \mathrm{~m} / \mathrm{s}, 760 \mathrm{mmHg}$, valor negativo ; b) $8,65 \mathrm{~m} / \mathrm{s}, 22 \mathrm{mmHg}$, $28,5{ }^{\circ} \mathrm{C}$; c) $8,22 \mathrm{~m} / \mathrm{s}, 23 \mathrm{mmHg}, 45,4{ }^{\circ} \mathrm{C}$; d) $8,22 \mathrm{~m} / \mathrm{s}, 20 \mathrm{mmHg}, 48{ }^{\circ} \mathrm{C}$.

Wildgen e Straub (1989), da mesma forma que Lienhard e Day (1970) e, Kitamura (1986) e outros, identificaram formas de nucleações que acontecem no núcleo de líquido em jatos evaporativos. Eles observaram jatos que apresentavam uma pulverização ao redor de um cone líquido proporcionando uma configuração similar ao observado por Ramamurthi e Nandakumar (1994), Fig. 1.3, e jatos que apresentavam descontinuidade do filete líquido em pontos discretos (Fig. 1.6b). Eles atribuem esta diferença de configuração à origem da ocorrência da nucleação, ou 
seja, a nucleação poderia iniciar na parede do bocal ou pelas partículas diluídas no fluido ou na superfície do jato. Se a nucleação heterogênea ocorrer na parede do bocal, ou devido às partículas suspensas no líquido, haverá uma freqüência de bolhas que levará a ocorrência da quebra do filete líquido, conforme visto na Fig. 1.6b. O surgimento destas bolhas somente teria início imediato na região interna ao bocal, se a causa da nucleação fosse a existência de particulados. No entanto, se o jato está submetido a altas pressões e altas temperaturas de injeção, a configuração se aproxima daquela vista na Fig. 1.3. Neste caso, pode haver um atraso no surgimento da bolha, após a saída do bocal. Uma síntese de resultados do estudo é visto no gráfico mostrado na Fig. 1.7. Nele, existem os tipos de evaporação que os jatos estão sujeitos em função da pressão e temperatura de injeção. $\mathrm{O}$ jato é descarregado na atmosfera.

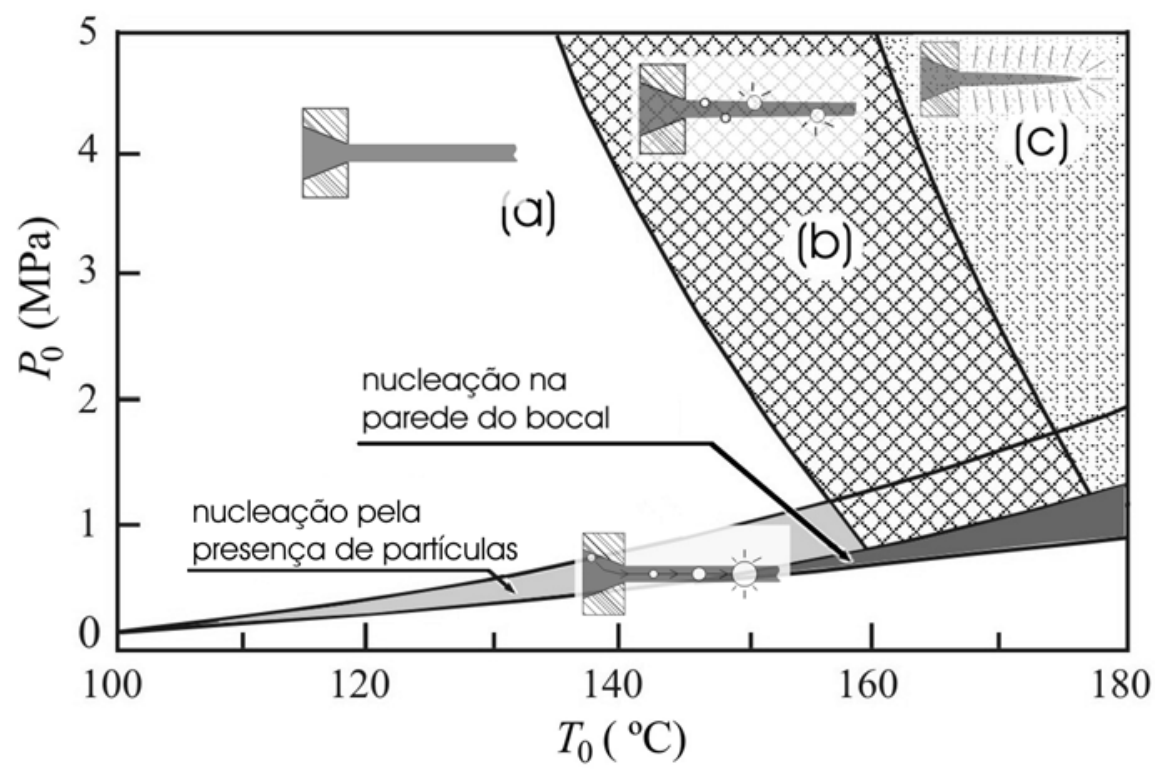

Figura 1.7 - Tipos de evaporação do jato de água descarregado na atmosfera emergente de um bocal com diâmetro de $0,5 \mathrm{~mm}$. Suas características estão em função da pressão e temperatura de injeção. Na região "a" não existe nucleação. Na região "b", a nucleação está na superfície do jato. Na região "c", o jato é totalmente pulverizado com a presença do núcleo de líquido. Nucleações provenientes da parede interna do bocal ou pela presença de partículas estão na região inferior do gráfico e tem a mesma configuração de jato (em destaque). 


\subsubsection{A Condição de Líquido Metaestável}

Também é comum que estes jatos evaporativos estejam associados ao fenômeno de metaestabilidade, ou seja, o líquido pode estar submetido a uma pressão abaixo de sua pressão de saturação sem que o mesmo mude para o estado de vapor. Quando o líquido assume esta condição, é dito que ele está superaquecido ou metaestável. Neste caso, é importante destacar este fenômeno e as conseqüências desta evaporação em líquidos metaestáveis, que possui características diferentes da evaporação comum. A energia interna acumulada durante o processo de metaestabilidade pode levar o líquido até a uma evaporação muito rápida, ou até mesmo explosiva sob determinadas situações. Reid (1976) cita que, longe de ser uma curiosidade experimental, a possibilidade de acidentes no meio industrial é muito grande. Um exemplo da potencialidade de acidentes está na manipulação de hidrocarbonetos leves, como o propano, cuja temperatura de ebulição é $-42{ }^{\circ} \mathrm{C}$, à pressão atmosférica. Sob determinadas condições, esta substância pode atingir uma temperatura de até $53{ }^{\circ} \mathrm{C}$, à pressão atmosférica sem sofrer a vaporização. Isto se pontos de nucleação de vapor forem inibidos. Considerando agora o seguinte, se o propano se misturar acidentalmente com água, que esteja em uma faixa de temperatura de 55 a $71{ }^{\circ} \mathrm{C}$, a evaporação deste hidrocarboneto se tornará explosiva. Esse tipo de fenômeno também foi constatado em outros hidrocarbonetos leves.

Assim como Lienhard e Day (1970), os ensaios de Kitamura e outros (1986) já associam o fenômeno da metaestabilidade no líquido injetado à queda repentina de pressão neste processo. A Fig. 1.6 ilustrou um jato que sofre a desintegração de seu filete líquido (caso d) em função da energia acumulada no processo de superaquecimento do líquido. Estes colocam em destaque esta energia interna armazenada pelo líquido durante o processo de superaquecimento representado pelo número de Jacob e associam ao número de Weber. Eles encontraram uma correlação para os ensaios. Aqueles pontos que estão acima da linha sólida sofreriam "flashing" (ou seja, tem a tendência de evaporar devido ao processo de metaestabilidade, como nos casos $b, c$ e $d$ da Fig. 1.6), como pode ser visto na Fig. 1.8. 


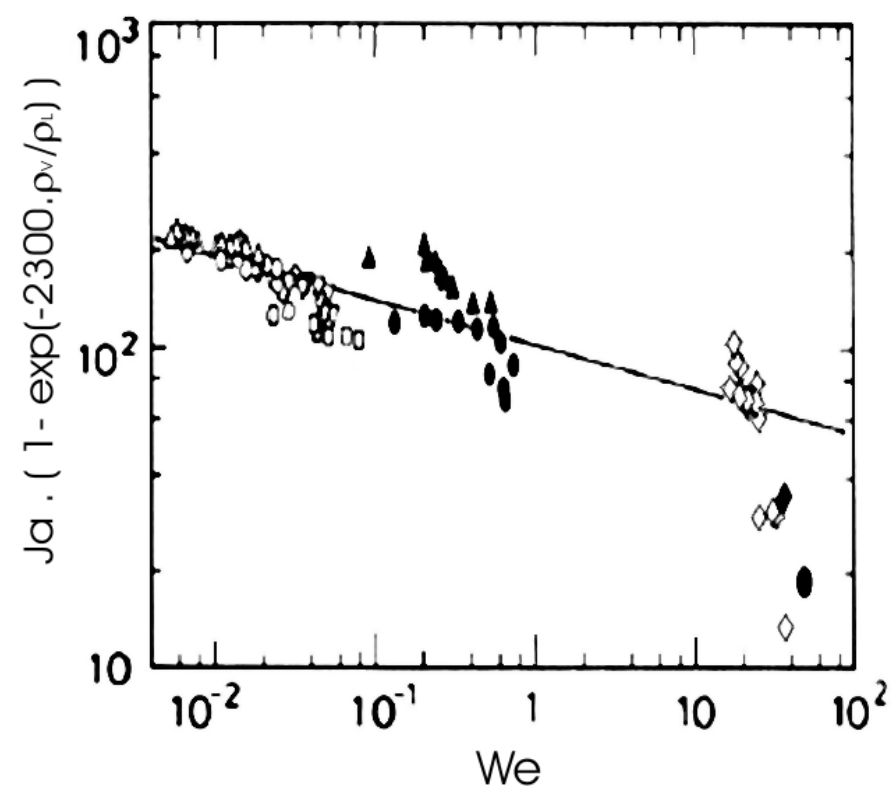

Figura 1.8- Através da correlação feita por Kitamura e outros (1986), foi verificado que sofrem "flashing" aqueles ensaios que se encontram acima da linha sólida. No gráfico, a abcissa é o número de Weber, $W e=\rho_{V} \cdot D_{b} \cdot u^{2} / \sigma \mathrm{e}$, na ordenada o número de Jacob, $J a=\rho_{L} \cdot C p_{L} \cdot \Delta T /\left(\rho_{V} . \Delta h_{L V}\right)$, sendo $\rho$ a massa específica do fluido, $u$ a velocidade do jato, $\sigma$ a tensão superficial do líquido, $C p_{\mathrm{L}}$ o calor específico do líquido, $\Delta h_{\mathrm{LV}}$ a entalpia de vaporização e, $\Delta T$ é a diferença entre a temperatura do líquido e a temperatura de saturação à pressão ambiente onde é descarregado o jato. Os subscritos "L" e "V" se referem às fases líquida e vapor.

\subsubsection{A Formação da Onda de Evaporação}

A evaporação de líquidos metaestáveis não acontece apenas de maneira explosiva, conforme foi visto pelo exemplo de Reid (1976). Simões-Moreira e outros (1993) indicam que os líquidos metaestáveis podem sofrer uma "evaporação rápida", em contraposição à "evaporação explosiva", que foi anteriormente exemplificada. No caso da evaporação rápida, a mudança de fase ocorre via uma onda de evaporação. Essa onda de evaporação avança sobre o líquido metaestável, formando uma descontinuidade ou frente de evaporação que transforma o líquido metaestável em uma mistura bifásica de alta velocidade. Simões-Moreira (1994) observou o fenômeno em experimentos unidimensionais e documentou o fenômeno de forma fotográfica como aquela fotografia da Fig. 1.9. Nessa figura, uma onda de evaporação se propaga de cima para baixo em n-dodecano líquido e metaestável. 


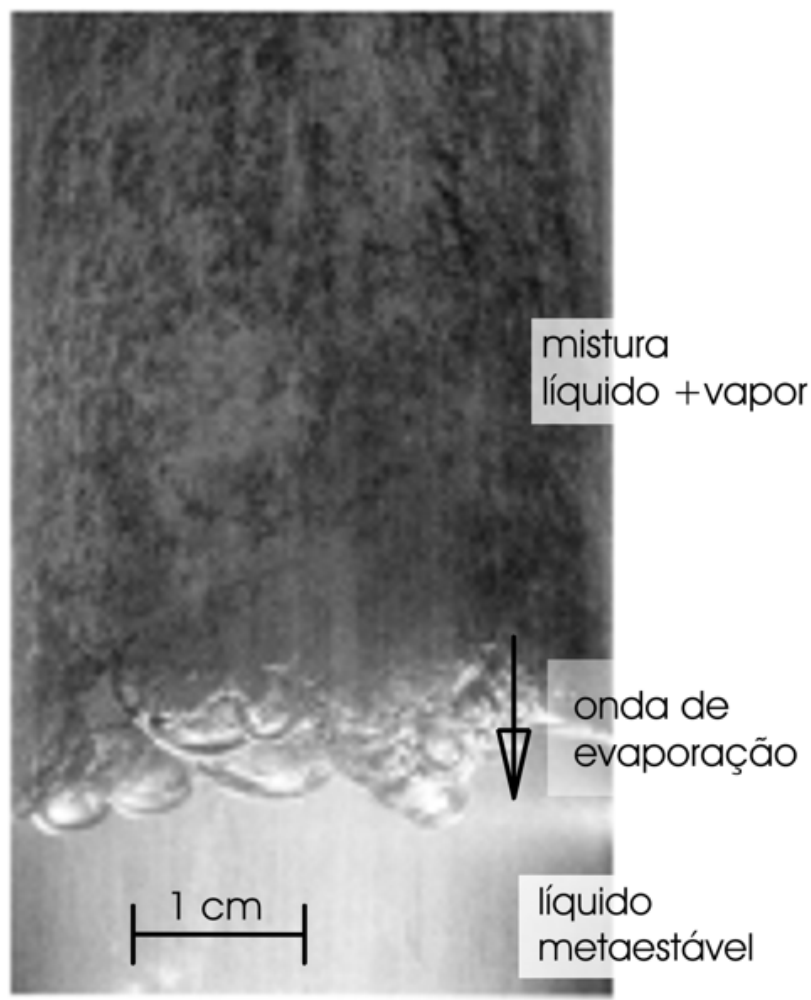

Figura 1.9 - Onda de evaporação em n-dodecano metaestável.

Condições: A temperatura do líquido é de $230^{\circ} \mathrm{C}$, a pressão abaixo da onda é de $59 \mathrm{kPa}$, a pressão acima da onda de evaporação é de $37 \mathrm{kPa}$ e velocidade da onda sob o líquido estacionário é de 47,2 cm/s (Simões Moreira, 1994).

De uma forma geral, os experimentos com ondas de evaporação indicam que, quando uma interface de líquido-vapor é exposta de forma súbita a um ambiente de baixa pressão, se observa a formação de uma onda de evaporação (Hill, 1991; Simões-Moreira, 1994, entre outros), a qual é caracterizada por uma queda significativa da pressão e uma evaporação circunscrita a uma região interfacial discreta e observável. Dentre alguns autores, é possível também destacar o trabalho de Emrich (1985) que observou a onda de evaporação em experimentos com $\mathrm{CO}_{2}$ líquido cuja expansão ocorria de forma unidimensional em direção radial.

Kurschat e outros (1992) conduziram experimentos com jatos evaporativos e assumiram a hipótese de que o líquido emergente do bocal se encontra no estado metaestável em função da observação experimental de sua documentação fotográfica (Fig. 1.10) e do comportamento da vazão, a qual era limitada. Eles conjeturaram que o fenômeno obedeceria às condições de salto evaporativo entre o líquido e a região 
de expansão bifásica que circunda esta porção seria uma onda de evaporação. A substância utilizada foi $\quad \mathrm{o} \quad \mathrm{C}_{6} \mathrm{~F}_{14} \quad$ (n-perfluorohexano, cujas propriedades termodinâmicas do ponto crítico são: $T_{\mathrm{C}}=178^{\circ} \mathrm{C}, P_{\mathrm{c}}=1,87 \mathrm{MPa}$ e $v_{\mathrm{c}}=1,58 \mathrm{l} / \mathrm{kg}$ ).

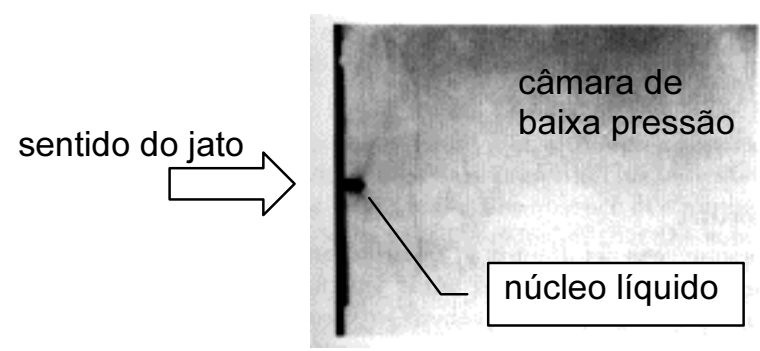

Figura 1.10 - Imagem do núcleo de líquido de um jato (Kurschat, 1992).

No trabalho anterior do autor (Vieira, 1999), foram apresentados ensaios de jatos evaporativos com substâncias como querosene, óleo diesel e, apenas três ensaios com n-dodecano $\left(\mathrm{C}_{12} \mathrm{H}_{26}\right)$. O querosene compreendeu $80 \%$ de todos ensaios daquele trabalho, e teve por objetivo, obter dados iniciais do uso de n-dodecano que é uma substância de alto custo (aproximadamente US\$ 30,00 para cada $100 \mathrm{ml}$, sem as taxas de importação), assim como, é feita a aplicação de substâncias puras como indolene e ou iso-octano $\left(\mathrm{C}_{8} \mathrm{H}_{18}\right)$ que simulam o comportamento da gasolina. Porém, o fato do querosene não ser uma substância pura, dificultou a parametrização do comportamento termodinâmico dos ensaios com a pressão de injeção ou pressão da câmara onde é descarregado o jato, pois não se tem um valor fixo de pressão de vaporização a uma certa temperatura de injeção destes fluidos. Assim como no trabalho de Kurschat e outros (1992), as imagens do trabalho anterior do autor (Fig. 1.2) que mostram a presença do núcleo líquido também corroboram para a hipótese da existência de uma onda de evaporação sobre o núcleo de líquido.

\subsubsection{A Configuração do Jato Evaporativo}

Oza (1984) realizou um estudo de "flashing" em mecanismos de injeção de combustíveis. Ele utilizou substâncias puras como o metanol $\left(\mathrm{CH}_{3} \mathrm{OH}\right)$ e o indolene $\left(\mathrm{C}_{6} \mathrm{H}_{9} \mathrm{~N}\right)$ em injetores que permitiam o pré-aquecimento do líquido. Ele também utilizou propano $\left(\mathrm{C}_{6} \mathrm{H}_{8}\right)$ e verificou que, quanto maior a razão entre as pressões de injeção e da câmara onde foi feita a injeção destas substâncias, maior seria o ângulo 
do cone de dispersão do jato pulverizado.

Em uma visão geral, existe uma caracterização dos tipos de jatos conforme a temperatura inicial de injeção e a pressão do ambiente onde é descarregado o jato, principalmente, como visto por Kurschat (1992) e Peter e outros (1994). Jatos descarregados em ambientes com pressões pouco abaixo de sua pressão de saturação possuíam a forma de um filete líquido contínuo que ao longo do percurso se quebrava devido às nucleações esporádicas (também chamado de "breakup points", na literatura inglesa), tal como observou Lienhard e Day (1970). Diminuindo ainda mais a pressão do ambiente em relação à pressão de vapor, também se verificava o aumento da dispersão do jato. No caso de Peter e outros (1994), a temperatura e o tamanho das gotículas dispersas de água também foram dados coletados no ensaio. A câmara onde expandia o jato alcançava uma pressão mínima de $600 \mathrm{~Pa}$ o que proporcionava ao jato de água de $19{ }^{\circ} \mathrm{C}$ uma grande dispersão das gotículas, enquanto Fuchs e Legge (1979), com praticamente as mesmas condições de injeção, mas com uma pressão de câmara muito menor, com valor de 0,1 Pa abs, conseguiram observar partículas de gelo devido ao congelamento das gotículas durante a expansão do jato. Neste último caso, estes simulavam a expulsão do condensado do vapor de água da atmosfera de dentro de cabines de naves espaciais em órbita.

Especificando melhor a classificação visual dos jatos de água realizada por Peter e outros (1994) tem-se que os jatos contínuos, do tipo 1, conforme ilustrado na Fig. 1.11, possuem o filete de líquido sem interrupção do mesmo e são jatos cuja pressão da câmara era ligeiramente menor que a pressão de saturação do líquido. Com o aumento da temperatura de injeção ou, alternativamente, pelo decréscimo da pressão da câmara, o jato se caracterizava pelo espalhamento das gotículas e um núcleo líquido definido (Fig. 1.11, tipo 2), cujo ângulo de espalhamento aumentava quando se acentuavam estes parâmetros (tipo 3). Como exemplo, no jato de água (Tipo 2), a razão entre a pressão de saturação e a pressão da câmara era igual a 3,1 com uma temperatura de injeção de $52,6^{\circ} \mathrm{C}$ e, o outro tipo possuía uma temperatura de injeção $30,2^{\circ} \mathrm{C}$, e uma razão de pressões no valor de 6,8 (Tipo 3). Em estágios de maior temperatura de injeção ou menores pressões da câmara, o jato assumia uma pulverização quase completa na saída do bocal. Fica evidente que os autores descrevem um jato com uma porção contínua da parte líquida após a saída do bocal, 
como mostrados pelo segundo e terceiro tipo da Fig. 1.11, caracterizando a existência de um núcleo de líquido.

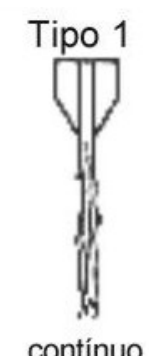

Tipo 3

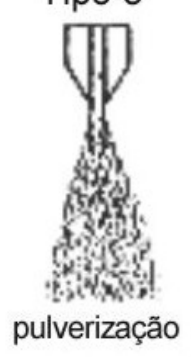

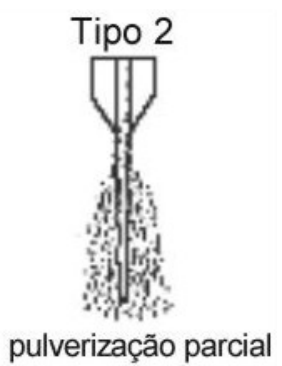

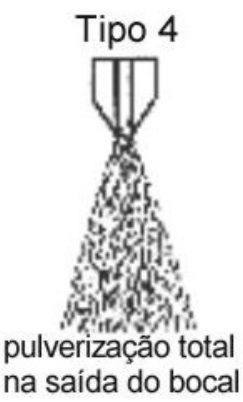

Figura 1.11 - Perfis de jatos de água (Peter e outros, 1994). O primeiro jato tem uma baixa taxa de evaporação no filete do jato. O segundo tipo, com um pequeno acréscimo da razão entre as pressões de saturação e da câmara, já possui uma dispersão de gotículas devido à evaporação na periferia do núcleo líquido. $\mathrm{Na}$ seqüência, o terceiro jato tem um núcleo de líquido mais definido que o anterior com uma acentuada taxa de evaporação. No último caso, por causa da elevada razão entre as pressões de saturação e da câmara, o jato possui uma elevada taxa de evaporação proporcionando a dispersão imediata das gotículas logo na saída do bocal.

Resultados semelhantes dos diversos perfis de jatos evaporativos foram publicados por Kurschat e outros (1992) e podem ser vistos na Fig. 1.12. Porém, em suas observações, os ensaios com baixíssimas pressões na câmara, configuravam um jato com a presença do núcleo líquido que, imediatamente após passar pela onda de evaporação, se expandia em um escoamento supersônico que terminava por meio de ondas de choque registradas em suas fotografias, como aquelas vistas nas Figs. 1.12(d-f). Eles avaliaram os diversos tipos de jato em função do parâmetro $H$ ou $R_{\mathrm{P}}=$ $P_{\text {sat }}\left(T_{0}\right) / P_{\infty}$. Como nota, este parâmetro $H$ foi denominado como grau de superaquecimento pelos pesquisadores, e neste trabalho o símbolo $R_{\mathrm{P}}$ é empregado. O ensaio consistia na injeção do fluido que estava a pressão e temperatura iniciais de 
reservatório constante. $\mathrm{O}$ bocal tinha um perfil cônico convergente, com um semiângulo de $10^{\circ}$, diâmetro de saída de $0,35 \mathrm{~mm}$ e comprimento de $5,7 \mathrm{~mm}$. A injeção era feita em uma câmara de vácuo. A documentação fotográfica foi feita pelos métodos de "shadowgraph" e de interferômetria, sendo este último utilizado para conseguir observar ondas de choque na condição de baixas pressões da câmara. No primeiro quadro, Fig. 1.12a, tem-se um jato de líquido subresfriado, ou seja, $R_{\mathrm{P}}<1$, sem a ocorrência de mudança de fase. Com a diminuição da pressão da câmara, abaixo da pressão de saturação, dá-se início a pontos de nucleação heterogênea, de onde a evaporação começa (Fig. 1.12b). Na seqüência, foi diminuída ainda mais a pressão da câmara que teve como conseqüência uma mudança radical na estrutura do jato (Figs. 1.12c e seguintes). Em seguida, visualiza-se um núcleo líquido circundado por uma região supersônica terminada em um choque de forma mais ou menos elipsóide e estacionária, como exemplificado na Fig. 1.12d. A Fig. 1.12e mostra o núcleo líquido do jato. E na Fig. 1.12f é mostrada uma evaporação com altíssima razão, $R_{\mathrm{p}}$. 


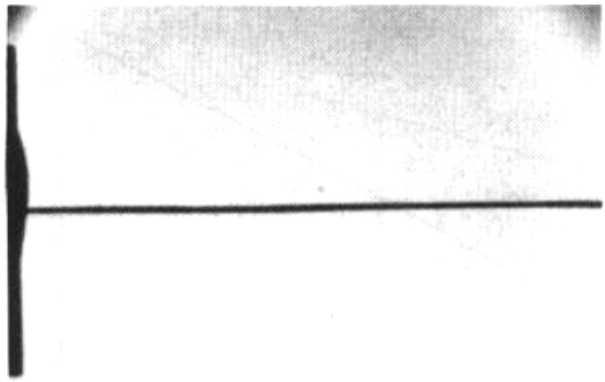

(a)

$$
\begin{gathered}
R p=0.5 \\
T_{0}=20^{\circ} \mathrm{C}, p_{0}=2 \text { bar, } p_{\infty}=500 \mathrm{mbar}
\end{gathered}
$$

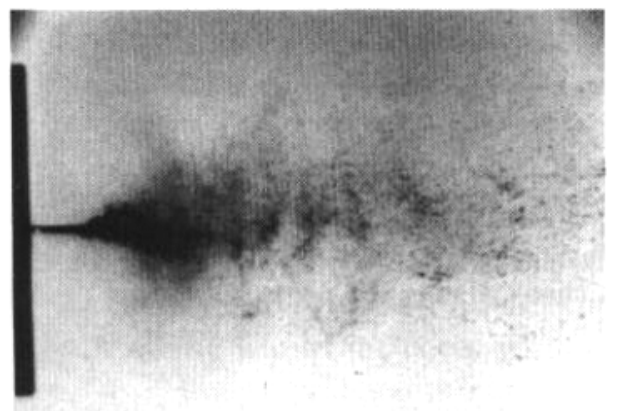

(c)

$$
\begin{gathered}
R p=6.8 \\
T_{0}=20^{\circ} \mathrm{C}, p_{0}=2 \text { bar, } p_{\infty}=35 \mathrm{mbar}
\end{gathered}
$$

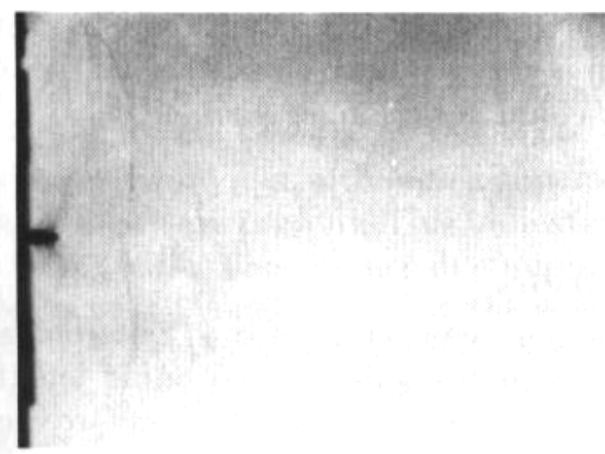

$$
\text { (e) } \begin{aligned}
R \mathrm{p} & =600 \\
T_{0}=120^{\circ} \mathrm{C}, p_{0} & =15 \text { bar, } p_{\infty}=10 \mathrm{mbar}
\end{aligned}
$$

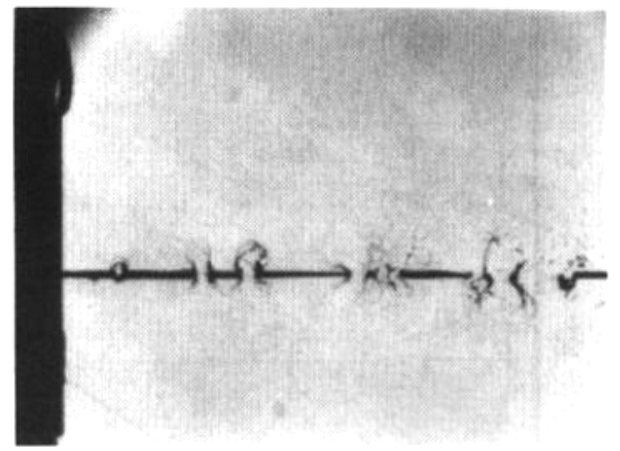

(b) $\quad R \mathrm{p}=2.4$

$T_{0}=20^{\circ} \mathrm{C}, p_{0}=2$ bar, $p_{\infty}=100 \mathrm{mbar}$

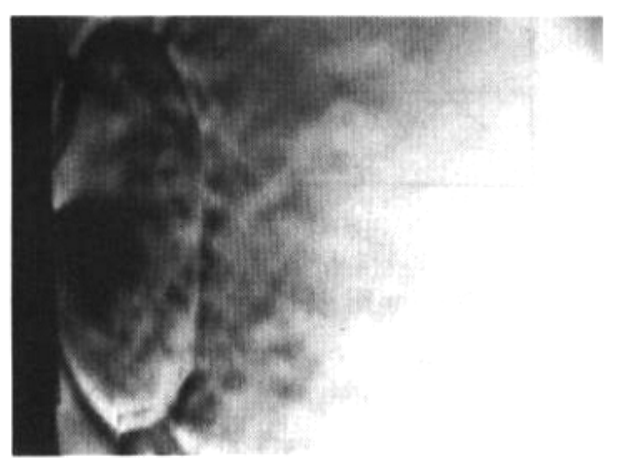

(d)

$R \mathrm{p}=370$

$T_{0}=100{ }^{\circ} \mathrm{C}, p_{0}=15$ bar, $p_{\infty}=10 \mathrm{mbar}$

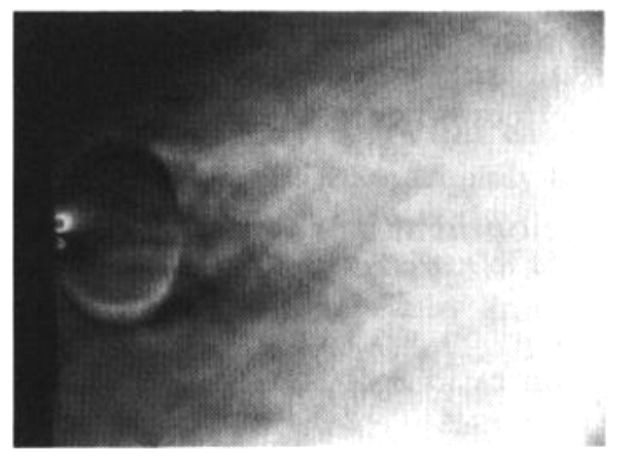

(f) $\quad p_{0} / p_{\infty}=1600$

$T_{0}=175^{\circ} \mathrm{C}, p_{0}=15 \mathrm{bar}, p_{\infty}=10 \mathrm{mbar}$

Figura 1.12 - Jatos de diferentes tipos dependentes do parâmetro $R_{\mathrm{P}}$ (Kurschat e outros, 1992). Imagens obtidas pela técnica de interferometria. O primeiro jato não possui evaporação. No segundo, existem nucleações esporádicas quebrando a continuidade do jato. O jato apresentado em "c" pulveriza-se totalmente, com o acréscimo da razão da pressão de vapor e da câmara, $R_{\mathrm{P}}$. A imagem seguinte, com um elevado valor de $R_{\mathrm{P}}$, apresenta a formação da onda de choque. A penúltima imagem ("e") mostra um jato semelhante ao anterior, porém destaca a presença do núcleo de líquido, além da onda de choque. Por último, um jato contendo um núcleo de líquido menor que o anterior e, uma onda de choque menor, embora a pressão da câmara seja a mesma comparada ao anterior, porém a temperatura de injeção é maior. 


\subsubsection{O Escoamento a Jusante da Onda de Evaporação}

Existindo uma onda de evaporação circundando o núcleo de líquido, é importante verificar como é o comportamento do escoamento do fluido após esta onda. Segundo Kurschat e outros (1992), com elevadas razões entre pressão de saturação e pressão da câmara eles observaram um escoamento supersônico associado à formação de ondas de choque. Em seus estudos, verificaram que quanto menor a pressão da câmara, maior era a dimensão do diâmetro da estrutura da onda de choque, com formato cilíndrico, semelhante ao fenômeno de formação de um disco de Mach, que ocorre em escoamento de jatos de gás subexpandidos (ver próxima seção). Em seu modelo matemático unidimensional para a simulação do fenômeno, os mesmos adotaram as hipóteses simplificadoras como: o líquido estaria na condição de metaestável após sair pelo bocal; o escoamento após a onda de evaporação sofria uma expansão isentrópica e supersônica na direção perpendicular do eixo principal do jato, ou seja, apenas no sentido radial em coordenadas cilíndricas e, a pressão imediatamente após a onda de choque era a pressão da câmara. Sendo assim, foi possível determinar a pressão metaestável do líquido e os processos termodinâmicos que o fluido sofreu em todo o escoamento em função do diâmetro da estrutura da onda de choque obtida pela fotografia do ensaio. No entanto, suas imagens não proporcionam conclusões de como seria o escoamento após a onda de evaporação. Com o objetivo de esclarecer estes pontos, o autor desta tese utilizou o sistema "Schlieren" como método óptico, já que o mesmo proporciona uma visualização do gradiente de densidade do fluido no escoamento, e assim, oferecia uma idéia do comportamento do fluxo após a onda de evaporação (Vieira, 1999). Na Fig. 1.13, a primeira imagem é o registro fotográfico do jato adquirido pelo método "Schlieren" que possui a informação do gradiente de densidade através da intensidade de luz registrada na imagem. Desta imagem são obtidas as outras duas, através de processamento matemático. A primeira destaca bem o núcleo de líquido, algo que também pode ser visto nas outras duas imagens. Do núcleo de líquido, há um escoamento bifásico cuja terceira imagem da figura revela que, próximo do núcleo, a variação de densidade do fluido é maior que a variação ocorrida na região próxima a montante da onda de choque, pois é mostrada uma 
grande concentração de iso-densidades próxima do núcleo. Além disso, as iso-linhas de densidade do fluido desta imagem apresentam um escoamento assumindo uma forma um pouco mais complexa do que propriamente radial. Por fim, a segunda imagem mostra a onda de choque resultante deste escoamento supersônico.

a)

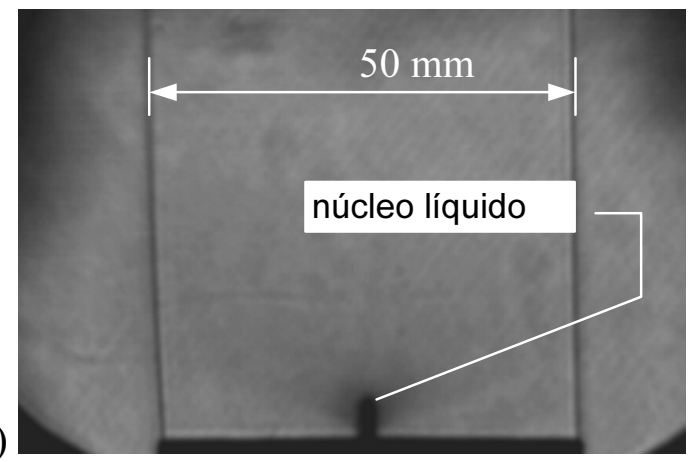

b)

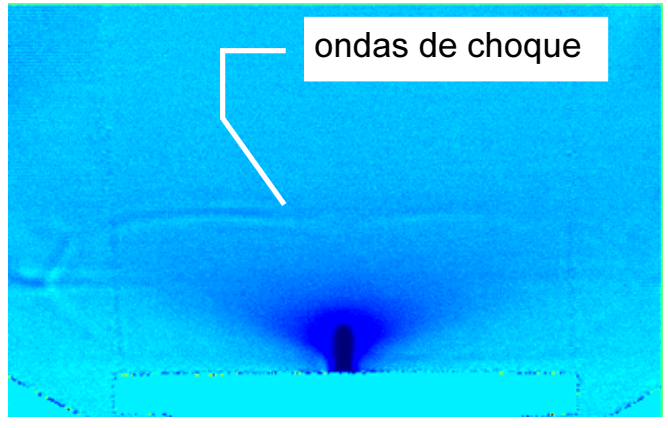

c)

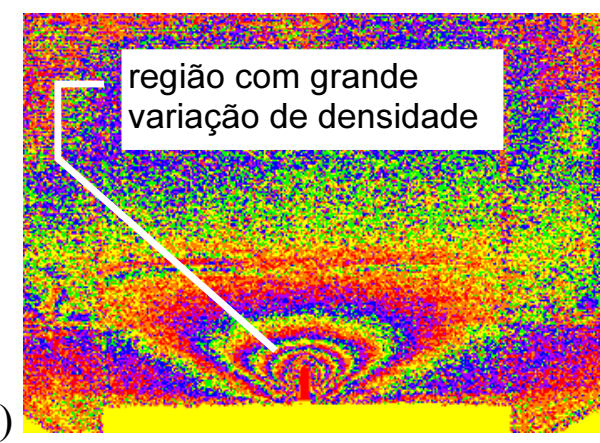

Figura 1.13 - Imagens de um jato com elevada taxa de evaporação. A primeira é a fotografia original e as outras correspondem às imagens filtradas e processadas matematicamente (Vieira, 1999).

Retomando ao trabalho de Athans (1994), é interessante observar na Fig. 1.4 que as linhas quase horizontais que se originam da visualização da trajetória das gotículas que saem do núcleo de líquido. Em virtude desta observação, SimõesMoreira (1999) introduziu a teoria das ondas de evaporação oblíquas, cujo tratamento matemático é semelhante ao das ondas de choque oblíquas da teoria clássica de escoamento de gases. De acordo com esta teoria, o fluido sofre um desvio angular ao passar por uma frente de evaporação. Esta frente de evaporação ocorre na superfície do cone de líquido, conforme esquema da Fig. 1.14. Na figura, a superfície do cone representaria a onda de evaporação cujo ângulo entre a geratriz e o eixo de simetria é denominado de $\beta$ (ângulo da onda). O líquido metaestável, com velocidade $u_{1}$, passa pela base do cone, que seria a seção de saída do bocal, alcança a onda de 
evaporação oblíqua, sofrendo um desvio de direção cujo ângulo de giro está representado por $\theta$, assumindo a velocidade $u_{2}$. Conforme Simões-Moreira (1999) este giro, $\theta$, é função da razão dos volumes específicos do líquido metaestável e da mistura líquido-vapor imediatamente após a onda de evaporação e, do ângulo da onda de evaporação, $\beta$.

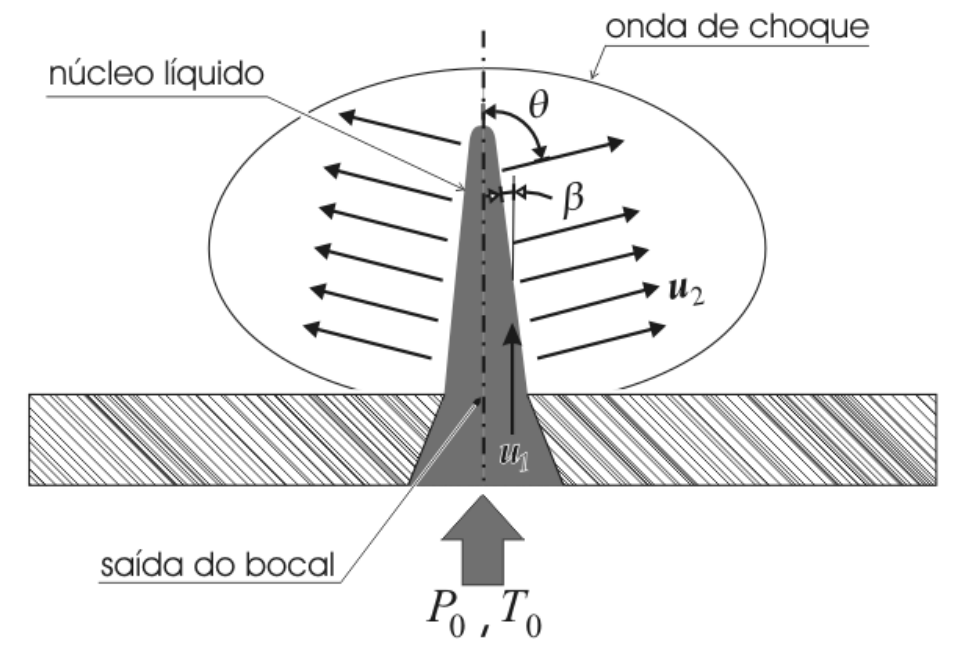

Figura 1.14 - Esquema de uma onda de evaporação com a formação de uma estrutura de onda de choque.

Peter e outros (1994) fizeram medições da temperatura da mistura bifásica que expande do núcleo de líquido. Estes ensaios eram feitos com água emergente de um bocal cilíndrico de vidro com diâmetro de $1 \mathrm{~mm}$. A pressão de injeção era atmosférica e o líquido era descarregado em uma câmara de baixa pressão criando condições para a evaporação. Na Fig. 1.15a, é mostrado um gráfico com a temperatura das gotículas em função da distância ao longo do eixo central e, tomando como exemplo o terceiro tipo de jato (conforme visto na Fig. 1.11), é observada uma temperatura quase constante e igual à temperatura de injeção do líquido até $3 \mathrm{~mm}$, onde ocorre o "breakup point", ou seja, o ponto onde o filete contínuo da parte líquida do jato é rompido. Logo após, existe uma queda abrupta da temperatura até alcançar a distância de 29 mm desta distância axial e, em seguida, existe uma estabilização. O tipo 2 e tipo 4 também apresentavam semelhante comportamento relativo ao terceiro tipo, porém era menos perceptível. Fazendo 


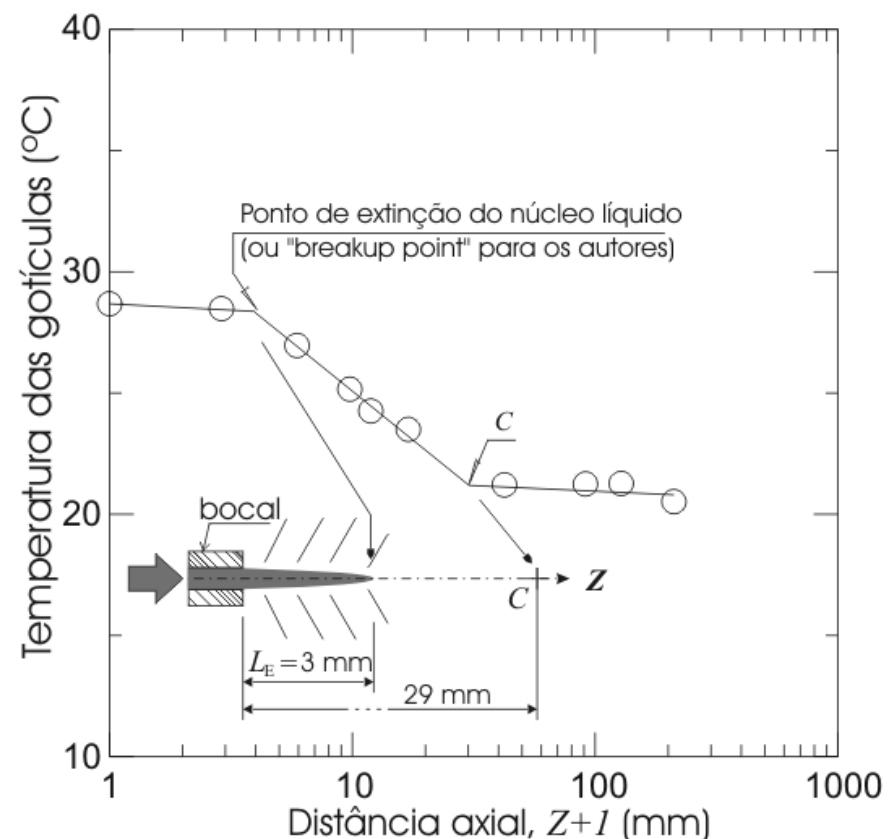

a)

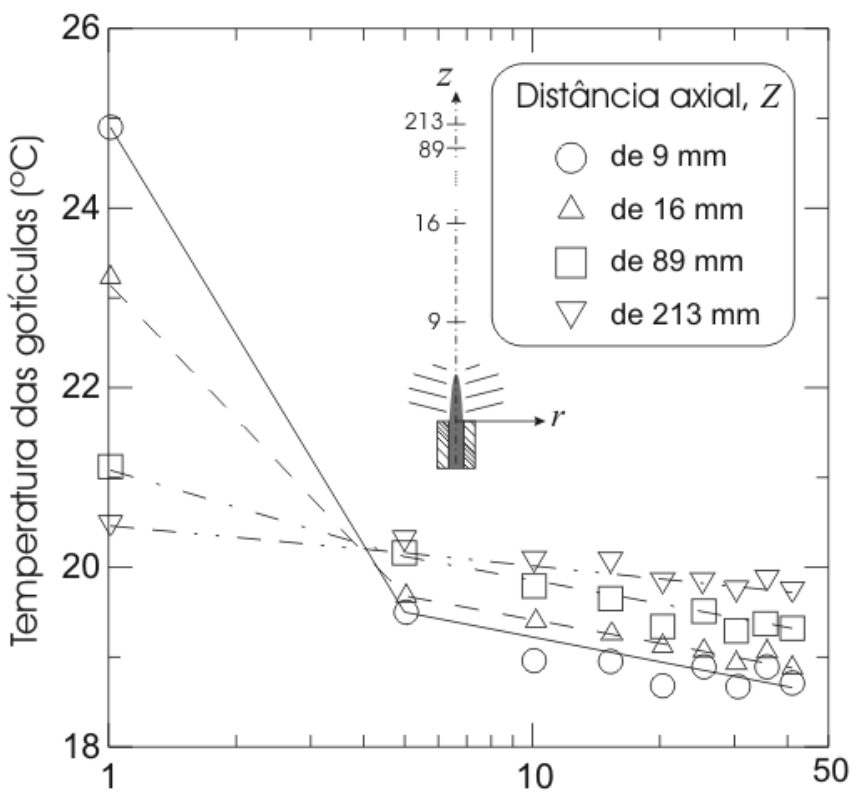

b)

Distância radial, $\boldsymbol{r}(\mathrm{mm})$

Figura 1.15 - Gráficos que ilustram o comportamento da temperatura de estagnação das gotículas durante a expansão do jato de água com temperatura e pressão de injeção de 30,3 ${ }^{\circ} \mathrm{C}, 100 \mathrm{kPa}$, respectivamente e, pressão da câmara de $0,63 \mathrm{kPa}$. O primeiro corresponde à temperatura em função da distância axial destacando o ponto onde ocorreu a interrupção da continuidade do filete líquido e, o ponto "C" seria o início da estabilização da temperatura das gotículas com o ambiente. O segundo indica as temperaturas em função da distância radial apenas para o jato Tipo 3 (Peter e outros, 1994).

menção à temperatura de injeção, que é de $30,3{ }^{\circ} \mathrm{C}$, é observado neste gráfico que a temperatura já sofre uma queda, com valor de $28,7{ }^{\circ} \mathrm{C}$, logo na saída do bocal. 
Provavelmente isto ocorreu devido à influência da inserção do termopar neste local ou problemas de condução de calor, proporcionando a evaporação. No segundo gráfico da Fig. 1.15b, a temperatura das gotículas está em função da distância radial cujas curvas referem-se a regiões afastadas do bocal, perpendicularmente ao eixo axial. Nele também se observa a queda abrupta da temperatura e depois a estabilização. Os autores identificaram apenas como uma região que sofria uma forte vaporização das gotículas, mesmo porque, eles não possuíam os meios para visualização da onda de choque e do escoamento supersônico.

Simões-Moreira e outros (2002) conduziram uma simulação numérica do escoamento da mistura bifásica que ocorre depois onda de evaporação. Um estudo deste comportamento das propriedades de temperatura e pressão foi feito e está exemplificado na simulação do ensaio 2349100, $\mathrm{n}^{\circ} 16$, cujos dados experimentais estão apresentados na Tab. B.1 do Anexo B. Resumidamente, seu modelo matemático compunha o jato de líquido metaestável, com valores de temperatura e pressão obtidos experimentalmente. A expansão da mistura bifásica após passar pela onda de evaporação possuía velocidade supersônica, até alcançar a onda de choque. A jusante da onda de choque, a mistura assumia um escoamento subsônico que se equilibrava com a pressão do ambiente. $\mathrm{O}$ modelo era unidimensional de expansão radial em coordenadas esféricas com a hipótese de um escoamento bifásico homogêneo. Na Fig. 1.16, um dos gráficos ilustra o campo de pressões em todo o escoamento, assim como, outras grandezas importantes como o título, $x$, e o número de Mach, $M$, calculados de acordo com este modelo1-D simplificado. Neste mesmo ensaio, 2349100, a Fig. 1.17 descreve o comportamento de distribuição de temperatura. 


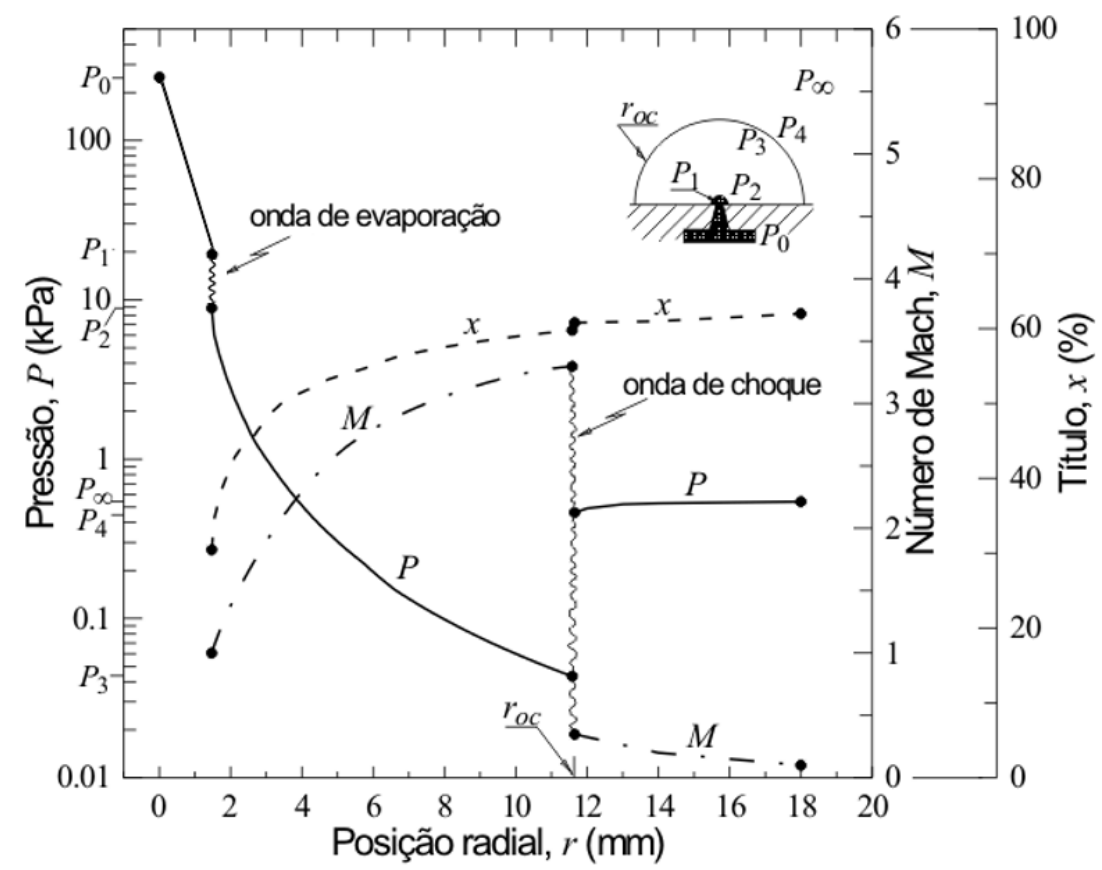

Figura 1.16 - Simulação numérica feita para o ensaio 2349100, cujas condições de injeção eram de $250 \mathrm{kPa}$ e $76^{\circ} \mathrm{C}$. A linha contínua indica o comportamento da pressão, a linha tracejada corresponde o título da mistura e a linha traço-ponto indica o número de Mach. São indicadas as posições da onda de evaporação e da onda de choque (Simões-Moreira e outros, 2002).

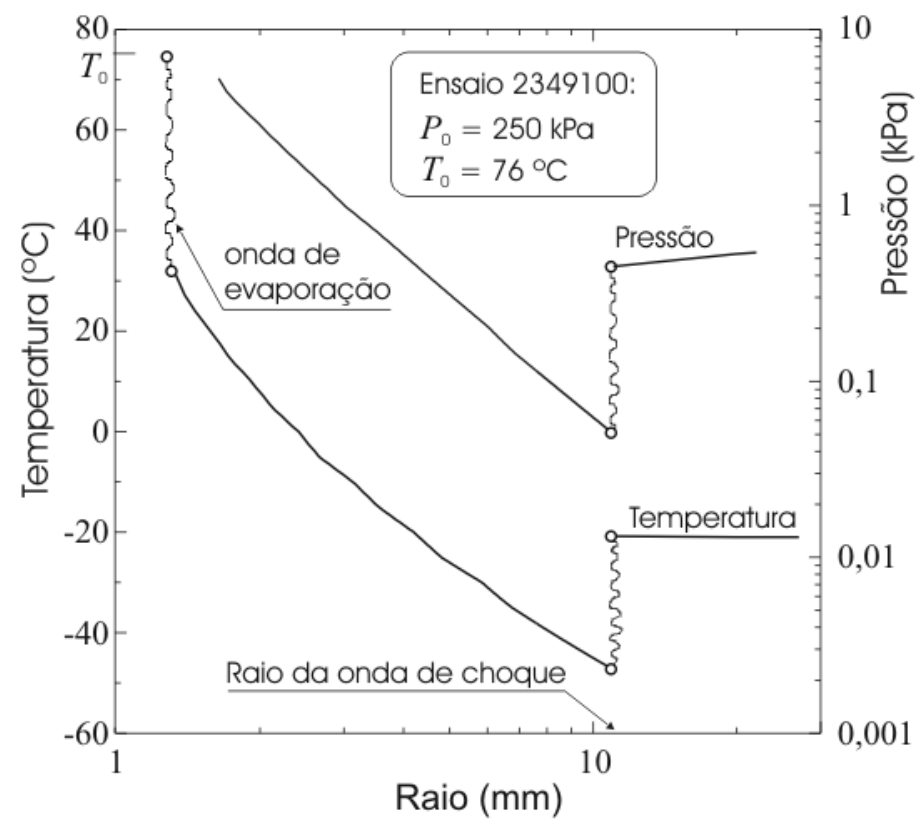

Figura 1.17 - A mesma simulação numérica da Fig. 1.16 acrescentando o comportamento da temperatura com ênfase para regiões a montante e a jusante da onda de choque. Outra informação importante deste gráfico pode ser feita na observação do salto de propriedades na posição da onda de choque, considerando a hipótese de modelo homogêneo. 
Como observação, é importante salientar que estes trabalhos experimentais (Lienhard e Day, 1970, Kitamura e outros, 1986 e, Peter e outros, 1994) assumem que a metaestabilidade alcançada pelo líquido é função apenas da temperatura de injeção do líquido e da pressão do ambiente onde é descarregado o jato, dispensando qualquer análise do campo de pressões na região circunvizinha da parte líquida do jato. Pelos trabalhos experimentais de Kurschat e outros (1992), Athans (1994), Vieira (1999) e Simões-Moreira e outros (2002) ficou comprovado que a pressão na saída do bocal é diferente da pressão da câmara onde são descarregados devido à presença da onda de evaporação e de um escoamento compressível supersônico com presença de ondas de choque. Simões-Moreira e outros (2002) e de Angelo (2004) também são trabalhos que comprovaram isto. Eles empregaram a teoria das ondas de evaporação oblíquas e conduziram uma solução bidimensional para esta expansão da mistura bifásica, obtendo bons resultados como será mostrado no capítulo seguinte.

Yildiz e outros (2003), de forma experimental, fez um levantamento do comportamento da temperatura após a evaporação do jato de R134a. O refrigerante foi armazenado com pressão e temperatura iniciais de $700 \mathrm{kPa}$ e $22{ }^{\circ} \mathrm{C}$ (Fig 1.18). Este fluido é descarregado ao ambiente atmosférico através de bocais de 1, 2 e $4 \mathrm{~mm}$. Injetado em condições de regime permanente, ou seja, à pressão e temperatura constantes, imediatamente a montante do bocal foi introduzido um termopar que mede a temperatura do fluido igual ao valor da temperatura do tanque de armazenamento do R134a. Eles usaram duas técnicas para a medição do comportamento da temperatura do jato. A primeira técnica (Fig. 1.18b), não intrusiva, é feita por intermédio de uma imagem termográfica obtida de uma câmara sensível ao infravermelho. A outra técnica de medição foi feita através de termopares dispostos ao longo do jato em intervalos de $5 \mathrm{~cm}$. O exemplo da Fig. 1.18a mostra um jato emergindo de um bocal com diâmetro de saída de $1 \mathrm{~mm}$. Pelas duas técnicas (Fig. 1.18b e 1.18c), eles verificaram que a temperatura do jato salta de +22 para -20 ${ }^{\circ} \mathrm{C}\left(P_{\text {sat }}=132,8 \mathrm{kPa}\right)$, imediatamente a jusante do bocal. Neste instante, o fluido evolui para uma mistura líquido-vapor, corroborando para a hipótese da onda de evaporação. Esta mistura, enquanto se expande, poderia escoar deixando cair a sua temperatura para $-26,7^{\circ} \mathrm{C}$, que é sua temperatura de saturação a pressão ambiente de 1 atm. Porém, ao longo do jato, na distância de $500 \mathrm{~mm}$, as gotículas do fluido 
alcançaram a temperatura mínima de $-55^{\circ} \mathrm{C}$. Durante este percurso, se houvesse significativa influência da temperatura do meio $\left(+25^{\circ} \mathrm{C}\right)$, o jato expandido com uma temperatura de $-26,7{ }^{\circ} \mathrm{C}$ tenderia a aumentar a sua temperatura para entrar em equilíbrio térmico com o meio, em contraposição, foi observado que a temperatura diminui para este patamar mínimo. Isto corrobora para o fato de que houve uma diminuição da pressão após a onda de evaporação, decorrente de um escoamento supersônico, porque proporcionalmente a temperatura diminuiu para este patamar mínimo, como ocorre com escoamentos supersônicos. A pressão de equilíbrio da mistura para $-55^{\circ} \mathrm{C}$ é de $21,9 \mathrm{kPa}$, cinco vezes menor que a atmosférica. 
a)
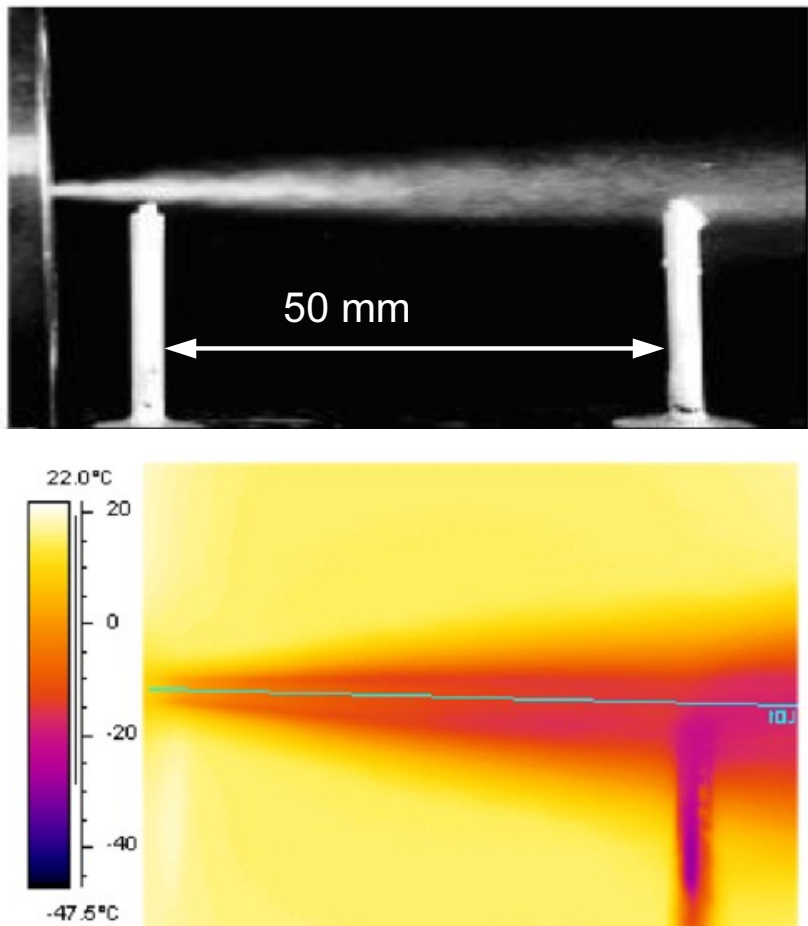

b)

c)

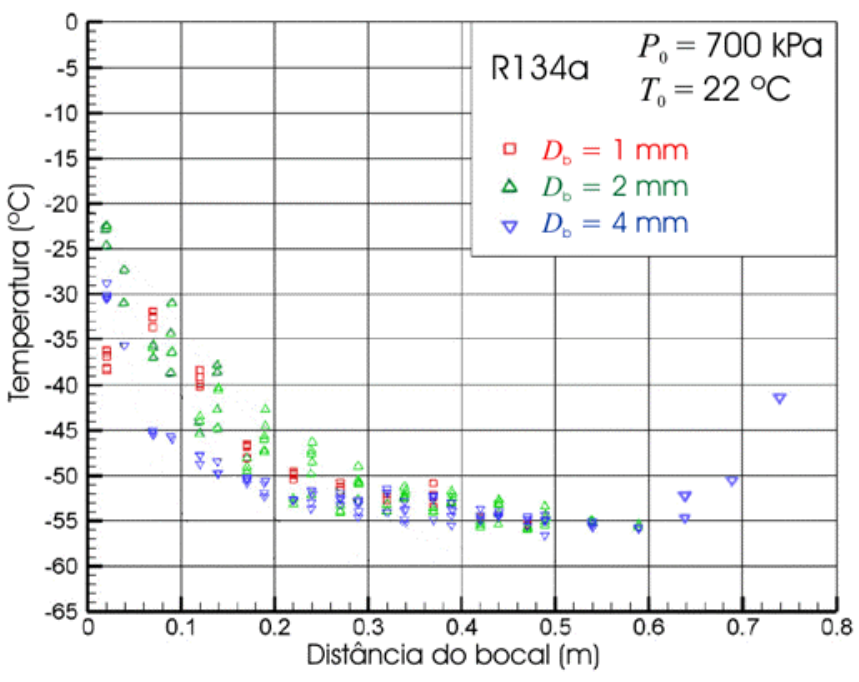

Figura 1.18 - (a) Fotografia do jato de R134a descarregado no ambiente proveniente de um bocal de $1 \mathrm{~mm}$. As torres verticais são os termopares dispostos a uma distância de $50 \mathrm{~mm}$ entre eles. (b) Fotografia termográfica do jato do bocal de $1 \mathrm{~mm}$. (c) Gráfico da temperatura em função da posição axial de afastamento do bocal. Foram testados 3 bocais com diâmetros, $D_{\mathrm{b}}$, de 1 , 2 e $4 \mathrm{~mm}$ (Yildiz e outros, 2003). 


\subsubsection{Considerações sobre o Efeito Transitório e o Comportamento do Jato em Regime Permanente}

Em regimes transitórios de expansão de um jato de gás, nos instantes iniciais, é observada uma onda de choque à frente do jato, que na literatura inglesa é chamada de "bow shock". Tomando dois ensaios feitos por Lacerda (1986) com razões entre pressão de reservatório $\left(P_{0}\right)$ e pressão da câmara $\left(P_{\infty}\right)$ iguais a 10 e 3 , são obtidas uma seqüência de imagens que consta a evolução da formação da frente de onda de choque do jato (Fig. 1.19). Os intervalos de tempo de aquisição de cada imagem segue com os valores de 0,020,0,040, 0,100, 0,500, 1,000 e 5,000 ms. Esta frente de onda se destaca até o instante de 0,100 ms. Já no instante de 5,0 ms, o jato assume um formato que se configura no regime permanente.

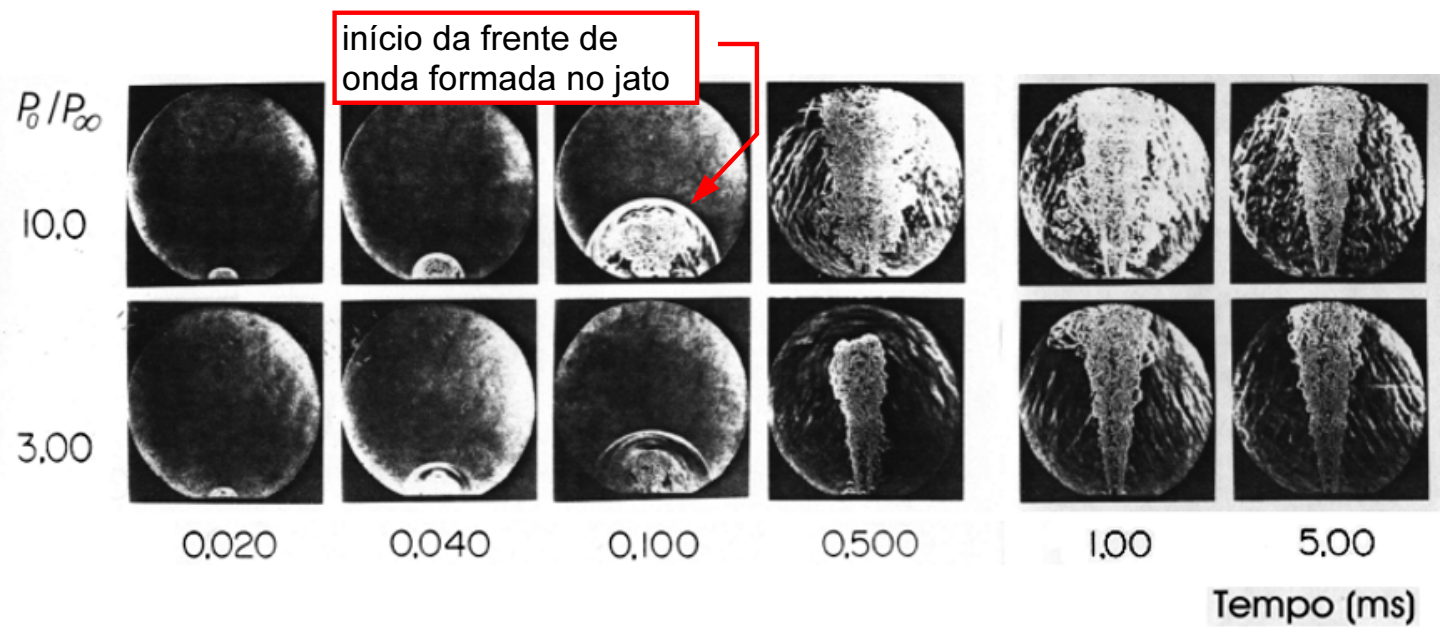

Figura 1.19 - Fotografias obtidas pelo método "Schlieren" com jatos de gás hélio em uma câmara contendo gás nitrogênio. As fotografias acima se referem a um jato descarregado em uma câmara cuja pressão é 10 vezes menor que a pressão de injeção, enquanto a segunda fileira, esta relação é de 3 vezes (Lacerda, 1986).

$\mathrm{O}$ mesmo autor obteve registros fotográficos com jato de gás $\mathrm{SF}_{6}$ (hexafluoreto de enxofre) também descarregado em um ambiente do mesmo gás com razão de pressões igual a 20. Neste ensaio, as imagens obtidas após o transitório inicial do jato demonstram a formação do disco de Mach que se refere a uma onda de choque normal do jato subexpandido de um gás. Sua formação ocorre internamente ao "bow shock" e se mantém durante o regime permanente em um formato regular. 
A Fig. 1.20 mostra um exemplo de jato subexpandido típico. Como observação, na Fig. 1.19 também existe este fenômeno, no entanto, seu diminuto tamanho tornou-o imperceptível nestas imagens.

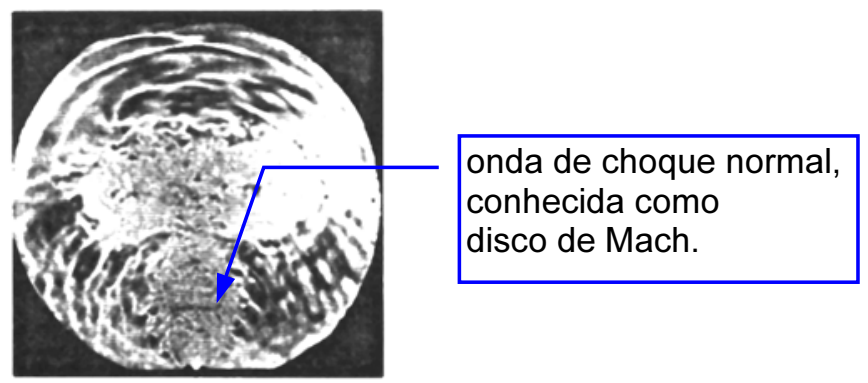

Figura 1.20 - Evolução de um jato de gás subexpandido com a formação do disco de Mach. Segundo Lacerda (1986), a frente de onda já não aparece porque ela assumiu uma dimensão maior que o quadro da fotografia.

Envolvendo a questão do transitório de um jato supersônico de líquido que é pulverizado na câmara onde é descarregado, a presença do frente de onda de choque, ou "bow shock", também é observada. Pianthong e outros (2002) registraram a sua presença fotograficamente. As imagens da Fig. 1.21 mostram o desenvolvimento desta frente de onda de choque expandindo em uma escala de tempo na ordem de microssegundos.
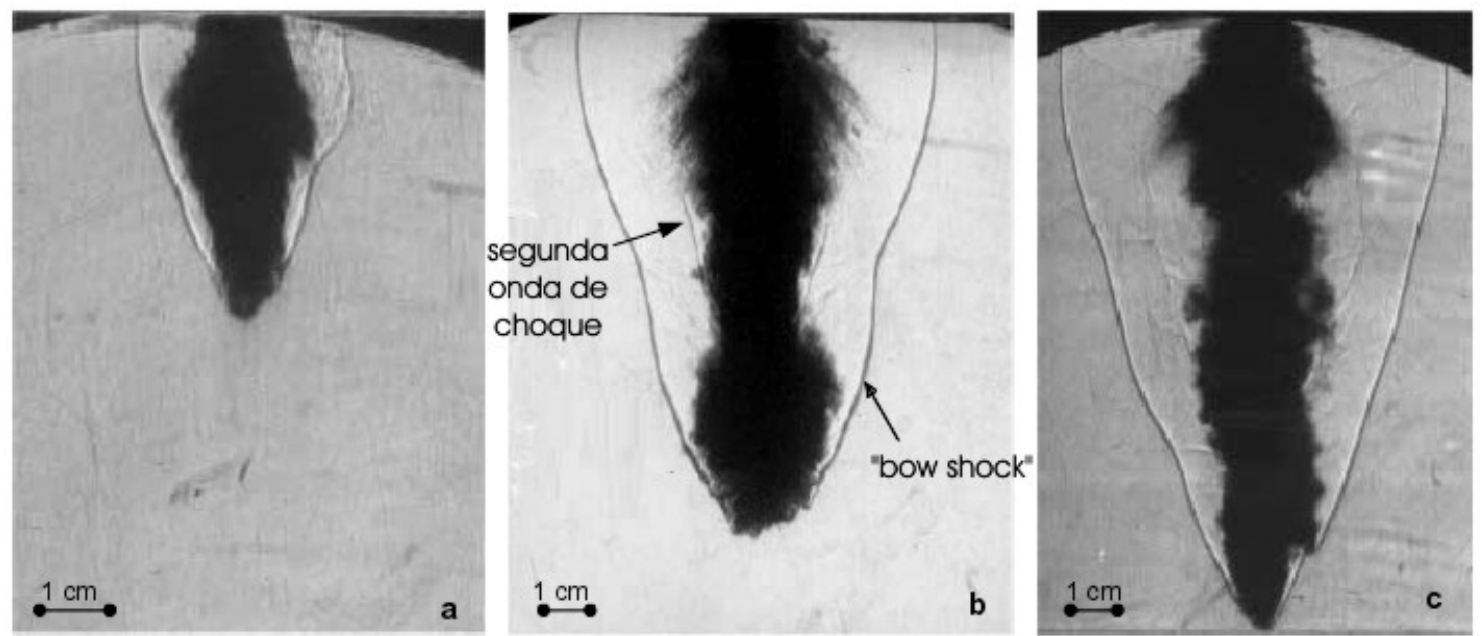

Figura 1.21 - Evolução de um jato supersônico de óleo diesel emergente de um bocal de $1 \mathrm{~mm}$. O instante de aquisição de cada fotografia foi $22 \mu \mathrm{s}, 41 \mu \mathrm{s}$ e 64 $\mu s$, respectivamente (Pianthong e outros, 2002). 
A formação do Disco de Mach é vista nos gases de exaustão do motor de um foguete que atinge grandes altitudes. Os produtos de combustão, a alta pressão, passam através de um bocal cuja pressão de saída do bocal é muito maior que a pressão ambiente, sofre uma expansão rápida (jato subexpandido). A Fig. 1.22 ilustra um esquema do fenômeno. Logo, na borda do bocal, se forma um leque de expansão (expansão de Prandtl-Meyer), fazendo com que o fluxo se expanda radialmente para a região de baixa pressão. O contorno do jato tangencia o máximo ângulo do leque, $v_{\mathrm{j}}$, se estendendo adjacente às ondas de choque reflexivas que, em seguida, ruma quase paralelamente a onda de choque que detém a região hipersônica $(M>>1)$, conforme o esquema. Devido ao formato e a permanência desta formação de onda de choque durante a toda a injeção, Kurschat e outros (1992) assemelharam este fenômeno do disco de Mach ao que ocorre nos jatos evaporativos.

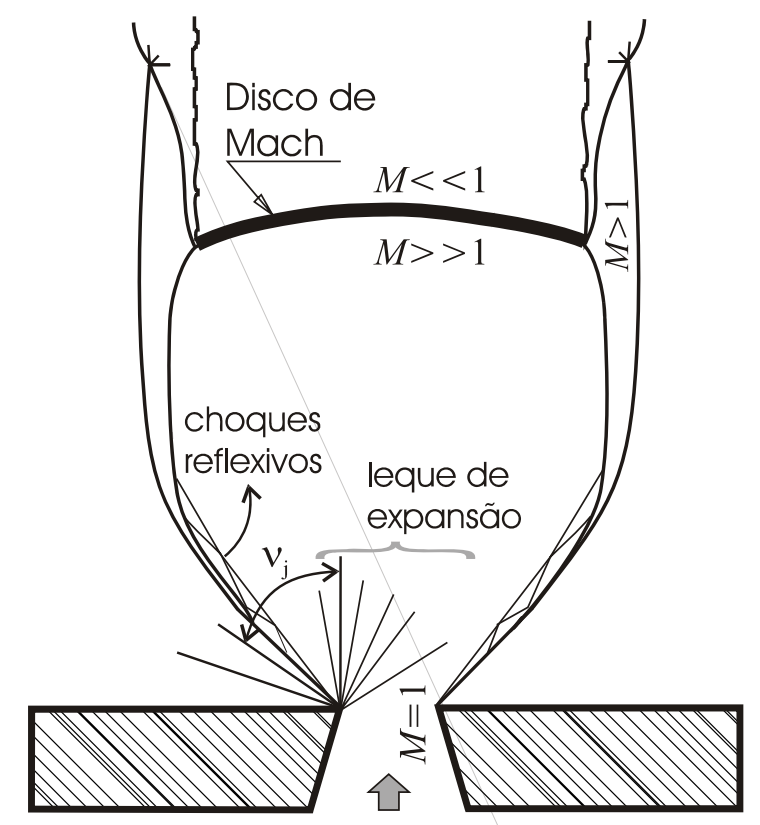

Figura 1.22 - Esquema do escoamento de um jato de gás subexpandido.

É necessário colocar que os casos de estudo desta tese são em regime permanente e não houve a preocupação com transitórios como ocorreu nos ensaios de Lacerda ou Pianthong e outros. Os fenômenos estudados por eles ocorreram no período inicial máximo de $0,5 \mathrm{~ms}$, intervalo por demais pequeno para que a instrumentação aqui apresentada pudesse registrá-lo, de forma seqüencial. 
A regularidade do formato da onda de choque nas imagens adquiridas na bancada deste trabalho foi exemplificada na Fig. 1.5. As imagens, geralmente, são obtidas em 0,2 $s$ após a abertura do injetor. Imagens subseqüentes à primeira, obtidas em intervalos de $0,5 \mathrm{~s}$, comprovam que o núcleo de líquido se mantém constante e a onda de choque não se expande, conservando praticamente o seu tamanho. A Fig. 1.5 não foi um mero teste, nos demais ensaios de Vieira (1999) também foram adquiridas quatro imagens de um único jato, durante o intervalo de abertura e fechamento do injetor. Esta regularidade da forma e tamanho do núcleo de líquido e da onda de choque, em função das condições de injeção, foi mantida em todos os ensaios, comprovando que os experimentos foram conduzidos na condição de regime permanente.

\subsubsection{A Questão da Vazão}

Para a parte de expansão do líquido dentro do bocal é bastante razoável assumir a hipótese de fluido incompressível. De forma que a vazão pode ser determinada através da equação de descarga para bocais. De forma recíproca, a medição da vazão experimental em conjunto com as condições de injeção $\left(P_{0}\right.$ e $\left.T_{0}\right)$ e o coeficiente de descarga, $C_{\mathrm{D}}$, é possível determinar a pressão do líquido na seção de descarga. Verifica-se que o líquido vai adentrar na condição de metaestabilidade para os casos estudados neste trabalho.

Benjamin e Miller (1941) propõem um cálculo de seleção de placas de orifício para medição de vazão de água saturada com seus gráficos orientativos levantados experimentalmente. Um comportamento do fluxo de água saturada nestes dispositivos pode ser visto na Fig. 1.23. A condição de fluxo experimental assume uma vazão maior que o cálculo teórico que admite a vaporização do fluido na seção da placa de orifício. Isto é atribuído, conforme eles visualizaram nos jatos em seus registros fotográficos, ao fato da não evaporação da água na passagem da restrição da placa de orifício. Baseado nos resultados destes pesquisadores, Burnell (1947) também propõe que o fluido tem comportamento incompressível e adota uma correlação que a pressão na passagem de restrição, ou seja, a pressão metaestável, é função da pressão de vapor, da tensão superficial e de dados experimentais do dispositivo, no caso, um bocal ou placa de orifício. 


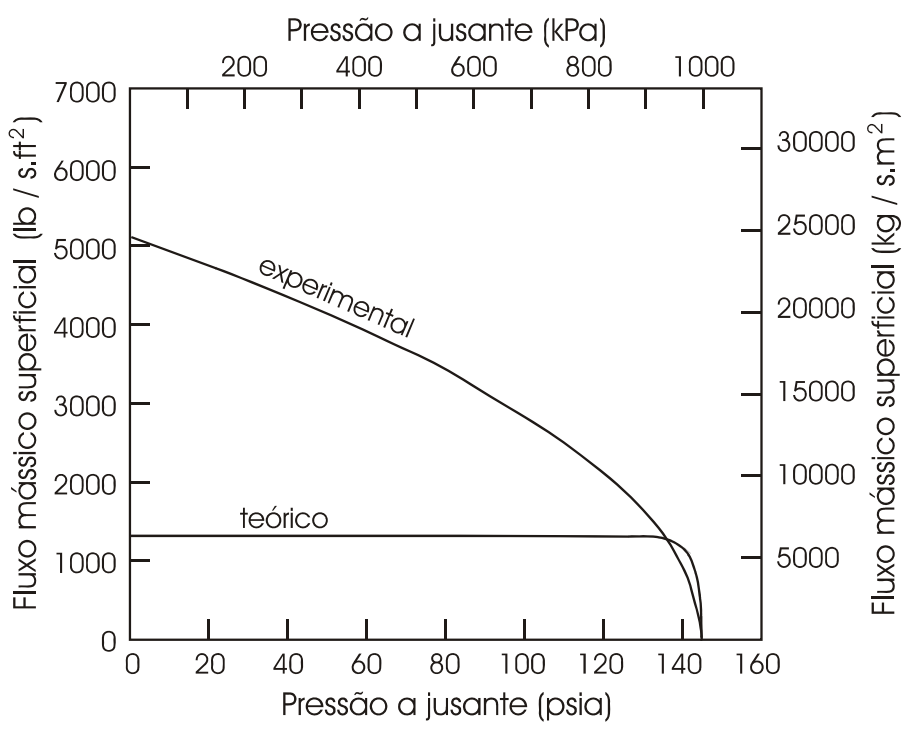

Figura 1.23 - Gráfico que compara a vazão superficial mássica teórica em função da pressão a jusante com aquela obtida experimentalmente com uma placa de orifício. Refere-se a um escoamento de água saturada com pressão a montante de 145 psia (1000 kPa). O cálculo teórico, que Benjamin e Miller (1941) se embasaram, assume que a mínima pressão é de 135 psia, ou 930,8 kPa.

Atualmente, a norma ISA-S75.01-1985 (1995) apresenta um método para a determinação de uma vazão crítica, para escoamento de líquidos que são submetidos a uma pressão abaixo da pressão de saturação a jusante de uma válvula. Se existe a vaporização, a pressão a jusante usada para o cálculo é igual à pressão de saturação do líquido multiplicado por um fator da válvula que é função da tensão superficial. Além disso, a vazão encontrada é multiplicada por outro fator que tem valor entre 0,5 e 0,9 (Anexo D da Norma). Baumann (1963), que é uma das referências desta norma, conduziu alguns estudos experimentais da blocagem da vazão em função da diferença de pressão. Um exemplo típico está na Fig. 1.24. É utilizada uma válvula globo para observação do comportamento da vazão em função da queda de pressão. 


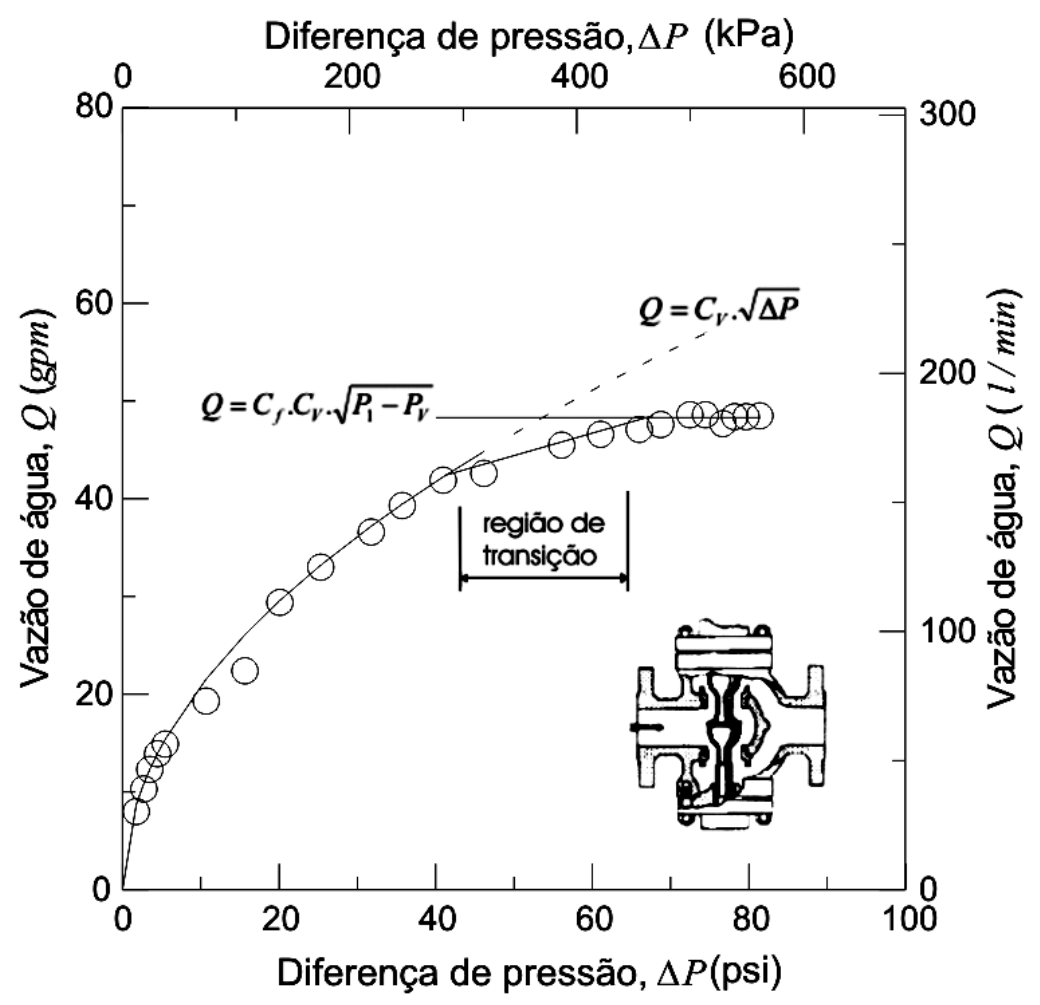

Figura 1.24 - Gráfico que ilustra a vazão em função da diferença de pressões entre a jusante e a montante, $\Delta P=P_{1}-P_{2}$, sendo $P_{1}$ igual a 100 psia, $C_{\mathrm{v}}$, o coeficiente da válvula igual $6,6, C_{\mathrm{f}}$, o coeficiente para a condição de blocagem da válvula globo igual a 0,74 (Baumann, 1963). Entre a região de transição, que corresponde um escoamento suscetível à cavitação da válvula globo (em destaque), à esquerda existe a curva que respeita o regime hidráulico, e à direita, assume um regime de vazão crítica.

Portanto, há dois casos: o primeiro em que existe a evaporação externa ao bocal resultando em um aumento contínuo da vazão, podendo alcançar uma condição máxima, mesmo que a pressão a jusante diminua para patamares abaixo da pressão de saturação do líquido, e em outra situação, a evaporação ocorre na restrição proporcionando uma condição de máxima vazão em estágios cuja pressão a jusante é um pouco maior que a pressão de vapor. Como exemplo, na Fig. 1.24, a vazão é de $74 \%$ daquela estimada pelo fluido na condição de incompressível com pressão a jusante igual à pressão de saturação do líquido.

Geralmente, conforme Wildgen e Straub (1989), esta condição de metaestabilidade é alcançada em bocais curtos cuja razão comprimento-diâmetro do bocal é menor que 1 , ou seja, $\mathrm{L} / \mathrm{D}<1$, relação comum encontrada nas placas de orifício e passagem de válvulas. 
Labuntsov e Avdeev (1982a e 1982b) resolveram o caso de um escoamento de $\mathrm{CO}_{2}$ (gás carbônico) líquido em um bocal, considerando a formação da onda de evaporação interna e externa ao bocal. A principal premissa para isto foi caracterizar que a mínima pressão metaestável era alcançada na curva espinodal (ver Capítulo 2). Seus cálculos forneceram bons resultados quando comparados aos casos experimentais que envolviam a expansão de líquido em bocais (Labuntsov e Avdeev, 1982b).

Alamgir e Lienhard (1981) versam que a máxima pressão metaestável é também função da pressão de injeção. Sua correlação motivada pela teoria cinética de nucleação alcançou bons resultados em escoamentos com um fluido possuindo uma temperatura de injeção entre $62 \%$ e 93,5 \% da temperatura crítica e uma taxa de despressurização no bocal entre 405,3 e $182689 \mathrm{MPa} / \mathrm{s}$.

Uma análise indireta do valor da pressão metaestável foi feita por Kurschat e outros (1992). Seu modelo matemático, através da dimensão da onda de choque de seus registros fotográficos, determinava por meio indireto a pressão metaestável alcançada e, com isso, comparava com a vazão encontrada experimentalmente. Isto pode ser visto no gráfico da Fig. 1.25. A vazão experimental ficou abaixo da esperada, quando tomados os dados da pressão de injeção e pressão da câmara e propriedades termodinâmicas utilizando a equação de descarga do bocal adaptada para um escoamento de fluido incompressível (linha tracejada da Fig. 1.25). Este modelo matemático sugerido, que tem como dado a dimensão da onda de choque, melhorou esta estimativa da vazão (indicado pela linha contínua).

Simões-Moreira (1999) especulou que a pressão metaestável alcançada pelo fluido é obtida em um ponto de máximo quando é levantado o aumento de entropia multiplicado pelo fluxo superficial mássico da onda de evaporação. Sua análise foi baseada no fato de que ondas de evaporação apresentam uma solução singular conhecida como condição de Chapman-Jouguet (ver Capítulo 2), a qual também é um ponto de máximo local de entropia. No entanto, novos experimentos indicaram que a máxima geração de entropia para casos de jato evaporativo é apenas uma aproximação sem uma confirmação experimental definitiva.

Nos experimentos apresentados no Capítulo 4 uma proposta de análise será feita determinando se existe a blocagem da vazão com a diminuição progressiva da 
pressão da câmara, conforme o exemplo da Fig. 1.25, pois através da máxima vazão mássica é possível determinar a pressão metaestável que o líquido alcançou na saída do bocal ou mesmo, verificar se houve uma nucleação interna ao bocal.

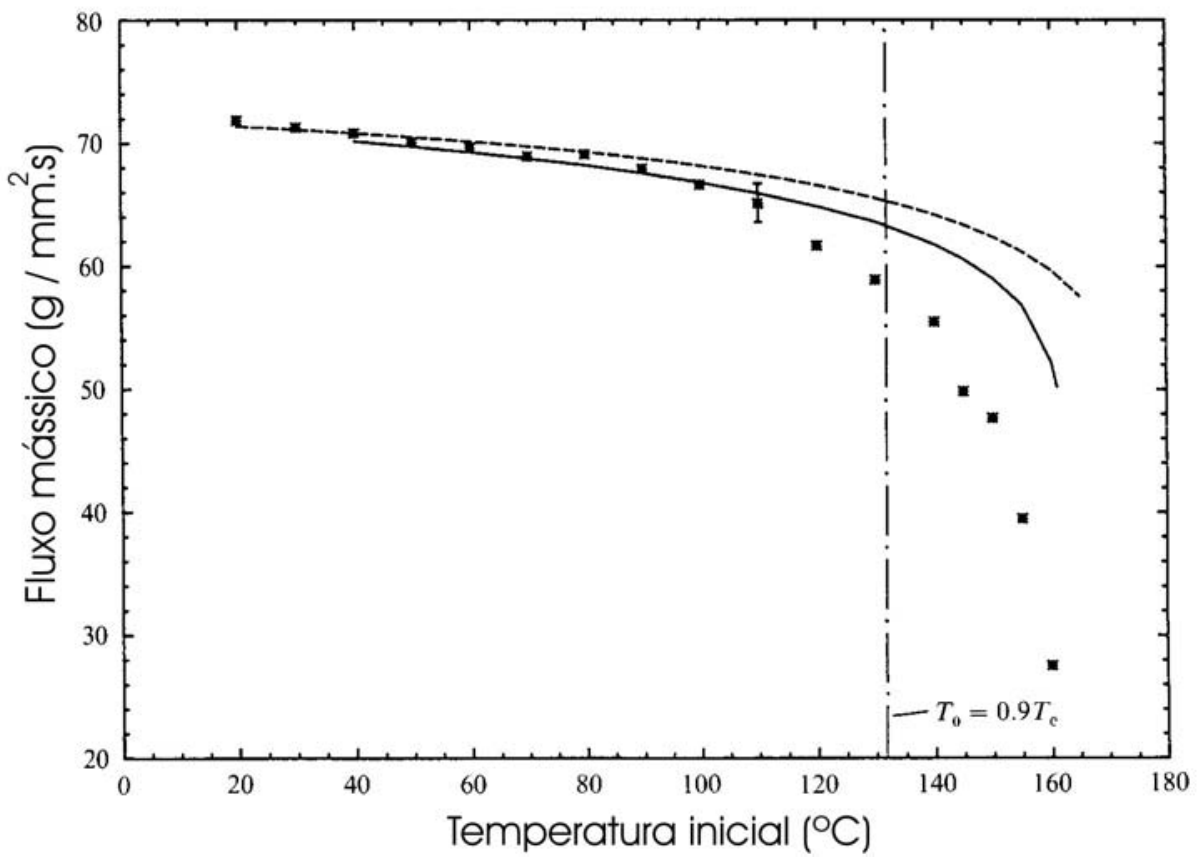

Figura 1.25 - Medições do fluxo mássico: - - - -, cálculo para incompressível (através da equação de Bernoulli); modelo de cálculo; *, resultados experimentais. $P_{0}=15$ bar e $P_{\infty}=10$ mbar (Kurschat e outros, 1992).

\subsubsection{Técnicas de Visualização Empregadas em Experimentos Anteriores}

O método óptico de interferometria usado por Kuschat e outros (1992) revelou imagens que destacaram principalmente a estrutura das ondas de choque, e o método "shadowgraph" (também usado por Kurschat e outros, 1992) destacava o comportamento das gotículas. O tempo de exposição de $10 \mu \mathrm{s}$ foi realizado em ambos os métodos. Conforme assinalado por Reitz (1990), o tempo de exposição da fotografia é fundamental para registrar a estrutura dos jatos evaporativos e, devido a isso, ele contesta as conclusões de Oza e Sinnamon (1983) que registraram o fenômeno com imagens de fotografias com tempo convencional de exposição, conseqüentemente, configuram uma pouca nitidez da estrutura do jato evaporativo. 
Reitz comparou fotografias de jatos evaporativos de água com intervalos de exposição de 1/250 $s$ (Fig. 1.26a) e $20 n s$ de exposição (Fig. 1.26b). As condições de ensaio são as mesmas, porém, o caso "b", é mais nítido, sendo possível observar um núcleo líquido e o desprendimento de gotículas, enquanto o primeiro caso oferece uma imagem com pouca nitidez. Isso leva a conclusão que a exposição de 1/250 sé um intervalo por demais grande para que a imagem possa captar detalhes dos processos de evaporação, e no segundo caso podem ser observadas imagens bem definidas que melhor registram o núcleo de líquido. Além de Reitz, Athans (1994) e Athans e Hirsa (1995) usaram o método de visualização de iluminação lateral do evento, conhecido na literatura inglesa de "side-lighting". Nesta, a fonte de luz incide na lateral e perpendicularmente ao eixo de visualização do jato. O método de iluminação por detrás do evento do jato em relação ao observador ("back-lighting") também foi empregado por eles. Athans e Hirsa também utilizaram o método de "laser sheet" que nada mais é que o método de iluminação lateral com o feixe luminoso de uma fonte "laser" em formato de lâmina que corta a seção do jato paralela ao eixo do mesmo (Fig. 1.4). Seus experimentos tinham um intervalo de exposição de $0,65 \mu$ s para o método de iluminação por detrás do jato e de $5 n s$ para os métodos de iluminação lateral e por lâmina de "laser".

a)

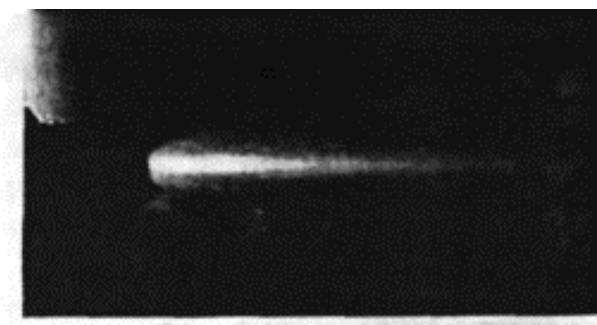

b)

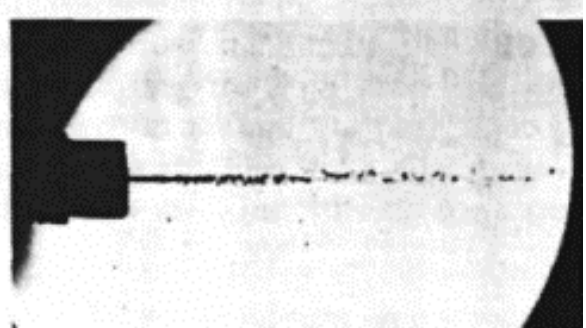

Figura 1.26 - Fotografia com (a) tempo de exposição de 1/250 $s$ com iluminação lateral e, (b) tempo de $20 \mathrm{~ns}$ com iluminação por detrás de um jato de água a uma temperatura de $146{ }^{\circ} \mathrm{C}$ e pressão de injeção de $697 \mathrm{kPa}$ descarregado em ambiente atmosférico (Reitz, 1990). 


\subsection{Objetivos}

Este trabalho experimental tem por objetivo principal o estudo de jatos evaporativos de líquidos superaquecidos expandindo em um ambiente de baixa pressão de forma que as condições de evaporação por rebaixamento de pressão, ou "flashing", fossem estabelecidas. Dentre os trabalhos que tratam sobre os jatos evaporativos, poucos observaram fenômenos compressíveis, como ondas de choque, porque isto só é permitido mediante o uso de técnicas especiais de visualização como o "Schlieren". Entretanto, nos poucos trabalhos existentes, se observa a existência de um núcleo de líquido, a partir do qual a evaporação ocorreria. Poucas informações ou mesmo análise sobre o comportamento deste núcleo foram efetuadas. Nessas observações também foi notada a condição de vazão mássica máxima, o que caracteriza a blocagem do escoamento.

Para o presente estudo, foi feita a escolha de um líquido de testes adequado às condições de pressões e temperaturas de trabalho. Além disto, optou-se por uma substância de complexidade molecular elevada, SCME, que pode alcançar uma taxa de evaporação maior que os demais fluidos comuns, como será visto na Subseção 2.1.1. Dentro destes requisitos, será utilizado o iso-octano, que é uma substância SCME, cujo grande potencial de evaporação permite uma documentação fotográfica do fenômeno com maior nitidez, especificamente, para os fenômenos como o núcleo de líquido e o escoamento supersônico.

Partindo destas considerações de um estudo experimental de jato evaporativo que preza pela visualização dos fenômenos de escoamento compressível e do núcleo líquido tem-se por objetivo:

1) documentar os diversos tipos ou regimes de jatos com registros fotográficos e analisá-los, verificando a influência das condições de injeção como: pressão inicial, temperatura inicial e pressão da câmara onde é descarregado o jato. A literatura indica que o jato de líquido assume um formato retilíneo, quando não há evaporação, sendo este um regime puramente hidrodinâmico. À medida que a pressão da câmara é ligeiramente abaixo da pressão de saturação existe a formação de pontos de nucleação quebrando o filete do líquido. Em estágios mais avançados, existe a formação de um núcleo de líquido a partir do qual a 
evaporação ocorre. Finalmente, em situações extremas de baixa pressão do ambiente em que o jato é descarregado, são visíveis ondas de choque. Objetiva-se estudar estes últimos dois regimes. Também é de interesse deste trabalho verificar peculiaridades pertinentes de cada tipo de jato, apresentando-as e descrevendo através de imagens fotográficas representativas;

2) certificar-se da estabilidade do núcleo de líquido, ou seja, através dos registros fotográficos, é verificada a repetibilidade do perfil axissimétrico do núcleo de líquido comprovando a inexistência de nucleações internas ao núcleo;

3) através do método "Schlieren", além de visualizar ondas de choque, tem-se por objetivo registrar o gradiente de densidade no escoamento após a evaporação do núcleo de líquido. A confirmação da presença de um núcleo de líquido com formato estável e o registro fotográfico da abrupta queda de densidade do fluido próximo do núcleo comprovam a existência de uma onda de evaporação seguida de um escoamento supersônico. É de interesse analisar de forma paramétrica as dimensões da onda de choque em função das condições de ensaio $\left(P_{0}, T_{0}\right.$ e $\left.P_{\infty}\right)$;

4) aplicar o método de iluminação por detrás (ou "backlightening") que visualiza com mais nitidez o núcleo de líquido e pode registrar a direção do escoamento das gotículas a partir da superfície do núcleo líquido. A observação da trajetória das gotículas compõe importante informação para a análise da modelagem da onda de evaporação na periferia do núcleo. Para o método "Schlieren" o tempo de exposição será de $2 \mu s$ e para o método de iluminação por detrás, será de $1000 \mu \mathrm{s}$. Filtragem matemática das imagens do jato através de processamento matemático serão utilizados para melhor destacar os fenômenos envolvidos em cada tipo de jato;

5) fazer um estudo do comportamento da vazão em função da pressão da câmara, para determinadas condições de injeção. Sob a análise de um escoamento incompressível internamente ao bocal, ou seja, sem uma evaporação nesta região de expansão, é provável que o líquido alcance a 
condição metaestável. E, através das condições de injeção, e da pressão metaestável calculada pela vazão mássica medida, pode-se calcular as condições a jusante da onda de evaporação. Com o uso da teoria de ondas de evaporação oblíquas, pretende-se aplicar os cálculos da onda de evaporação nestes jatos e estimar o comprimento de extinção do núcleo de líquido. Além disso, este trabalho realizará um estudo da pressão a jusante da onda de evaporação em virtude da influência do grau de metaestabilidade e da temperatura inicial do fluido será analisado e para tal fato, a seção seguinte propõe uma solução analítica para explicar a influência destes parâmetros;

6) apresentar um diagrama termodinâmico que indique todos os estados que o fluido obteve durante a injeção na câmara, em virtude da observação de uma expansão incompressível no interior do bocal, com a existência de um núcleo de líquido que possui uma evaporação em sua superfície, seguida de uma expansão bifásica com velocidade supersônica e a formação de uma onda de choque, como observado experimentalmente;

7) testar bocais de materiais distintos. Verificar a influência do acabamento superficial interno do bocal com o objetivo de analisar a possibilidade de nucleação interna nas paredes do bocal. Um bocal de material "liso", como o vidro reflete a preocupação da verificação da influência ou não de pontos de nucleação interna. Os outros bocais de aço podem apresentar uma evaporação interna ao bocal em virtude das ranhuras obtidas pelo acabamento da usinagem. Além disso, dimensões distintas das seções de saída dos bocais convergentes também devem ser analisadas.

\subsection{Divisão do trabalho}

O presente capítulo de introdução tem por objetivo discutir sobre o tema aqui estudado e fazendo uma revisão bibliográfica, colocando o problema em perspectiva.

No Capítulo 2, faz-se uma revisão teórica de assuntos pertinentes ao tema 
como: o comportamento dos líquidos (substâncias SCME), a influência do grau de metaestabilidade dos mesmos, o equacionamento de uma onda de evaporação e sua aplicação em jatos evaporativos através da teoria das ondas de evaporação oblíquas e, finalmente, é discutido sobre todo o processo termodinâmico associado a estes jatos evaporativos.

O Capítulo 3 apresenta uma descrição de todo o arranjo experimental, abordando a instalação, equipamentos, registro de dados e procedimentos nos ensaios.

O Capítulo 4 tem por objetivo mostrar dados obtidos e gráficos relevantes dos ensaios. A completa apresentação de dados e registros fotográficos de todos os ensaios pode ser vista nos Anexos B e C desta tese. Como observação, o Anexo A expõe as propriedades termodinâmicas do iso-octano nos estados de líquido e vapor saturados.

Uma análise mais aprofundada dos resultados obtidos é feita no Capítulo 5. Dos jatos obtidos são mostrados e comparados os perfis, as vazões, pressões metaestáveis, núcleo de líquido e onda de choque formada.

O Capitulo 6 descreve sobre a aplicação da teoria de ondas de evaporação nestes jatos, comparando os dados calculados com os resultados experimentais.

O Capítulo 7 versa sobre as possibilidades de continuidade deste trabalho e as conclusões gerais e específicas deste trabalho.

Após estes capítulos, estão em seqüência os três anexos já mencionados. Em seguida, está a lista de referências deste trabalho.

Em seguida é apresentada a análise de incerteza no Apêndice I. No Apêndice II, é mostrado o processamento de filtragem das imagens do jato. O Apêndice III apresenta o desenvolvimento de uma solução analítica para a onda de evaporação. $\mathrm{O}$ desenvolvimento do programa de aquisição de imagens da bancada experimental e algumas tentativas de técnicas ópticas são apresentados no Apêndice IV. Finalmente, alguns desenhos esquemáticos e fotografias da bancada experimental foram inseridos no Apêndice V. 


\section{TEORIA}

\subsection{A substância iso-octano}

A substância iso-octano, também chamada de 2,2,4 tri-metil-pentano, é um hidrocarboneto cuja fórmula química é representada por $\mathrm{C}_{8} \mathrm{H}_{18}$. As principais propriedades termodinâmicas e de transporte do líquido saturado, como volume específico, viscosidade dinâmica e pressão de vapor, que foram utilizadas ao longo deste trabalho, podem ser visualizados na Fig. 2.1. Outras propriedades como: massa molecular $(M)$, pressão crítica $\left(P_{\mathrm{c}}\right)$, temperatura crítica $\left(T_{\mathrm{c}}\right)$, volume crítico $\left(v_{\mathrm{c}}\right) \mathrm{e}$ fator de compressibilidade crítica $\left(Z_{\mathrm{c}}\right)$ e, finalmente, temperatura de ebulição à pressão normal de 101,325 kPa $\left(T_{\mathrm{b}}\right)$, estão mostradas na Tab. 2.1, respectivamente.

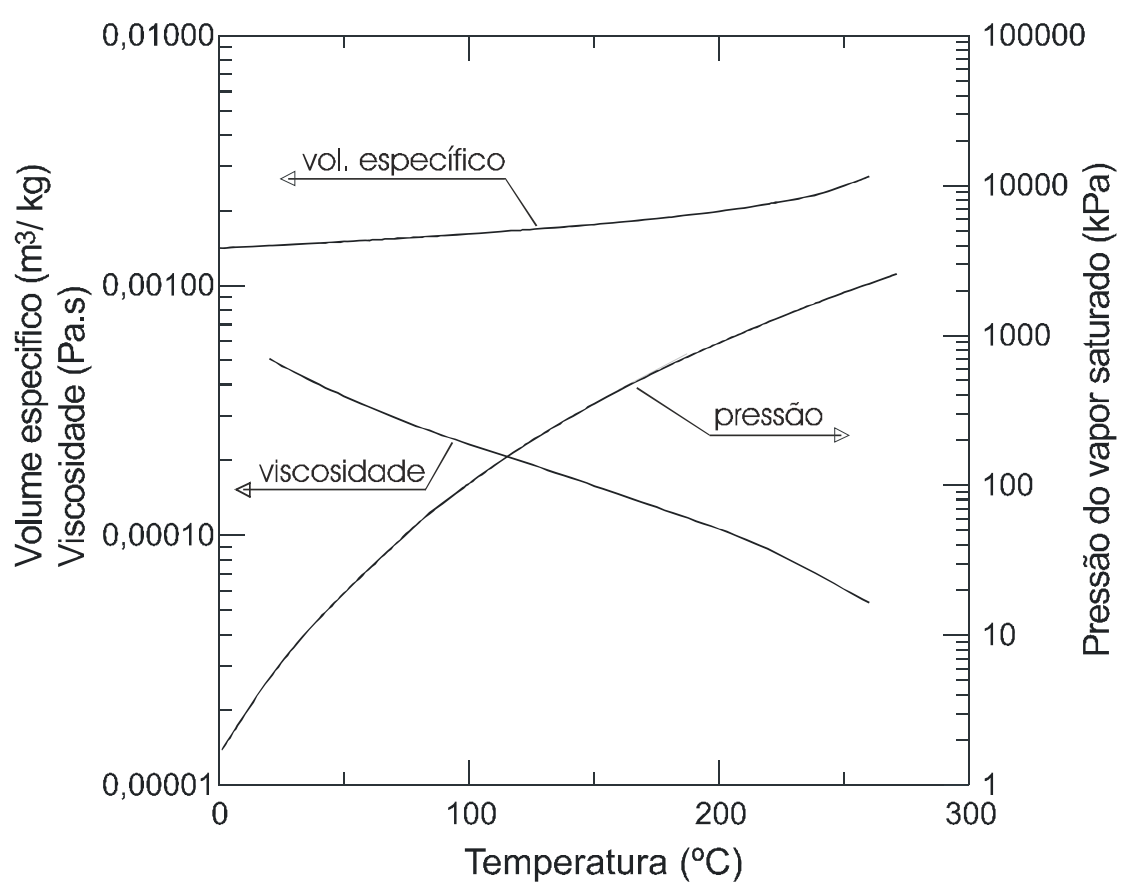

Figura 2.1 - Gráficos com dados relevantes do líquido saturado iso-octano em função da temperatura. Os dados são: volume específico, viscosidade dinâmica e pressão de vapor (Vargaftik, 1996). 
Tabela 2.1 - Tabela comparativa das propriedades termodinâmicas de alguns líquidos.

\begin{tabular}{llcccccc}
\hline Substância & Fórmula & $\begin{array}{c}M \\
(\mathrm{~g} / \mathrm{gmol})\end{array}$ & $\begin{array}{c}P_{\mathrm{c}} \\
(\mathrm{MPa})\end{array}$ & $\begin{array}{c}T_{\mathrm{c}} \\
\left({ }^{\circ} \mathrm{C}\right)\end{array}$ & $\begin{array}{c}v_{\mathrm{c}} \\
\left(\mathrm{m}^{3} / \mathrm{kg}\right)\end{array}$ & $Z_{\mathrm{c}}$ & $\begin{array}{c}T_{\mathrm{b}} \\
\left({ }^{\circ} \mathrm{C}\right)\end{array}$ \\
\hline \hline Iso-octano & $\mathrm{C}_{8} \mathrm{H}_{18}$ & 114,2 & 2,58 & 271,0 & 0,004219 & 0,259 & 99,2 \\
Metano & $\mathrm{CH}_{4}$ & 16,0 & 4,61 & $-82,9$ & 0,006147 & 0,287 & $-162,2$ \\
Água & $\mathrm{H}_{2} \mathrm{O}$ & 18,0 & 22,1 & 374,1 & 0,003155 & 0,235 & 100,0 \\
N-dodecano & $\mathrm{C}_{12} \mathrm{H}_{26}$ & 170,3 & 18,3 & 385,1 & 0,004216 & 0,238 & 216,4 \\
\hline
\end{tabular}

Tabela 2.2 - Valores da tensão superficial em função da temperatura. Os valores para as temperaturas de 20 e $90{ }^{\circ} \mathrm{C}$ são obtidos por Vargaftik (1996), e para temperaturas acima, são estimados através de polinômio.

\begin{tabular}{lccc}
\hline Temperatura & $20^{\circ} \mathrm{C}$ & $90^{\circ} \mathrm{C}$ & $180^{\circ} \mathrm{C}$ \\
\hline \hline Tensão Superficial $(\mathrm{N} / \mathrm{m})$ & 0,0188 & 0,0127 & 0,00546 \\
\hline
\end{tabular}

A Tab. 2.2 tem o objetivo de mostrar os valores da tensão superficial do isooctano líquido e saturado que possui um comportamento de proporcionalidade linear com a temperatura.

Uma tabela mais completa sobre as propriedades termodinâmicas do isooctano, na condição de saturação, está no Anexo A.

\subsubsection{Comportamento da Substância SCME}

A possibilidade de uma completa mudança de fase, de forma quase adiabática, está intimamente relacionada a certos fluidos denominados SCME Substância de Complexidade Molecular Elevada (na literatura inglesa é chamado de "retrograde", Thompson e Sulivan, 1975), que apresentam uma grande potencialidade de armazenar energia interna devido ao seu elevado calor específico adimensional, conforme definido por Thompson e Sulivan (1975) e indicado a seguir. Tomando como exemplo o n-dodecano, esta substância possui um alto valor de calor específico adimensional e, com isto, seu comportamento se diferencia das substâncias simples comuns, como a água, como é mostrado no diagrama temperatura-entropia específica da Fig. 2.2. Pode-se notar que o ramo de vapor da curva de saturação é inclinado para a direita.

Experimentos foram realizados no sentido de simular este processo com estes 
fluidos. Simões Moreira (1994) e Simões Moreira e Shepherd (1993 e 1999), demonstraram a possibilidade da completa evaporação em n-dodecano, uma substância SCME.

Um parâmetro que caracteriza estas substâncias é o calor específico adimensional $\tilde{c}_{v}$ que é a razão de $c_{v} / \bar{R}$ cujo numerador refere-se ao calor específico a volume constante e $\bar{R}$ é a constante universal dos gases. O limiar entre uma substância SCME e um fluido comum é dado por $\widetilde{c}_{v}=11$ (Lambrakis, 1972), que é a condição em que existe uma porção vertical da linha de saturação de vapor do diagrama temperatura - entropia específica, como ocorre com a substância isooctano. Observando a Fig. 2.2, nota-se que o fluido no estado inicial de líquido pode, através de um processo isoentrópico, sofrer uma evaporação completa. Estudos de Shepherd e outros (1989), determinaram que os fluidos com o valor de $\widetilde{c}_{v}>33$ podem em princípio, sofrer esta completa evaporação de forma adiabática. A substância iso-octano também possui esta característica, como se vê na Fig. 2.2.

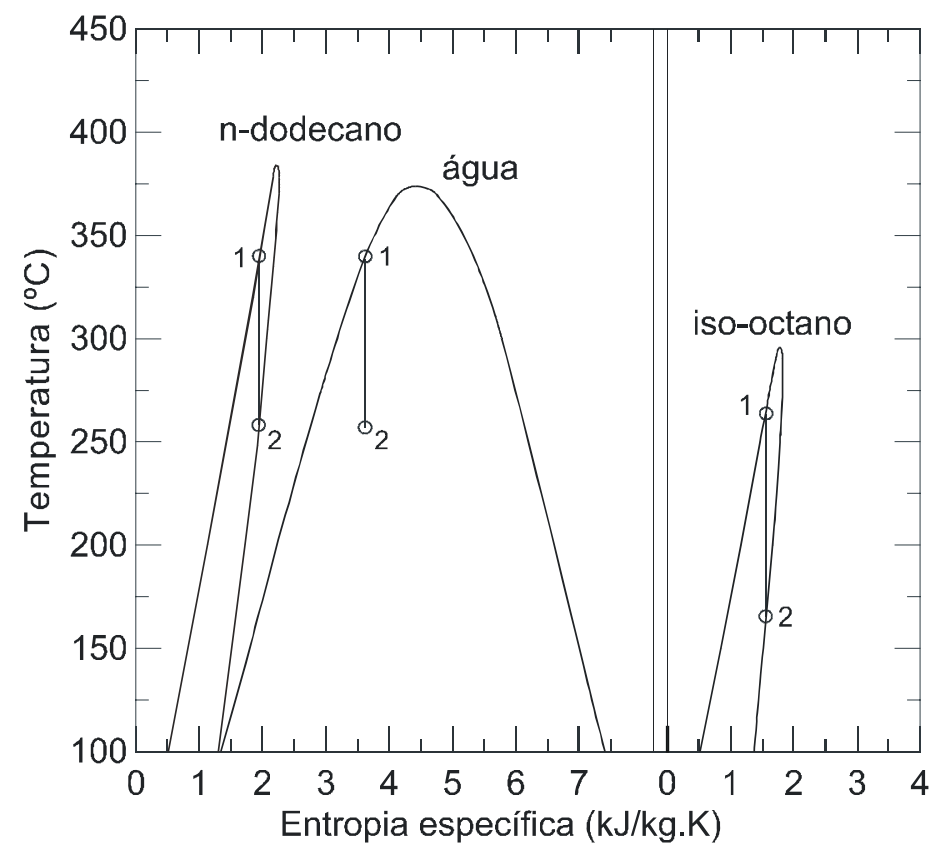

Figura 2.2 - Diagrama T-s de uma substância SCME (n-dodecano e iso-octano) e uma substância simples (água).

Neste trabalho, foi utilizada a substância iso-octano $\left(\mathrm{C}_{8} \mathrm{H}_{18}\right)$, que é uma substância SCME. Isto é interessante porque a possibilidade de uma taxa elevada de 
evaporação do jato oferece a oportunidade de uma melhor visualização da porção líquida que está em seu eixo axial, além da análise da estrutura de escoamento e a presença de ondas de choque.

\subsubsection{O Limite de Metaestabilidade do Líquido}

Pelo equilíbrio termodinâmico estável em uma interface líquido-vapor plana, uma substância pura alcançando a linha de saturação iniciaria um processo de mudança de fase. No entanto, por exemplo, uma substância no estado líquido saturado pode ter sua temperatura aumentada a uma pressão constante, adentrando na região de saturação, e, ainda assim, permanecer no estado de líquido, que é o que caracteriza a metaestabilidade. Tal comportamento ocorre em sistemas simples devido à ausência de forças externas ou efeitos de superfície. O estado metaestável pode ser alcançado por vários processos, como, por exemplo: no processo isobárico o líquido metaestável sofre um aumento de temperatura a uma pressão constante. No processo isotérmico um decréscimo de pressão é realizado mantendo a sua temperatura constante. Finalmente, para o processo adiabático reversível, existe um decréscimo de temperatura onde a sua entropia se mantém constante.

A metaestabilidade tem um limite, também conhecido como limite de superaquecimento. Sob o critério termodinâmico, este limite de metaestabilidade se encontra quando

$$
\left.\frac{\partial P}{\partial v}\right|_{T}=0
$$

ou seja, sob uma linha isotérmica do fluido quando a derivada da pressão $(P)$ em função do volume específico (v) é nulo. Este limite é chamado de limite de estabilidade mecânica.

Isto também acontece no fluido no estado de vapor. Neste caso, o vapor metaestável é também chamado de vapor subresfriado. $\mathrm{O}$ conjunto dos pontos que consistem no limite de metaestabilidade das várias isotérmicas formam a curva espinodal, no diagrama de $P$-v. A Fig. 2.3 ilustra um diagrama pressão-volume específico com a curva de saturação característica. A região escura destacada representa a região de estado metaestável, delimitado pela curva de saturação e a curva espinodal, sendo, a região esquerda associada à metaestabilidade de líquido e a 
direita ao subresfriamento do vapor.

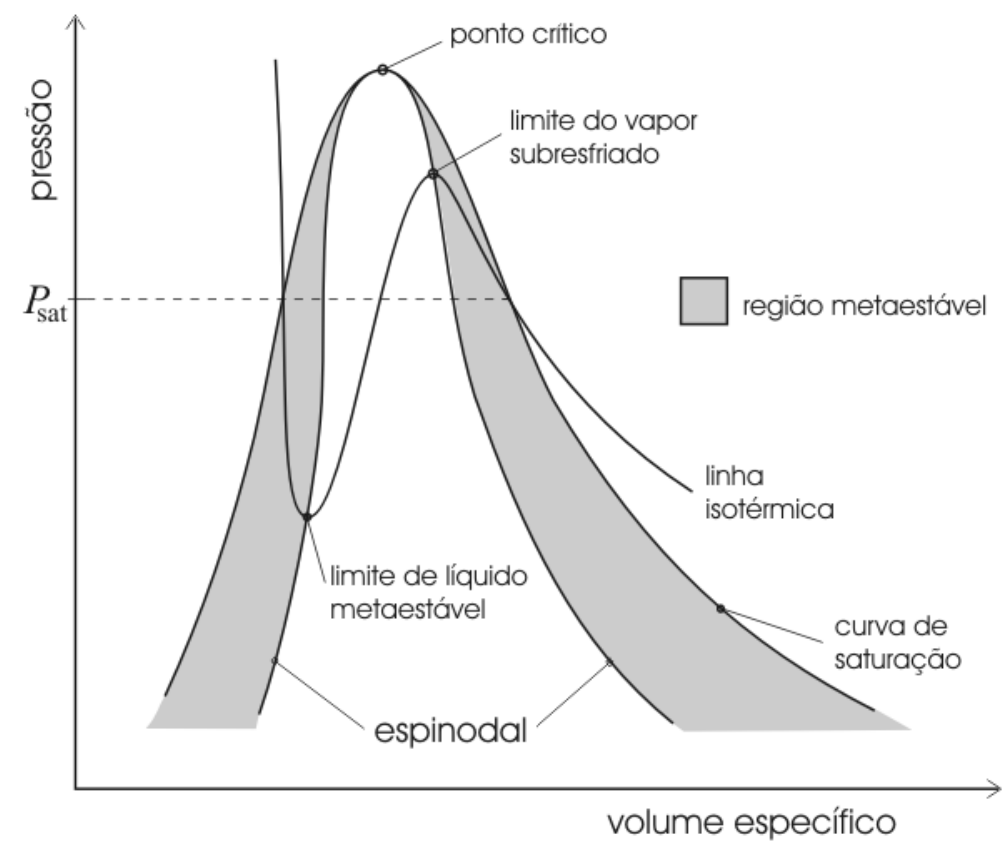

Figura 2.3 - Representação da região metaestável de um fluido em diagrama temperatura - volume específico (Simões-Moreira, 1994).

Para que não haja nucleação homogênea, é necessário conhecer o máximo grau de metaestabilidade que o líquido alcançou e, se esta condição não coincide com o ponto espinodal. Para o cálculo do limite de metaestabilidade do líquido, aqui é utilizada a teoria cinética clássica de nucleação. $O$ limite cinético de metaestabilidade é associado com a probabilidade de formação de nucleação homogênea em todo o volume do líquido. Pela teoria cinética de nucleação (Carey, 1994), define-se a taxa de nucleações do vapor crítico por unidade de volume $J_{n}$, como

$$
J_{n}=N_{0}\left(\frac{3 \sigma}{\pi m}\right)^{1 / 2} \exp \left(\frac{-16 \pi \sigma^{3}}{3 k T\left(P_{V}-P_{L}\right)^{2}}\right),
$$

sendo, $N_{0}$ é o número da densidade molecular do líquido $\left(N_{0}=N_{A} / v_{L} M\right), N_{A}$ é o número de Avogadro $\left(6,02 \times 10^{26}\right.$ moléculas $\left./ \mathrm{kg}-\mathrm{mol}\right), M$ é a massa molecular $(\mathrm{kg} / \mathrm{kg}$ $\mathrm{mol}), v_{L}$ é o volume específico do líquido $\left(\mathrm{m}^{3} / \mathrm{kg}\right), \sigma$ é a tensão superficial $(\mathrm{N} / \mathrm{m}), m$ é a massa de uma simples molécula de líquido $\left(m=M / N_{A}\right), k$ é a constante de Boltzmann $\left(1,3805 \times 10^{-23} \mathrm{~J} / \mathrm{K}\right), P_{v}$ é a pressão interna da nucleação de vapor $(\mathrm{Pa}), P_{L}$ 
é a pressão do líquido, e $T$ é a temperatura do líquido (K). Usando a hipótese de gás perfeito para a fase vapor, pode-se mostrar (Carey, 1994) que

$$
P_{V} \cong P_{s a t}(T) \exp \left(\frac{v_{L}\left(P_{L}-P_{s a t}(T)\right)}{R T}\right),
$$

onde $R$ é constante do gás $(R=\bar{R} / M)$, e $\bar{R}$ é a constante universal dos gases $(8,314$ $\mathrm{J} / \mathrm{mol} . \mathrm{K})$. Carey (1994) sugere que valores de $J_{\mathrm{n}}$ acima de $10^{12}$ nucleações. $\mathrm{s}^{-1} \cdot \mathrm{m}^{-3}$ promovem a nucleação homogênea.

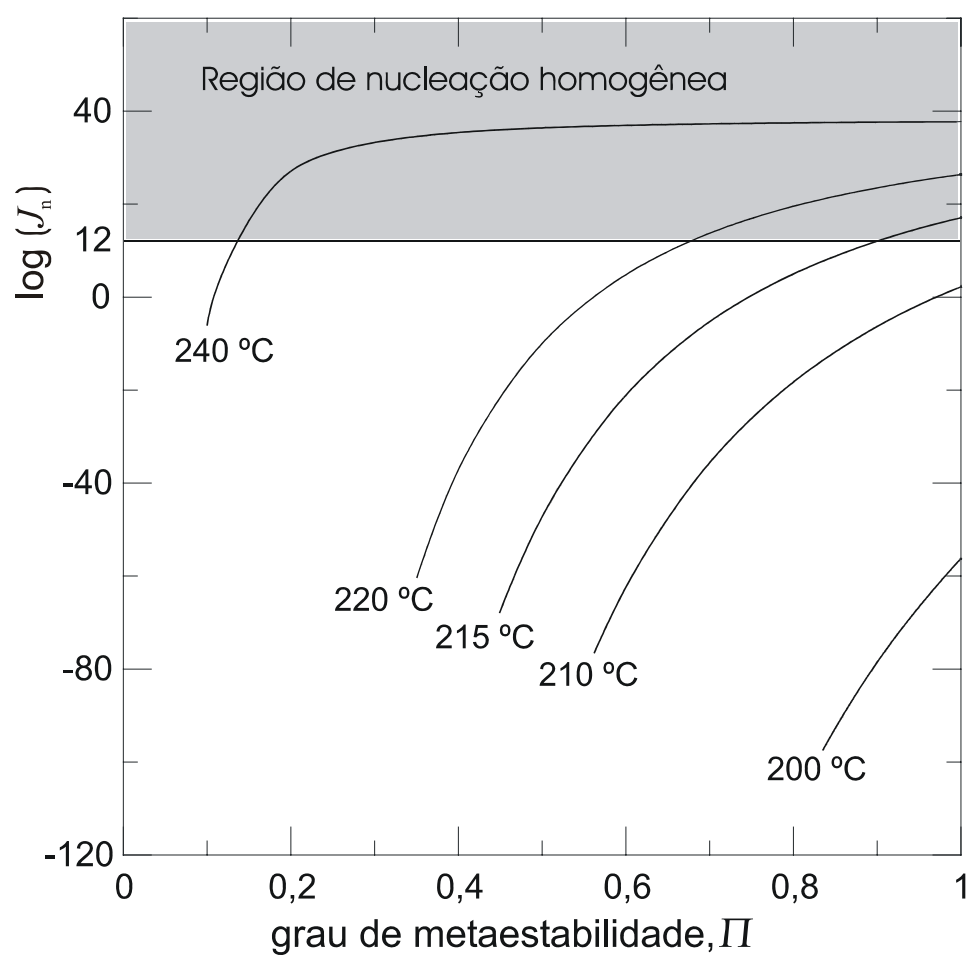

Figura 2.4 - Taxa de densidade de nucleações, $J_{n}$, em função do grau de metaestabilidade, $\Pi$, do iso-octano.

Fazendo um estudo da taxa de nucleação de vapor em função do grau de metaestabilidade, $\Pi$, definido por

$$
\Pi=\frac{P_{\text {sat }}-P_{1}}{P_{\text {sat }}}
$$

sendo $P_{\text {sat }}$, a pressão de saturação e $P_{1}$ é a pressão metaestável da iso-octano, é verificada uma curva desta taxa de nucleação de vapor em função do grau de 
metaestabilidade representada pelo gráfico da Fig. 2.4. Na figura verifica-se que não é esperada uma nucleação homogênea em temperaturas abaixo de $210^{\circ} \mathrm{C}$ do líquido, conseqüentemente, também não devem ocorrer nos ensaios aqui realizados, pois se encontram com temperaturas abaixo de $180{ }^{\circ} \mathrm{C}$ ( $83 \%$ da temperatura crítica). Em alguns ensaios de Athans (1995), que são citados, a temperatura máxima de injeção alcançou o valor de $226{ }^{\circ} \mathrm{C}$, que está a $92 \%$ da temperatura crítica.

\subsection{Ondas de Evaporação}

Esta seção tem o objetivo de apresentar a teoria de ondas de evaporação. $\mathrm{Na}$ modelagem deste tipo de evaporação, é assumido que o fenômeno é uma descontinuidade no escoamento como acontece em reações químicas de combustão do tipo de deflagração.

Aqui é imaginado o líquido no estado metaestável adentrando uma onda de evaporação estacionária, à sua montante (índice “1"). Após o líquido passar pela onda, assume outro estado termodinâmico (índice "2") em um processo parcial de evaporação adiabático. As equações de continuidade, de conservação de quantidade de movimento e de energia, para o modelo de volume de controle unidimensional da Fig. 2.5, são:

$$
\begin{aligned}
& {[J]=0,} \\
& {\left[P+\frac{W^{2}}{v}\right]=0, \mathrm{e}} \\
& {\left[h+\frac{1}{2} W^{2}\right]=0,}
\end{aligned}
$$

onde, o termo $J$ significa a vazão mássica superficial $(J=W / v)$; $P$ é a pressão; $v$ é o volume específico; $h$ é a entalpia específica e $W$ é a velocidade relativa do fluido, em seus respectivos estados. Os colchetes representam a diferença da propriedade entre os estados a jusante e a montante da grandeza inclusa, isto é, $[f]=f_{2}-f_{1}$. 


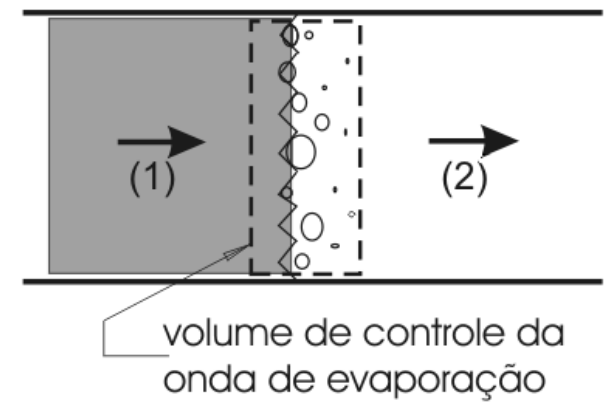

Figura 2.5 - Volume de controle englobando uma onda de evaporação. Estado "1" é o líquido metaestável e o estado "2" é a mistura bifásica.

Combinando as equações (2.5), (2.6) e (2.7), pode-se obter as equações clássicas de Rankine-Hugoniot (Eq. 2.8) e Rayleigh (Eq. 2.9).

$$
\begin{aligned}
& {[h]=\frac{1}{2}\left(v_{1}+v_{2}\right) \cdot[P], \mathrm{e}} \\
& J^{2}=-\frac{[P]}{[v]} .
\end{aligned}
$$

A representação da curva de Rankine-Hugoniot a partir de um estado (1) metaestável é a curva da Fig. 2.6, com a identificação $R-H$. A curva de Rayleigh é uma linha reta, e está representada pela curva genérica $R$, que possui os pontos $A$ e $B$ na interceptação da curva $R-H$ ilustrado na Fig. 2.6. A inclinação desta linha corresponde ao valor do quadrado da vazão mássica que encontra seu valor máximo quando a reta da linha de Rayleigh tangencia a curva de Rankine-Hugoniot, no ponto $C$, representada pela reta $R^{\prime}$, cuja solução é chamada de condição de ChapmanJouguet (ou simplesmente, $C J$ ), e corresponde à condição sônica em fenômenos de combustão. Soluções encontradas à direita do ponto $C$ são condições supersônicas e são descartadas em experimentos unidimensionais. Hill e Sturtevant (1990) e Simões-Moreira (1994), confirmaram a existência do ramo subsônico e verificaram a ocorrência da existência do ponto $C$, em experimentos com ondas evaporativas. 


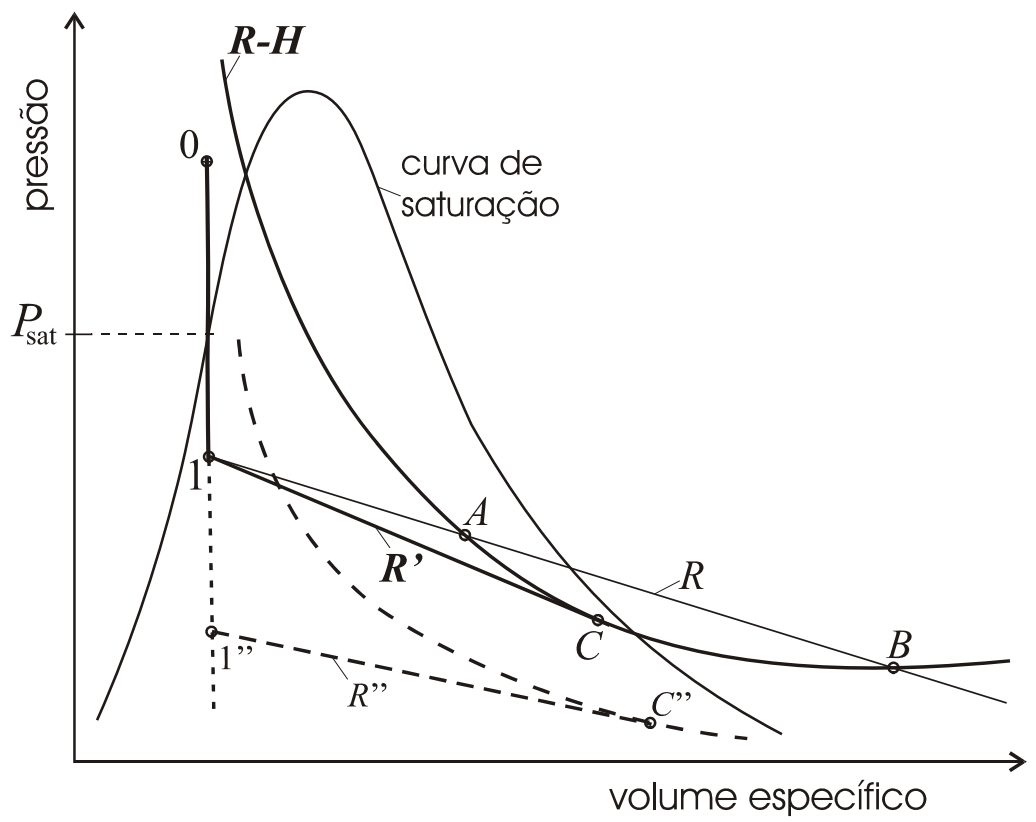

Figura 2.6 - Representação das curvas de Rankine-Hugoniot $(R-H)$ e de Rayleigh $(R)$ em uma evaporação. O ponto " $C$ " corresponde à condição de Chapman-Jouguet referente ao estado " 1 ".

A condição de Chapman-Jouguet aqui assume fundamental importância como solução chave para explicar a existência do escoamento supersônico na evaporação do núcleo. Assim como ocorre em um bocal convergente-divergente que possui em sua entrada um escoamento inicialmente subsônico alcançando a velocidade sônica na restrição podendo assumir um escoamento supersônico, dependendo da pressão a jusante, a mistura bifásica com velocidade sônica também provém da onda de evaporação. Esta velocidade sônica da mistura é determinada pela condição de Chapman-Jouguet e, por analogia, a superfície evaporativa do núcleo de líquido seria a área de restrição do bocal convergente-divergente.

Como visto, a solução de Chapman-Jouguet depende das condições de injeção $\left(P_{0}\right.$ e $\left.T_{0}\right)$ e da pressão metaestável $\left(P_{1}\right)$. A Fig. 2.6 também mostra esquematicamente uma solução de Chapman-Jouguet para uma pressão menor que o estado 1 (ponto 1”). Pela Eq. (2.9), a tangente da curva corresponde à própria vazão superficial e, na figura, a curva de Rayleigh, $R$ ”, deste novo ponto é menos inclinada que a curva $R$ ', mostrando esquematicamente a diminuição da vazão mássica superficial sônica, $J_{\mathrm{CJ}}$, com o aumento do grau de metaestabilidade. Esta diminuição da vazão superficial foi comprovada através dos resultados obtidos por Simões- 
Moreira (1999) e Simões-Moreira e Bullard (2003). O primeiro trabalho conduz simulações da onda de evaporação com iso-octano, e o segundo utiliza fluidos refrigerantes como: R22, R134a e R600a.

Quando a evaporação não é completa, algo comum para a grande maioria dos casos, é conveniente reescrever a equação de Rankine-Hugoniot (Eq. 2.8) para isolar o título $\left(x_{2}\right)$ da mistura e deixá-lo dependente das propriedades termodinâmicas inicias e de saturação após a onda (Simões-Moreira, 1999), logo

$$
x_{2}=\frac{2\left(h_{1}-h_{\mathrm{L} 2}\right)+\left(P_{2}-P_{1}\right)\left(v_{1}+v_{\mathrm{L} 2}\right)}{2 h_{\mathrm{LV} 2}-\left(P_{2}-P_{1}\right) v_{\mathrm{LV} 2}},
$$

onde os índices "L" e "V" indicam as fases líquida e vapor e o índice "LV" é denominado para a diferença de valor da propriedade entre a fase vapor e a fase líquida.

Através da Eq. (2.10) e da condição de Chapman-Jouguet da Eq. (2.9), foi realizado um levantamento da curva da razão de pressões a jusante e a montante da onda de evaporação em função do grau de metaestabilidade (Eq. 2.4), como está exposto na Fig.2.7. Todas as curvas estão em função da temperatura inicial, $T_{0}$, do líquido. A pressão de estagnação, $P_{0}$, é igual à pressão de saturação, $P_{\text {sat }}\left(T_{0}\right)$. As informações das propriedades termodinâmicas da saturação obtidas para o cálculo destas curvas estão no Anexo A. Todas as propriedades foram determinadas por interpolação.

$\mathrm{Na}$ Fig. 2.7, é visto que as curvas estão muito próximas permitindo a conclusão que a temperatura tem um efeito relativamente fraco sobre a intensidade da onda. Embora não estejam apresentadas neste gráfico, temperaturas de 0 e $220{ }^{\circ} \mathrm{C}$ também estariam dentro da tendência mostrada por estas curvas. Neste caso, foram representadas aquelas utilizadas nos experimentos.

As temperaturas de 162 e $178{ }^{\circ} \mathrm{C}$ são as únicas daquelas apresentadas no gráfico que podem ter evaporação completa com graus de metaestabilidade elevado, iguais a 0,99 e 0,96, respectivamente, para uma razão de pressões igual a 0,50, praticamente. Simões-Moreira (1998) realizou cálculos com ondas cujos fluidos teriam a completa evaporação quando a razão entre as pressões era

$$
\frac{P_{2}}{P_{1}}=\frac{1}{1+\gamma},
$$


onde $\gamma$ é a razão entre os calores específicos à pressão e à volume constantes. Para o iso-octano, este valor é de 1,035. Necessariamente, esta regra é válida quando o vapor tem um comportamento de gás perfeito, pois esta igualdade é encontrada quando se substitui da velocidade sônica do gás perfeito (c) na Eq. (2.9), com a expressão

$$
J_{C J}=\frac{c_{2}}{v_{2}}=\frac{\sqrt{\gamma \cdot P_{2} \cdot v_{2}}}{v_{2}} .
$$

Por outro lado, sob uma temperatura inicial de $56{ }^{\circ} \mathrm{C}$, quando seu grau de metaestabilidade se aproxima do valor unitário, o título de vapor não é maior que a $55,05 \%$.

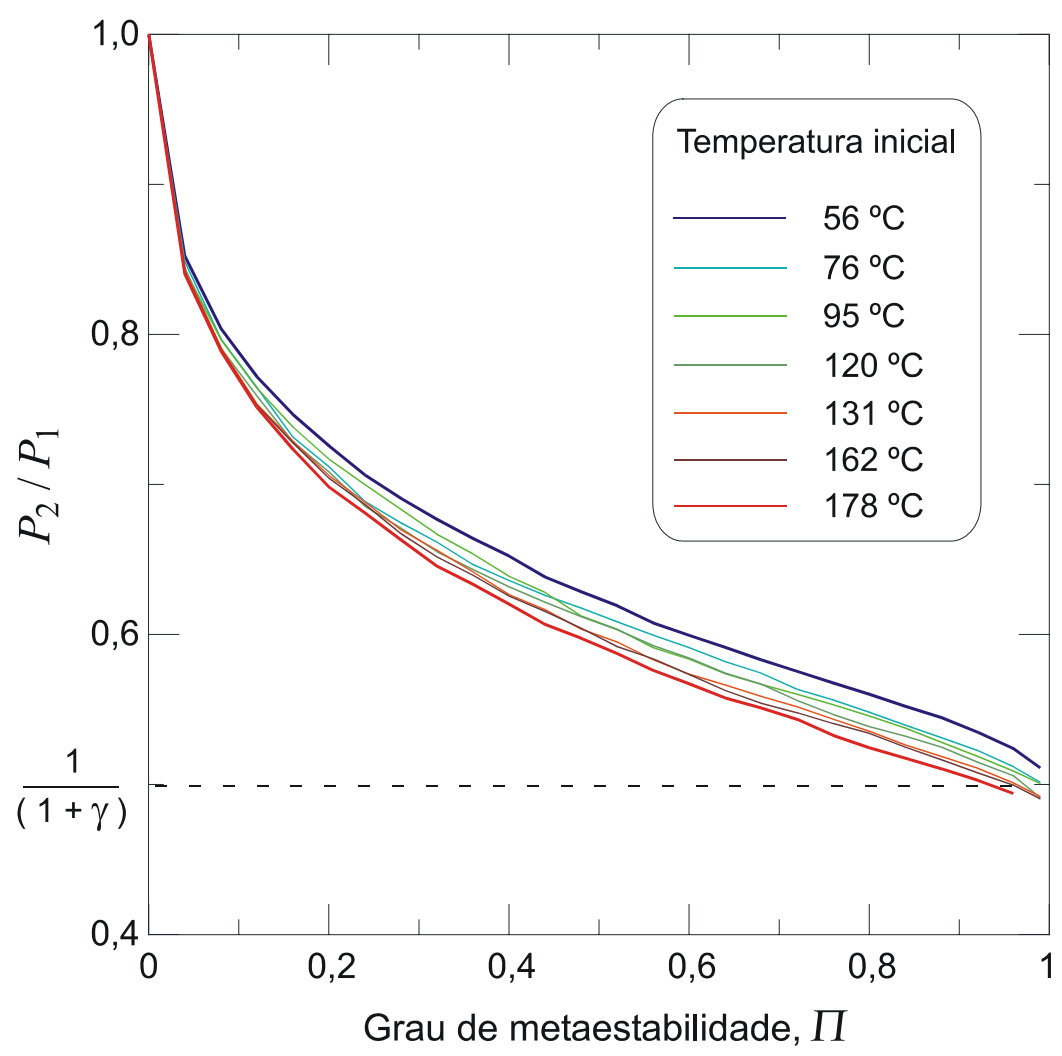

Figura 2.7 - Representação do comportamento da razão de pressões a jusante e a montante da onda de evaporação em função do grau de metaestabilidade do isooctano. 


\subsection{Solução Analítica Proposta para Determinação da Pressão a Jusante em Função do Grau de Metaestabilidade}

A semelhança das curvas existente no gráfico da Fig. 2.7 estimulou este estudo do comportamento da razão das pressões a jusante e montante da onda em função do grau de metaestabilidade. Inicialmente, aproximou-se a curva de saturação pela seguinte expressão simplificada de Clausius-Clapeyron na forma integrada:

$$
\ln \left(P_{\text {sat }}\right)=A-\frac{B}{T_{0}},
$$

sendo $A$ e $B$ constantes, a derivada da pressão de saturação em função da temperatura para esta equação é:

$$
\left(\frac{d P}{d T}\right)_{\text {sat }}=B \frac{P_{\text {sat }}}{T_{\text {sat }}^{2}}
$$

Como hipótese simplificadora, a jusante da onda, o fluido forma uma mistura bifásica ou, pelo menos, está na condição de vapor saturado para completa evaporação, e nesta condição, a temperatura a jusante pode ser escrita como: $T_{2}=B /\left(A-\ln \left(P_{2}\right)\right)$. Segundo Abbot (1989), utilizando a equação de Clapeyron, $\left(\frac{d P}{d T}\right)_{s a t}=\frac{\Delta h_{L V}}{T_{s a t} . \Delta v_{L V}}$, na Eq. (2.14), tem-se:

$$
\frac{\Delta h_{L V 2}}{\Delta v_{L V 2}}=B \frac{P_{2}}{T_{2}}
$$

Simões-Moreira (1994) sugere o emprego do calor específico do líquido $\left(C p_{\mathrm{L}}\right)$, na condição de saturado. Aplicando este parâmetro, a diferença entre as entalpias a jusante e a montante pode ser reescrita como:

$$
h_{2}-h_{1}=C p_{L}\left(T_{2}-T_{0}\right)+x_{2} \cdot \Delta h_{L V 2}=C p_{L}\left(T_{2}-T_{0}\right)+\frac{v_{2}-v_{2 L}}{\Delta v_{L V 2}} \cdot \Delta h_{L V 2}
$$

Para a equação anterior também foi admitido que a temperatura inicial é igual a temperatura a jusante da onda. Se admitir que o volume específico do líquido a jusante e a montante são iguais $\left(v_{2 L}=v_{1}\right)$, substituindo a Eq. (2.15) em (2.16), substituindo as temperaturas envolvidas através da expressão da Eq. (2.13), e aplicando-as na equação de Rankine-Hugoniot, o volume específico a jusante será: 


$$
\begin{gathered}
v_{2}=\frac{C p_{L} B\left(\ln \left(P_{\text {sat }}\right)-\ln \left(P_{2}\right)\right)}{P_{2}\left(A-\ln \left(P_{\text {sat }}\right)\right)\left(A-\ln \left(P_{2}\right)\right)\left(\left(A-\ln \left(P_{2}\right)\right)+\frac{1}{2} \frac{P_{1}}{P_{2}}-\frac{1}{2}\right)}+ \\
\quad \frac{\left(\left(A-\ln \left(P_{2}\right)\right)-\frac{1}{2} \frac{P_{1}}{P_{2}}+\frac{1}{2}\right)}{\left(\left(A-\ln \left(P_{2}\right)\right)+\frac{1}{2} \frac{P_{1}}{P_{2}}-\frac{1}{2}\right)} v_{1}
\end{gathered}
$$

Para pequenos graus de metaestabilidade, o fator que multiplica $v_{1}$, no segundo termo da soma desta equação, é praticamente igual a 1. Quando se aumenta o grau de metaestabilidade, este fator decresce pouco e o primeiro termo da expressão, cresce exponencialmente. Para maiores detalhes, o Apêndice III detalha melhor o comportamento destes dois termos. É interessante que a equação é dependente apenas da pressão, $P_{2}$, e ela pode ser reescrita como:

$$
v_{2} \cong \frac{C p_{L} B\left(\ln \left(P_{s a t}\right)-\ln \left(P_{2}\right)\right)}{P_{2}\left(A-\ln \left(P_{s a t}\right)\right)\left(A-\ln \left(P_{2}\right)\right)\left(\left(A-\ln \left(P_{2}\right)\right)+\frac{1}{2} \frac{P_{1}}{P_{2}}-\frac{1}{2}\right)}+v_{1}
$$

Aplicando a equação de Rankine (Eq. 2.9), para a condição de ChapmanJouguet $\left(\mathrm{d} J^{2}=0\right)$, é desenvolvida a seguinte identidade:

$$
\frac{\mathrm{d} v_{2}}{\mathrm{~d} P_{2}}=\frac{v_{2}-v_{1}}{P_{2}-P_{1}}
$$

Combinando esta última expressão com a Eq. (2.18) e sua derivada, e sabendo que $P_{1}=P_{\text {sat. }}(1-\Pi)$, é obtida a seguinte expressão:

$$
\begin{aligned}
& 1-2 \frac{P_{2}}{P_{1}}-\frac{1-\frac{P_{2}}{P_{1}}}{\ln (1-\Pi)+\ln \left(\frac{P_{2}}{P_{1}}\right)}-\frac{1-\frac{P_{2}}{P_{1}}}{\frac{B}{T_{0}}-\ln (1-\Pi)-\ln \left(\frac{P_{2}}{P_{1}}\right)} \\
& +\frac{\left(1-\frac{P_{2}}{P_{1}}\right)\left(-1-\frac{1}{2} \frac{P_{1}}{P_{2}}\right)}{\frac{B}{T_{0}}-\ln (1-\Pi)-\ln \left(\frac{P_{2}}{P_{1}}\right)-\frac{1}{2}+\frac{1}{2} \frac{P_{1}}{P_{2}}}=0
\end{aligned}
$$

Como estudo desta solução, serão estudados os fluidos: iso-octano, água, R22, R134a e R600a (iso-butano). Os três últimos foram pesquisados por SimõesMoreira e Bullard (2003). Todos usam a pressão inicial igual à pressão de saturação a uma temperatura inicial de $40{ }^{\circ} \mathrm{C}\left(T_{0}=313,2 \mathrm{~K}\right)$. A constante $B$ será calculada 
através da Eq. (2.15) e dos dados de saturação à temperatura de $20{ }^{\circ} \mathrm{C}$ apresentados na Tab. 2.3.

Tabela 2.3 - Propriedades termodinâmicas dos fluidos para temperatura inicial de $40{ }^{\circ} \mathrm{C}$ e para determinação da constante $B$ a $20^{\circ} \mathrm{C}$ através da Eq. (2.14).

\begin{tabular}{lcccccrc}
\hline Fluido & $\begin{array}{c}P_{\text {sat }} \\
\left(40{ }^{\circ} \mathrm{C}\right) \\
{[\mathrm{Pa}]}\end{array}$ & $\begin{array}{c}v_{1} \\
\left(40{ }^{\circ} \mathrm{C}\right) \\
{\left[\mathrm{m}^{3} / \mathrm{kg}\right]}\end{array}$ & $\begin{array}{c}P_{\text {sat }} \\
\left(20{ }^{\circ} \mathrm{C}\right) \\
{[\mathrm{Pa}]}\end{array}$ & $\begin{array}{c}v_{\mathrm{V}} \\
\left(20{ }^{\circ} \mathrm{C}\right) \\
{\left[\mathrm{m}^{3} / \mathrm{kg}\right]}\end{array}$ & $\begin{array}{c}v_{\mathrm{L}} \\
\left(20{ }^{\circ} \mathrm{C}\right) \\
{\left[\mathrm{m}^{3} / \mathrm{kg}\right]}\end{array}$ & $\begin{array}{r}\Delta h_{\mathrm{LV}} \\
\left(20{ }^{\circ} \mathrm{C}\right) \\
{[\mathrm{kJ} / \mathrm{kg}]}\end{array}$ & \begin{tabular}{c}
\multicolumn{1}{c}{$B$} \\
$\left(20{ }^{\circ} \mathrm{C}\right)$ \\
{$[\mathrm{K}]$}
\end{tabular} \\
\hline \hline iso-octano & 12959 & 0,001480 & 5150 & 4,4444 & 0,001444 & 309,4 & 4234,4 \\
água & 7384 & 0,001008 & 2339 & 57,7900 & 0,001002 & 2501,4 & 5795,1 \\
R22 & 1534000 & 0,000886 & 910300 & 0,025978 & 0,000826 & 187,5 & 2564,5 \\
R134a & 1017100 & 0,000873 & 572100 & 0,035969 & 0,000816 & 182,3 & 2838,6 \\
R600a & 5286000 & 0,001882 & 302000 & 0,126423 & 0,001798 & 334,7 & 2784,8 \\
\hline
\end{tabular}

A Tab. 2.4 apresenta os resultados obtidos de $P_{2} / P_{1}$ através de um cálculo numérico e da solução analítica em função do grau de metaestabilidade, dentro da curva de saturação. Da tabela, a diferença entre o resultado numérico e o resultado analítico aqui proposto não foi maior que 2,7\%. O gráfico da Fig. 2.8 ilustra os resultados desta tabela.

Tabela 2.4 - Comparação dos resultados obtidos através de uma solução numérica e analítica para a razão das pressões de uma onda de evaporação em função do grau de metaestabilidade, $\Pi$.

\begin{tabular}{|c|c|c|c|c|c|c|c|c|c|c|}
\hline \multirow[b]{2}{*}{$\Pi$} & \multicolumn{2}{|c|}{ iso-octano } & \multicolumn{2}{|c|}{ água } & \multicolumn{2}{|c|}{ R22 } & \multicolumn{2}{|c|}{ R134a } & \multicolumn{2}{|c|}{ R600a } \\
\hline & $\begin{array}{c}\frac{P_{2}}{P_{1}} \\
\text { numérico }\end{array}$ & $\begin{array}{c}\frac{P_{2}}{P_{1}} \\
\text { analítico }\end{array}$ & $\begin{array}{c}\frac{P_{2}}{P_{1}} \\
\text { numérico }\end{array}$ & $\begin{array}{c}\frac{P_{2}}{P_{1}} \\
\text { analítico } \\
\end{array}$ & $\begin{array}{c}\frac{P_{2}}{P_{1}} \\
\text { numérico } \\
\end{array}$ & $\begin{array}{c}\frac{P_{2}}{P_{1}} \\
\text { analítico }\end{array}$ & $\begin{array}{c}\frac{P_{2}}{P_{1}} \\
\text { numérico } \\
\end{array}$ & $\begin{array}{c}\frac{P_{2}}{P_{1}} \\
\text { analítico }\end{array}$ & $\begin{array}{c}\frac{P_{2}}{P_{1}} * \\
\text { numérico }\end{array}$ & $\begin{array}{c}\frac{P_{2}}{P_{1}} \\
\text { analítico } \\
\end{array}$ \\
\hline 0 & 1 & 1 & 1 & 1 & 1 & 1 & 1 & 1 & 1 & 1 \\
\hline 0,1 & 0,767 & 0,788 & 0,790 & 0,792 & 0,768 & 0,776 & 0,770 & 0,779 & 0,771 & 0,778 \\
\hline 0,2 & 0,704 & 0,726 & 0,729 & 0,730 & 0,700 & 0,710 & 0,703 & 0,713 & 0,703 & 0,712 \\
\hline 0,3 & 0,693 & 0,685 & 0,686 & 0,689 & 0,654 & 0,665 & 0,657 & 0,670 & 0,657 & 0,669 \\
\hline 0,4 & 0,655 & 0,652 & 0,655 & 0,658 & 0,619 & 0,632 & 0,623 & 0,636 & 0,622 & 0,635 \\
\hline 0,5 & 0,604 & 0,626 & 0,629 & 0,632 & 0,590 & 0,604 & 0,595 & 0,609 & 0,594 & 0,607 \\
\hline 0,6 & 0,590 & 0,603 & 0,607 & 0,609 & 0,566 & 0,580 & 0,570 & 0,585 & 0,569 & 0,583 \\
\hline 0,7 & 0,564 & 0,581 & 0,585 & 0,588 & 0,544 & 0,558 & 0,548 & 0,563 & 0,547 & 0,561 \\
\hline 0,8 & 0,540 & 0,561 & 0,564 & 0,567 & 0,524 & 0,537 & 0,528 & 0,542 & 0,527 & 0,541 \\
\hline 0,9 & 0,524 & 0,539 & & $* *$ & 0,504 & 0,516 & 0,507 & 0,521 & 0,507 & 0,519 \\
\hline
\end{tabular}

\footnotetext{
${ }^{*}$ dados compilados de Simões-Moreira e Bullard (2003).

${ }^{* *}$ um grau de metaestabilidade acima de 0,81 congela a água, ou seja, $T_{2}<0^{\circ} \mathrm{C}$.
} 


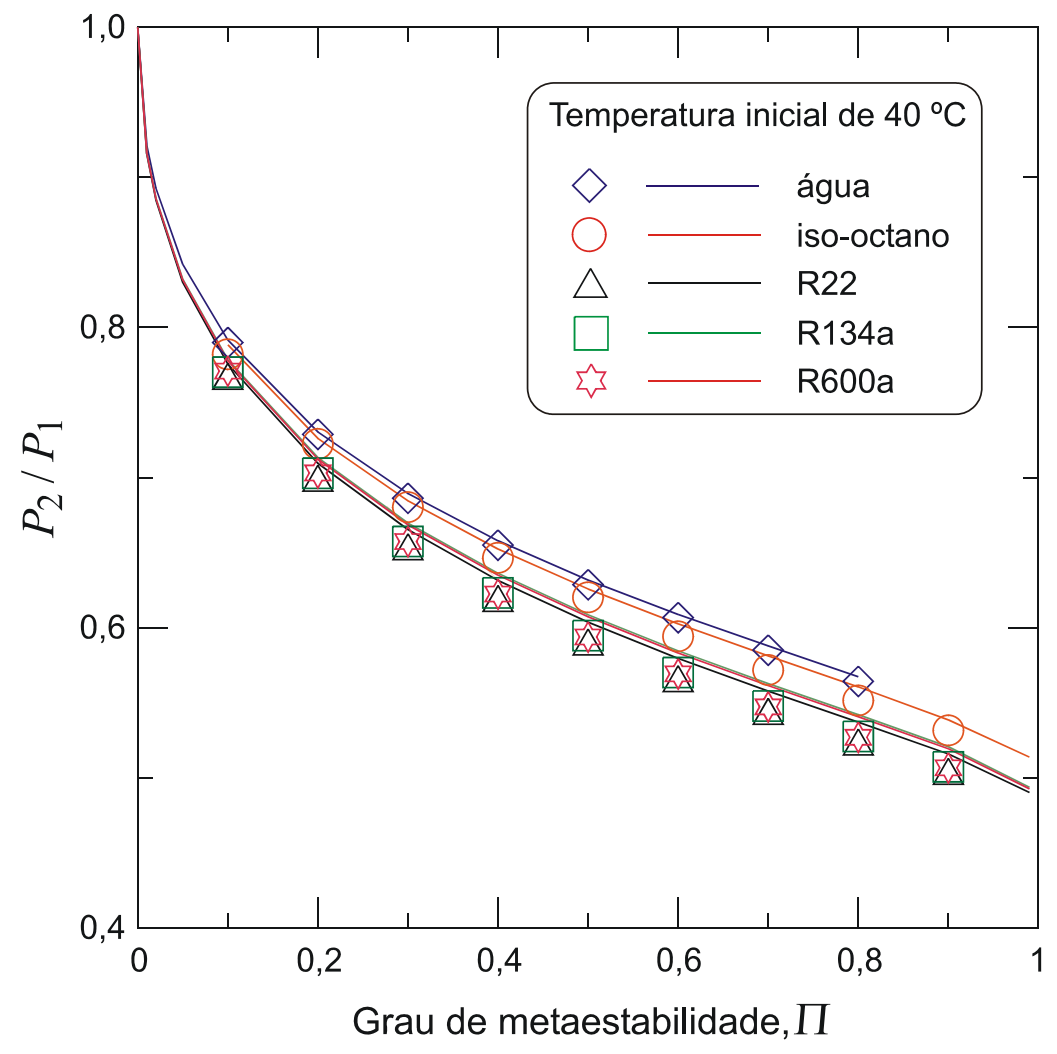

Figura 2.8 - Representação das curvas de $P_{2} / P_{1}$ em função de $\Pi$, para diversos fluidos apresentados na legenda. A linha contínua é a solução analítica proposta e os símbolos vêm da solução numérica da Tab. 2.4.

Quando a pressão inicial não coincide com a pressão de saturação, diferente do que foi desenvolvido até o momento, é necessário acrescentar a energia interna devido a esta compressão, ou seja, $h_{1} \cong h_{1 \mathrm{~L}}+v_{1}\left(P_{0}-P_{\text {sat }}\right)$. Inserindo este termo na Eq. (2.18), tem-se:

$$
v_{2} \cong \frac{C p_{L} B\left(\ln \left(P_{\text {sat }}\right)-\ln \left(P_{2}\right)+\Phi\left(P_{0}\right)\right)}{P_{2}\left(A-\ln \left(P_{\text {sat }}\right)\right)\left(A-\ln \left(P_{2}\right)\right)\left(\left(A-\ln \left(P_{2}\right)\right)+\frac{1}{2} \frac{P_{1}}{P_{2}}-\frac{1}{2}\right)}+v_{1},
$$

onde,

$$
\Phi\left(P_{0}\right)=\frac{v_{1}\left(P_{0}-P_{\text {sat }}\right)\left(\frac{B}{T_{0}}-\ln (1-\Pi)-\ln \left(\frac{P_{2}}{P_{1}}\right)\right)}{C p_{L} \cdot T_{0}}
$$

A Fig. 2.9 representa um estudo numérico de uma onda de evaporação em um 
fluido a $750 \mathrm{kPa}$ e temperatura inicial de $56{ }^{\circ} \mathrm{C}\left(P_{\text {sat }}=25 \mathrm{kPa}\right)$. A figura mostra a importância da energia acumulada devido à compressão para o salto das propriedades termodinâmicas quando o grau de metaestabilidade é próximo de zero. Esta afirmação é vista neste gráfico, pois a razão de pressões é de 0,9 , para um grau de metaestabilidade quase nulo.

No desenvolvimento da expressão final, o parâmetro, $\Phi\left(P_{0}\right)$, foi considerado constante apenas na Eq. (2.21). Isto simplifica todo o procedimento para a obtenção da solução final, como o que foi efetuado para a determinação da Eq. (2.20), principalmente para encontrar a derivada de $v_{2}$. Com esta simplificação, a expressão é escrita como:

$$
\begin{aligned}
& 1-2 \frac{P_{2}}{P_{1}}+\frac{1-\frac{P_{2}}{P_{1}}}{\Phi\left(P_{0}\right)-\ln (1-\Pi)-\ln \left(\frac{P_{2}}{P_{1}}\right)}-\frac{1-\frac{P_{2}}{P_{1}}}{\frac{B}{T_{0}}-\ln (1-\Pi)-\ln \left(\frac{P_{2}}{P_{1}}\right)} \\
& +\frac{\left(1-\frac{P_{2}}{P_{1}}\right)\left(-1-\frac{1}{2} \frac{P_{1}}{P_{2}}\right)}{\frac{B}{T_{0}}-\ln (1-\Pi)-\ln \left(\frac{P_{2}}{P_{1}}\right)-\frac{1}{2}+\frac{1}{2} \frac{P_{1}}{P_{2}}}=0
\end{aligned}
$$

Aplicando esta equação para o caso da Fig. 2.9, cuja pressão de injeção (750 $\mathrm{kPa})$ é 30 vezes maior que a pressão de saturação $\left(P_{\text {sat }}=25 \mathrm{kPa}\right)$, o maior desvio não passou de 2,1\%, ou seja, praticamente coincidiram os resultados numéricos e analíticos. Este desvio ocorreu quando o grau de metaestabilidade é igual a 0,26 fornecendo resultados iguais a 0,683 e 0,697, respectivamente para a análise numérica e a proposta. No cálculo, o calor específico do iso-octano na condição de saturado, $C p_{\mathrm{L}}$, é de $2,4 \mathrm{~kJ} / \mathrm{kg} . \mathrm{K}$. 


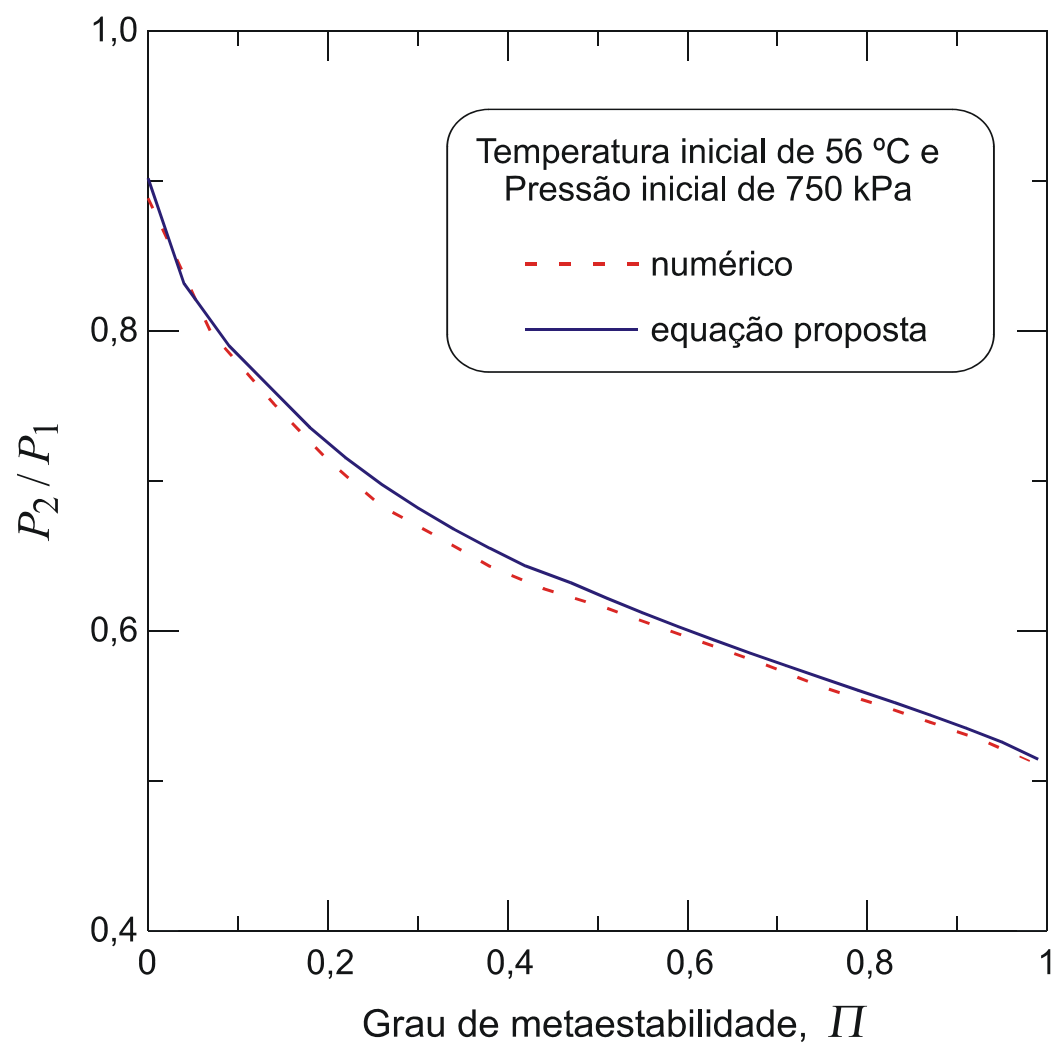

Figura 2.9 - Representação do comportamento da razão de pressões a jusante e a montante da onda de evaporação em função do grau de metaestabilidade do líquido para a iso-octano com temperatura inicial de $56^{\circ} \mathrm{C}$ com pressão inicial de $750 \mathrm{kPa}$.

É interessante que esta última expressão (Eq. 2.23), mostra a razão das pressões envolvida tendendo ao valor de 0,5 quando o grau de metaestabilidade se aproxima de 1, sem necessariamente haver completa evaporação. Como exemplo, a água a $310{ }^{\circ} \mathrm{C}(89 \%$ da temperatura crítica) e pressão inicial igual à saturação ( 9820 $\mathrm{kPa}$ ), assumindo um grau de metaestabilidade de 0,99 , alcança um título de vapor no valor de $44,6 \%$, a uma temperatura de $80{ }^{\circ} \mathrm{C}$ e pressão de $48 \mathrm{kPa}$ (cálculo numérico). Pelo cálculo sugerido nesta seção, considerando o valor de $B$ da Tab. 2.3, a pressão da mistura era de $49 \mathrm{kPa}$, ou seja, o erro é de $2 \%$. 


\subsection{Ondas de Evaporação Oblíquas}

Simões-Moreira (1999 e 2000) desenvolveu a hipótese da aplicação das ondas de evaporação oblíquas em jatos evaporativos. A teoria explanada nesta seção foi desenvolvida por ele baseada na teoria de ondas de choque oblíquas de escoamento em compressíveis, que pode ser vista em um livro texto de dinâmica de gases como, por exemplo, em Thompson (1998).

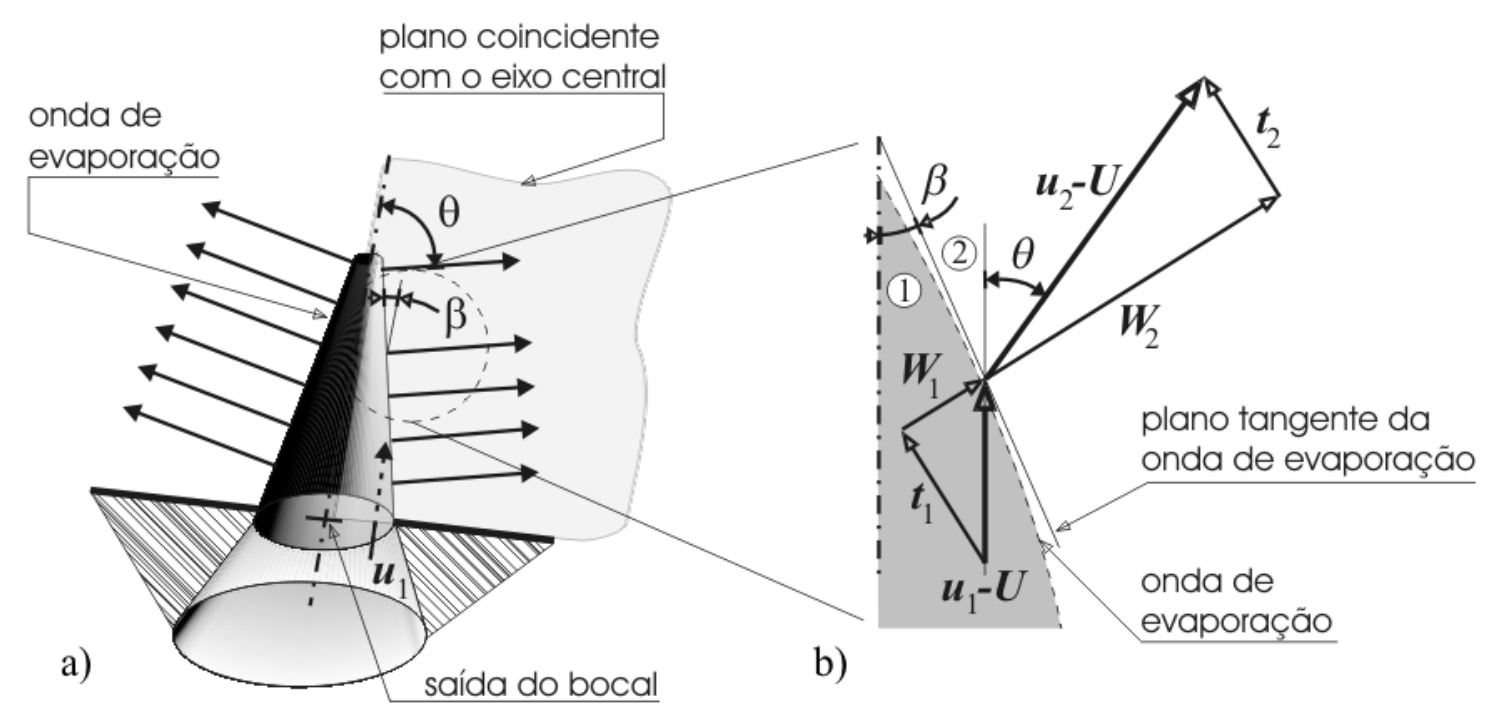

Figura 2.10 - Representação esquemática do jato à esquerda e, à direita, está em destaque a geometria da onda de evaporação com suas componentes de velocidade, em um plano coincidente ao eixo central.

A onda de evaporação oblíqua tem a direção da velocidade do líquido metaestável inclinada em relação à frente de evaporação, diferentemente do caso da onda de evaporação normal, em que a velocidade de propagação da onda é perpendicular a do líquido. A Fig. 2.10, à direita, apresenta o esquema da geometria da onda oblíqua. O modelo mostra uma onda de evaporação com velocidade $\boldsymbol{U}$ e o líquido metaestável com velocidade $\boldsymbol{u}_{1}$. A montante, o plano paralelo a frente evaporativa forma o ângulo $\beta$ com a componente da velocidade relativa $\boldsymbol{u}_{1}-\boldsymbol{U}$, e é chamado de ângulo da onda. As componentes de velocidades $\boldsymbol{W}_{1}$ e $\boldsymbol{W}_{2}$ são normais à onda e as componentes $\boldsymbol{t}_{\mathbf{1}}$ e $\boldsymbol{t}_{\mathbf{2}}$ são as componentes tangenciais. Após cruzar a onda, o fluido muda de direção, com uma inclinação de ângulo, $\theta$, denominado ângulo de giro. Conforme Simões-Moreira (1999 e 2000) estas ondas possuem as seguintes 
propriedades: a) as velocidades relativas $\boldsymbol{u}_{1}-\boldsymbol{U}$ e $\boldsymbol{u}_{2}-\boldsymbol{U}$ são coplanares com os vetores normais da onda, ou seja, estão no mesmo plano; b) as componentes da velocidade $\boldsymbol{t}_{\mathbf{1}}$ e $\boldsymbol{t}_{\mathbf{2}}$ tem mesma magnitude, ou seja, $\boldsymbol{t}_{\mathbf{1}}=\boldsymbol{t}_{\mathbf{2}}$. Esta propriedade mostra que a adição de uma componente de uma velocidade tangencial em uma onda de choque normal transforma-a em uma onda oblíqua; c) a entalpia específica de estagnação é constante em uma onda oblíqua estacionária $(\boldsymbol{U}=0)$, isto é, $h_{0}=h_{1}+W_{1}^{2} / 2=h_{2}+W_{2}^{2} / 2$.

Da geometria da Fig. 2.10 é extraída a seguinte relação trigonométrica:

$$
\tan \theta=\frac{\operatorname{sen} 2 \beta}{2\left(\operatorname{sen}^{2} \beta+\frac{W_{1}}{[W]}\right)}
$$

Aplicando a equação de conservação de massa (Eq. 2.1) a equação anterior pode ser escrita como:

$$
\tan \theta=\frac{\operatorname{sen} 2 \beta}{2\left(\operatorname{sen}^{2} \beta+\frac{1}{\left(v_{2} / v_{1}\right)-1}\right)}
$$

Obtendo, assim, uma relação entre os ângulos e a razão entre os volumes específicos envolvidos na onda. O gráfico da Fig. 2.11 apresenta a dependência do ângulo de giro com o ângulo da onda. As curvas estão parametrizadas para as diversas razões entre os volumes específicos, $v_{2} / v_{1}$ e, para cada curva, o ângulo de giro máximo é determinado pela seguinte expressão:

$$
\tan \theta_{\text {máx }}=\frac{v_{2} / v_{1}-1}{2 \sqrt{v_{2} / v_{1}}} .
$$

E para este $\theta_{\text {máx }}$, é possível encontrar o $\beta_{\text {máx }}$ através de:

$$
\operatorname{sen} \beta_{\text {máx }}=\frac{1}{\sqrt{v_{2} / v_{1}+1}} .
$$

A combinação das duas equações anteriores (Eq. 2.26 e 2.27) resulta na seguinte relação:

$$
\theta_{\text {máx }}=90^{\circ}-2 \beta_{\text {máx }} \text {. }
$$




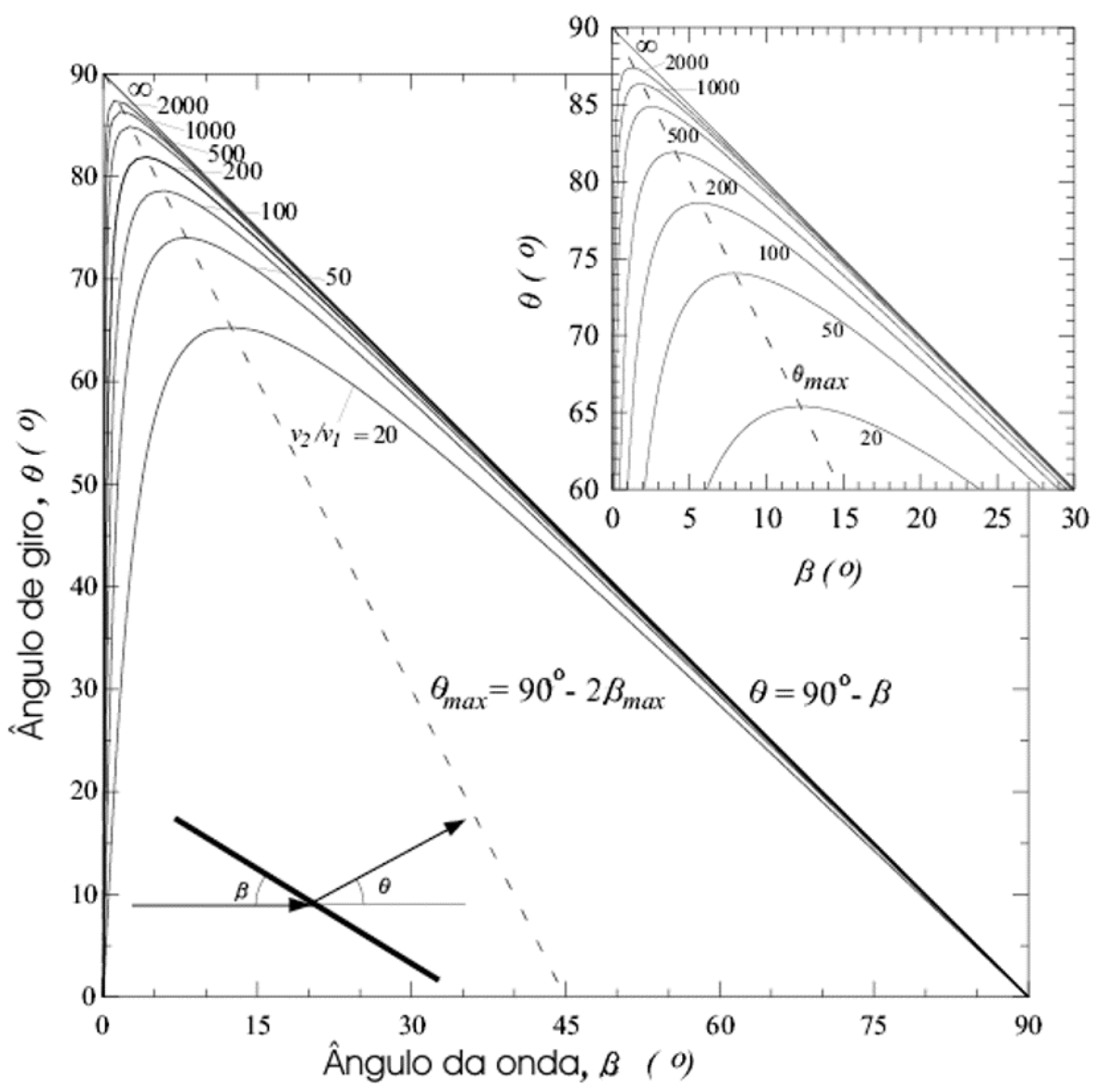

Figura 2.11 - Ângulo de giro como função do ângulo de onda parametrizado pela razão entre os volumes específicos a jusante e a montante relativos à onda de evaporação (Simões-Moreira, 1999).

\subsection{Formato de Cone do Núcleo de Líquido}

A análise de muitas fotografias e jatos evaporativos indica a presença de um núcleo central de líquido (metaestável), a partir do qual a evaporação ocorre (Fig. 2.10a). Para modelar este núcleo de líquido, as seguintes hipóteses são adotadas:

a. os efeitos viscosos são desprezíveis;

b. o líquido no interior do núcleo líquido mantém constante a temperatura e igual à temperatura inicial de injeção;

c. o líquido possui pressão uniforme na extensão do núcleo e coincidente com a pressão na saída do bocal;

d. as duas fases da mistura partem da onda de evaporação com velocidades e temperaturas iguais; 
e. a evaporação ocorre sob a condição de Chapman-Jouguet e inicia imediatamente na saída do bocal;

f. a onda de evaporação possui uma espessura desprezível e uniforme, e não se movimenta em relação ao bocal.

Os itens "b" até "d" constituem as hipóteses fundamentais para adotar um fluxo uniforme, sob a condição de Chapman-Jouguet, na superfície do núcleo. Dentro deste modelo, com um fluxo constante em toda a superfície uniforme, Simões-Moreira (1999) verificou que o núcleo líquido assume o formato de um cone cuja base coincide com a área de saída do bocal. Aplicando a lei de conservação de massa e adotando o cone como volume de controle:

$$
\begin{aligned}
A_{b} \cdot J_{b}=A_{L} \cdot J_{C J} & \Rightarrow \pi \cdot r_{b}^{2} \cdot J_{b}=\pi \cdot r_{b} \sqrt{r_{b}^{2}+L_{E}^{2}} \cdot J_{C J} \\
\operatorname{sen} \beta & =\frac{J_{C J}}{J_{b}},
\end{aligned}
$$

sendo, $A_{\mathrm{b}}$ e $A_{\mathrm{L}}$ as áreas do bocal e da lateral do cone, $J_{\mathrm{b}}$ e $J_{\mathrm{CJ}}\left[\mathrm{kg} / \mathrm{m}^{2} . \mathrm{s}\right]$ os fluxos mássicos superficiais que ocorrem na base do cone e na lateral do cone, respectivamente, e $\beta$ é o ângulo formado pela geratriz e o eixo central do cone e, conseqüentemente, é o mesmo ângulo gerado pela incidência do líquido na superfície da onda de evaporação por causa do formato cônico (Fig. 2.10).

\subsection{Comportamento Termodinâmico do Jato}

Através do modelo proposto por Kurschat e outros (1992), Angelo e SimõesMoreira (2004) aprimoraram o comportamento termodinâmico em seu estudo numérico dos jatos deste trabalho experimental. Pelo diagrama $P$ x $v$ da Fig. 2.12, pode-se tomar uma linha de corrente imaginária do jato partindo do estado de estagnação ou de injeção (0) e sofrendo uma expansão quase isentrópica, ao passar pelo bocal, até atingir o estado (1) na condição metaestável. Ao sair do bocal, continua como líquido metaestável até traspassar a superfície evaporativa, ou onda de evaporação oblíqua. O fluido, em virtude da evaporação, aumenta consideravelmente seu volume específico. Isto proporciona o aumento da velocidade, em contrapartida, sua pressão e temperatura diminuem. Este salto de propriedades decorrentes da onda evaporativa promove a condição sônica de velocidade da 
mistura líquido-vapor neste imediato instante (estado 2). Nesta ocasião, devem ser acrescentados dois fatores: a mistura possui espaço para expandir e, sua pressão, $P_{2}$, é maior que a pressão da câmara. A mistura bifásica comportando como um fluido compressível, sob tais fatores, é condicionada a elevar sua velocidade, em nível supersônico favorecendo a queda de sua pressão, conseqüentemente, a sua elevação do volume específico. Esta pressão, $P_{3}$, torna-se menor que a pressão da câmara e, para o ajuste das pressões, o fluido sofre outro salto de propriedades através da formação de uma onda de choque, assumindo o estado (4) da figura. Se a onda de choque é normal ao escoamento, a pressão $P_{4}$ vem a ser menor que a pressão da câmara, e como o fluido ainda pode expandir, a estabilização de sua pressão é feita através de um escoamento subsônico.

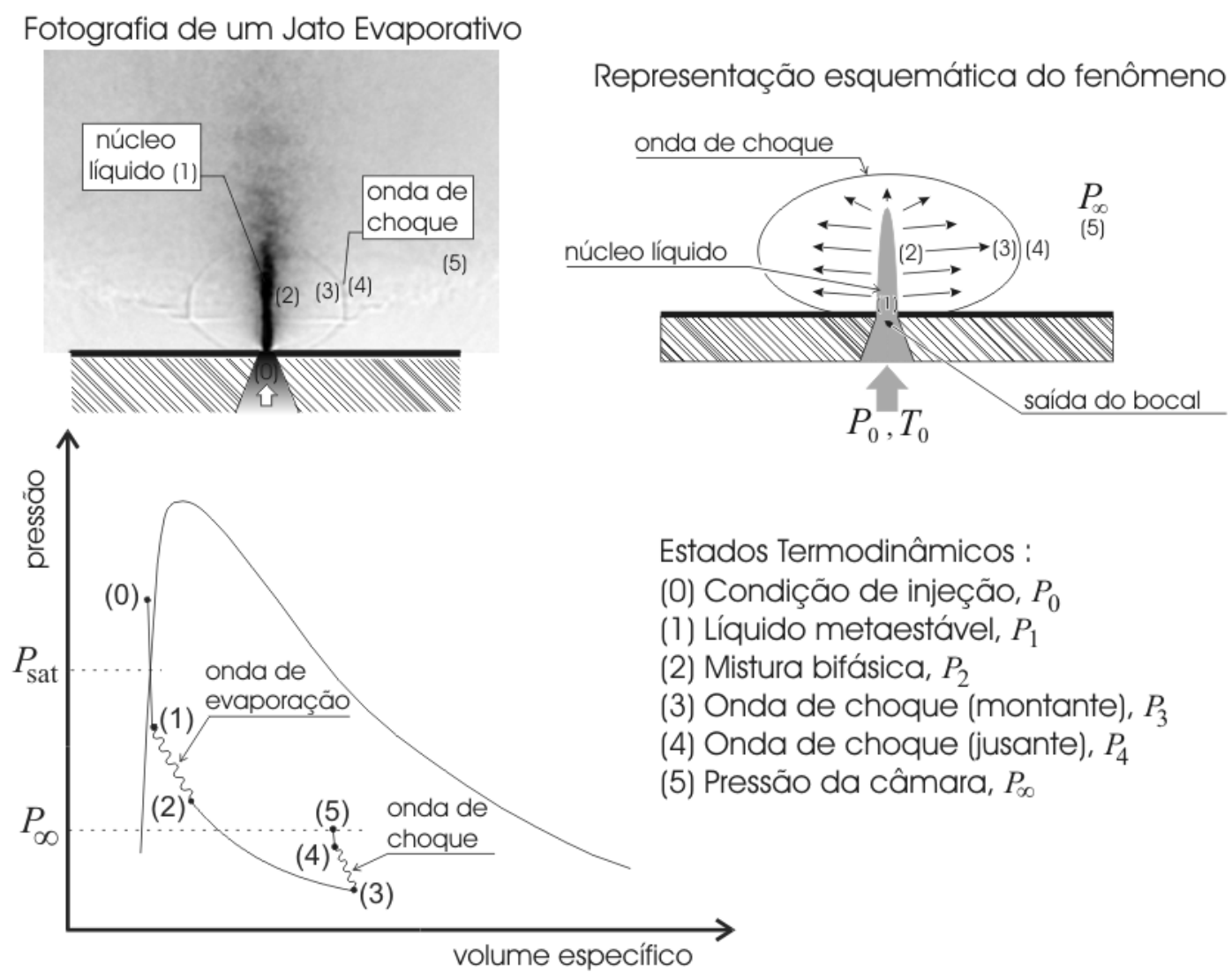

Figura 2.12 - Explicação para o comportamento termodinâmico do jato evaporativo.

Fica evidente que a formação desta onda de choque é uma comprovação do estabelecimento de uma velocidade supersônica. Porém, antes deste escoamento, o fluxo teve a sua velocidade sônica na onda de evaporação. Este fenômeno 
evaporativo condiciona a máxima vazão na superfície do cone líquido através da condição de Chapman-Jouguet.

Destaque deve ser feito para o trabalho de Angelo (2004) que usando os resultados dos ensaios experimentais aqui expostos obteve excelentes resultados em seu estudo numérico. Angelo resolveu o problema numérico bidimensional axissimétrico para a região de expansão da mistura bifásica usando o método clássico de MacCormack com um esquema de captura de choque. A equação de estado de Lee-Kesler foi empregada com a hipótese de escoamento homogêneo bifásico. Um exemplo é mostrado na Fig. 2.13 que mostra o ensaio 2329500, com uma fotografia do jato e, ao lado, estão os resultados numéricos da pressão, temperatura, título e número de Mach, além da representação da localização da onda de choque e do traçado de duas linhas de correntes ( $L c 1$ e $L c 2)$. Pelo gráfico de campo de pressões da figura, estas linhas de correntes estão quase normais às faixas isobáricas e a $L c 1$ possui uma trajetória praticamente radial. Próximo do núcleo de líquido a pressão e a temperatura calculadas decrescem drasticamente. Inicialmente estão a $8487 \mathrm{~Pa}$ e 281 $\mathrm{K}$ (ou $7{ }^{\circ} \mathrm{C}$ ) e, em um raio de $2 \mathrm{~mm}$, assumem valores de $502 \mathrm{~Pa}$ e $242 \mathrm{~K}\left(-31^{\circ} \mathrm{C}\right.$ ). Em contrapartida, o número de Mach que começa igual ao valor unitário, na evaporação, nesta mesma posição radial, alcança valores da ordem de 2,6, assim como, no cálculo do título, inicialmente a 0,18 , assume um valor da ordem de 0,42 , neste raio. As propriedades estimadas a montante da onda de choque como pressão, temperatura, título e número de Mach apresentam valores correspondentes a 1,8 Pa, $203 \mathrm{~K}$ (ou $\left.-70{ }^{\circ} \mathrm{C}\right), 0,53$ e 3,70, respectivamente. Especificamente não está mostrado nesta figura, mas em seu trabalho é visto que a entropia, ao longo de uma linha de corrente é praticamente constante. A posição e formato da onda de choque calculada coincidiram com o resultado experimental mostrando que os fenômenos envolvidos estão condizentes a realidade, já que o autor desenvolveu seu código sob a hipótese do cone líquido com uma onda de evaporação na superfície. 
•

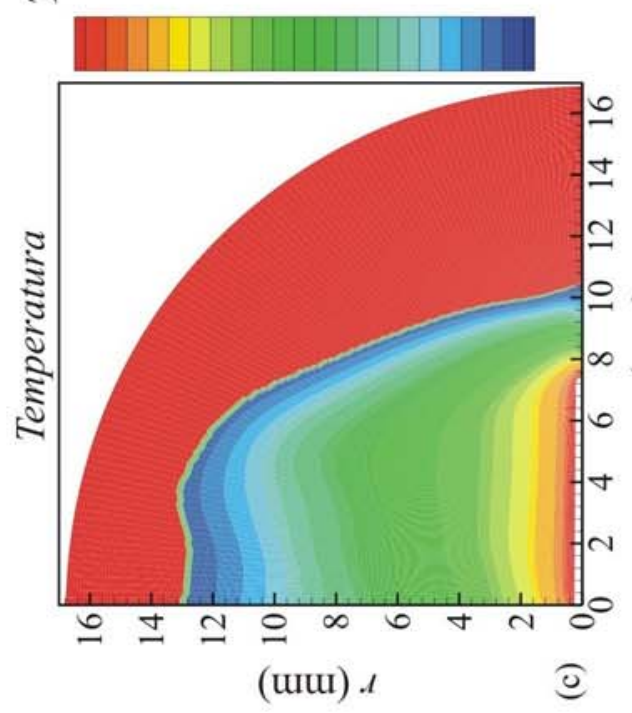

ส

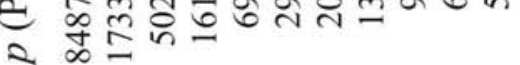
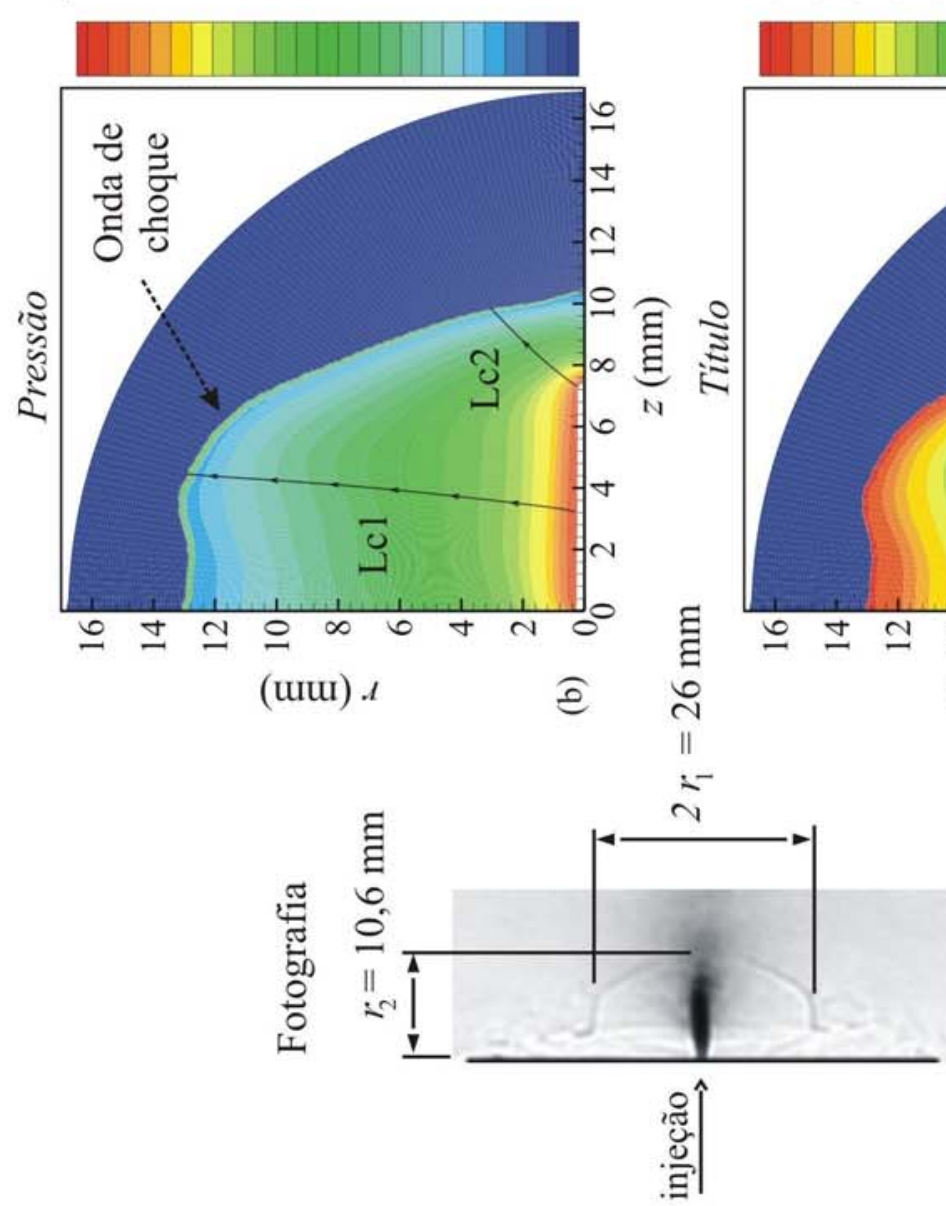

z

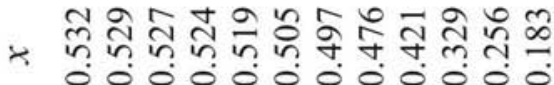
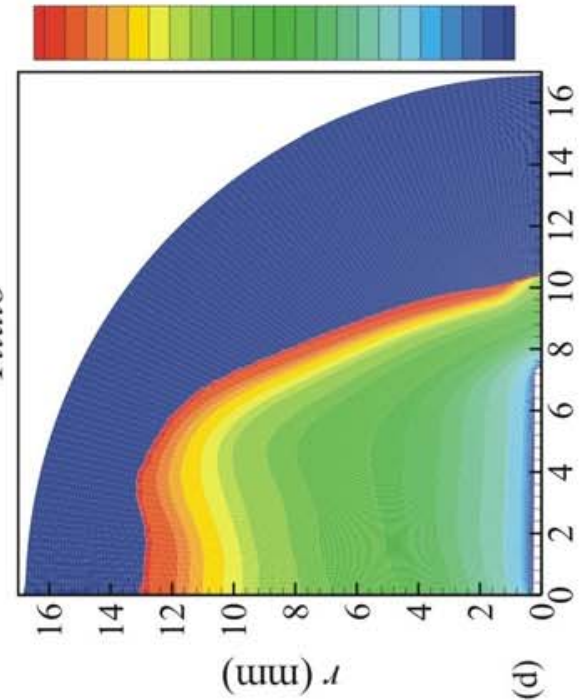

)

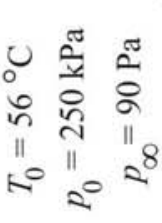

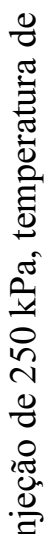

ช

范 긍 ह $\frac{0}{8}$ 8 这 ते तิ 응 承 ए

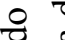
๘ : 들 奉 용 


\section{Arranjo e Procedimento Experimental}

Um arranjo experimental foi construído para visualizar os jatos evaporativos com controle de pressão e temperatura de injeção constantes. Uma das condições importantes do arranjo era que o tempo de injeção fosse pequeno para se evitar o aumento exagerado da pressão do ambiente onde o jato é descarregado. Todo o experimento e a instrumentação foram dimensionados para que o regime permanente ocorresse muito rapidamente, na ordem de até 0,01 s. Uma visão geral deste arranjo experimental descrito neste trabalho está esquematizada na Fig. 3.1. O sistema de injeção foi projetado para manter constante e controlar a pressão de injeção durante o curto período de injeção. A temperatura do líquido de injeção é controlada por um sistema de aquecimento formado por óleo em circulação, como ilustra a Fig. 3.1. O jato é descarregado em uma câmara de baixa pressão que é controlada e mantida pelo sistema de vácuo e de pressurização, também indicado na Fig. 3.1. Durante a injeção são feitas medições da pressão e temperatura do fluido a montante do jato, junto ao bocal de injeção a fim de comprovar, através dos dados experimentais obtidos, a regularidade da condição de regime permanente do processo. Todas as medições, registros fotográficos e aquisições são feitas de forma automática pelos computadores. Isso inclui também o sincronismo dos eventos, como o tempo de injeção e aquisição das imagens do jato. E, por fim, têm-se os sistemas ópticos que são baseados no método "Schlieren" e no método de iluminação por detrás. Fotografias da bancada, de acessórios e das instalações podem ser vistas nas Figs. 3.2 e 3.3. Nas próximas seções cada um dos conjuntos do esquema da Fig. 3.1 será discutido de forma pormenorizada. Este arranjo experimental utilizado é o mesmo empregado por Vieira (1999) com algumas adaptações. Nas próximas subseções, cada uma das partes importantes do arranjo experimental é discutida com detalhes. 


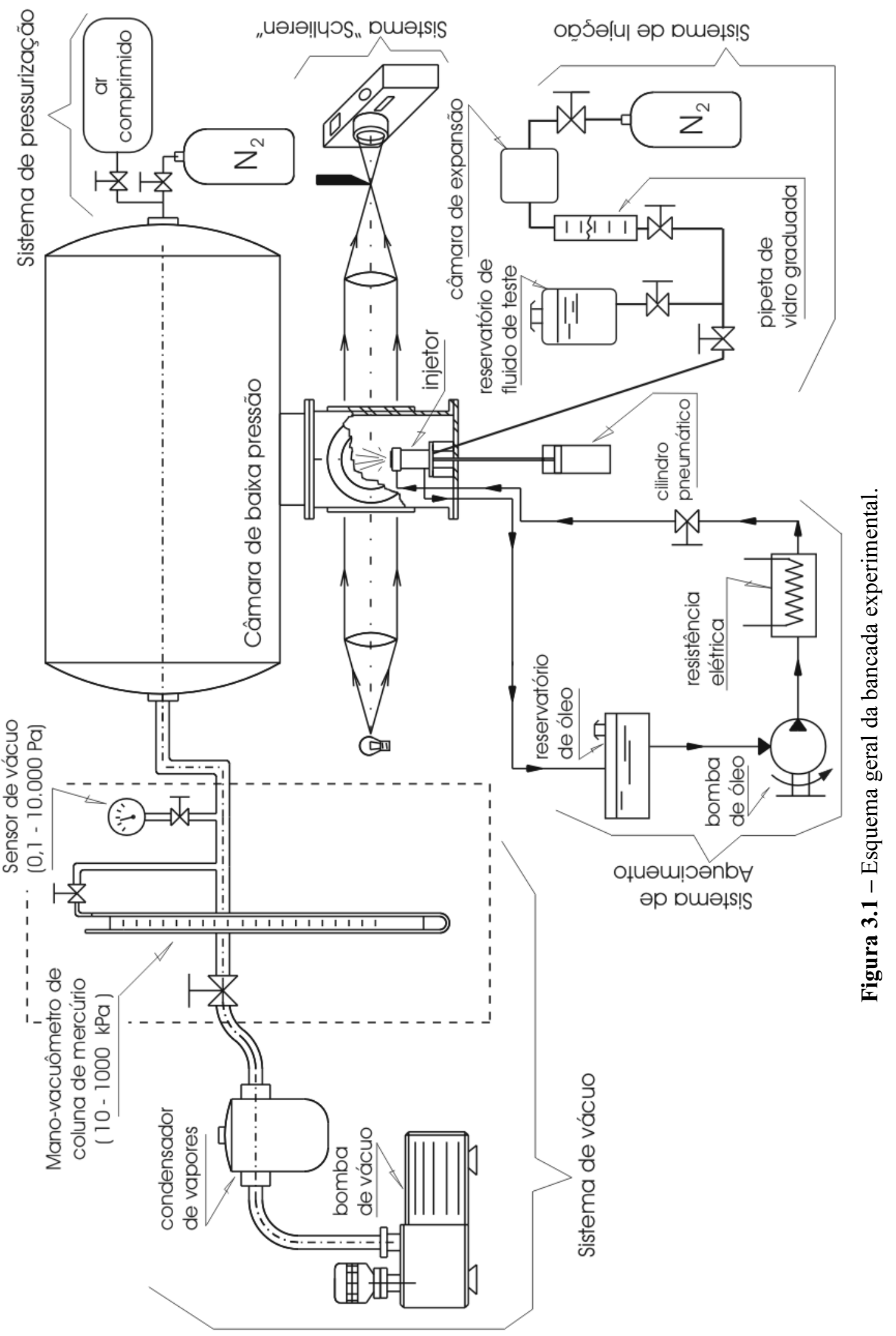




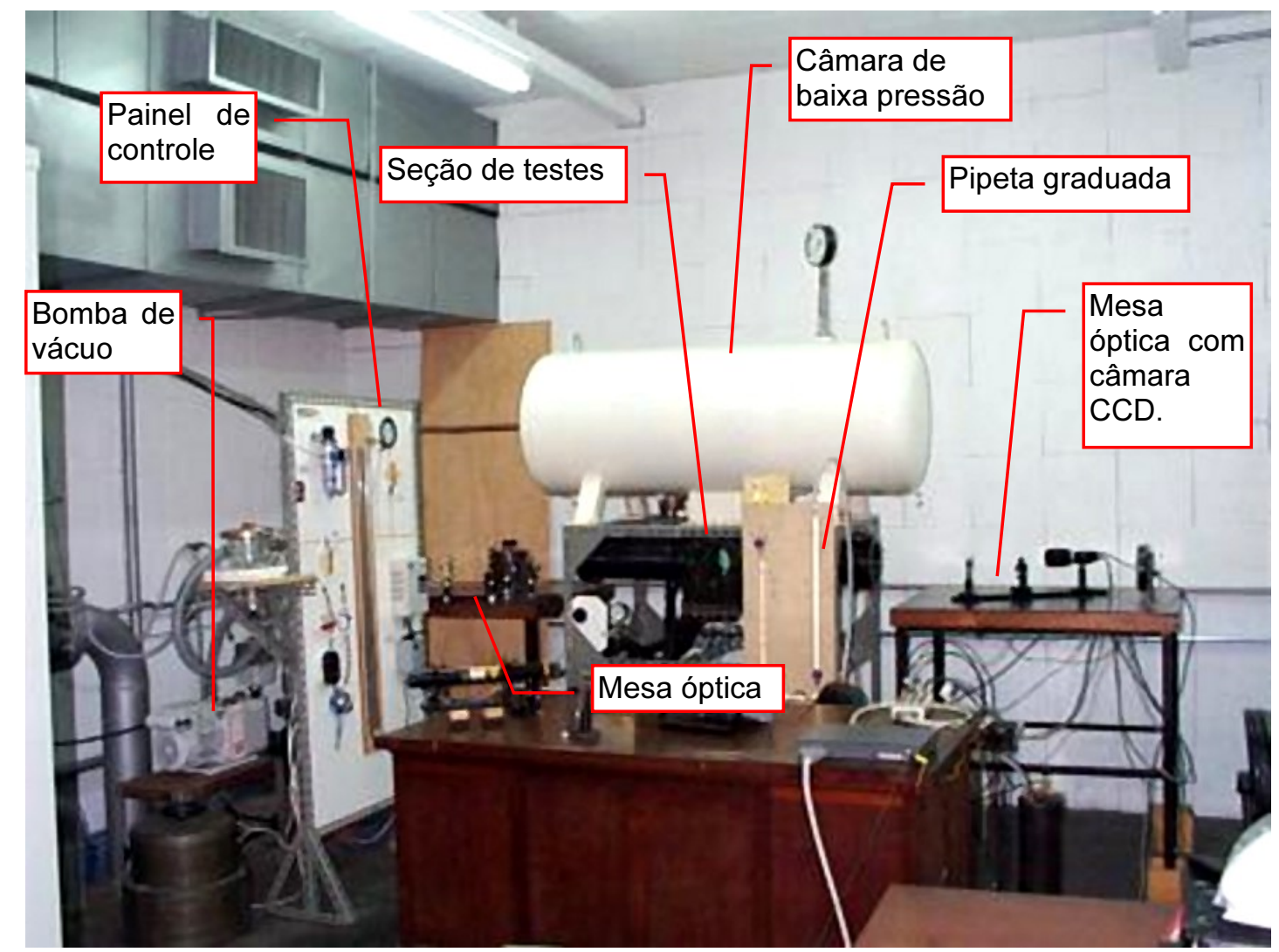

Figura 3.2 - Fotografia da câmara de baixa pressão, painel de controle e mesas ópticas com lentes, espelhos parabólicos e filtro espacial. 


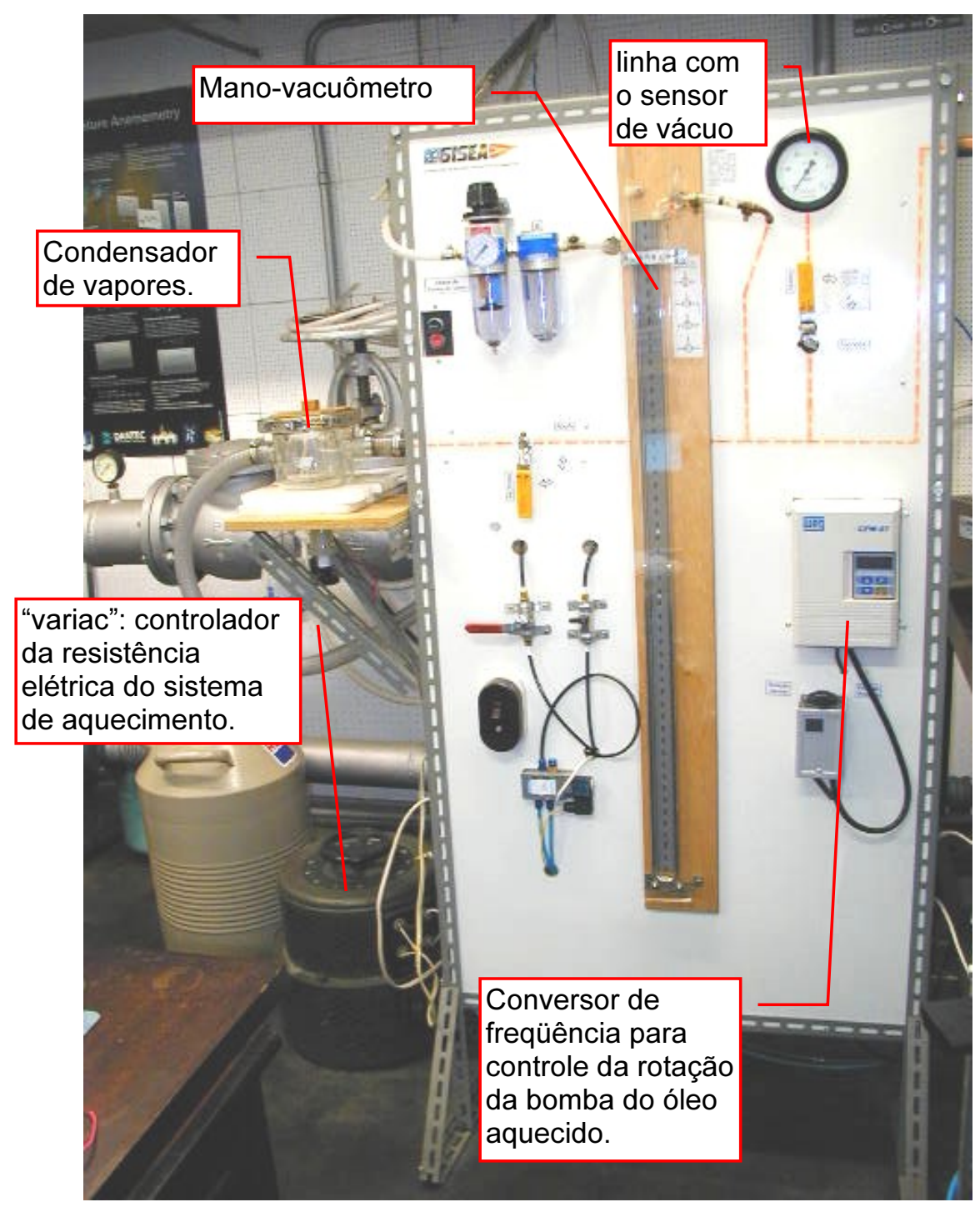

Figura 3.3 - Fotografia da bomba de vácuo e do painel com mano-vacuômetro de mercúrio e vacuômetro analógico de precisão.

\subsection{Sistema de Pressurização e de Vácuo}

Este sistema controla e proporciona uma condição de pressão quase constante do ambiente onde o jato será expandido. Ele consiste de um reservatório acoplado à seção de observação, cujo volume total conjugado é de aproximadamente 440 litros. Estimativas indicaram que esse volume é suficiente para proporcionar um ensaio de volume de até $12 \mathrm{~cm}^{3}$ de líquido, sem que a pressão da câmara aumente significantemente.

$\mathrm{Na}$ operação deste sistema, deve-se despressurizar a câmara até que o sistema 
alcance uma pressão absoluta de 0,1 mbar ou $100 \mathrm{~Pa}$. Após este procedimento, o reservatório é pressurizado com gás nitrogênio até alcançar a pressão desejada de ensaio. Isso se faz por questões de segurança para evitar a exposição do vapor do líquido de teste com o ar, o que poderia acarretar em uma ignição espontânea devido às elevadas temperaturas envolvidas. Para realizar a operação de sucção do reservatório ("vácuo"), o laboratório dispõe de uma bomba de vácuo de $18 \mathrm{~m}^{3} / \mathrm{h}$ de fabricação BOC-Edwards, modelo E1M18. Isto dá uma capacidade de alcançar 10 mbar em cerca de 15 minutos, para o volume total do arranjo. O esquema da linha de vácuo está na Fig. 3.4. Instalou-se antes da bomba um condensador de vapores (também conhecido como "dedo frio" ou "vacuum trap"). Sua função é resfriar os gases succionados a fim de condensar e drenar os vapores que causariam a contaminação do óleo da bomba, e por conseqüência a deterioração da mesma, sobretudo se for o vapor de água. Nitrogênio líquido é usado para condensar os vapores.

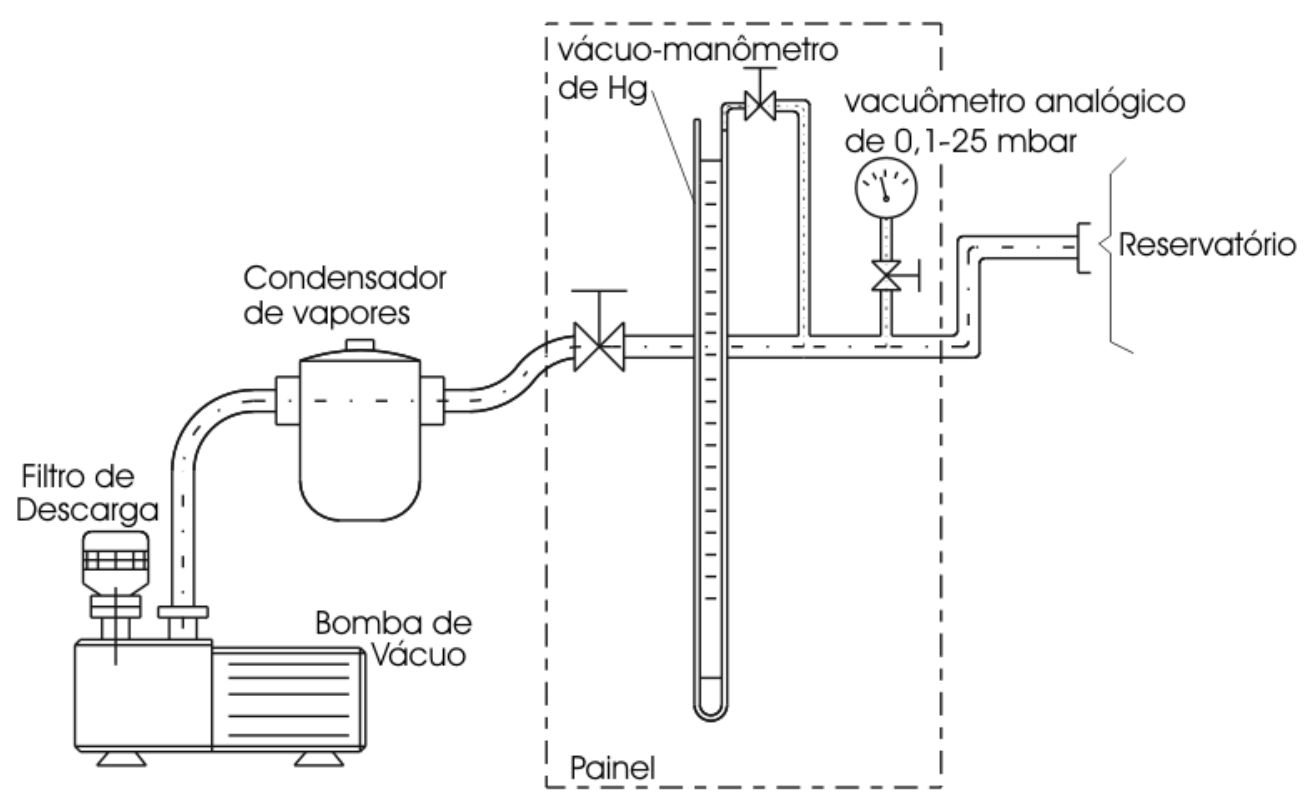

Figura 3.4 - Esquema do sistema de vácuo.

Na linha de vácuo, a medição de pressão é feita por um mano-vacuômetro de coluna de mercúrio, que a abrange uma faixa de $220 \mathrm{kPa}$ até $2,5 \mathrm{kPa}$ (equivalente a 2,2 até 0,025 bar ou, 1650 até $18,75 \mathrm{mmHg}$ ) absoluto e, na faixa de $2500 \mathrm{~Pa}$ a $10 \mathrm{~Pa}$ (ou 25 a 0,1 mbar), um vacuômetro analógico de precisão da BOC-Edwards, modelo 
CGK-16. As precisões destes equipamentos são de $67 \mathrm{~Pa}$ e $25 \mathrm{~Pa}$ (equivalente a 0,670 mbar e 0,250 mbar), respectivamente. Optou-se pela utilização destes dois equipamentos devido à melhoria da precisão de leitura e, principalmente, evitar riscos de contaminação ambiental de mercúrio na medição de pressões abaixo de $2500 \mathrm{~Pa}$ (a pressão de vapor do mercúrio a $20^{\circ} \mathrm{C}$ é menor que $1 \mathrm{~Pa}$ ). Nesta faixa menor de pressão, a coluna de mercúrio é desconectada da linha de vácuo e pressurizada até a pressão atmosférica por uma válvula de três vias. No entanto, em uma segunda etapa dos experimentos (séries RUN2 e RUN3), este sistema foi implementado com um sensor de vácuo de melhor precisão da marca BOC-Edwards, modelo APGX, tornando viável a aquisição eletrônica de dados desta medição.

Outra medida de segurança foi tomada utilizando filtros de descarga da bomba de vácuo, evitando a contaminação de vapores nocivos à saúde no laboratório, já que a descarga da mesma era voltada para dentro do laboratório.

\subsection{Sistema de Aquecimento}

Este sistema tem o objetivo de aquecer o líquido de teste até a temperatura desejada de injeção. A faixa de temperatura, que pode ser ensaiada situa-se entre 20 a $300{ }^{\circ} \mathrm{C}$. Esquematizado na Fig. 3.5, o óleo é aquecido por uma resistência elétrica e, em seguida, dirigido para aquecer o conjunto de injeção.

A temperatura é regulada por um termostato que é ligado em série com a resistência elétrica. Após a passagem do óleo pelo conjunto de injeção, eventualmente, será resfriado a fim de que a sua temperatura seja compatível com a temperatura máxima da bomba de óleo. Na seqüência, tem-se a bomba que faz recircular este óleo para a resistência elétrica a qual aquecerá novamente, fechando o ciclo, conforme indicado na figura. O sistema cumprirá sua função quando o líquido de teste alcançar a desejada temperatura de ensaio. 


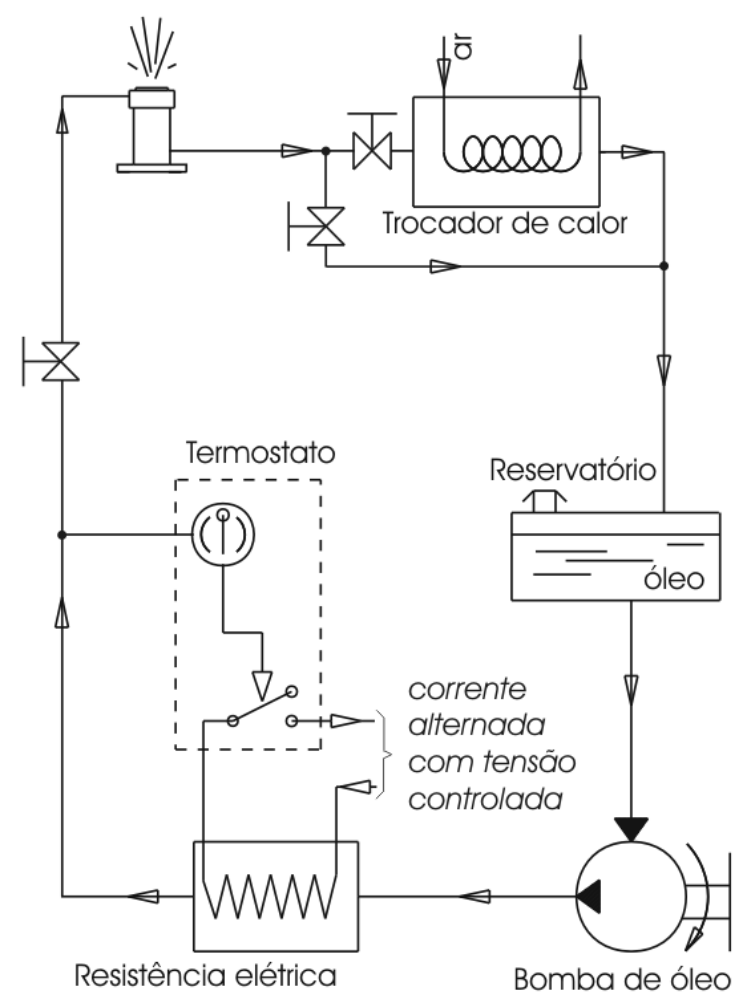

Figura 3.5 - Esquema do sistema de aquecimento.

\subsection{Sistema de Injeção}

Compete a este sistema injetar o líquido de teste a uma pressão constante de injeção e em tempo determinado. No intervalo deve-se garantir que as vazões transitórias, entre a abertura e o fechamento do bocal, sejam amortecidas em condições de regime permanente.

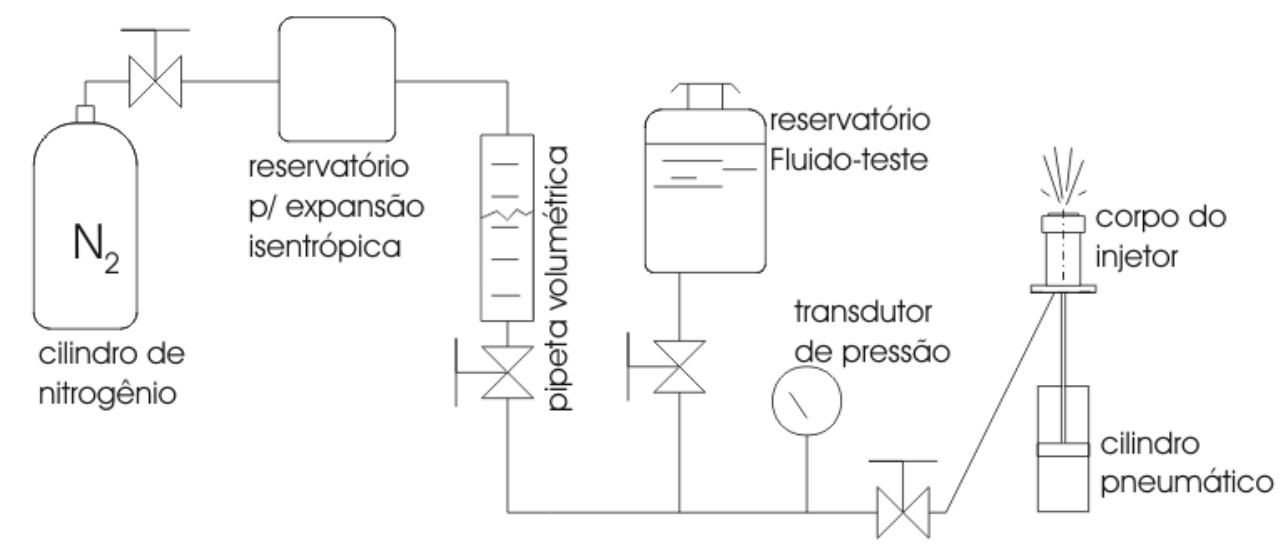

Figura 3.6 - Esquema da linha de injeção. 
Neste sistema, ilustrado na Fig. 3.6, estão contidos: (1) a linha de injeção que mantém a pressão constante durante a injeção e permite medir o volume injetado, (2) o corpo do injetor onde o volume de líquido de teste se encontra e, (3) o cilindro pneumático de acionamento da injeção.

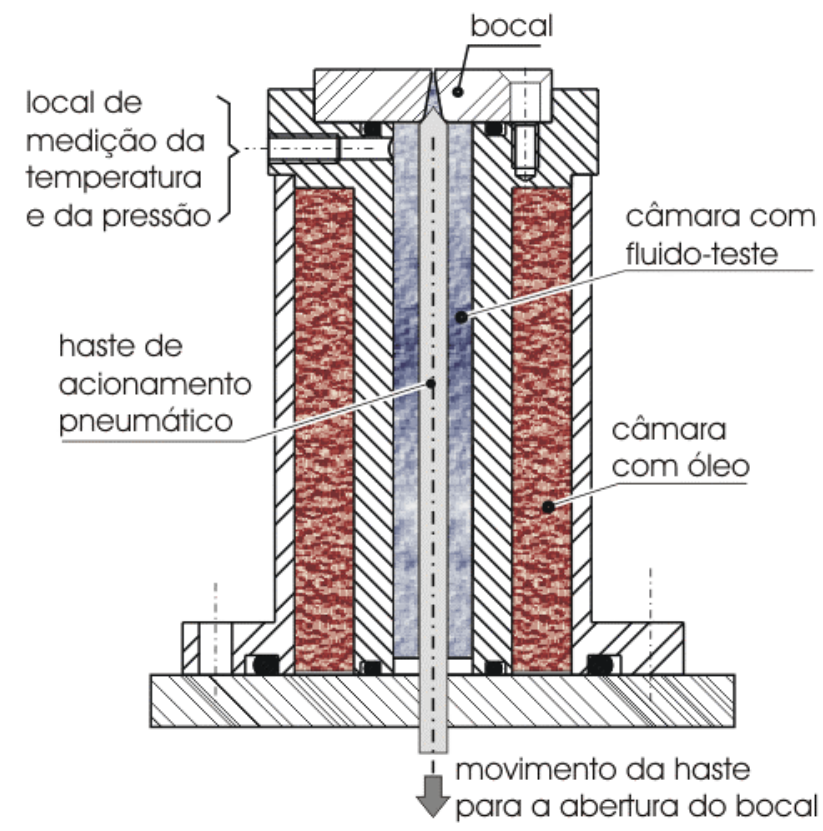

Figura 3.7 - Esquema do corpo de injeção. Mediante acionamento pneumático da haste, o líquido é subitamente expandido para fora do bocal. A temperatura inicial é obtida através da circulação de óleo aquecido no espaço anular.

No corpo de injetor, ilustrado na Fig. 3.7, existem duas câmaras. A câmara central contém o líquido de teste. A segunda câmara consiste em uma cavidade anular e por onde circula o óleo de aquecimento que mantém a temperatura do líquido de teste no valor desejado. Para a abertura e fechamento do bocal de injeção, existe uma haste no centro do injetor que obstrui a passagem do fluido pelo bocal e é ligada axialmente a um cilindro de acionamento pneumático (marca Festo com diâmetro de $10 \mathrm{~mm}$ e curso de $10 \mathrm{~mm}$ ). Um termopar do tipo T, AWG 30, marca Omega, indica a temperatura do líquido. Os bocais de injeção são do tipo cônico e convergente, feito de aço-carbono, com o perfil interno do canal usinado por eletroerosão e outro feito de vidro. Um desenho esquemático do bocal encontra-se na Fig. 3.8a. No detalhe desta figura, estão esquematizadas as dimensões internas do bocal onde consta que, $0,3 \mathrm{~mm}$ é o menor diâmetro, $3,0 \mathrm{~mm}$ é o outro diâmetro e $10^{\circ}$ 
de convergência entre a linha de centro e a geratriz do bocal. Sua fotografia está na Fig. 3.8b. Um outro bocal com as mesmas dimensões, praticamente, apenas se diferenciando com o diâmetro da saída, que é de $0,8 \mathrm{~mm}$, está na Fig. 3.8c. Um terceiro bocal, feito de vidro, cujo diâmetro da saída é de $0,35 \mathrm{~mm}$ está na Fig. 8.3d. Nela é vista apenas o inserto, e a borda da seção de saída é toda arredondada, diferente dos bocais anteriores em que a borda forma um canto vivo.

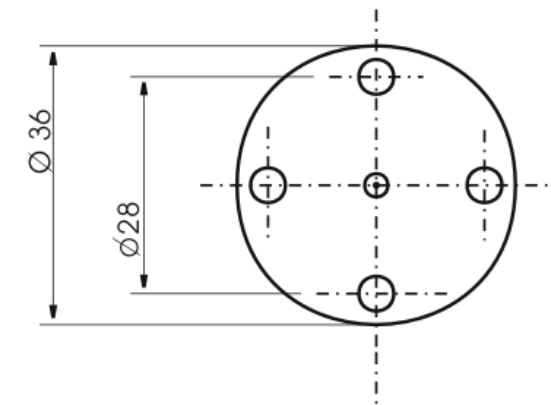

a)

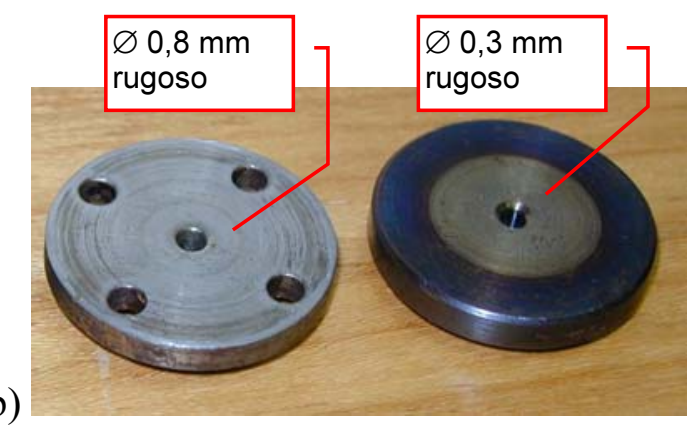

c)

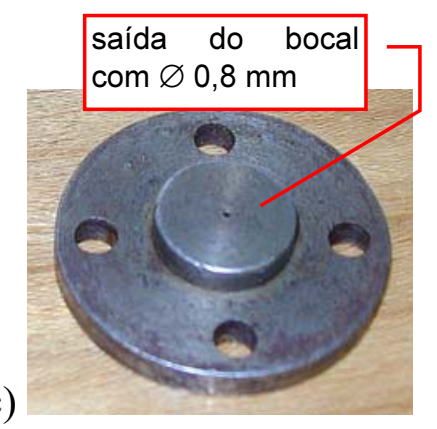

d)

$\varnothing 0,35 \mathrm{~mm}$ liso com a borda arredondada na saída

Figura 3.8 - A primeira figura é um esquema das dimensões gerais de um bocal. A segunda figura mostra os dois bocais usinados com diâmetro de saída de $0,8 \mathrm{e}$ $0,3 \mathrm{~mm}$, respectivamente. Ao lado está a vista do orifício de saída do jato de um bocal. A quarta fotografia mostra o inserto de vidro utilizado, cujo diâmetro de saída é de $0,35 \mathrm{~mm}$. Seu comprimento é de $12 \mathrm{~mm}$, diferente dos outros dois que possuem uma cota de $8 \mathrm{~mm}$, como na imagem "a". 
Quanto ao esquema de funcionamento da injeção tem-se o cilindro de gás nitrogênio e o reservatório de expansão (Fig. 3.6), com capacidade de cinco litros, que mantêm constante a pressão durante a injeção do jato. Em série com esses equipamentos está a pipeta graduada que indica o volume consumido pela injeção, através da leitura do nível de líquido antes e depois do ensaio. A linha da pipeta até o corpo do injetor é totalmente preenchida com o líquido de teste. Durante o ensaio, o volume consumido pela injeção proporcionará uma expansão do gás (processo quase isentrópico) que, para uma variação de volume igual a $0,01 \%$, a pressão da linha varia em $0,02 \%$, que é algo desprezível. Sabendo o volume deslocado na pipeta e o intervalo de abertura e fechamento do injetor, determina-se a vazão de líquido injetado. Além da medição do volume total deslocado durante a injeção pela simples leitura de níveis de líquido, também se pode obter valores próximos ao instantâneo usando o dispositivo de medição de vazão descrito a seguir. Esse dispositivo de medição da vazão da injeção contém seis pares de sensores ópticos instalados através da seção transversal do tubo de vidro graduado, separados a uma distância equivalente a um volume de 1,90 m $\ell$, conforme esquematizado na Fig. 3.9. Quando o nível do líquido passa pelo par emissor-fotodetector, existe a mudança do sinal no respectivo tempo registrado pelo sistema de aquisição, o que é detectado por um sistema eletrônico de lógica digital. Os seis sinais digitais são combinados em um único sinal digital e adquiridos pelo sistema de aquisição de dados. Ao final, pode-se ter valores precisos de vazão nos intervalos de tempo considerados. Verifica-se que a vazão permanece essencialmente constante nesse período, com pequenas variações em torno de 1 a $2 \%$ em vazão mássica, as quais são tratadas estatisticamente. Um exemplo de sinal adquirido está na Fig. 3.10. Neste gráfico, primeiramente, é mostrado o sinal da pressão de injeção. Os transitórios relativos a abertura e fechamento da injeção coincidem com o sinal do sensor que está solidário à haste (Fig. 3.7). Durante a injeção, foi obtido uma média da pressão de 505,5 kPa, com um desvio padrão de $2,9 \mathrm{kPa}$ do sinal. A pressão da câmara aumenta de forma linear no intervalo da injeção, e sua pressão inicial de $0,22 \mathrm{kPa}$, elevou-se ao patamar de 0,44 $\mathrm{kPa}$. As rampas de subida e descida do sinal do sensor de nível indicam os instantes que o líquido ultrapassou o caminho óptico de cada par emissor-receptor do sensor. 
O intervalo de duas rampas corresponde a um volume injetado de $1,90 \mathrm{~m} l \mathrm{e}$, no caso do gráfico, existem dois intervalos entre os instantes $t_{\mathrm{a}}=3,834 \mathrm{~s}, t_{\mathrm{b}}=4,654 \mathrm{~s}$ e $t_{\mathrm{c}}=$ 5,506 s. Finalmente, a temperatura de injeção é indicada com um valor médio de $122,2{ }^{\circ} \mathrm{C}$ e um desvio padrão do sinal coletado de $0,3{ }^{\circ} \mathrm{C}$.

Um transdutor de pressão, da marca Kulite, modelo XTE-190-250-A e com faixa de 0 a $750 \mathrm{kPa}$, é fixado na linha de injeção para descrever o comportamento durante o ensaio.

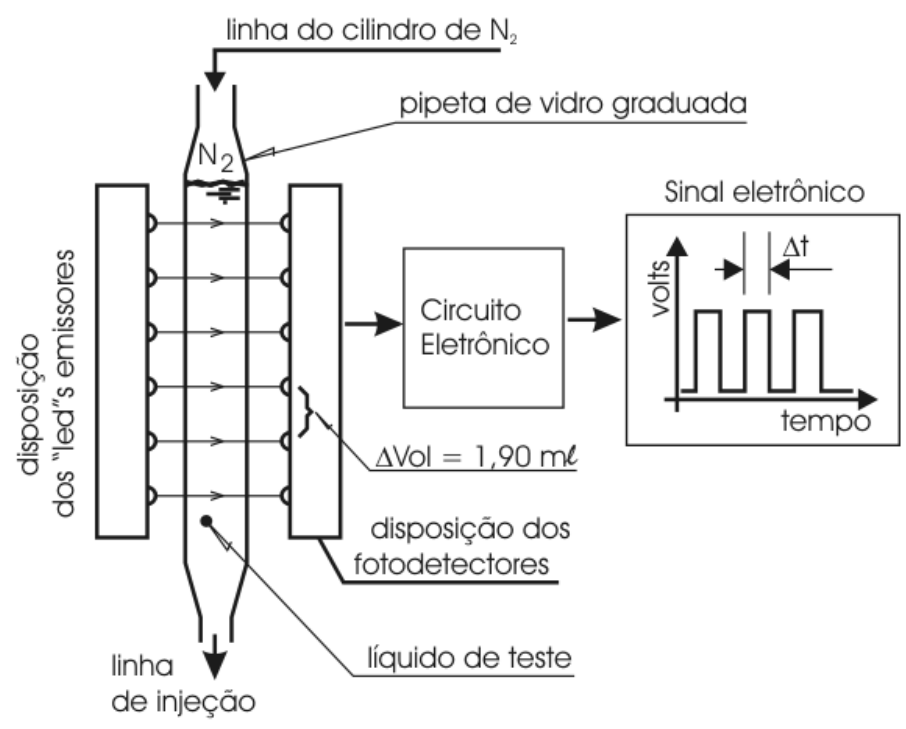

Figura 3.9 - Arranjo de medição instantânea da vazão através do nível de líquido no tubo de vidro graduado. 


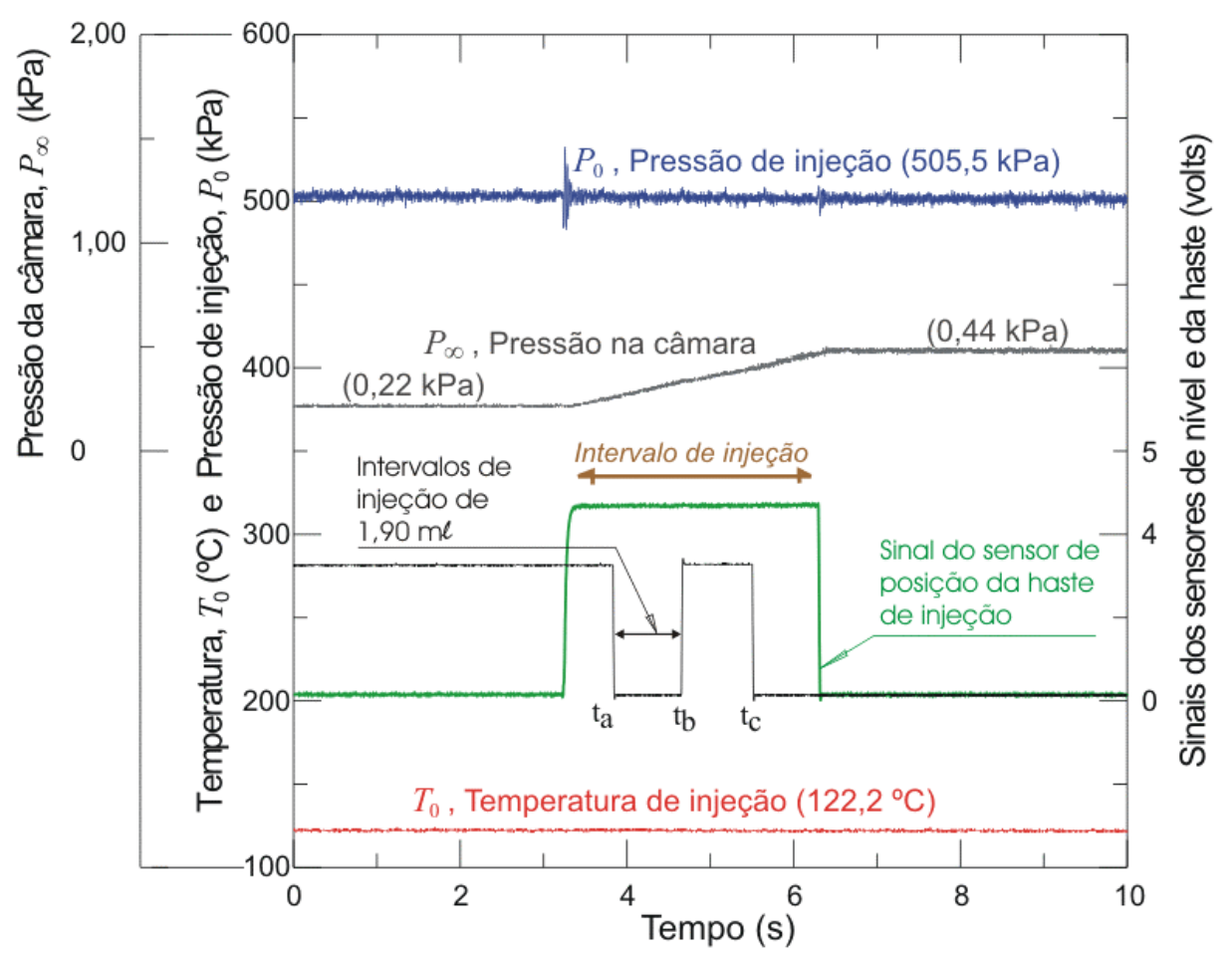

Figura 3.10 - Sinais típicos adquiridos no ensaio. É possível observar os sinais de pressão e temperatura de injeção, com um ruído representado por um desvio padrão de $2,9 \mathrm{kPa}$ e $0,3{ }^{\circ} \mathrm{C}$. Estão representados também os sinais da pressão da câmara, do sensor de posição da haste do injetor que indica o tempo de duração da injeção e do sensor de nível de líquido que indica os intervalos de deslocamento do volume a cada $1,90 \mathrm{~m} l$, representado por $t_{\mathrm{a}}, t_{\mathrm{b}}$ e $t_{\mathrm{c}}$.

\subsection{Sistema Óptico - Método "Schlieren"}

Esse tradicional método "Schlieren" permite o registro do gradiente de densidade em torno do jato além se ser empregado para visualizar ondas de choque, entre outros fenômenos, que podem estar presentes na evaporação de líquidos metaestáveis. Em uma primeira etapa, foi obtida uma série de ensaios, denominada de "Run1", com registros fotográficos através de uma câmara CCD ("Charge Coupled Device", que corresponde ao dispositivo fotossensível deste tipo de câmara) com um tempo de exposição de $250 \mu s$. Na etapa seguinte, foi realizada uma implementação do sistema óptico, introduzindo uma lâmpada do tipo "flash", que possui um intervalo de tempo de iluminação de $2 \mu s$, caracterizando uma imagem mais instantânea para a visualização no método "Schlieren". Em adição, também foi implementada uma segunda câmara CCD que adquire imagens do jato evaporativo 
concomitante com a primeira câmara, através do sistema de "iluminação por detrás" que, por sua vez, deu suporte para correlacionar as imagens obtidas pelos dois métodos de visualização. As imagens registradas digitalmente, através do método "Schlieren", são submetidas às ferramentas matemáticas de processamento e filtragem e este procedimento é pormenorizado no Apêndice II. As substâncias como o óleo diesel e o querosene já foram utilizados como fluidos de teste (Vieira, 1999), nesta bancada. Em ensaios atuais, utilizou-se a substância pura iso-octano $\left(\mathrm{C}_{8} \mathrm{H}_{18}\right)$, que também é uma substância SCME. É interessante notar que é uma vantagem utilizar uma substância SCME porque devido ao seu potencial de armazenamento de energia durante a metaestabilidade, maior será a taxa de evaporação, conseqüentemente, menor será a quantidade de gotículas oriundas da onda de evaporação proporcionando uma imagem mais nítida do núcleo de líquido.

O método "Schlieren" consiste de um feixe luminoso paralelo que atravessa a região do fenômeno e depois é focalizado por meio de um espelho parabólico ou lente sobre um filtro espacial, também chamado de faca, ou "pin-hole". Se um raio de luz sofrer um desvio considerável devido às variações de densidade do meio, este será refletido e não atravessará o "pin-hole" e, portanto, não será projetado sobre o filme ou sensor de CCD. Caso contrário, o raio de luz que atravessa uma região com uma variação de densidade desprezível, não sofre desvio e, seu foco continua sendo o "pin-hole" que não bloqueia o raio, fazendo-o atingir o filme fotográfico ou o sensor CCD. As regiões onde o gradiente de densidade é elevado aparecem na imagem do filme como sombras em virtude do desvio do raio luminoso. Isso caracteriza a intensidade luminosa na imagem como algo inversamente proporcional ao gradiente da densidade.

A geometria do arranjo óptico está mostrada na Fig. 3.11. Na seqüência, as Figs. 3.12 e 3.13, são fotografias das mesas ópticas com os equipamentos ópticos. Vê-se que no esquema da Fig. 3.11, o feixe da fonte luminosa é concentrado ao passar pela lente convergente, coincidindo o foco do feixe com a posição do filtro espacial. Isso faz com que a fonte luminosa tome um caráter pontual, pois o diâmetro do "pin-hole" é de 0,28 mm. Como na lente, a posição do "pin-hole" coincide com a distância focal do espelho parabólico, fazendo com que o feixe expandido após o "pin-hole", atravesse a seção do evento, de forma paralela. O segundo espelho recebe 
o feixe paralelo e focaliza-o no outro "pin-hole" com diâmetro de 0,42 mm.

Uma descrição mais detalhada do sistema "Schlieren" utilizado encontra-se no trabalho realizado por Guimarães (1999).

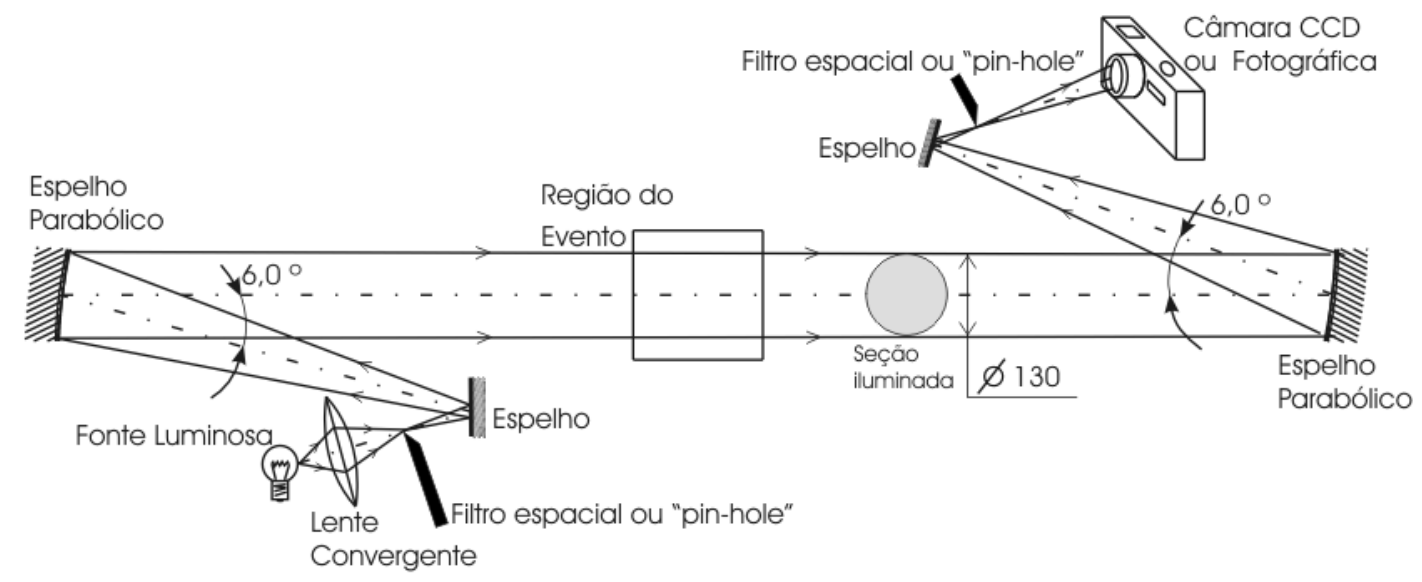

Figura 3.11 - Geometria do aparato óptico.

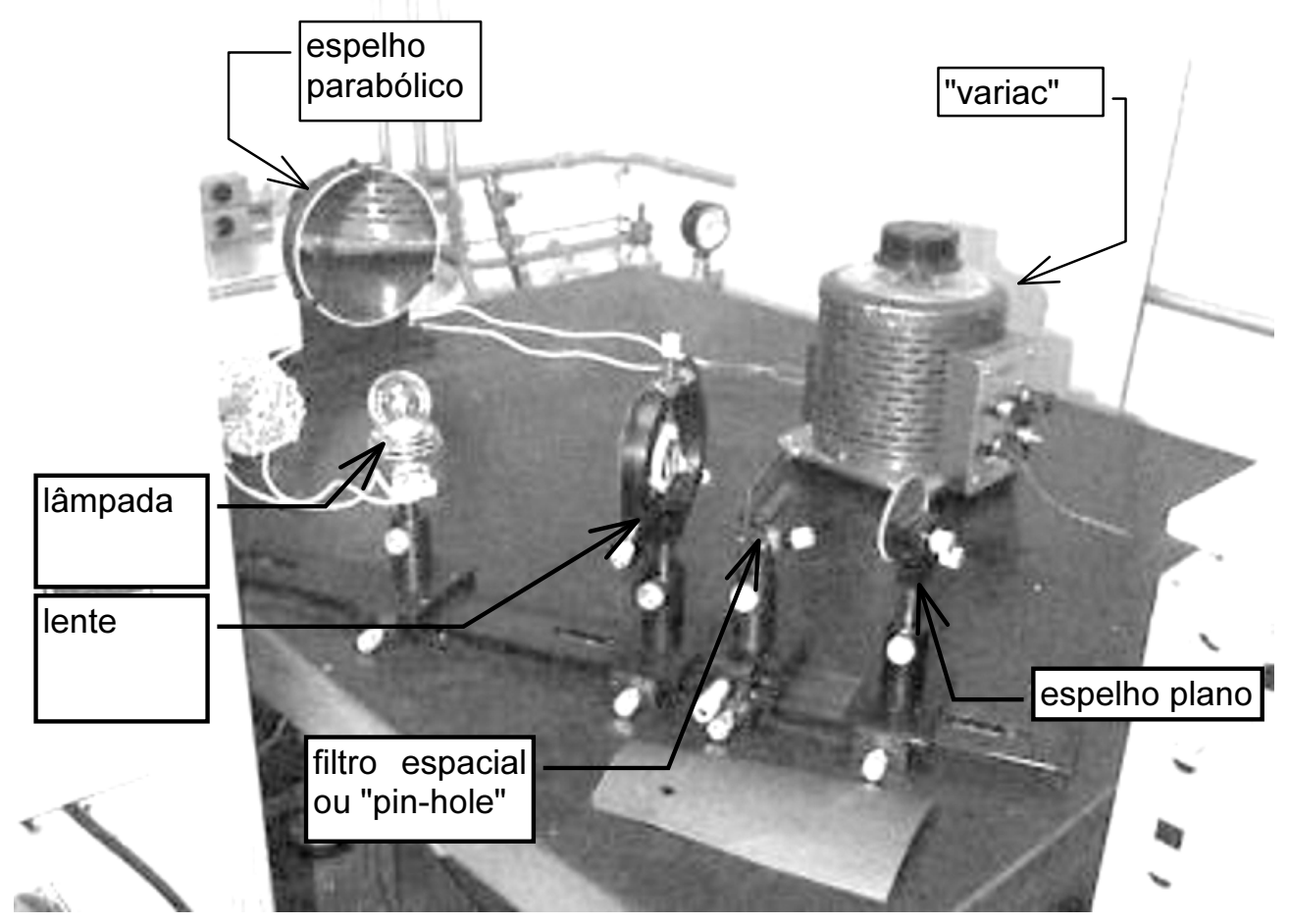

Figura 3.12 - Equipamentos: espelhos, lâmpada, lente convergente e filtro espacial. 


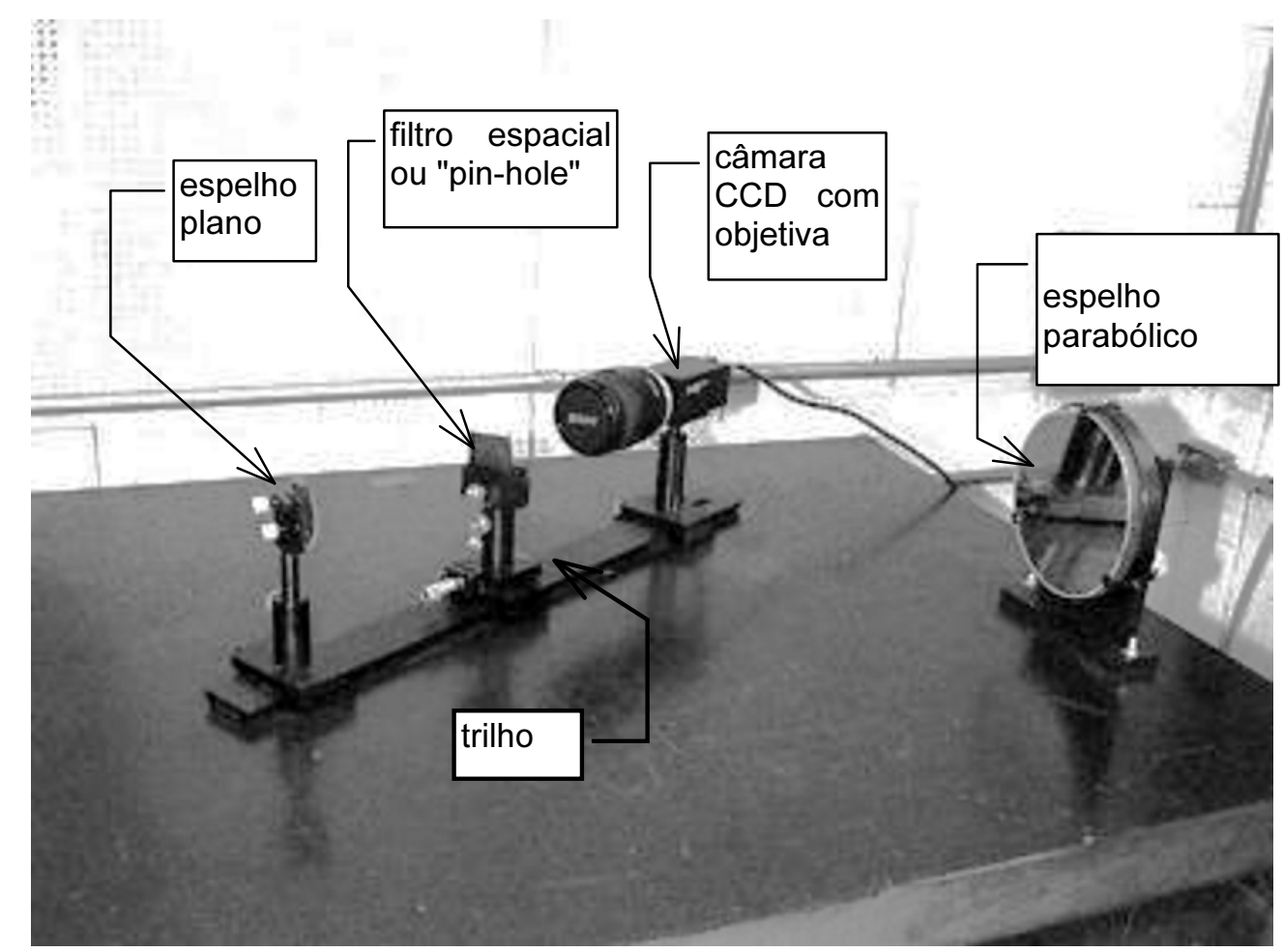

Figura 3.13 - Equipamento: espelhos, filtro espacial e câmara CCD.

Basicamente, nesta configuração, utiliza-se uma lâmpada halógena automotiva de $40 \mathrm{~W}$ (lâmpada de filamento de tungstênio preenchida com gás halógeno), cuja intensidade é regulada por um "variac", dois espelhos parabólicos de diâmetro de $150 \mathrm{~mm}$ com $800 \mathrm{~mm}$ de foco, uma lente de $45 \mathrm{~mm}$ de foco, dois filtros espaciais ou "pin-hole", dois espelhos planos com a primeira superfície reflexiva e uma câmara CCD com objetiva. Em uma outra configuração, no lugar da lâmpada convencional, foi empregada a utilização de uma lâmpada do tipo "flash".

\subsection{Sistema de Aquisição de Dados}

Existe um computador (computador 1 da Fig. 3.14) que gerencia todo o ensaio obtendo os dados de pressão e temperatura iniciais, posição da haste do injetor, e sinais de saída para disparo da injeção e da aquisição das imagens. Este possui uma placa de aquisição de dados da marca Lynx com 16 canais, 2 saídas de expansão e resolução de 12 bits. São adquiridos dados: a) da temperatura do líquido através de um termopar do tipo "T"; b) da pressão da linha de injeção pelo transdutor de pressão, marca Kulite, modelo XTE-190-250-A; c) do posicionamento da haste do 
cilindro pneumático através de um sensor óptico; d) do sensor de nível da pipeta graduada, e; e) da pressão da câmara onde é descarregado o jato. Se necessário, os dados são amplificados em um módulo de 8 canais, modelo MSC-1000-V2-8, da Lynx.

A aquisição de imagens é feita através de um outro computador (computador 2 da Fig. 3.14) que possui uma placa de aquisição de imagens. Este recebe o sinal de saída de expansão, canal "1" do computador "1" para capturar as imagens do jato. O outro sinal de expansão, canal "0" do computador "1", é dedicado para o acionamento da injeção. A imagem é obtida por uma câmara CCD, monocromática, com tamanho de sensor de 1/2 polegada, da marca Coastar, modelo CV-M50. A placa de processamento de imagens é da Data Translation, modelo DT-3152, e as bibliotecas do "Frame Grabber - SDK", da Data Translation, foram utilizadas para construir o programa computacional que controla esta aquisição de imagens. Na Fig. 3.14, está esquematizado o sistema.

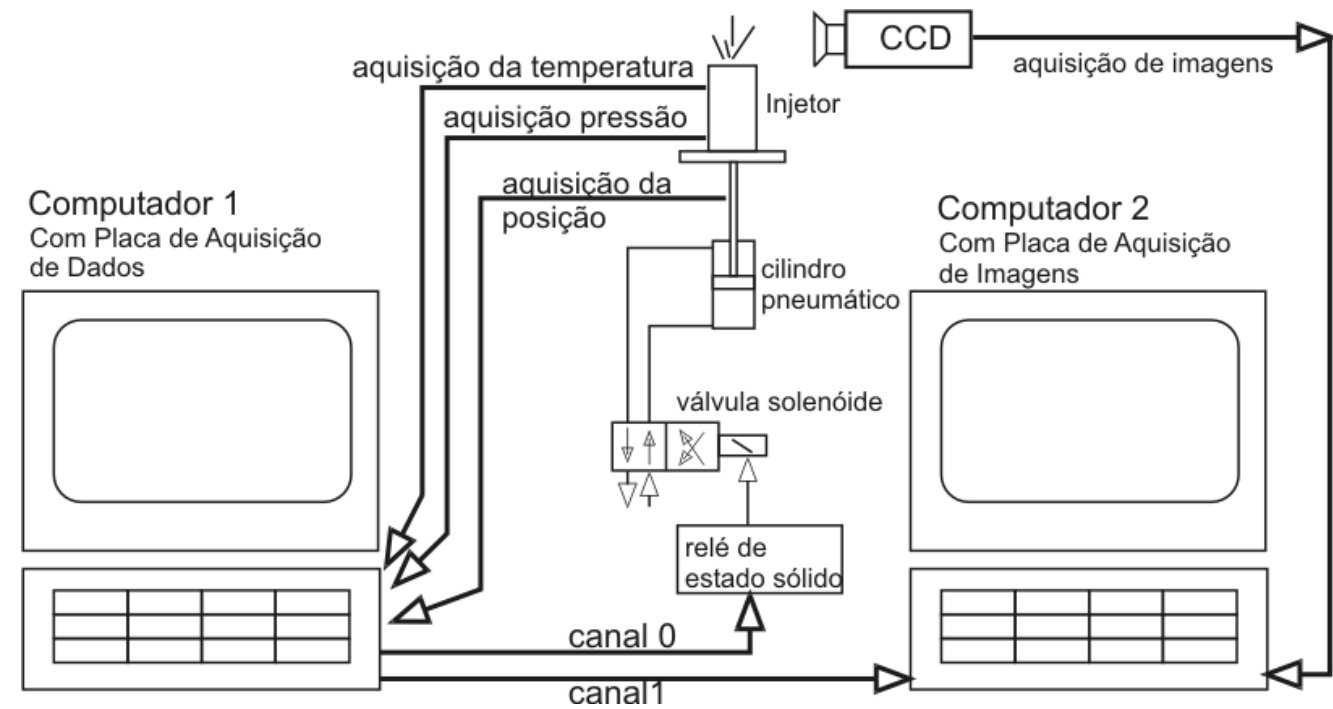

Figura 3.14 - Sistema de aquisição de dados, onde o canal "0" dispara o injetor e o canal "1" dispara a aquisição das imagens.

O computador "1", conforme a Fig. 3.14, monitora a temperatura do fluido de teste e a linha da pressão de injeção. Quando os valores desejados dessas grandezas são alcançados para o ensaio, o sistema de aquisição de dados do computador 1 é acionado. Os dados de pressão, temperatura e posição da haste começam a ser coletados. Após $0,20 \mathrm{~s}$, é obtida uma fotografia da seção sem o disparo efetivo do 
jato, a qual será uma referência para posterior tratamento da imagem, que será visto mais adiante (Apêndice II). O instante de disparo da fotografia corresponde à descida de patamar de voltagem do canal "1". Depois são coletadas mais quatro imagens que se sucedem em intervalos de $0,20 \mathrm{~s}$, durante o jato. A Fig. 3.15 mostra o sinal do canal "1" e também, exibe o gráfico do canal "0" que aciona o injetor durante o intervalo de $5 V$ do sinal, em função do tempo. Este canal, ao mesmo tempo em que energiza um relê de estado sólido, também aciona a válvula solenóide para o acionamento do cilindro pneumático, que movimenta a haste para a abertura do bocal do injetor. No intervalo de $0,20 \mathrm{~s}$, após o início do ensaio, ele é disparado com uma defasagem de $0,08 s$, aproximadamente, entre o tempo do disparo do canal "1" no computador e a efetiva injeção do fluido. Quanto à duração da injeção, neste exemplo, ficou em torno de $0,75 \mathrm{~s}$, pois a defasagem entre o sinal e o fechamento da injeção é de $0,04 s$, aproximadamente.

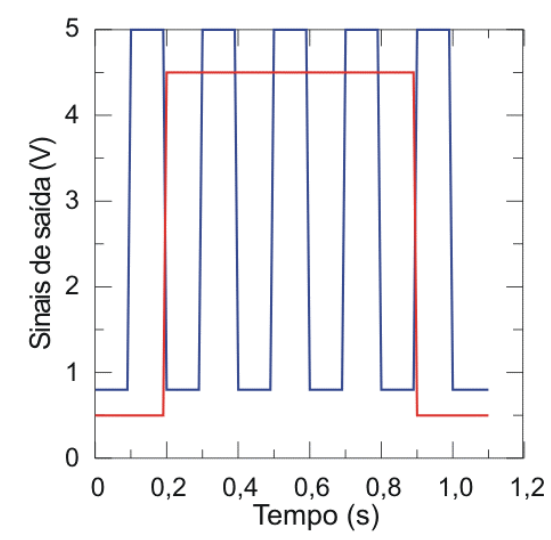

Figura 3.15 - Esquema dos sinais de saída. A linha vermelha corresponde ao sinal do acionamento do injetor, ou canal " 0 ", e a linha azul corresponde ao sinal de disparo para a aquisição das imagens, canal "1".

A indicação do tempo destes sinais é repetida no gráfico da Fig. 3.16. Nele são ilustrados os sinais referentes ao transdutor que monitora a pressão da linha de injeção e o sinal referente ao sensor de posição da haste do injetor. O recuo da haste do injetor proporciona a abertura do bocal, efetuando a injeção. O sensor óptico de posicionamento do cilindro pneumático marca um sinal de $0 \mathrm{~V}$ quando o bocal está fechado, após a haste deslocar-se 1,0 mm, o sinal sobe para $5 \mathrm{~V}$, depois retorna para 
voltagem nula após deslocar-se $2,0 \mathrm{~mm}$ e com o deslocamento de 3,0 até 4,0 $\mathrm{mm}$ o sinal é de $5 V$. A haste que obstrui o bocal está solidária aos dentes. Na medida que se movimenta a haste, o posicionamento dos dentes pode bloquear ou abrir o caminho óptico do sensor. Tomando o sinal do sensor, verifica-se que a rampa é bastante inclinada no fechamento da injeção. Isso acontece em virtude da inércia da energização do sensor e também pelo fato que a força aplicada para a abertura do injetor é menor que a força no encerramento da injeção no cilindro pneumático.

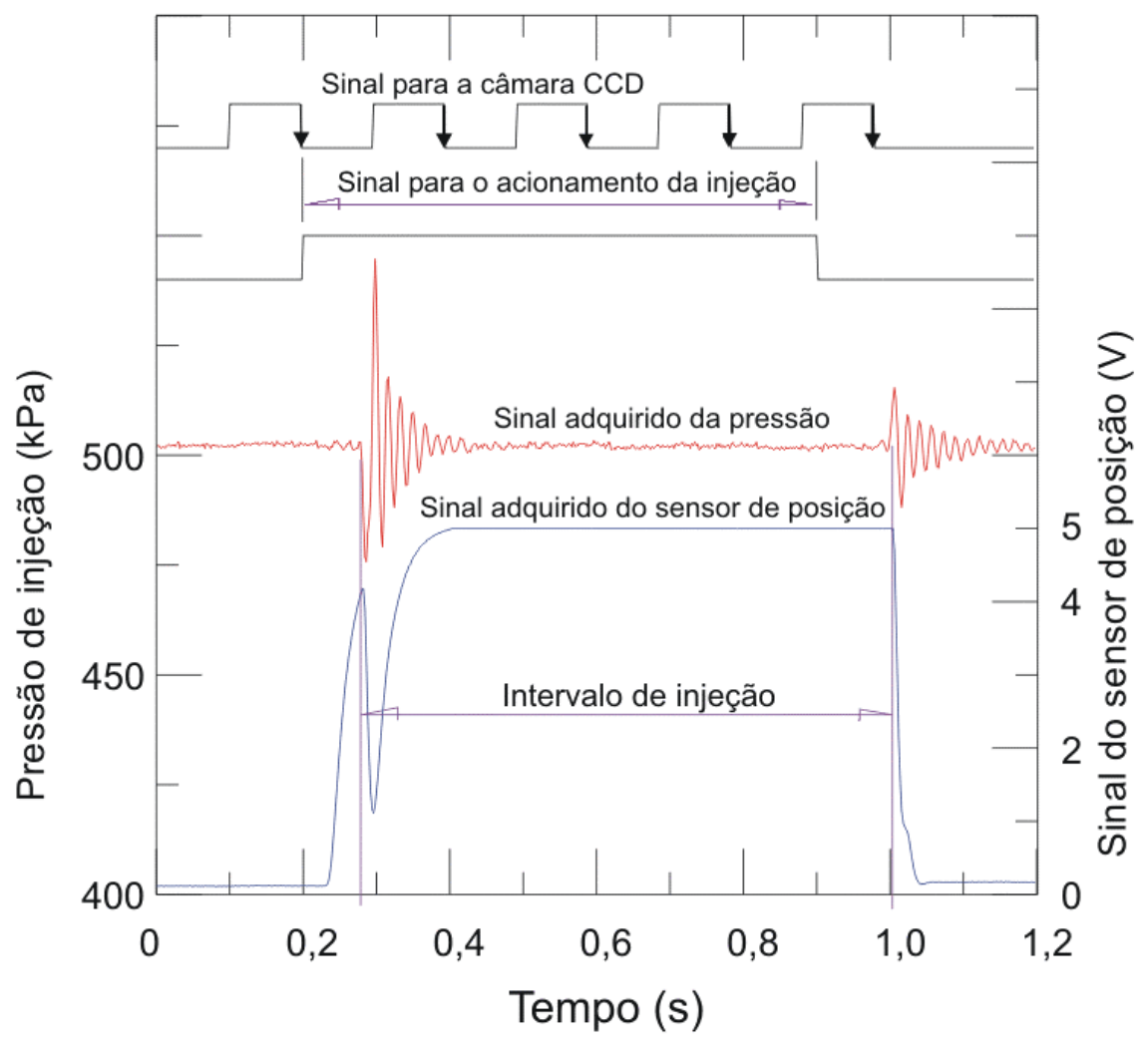

Figura 3.16 - Comparação dos tempos dos sinais de saída e de entrada. O primeiro sinal representa o sinal para a câmara CCD habilitar a aquisição das imagens na rampa de descida, indicada pelas setas. O segundo sinal apenas apresenta o tempo em que o computador habilitou a abertura do injetor. Estes dois sinais não possuem a representação da voltagem em sua amplitude. $O$ terceiro e o quarto sinal são as representações típicas de um sinal adquirido da pressão de injeção e do sinal de posição da haste, respectivamente. Neles constam as coincidências dos transitórios devido à abertura e fechamento da injeção. 


\subsection{Implementação do Sistema Óptico}

Em virtude da grande utilização da câmara CCD para a obtenção de imagens ou filmagens em nosso laboratório, já que esta técnica possibilita o processamento digital destas imagens, houve a necessidade de buscar um melhor entendimento do princípio de funcionamento do equipamento e alguns tópicos deste tema foram estudados, como:

- Característica do sinal da imagem e comparação entre NTSC, PAL e SECAM;

- Características do sensor CCD;

- Parâmetros ajustáveis à câmara CCD (tempo de exposição, ganho, sincronismo, entrelaçamento de campos, etc.);

- Características das placas de aquisição de imagens;

- Comunicação entre câmara CCD e Placa (cabeamento, sinais de sincronismo, sinais de disparo, RS170, etc.);

- Parâmetros ajustáveis aos softwares de aquisição;

- Tópicos para o desenvolvimento de um software de aquisição em função dos pacotes oferecidos pelos revendedores.

Tal estudo proporcionou verificar a estrutura atual das imagens obtidas que, devido à câmara CCD estar configurada para o modo "entrelaçado" (ou seja, primeiro a câmara obtêm um campo das linhas ímpares e, após o intervalo de 1/60 $s$, a câmara adquire o campo das linhas pares, que recombinadas, constituem um quadro), se observa uma defasagem de tempo entre os campos, dentro da imagem. Um exemplo disto está mostrado nas imagens que se seguem (Fig. 3.17). Nota-se a distinção dos eventos ilustrados nas Figs. 3.17b e 3.17c. Acrescentado a este fato, pode-se observar na região do jato da fotografia da Fig. 3.17a, uma seqüência de riscos horizontais, no filete líquido, concluindo a descontinuidade do jato. 
a)

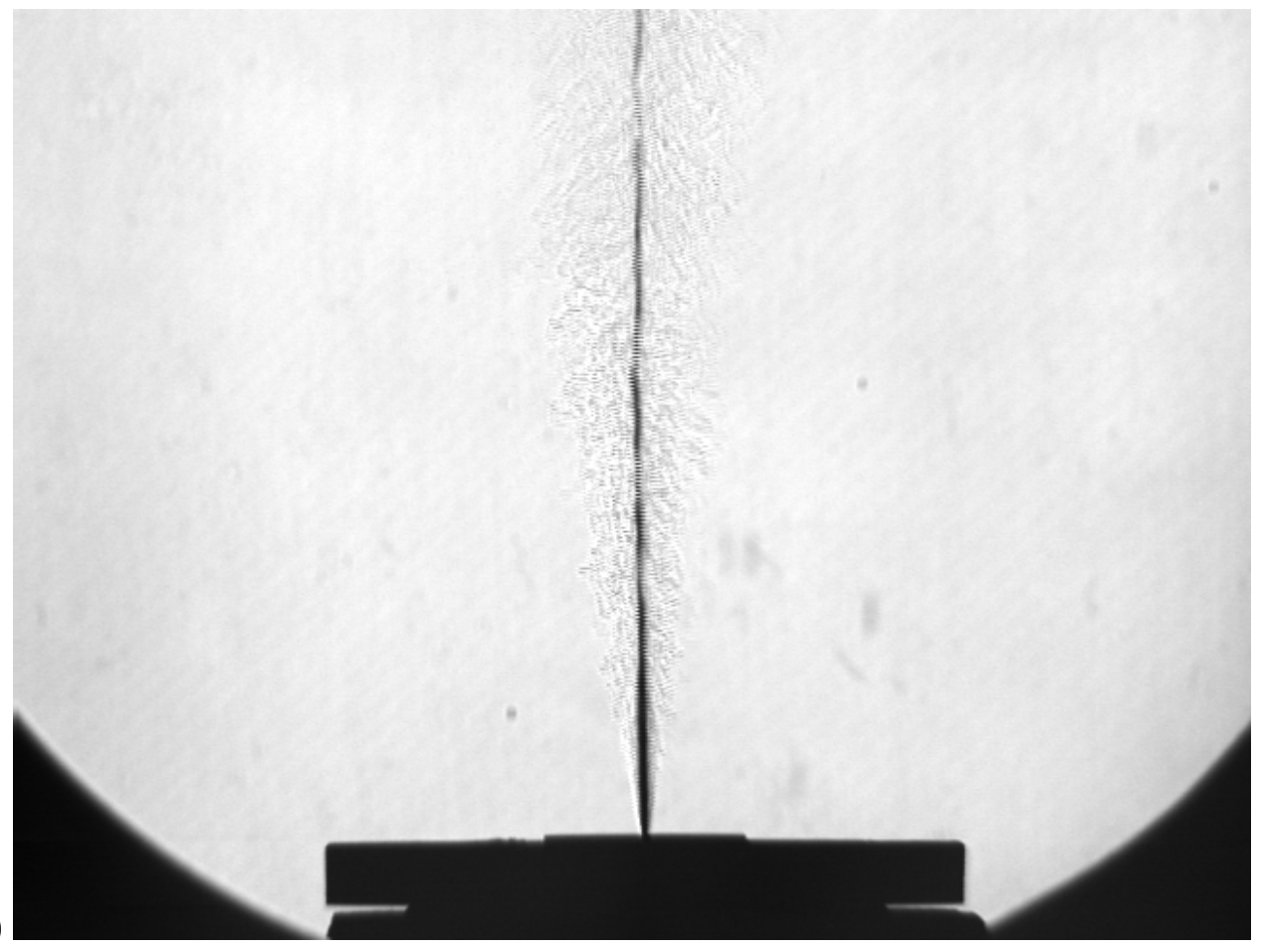

b)

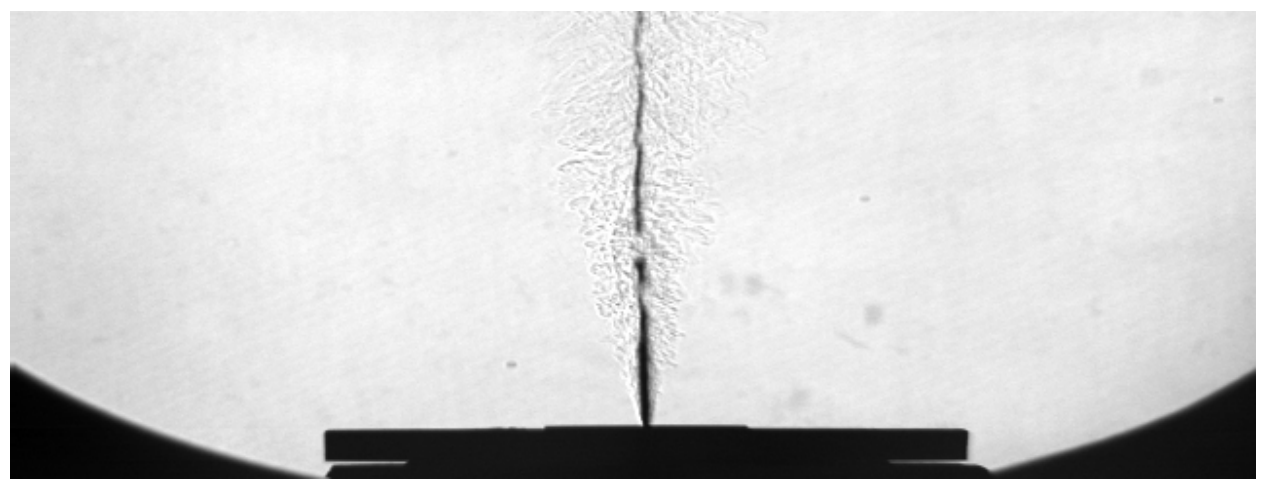

c)

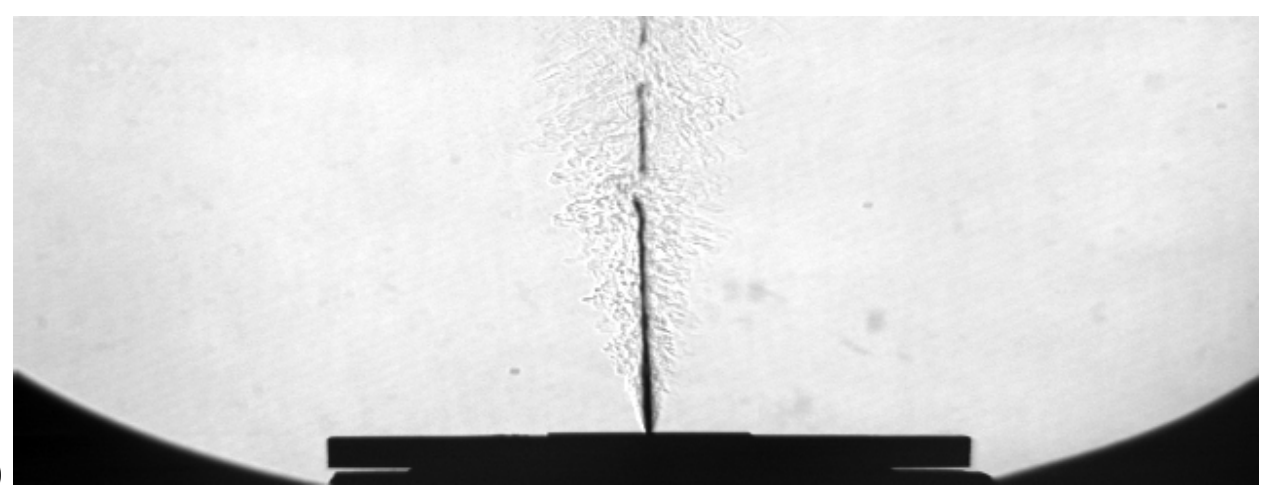

Figura 3.17 - A primeira fotografia, corresponde à imagem original obtida na câmara CCD. As duas imagens seguintes, b) e c), correspondem ao campo das linhas ímpares e pares da original, respectivamente. Com esta decomposição, é possível notar as descontinuidades no jato devido à evaporação. 
Cabe lembrar que as imagens já obtidas nos ensaios não perderam a sua integridade diante deste fato, pois, em cada ensaio, são registradas quatro fotografias do evento dando a característica de permanência do fenômeno como, por exemplo, posição da onda de choque e comprimento de extinção do líquido devido à evaporação. Um exemplo disto está mostrado na Fig. 3.18 onde estão as quatro imagens obtidas do ensaio com as seguintes condições: pressão de injeção de 500 $\mathrm{kPa}$, pressão da câmara de $0,41 \mathrm{kPa}$ e temperatura de injeção de $162{ }^{\circ} \mathrm{C}$. Seqüencialmente, a primeira imagem é obtida no intervalo de $0,1 s$ após a abertura da injeção, depois de $0,5 s$ tem-se uma nova aquisição e, as próximas duas imagens são obtidas em intervalos de $2 s$ a partir da segunda imagem obtida. Esta repetibilidade das imagens fornece uma segurança da regularidade do ensaio, agregado à análise dos dados de sinais que são adquiridos pelos sensores de vazão, pressão e temperatura de injeção. Alternativa para contornar isto foi a utilização de uma lâmpada de disparo rápido ("flash") com o sincronismo do "shutter" da câmara CCD (Fig. 3.19).

a)

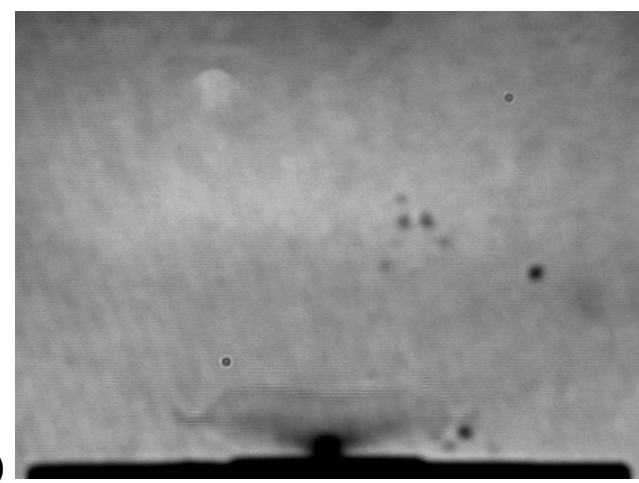

c)

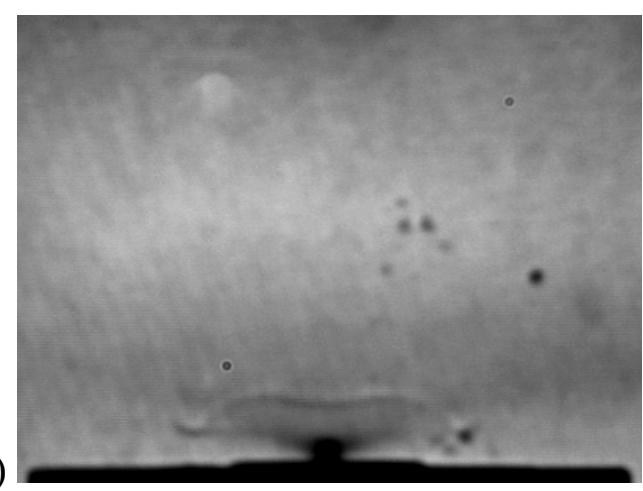

b)

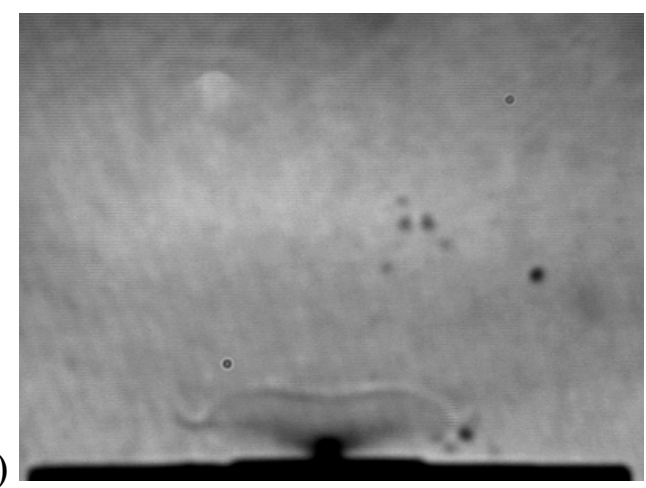

d)

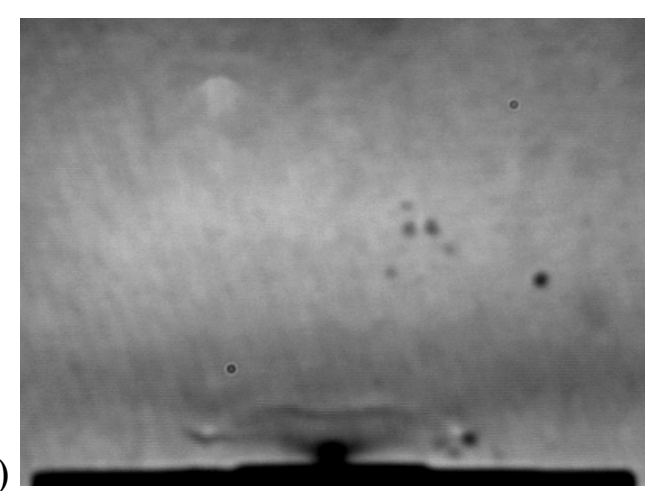

Figura 3.18 - Seqüência de fotografias obtidas em um único ensaio conforme os intervalos de $0,10,0,50,2,50$ e 4,50 segundos, após a abertura do injetor. 


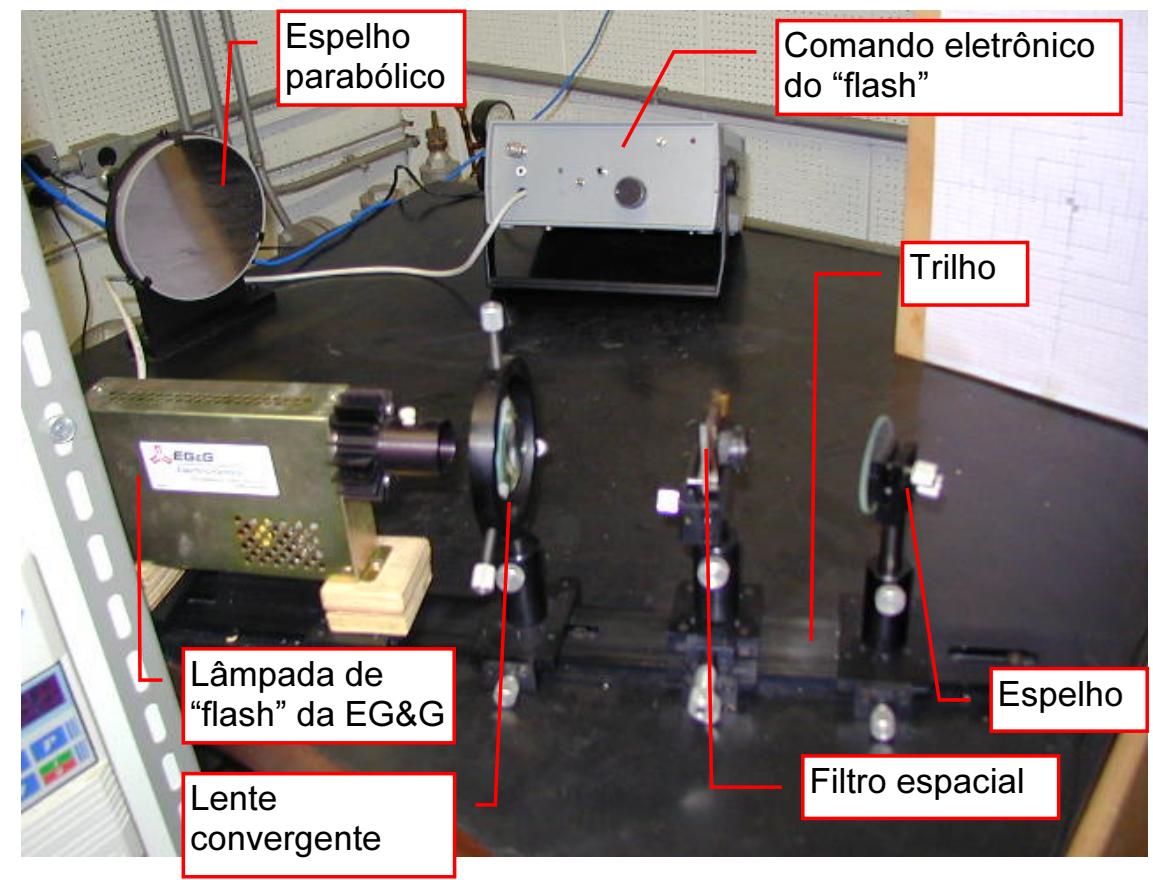

Figura 3.19 - Fotografia da mesa óptica que possui a fonte de luz. No caso, esta imagem mostra o "flash" empregado que possui um tempo de exposição de $2 \mu \mathrm{s}$.

A lâmpada halógena, que foi utilizada na série de ensaios "RUN1" (primeira etapa dos ensaios aqui apresentados), foi substituída e implementada por um sistema de sincronismo com lâmpada de "flash", marca EG\&G e modelo LS-1130, que consegue suprir as necessidades de iluminação do experimento, sem que a mesma câmara CCD possua o recurso de varredura "Progressive Scan", ou seja, adquire os campos das linhas pares e ímpares no mesmo instante de tempo, sem a defasagem tradicional de 1/60 s. Com a utilização deste "flash", foi possível adquirir uma imagem mais instantânea do jato, pois o mesmo possui um tempo de iluminação da ordem de $2 \mu s$, enquanto, na configuração anterior, este tempo de exposição ficava em torno de $250 \mu s$, portanto, há um ganho em termos de resolução temporal de cerca de 125 vezes. Resumindo, com uma câmara CCD que apenas possui a função de modo entrelaçado e com tempo de exposição de $250 \mu$ s, foi possível obter o recurso de "Progressive Scan" com um tempo de exposição de $2 \mu s$.

Para tanto, foi elaborado um programa computacional (Fig. 3.20), em linguagem "Visual Basic", que gerencia a placa de aquisição de imagens (marca Data Translation e modelo DT3152). O programa controla o tempo de exposição da câmara CCD (opção "Sync Máster”), a quantidade de imagens a serem adquiridas no 
ensaio, a duração do ensaio e, oferece a opção de utilizar a segunda câmara. Cabe lembrar que a metodologia de filtragem matemática das imagens adquiridas pelo método "Schlieren" e o próprio método não foram alterados, pois a lógica de adquirir uma imagem antes do jato e quatro durante o jato, empregada pelo programa anterior de aquisição de imagens, desenvolvido por Guimarães (1999), foi mantida.

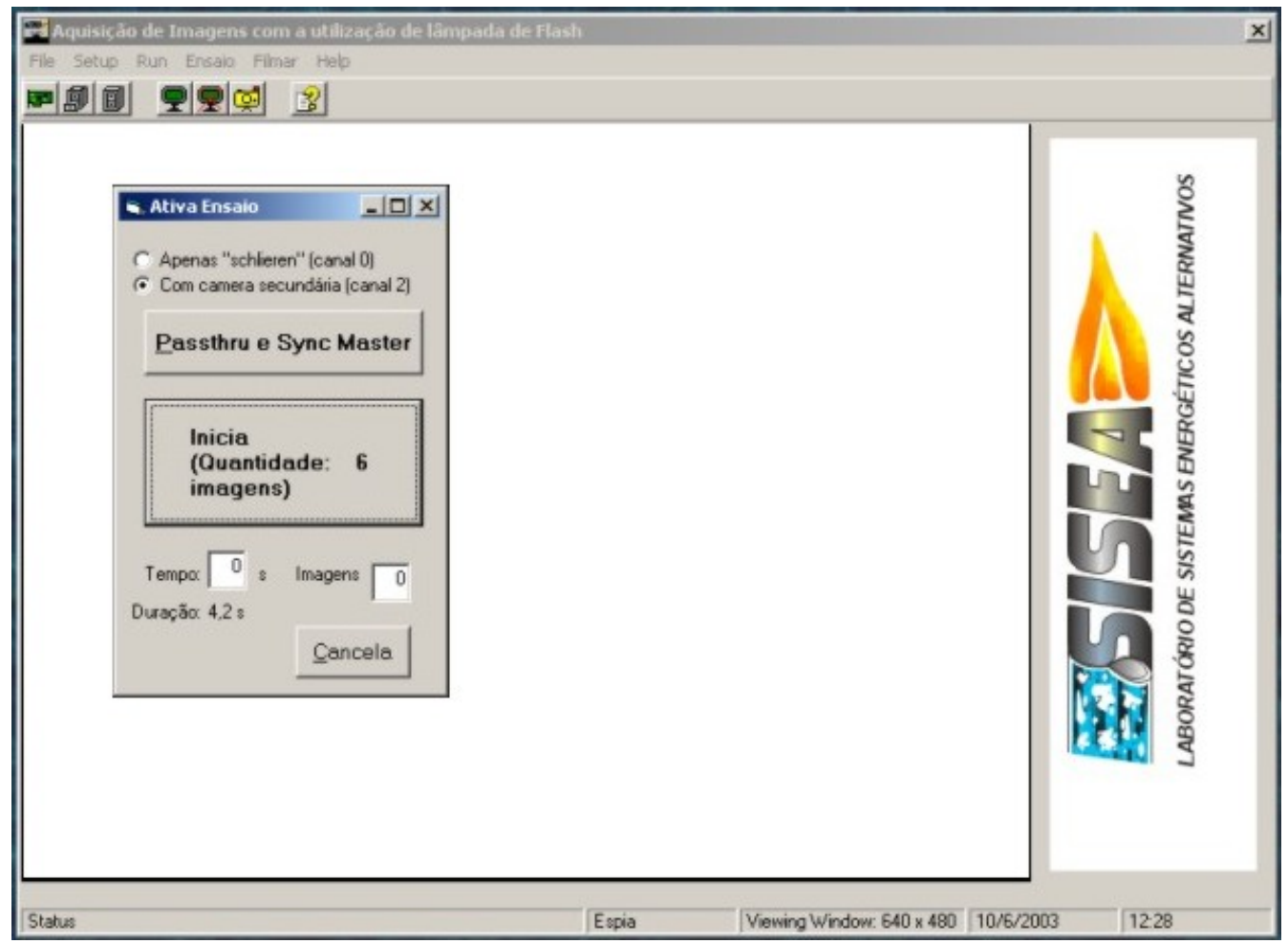

Figura 3.20 - Interface do programa computacional "Aqjatos" projetado e programado para adquirir as imagens dos jatos desta bancada. Nele se regula o tempo de exposição da câmara CCD (Sync Master), quantidade de imagens adquiridas no ensaio, duração do ensaio e, utilização de uma segunda câmara.

O seu maior diferencial, em relação ao programa anterior, está no sincronismo entre a câmara CCD e a lâmpada de "flash". Como exemplo do seu funcionamento, na grande maioria dos ensaios, o sinal de controle do tempo de exposição da câmara CCD, ou "freqüência de imagens", é configurado para $10 \mathrm{~Hz}$ (o comum é $60 \mathrm{~Hz}$ ). Simultaneamente, existe um sinal de $2 \mathrm{~Hz}$ que é originado pela placa de aquisição de dados. Estes dois sinais elétricos de controle, que variam de 0 a 5 volts, são combinados em uma porta lógica AND, do tipo CMOS, que origina um sinal de saída único para disparar a lâmpada de "flash" no instante em que o tempo 
de exposição da câmara CCD está habilitado pelo sinal de $10 \mathrm{~Hz}$ de freqüência. $\mathrm{O}$ esquema está ilustrado na Fig. 3.21.

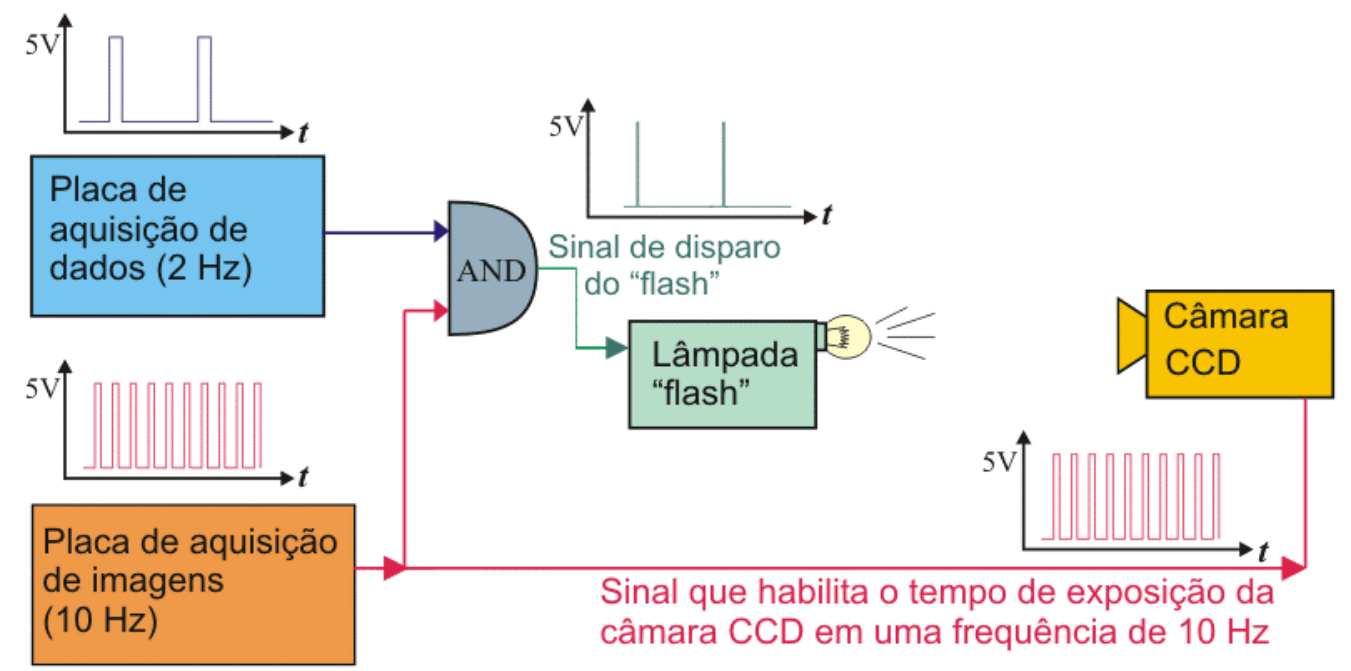

Figura 3.21 - Esquema dos sinais que fazem o sincronismo entre a lâmpada de "flash" e a câmara CCD.

Conforme a Fig. 3.21, a placa de aquisição de imagens dirige um sinal controlador da câmara CCD de $10 \mathrm{~Hz}$. Deste sinal, cada pico controla o tempo de exposição de cada campo da imagem, ou seja, a câmara CCD envia 5 imagens por segundo nesta configuração $(10 \mathrm{~Hz})$, pois cada imagem possui dois campos. Porém, não é possível saber em que instante o "flash" dispara para sensibilizar os dois campos da imagem, porque no primeiro pico, o sensor da câmara CCD pode ser sensibilizado nos dois campos, mas no segundo pico, ele apenas sensibiliza um campo. Para isto, existe a combinação de freqüências de $10 \mathrm{~Hz}$ com a freqüência de 2 $\mathrm{Hz}$ para que na seqüência de aquisição das imagens, possam obter intercaladas as imagens boas, que possui os dois campos, e as outras com apenas um campo, porque a cada 5 picos do sinal controlador da CCD, o "flash" dispara. Além disto, o intervalo de duração do pico é ajustado para que o "flash" dispare no instante que a CCD está disponível para adquirir os dois campos da imagem (ímpares e pares), ou apenas um deles (o campo das linhas pares), que não é desejável. Em um único ensaio, no mínimo, quatro imagens são obtidas para que haja pelo menos uma imagem com boa qualidade, ou seja, com os dois campos. Se não houvesse esta intercalação de imagens com um e dois campos, um único ensaio estava sujeito a 
adquirir somente imagens boas ou, somente imagens com um campo. Na Fig. 3.22 estão ilustradas imagens obtidas em um ensaio de jato de iso-octano com temperatura e pressão de injeção de $95^{\circ} \mathrm{C}$ e $250 \mathrm{kPa}$, respectivamente, e pressão do reservatório 200 vezes menor que a pressão de vapor.

a)

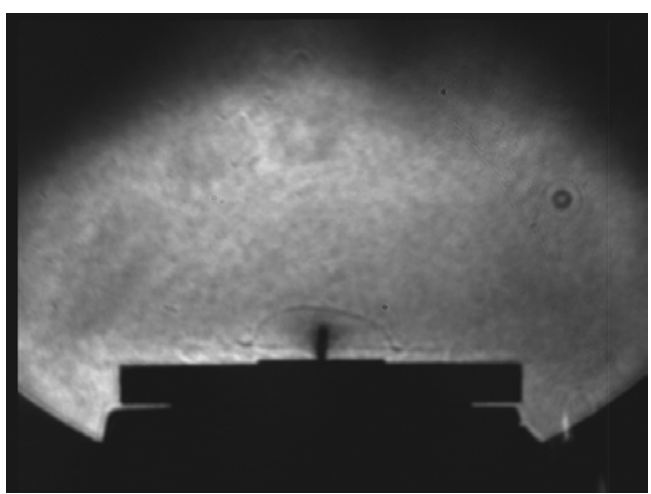

c)

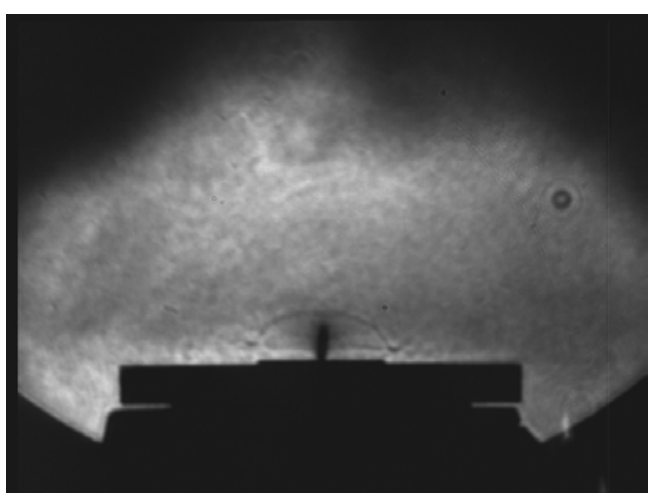

b)

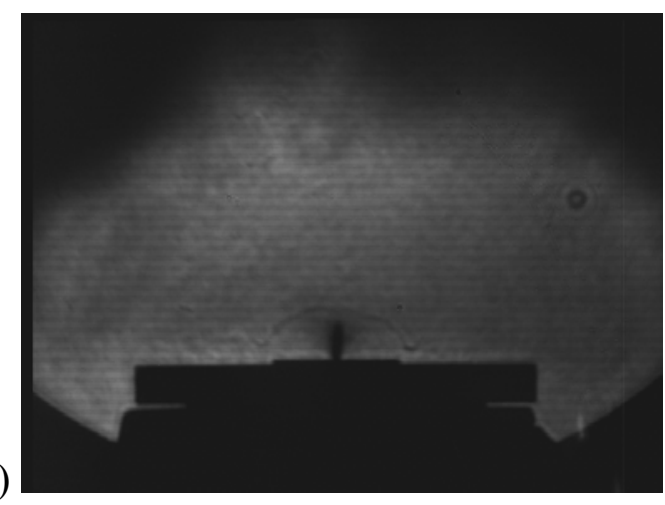

d)

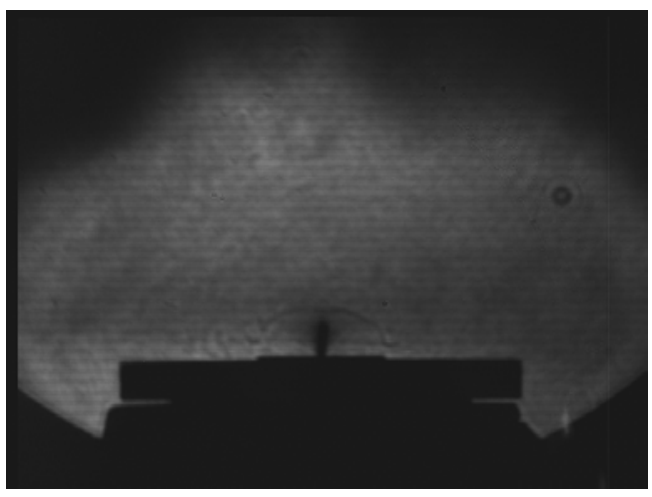

Figura 3.22 - Exemplo de seqüência de imagens adquiridas em um único ensaio. Observa-se que as imagens do lado esquerdo possuem os dois campos, enquanto as outras estão com um único campo, e por isso estão mais escurecidas.

O laboratório dispõe de uma segunda câmara CCD que foi implementada no experimento. Enquanto a primeira adquire as imagens pelo sistema "Schlieren", a outra adquire a imagem, observando o jato iluminado por uma lâmpada que fica por detrás do evento que, no entanto, não está situado no campo de visão da câmara. A lâmpada ilumina de forma difusa, diferentemente do método "Schlieren" que a fonte luminosa gera feixes de luz que traspassam o jato de forma colimada. Isto está ilustrado na disposição da Fig. 3.23. 


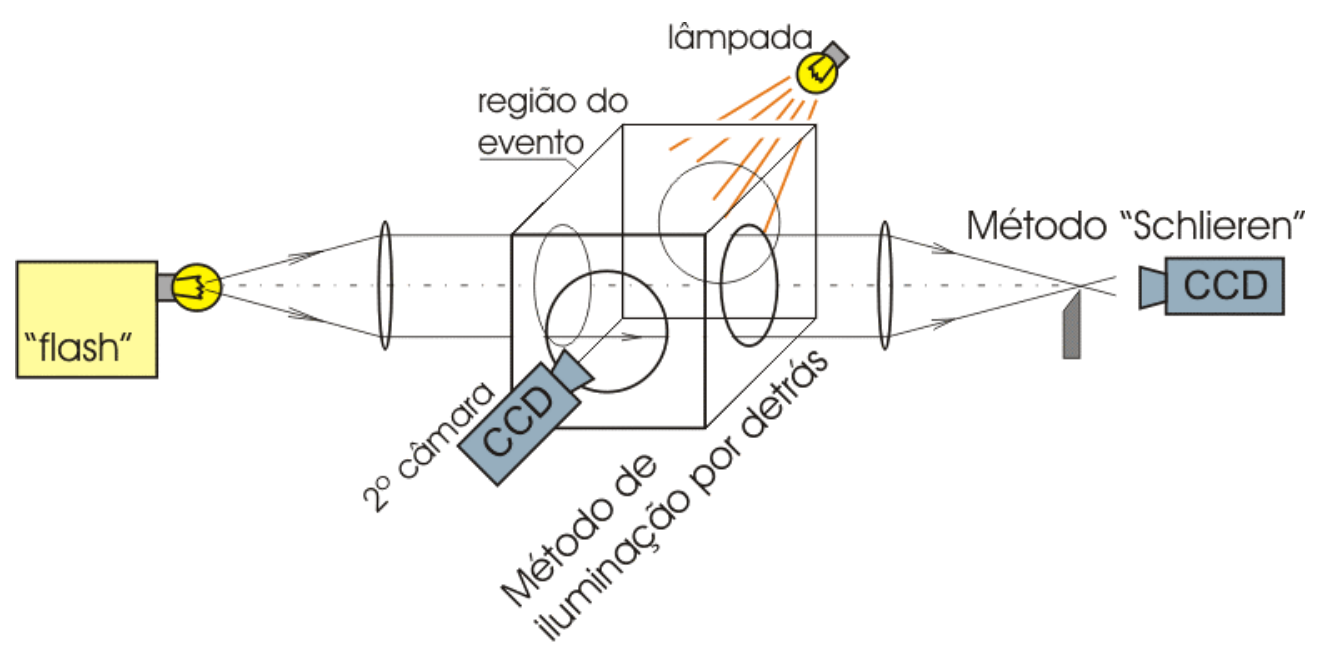

Figura 3.23 - Figura esquemática da disposição das câmaras CCDs.

Uma correlação das imagens obtidas pelas duas técnicas é possível de se fazer e extrair algumas conclusões importantes. No exemplo a seguir da Fig. 3.24, tem-se um único experimento realizado com injeção de iso-octano cuja pressão de saturação é duas vezes menor que a pressão no reservatório $(12,4 \mathrm{kPa})$. A primeira imagem, pelo "Schlieren" com tempo de exposição de $2 \mu s$, mostra a movimentação e evaporação do líquido ao longo do jato. Pela segunda imagem, já se observa o ângulo de dispersão do jato devido ao espalhamento das gotículas. Neste caso, a iluminação foi feita pela lâmpada que incidia por detrás do evento e, em função desta incidência difusa, a intensidade luminosa é amplificada no filete de líquido. Como o tempo de exposição é bem maior, de $1000 \mu s$, existe a impressão de um jato uniforme, ou seja, não foi fragmentado em gotículas. 
a)

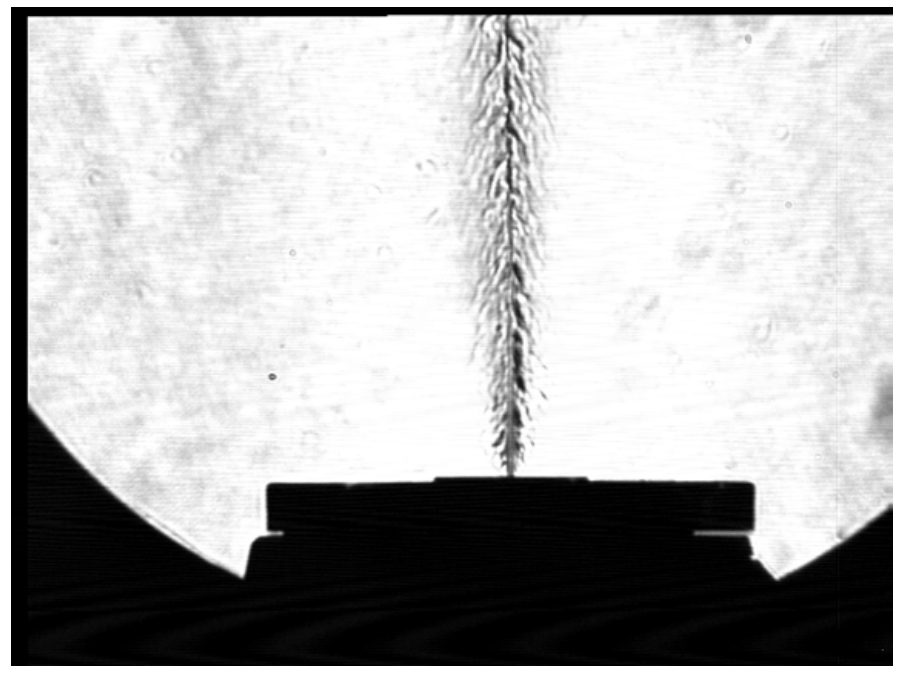

b)

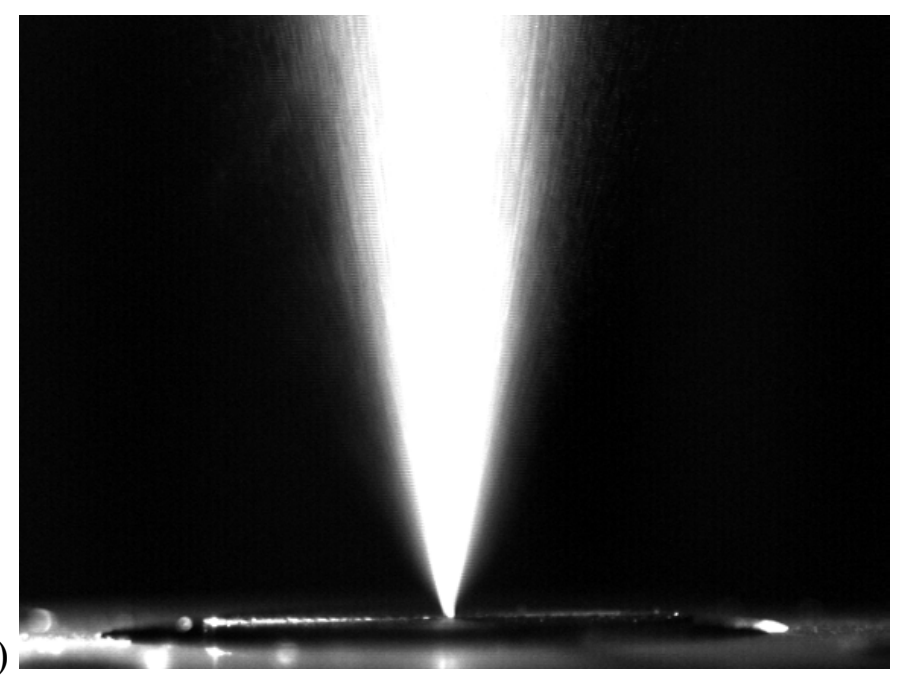

Figura 3.24 - Comparação de duas imagens de um mesmo ensaio. a) A primeira foi obtida pelo método "Schlieren" que destaca bastante a movimentação e evaporação do fluido em volta do jato e b) a outra foi adquirida pela segunda câmara CCD que destaca a trajetória das gotículas. A primeira imagem possui um tempo de exposição de $2 \mu s$ e a segunda de $1000 \mu s$. O líquido foi injetado a uma pressão de injeção de $750 \mathrm{kPa}$ e temperatura de injeção de $56^{\circ} \mathrm{C}$. A pressão do reservatório é a metade da pressão de saturação da substância, iso-octano, que é de $25 \mathrm{kPa}$.

\subsection{Filtragem de Imagens}

Esta seção tem o objetivo de mostrar um exemplo de filtragem de imagens de um jato. Maiores detalhes são obtidos no Apêndice II. O procedimento adotado requer a obtenção de uma imagem prévia, imediatamente anterior ao jato, para eliminar efeitos comuns às duas imagens. Após adquirir as imagens do jato, estas 
podem ser subtraídas da imagem inicial, retirando aspectos visuais indesejados para tornar mais nítido os fenômenos envolvidos pelo jato. No exemplo a seguir, têm-se duas imagens, em que a primeira, Fig. 3.25a, foi realizada antes do jato e a outra, na Fig. 3.25b, durante a injeção. A terceira imagem (Fig. 3.25c) é o resultado da subtração dessas duas imagens anteriores. Claramente, se nota a qualidade superior da imagem tratada, já que os elementos comuns foram eliminados e, como conseqüência, somente os fenômenos de interesse ficam evidentes.

a)

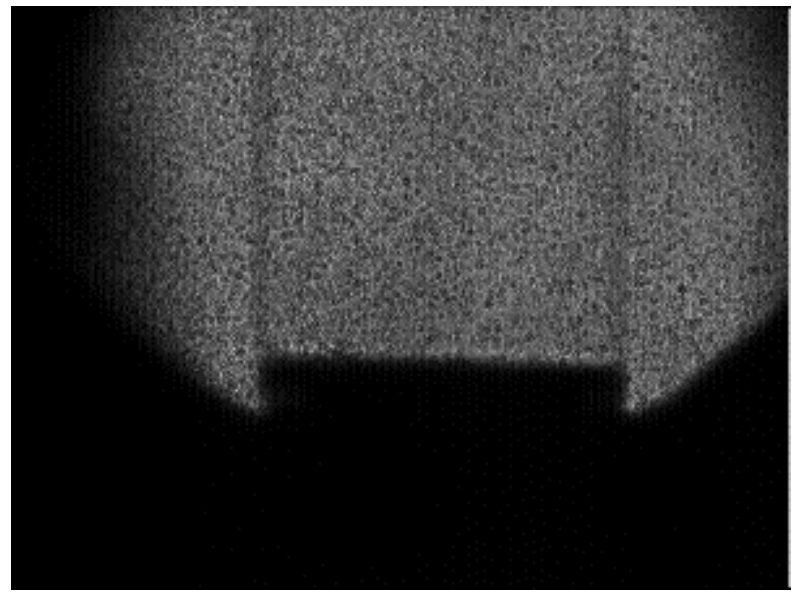

b)

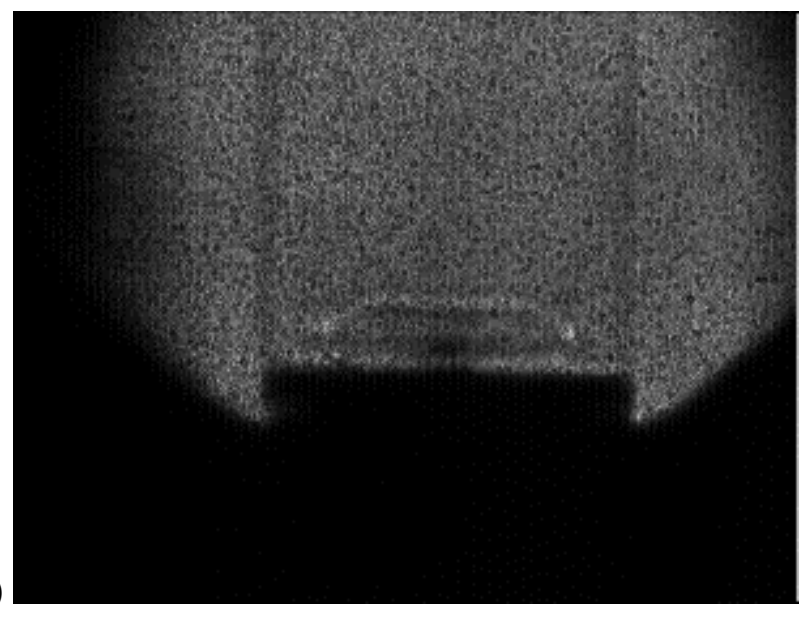

c)

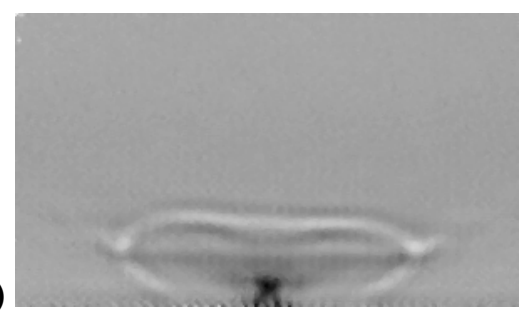

Figura 3.25 - A primeira é a fotografia sem o jato e a seguinte contém o jato. A subtração da segunda fotografia pela fotografia sem o jato resulta na última imagem com um jato visualmente mais evidente. 


\subsection{Procedimento do Ensaio}

Um ensaio é feito tendo primeiramente o cuidado de carregar o condensador de vapor ("vapor trap") com nitrogênio líquido ou gelo seco. Além disso, se a linha de injeção não estiver preenchida com o líquido de teste, também é feita a despressurização na linha de injeção, mantendo o bocal do injetor aberto. Alcançando a pressão absoluta de 0,1 mbar (ou $10 \mathrm{~Pa}$ ), é fechado o bocal para que o líquido do reservatório preencha esta porção da linha despressurizada. Este fechamento acontece através da pressurização do pistão pneumático solidário à haste que faz a obstrução do bocal, isolando a comunicação entre o fluido contido no injetor e a câmara onde o jato é descarregado.

Novamente é feita a abertura do bocal nesta mínima pressão. O líquido contido no injetor tende a evaporar, isto promove a retirada de algum gás que esteja diluído no fluido. Após este procedimento de enchimento, é fechado o bocal e a linha de injeção é pressurizada até alcançar a pressão de injeção desejada. O computador monitora esta pressão através do transdutor instalado na linha de injeção.

A câmara de baixa pressão é pressurizada com gás nitrogênio até alcançar a pressão absoluta predeterminada pelo ensaio. Seu controle de medição é feito, principalmente, pelo mano-vacuômetro ou pelo vacuômetro analógico.

$\mathrm{O}$ sistema de aquecimento começa a funcionar com o acionamento da bomba de óleo e a conexão da resistência elétrica que vai aquecer o óleo de circulação. $O$ controle da temperatura é feito pelo computador e a manutenção da temperatura fica sob o comando do termostato e do "variac", que estão ligados em série à resistência elétrica que aquece o óleo.

Antes do ensaio, os computadores devem estar preparados com os programas de gerenciamento de dados (Aqdados, da empresa Lynx) e de aquisição de imagens (Aqjatos, feito no laboratório utilizando as bibliotecas do programa computacional "DT Open Layer" da empresa Data Translation).

Sabendo que os valores desejados das pressões de injeção e da câmara de baixa pressão foram atingidos, e a temperatura do fluido foi alcançada, falta apenas anotar o nível inicial do volume do fluído. Em seguida, deve-se acionar o ensaio propriamente dito pelo computador principal, aquele que adquire as imagens. Este envia um sinal de disparo para o outro computador que faz a aquisição dos dados de 
pressão, temperatura de injeção, posição da haste, nível do volume injetado e pressão da câmara. Automaticamente são feitos os comandos de abertura do injetor, aquisição de imagens com sincronismo da lâmpada de "flash”. Após o ensaio efetivo, registra-se o nível total injetado do líquido, e também, carrega-se os dados obtidos em arquivos.

Dos dados de pressão de injeção são analisados a média e o desvio padrão que fica na faixa de $1,7 \mathrm{kPa}$. Dos dados de temperatura também são registrados o desvio padrão e a temperatura média que costuma ser da ordem de $0,20{ }^{\circ} \mathrm{C}$. Do sinal do sensor de posição da haste, são extraídos o tempo inicial e o tempo final de injeção, como visto na Seção 3.5. Do sinal do sensor de nível de volume injetado da coluna de vidro graduada, é obtida a informação da vazão. E finalmente, quando a pressão é menor que 20 mbar (ou $2 \mathrm{kPa}$ ), é possível registrar eletronicamente a pressão da câmara onde é descarregado o jato. Caso contrário esta medição é documentada através do mano-vacuômetro de coluna de mercúrio ou pelo vacuômetro analógico. 


\subsection{Faixas de Incertezas}

$\mathrm{Na}$ Tab. 3.1 são apresentadas as faixas de medições de cada variável da bancada e as respectivas incertezas com $95 \%$ de confiabilidade. O levantamento completo das incertezas, bem como a sua propagação, estão no Apêndice I.

Tabela 3.1 - Incertezas relativas às medições realizadas.

\begin{tabular}{lll}
\hline Medições & Faixa & Incerteza \\
\hline \hline & & \\
Pressão da câmara de vácuo & 60 a $2000 \mathrm{~Pa}$ & $\pm 54 \mathrm{~Pa}$ \\
& 2 a $100 \mathrm{kPa}$ & $\pm 0,1 \mathrm{kPa}$ \\
& & \\
Pressão de injeção & 0 a $700 \mathrm{kPa}$ & $\pm 1,96 \mathrm{kPa}$ \\
Temperatura de injeção & 20 a $300{ }^{\circ} \mathrm{C}$ & $\pm 1,2{ }^{\circ} \mathrm{C}$ \\
Vazão experimental & 0 a $3,5 \mathrm{ml} / \mathrm{s}$ & $\pm 1,99 \%$ \\
Coeficiente de descarga & 0,93 & $\pm 0,0176$ \\
& & \\
Pressão do líquido metaestável: & para $\left(P_{0}-P_{1}\right)$ entre: & a incerteza de $P_{1}$ é: \\
& 5 a $100 \mathrm{kPa}$ & $\pm 4,99 \mathrm{kPa}$ \\
- depende da diferença entre a pressão & 200 & $\pm 8,76$ \\
de injeção e a pressão metaestável & 300 & $\pm 12,77$ \\
$\left(\Delta P=P_{0}-P_{1}\right)$. Praticamente, a incerteza & 400 & $\pm 16,85$ \\
da pressão metaestável é: & 500 & $\pm 20,96$ \\
$U_{P 1} \cong 0,042^{*}\left(P_{0}-P_{1}\right)$. & 600 & $\pm 25,09$ \\
& 700 & $\pm 29,22$ \\
& & $\pm 0,1 \mathrm{~mm}$ \\
Dimensões nas imagens & 1 a $150 \mathrm{~mm}$ & \\
\hline
\end{tabular}




\section{RESULTADOS EXPERIMENTAIS}

Neste capítulo, são apresentados os resultados obtidos nos ensaios. Primeiramente são apresentados os dados de vazão mássica, depois são mostrados os resultados do comprimento de extinção da parte líquida do jato e, em seguida, as dimensões características da estrutura da onda de choque formada. Tabelas detalhadas sobre os resultados conjuntamente com as principais imagens de cada ensaio estão no Anexo B e C deste trabalho.

\subsection{Resultados Experimentais: Bocal de aço com 0,3 $\mathrm{mm}$ de diâmetro (séries: Run1, Run2 e Run3)}

Nesta seção, são apresentados os dados experimentais do bocal rugoso, cônico-convergente com diâmetro de saída de $0,3 \mathrm{~mm}$, que será denominado para a série "Run1", "Run2" e "Run3", que apenas se diferenciam pela metodologia de aquisição das imagens em virtude das implementações feitas na bancada experimental. Deste bocal foram feitos ensaios em função da pressão de injeção $\left(P_{\text {inj }}\right): 125,250,500$ e $750 \mathrm{kPa}$. E as temperaturas de injeção $\left(T_{\text {inj }}\right)$ foram: $56,76,95$, $120,130,162$ e $178^{\circ} \mathrm{C}$, cujas pressões de saturação são $25,50,90,177,230,450 \mathrm{e}$ $600 \mathrm{kPa}$, respectivamente. As pressões da câmara $\left(P_{\infty}\right)$ se situaram na faixa de 0,05 $\mathrm{kPa}$ até $200 \mathrm{kPa}$. O esquema gráfico da Fig. 4.1 ilustra a combinação destas condições iniciais e a faixa da pressão da câmara onde o jato é descarregado. Estas condições de pressão e temperatura de injeção e da pressão da câmara foram monitorados em todos os ensaios para se ter a garantia de que não ocorreu nenhuma variação destes parâmetros durante o processo de injeção, garantindo a condição de regime permanente, como foi discutido na Seção 3.3. Para cada ensaio, é feito o cálculo da análise da vazão, pelo método do volume total consumido pela injeção durante o intervalo de tempo correspondente registrado eletronicamente. Esta vazão medida é comparada com aquela obtida pelo sensor de nível do volume. Uma eventual desigualdade destas duas medições da vazão corresponde a uma injeção irregular ou, pode estar associada com a possibilidade de formação de bolhas no 
interior do injetor. Caso não haja irregularidade da vazão mássica medida $(\dot{m})$, é possível obter a velocidade média do jato no bocal $\left(u_{1}\right)$. Com esta velocidade e as propriedades do líquido à temperatura de injeção como a densidade, a viscosidade dinâmica, se obtém o número de Reynolds, Re, através de Eq. (4.1). O coeficiente de descarga $\left(C_{\mathrm{D}}\right)$ é determinado pela Eq. (4.2) que foi obtida experimentalmente cujo levantamento de dados está no Apêndice I. A equação de descarga do bocal (Eq. 4.3) calcula a vazão teórica estimada, $\dot{m}_{e}$, para uma pressão a jusante do bocal igual a pressão da câmara. E a pressão do líquido $\left(P_{1}\right)$ na saída do bocal é calculada pela Eq. (4.4), através da vazão mássica experimental, $\dot{m}$, e considera que o escoamento do fluido é incompressível, ou seja, mantém a condição metaestável:

$$
\begin{aligned}
& \operatorname{Re}=\frac{\rho_{l} \cdot u \cdot D_{b}}{\mu}, \\
& C_{D}=0,9673-5,6682 / \sqrt{\mathrm{Re}}, \\
& \dot{m}_{e}=C_{D} \cdot A_{b} \cdot \sqrt{2 \cdot \rho_{l} \cdot\left(P_{0}-P_{\infty}\right)}, \\
& P_{1}=P_{0}-\frac{1}{2 \cdot \rho_{l}}\left(\frac{\dot{m}}{C_{D} \cdot A_{b}}\right)^{2},
\end{aligned}
$$

onde $A_{\mathrm{b}}$ é a área da seção transversal de saída do bocal.

Nas imagens adquiridas, conforme o tipo do jato observado, é possível obter os seguintes dados: comprimento de extinção do núcleo líquido do jato $\left(L_{\mathrm{E}}\right)$ e dimensões características das ondas de choque $\left(r_{1}\right.$ e $\left.r_{2}\right)$. Todas estas características estão ilustradas na Fig. 4.2. Cabe lembrar que, conforme apresentado na Seção 3.3, Fig. 3.10, a pressão da câmara eleva-se durante a injeção. Assim, cada imagem do jato foi adquirida em um instante que possuía um determinado valor de pressão da câmara, que também era registrado. Da imagem, eram obtidos os valores de $r_{1}$ e $r_{2}$, que eram associados com a pressão da câmara correspondente ao instante de aquisição da imagem. 


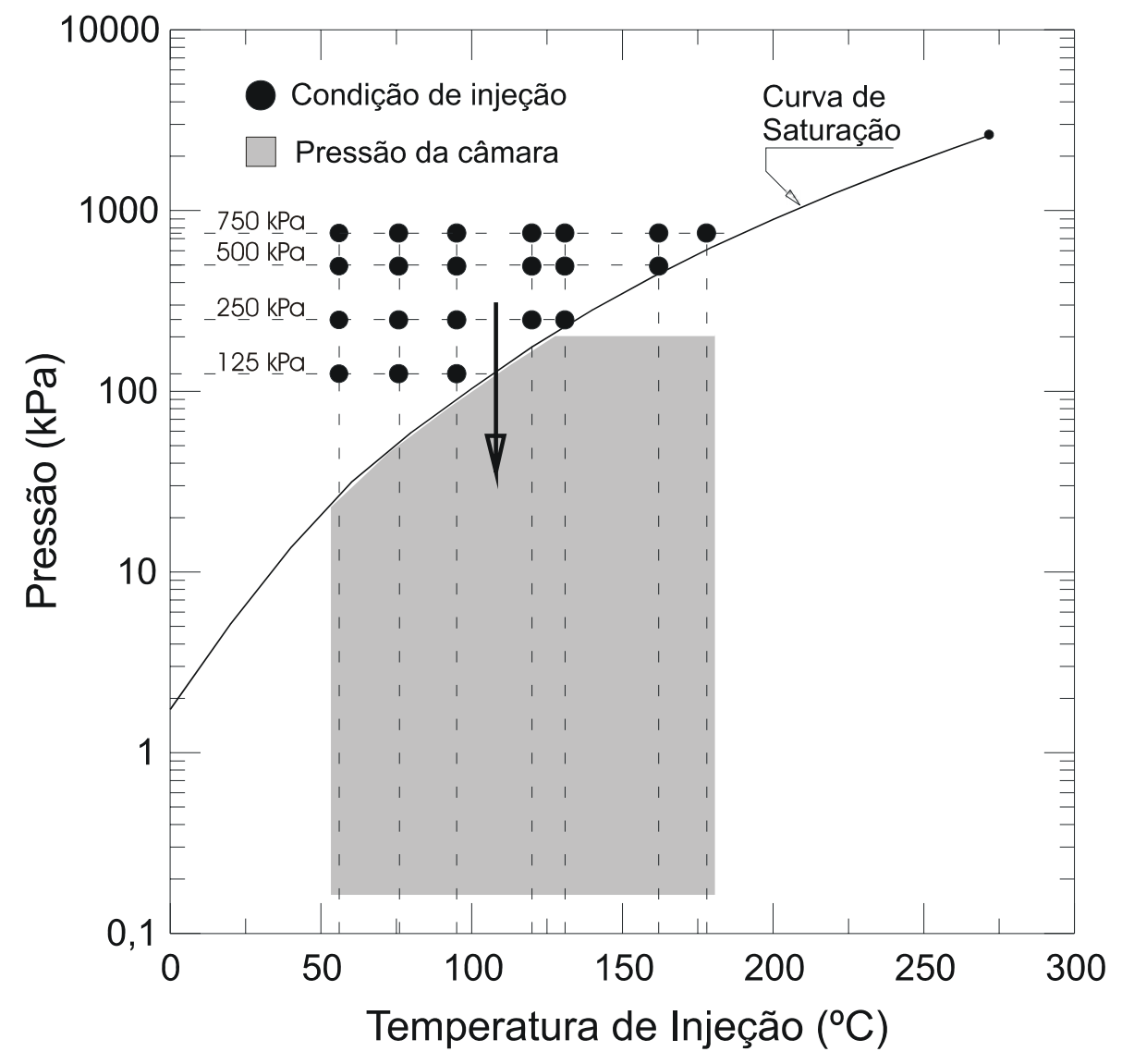

Figura 4.1 - Representação gráfica das condições de injeção e a pressão da câmara onde é descarregado o jato pelo bocal de $0,3 \mathrm{~mm}$, rugoso.

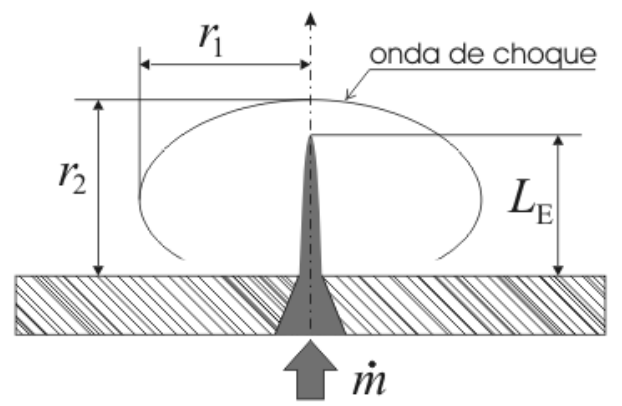

Figura 4.2 - Representação dos parâmetros geométricos relevantes de um experimento típico. 


\subsubsection{Resultados das Medidas das Vazões Mássicas}

Os gráficos das Figs. 4.3 a 4.6 mostram o comportamento do jato em função da diminuição da pressão da câmara $\left(P_{\infty}\right)$, quando se mantém constante a pressão $\left(P_{0}\right)$ e temperatura de injeção $\left(T_{0}\right)$. Em todos estes gráficos, se constata que se alcança um patamar máximo de vazão em função da diminuição da pressão da câmara. A barra de desvio desta medição está em alguns pontos do gráfico, mas esta regra se estende aos demais dados, cujo valor é de $\pm 2,0 \%$ da vazão medida. Nos gráficos, também são indicados os pontos da pressão de saturação para a temperatura de injeção.

Os dados completos referentes a estes gráficos estão no Anexo B, nas Tabs. B.1, B.2 e B.3 que são relativas às séries de ensaio "Run1", "Run2" e "Run3", respectivamente, no entanto, a metodologia de coleta das vazões não é diferente em nenhuma destas séries.

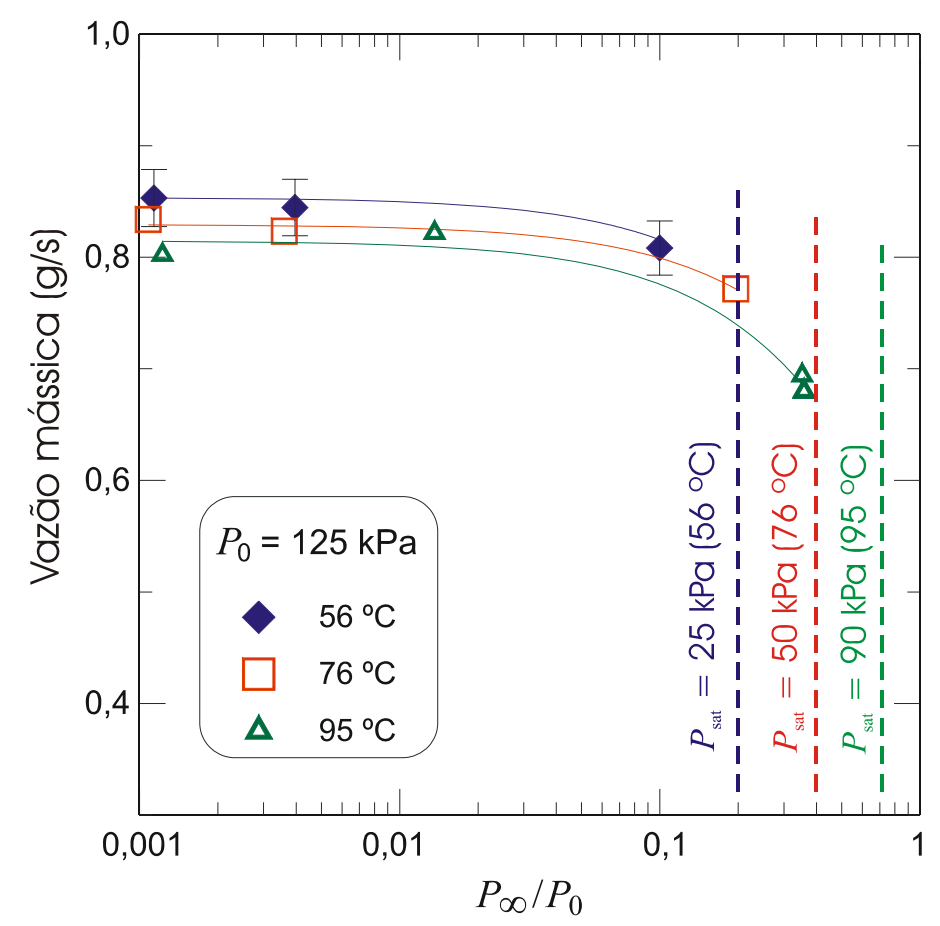

Figura 4.3 -Vazão mássica em função da razão da pressão da câmara e a pressão de injeção. A pressão de injeção é de $125 \mathrm{kPa}$. 


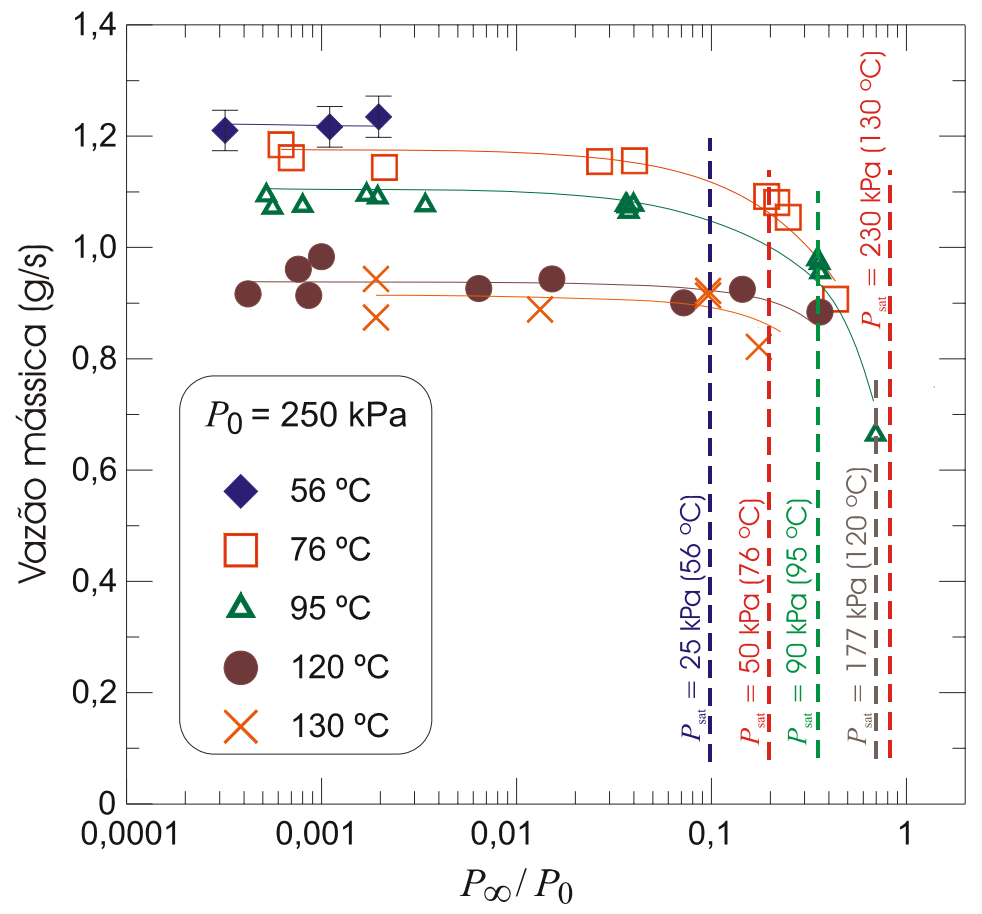

Figura 4.4 -Vazão mássica em função da razão da pressão da câmara e a pressão de injeção. A pressão de injeção é de $250 \mathrm{kPa}$.

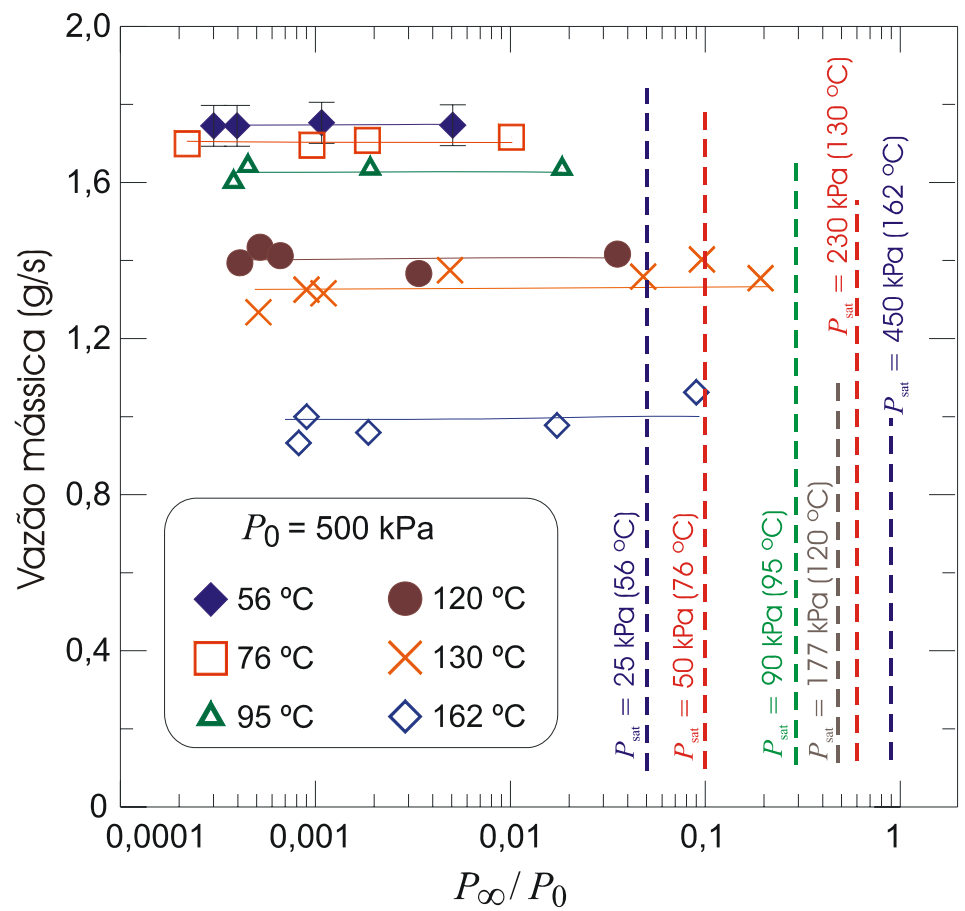

Figura 4.5 -Vazão mássica em função da razão da pressão da câmara e a pressão de injeção. A pressão de injeção é de $500 \mathrm{kPa}$. 


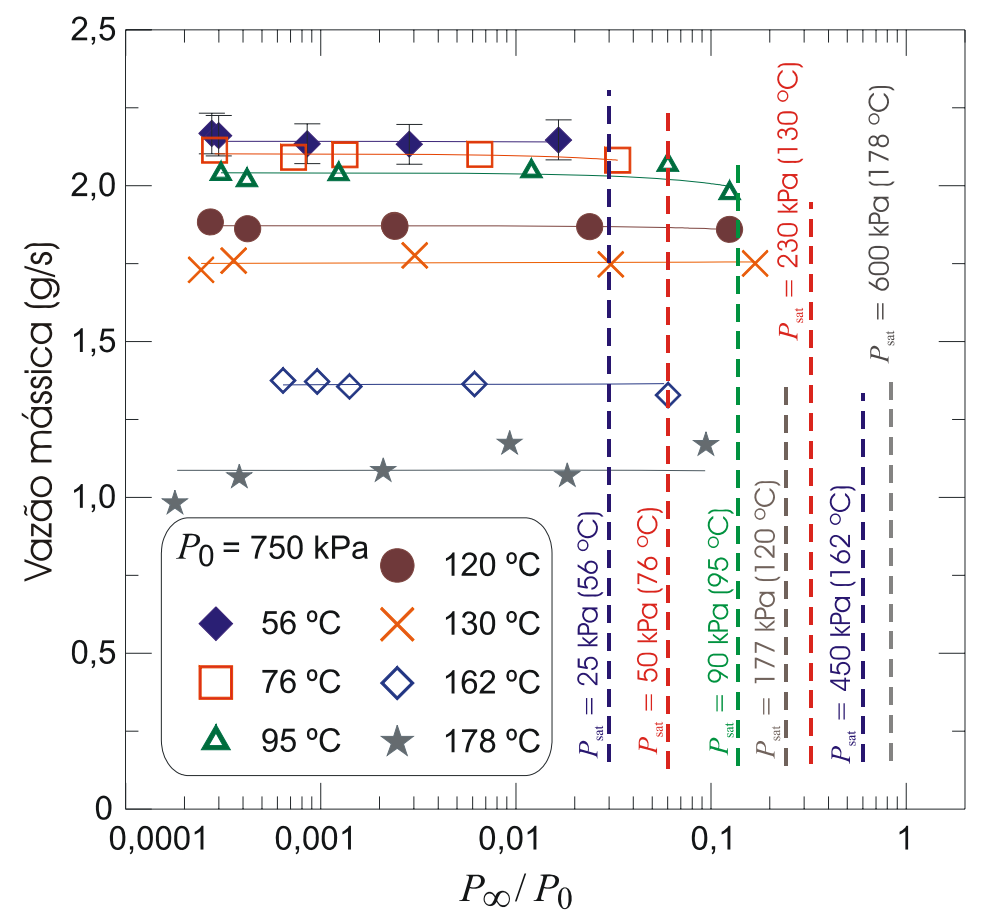

Figura 4.6 -Vazão mássica em função da razão da pressão da câmara e a pressão de injeção. A pressão de injeção é de $750 \mathrm{kPa}$.

\subsubsection{Comprimento de Extinção do Núcleo Líquido}

Um parâmetro medido nas imagens dos ensaios foi o comprimento de extinção do núcleo de líquido, $L_{\mathrm{E}}$. Esta distância tem sua representação esquemática no detalhe inferior esquerdo da Fig. 4.7. É uma dimensão que se manifestou insensível à variação da pressão da câmara, quando a vazão está blocada. $\mathrm{Na} \mathrm{Tab}$. B.4, do Anexo B, são encontrados todos os valores desta dimensão em função das condições iniciais $\left(P_{0}\right.$ e $\left.T_{0}\right)$ de cada ensaio. O gráfico da Fig. 4.7 é uma amostra deste comportamento do comprimento de extinção do líquido em função da temperatura e pressão de injeção. Cada classe de pressão de injeção foi diferenciada pelos respectivos símbolos representados na legenda deste gráfico. De imediato, é possível afirmar que quanto maior é a pressão de injeção maior será seu comprimento da parte líquida. Este comportamento se inverte com relação à temperatura de injeção. 


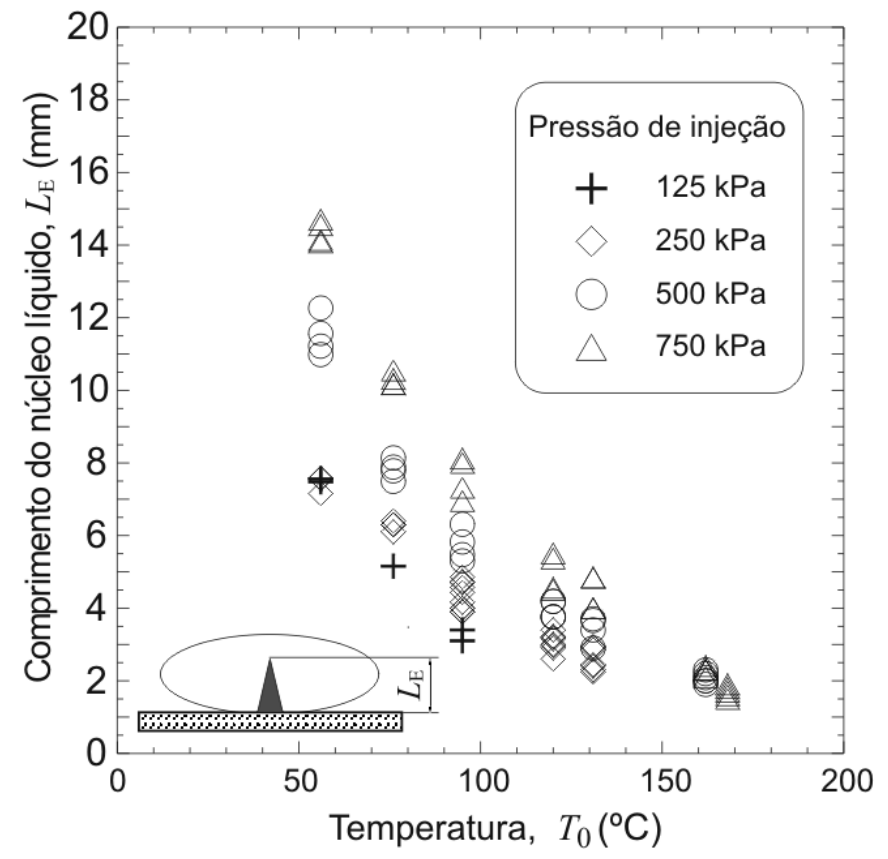

Figura 4.7 - Comportamento do comprimento de extinção do núcleo líquido, $L_{\mathrm{E}}$, em função da temperatura de injeção. São diferenciados os ensaios com pressão de injeção de $125 \mathrm{kPa}, 250 \mathrm{kPa}, 500 \mathrm{kPa}$ e $750 \mathrm{kPa}$ (bocal rugoso com 0,3 mm de diâmetro).

\subsubsection{Dimensões Características da Estrutura da Onda de Choque}

A dimensão radial da onda de choque, $r_{1}$, e sua distância axial em relação à saída do bocal, $r_{2}$, foram as principais medidas tomadas das imagens adquiridas para caracterizar as dimensões principais da onda de choque, conforme indicados na Fig. 4.8. Os dados obtidos destas dimensões do bocal de $0,3 \mathrm{~mm}$ estão na Tab. B.5, do Anexo B. Na representação gráfica das Figs. 4.9 a 4.12 são mostrados os comportamentos destas dimensões características da onda de choque em função da pressão da câmara. Quanto menor é a pressão da câmara, maiores serão os valores de $r_{1} \mathrm{e} r_{2}$.

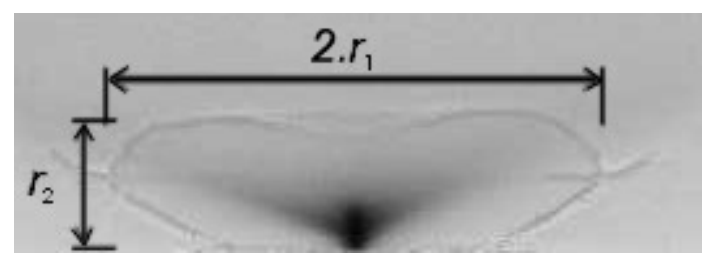

Figura 4.8 - Representação das dimensões medidas na estrutura da onda de choque. 


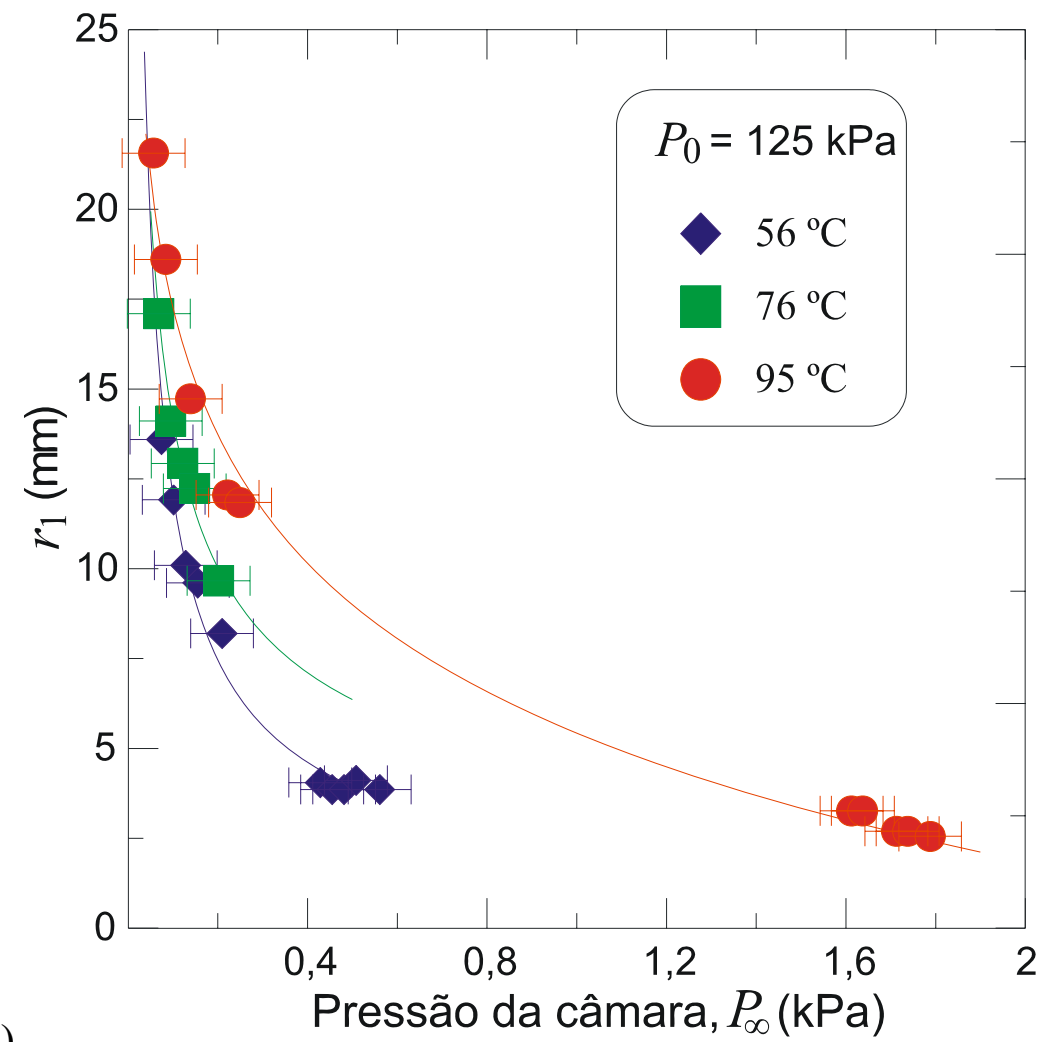

a)

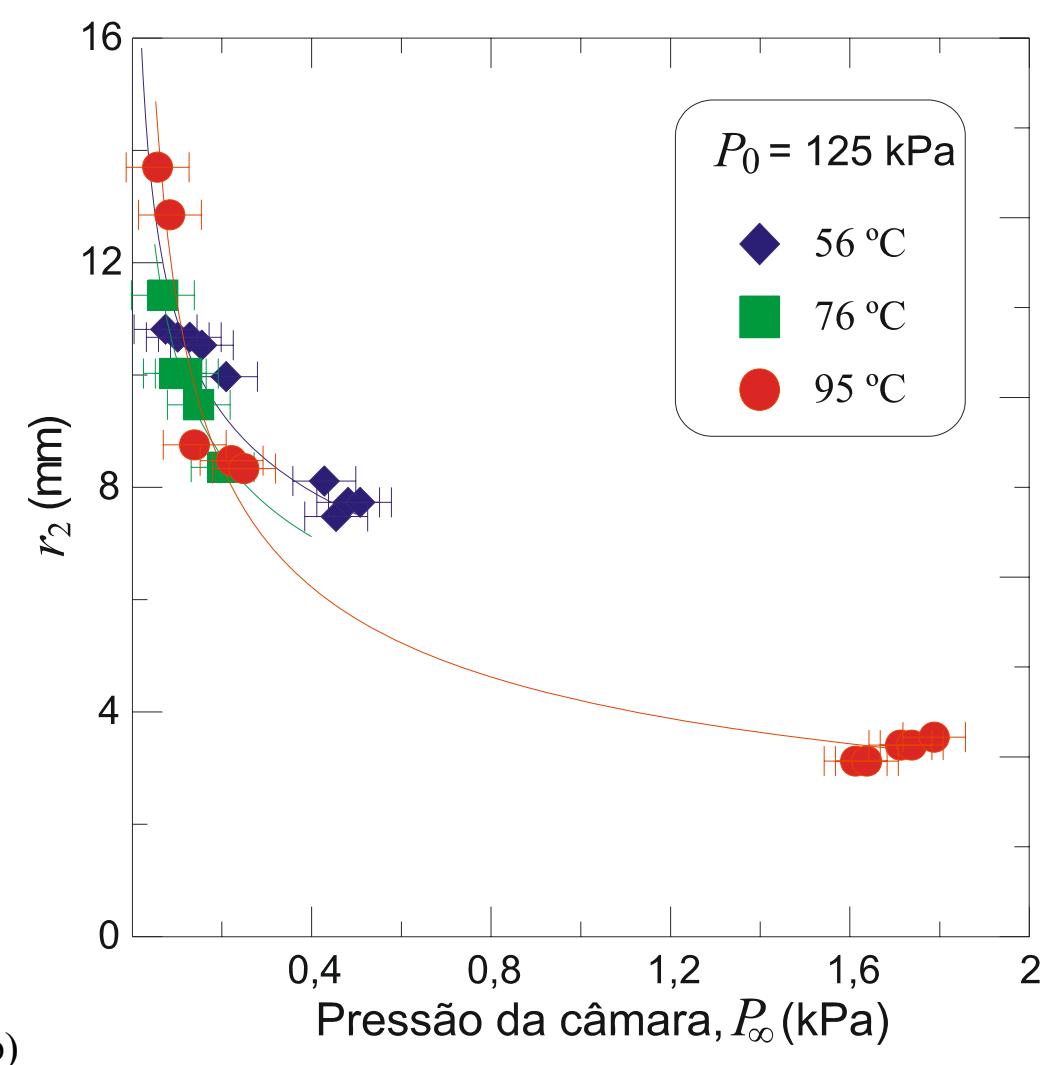

Figura 4.9 - O comprimento representativo, $r_{1}$ (no primeiro gráfico) e $r_{2}$ são indicados em função da pressão da câmara para os ensaios cuja pressão de injeção é $125 \mathrm{kPa}$ (bocal rugoso com $0,3 \mathrm{~mm}$ de diâmetro). 


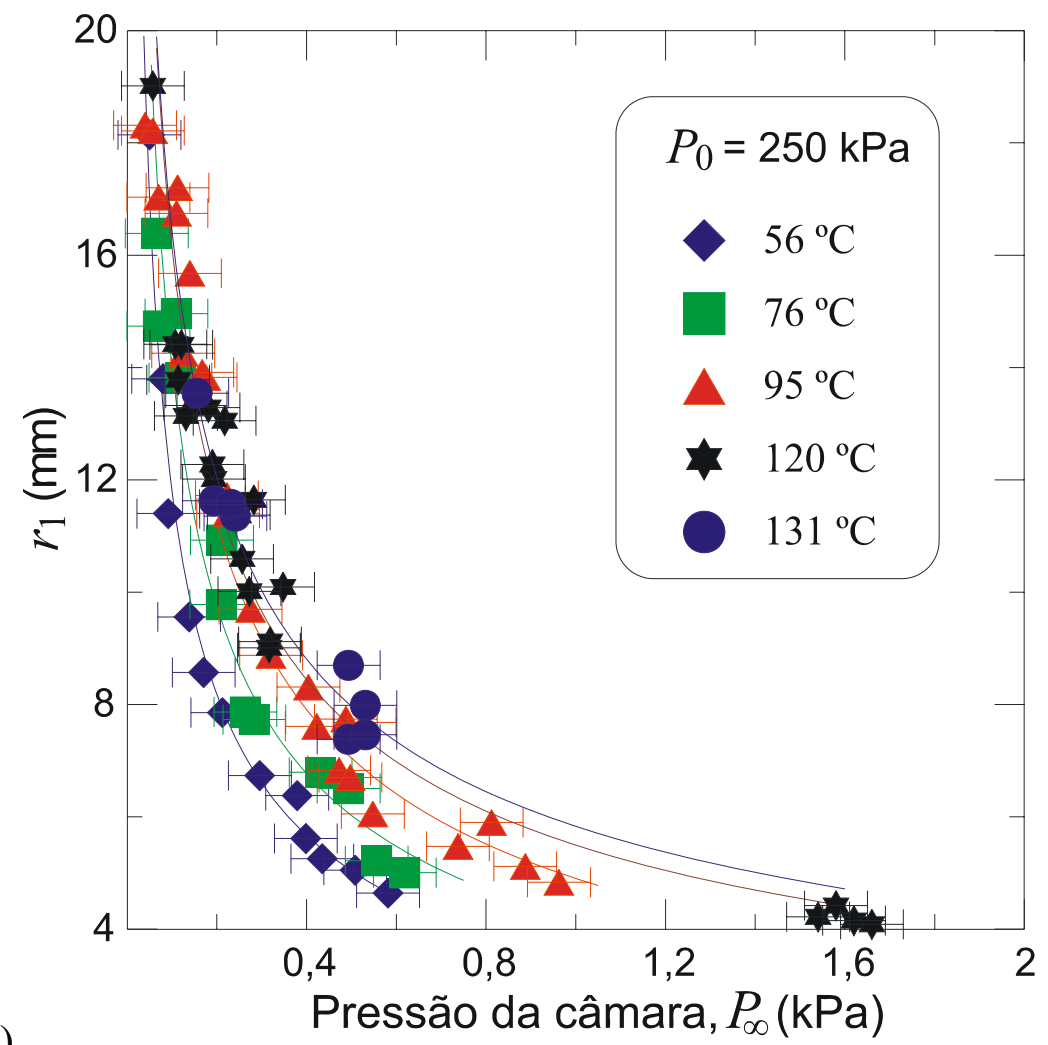

a)

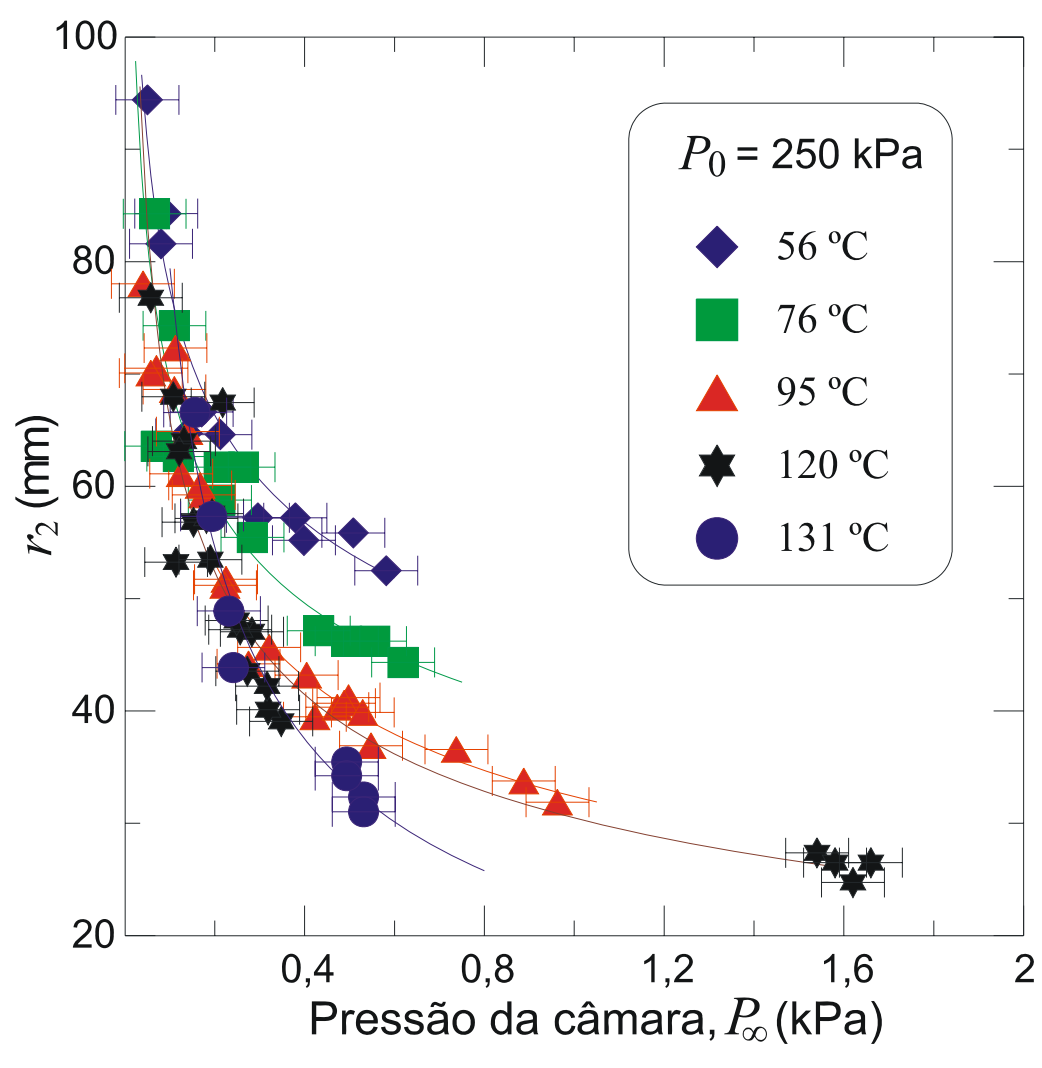

Figura 4.10 - O comprimento representativo, $r_{1}$ (no primeiro gráfico) e $r_{2}$ são indicados em função da pressão da câmara para os ensaios cuja pressão de injeção é $250 \mathrm{kPa}$ (bocal rugoso com $0,3 \mathrm{~mm}$ de diâmetro). 


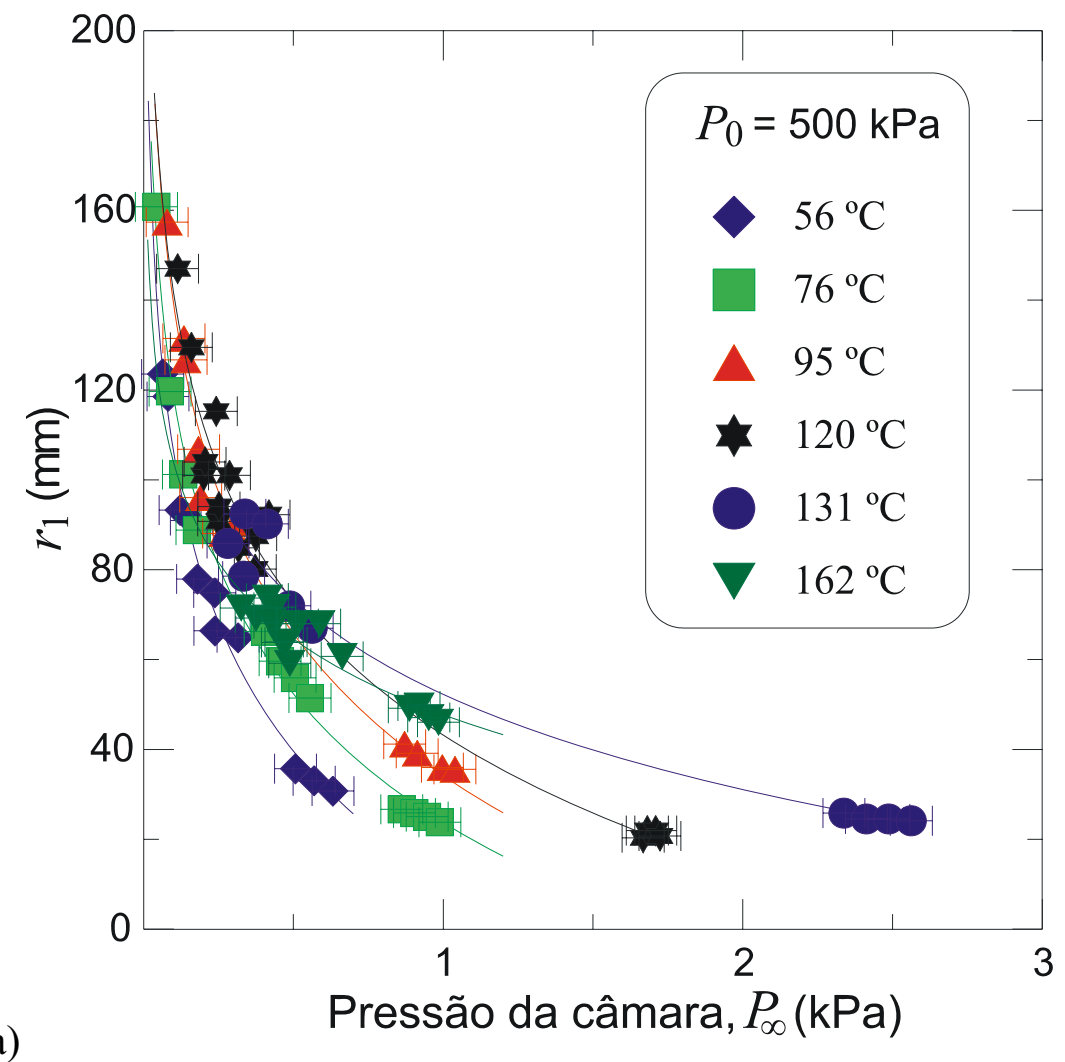

a)

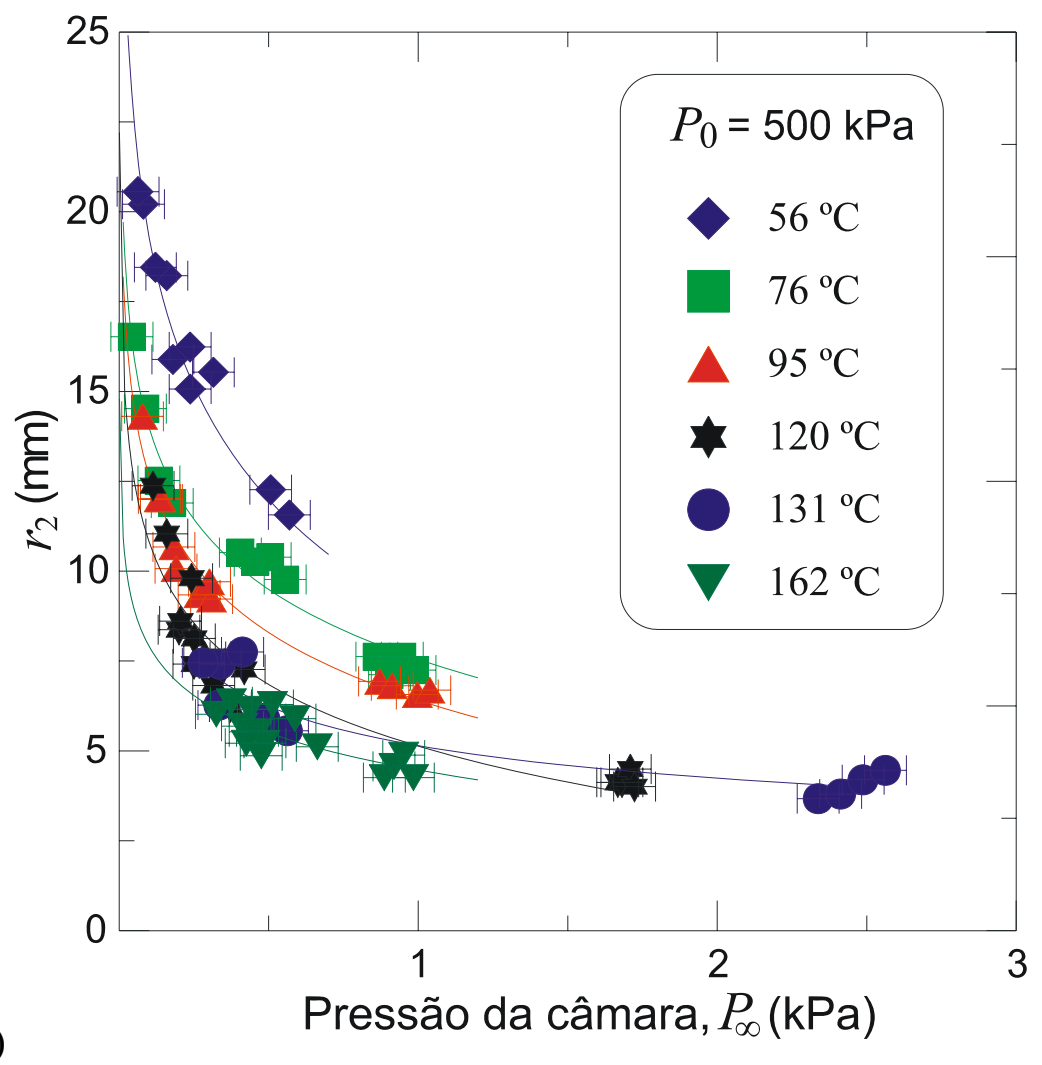

Figura 4.11 - O comprimento representativo, $r_{1}$ (no primeiro gráfico) e $r_{2}$ são indicados em função da pressão da câmara para os ensaios cuja pressão de injeção é $500 \mathrm{kPa}$ (bocal rugoso com $0,3 \mathrm{~mm}$ de diâmetro). 


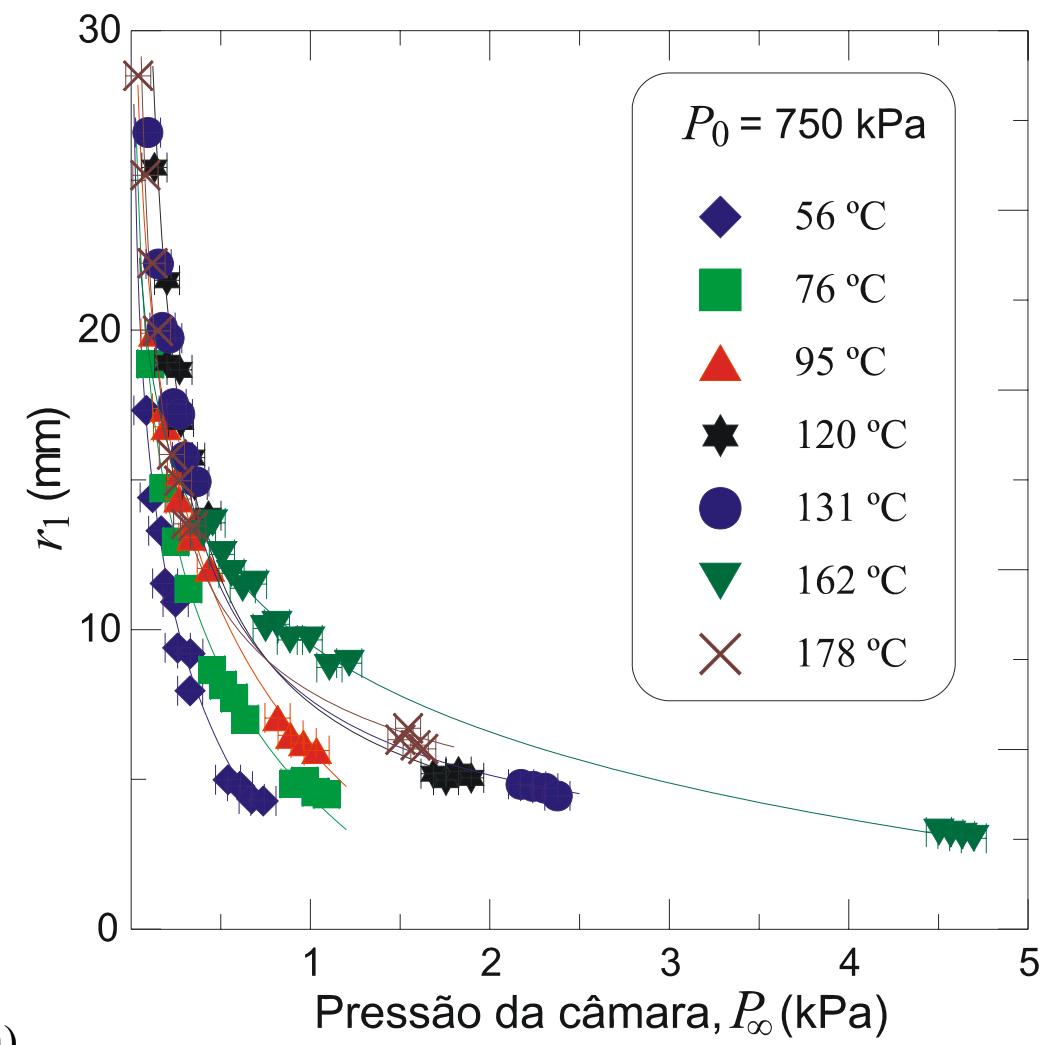

a)

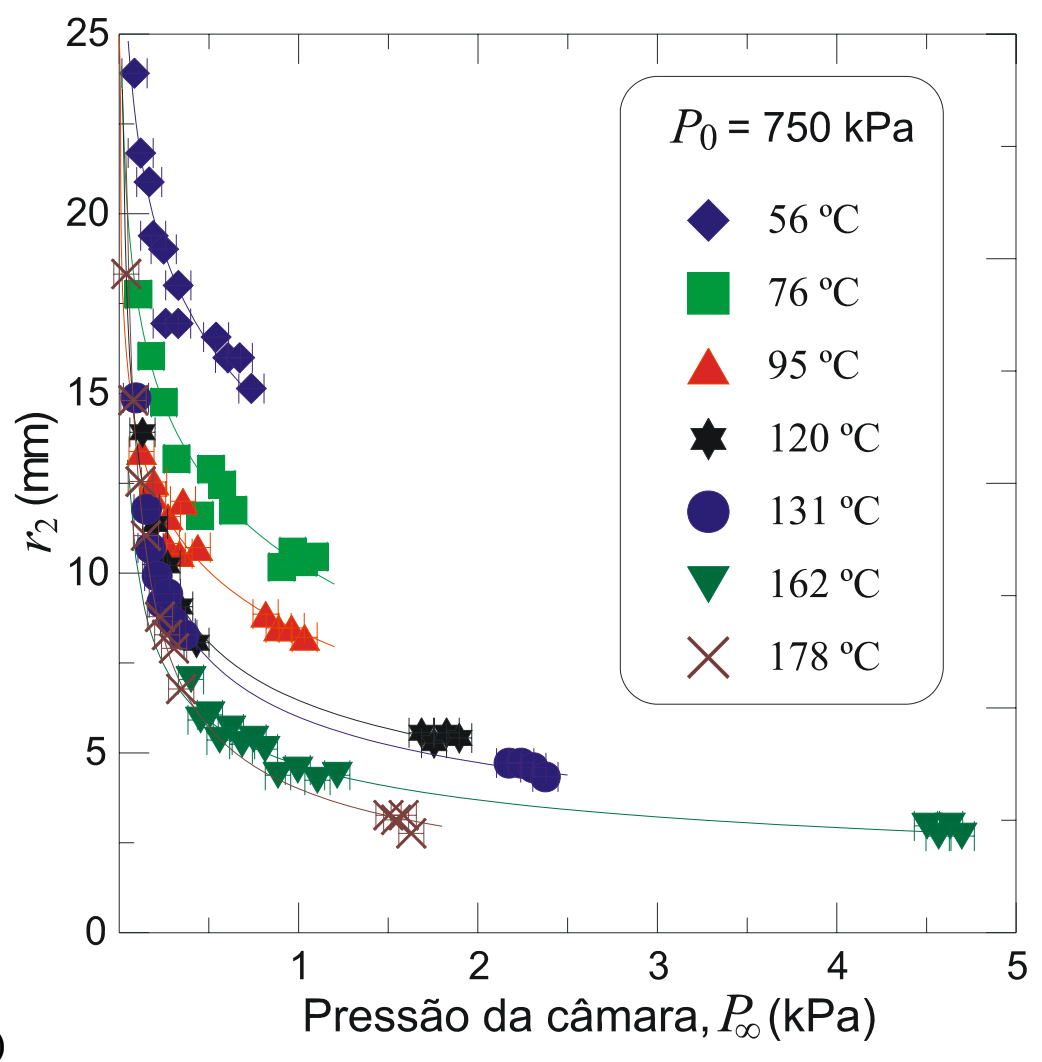

Figura 4.12 - O comprimento representativo, $r_{1}$ (no primeiro gráfico) e $r_{2}$ são indicados em função da pressão da câmara para os ensaios cuja pressão de injeção é $750 \mathrm{kPa}$ (bocal rugoso com $0,3 \mathrm{~mm}$ de diâmetro). 


\subsubsection{Influência da Pressão da Câmara sobre as Dimensões da Onda de Choque}

Esta subseção indica a variação da onda de choque como função do aumento da pressão da câmara durante a injeção. A Fig. 4.13 possui duas imagens de um mesmo ensaio sendo o intervalo de tempo entre elas de $1 s$. Nota-se que nestas duas imagens, não houve mudança dimensional no comprimento do núcleo líquido. $\mathrm{O}$ formato da onda de choque continuou axissimétrico e apenas o raio médio da onda de choque se contraiu quase imperceptivelmente, de 3,9 mm (Fig. 4.13a) para 3,6 mm (Fig. 4.13b). Um outro está mostrado na seqüência da Fig. 4.14, onde ilustram três imagens de um jato descarregando na câmara, cuja pressão aumentou ligeiramente, resultando em uma diminuição das dimensões da onda de choque. Mesmo assim, o jato não perdeu seu perfil axissimétrico e também manteve seu comprimento do núcleo líquido. Portanto, em função deste aumento da pressão da câmara, que é da ordem de 0,2 kPa por injeção, se tem o cuidado de associar a pressão da câmara ao instante de aquisição de cada imagem do ensaio.

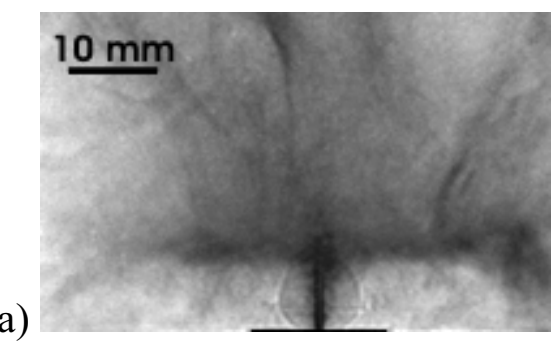

b)

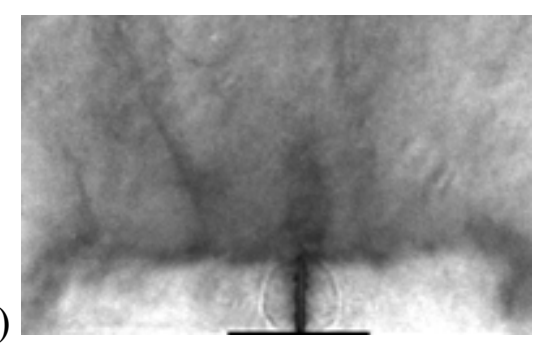

Figura 4.13 - Seqüência de duas imagens de um mesmo ensaio onde a pressão e temperatura de injeção é de $500 \mathrm{kPa}$ e $76{ }^{\circ} \mathrm{C}$ e, o $R_{\mathrm{P}}$ é de 50 , praticamente, pois a pressão da câmara variou de 0,90 a $0,99 \mathrm{kPa}$, respectivamente, em um intervalo de $1 \mathrm{~s}$.

a)
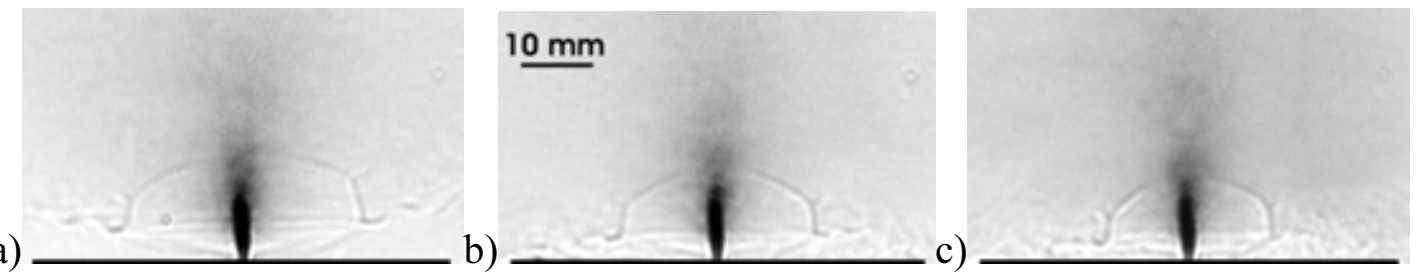

Figura 4.14 - Seqüência de imagens de um mesmo ensaio onde a pressão de injeção é de $250 \mathrm{kPa}$ e temperatura de $56^{\circ} \mathrm{C}$ e o $R_{\mathrm{P}}$ é de 500 , praticamente. No entanto, a pressão da câmara, desde a primeira imagem elevou de 0,05, 0,09 e, por último, 0,14 $\mathrm{kPa}$ em um intervalo de tempo de $1 s$ entre cada imagem obtida. 


\subsection{Ensaios com o Bocal Rugoso de 0,8 $\mathrm{mm}$ de Diâmetro na Saída - Série R08}

$\mathrm{Na}$ Seção 4.1, foram mostrados os resultados experimentais de um bocal cônico-convergente com diâmetro de saída de 0,3 mm (séries Run1, Run2 e Run3). Este foi caracterizado como rugoso pelo simples fato de seu acabamento superficial do canal é típico de um acabamento feito através de furação com broca. Outro bocal testado, apresentado neste capítulo, também possui este aspecto rugoso e seu diâmetro de saída é de $0,8 \mathrm{~mm}$. A Fig 4.15 mostra as condições iniciais de injeção para este bocal. Suas pressões de injeção são de 125 e $250 \mathrm{kPa}$ e as temperaturas de injeção são de 56,95 e $120^{\circ} \mathrm{C}$. Um desenho ilustrativo deste bocal é visto no detalhe da figura.

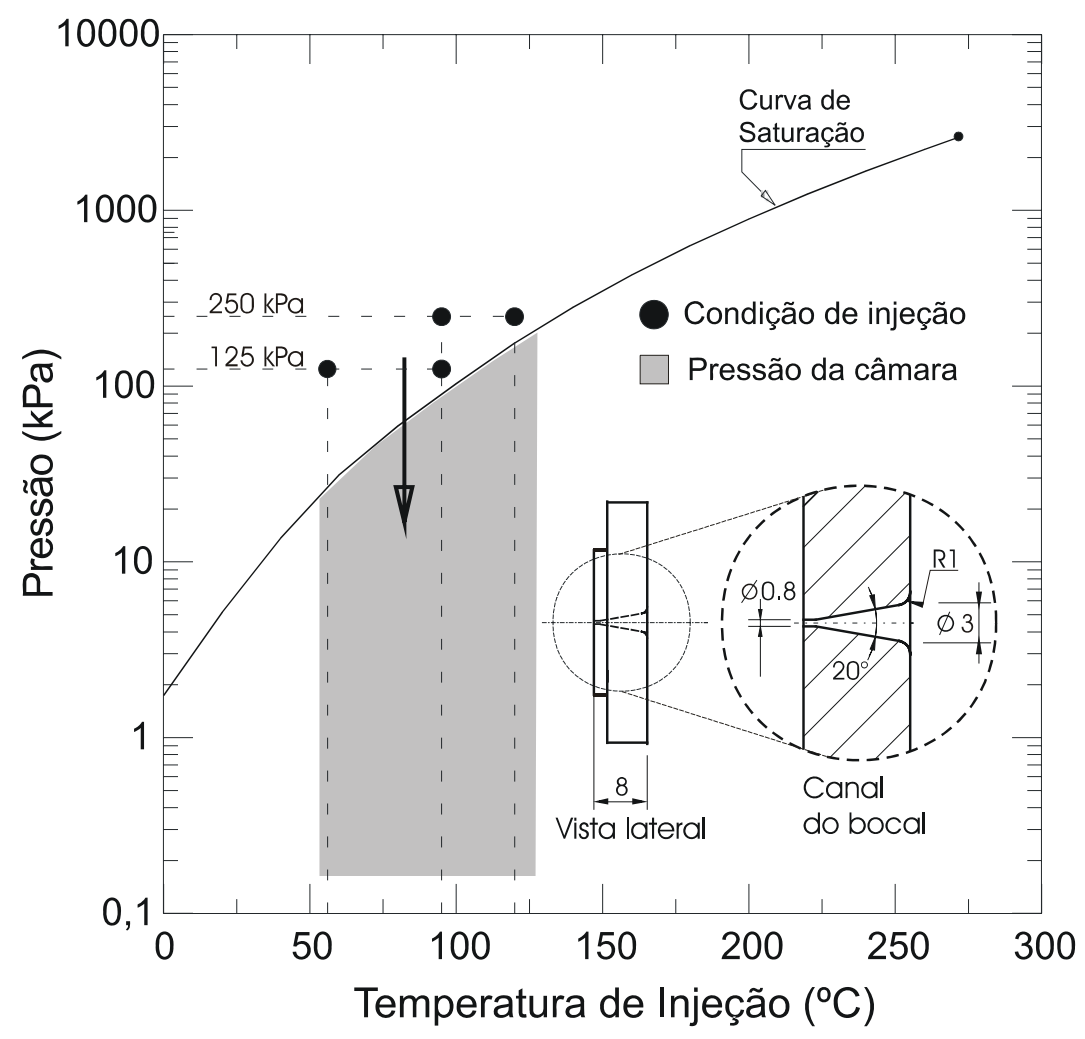

Figura 4.15 - Representação gráfica das condições de injeção e a pressão da câmara onde é descarregado o jato pelo bocal rugoso de $0,8 \mathrm{~mm}$ - Série R08. Um desenho do bocal é visto no detalhe da figura. 


\subsubsection{Resultados das Medidas das Vazões Mássicas - Série R08}

O gráfico da Fig. 4.16 classifica os dados da vazão em função da condição inicial $\left(P_{0}\right.$ e $\left.T_{0}\right)$ e mostra este comportamento em função da pressão da câmara $\left(P_{\infty}\right)$ e. A barra de desvio desta medição é de $\pm 2,0 \%$ da vazão medida.

Os dados numéricos referentes a estes gráficos estão no Anexo C, nas Tabs. C.1, onde constam outras informações sobre cada ensaio desta série.

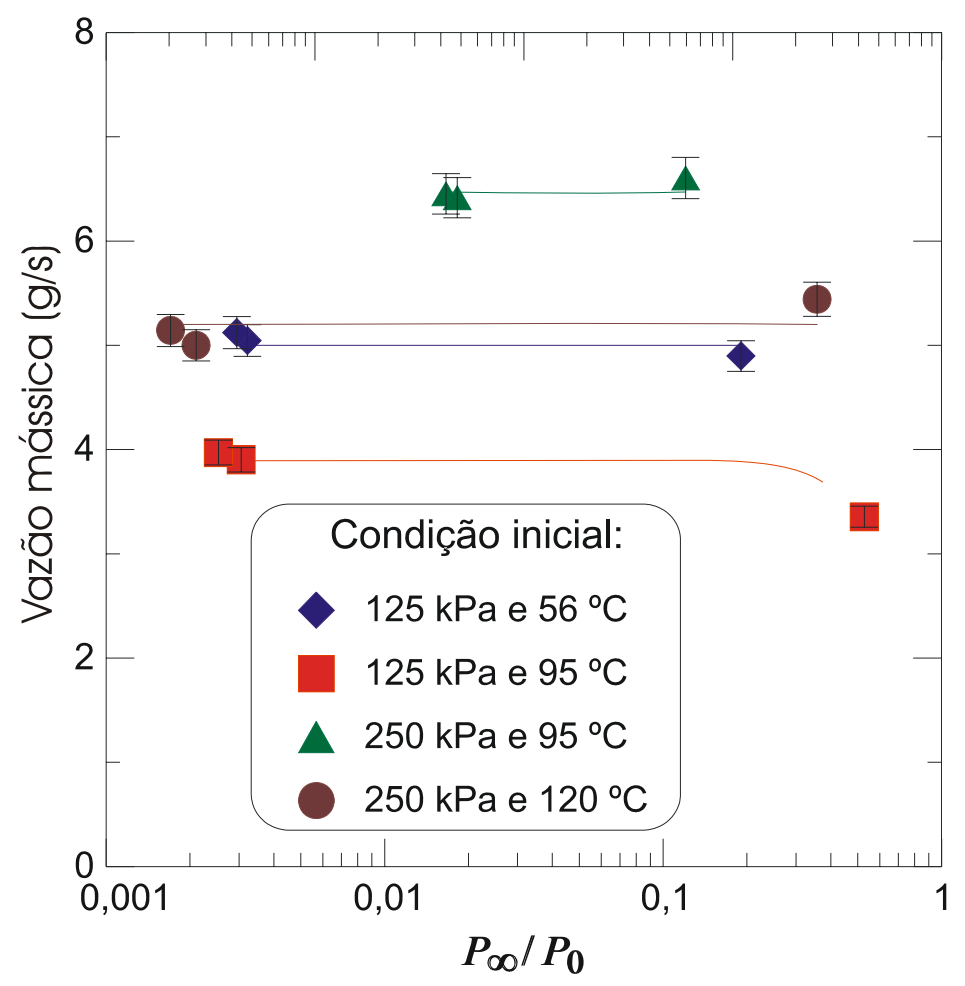

Figura 4.16 -Vazão mássica em função da razão da pressão da câmara e a pressão de injeção obtida dos ensaios com o bocal de aço de diâmetro $0,8 \mathrm{~mm}$.

\subsubsection{Comprimento de Extinção do Núcleo Líquido - Série R08}

No gráfico da Fig. 4.17, o comprimento de extinção do líquido está representado em função da temperatura e pressão de injeção. Cada classe de pressão de injeção tem seu respectivo símbolo representado na legenda deste gráfico. A tabela informativa dos resultados referentes desta medição está na Tab. C.2, do Anexo C. 


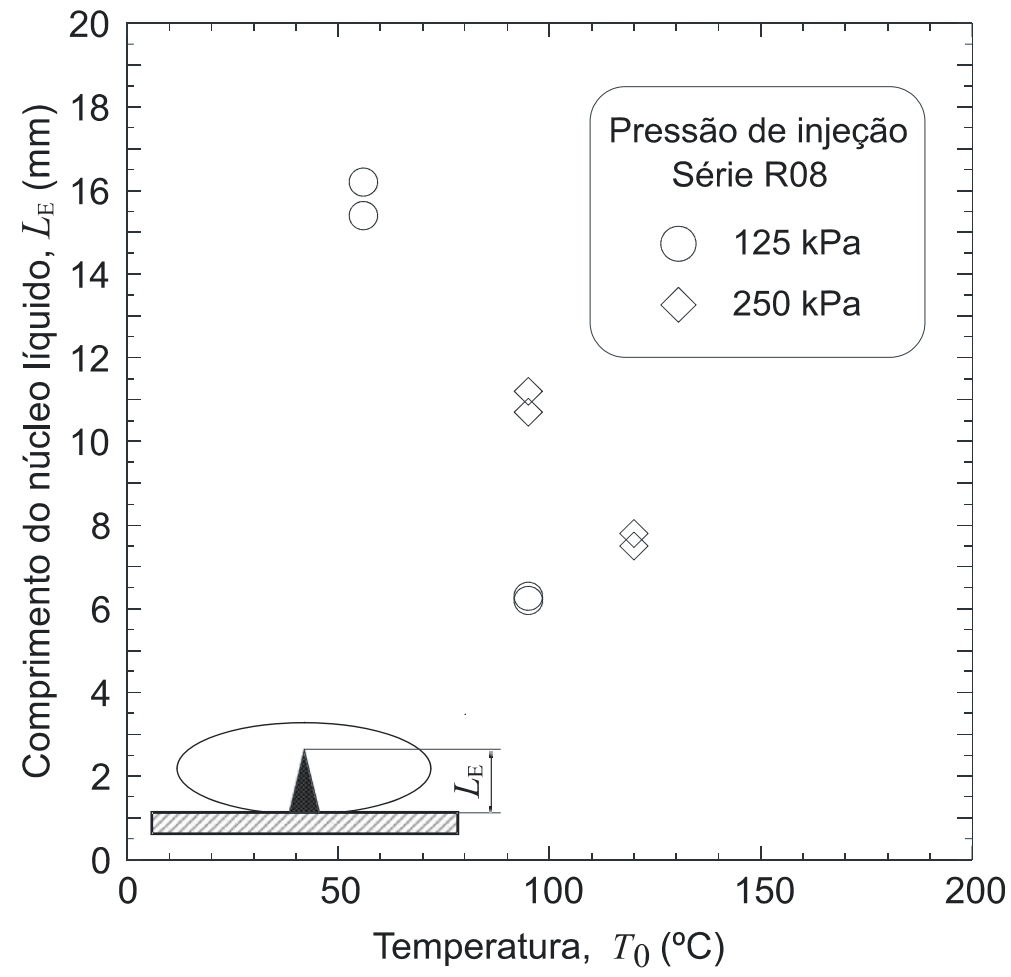

Figura 4.17 - Comportamento do comprimento de extinção do núcleo líquido em função da temperatura de injeção. São diferenciados os ensaios com pressão de injeção de $125 \mathrm{kPa}$ e $250 \mathrm{kPa}$ (bocal rugoso com 0,8 mm de diâmetro).

\subsubsection{Dimensões Características da Estrutura da Onda de Choque - Série R08}

A representação da tendência da dimensão radial da onda de choque, $r_{1}$, e da distância axial em relação à saída do bocal, $r_{2}$, desta série de ensaios, todos obtidos através de ensaios deste bocal de $0,8 \mathrm{~mm}$, está mostrada no gráfico da Fig. 4.18. Conforme esperado, verifica-se que estas dimensões são maiores em pequenas pressões da câmara. As imagens principais dos ensaios desta série estão no Anexo C, Seção C.4, porém a tabela com os valores deste gráfico está na Seção C.3. 


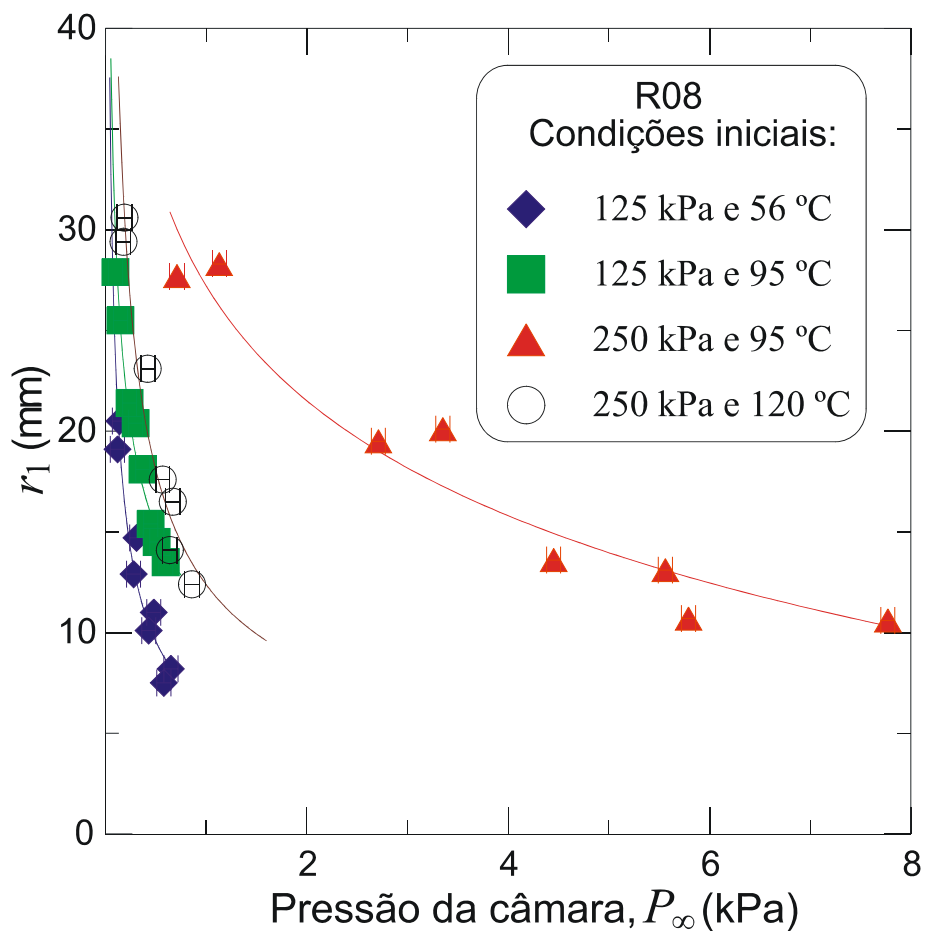

a)

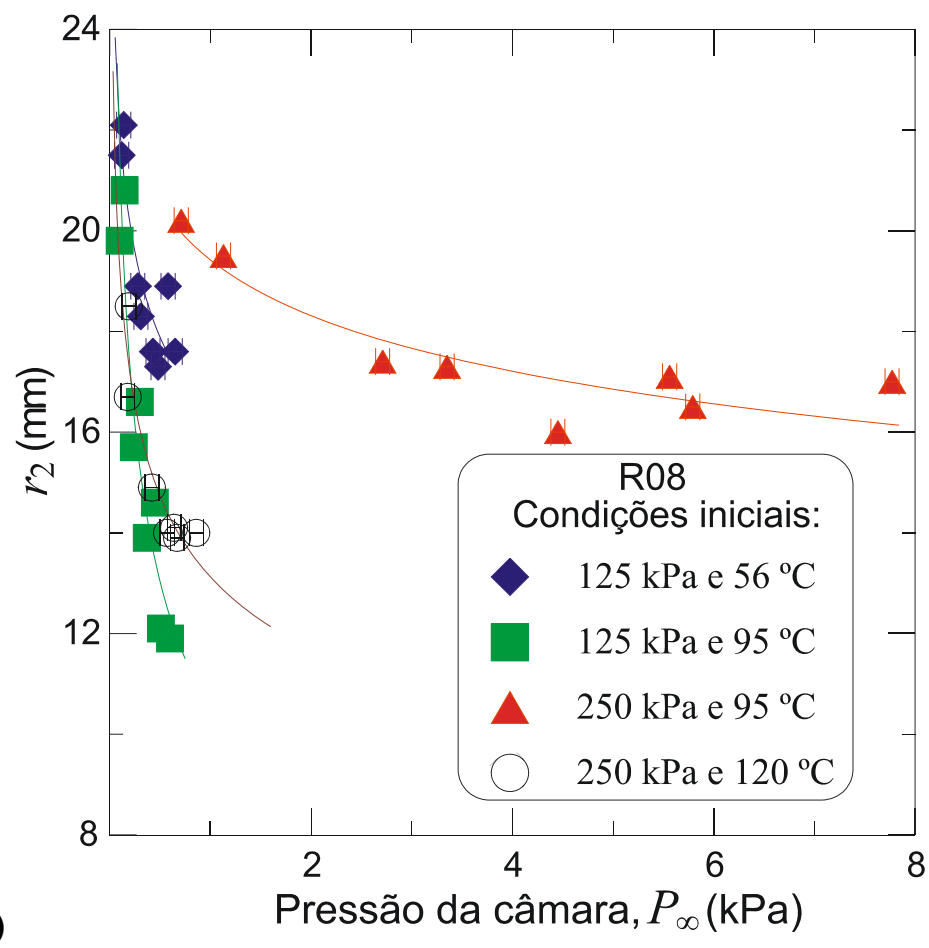

Figura 4.18 - Os comprimentos, $r_{1}$ (no primeiro gráfico) e $r_{2}$ são representados nos gráficos acima que contêm todos os ensaios da série R08 (bocal rugoso com $0,8 \mathrm{~mm}$ de diâmetro). 


\subsubsection{Considerações sobre o Regime Permanente da Série R08}

Infelizmente, as vazões experimentais eram demasiadamente grandes por causa do diâmetro deste bocal. Neste ensaio (código V08\1056500) da Fig. 4.19, a temperatura, $T_{0}$, sofre uma queda considerável, ou seja, alcança um valor de $50{ }^{\circ} \mathrm{C}$ para uma temperatura que inicialmente era de $56^{\circ} \mathrm{C}$. Esta diminuição da temperatura compromete a análise dos dados. Por exemplo, a pressão de saturação de $25 \mathrm{kPa}$ cai para $20 \mathrm{kPa}$ ou $20 \%$ menos. Para que não haja desconsideração destes ensaios, foram coletados aqueles dados que estão dentro deste padrão de regime permanente, ou seja, com temperatura de injeção constante, como indicado nesta figura. Os outros dados como pressão de injeção, $P_{0}$, pressão da câmara, $P_{\infty}$, e sinal do sensor de nível, dentro deste intervalo, tiveram o comportamento esperado, semelhante ao que foi visto na Fig. 3.10 da Seção 3.3.

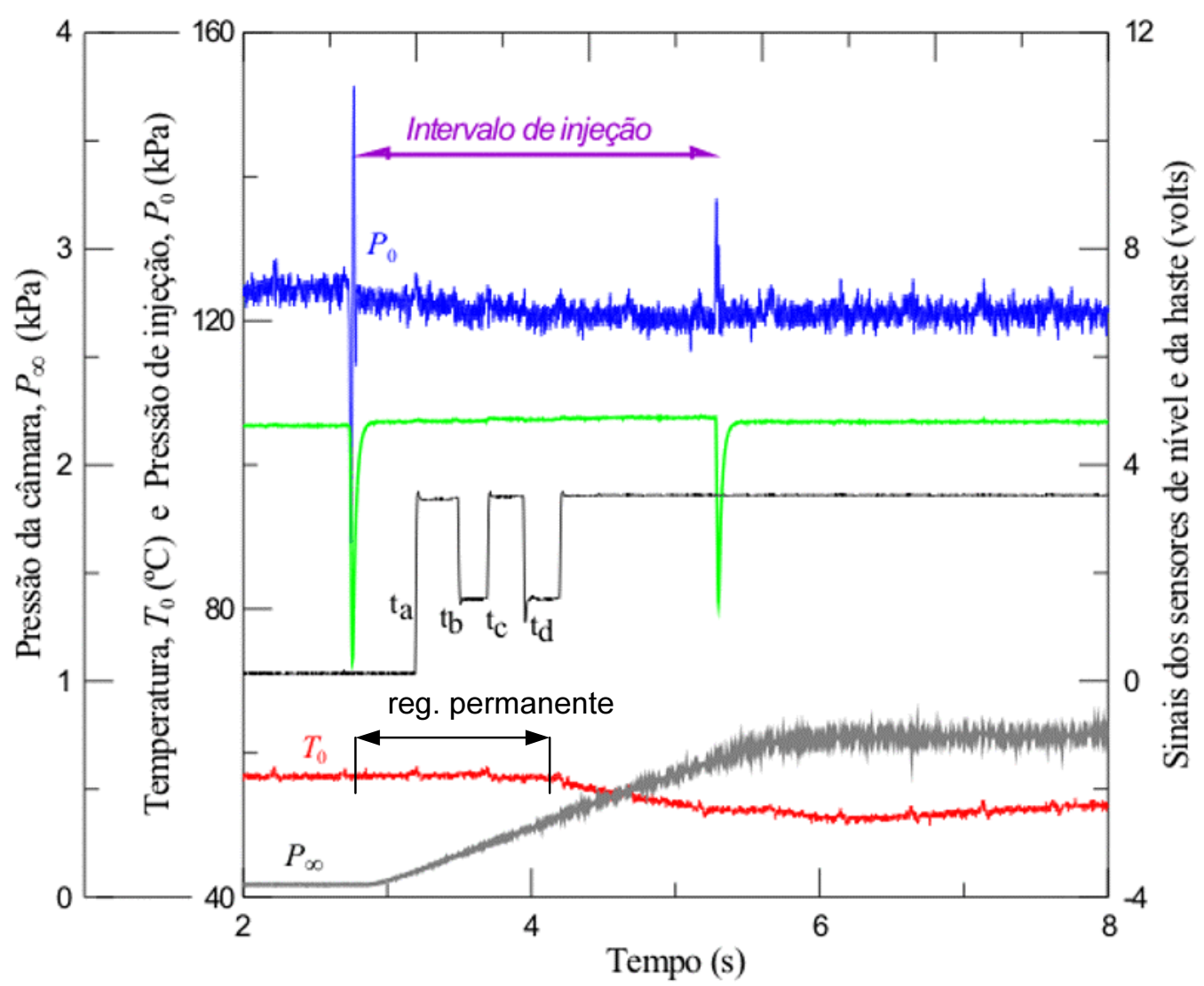

Figura 4.19 - Gráfico dos dados coletados do ensaio com pressão de injeção de $125 \mathrm{kPa}$ e temperatura de $56{ }^{\circ} \mathrm{C}$ (ensaio R08\1056500). A duração do regime permanente é indicada para o intervalo com temperatura de injeção constante. 


\subsection{Ensaios com o Bocal de Vidro de $0,35 \mathrm{~mm}$ de Diâmetro na Saída - Série V03}

O terceiro e último tipo de bocal foi feito de vidro, com formato cônicoconvergente e seu diâmetro na saída de $0,35 \mathrm{~mm}$. Diferente dos demais, este bocal possui os cantos arredondados na borda da saída do jato. Além disso, o vidro possui uma superfície bastante lisa, o que dificulta possíveis nucleações heterogêneas nas paredes internas do bocal. A Fig 4.20 mostra as condições iniciais de injeção dos ensaios com este bocal. Suas pressões de injeção foram 125, 250 e $500 \mathrm{kPa}$ e as temperaturas de injeção foram de 56, 76,95 e $120^{\circ} \mathrm{C}$. No detalhe desta figura é indicado um desenho ilustrativo deste bocal.

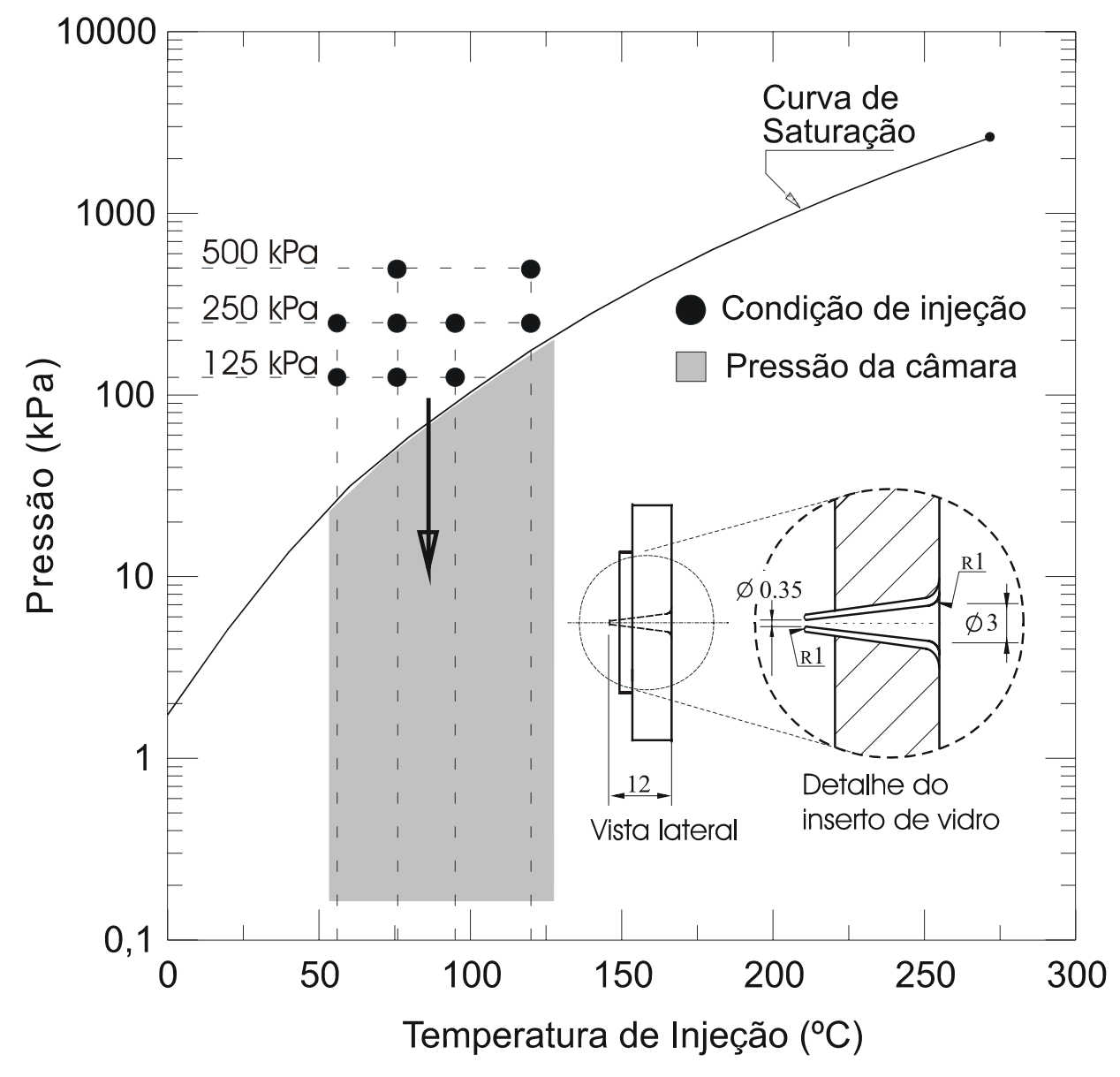

Figura 4.20 - Representação gráfica das condições de injeção e a pressão da câmara onde é descarregado o jato pelo bocal de vidro de $0,35 \mathrm{~mm}$ - Série V03. Um desenho do inserto de vidro é visto no detalhe da figura. 


\subsubsection{Resultados das Medidas das Vazões Mássicas - Série V03}

Todos os ensaios realizados com este bocal estão com a pressão da câmara muito abaixo da pressão de saturação, com valores 20 vezes menores. Para uma visão geral, nesta seção são apresentados os valores da vazão em função da razão entre a pressão de injeção e pressão da câmara (Fig. 4.21 a 4.23). Os dados deste gráfico podem ser encontrados no Anexo C, Tab. C.4.

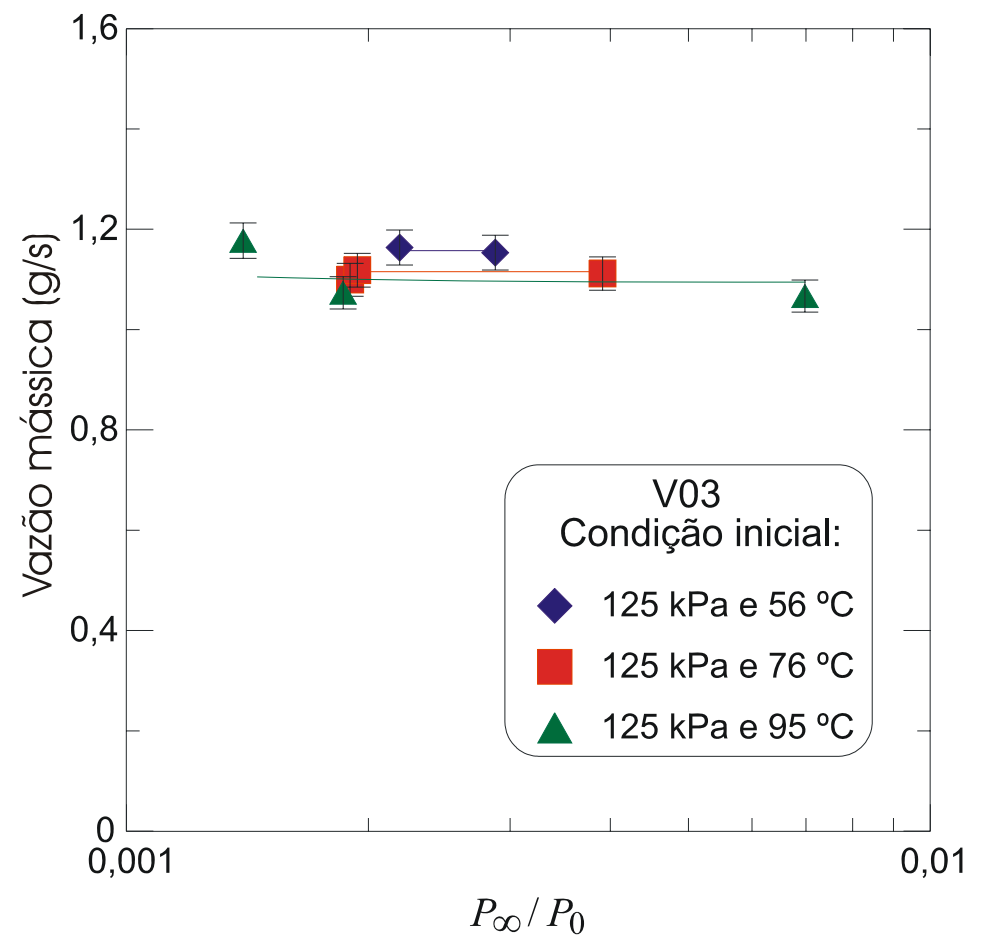

Figura 4.21 -Vazão mássica em função da razão da pressão da câmara e a pressão de injeção obtida dos ensaios com pressão de injeção de $125 \mathrm{kPa}$ e bocal de vidro de diâmetro $0,35 \mathrm{~mm}$. 


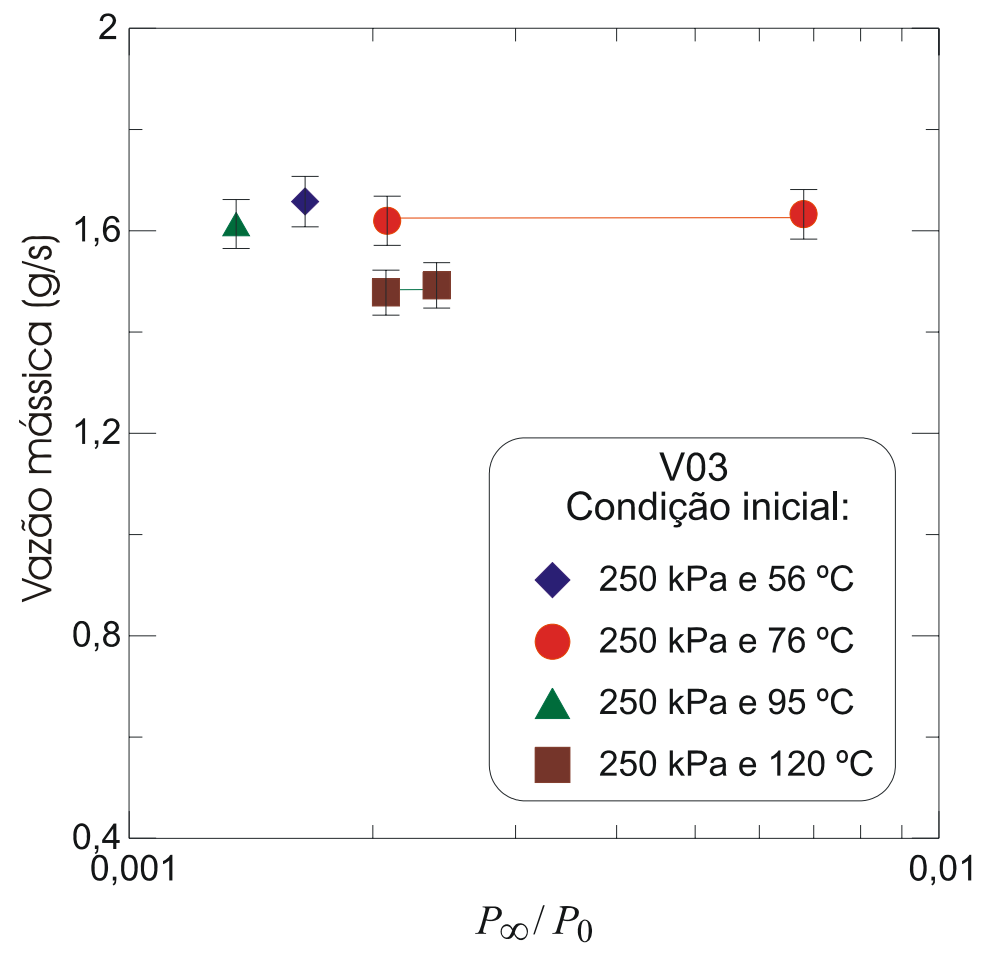

Figura 4.22 -Vazão mássica em função da razão da pressão da câmara e a pressão de injeção obtida dos ensaios com pressão de injeção de $250 \mathrm{kPa}$ e bocal de vidro de diâmetro $0,35 \mathrm{~mm}$.

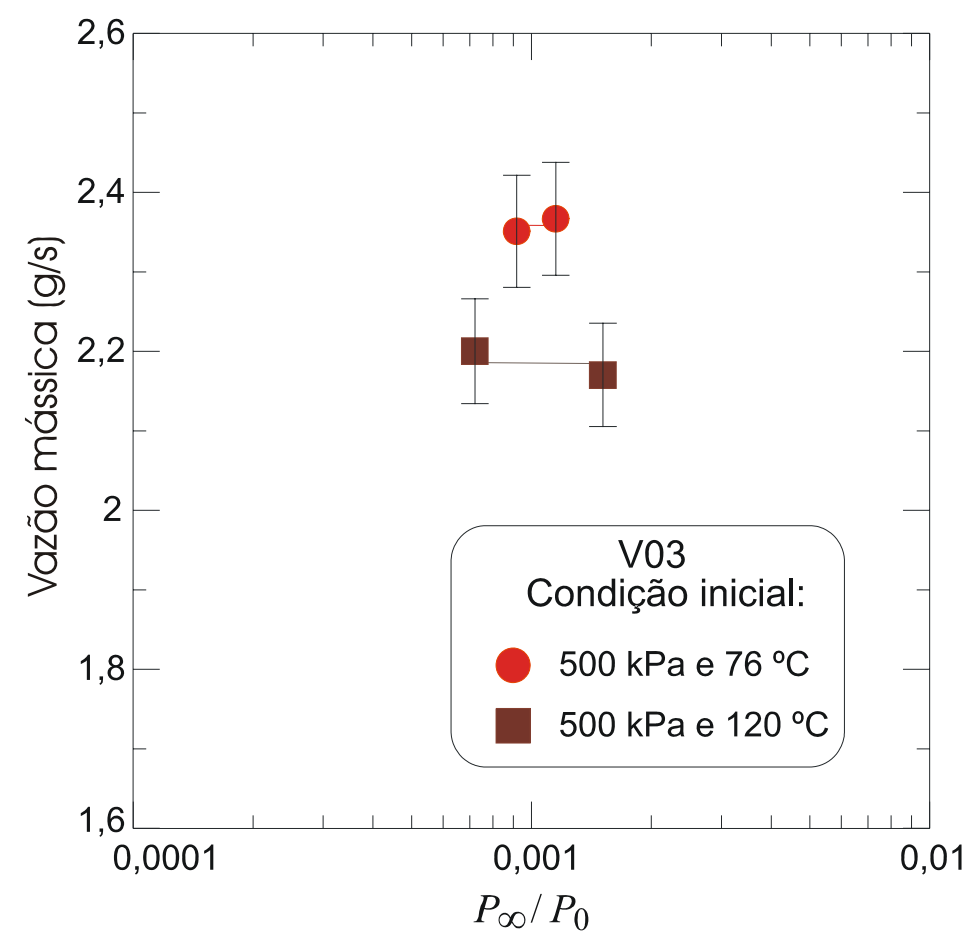

Figura 4.23 -Vazão mássica em função da razão da pressão da câmara e a pressão de injeção obtida dos ensaios com pressão de injeção de $500 \mathrm{kPa}$ e bocal de vidro de diâmetro $0,35 \mathrm{~mm}$. 


\subsubsection{Comprimento de Extinção do Núcleo Líquido - Série V03}

No gráfico da Fig. 4.24, o comprimento de extinção do líquido, $L_{\mathrm{E}}$, está representado em função da temperatura e pressão de injeção. Cada classe de pressão de injeção foi diferenciada pelos respectivos símbolos representados na legenda deste gráfico.

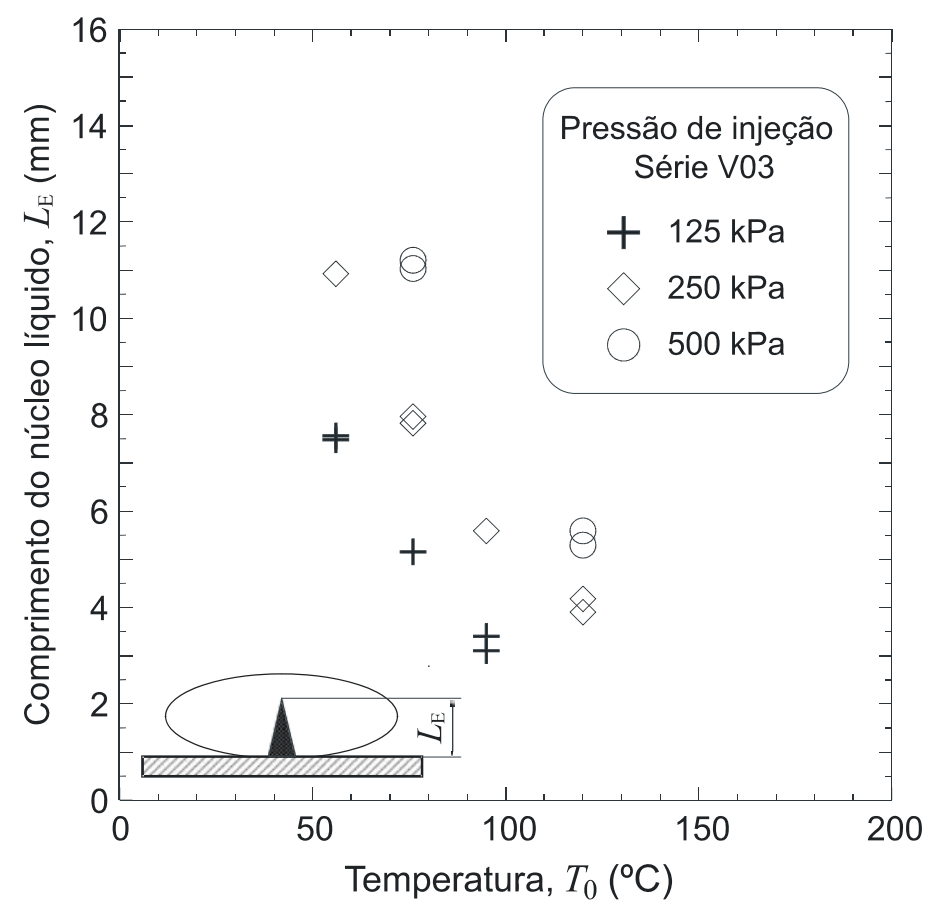

Figura 4.24 - Comportamento do comprimento de extinção do núcleo líquido em função da temperatura de injeção. São diferenciados os ensaios com pressão de injeção de 125, 250 e $500 \mathrm{kPa}$ (bocal de vidro com 0,35 mm de diâmetro).

\subsubsection{Dimensões Características da Estrutura da Onda de Choque - Série V03}

Foram tomadas as principais medidas da onda de choque como a dimensão radial da onda de choque, $r_{1}$, e a distância axial em relação à saída do bocal, $r_{2}$. Os dados obtidos destas dimensões pelo bocal de vidro com $0,35 \mathrm{~mm}$ estão na Tab. C.6, do Anexo C. E as principais imagens adquiridas desta série estão na Seção C.8 do Anexo C. A seguir são apresentados os gráficos que mostram as principais dimensões medidas da onda de choque em função da pressão da câmara (Fig. 4.25 a 4.27). 


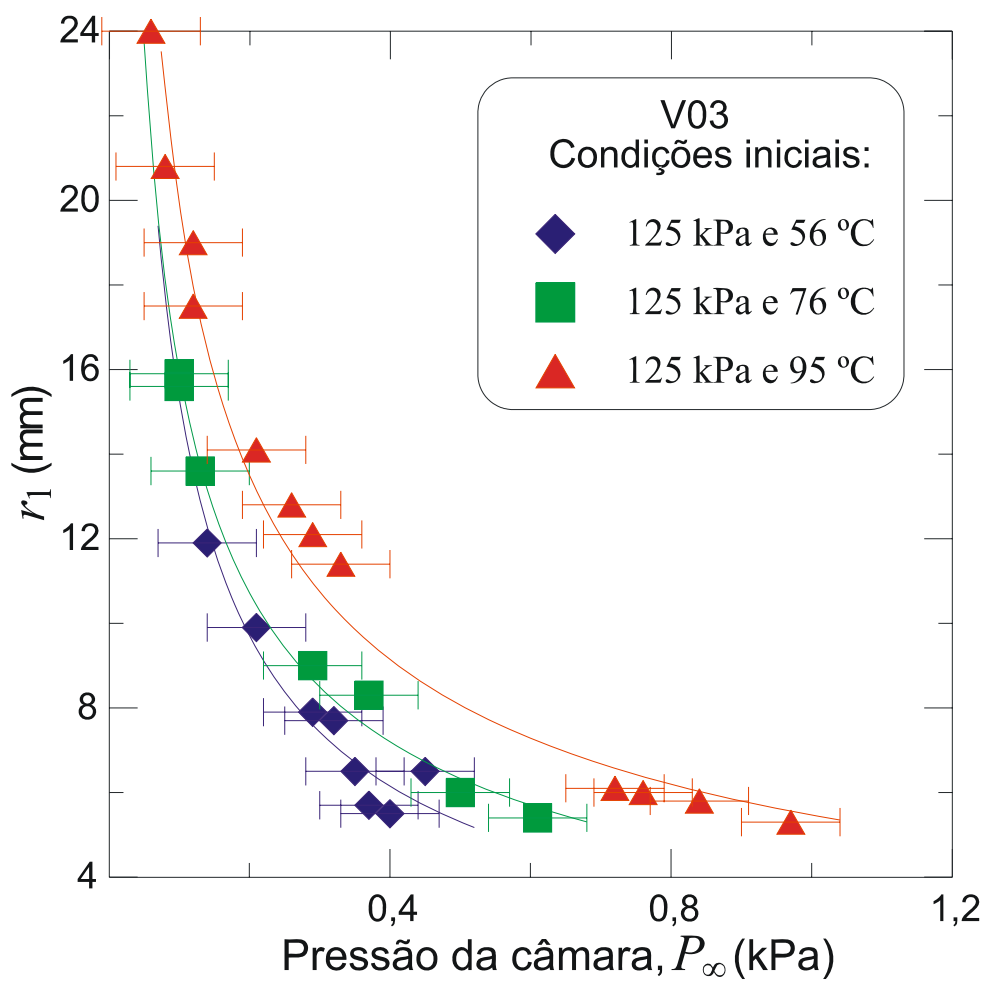

a)

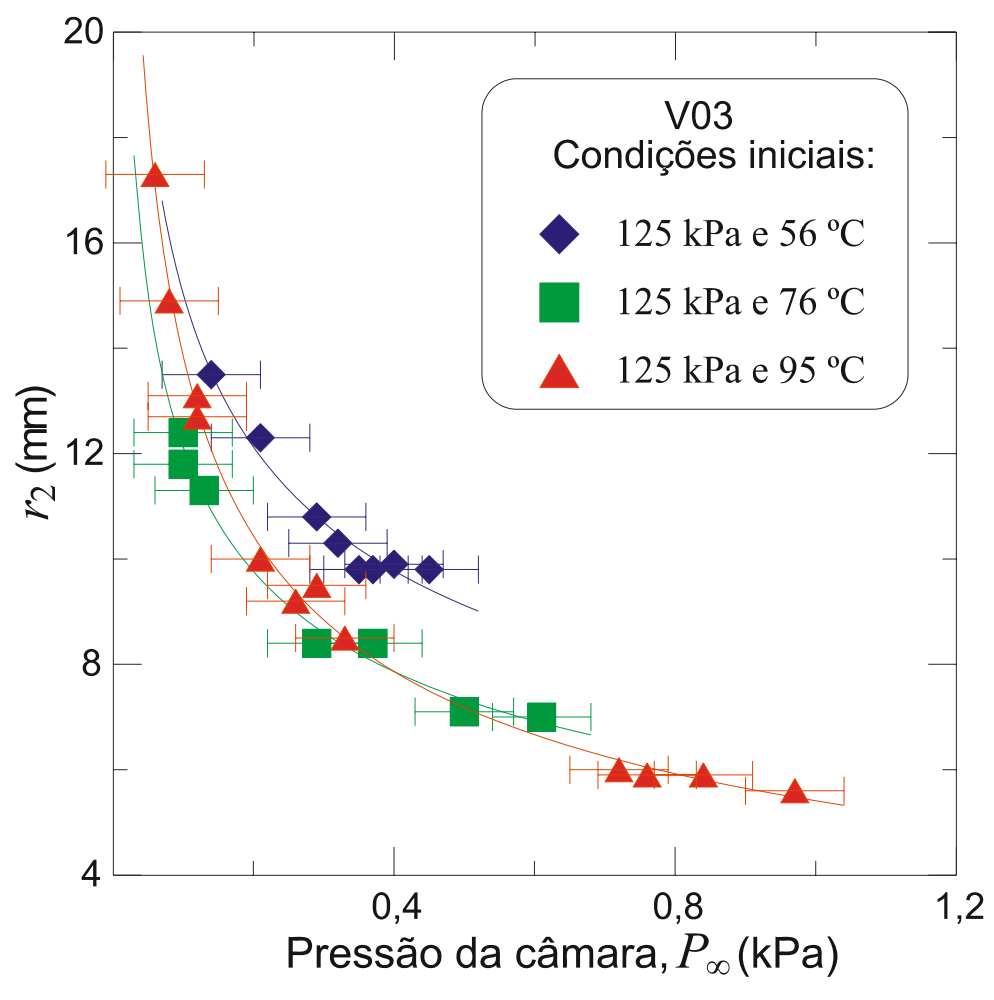

Figura 4.25 - Os comprimentos, $r_{1}$ (no primeiro gráfico) e $r_{2}$ são representados nos gráficos acima que contêm os ensaios da série V03 (bocal de vidro com 0,35 $\mathrm{mm}$ de diâmetro) com pressão de injeção de $125 \mathrm{kPa}$. 


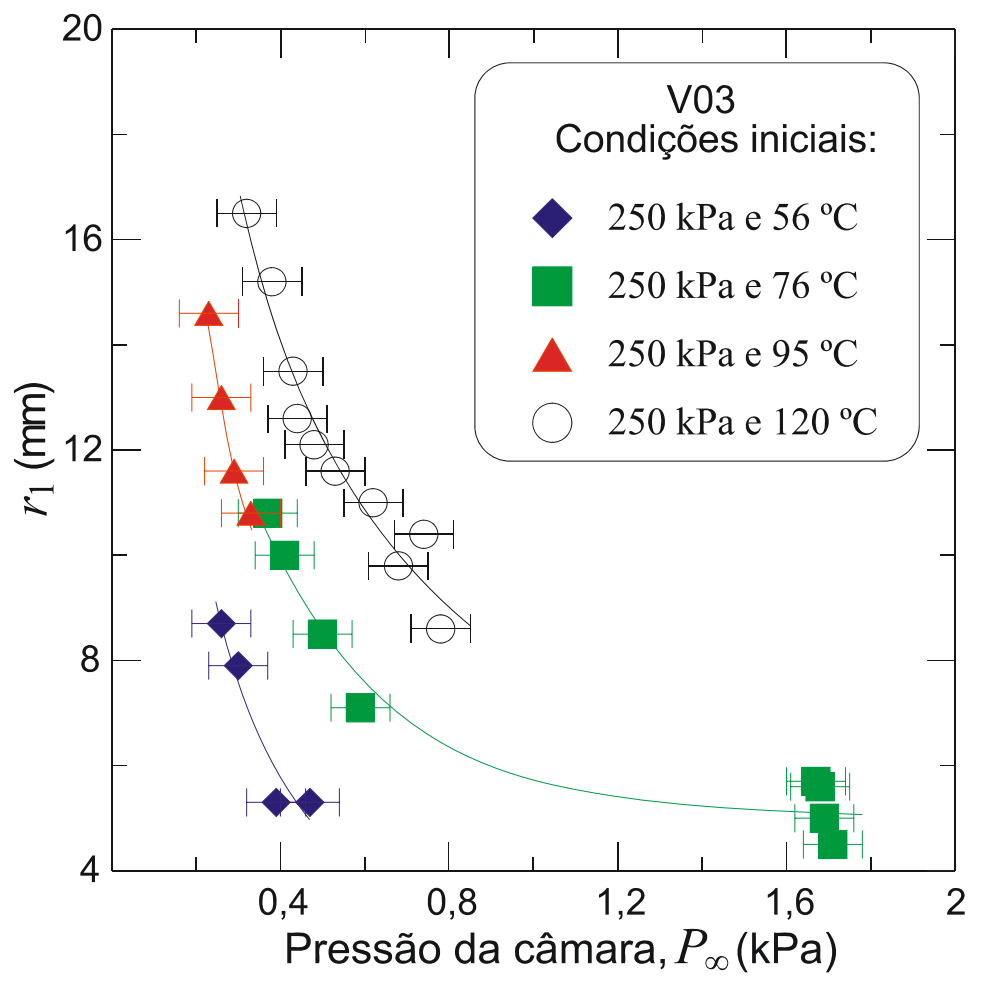

a)

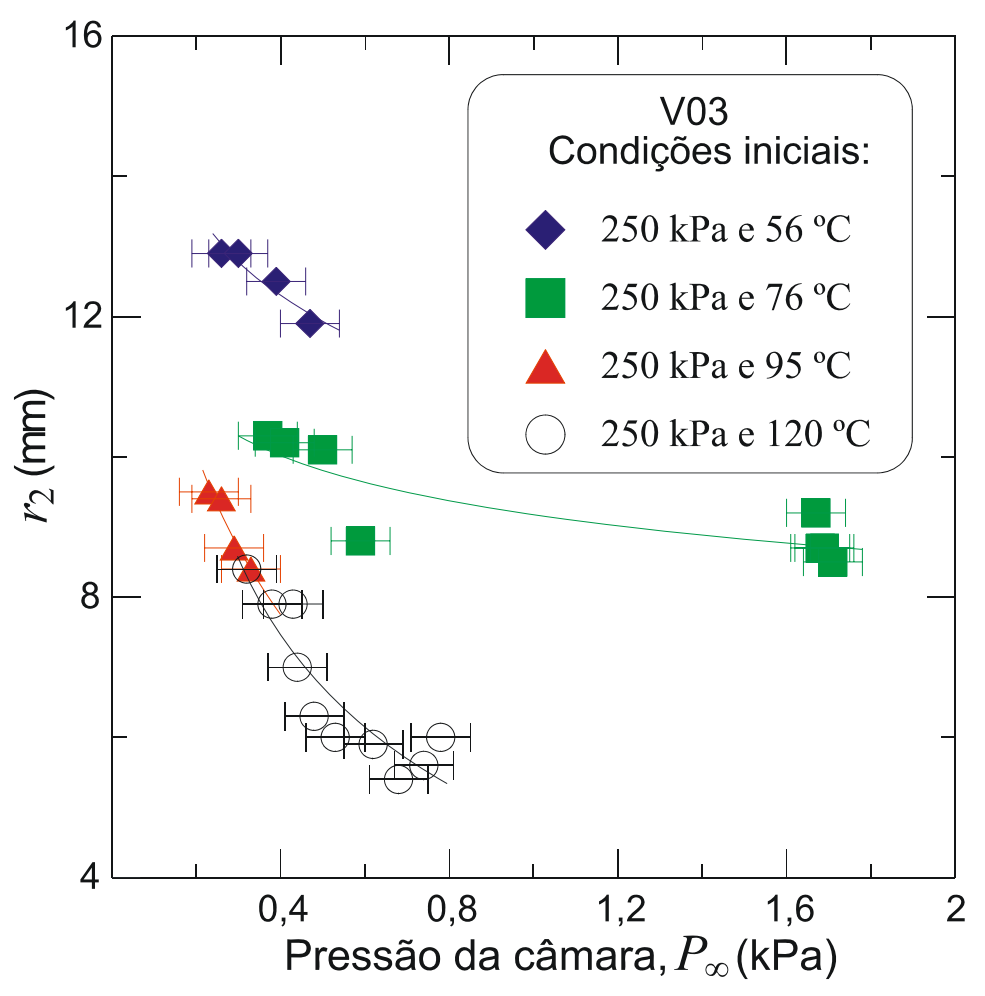

Figura 4.26 - Os comprimentos, $r_{1}$ (no primeiro gráfico) e $r_{2}$ são representados nos gráficos acima que contêm os ensaios da série V03 (bocal de vidro com 0,35 $\mathrm{mm}$ de diâmetro) com pressão de injeção de $250 \mathrm{kPa}$. 


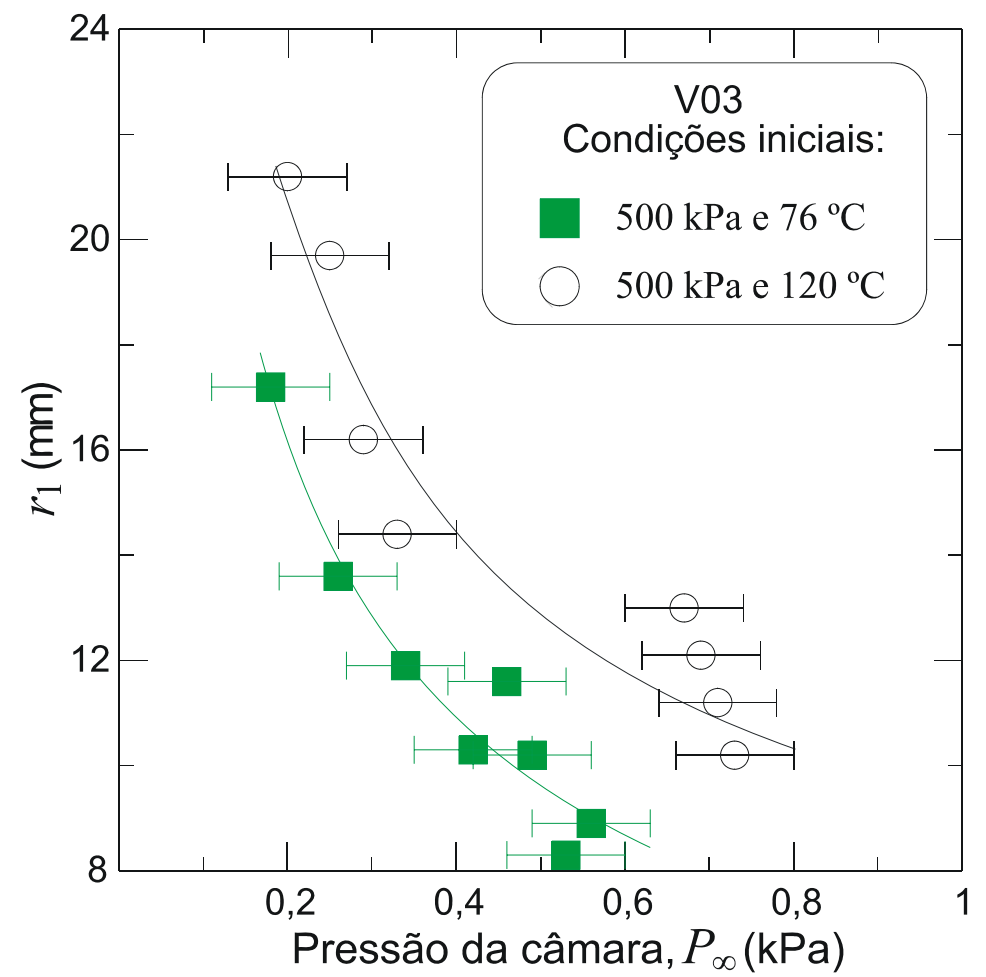

a)

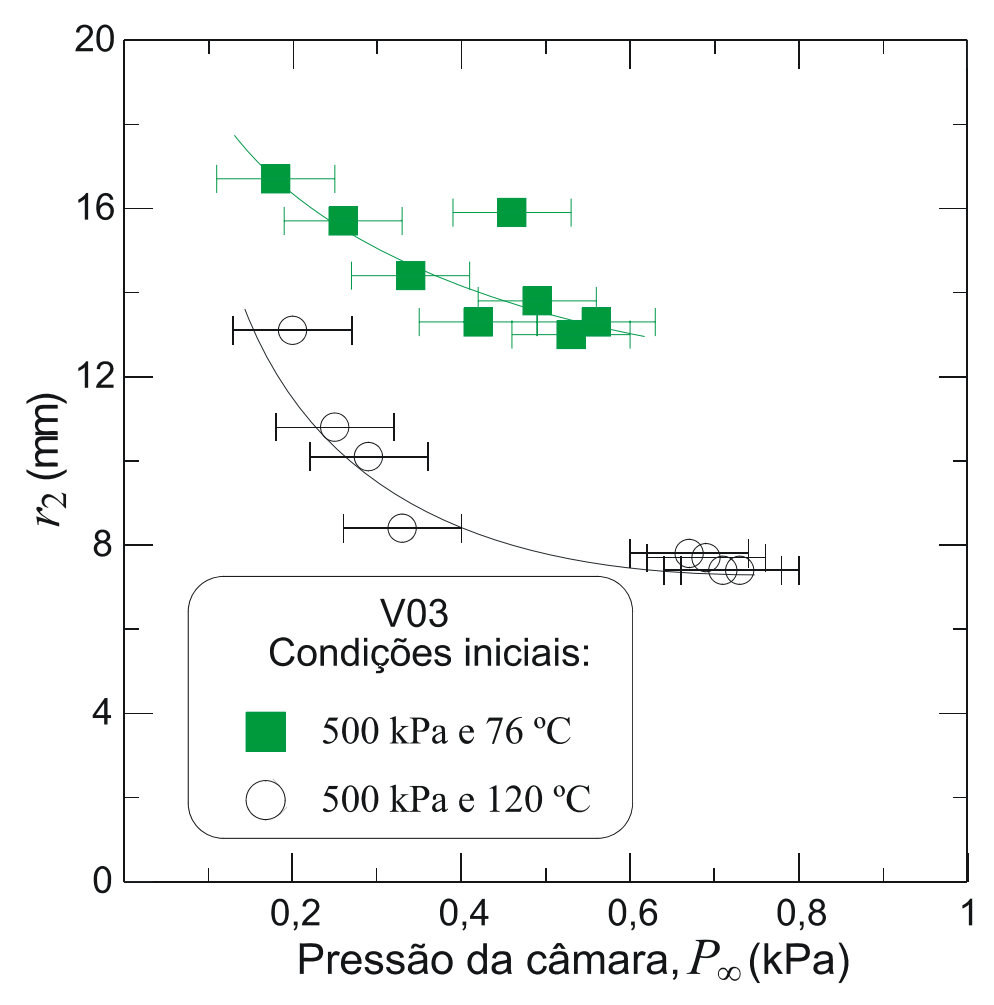

Figura 4.27 - Os comprimentos, $r_{1}$ (no primeiro gráfico) e $r_{2}$ são representados nos gráficos acima que contêm os ensaios da série V03 (bocal de vidro com 0,35 $\mathrm{mm}$ de diâmetro) com pressão de injeção de $500 \mathrm{kPa}$. 


\section{AnÁlise e Discussão dos Resultados EXPERIMENTAIS}

Este capítulo contém duas seções. Nesta primeira seção, são discutidos e analisados os resultados obtidos pelo bocal de $0,3 \mathrm{~mm}$ com superfície rugosa. Primeiramente, é apresentada uma visão geral dos tipos de jatos encontrados, através das imagens obtidas. Em seguida, é mostrado o comportamento da vazão em função das condições de injeção e da pressão da câmara. A seguir se tem por objetivo mostrar com mais detalhes algumas peculiaridades que existem nos jatos em virtude das condições de injeção. São imagens ampliadas que são relacionadas com as observações feitas. Também é feita uma análise do comprimento do núcleo líquido em função da pressão e temperatura de injeção. Em seguida, em função das observações obtidas nas imagens dos jatos evaporativos, é feita uma análise descritiva do escoamento a jusante da onda de evaporação. E na seção seguinte, os resultados do bocal de aço de $0,8 \mathrm{~mm}$ de diâmetro e do bocal de vidro de $0,35 \mathrm{~mm}$ de diâmetro são analisados e comparados com o bocal de aço com 0,3 mm de diâmetro.

\subsection{Análise e Discussão do Bocal de Aço com 0,3 mm de diâmetro}

As Figs. 5.1 a 5.4 mostram uma seleção de fotografias que podem exemplificar os tipos de jatos obtidos. Cada figura possui imagens dos jatos para uma determinada temperatura $\left(T_{0}\right)$ e pressão $\left(P_{0}\right)$ de injeção, e em cada imagem existem tipos de jatos diferentes em função da pressão da câmara $\left(P_{\infty}\right)$, conseqüentemente, também é inferido o valor de $R_{\mathrm{p}}$. As dimensões geométricas dos jatos foram obtidas através do diâmetro da plataforma do injetor que possui o valor de $50 \mathrm{~mm}$, a qual é plenamente visível nas Figs. $5.1 \mathrm{~b}$ e $5.3 \mathrm{c}$.

A Fig. 5.1a mostra um primeiro tipo de jato que possui uma pressão de saturação menor que a pressão da câmara e, que não sofre fragmentação nem perturbações devido às condições ambientes. Quando a pressão da câmara se iguala à pressão de saturação do fluido, é possível notar uma evaporação superficial no filete líquido do jato (Fig. 5.1b). 
No segundo tipo de jato, existe uma evaporação com dispersão de gotículas e pode ser visto nas Figs. (5.1c), (5.2a), (5.2b), (5.3a), (5.3b), (5.4a) e (5.4b). São ensaios que a pressão de saturação é maior que a pressão da câmara compreendendo valores de $R_{\mathrm{p}}$ entre 2 e 10 , dependendo da pressão e temperatura de injeção, como será visto na subseção seguinte. Com valores nominais de $R_{\mathrm{p}}$ acima de 50 , é observada a formação de ondas de choque. Alguns jatos já apresentam a formação do núcleo de líquido e, portanto, possuem uma onda de evaporação uniforme deste núcleo (Fig. 5.1c). Os outros jatos deste tipo, a onda de evaporação não apresenta uniformidade, mostrando um jato sem uma direção definida do núcleo de líquido (Fig. 5.2a e 5.2b).

Neste terceiro tipo, o fluido no estado líquido emerge do bocal com um núcleo de líquido mais definido e corresponde à região totalmente escura, localizada na saída do bocal. A expansão supersônica resulta em uma onda de choque, e pode ser vista nas Figs. (5.1d) e (5.1e), (5.2d) e (5.2e), (5.3c), (5.3d), (5.3e), (5.4d) e (5.4e). Nas Figs. (5.2c) e (5.4c), não é possível visualizar a onda de choque porque, provavelmente, ela se forme muito próxima do núcleo de líquido. Quando as ondas de choque de dimensões estão mais afastadas do núcleo de líquido, a sua visualização é mais nítida. Isto mostra que na região de expansão supersônica existe uma evaporação do fluido tornando claro os detalhes das imagens. Em contraposição, nos jatos que apenas há dispersão de gotículas em virtude da evaporação, com baixos valores de $R_{\mathrm{P}}$, é difícil a visualização do núcleo de líquido. Geralmente, os jatos com baixas temperaturas de injeção que possuem a onda de choque visível têm valores de $R_{\mathrm{P}}$ maiores que 50 . Altas temperaturas, ou seja, acima de $120^{\circ} \mathrm{C}$, possuem a onda de choque visível com $R_{\mathrm{P}}$ maior que 200. E quanto menor é a pressão da câmara, maiores são as dimensões da onda de choque formada. Como exemplo, o caso das Figs. 5.1d e 5.1e mostram a evolução da onda de choque em virtude da pressão da câmara. Da primeira imagem (Fig. 5.1d) o raio da onda está próximo do núcleo de líquido $(5,7 \mathrm{~mm})$, e na distância axial, a onda de choque situa na mesma distância do núcleo de líquido $(5,2 \mathrm{~mm})$. $\mathrm{Na}$ imagem seguinte (Fig. 5.1e), o raio aumentou para $18 \mathrm{~mm}$ e a distância axial da onda de choque também aumentou para $13 \mathrm{~mm}$ devido a queda da pressão da câmara. Para este tipo de jato, basta saber se o núcleo de líquido se modifica, algo que será visto na Seção 5.1.6. 

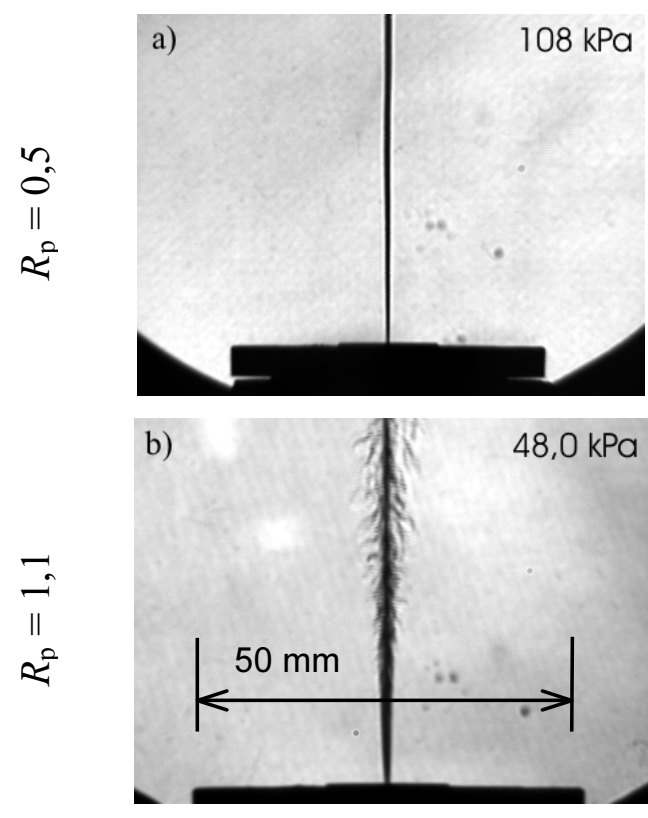

c)

$6,67 \mathrm{kPa}$

N

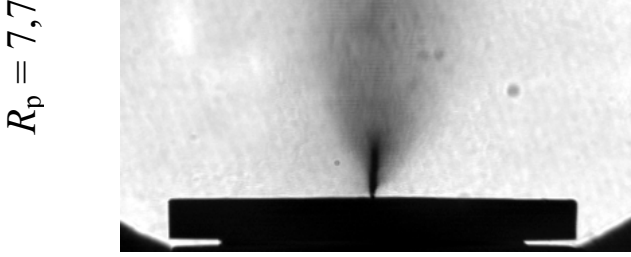

d)

$0,44 \mathrm{kPa}$
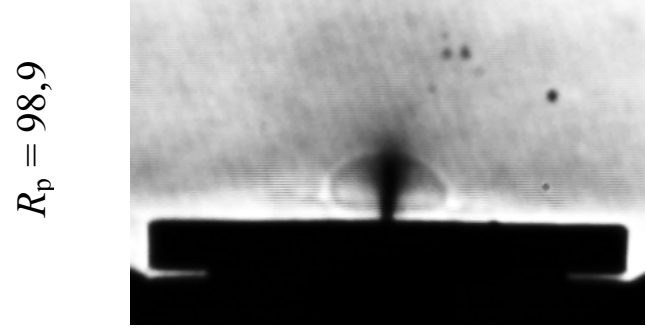

e)

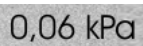

ñ

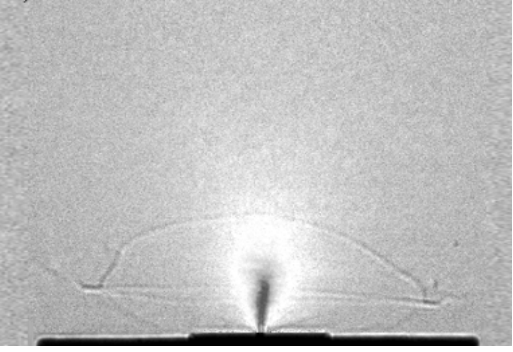

Figura 5.1 - Alguns ensaios de valores de injeção nominais $P_{0}=250 \mathrm{kPa}$ e $T_{0}=76{ }^{\circ} \mathrm{C}$ $\left(P_{\text {sat }}=54 \mathrm{kPa}\right)$.

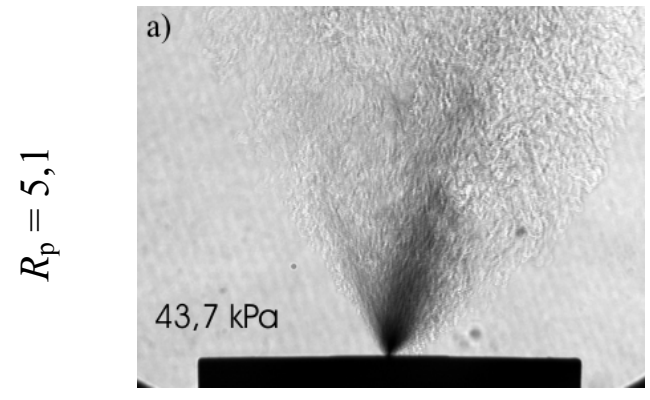

b)

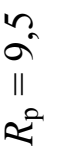

0
a
a

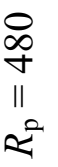

d)

$0,48 \mathrm{kPa}$

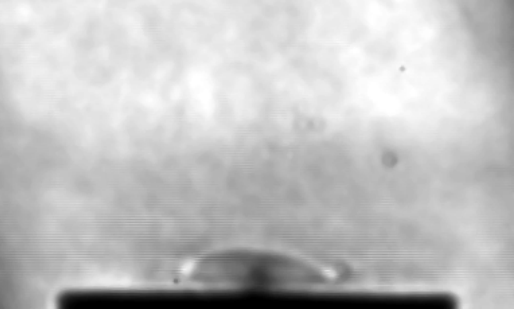

e)

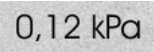

$\frac{\infty}{n}$
स्थ

Figura 5.2 - Alguns ensaios de valores de injeção nominais $P_{0}=250 \mathrm{kPa}$ e $T_{0}=130{ }^{\circ} \mathrm{C}$ $\left(P_{\text {sat }}=220 \mathrm{kPa}\right)$. 

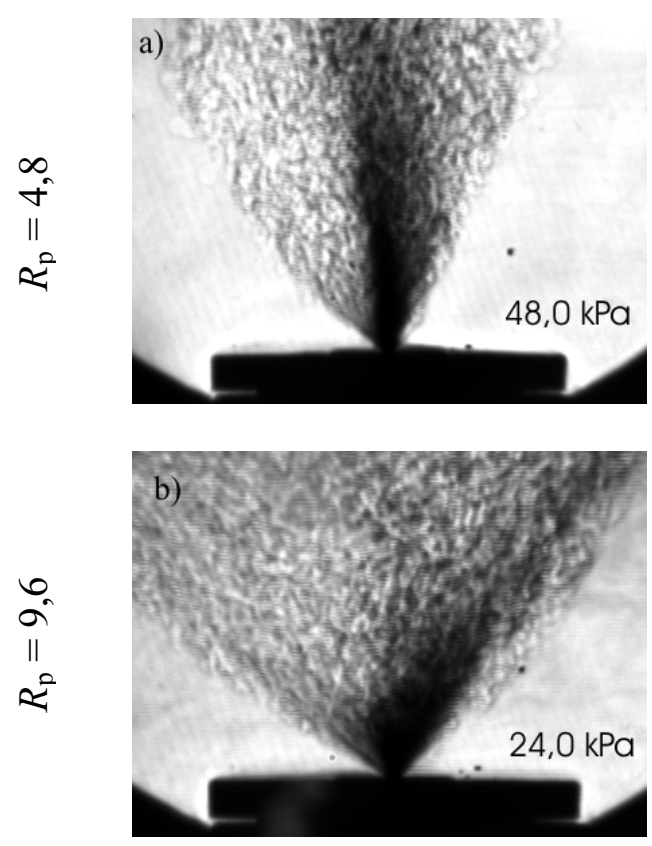

c)

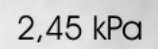

$n$
$n$
2

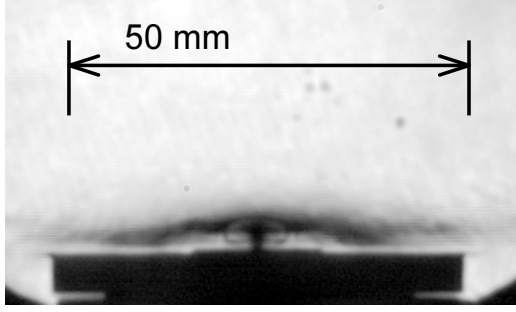

d)

$0,43 \mathrm{kPa}$

0
$\stackrel{0}{7}$
II

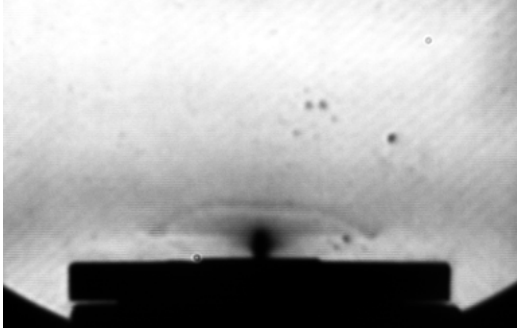

e)

$0,26 \mathrm{kPa}$

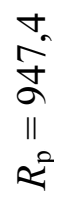

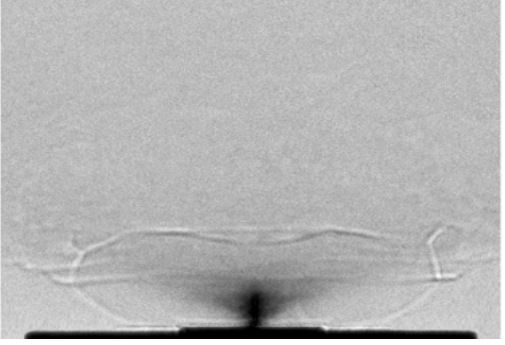

Figura 5.3 - Alguns ensaios de valores de injeção nominais $P_{0}=500 \mathrm{kPa}$ e $T_{0}=130{ }^{\circ} \mathrm{C}$ $\left(P_{\text {sat }}=220 \mathrm{kPa}\right)$.
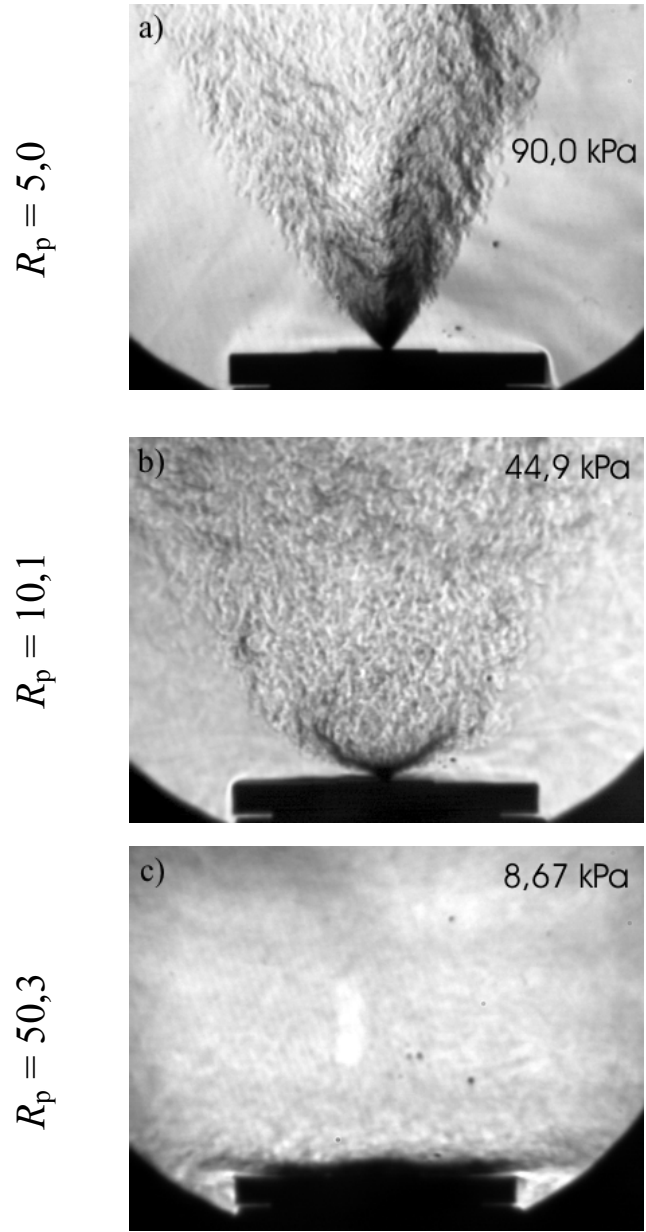

d)

$0,94 \mathrm{kPa}$

+
$\infty$
$i$
$I$
2

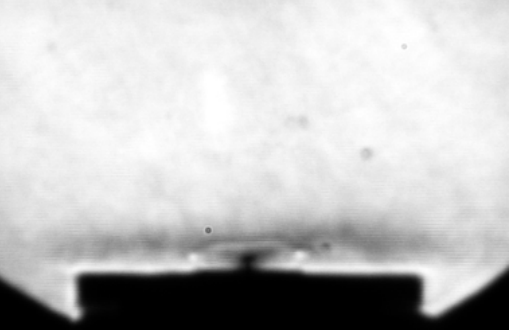

e) $\quad 0,55 \mathrm{kPa}$

0
\pm
$\infty$
$\|$
2

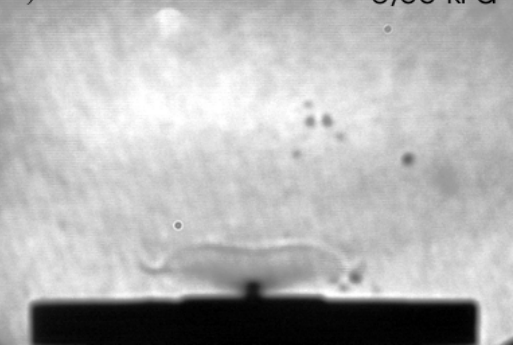

Figura 5.4 - Alguns ensaios de valores de injeção nominais $P_{0}=500 \mathrm{kPa}$ e $T_{0}=162{ }^{\circ} \mathrm{C}$ $\left(P_{\text {sat }}=440 \mathrm{kPa}\right)$. 


\subsubsection{A Condição de Máxima Vazão}

Mantendo constantes a pressão e a temperatura de injeção e apenas variando a pressão da câmara, obtém-se um comportamento geral da vazão como aquele ilustrado na Fig. 5.5. Os pontos indicados são aos dados experimentais coletados nesta condição de pressão e temperatura de injeção, mostrado na legenda. A curva de descarga do bocal é obtida pela Eq. 4.2 que admite um comportamento incompressível na região interna do bocal. Esta equação utiliza a pressão da câmara como a pressão do líquido na saída do bocal. Nota-se que a curva de descarga do bocal é apresentada apenas como referência geral, uma vez que os experimentos indicaram fenômenos compressíveis complexos na saída do bocal fazendo com que na seção de saída do mesmo, a pressão esteja longe de ser a pressão da câmara onde o jato é descarregado.

Conforme é visto no gráfico, a curva de vazão de descarga do bocal, alcança um maior patamar de vazão. Porém, os ensaios indicaram que a vazão é blocada em um outro patamar, menor que o anterior. No entanto, os dados experimentais coincidem com a curva quando a pressão da câmara é maior que a metade da pressão de saturação, conforme a Fig. 5.5.

Necessariamente, o valor da pressão da câmara cuja vazão é máxima é encontrado graficamente através da média das vazões de ensaios blocados. Por exemplo, no gráfico da Fig. 5.5, a média da vazão máxima experimental foi de 1,131 g/s. Através deste valor médio experimental e da Eq. 4.4, que admite que o fluido é incompressível na expansão do bocal, é possível determinar a máxima pressão da câmara que proporciona esta máxima vazão. Neste exemplo, a pressão é de $37 \mathrm{kPa}$. Geralmente, esta pressão se encontra abaixo da pressão de saturação do líquido e, portanto, é metaestável. Para cada série de ensaio com uma pressão e temperatura de injeção, foi obtida uma máxima vazão, ou vazão crítica, semelhante a este gráfico que possui uma temperatura de $95^{\circ} \mathrm{C}$ e uma pressão de $250 \mathrm{kPa}$ de injeção. Em outras condições de injeção, gráficos similares foram apresentados na Seção 4.1. Uma média da pressão metaestável através da condição de blocagem da vazão é vista na Tab. 5.1. 


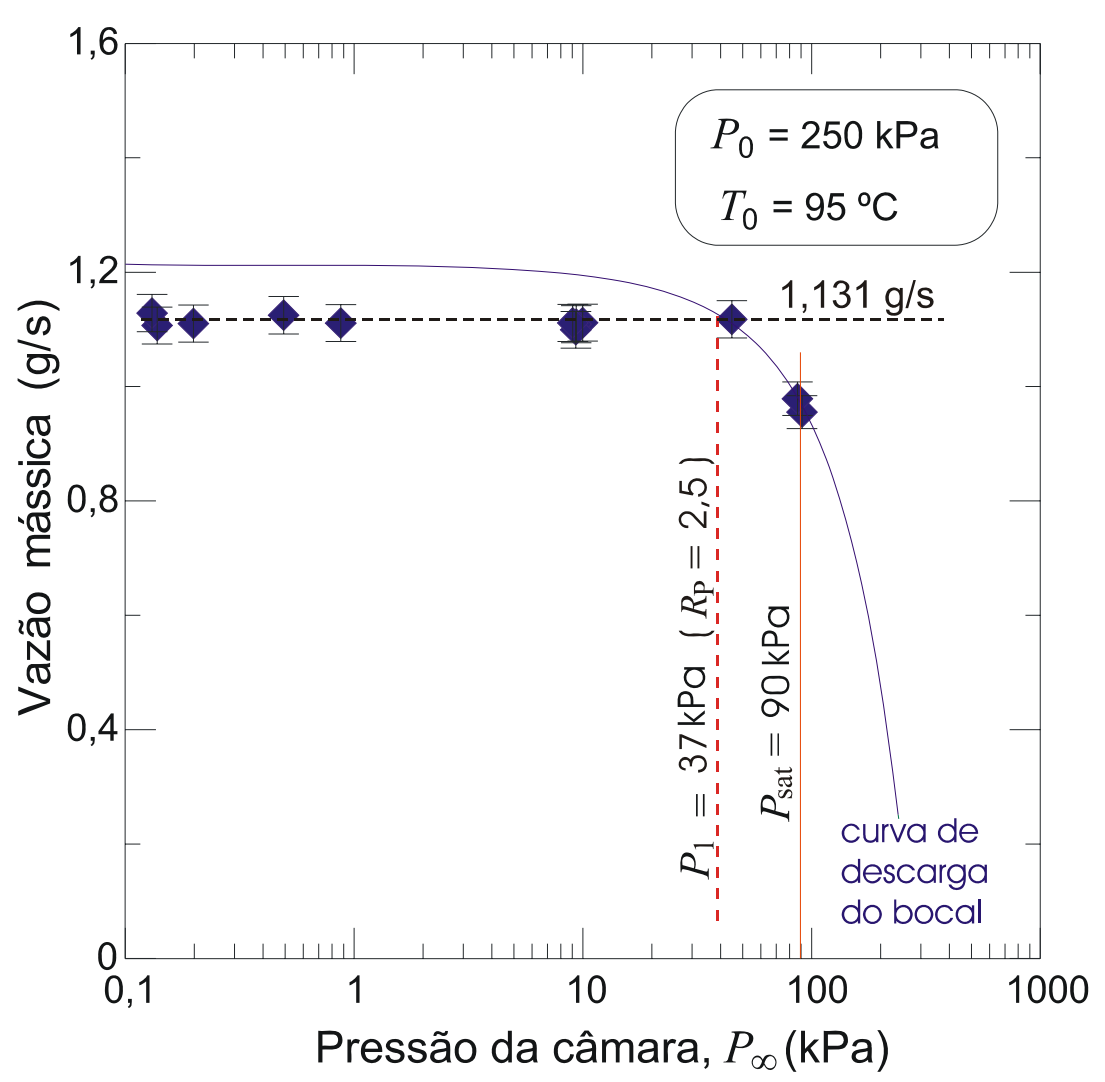

Figura 5.5 - Caso típico de um comportamento da vazão. Os pontos correspondem aos ensaios realizados a uma pressão e temperatura de injeção de $250 \mathrm{kPa}$ e $95^{\circ} \mathrm{C}$, respectivamente. A linha vertical contínua se refere à pressão de vapor de $90 \mathrm{kPa}$ a outra linha contínua corresponde à vazão mássica estimada através da Eq. 4.3.

A Tab. 5.1 apresenta os dados médios das categorias de ensaios, ou seja, para cada condição inicial de injeção, existe um valor médio da vazão máxima e da pressão metaestável. Através dos valores desta tabela como: a razão entre pressão de saturação e pressão de injeção, razão entre pressão de saturação e pressão metaestável do líquido e o grau de metaestabilidade, são obtidos os gráficos das Figs. 5.6 a 5.8. A primeiro gráfico (Fig. 5.6) mostra a pressão metaestável alcançada pelo líquido em função da pressão e temperatura de injeção. O gráfico da Fig.5.7 ilustra o comportamento do grau de metaestabilidade em função da pressão de injeção. Nele se verifica que pressões mais baixas têm a tendência de alcançar maiores graus de metaestabilidade do líquido, ou seja, a pressão metaestável é bem menor que a pressão de saturação, como também visto no gráfico da Fig. 5.6. Como exemplo, a injeção de líquido a $56{ }^{\circ} \mathrm{C}$, para uma pressão de $125 \mathrm{kPa}$, assume graus de 
metaestabilidade próximo de 0,8, enquanto, a uma pressão de $750 \mathrm{kPa}$, a metaestabilidade alcançada é de 0,2. O gráfico da Fig. 5.8 mostra curvas referentes à pressão de injeção. Nele, quando se aumenta a temperatura de injeção, ou seja, a pressão de saturação se aproxima da pressão de injeção, a tendência de $R_{\mathrm{P}}$ é diminuir. Este parâmetro, quando sofre um decréscimo, conseqüentemente, proporciona uma diminuição do grau de metaestabilidade, conforme indicado na Tab. 5.1. Este gráfico da Fig. 5.8 também é bastante representativo quando se tem por objetivo saber qual é o mínimo valor de $R_{\mathrm{P}}$ para alcançar a vazão crítica.

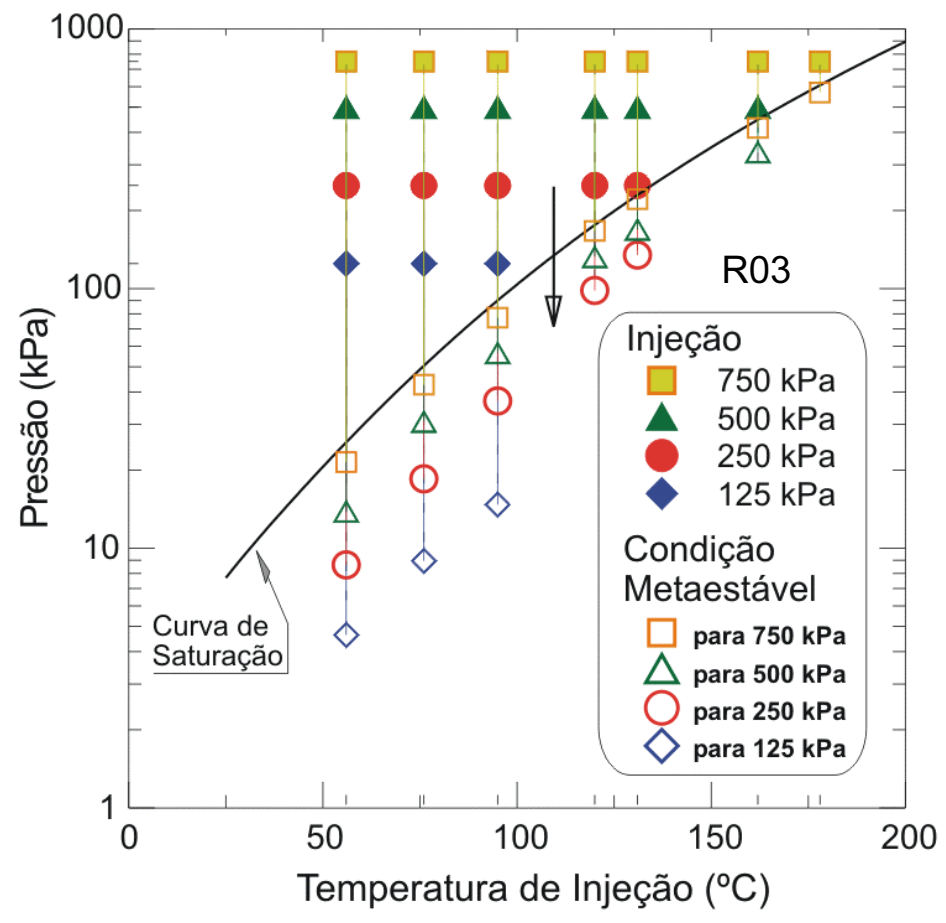

Figura 5.6 - Gráfico que mostra as condições de injeção dos ensaios feitos para o bocal de aço com $0,3 \mathrm{~mm}$ de diâmetro (R03) e a pressão metaestável alcançada pelo ensaio. 
Um exemplo de como foram calculados os dados da Tab. 5.1, está mostrado na Tab. 5.2. Esta tabela mostra a média obtida da vazão e o desvio padrão da amostra multiplicado por 2. A Tab. 5.3 faz uma comparação do valor de $2 \sigma_{P 1}$ com a faixa de incerteza calculada $\left(U_{P 1}\right)$, conforme Apêndice I. Na tabela, verifica-se que o desvio da amostra, $2 \sigma_{P 1}$, aumenta a medida que a pressão de saturação se aproxima da pressão de injeção, assumindo um valor maior que a incerteza estimada $\left(U_{P 1}\right)$, e que veio a ser inesperado.

Tabela 5.1 - Em função das categorias das condições de injeção, $P_{\text {inj }}$ e $T_{\text {inj, }}$, respectivamente, são mostrados a média da pressão de saturação, a pressão metaestável média das categorias de ensaio e seu desvio, vazão superficial mássica e as razões entre a pressão de saturação e a pressão de injeção, assim como, a pressão de saturação e a pressão metaestável do líquido. Finalmente, é apresentado o grau de metaestabilidade médio alcançado em cada série de experimentos. $O$ desvio de $2 \sigma_{P 1 \mathrm{~m}}$ é duas vezes o desvio padrão da amostra coletada de cada categoria de ensaio.

\begin{tabular}{|c|c|c|c|c|c|c|c|c|c|c|}
\hline $\begin{array}{c}\boldsymbol{P}_{\text {inj }} \\
(\mathrm{kPa}) \\
\end{array}$ & $\begin{array}{l}T_{\text {inj }} \\
\left({ }^{\circ} \mathrm{C}\right) \\
\end{array}$ & $\begin{array}{c}\boldsymbol{P}_{\mathbf{0 m}} \\
(\mathrm{kPa})\end{array}$ & $\begin{array}{l}T_{0 \mathrm{~m}} \\
\left({ }^{\circ} \mathrm{C}\right) \\
\end{array}$ & $\begin{array}{c}\boldsymbol{P}_{\text {sat }}\left(\boldsymbol{T}_{\mathbf{0 m}}\right) \\
(\mathrm{kPa}) \\
\end{array}$ & $\begin{array}{c}\boldsymbol{P}_{\mathbf{1 m}} \\
(\mathrm{kPa})\end{array}$ & $\begin{array}{l}2 \sigma_{P_{1}} \\
(\mathrm{kPa})\end{array}$ & $\begin{array}{c}\boldsymbol{J}_{\mathbf{b m}} \\
\left(\mathrm{kg} / \mathrm{m}^{2} . \mathrm{s}\right) \\
\end{array}$ & $\boldsymbol{P}_{\mathrm{sat}} / \boldsymbol{P}_{0 \mathrm{~m}}$ & $\boldsymbol{P}_{\mathrm{sat}} / \boldsymbol{P}_{1 \mathrm{~m}}$ & $\Pi_{m}$ \\
\hline 125 & 56 & 122,1 & 56,5 & 27,1 & 4,6 & 0,9 & 11177 & 0,222 & 5,841 & 0,829 \\
\hline 125 & 76 & 125,1 & 76,1 & 50,5 & 8,9 & 6,7 & 11086 & 0,403 & 5,641 & 0,823 \\
\hline 125 & 95 & 124,3 & 94,1 & 87,4 & 12,9 & 5,0 & 10863 & 0,703 & 6,750 & 0,852 \\
\hline 250 & 56 & 252,1 & 56,6 & 27,7 & 8,6 & 1,4 & 16331 & 0,110 & 3,214 & 0,689 \\
\hline 250 & 76 & 250,6 & 76,3 & 51,3 & 16,0 & 17,6 & 15931 & 0,205 & 3,199 & 0,687 \\
\hline 250 & 95 & 250,4 & 94,9 & 89,5 & 36,3 & 9,5 & 15110 & 0,357 & 2,463 & 0,594 \\
\hline 250 & 120 & 251,0 & 120,2 & 176,7 & 97,5 & 33,8 & 12584 & 0,704 & 1,812 & 0,448 \\
\hline 250 & 131 & 255,5 & 129,7 & 222,6 & 133,0 & 43,9 & 11105 & 0,871 & 1,674 & 0,403 \\
\hline 500 & 56 & 501,2 & 56,5 & 27,2 & 13,9 & 4,2 & 23392 & 0,054 & 1,959 & 0,490 \\
\hline 500 & 76 & 498,6 & 76,6 & 51,5 & 30,8 & 1,0 & 22755 & 0,103 & 1,672 & 0,402 \\
\hline 500 & 95 & 501,6 & 95,3 & 90,5 & 49,6 & 35,4 & 22176 & 0,181 & 1,825 & 0,452 \\
\hline 500 & 120 & 493,9 & 121,8 & 183,8 & 128,3 & 29,5 & 19663 & 0,372 & 1,433 & 0,302 \\
\hline 500 & 131 & 501,3 & 131,4 & 231,3 & 166,9 & 39,5 & 18669 & 0,461 & 1,385 & 0,278 \\
\hline 500 & 162 & 510,4 & 161,5 & 442,1 & 334,8 & 41,9 & 13442 & 0,866 & 1,321 & 0,243 \\
\hline 750 & 56 & 751,3 & 56,3 & 26,8 & 21,5 & 20,5 & 28744 & 0,036 & 1,249 & 0,199 \\
\hline 750 & 76 & 751,4 & 76,8 & 51,1 & 42,7 & 14,2 & 28111 & 0,068 & 1,198 & 0,165 \\
\hline 750 & 95 & 751,2 & 95,9 & 92,1 & 77,3 & 21,1 & 27044 & 0,123 & 1,191 & 0,161 \\
\hline 750 & 120 & 751,8 & 121,0 & 180,3 & 167,0 & 9,1 & 24969 & 0,240 & 1,080 & 0,074 \\
\hline 750 & 131 & 751,3 & 131,8 & 233,7 & 221,5 & 8,7 & 23654 & 0,311 & 1,055 & 0,052 \\
\hline 750 & 162 & 748,6 & 161,6 & 443,7 & 416,4 & 17,2 & 18178 & 0,593 & 1,066 & 0,062 \\
\hline 750 & 178 & 753,6 & 177,9 & 607,4 & 545,3 & 32,4 & 14044 & 0,806 & 1,114 & 0,102 \\
\hline
\end{tabular}


Tabela 5.2 - Determinação dos dados médios obtidos, sob a condição de máxima vazão, exemplificada para a categoria com $P_{\text {inj }}=750 \mathrm{kPa}$ e $T_{\text {inj }}=162^{\circ} \mathrm{C}$.

\begin{tabular}{|c|c|c|c|c|c|}
\hline Ensaios & $\begin{array}{c}\boldsymbol{P}_{\mathbf{0}} \\
(\mathrm{kPa}) \\
\end{array}$ & $\begin{array}{c}\boldsymbol{T}_{\mathbf{0}} \\
\left({ }^{\circ} \mathrm{C}\right) \\
\end{array}$ & $\begin{array}{c}\boldsymbol{P}_{\text {sat }}\left(\boldsymbol{T}_{\mathbf{0}}\right) \\
(\mathrm{kPa}) \\
\end{array}$ & $\begin{array}{c}\dot{m} \\
(\mathrm{kPa}) \\
\end{array}$ & $\begin{array}{c}\boldsymbol{P}_{1} \\
(\mathrm{kPa}) \\
\end{array}$ \\
\hline $\operatorname{run} 3 \backslash 7435 \mathrm{~m} 20$ & 749,2 & 161,8 & 445,1 & 0,0013746 & 409,20 \\
\hline $\operatorname{run} 3 \backslash 7435 \mathrm{~m} 10$ & 747,7 & 161,3 & 440,7 & 0,0013720 & 409,37 \\
\hline run3 37435500 & 749,5 & 161,7 & 444,3 & 0,0013561 & 418,54 \\
\hline run3\} \backslash 7 4 3 5 1 0 0 $&{749,3} &{161,8} &{445,1} &{0,0013635} &{414,71} \\
{\hline \operatorname{run} 3 \backslash 7435010} &{747,4} &{161,6} &{443,4} &{0,0013277} &{430,05} \\
{\hline \text { média }} &{748,6} &{161,6} &{443,7} &{0,0013588} &{416,37} \\
{\hline \text { desvio padrão }} &{0,988} &{0,207} &{1,821} &{0,0000189} &{8,59} \\
$\hline
\end{tabular}

Tabela 5.3 - Em função das categorias das condições de injeção, $P_{\text {inj }}$ e $T_{\text {inj, }}$, estão os valores do desvio da amostra e das incertezas de $P_{1 \mathrm{~m}}\left(U_{P 1}\right)$. Esta última incerteza depende da vazão medida e é calculada conforme deduzida no Apêndice I.

\begin{tabular}{rrrrrr}
\hline $\begin{array}{c}\boldsymbol{P}_{\text {inj }} \\
(\mathrm{kPa})\end{array}$ & $\begin{array}{c}\boldsymbol{T}_{\text {inj }} \\
\left({ }^{\circ} \mathrm{C}\right)\end{array}$ & $\begin{array}{c}\boldsymbol{P}_{\mathbf{0 m}} \\
(\mathrm{kPa})\end{array}$ & $\begin{array}{c}\boldsymbol{P}_{\mathbf{1 m}} \\
(\mathrm{kPa})\end{array}$ & $\begin{array}{c}\mathbf{2 \sigma}_{\boldsymbol{P}_{\mathbf{1}}} \\
(\mathrm{kPa})\end{array}$ & $\begin{array}{c}\boldsymbol{U}_{\boldsymbol{P}_{\mathbf{1}}} \\
(\mathrm{kPa})\end{array}$ \\
\hline & & & & & \\
125 & 56 & 122,1 & 4,6 & 0,9 & 5,4 \\
125 & 76 & 125,1 & 8,9 & 6,7 & 5,4 \\
125 & 95 & 124,3 & 12,9 & 5,0 & 5,2 \\
& & & & & \\
250 & 56 & 252,1 & 8,6 & 1,4 & 10,7 \\
250 & 76 & 250,6 & 16,0 & 17,6 & 10,3 \\
250 & 95 & 250,4 & 36,3 & 9,5 & 9,4 \\
250 & 120 & 251,0 & 97,5 & 33,8 & 6,9 \\
250 & 131 & 255,5 & 133,0 & 43,9 & 5,6 \\
& & & & & \\
500 & 56 & 501,2 & 13,9 & 4,2 & 21,0 \\
500 & 76 & 498,6 & 30,8 & 1,0 & 20,2 \\
500 & 95 & 501,6 & 49,6 & 35,4 & 19,5 \\
500 & 120 & 493,9 & 128,3 & 29,5 & 15,9 \\
500 & 131 & 501,3 & 166,9 & 39,5 & 14,5 \\
500 & 162 & 510,4 & 334,8 & 41,9 & 7,8 \\
& & & & & \\
750 & 56 & 751,3 & 21,5 & 20,5 & 31,4 \\
750 & 76 & 751,4 & 42,7 & 14,2 & 30,5 \\
750 & 95 & 751,2 & 77,3 & 21,1 & 29,0 \\
750 & 120 & 751,8 & 167,0 & 9,1 & 25,2 \\
750 & 131 & 751,3 & 221,5 & 8,7 & 22,9 \\
750 & 162 & 748,6 & 416,4 & 17,2 & 14,4 \\
750 & 178 & 753,6 & 545,3 & 32,4 & 9,2 \\
\hline
\end{tabular}




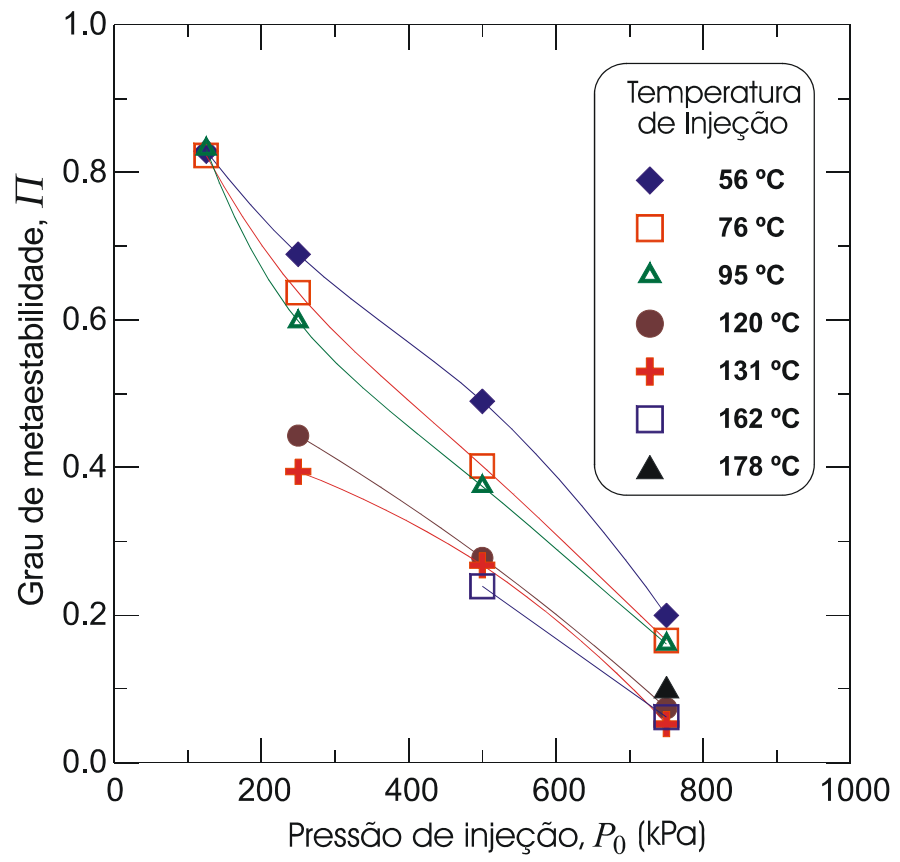

Figura 5.7 - Gráfico que mostra o grau de metaestabilidade em função da pressão de injeção.

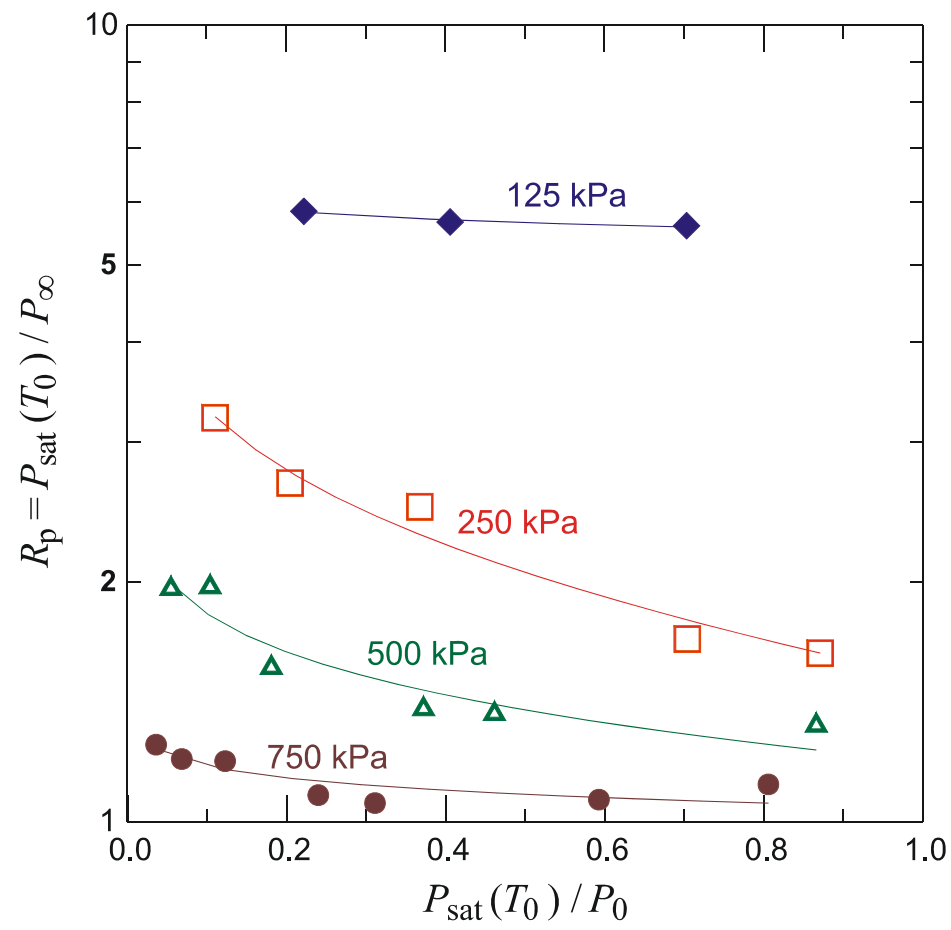

Figura 5.8 - Gráfico que mostra a razão de pressões $\left(R_{\mathrm{p}}\right)$ em função da razão entre a pressão de saturação e de injeção. Dependendo da pressão de injeção, ensaios acima da curva possuem a condição de máxima vazão. 


\subsubsection{Jatos com pressão de saturação abaixo ou próxima da pressão da câmara}

Nesta subseção discutem-se os resultados dos jatos que foram descarregados na câmara sob uma pressão pouco abaixo e próxima da pressão de saturação. A simples observação do jato condiz para um jato sem fragmentações. Pelo método “Schlieren”, quando o jato está com sua pressão de saturação abaixo da pressão da câmara $\left(R_{\mathrm{P}}<1\right)$ é quase imperceptível a evaporação, no entanto, quando a pressão de saturação vem se igualando com a pressão da câmara $\left(R_{\mathrm{P}} \sim 1\right)$ existe uma pequena evaporação ao longo do filete do jato. As Figs. 5.9 , 5.10a e 5.10b retratam este quadro.

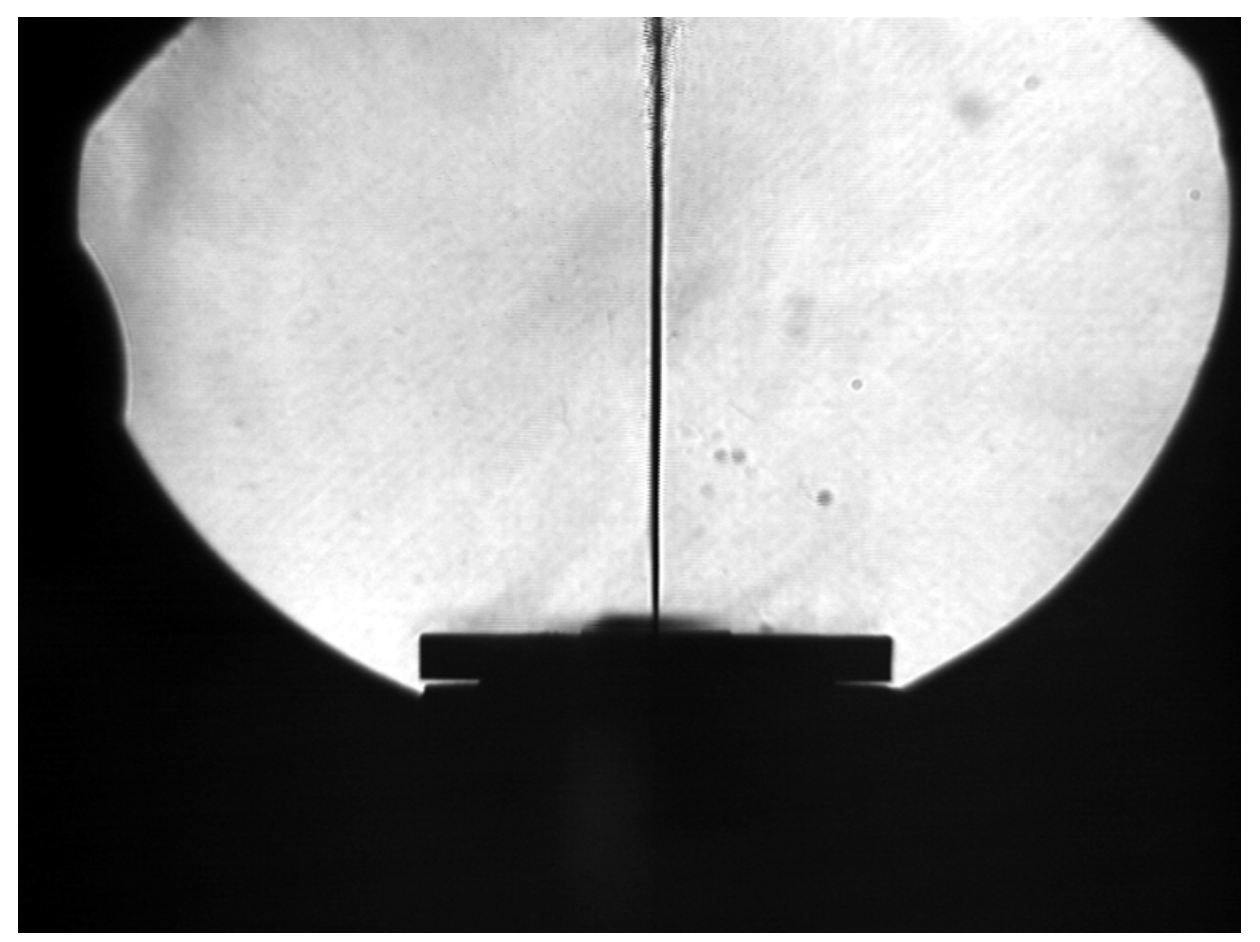

Figura 5.9 - Jato com pressão e temperatura de injeção de $250 \mathrm{kPa}$ e $95{ }^{\circ} \mathrm{C}$. A pressão da câmara é de $174 \mathrm{kPa}$ e a razão entre as pressões de saturação e câmara é de 0,5 (método "Schlieren"). 


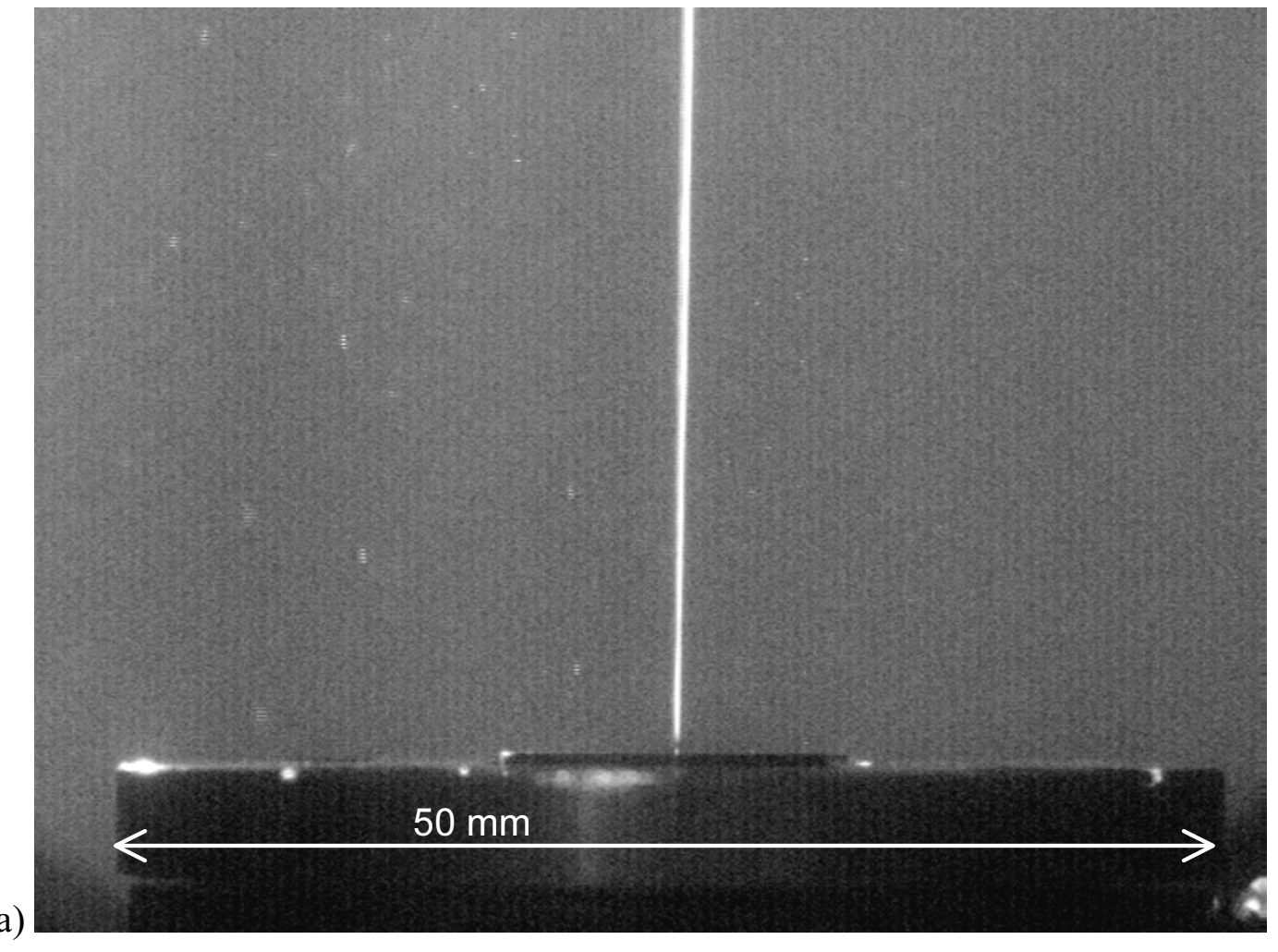

a)

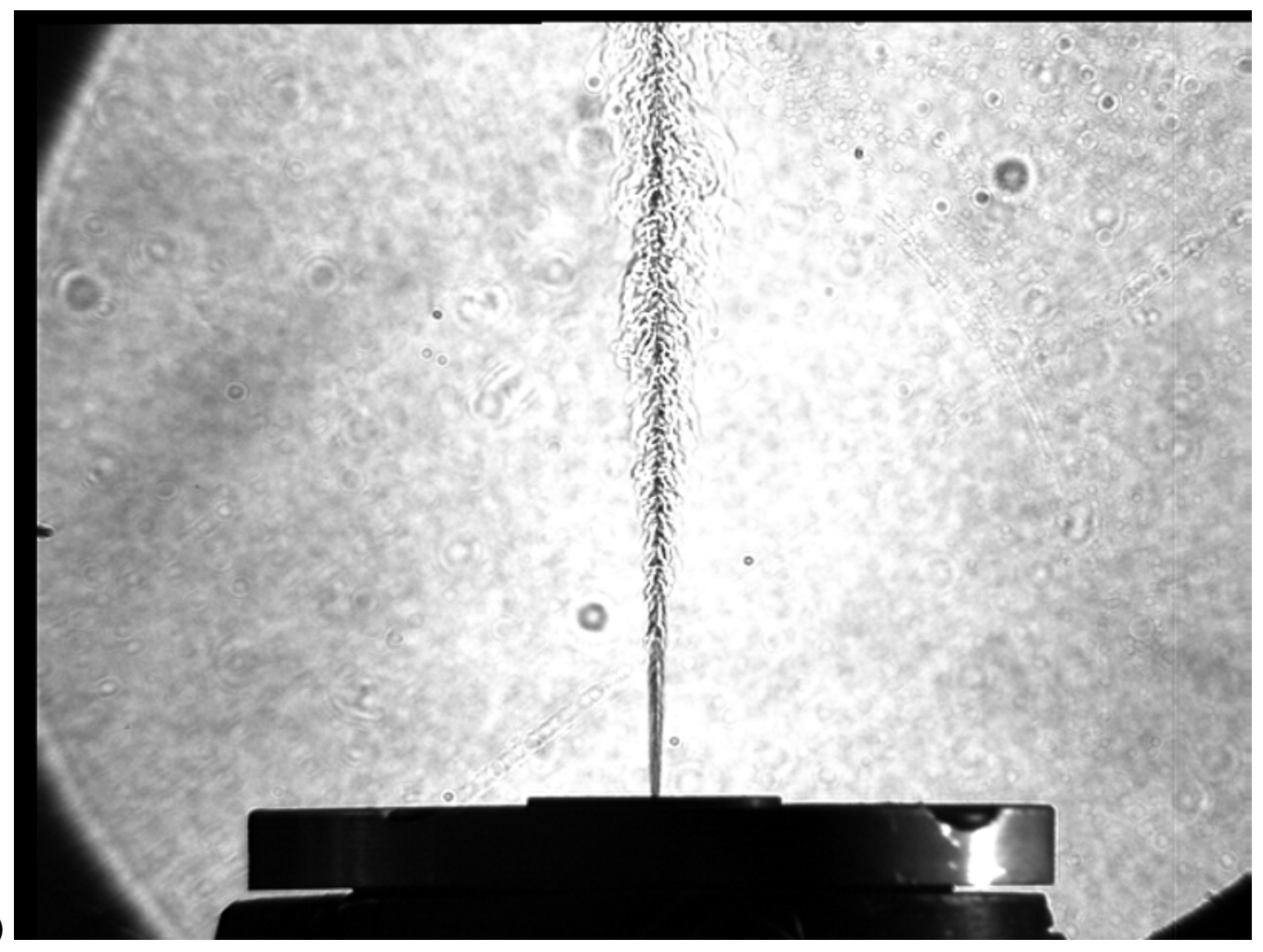

Figura 5.10 - Jato com pressão e temperatura de injeção de $250 \mathrm{kPa}$ e $95^{\circ} \mathrm{C}$. A pressão da câmara é de $90 \mathrm{kPa}$ e a razão entre as pressões de saturação e câmara é igual a 1. A primeira imagem foi adquirida pela câmara CCD que utiliza o recurso de "iluminação por detrás" e a segunda imagem, referente ao mesmo jato, foi obtida pelo método "Schlieren". 
Mesmo quando a pressão da câmara está abaixo da pressão de saturação, porém a pressão da câmara está com um valor acima daquela pressão metaestável encontrada em cada série de experimentos mostradas na Tab. 5.1 (ou seja, $P_{\text {sat }}>P_{\infty}>$ $\left.P_{1 \mathrm{~m}}\right)$, o jato ainda apresenta um filete contínuo. Como exemplo, a Fig. 5.11 apresenta imagens de um jato que teve a diminuição da pressão da câmara pela metade do valor da pressão de saturação $\left(R_{\mathrm{P}} \sim 2\right)$, na mesma temperatura $\left(95^{\circ} \mathrm{C}\right)$ indicada na Fig. 5.10. A pressão de injeção foi reduzida pela metade $(125 \mathrm{kPa})$. Aqui, a vazão ainda não alcançou a vazão máxima, pois conforme é visto na Tab. 5.1, a pressão da câmara deveria ser menor que $14,7 \mathrm{kPa}\left(R_{\mathrm{P}}=5,94\right)$ para alcançar a máxima vazão, com esta pressão e temperatura de injeção.

Novamente, existe grande semelhança do jato quando comparado às imagens da Fig. 5.10, mais precisamente pelo método "Schlieren". A imagem da Fig. 5.11a mostra um jato aparentemente descontínuo em seu filete em virtude do líquido ser transparente e, às vezes, seu filete funciona como uma lente que pode desviar a luz em função de pequenas variações no diâmetro do jato. $\mathrm{O}$ detalhe no canto superior esquerdo da Fig. 5.11a mostra que, de fato, o jato é contínuo. O detalhe da imagem foi possível de ser obtido com a amplificação do sinal da imagem original, feita matematicamente. Os círculos brancos deste detalhe são pequenas gotículas que estavam caindo e, por estarem fora do foco principal que é o plano axial do jato, opticamente tiveram o tamanho ampliado. A imagem "Schlieren" correspondente está na Fig. 5.11b. 

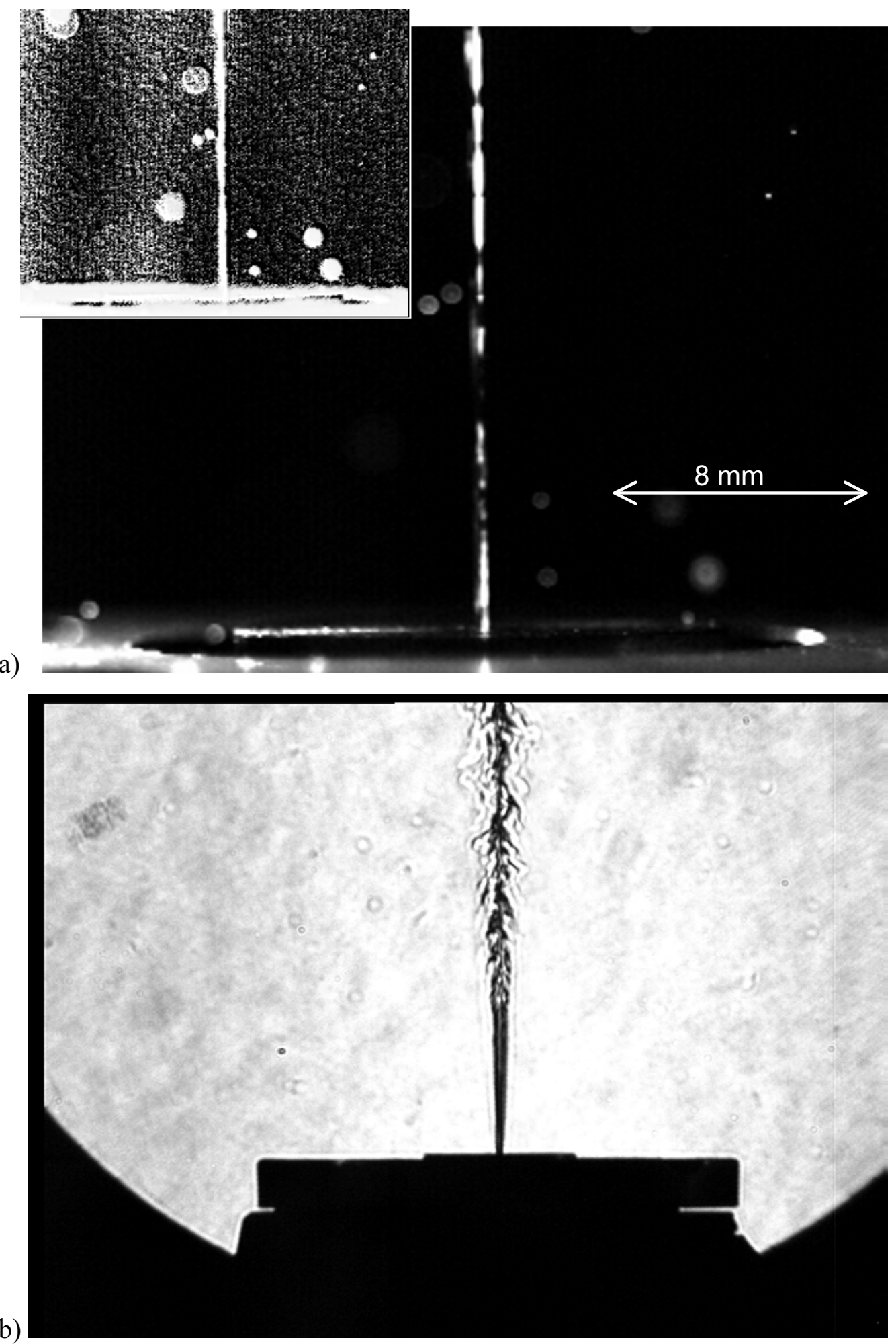

Figura 5.11 - Jato com pressão e temperatura de injeção de $124 \mathrm{kPa}$ e $93{ }^{\circ} \mathrm{C}$. A pressão da câmara é de $44 \mathrm{kPa}\left(R_{\mathrm{P}}=1,9\right)$. A primeira imagem foi adquirida pela câmara CCD que utiliza o recurso de "iluminação por detrás" e a segunda imagem, referente ao mesmo jato, foi obtida pelo método "Schlieren". O detalhe da primeira imagem comprova a continuidade do filete do jato. 


\subsubsection{Jatos no limiar da condição de blocagem}

Aqui são destacados os três ensaios cujo valor da pressão da câmara coincidiu, com o valor da pressão metaestável, aproximadamente, cuja vazão corresponde à vazão máxima. São os ensaios: 2368002, 7368001 e 2393002. Como observação, no primeiro e terceiro ensaios, apenas existem imagens obtidas pelo "Schlieren".

A Fig. 5.12 ilustra um jato nestas condições. A pressão de injeção é de 250 $\mathrm{kPa}$, a temperatura de injeção é de $95^{\circ} \mathrm{C}$ e a pressão da câmara é de $45 \mathrm{kPa}\left(R_{\mathrm{P}}=2\right)$.

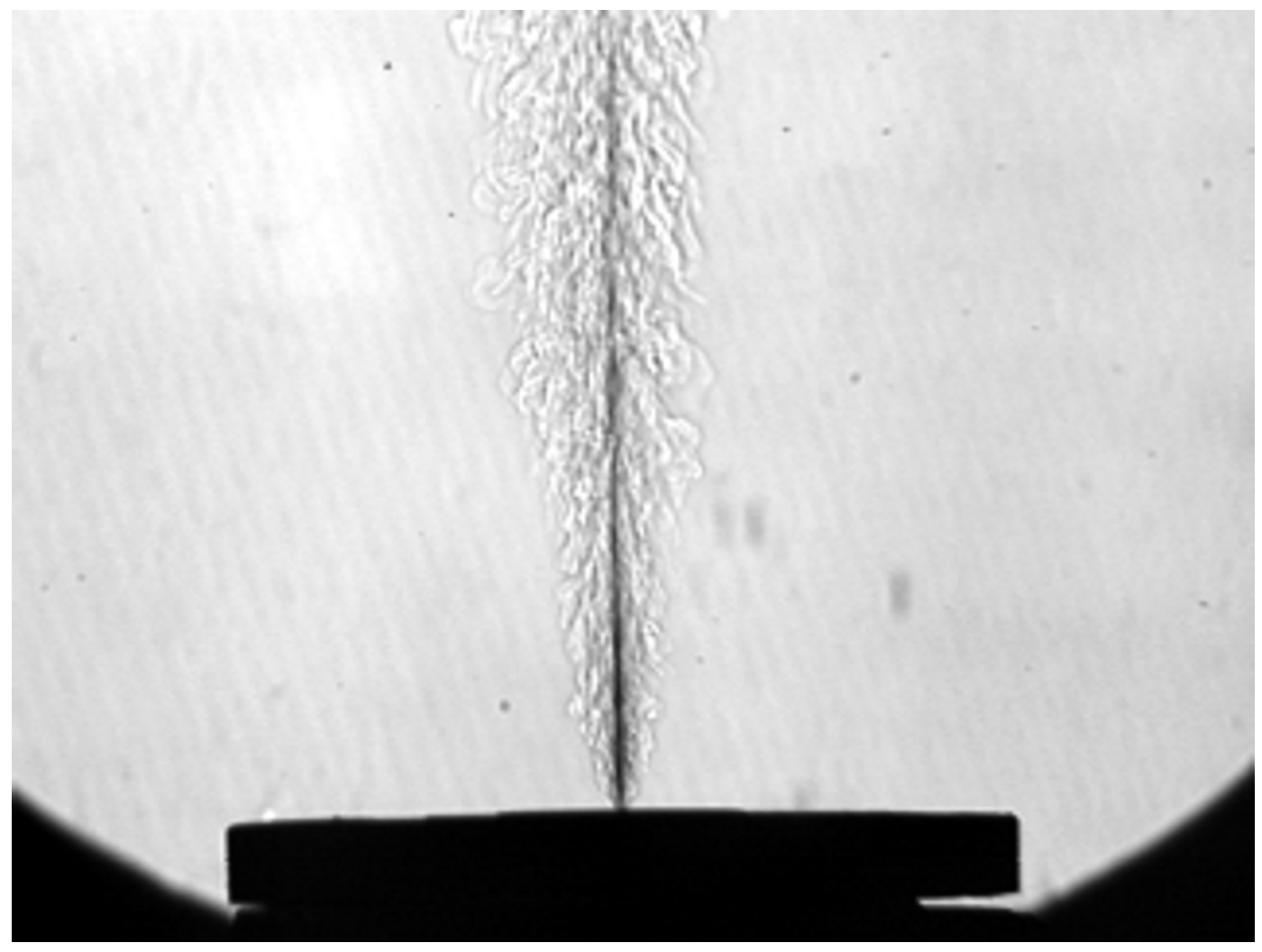

Figura 5.12 - Ensaio 2368002: Jato com pressão e temperatura de injeção de $250,3 \mathrm{kPa}$ e $95,3^{\circ} \mathrm{C}$. A pressão da câmara é de $45 \mathrm{kPa}\left(R_{\mathrm{P}}=2,0\right)$. Imagem obtida pelo método "Schlieren". 
O segundo ensaio (Fig. 5.13) tem a mesma temperatura de injeção do ensaio anterior e sua pressão de injeção é três vezes maior $(750 \mathrm{kPa})$. Logo, a pressão metaestável do líquido na condição de máxima vazão é de 77,3 kPa, pela Tab. 5.1. A pressão da câmara deste ensaio está próxima da pressão metaestável do líquido com valor igual a $93,3 \mathrm{kPa}\left(R_{\mathrm{P}}=1\right)$.

Já o último caso (Fig. 5.14), mostrou uma singularidade que nenhum outro ensaio registrou com tamanha nitidez. Nele houve nucleações ao longo do jato. Suas condições de injeção eram de $250 \mathrm{kPa}$ e $120^{\circ} \mathrm{C}$. Pela Tab. 5.1, a pressão metaestável para a máxima vazão deve ser de 97,5. A pressão da câmara está um pouco abaixo desta, com valor igual a $89,9 \mathrm{kPa}$. Kurschat e outros (1992) observaram esta ocorrência de nucleação, no meio do filete do jato quebrando sua continuidade, em pequenos valores de $R_{\mathrm{P}}$. Wildgen e Straub (1989) justificaram que tal fato ocorrido nos seus ensaios foi promovido pela presença de algum elemento particulado ou gás diluído no líquido. Porém, ensaios nestas mesmas condições de injeção e pressões da câmara bem abaixo desta $(90 \mathrm{kPa})$, não apresentaram descontinuidades ou ausência de simetria do núcleo de líquido, como será visto na Seção 5.1.6. Em virtude da ausência destas irregularidades nos resultados aqui apresentados, não é possível afirmar que a nucleação realmente iniciou no interior do bocal. 
a)

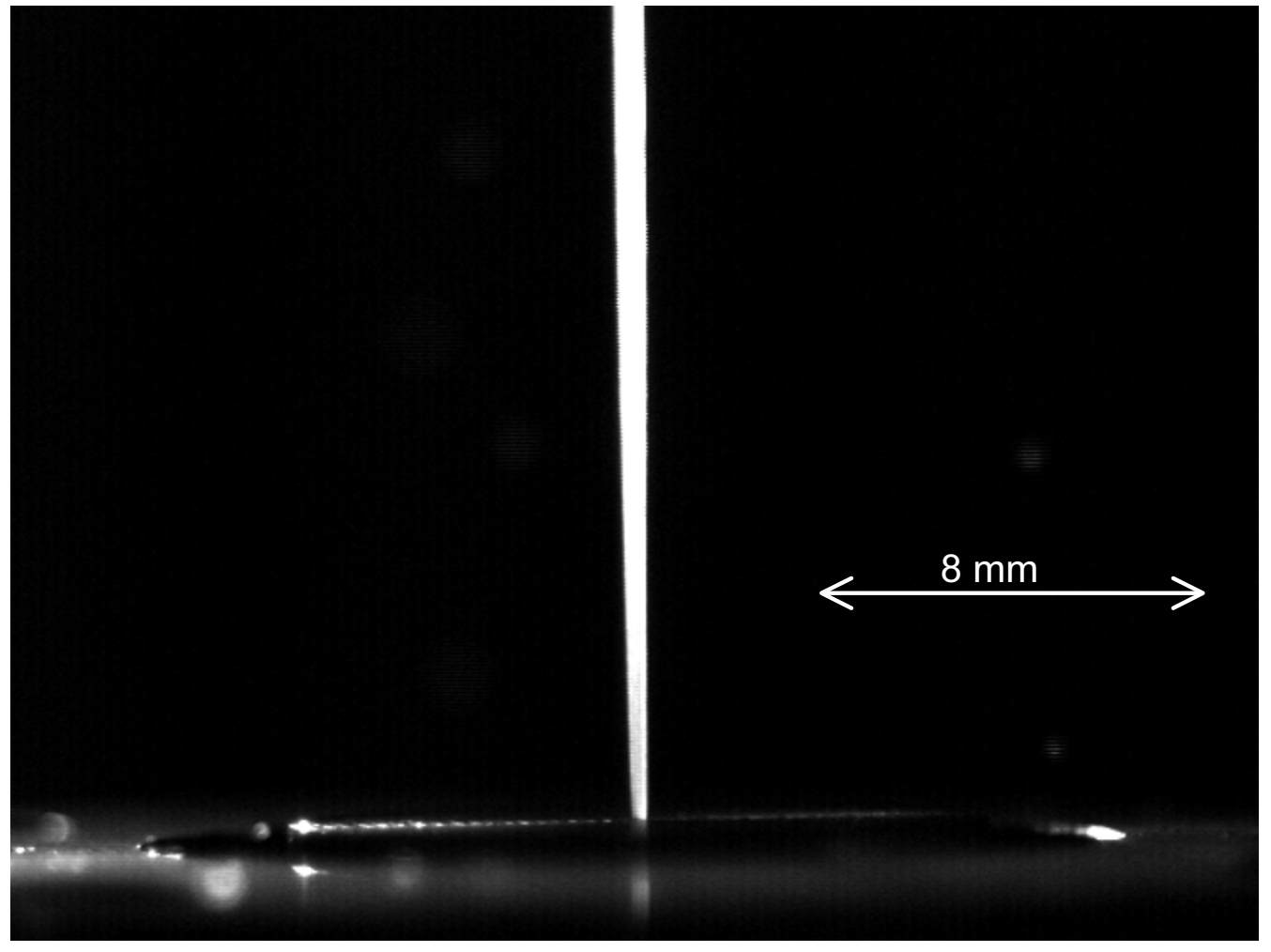

b)

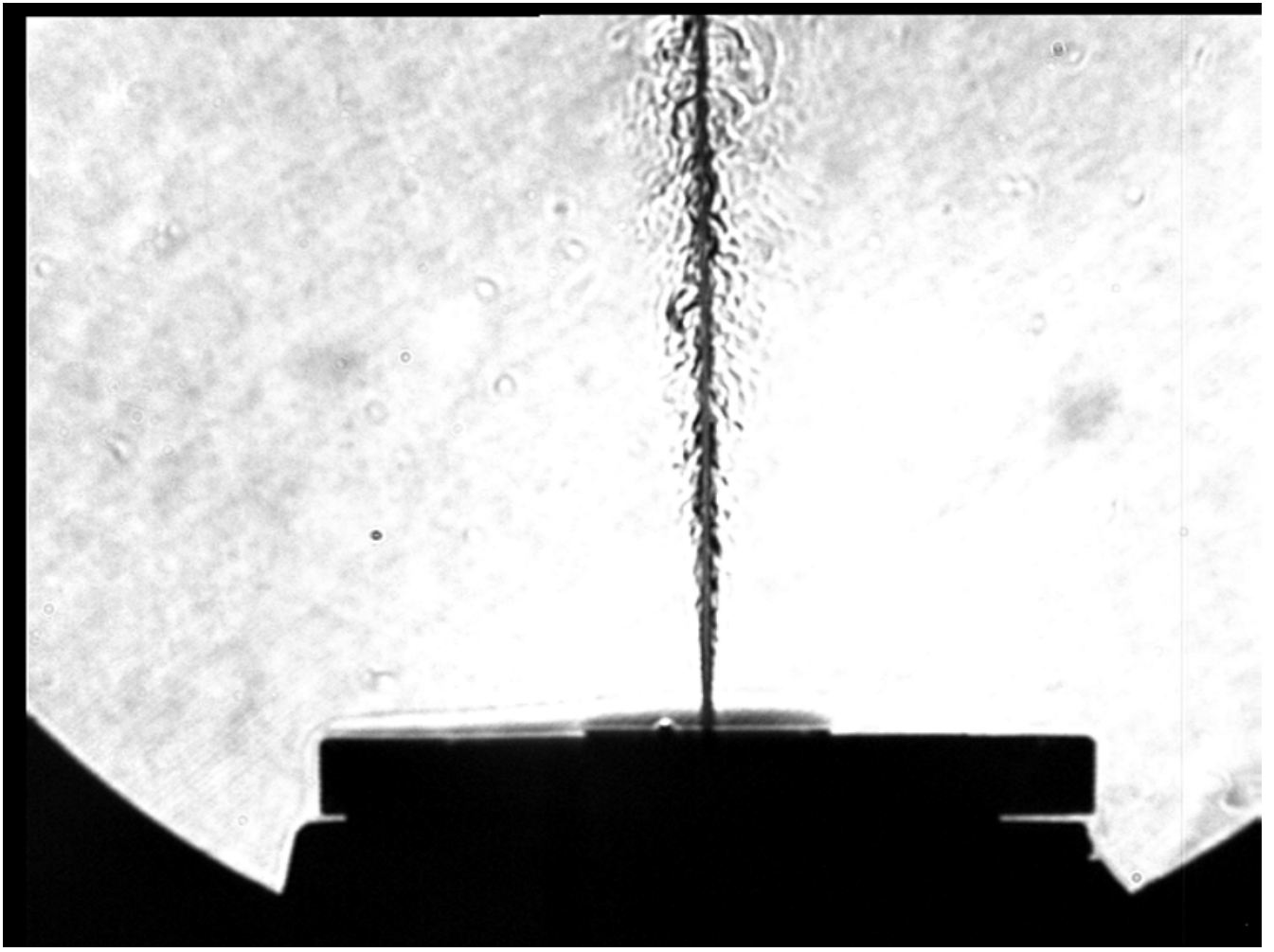

Figura 5.13 - Ensaio 7368001: jato com pressão e temperatura de injeção de 750 $\mathrm{kPa}$ e $95^{\circ} \mathrm{C}$. A pressão da câmara é de $93,3 \mathrm{kPa}$ e a razão entre as pressões de saturação e câmara é igual a 1 . A primeira imagem foi adquirida pela câmara CCD que utiliza o recurso de "iluminação por detrás" e a segunda imagem, referente ao mesmo jato, foi obtida pelo método "Schlieren". 


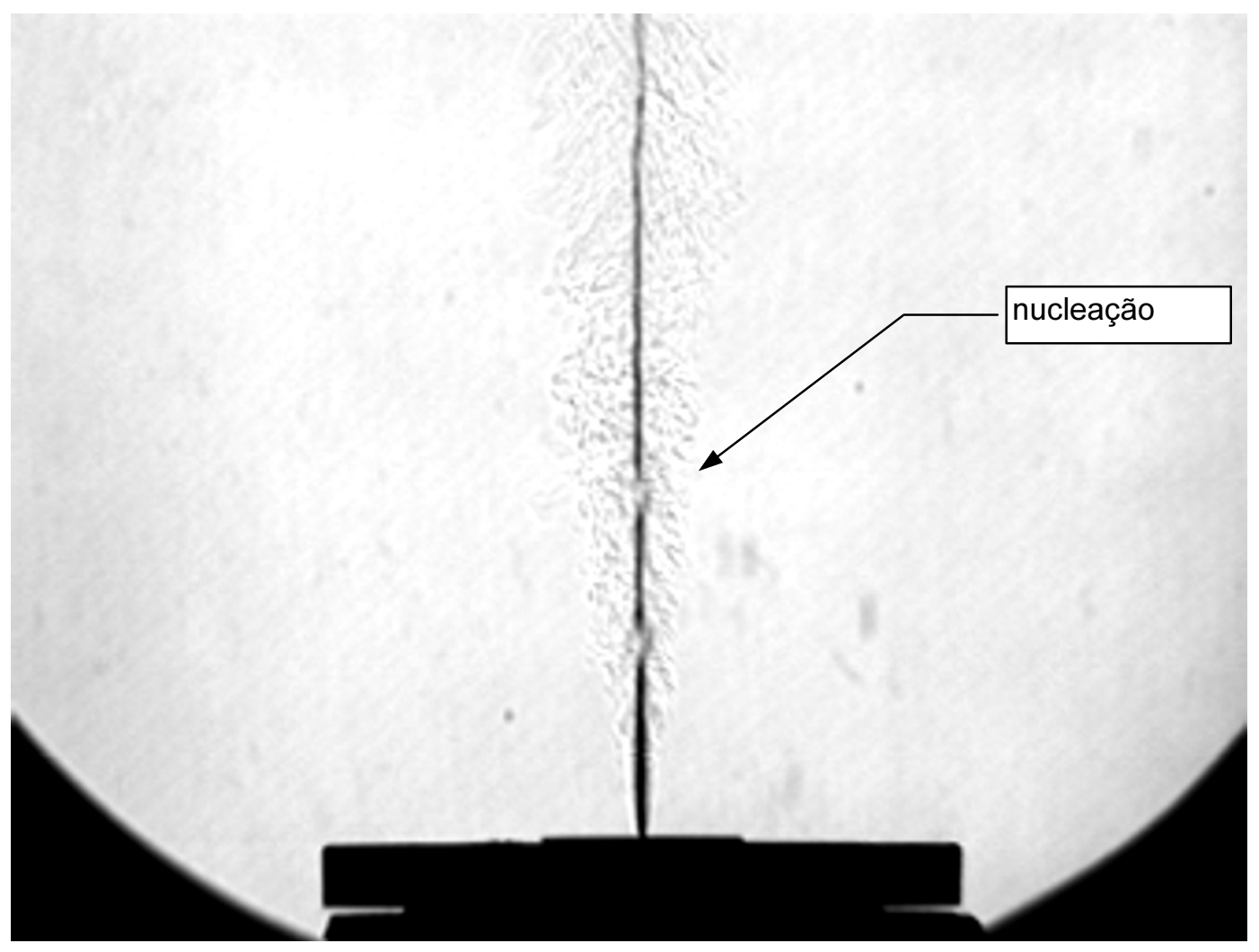

Figura 5.14 - Ensaio 2393002: jato com pressão e temperatura de injeção de 250 $\mathrm{kPa}$ e $120^{\circ} \mathrm{C}$. A pressão da câmara é de $89,9 \mathrm{kPa}$ e a razão entre as pressões de saturação e câmara é igual a 1,9. Imagem obtida pelo método "Schlieren".

Comparando esta seção, é verificado que estes jatos possuem um perfil muito semelhante com aqueles resultados encontrados na seção anterior. Os ensaios 2368002 e 7368001 não registraram, de forma nítida, a ocorrência de alguma nucleação ao longo do filete do jato, conforme bem ilustrado na Fig. 5.14.

\subsubsection{Jatos com vazão blocada sem a visualização da onda de choque}

Esta seção compreende os jatos cuja pressão da câmara é menor que aquela pressão metaestável indicada pela na Tab. 5.1, logo, a vazão está na condição máxima. Porém aqui ainda não se observa a formação da onda de choque.

Inicialmente serão mostrados dois ensaios: 7349005 e 2349005. Ambos tem temperatura de injeção igual a $76^{\circ} \mathrm{C}$ e sua pressões de injeção são de 750 e $250 \mathrm{kPa}$, 
respectivamente. O primeiro caso ilustra um jato mais fragmentado (Fig. 5.15). Devido à evaporação formada na periferia da parte líquida do jato, gotículas se desprendem aumentando o ângulo de espalhamento do jato. A formação de um núcleo de líquido, que é realmente visível, é mostrada no segundo caso (Fig. 5.16). O grau de metaestabilidade alcançado pelo líquido neste ensaio (2349005) é maior que o primeiro caso, conseqüentemente, a taxa de evaporação se torna maior, e deve ser por isso que o núcleo de líquido assumiu melhor nitidez.

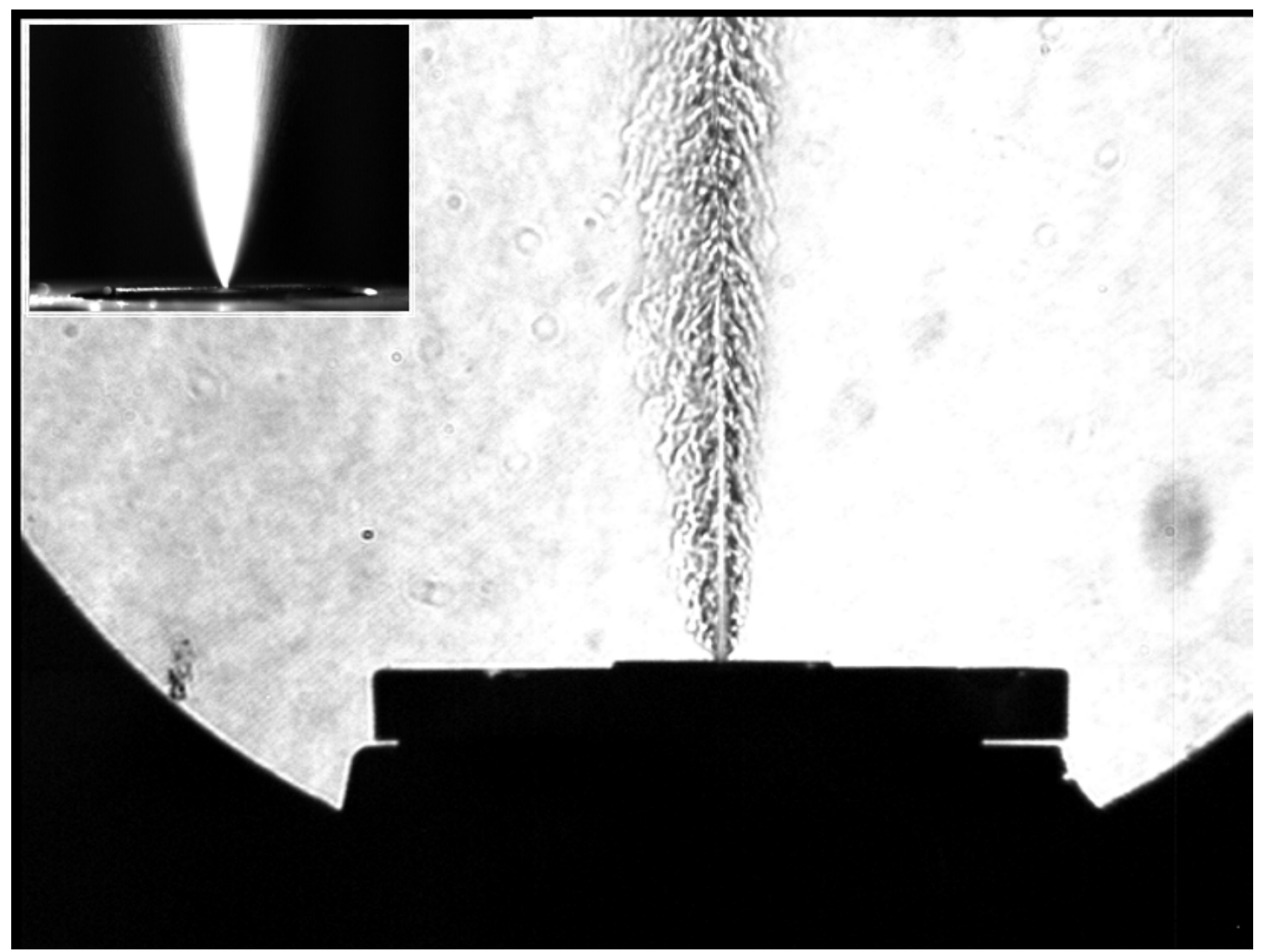

Figura 5.15 - Ensaio 7349002: jato com pressão e temperatura de injeção de 750 $\mathrm{kPa}$ e $76^{\circ} \mathrm{C}$. A pressão da câmara é de $24,9 \mathrm{kPa}$ e a razão entre as pressões de saturação e câmara é igual a 2,0. Imagem obtida pelo método "Schlieren". No canto superior esquerdo, na mesma escala de tamanho, a imagem obtida pelo método de "iluminação por detrás". Este retrata uma grande dispersão de gotículas. 


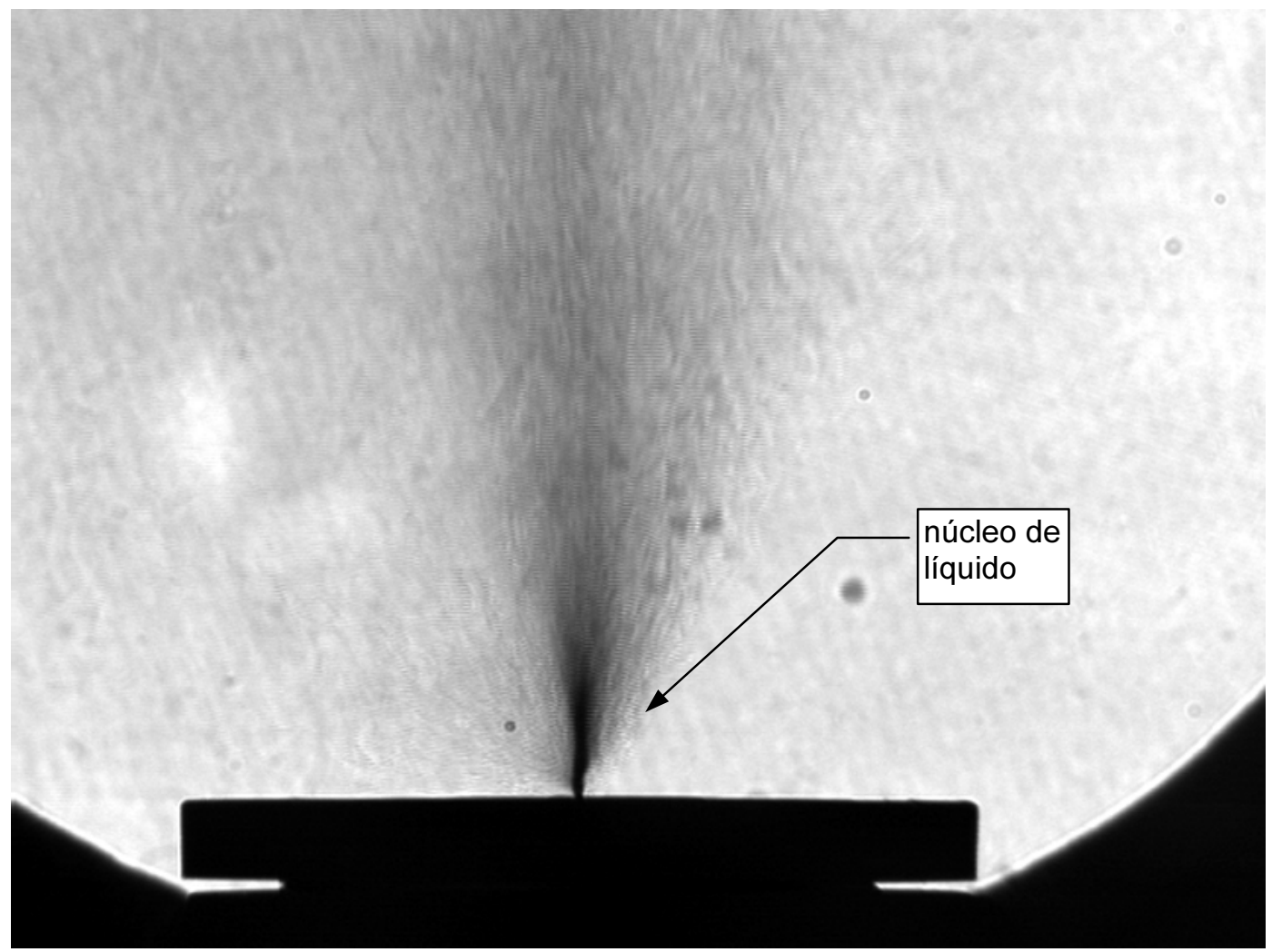

Figura 5.16 - Ensaio 2349005: jato com pressão e temperatura de injeção de 250 $\mathrm{kPa}$ e $76^{\circ} \mathrm{C}$. A pressão da câmara é de $10,1 \mathrm{kPa}$ e a razão entre as pressões de saturação e câmara é igual a 5,1. Imagem obtida pelo método "Schlieren".

Quando a pressão de saturação está próxima da pressão de injeção, para pequenos valores de $R_{\mathrm{P}}$, da ordem de 2 a 10, é possível observar uma instabilidade do núcleo de líquido. Necessariamente, seria um estágio anterior à formação do núcleo de líquido, propriamente dito, pois os ensaios das Figs. 5.17 e 5.18 mostram um jato que não apresenta simetria. Provavelmente, isto se deve à onda de evaporação que ainda não apresenta uma uniformidade em toda superfície do núcleo. Este formato assimétrico poderia oferecer a errônea conclusão que havia uma singularidade na seção de saída do bocal, porém esta hipótese é descartada em função do registro fotográfico destes dois diferentes ensaios que mostram que não há uma preferência da direção do jato (Figs. 5.17 e 5.18). Complementando a descrição destas duas figuras, tanto o destaque (jato no canto superior esquerdo) como a imagem principal foram adquiridas em um único ensaio em instantes diferentes, com um intervalo de $0,5 s$. 


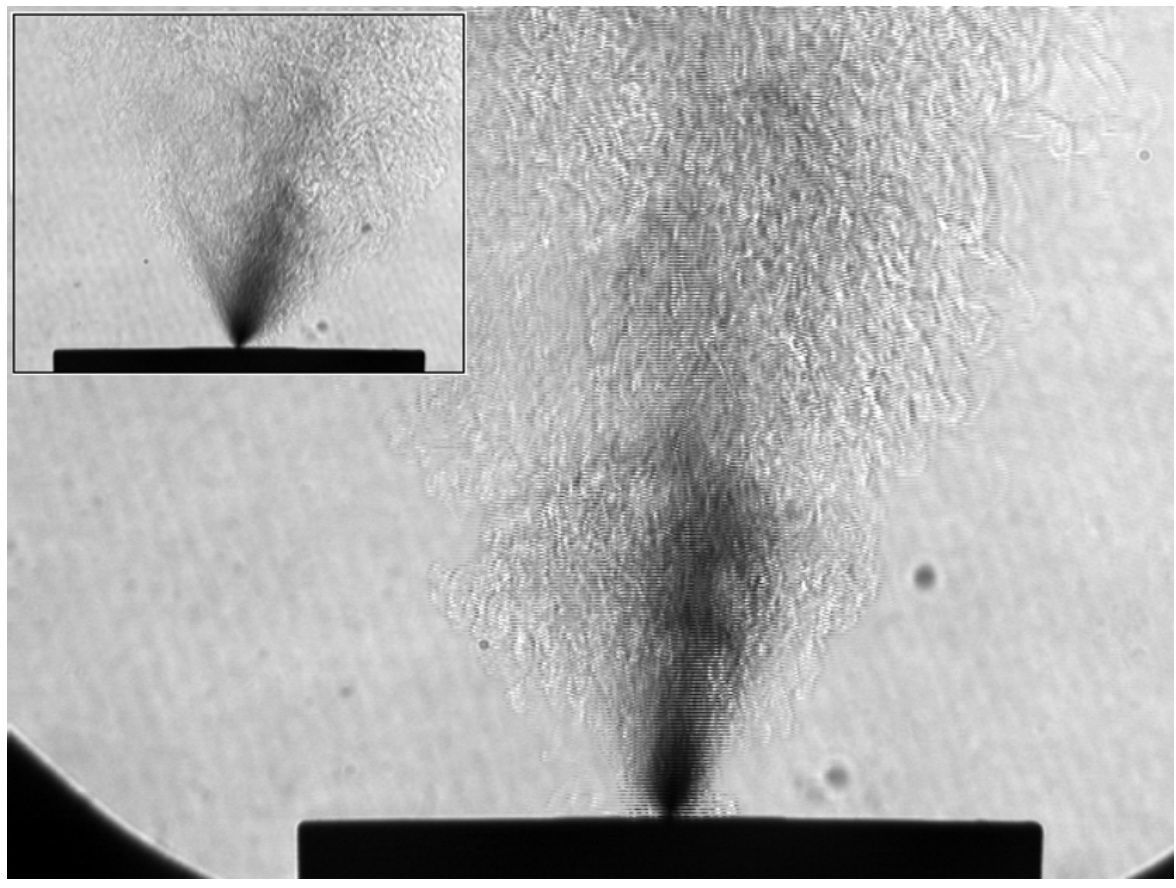

Figura 5.17 - Ensaio 2404005: jato com pressão e temperatura de injeção de 250 $\mathrm{kPa}$ e $131{ }^{\circ} \mathrm{C}$. A pressão da câmara é de $43,7 \mathrm{kPa}$ e a razão entre as pressões de saturação e câmara é igual a 5,1. Imagem obtida pelo método "Schlieren". O destaque foi obtido em $0,5 s$ após adquirir a fotografia principal.

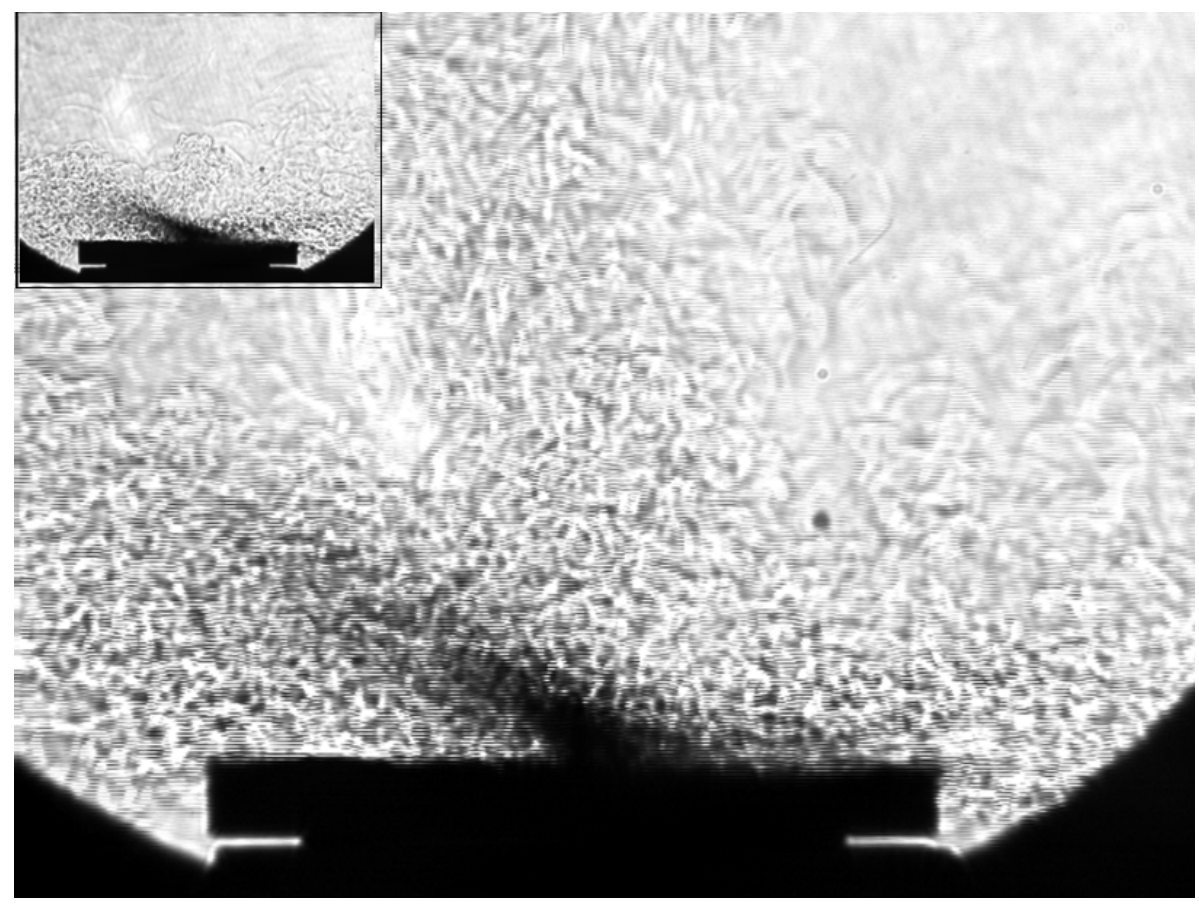

Figura 5.18 - Ensaio 2404010: jato com pressão e temperatura de injeção de 250 $\mathrm{kPa}$ e $131^{\circ} \mathrm{C}$. A pressão da câmara é de $24,0 \mathrm{kPa}$ e a razão entre as pressões de saturação e câmara é igual a 9,5. Imagem obtida pelo método "Schlieren". A imagem menor no detalhe foi obtida em $0,5 s$ após esta fotografia principal. 


\subsubsection{Jatos blocados com a visualização da onda de choque}

Todos os ensaios aqui estudados, que apresentaram onda de choque, necessariamente já estavam na condição de blocado. Nestes casos, também foi possível verificar que o núcleo de líquido tem uma forma regular e estável. Neste estágio, por mais que se diminua a pressão da câmara, não existe variação do comprimento do núcleo líquido. Isto será melhor analisado na seção seguinte. Contudo, à medida que a razão de pressões $R_{\mathrm{P}}$ aumenta, ou seja, diminui-se a pressão da câmara, as dimensões características da onda de choque são os únicos parâmetros que se alteram. A vazão mássica e, conseqüentemente, a pressão metaestável do líquido de cada ensaio continuava sem variação significativa.

Em temperaturas de injeção menores, é possível observar a formação da onda de choque com valores mínimos de $R_{\mathrm{P}}$ por volta de 50 . No caso de uma temperatura mais alta, para se observar uma onda de choque, este parâmetro deve aumentar para um valor da ordem de 100. Como exemplo, a Fig. 5.19 mostra um jato com temperatura de injeção de $76{ }^{\circ} \mathrm{C}$ enquanto a Fig. 5.20 mostra um jato com temperatura de $135^{\circ} \mathrm{C}$. Ambas possuem razões de pressão de saturação e da câmara de 50 e 100, respectivamente. No segundo caso, a onda de choque formada quase se confunde com a neblina que está ao redor dela, em função de seu pequeno tamanho. $\mathrm{O}$ caso da Fig. 5.4c também se assemelha a este fato. $\mathrm{O}$ tamanho do núcleo de líquido também diminuiu, mas este comportamento será melhor relatado na seção seguinte. 


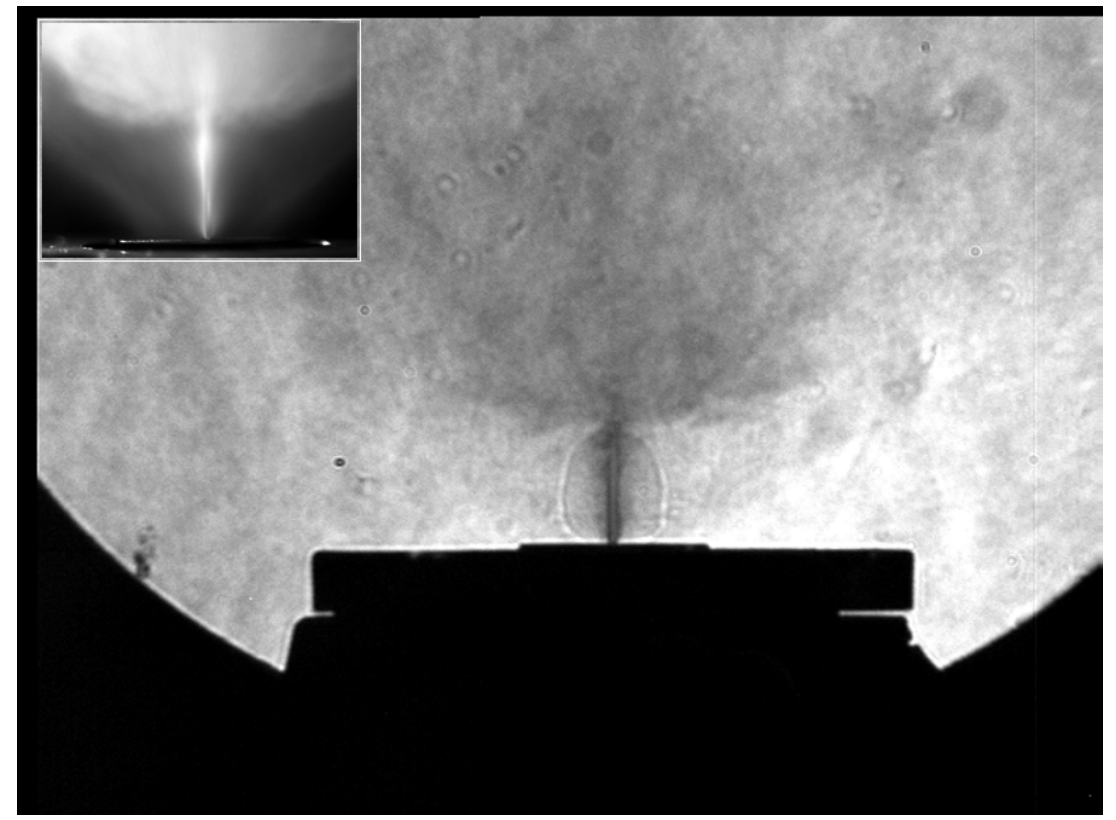

Figura 5.19 - Ensaio 7349050: jato com pressão e temperatura de injeção de $749,2 \mathrm{kPa}$ e $76,8^{\circ} \mathrm{C}$. A pressão da câmara é de $1,0 \mathrm{kPa}$ e a razão entre as pressões de saturação e câmara é igual a 51,3. Imagem obtida pelo método "Schlieren". O destaque se refere à imagem obtida pelo outro método, na mesma escala.

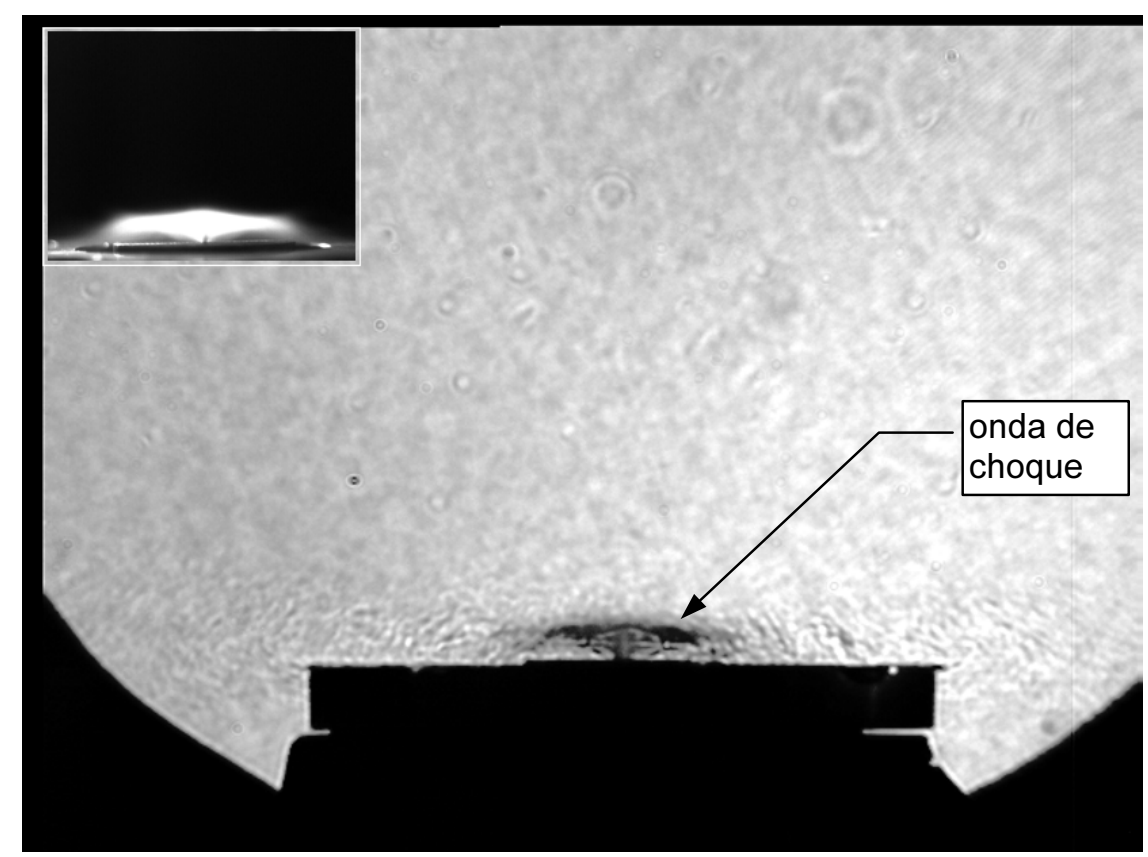

Figura 5.20 - Ensaio 7435100: jato com pressão e temperatura de injeção de $749,3 \mathrm{kPa}$ e $161,8{ }^{\circ} \mathrm{C}$. A pressão da câmara é de $4,6 \mathrm{kPa}$ e a razão entre as pressões de saturação e câmara é igual a 96,8. Imagem obtida pelo método "Schlieren". O destaque se refere a imagem obtida pelo outro método, na mesma escala. 
a)
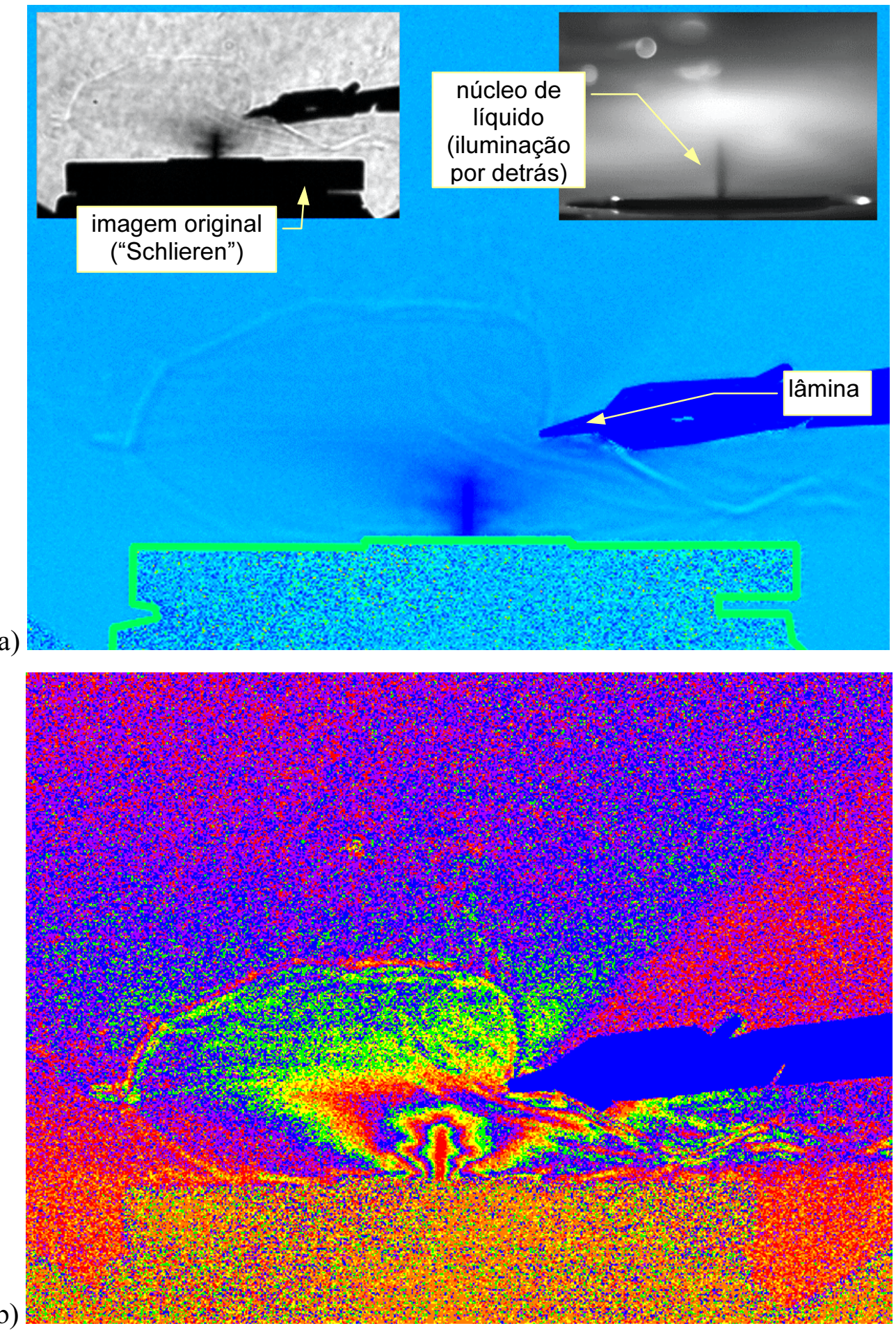

Figura 5.21 - Jato com pressão e temperatura de injeção de $744 \mathrm{kPa}$ e $132,1{ }^{\circ} \mathrm{C}$. A pressão da câmara é de $0,10 \mathrm{kPa}$. A primeira imagem foi uma filtragem da imagem original obtida pelo método "Schlieren" que está no canto superior esquerdo dela, assim como, a fotografia obtida pela iluminação por detrás está no outro canto. Neste pequeno quadro a lâmina está projetada atrás do jato e por isso não é visível. A segunda imagem também é outra filtragem do original com um mapa de cores diferente ("prism"). 
Antes de se aprofundar no assunto, é importante mostrar mais uma prova de que o fenômeno visto nestes jatos é realmente uma onda de choque. Para isto, um obstáculo na região onde ocorre o escoamento supersônico foi inserido (parte de uma lâmina de barbear). No lado esquerdo do jato, da Fig.5.21a, a onda de choque não sofre deformação alguma, enquanto, do outro lado, a presença da lâmina induz a deformação da onda de choque. Toda a região envolvida pela onda de choque, próximo do núcleo de líquido, tem mantido o perfil simétrico de escoamento (Fig. 5.21b). Como o escoamento é supersônico nesta região, os campos de velocidades e de pressões não sofrem influência da presença do obstáculo, até alcançar a onda de choque.

A onda de choque não deve ser entendida simplesmente como sendo normal ao escoamento. Ela se projeta de forma mais complexa. Como estudo de caso, o ensaio $5435 \mathrm{~m} 10 \mathrm{c}$ possui imagens que podem exemplificar o escoamento a jusante da onda de evaporação. Na Fig. 5.22a é colocada uma imagem original do ensaio. Já nas Fig. 5.22b e 5.22c são vistas imagens tratadas por um filtro matemático do tipo subtrativo que permitiu um melhor contraste do fenômeno. Verificando a variação de intensidade da imagem em função do eixo horizontal, tem-se, como conseqüência, a imagem mostrada na Fig. 5.22d que possui algumas características realçadas do jato, como o núcleo de líquido (devido ao salto abrupto de densidades destacado pelo método "Schlieren") e a onda de choque. Nessa interface, o líquido é transformado em uma mistura bifásica com alta velocidade. Essa mistura se expande livremente e termina com a formação de uma onda de choque, para se equalizar com a pressão da câmara ao longe.

Focalizando o escoamento que principia na região periférica ao núcleo de líquido, e tomando como exemplo a Fig. 5.22b, verifica-se que o formato cônico (região do escoamento com tonalidade amarela) provém de um escoamento de maior densidade, pois na fotografia original, Fig. 5.22a, esta mesma região possui uma tonalidade mais escura. A onda de choque, em forma de calota, que envolve este escoamento mais denso pode ser caracterizada como uma onda de choque quase normal, na parte frontal do jato. Observando a segunda formação de onda de choque, que está próxima à parede externa do bocal, que é perpendicular ao eixo axial do jato em sua saída, pode se concluir que é uma onda de choque de caráter oblíquo. E no 
encontro destas duas, existe uma terceira onda de choque, de caráter reflexivo.

Este escoamento mais denso, de formato cônico em tom amarelo, conforme a Fig. 5.22b, deve arrastar as gotículas que, quando se afastam do bocal, sofrem uma queda de temperatura (Peter e outros, 1994) e, conseqüentemente, essas gotículas podem traspassar pela onda de choque sem sofrerem uma desaceleração significativa em função do arraste aerodinâmico. Este fato também é corroborado pela Fig. 5.21b. A partir do ponto em que a lâmina bloqueia o fluxo, duas regiões de tonalidades diferentes passam a existir com maior nitidez. A faixa limite que divide a região predominantemente vermelha da região com tonalidades de azul, amarelo e verde, possui sua direção coincidente com a origem do jato líquido. A primeira região não contém um escoamento de gotículas devido ao bloqueio da lâmina, apenas a outra. Porém, alguns ensaios que possuíam a calota da onda de choque um pouco mais afastada da saída do bocal (diferente do ensaio da Fig.5.22), mostraram que também pode haver outras ondas de choque reflexivas. Geralmente, são ensaios com pressões de injeção maiores e temperaturas mais baixas. 
a)

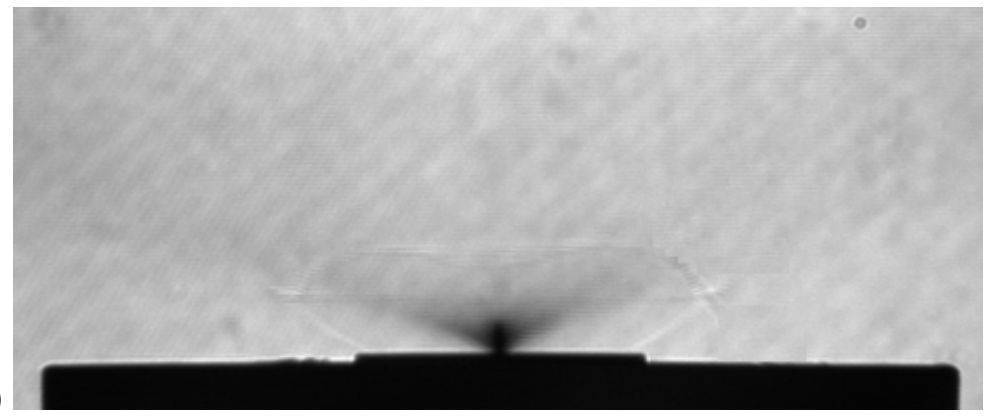

b)

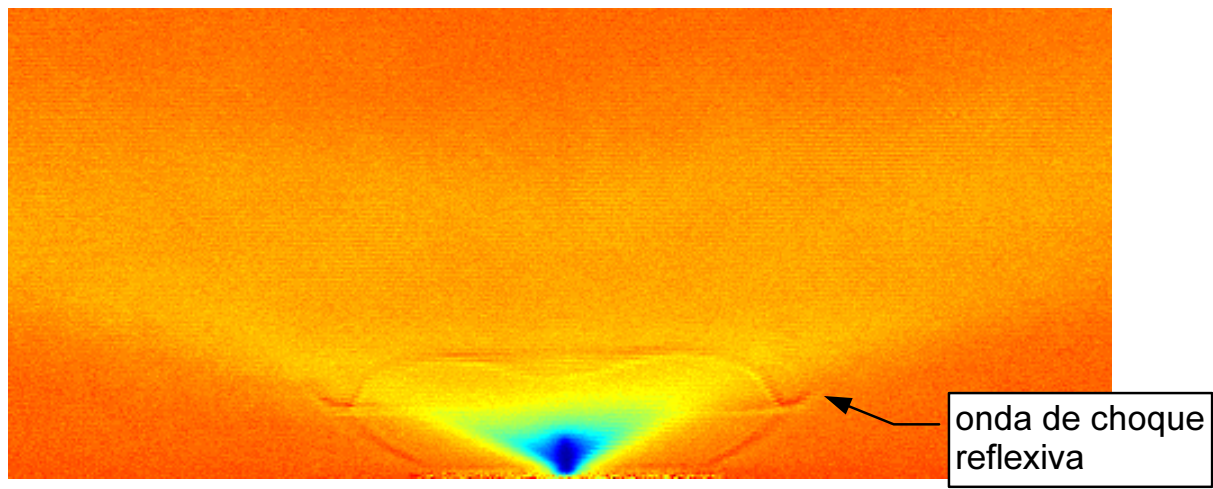

c)

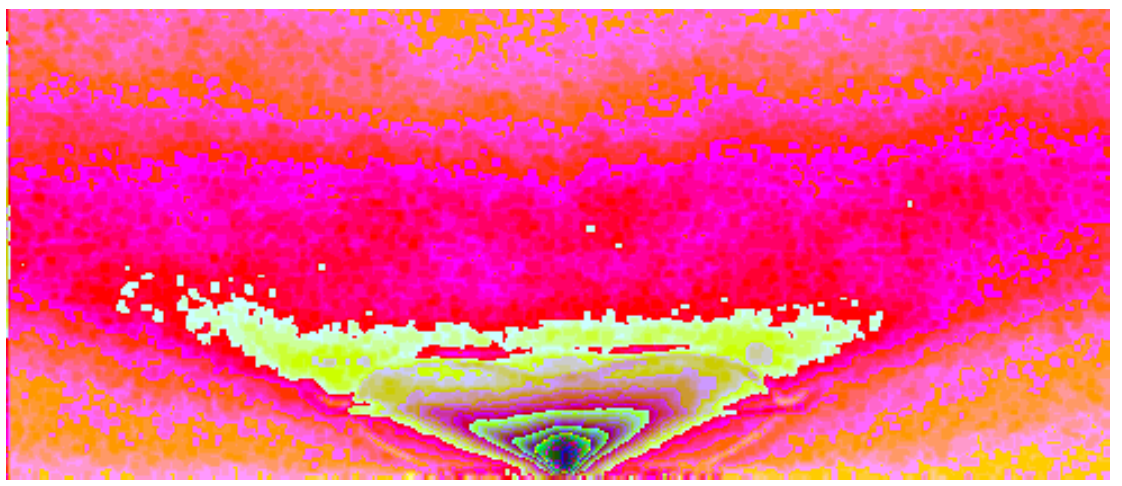

d)

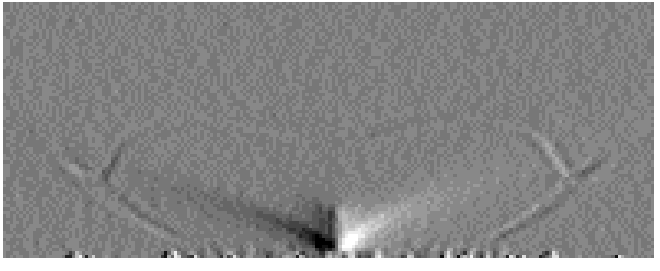

e)

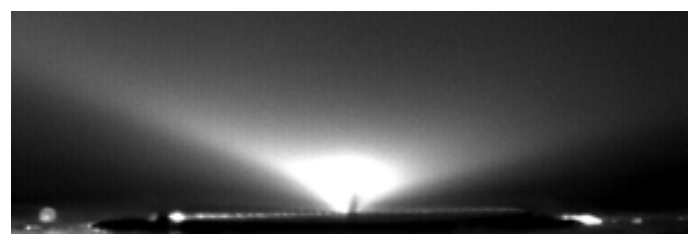

Figura 5.22 - A primeira corresponde à imagem original do jato do ensaio 5435m10c. Em seguida, são imagens filtradas e processadas matematicamente da original onde as imagens $b$ e $c$ foram submetidas a um filtro subtrativo que realça o campo de densidade do escoamento enquanto que, a quarta, foi processada para destacar o núcleo líquido e as ondas de choque. A última imagem se refere à fotografia obtida pelo método de iluminação por detrás. 
A seguir são apresentadas quatro imagens do ensaio 5349500 (Figs. $5.23 \mathrm{e}$ 5.24). Sua condições de injeção eram de $497,6 \mathrm{kPa}, 76,9{ }^{\circ} \mathrm{C}$ e a pressão da câmara era de 0,09 $\mathrm{kPa}$. A primeira imagem foi obtida através do "Schlieren" (Fig. 5.23a), a segunda pelo método de iluminação por detrás (Fig. 5.23b). As outras duas (Figs. 5.24a e 5.24b) são aquelas filtradas da fotografia da Fig. 5.23a. Na Fig. 5.24b, duas ondas reflexivas são vistas. Talvez isto deva acontecer quando, na extremidade radial da calota, o escoamento forme uma onda de choque com um caráter mais oblíquo. Entretanto na região entre estas duas ondas de choque reflexivas, a montante da onda de choque, o escoamento deve ser predominantemente radial ao eixo do jato, formando uma onda de choque normal a este escoamento. Esta hipótese está embasada na simulação bidimensional de Edvaldo (2004) cujo resultado está mostrado na Fig. 2.13. Nesta simulação, se observa a linha de corrente na trajetória radial, praticamente, cruzando perpendicularmente a onda de choque. Resumidamente, o encontro destas duas ondas de choque forma esta onda de choque reflexiva. Para explicar a segunda onda de choque reflexiva, que está abaixo da anterior, a hipótese aqui feita possui a mesma analogia. A onda de choque próxima do bocal de caráter oblíquo se encontra com esta onda de choque quase normal, que fica entre as duas ondas de choque reflexivas. Este encontro resulta nesta segunda onda de choque reflexiva.

Como observação, quando a onda de choque está próxima do núcleo líquido, com diâmetros menores que $15 \mathrm{~mm}$, aproximadamente, como exemplificado na Fig. 5.19, mal é possível observar ondas de choque reflexivas. Neste caso, o escoamento deve alcançar uma velocidade supersônica menor, portanto a velocidade a jusante da onda podem assumir uma velocidade menos contrastante que a supersônica, ou mesmo, sua velocidade se torna subsônica.

Na Fig. 5.23a, é verificada, após a onda de evaporação, uma grande variação da densidade do fluido, mas após passar pela onda de choque, esta variação se apresenta de forma mais amena. A Fig. 5.23b mostra uma idéia da trajetória do escoamento imediatamente a jusante da onda de evaporação. Próximas do núcleo líquido, pequenas gotículas desenham um traçado que parece caminhar de forma perpendicular à região central da onda de choque superior que assume formato de calota. 
a)
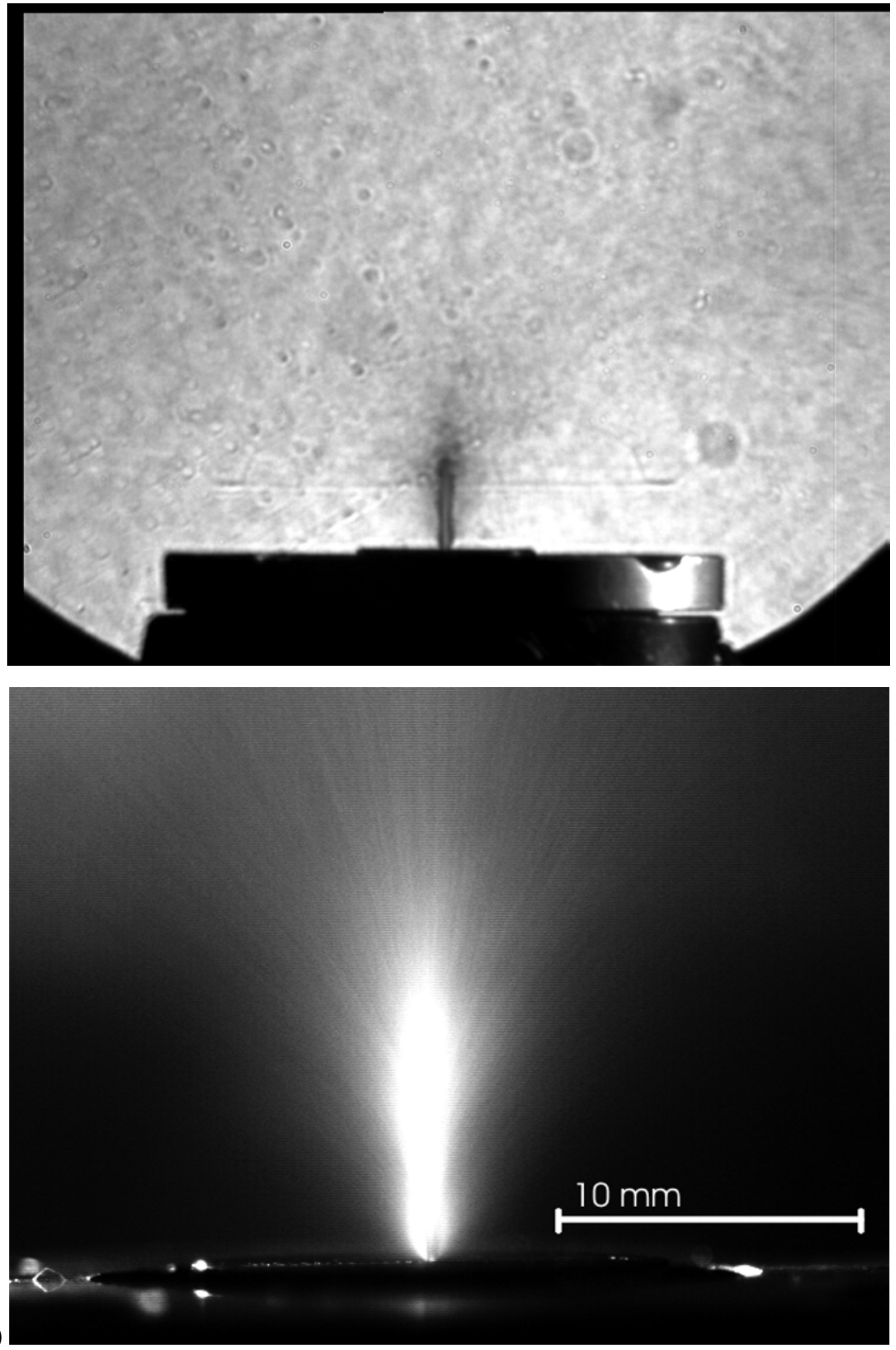

Figura 5.23 - Imagens originais do jato do ensaio 5349500, com condições de injeção de $497,6 \mathrm{kPa}, 76,9^{\circ} \mathrm{C}$ e a pressão da câmara de $0,09 \mathrm{kPa}$. A primeira obtida pelo método "Schlieren" e a outra pela "Iluminação por detrás". 
a)
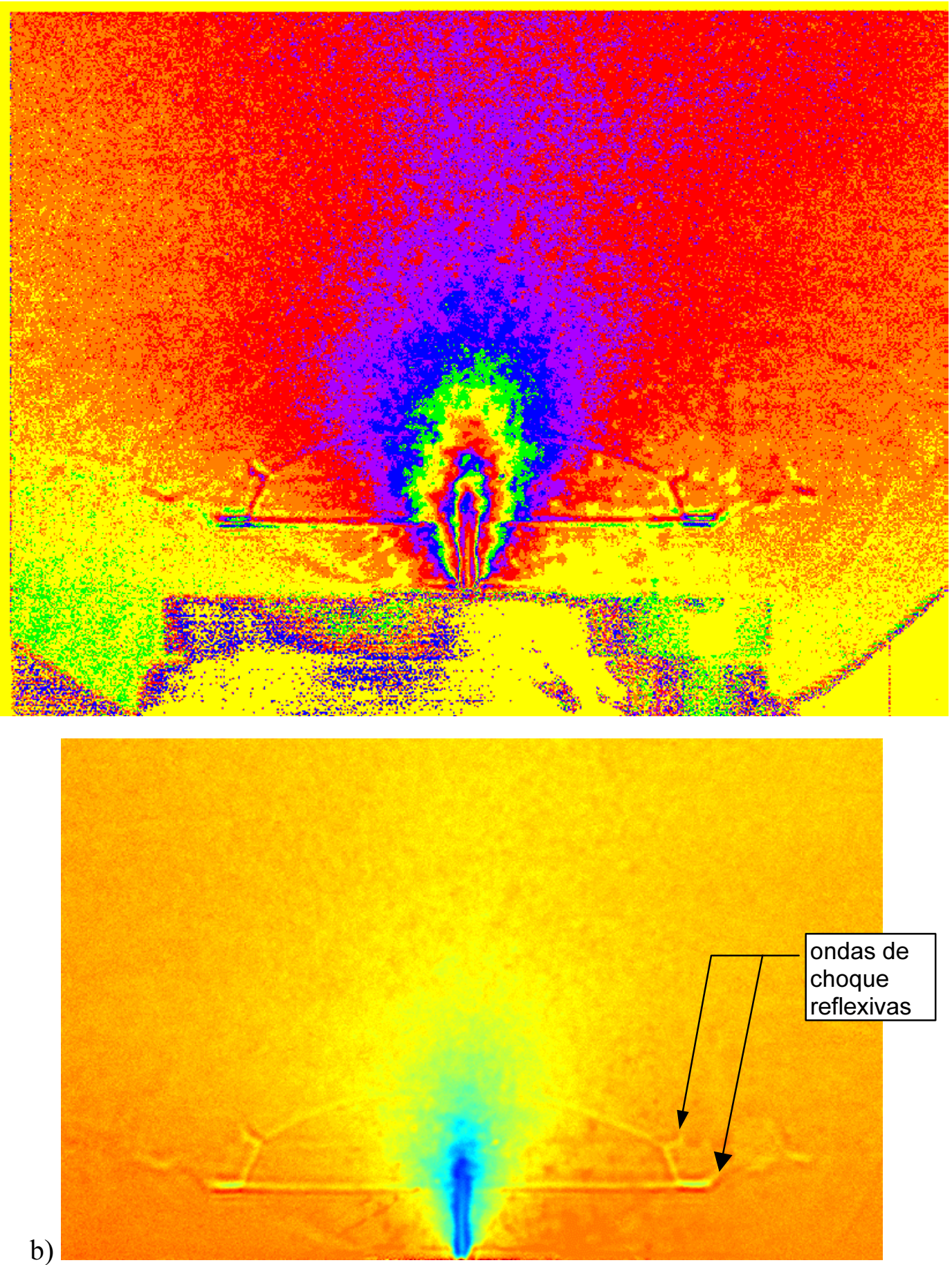

Figura 5.24 - Imagens filtradas do jato do ensaio 5349500 da Fig. 5.23a. 


\subsubsection{Análise de Comprimento de Extinção do Líquido}

Na seção anterior, foi visto que o núcleo de líquido é visualizável em ensaios com máxima vazão. É mais nítida sua presença quando existe a onda de choque, porém ela pode ser vista em estágios em que a pressão da câmara não é suficientemente baixa para destacar a presença da onda de choque porque a mesma pode estar muito próxima do núcleo líquido (Fig.5.16). A partir deste ponto, diminuindo a pressão da câmara é possível verificar que o núcleo de líquido assume uma forma regular e estável. E, por mais que se diminua a pressão da câmara, não existe variação do comprimento do núcleo líquido. A série de ensaios com pressão e temperatura de injeção com $500 \mathrm{kPa}$ e $56^{\circ} \mathrm{C}$ é um exemplo típico e está mostrada na Tab. 5.4 e retratada na Figs. 5.25 a 5.27. Nelas, sob a técnica de "iluminação por detrás", os núcleos líquidos ficam iluminados e, em sua adjacência, o arrasto de pequenas gotículas é observado. A jusante da onda de evaporação, as gotículas registram um desvio angular do escoamento, em relação ao eixo axial.

Tabela 5.4 - Representação do comprimento do núcleo líquido, $L_{\mathrm{E}}$, para a série de ensaios com pressão e temperatura de injeção de $500 \mathrm{kPa}$ e $56{ }^{\circ} \mathrm{C}$, respectivamente.

\begin{tabular}{|c|c|c|c|c|}
\hline $\begin{array}{c}\boldsymbol{P}_{\text {inj }} \\
(\mathrm{kPa})\end{array}$ & $\begin{array}{l}T_{\mathrm{inj}} \\
\left({ }^{\circ} \mathrm{C}\right)\end{array}$ & $\begin{array}{c}\boldsymbol{P}_{\infty} \\
(\mathrm{kPa})\end{array}$ & $\boldsymbol{R}_{\mathrm{P}}=\boldsymbol{P}_{\text {sat }} / \boldsymbol{P}_{\infty}$ & $\begin{array}{c}\boldsymbol{L}_{\mathbf{E}} \\
(+/-0,5 \mathrm{~mm})\end{array}$ \\
\hline $\begin{array}{l}500 \\
500 \\
500 \\
500\end{array}$ & $\begin{array}{l}56 \\
56 \\
56 \\
56\end{array}$ & $\begin{array}{l}0,15 \\
0,20 \\
0,54 \\
2,53\end{array}$ & $\begin{array}{c}500 \\
100 \\
50 \\
10 \text { * }\end{array}$ & $\begin{array}{l}12,3 \\
11,6 \\
11,2 \\
11,0\end{array}$ \\
\hline $\begin{array}{l}\text { Obs.: } \\
\text { Dorém is } \\
\text { ormação } \\
\text { dificultari }\end{array}$ & & $\begin{array}{l}0 \text { não } \\
\text { r dizer } \\
\text { ar tão } \\
\text { lizaçãc }\end{array}$ & $\begin{array}{l}\text { bservada a } \\
\text { ela não e } \\
\text { ima do nú }\end{array}$ & $\begin{array}{l}\text { da de choque } \\
\text { a, pois a sua } \\
\text { o líquido que }\end{array}$ \\
\hline
\end{tabular}


a)

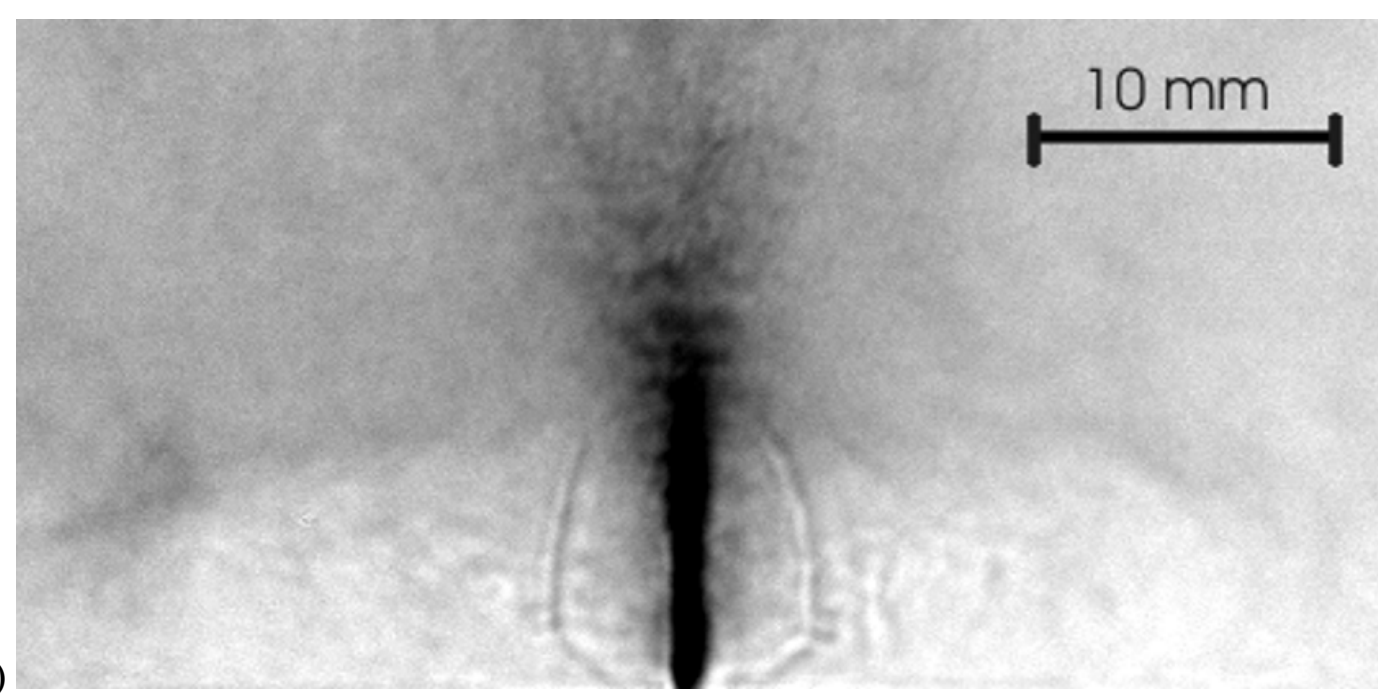

a)

b)

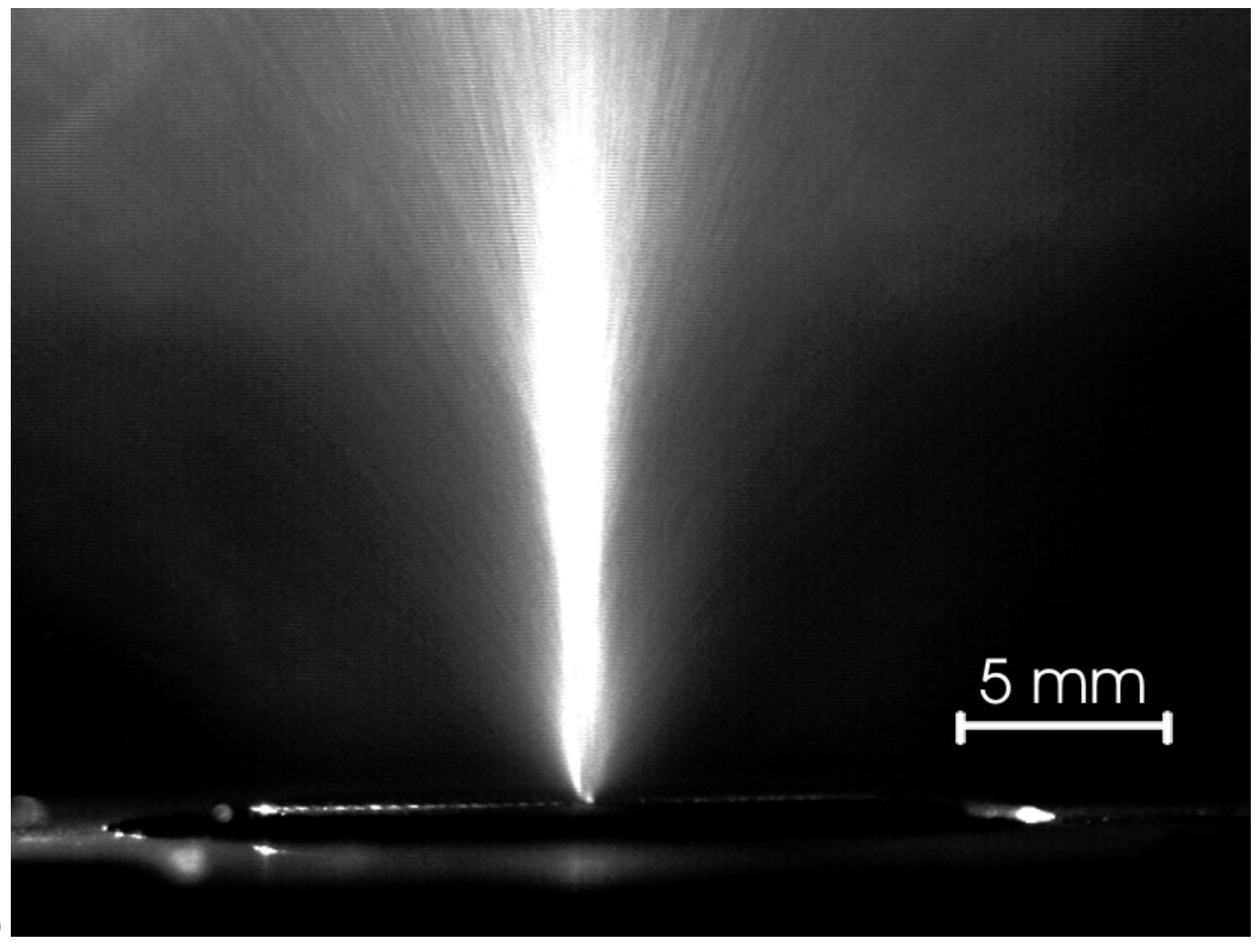

Figura 5.25 - Imagens originais do jato do ensaio 5329050, com condições de injeção de $501,6 \mathrm{kPa}, 56,6^{\circ} \mathrm{C}$ e a pressão da câmara de $0,50 \mathrm{kPa}$. A primeira obtida pelo método "Schlieren" e a outra pela "Iluminação por detrás". 

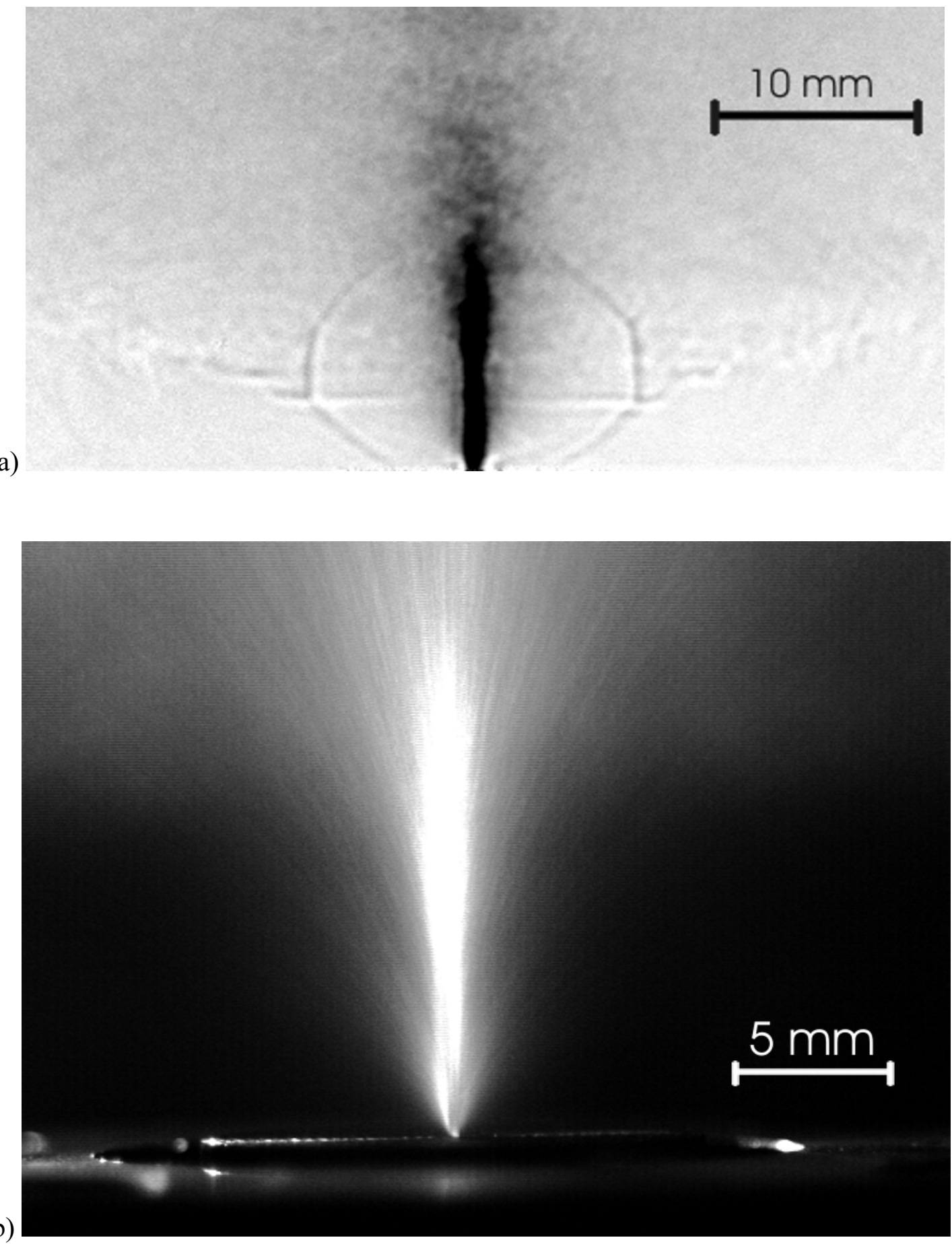

Figura 5.26 - Imagens originais do jato do ensaio 5329100, com condições de injeção de $501,6 \mathrm{kPa}, 56,6^{\circ} \mathrm{C}$ e a pressão da câmara de $0,31 \mathrm{kPa}$. A primeira obtida pelo método "Schlieren" e a outra pela "Iluminação por detrás". 
a)
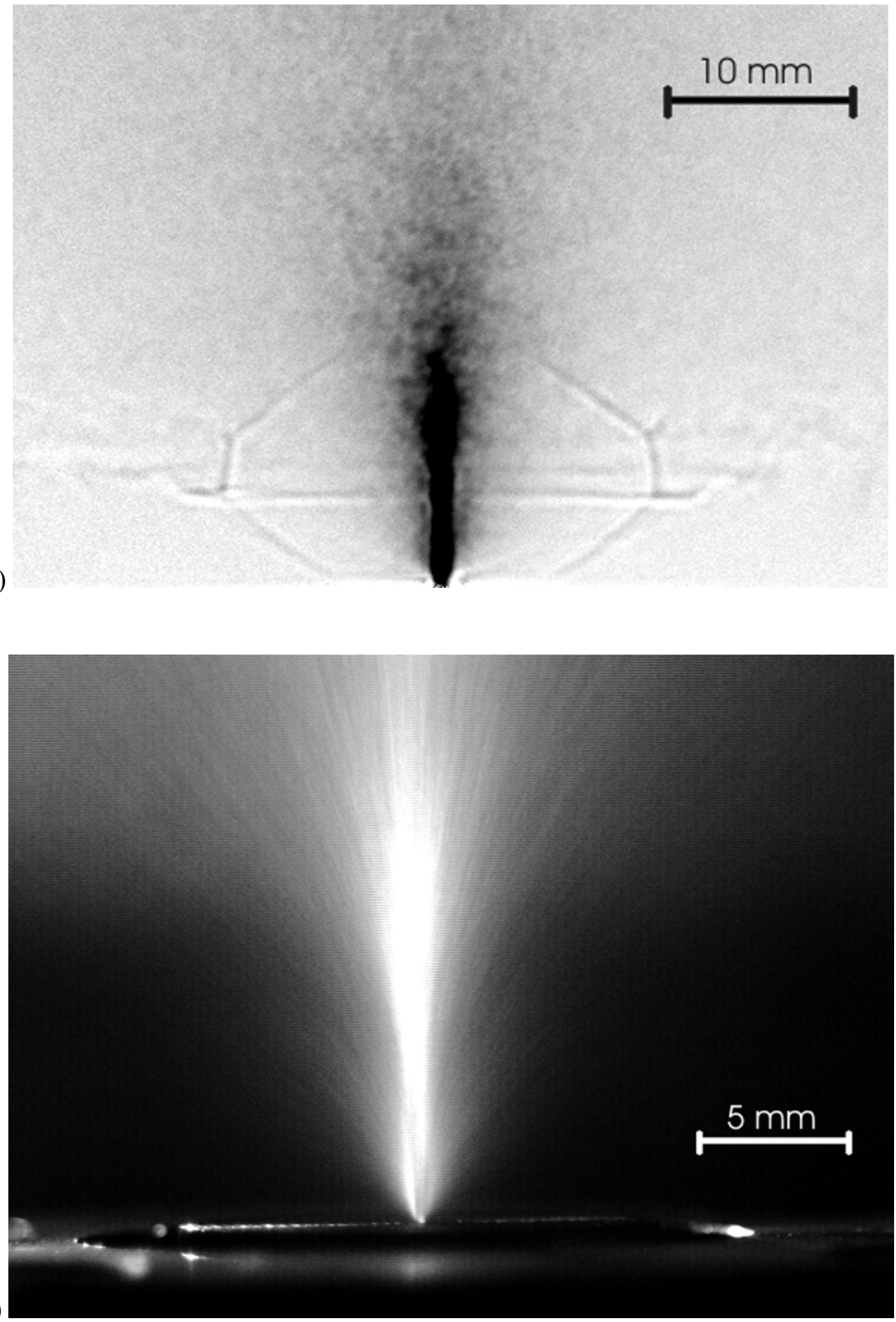

Figura 5.27 - Imagens originais do jato do ensaio 5329500, com condições de injeção de $504,1 \mathrm{kPa}, 57,1^{\circ} \mathrm{C}$ e a pressão da câmara de $0,12 \mathrm{kPa}$. A primeira obtida pelo método "Schlieren" e a outra pela "Iluminação por detrás". 


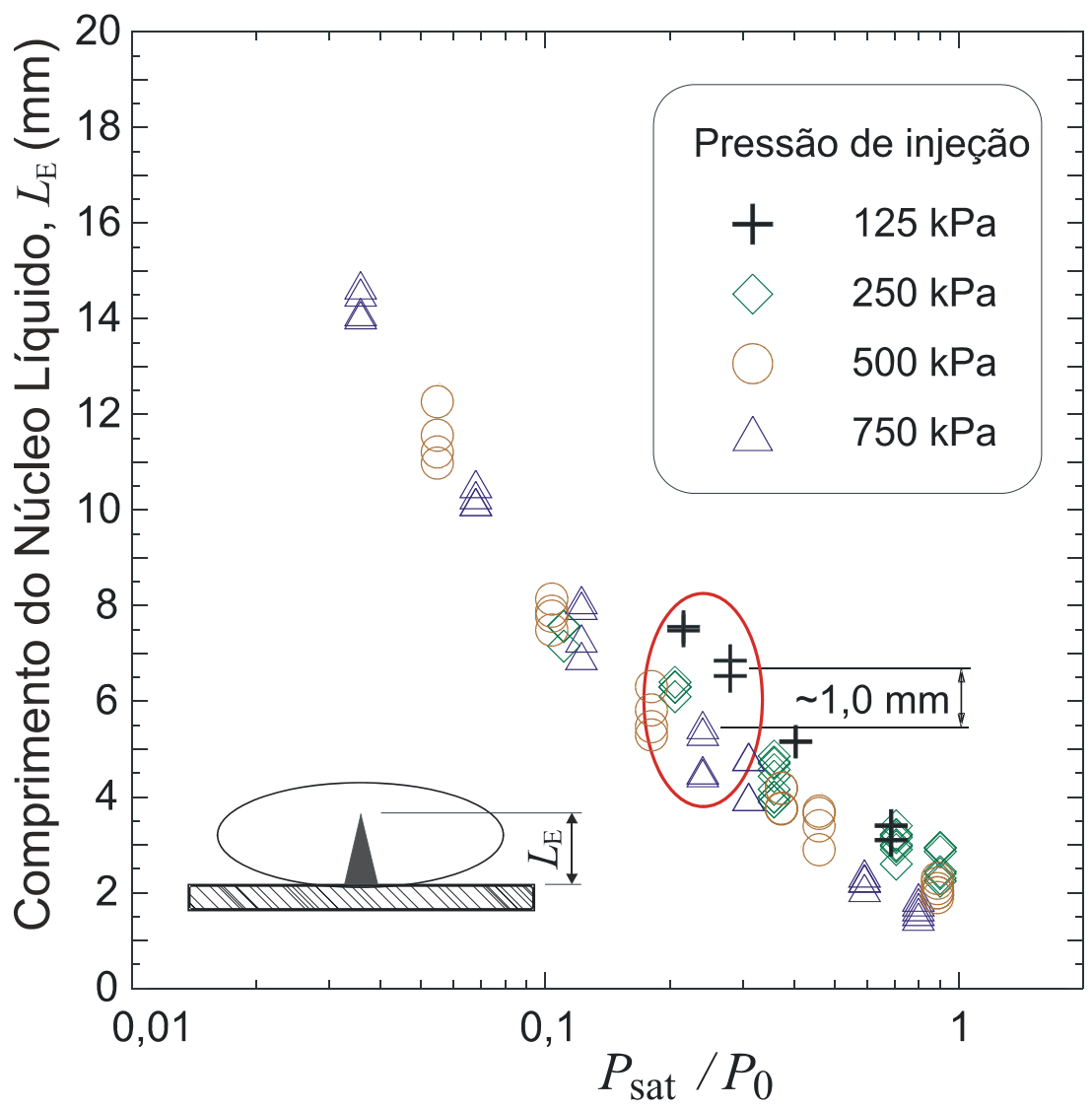

Figura 5.28 - Comparação do comprimento de extinção do núcleo líquido, $L_{\mathrm{E}}$, em função da razão da pressão de saturação e de injeção. Uma curva de ajuste para estes dados pode ser escrita através da seguinte equação: $L_{E}=2,04 .\left(P_{s a t} / P_{0}\right)^{-0,6}$. O destaque no gráfico se refere à diferença de comprimento esperada nestes ensaios.

Também foi encontrada uma correlação empírica do comprimento do núcleo líquido em função da razão entre a pressão de saturação e a de injeção, que está mostrada no gráfico da Fig. 5.28. Isto proporcionou uma condensação dos pontos experimentais apresentados no gráfico da Fig. 4.7. Esta não é ainda uma análise conclusiva, mas oferece uma idéia da contribuição da razão das pressões de saturação e de injeção para o fenômeno. Dentro disso, pode-se observar que existe a tendência de diminuir o comprimento de extinção do líquido quando se aumenta a temperatura de injeção, ou seja, aumenta a pressão de saturação do líquido injetado. No entanto, se a temperatura de injeção se mantiver constante, aumentando a pressão de injeção, a tendência do comprimento de extinção de líquido é de aumentar também. 
Tomando como exemplo os ensaios 1329050 e 1329500 que possuem pequenas velocidades e, conseqüentemente, um baixo número de Reynolds, com valores médios de $14 \mathrm{~m} / \mathrm{s}$ e $10^{4}$, respectivamente, apresentam em suas imagens o atraso da formação da onda de evaporação, nitidamente observado nas Figs. 5.29 e 5.30. É também interessante conferir no gráfico da Fig. 5.28 que estes ensaios com pressão de injeção de $125 \mathrm{kPa}$ se destacam da maioria dos outros. Eles, em média, possuem um comprimento de extinção do líquido 1,0 $\mathrm{mm}$ maior que os demais. 
a)
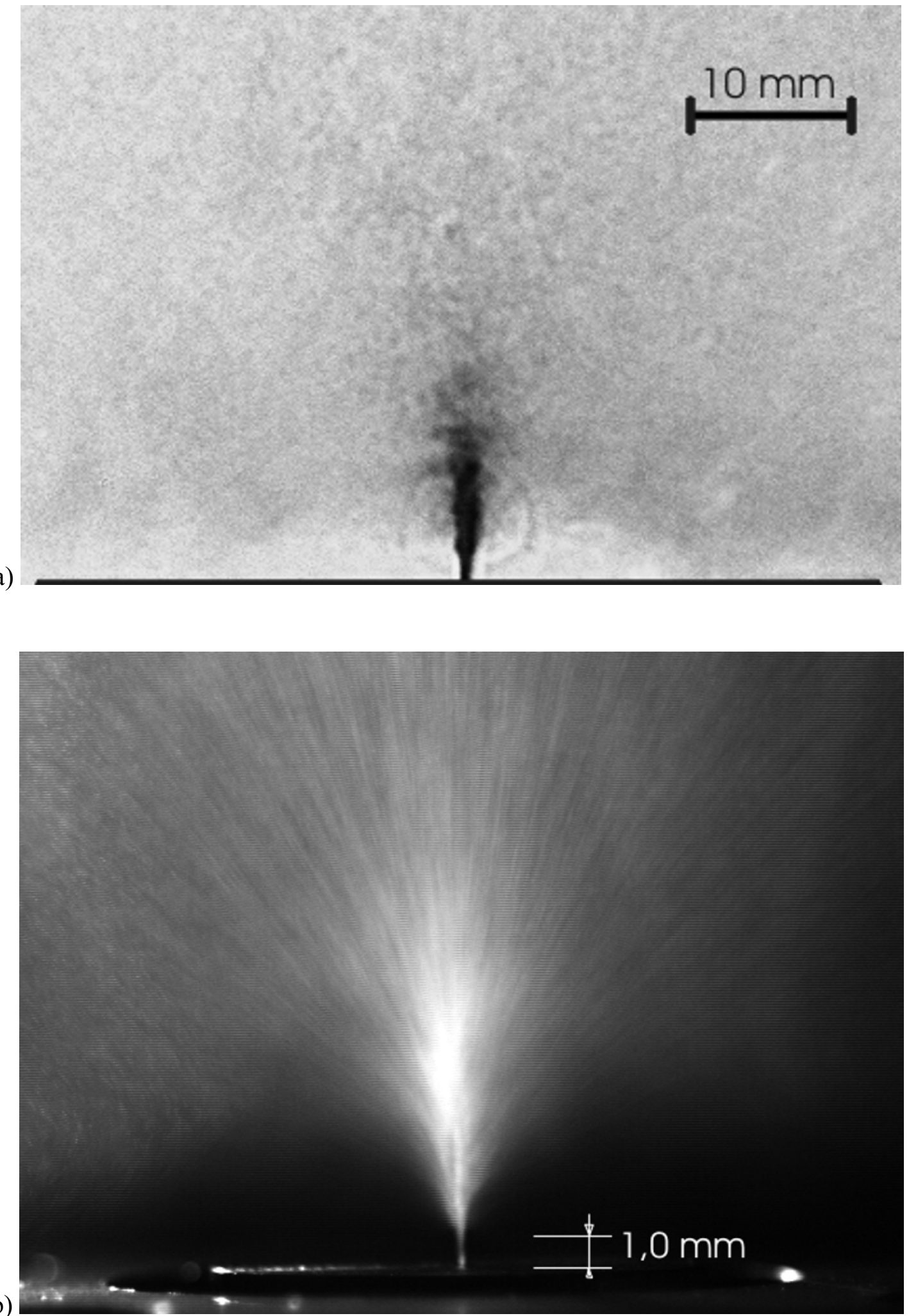

Figura 5.29 - Imagens originais do jato do ensaio 1329050, com condições de injeção de $122,1 \mathrm{kPa}, 56,4^{\circ} \mathrm{C}$ e a pressão da câmara de $0,49 \mathrm{kPa}$. A primeira obtida pelo método "Schlieren" e a outra, que indica o atraso da onda de evaporação, pela "Iluminação por detrás". 
a)
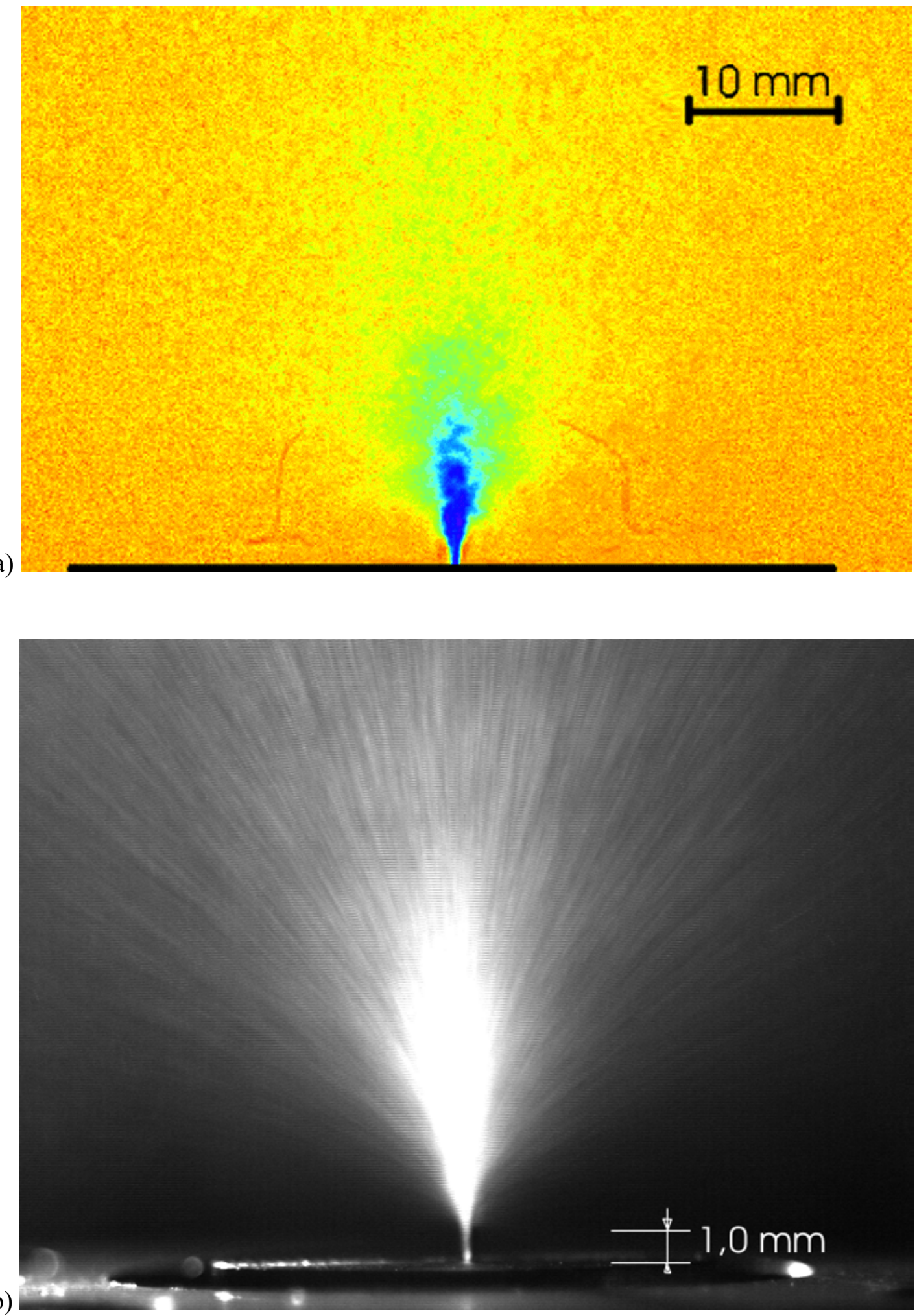

Figura 5.30 - Imagens originais do jato do ensaio 1329500, com condições de injeção de $123,0 \mathrm{kPa}, 56,5^{\circ} \mathrm{C}$ e a pressão da câmara de $0,10 \mathrm{kPa}$. A primeira obtida pelo método "Schlieren" e a outra, que indica o atraso da onda de evaporação, pela "Iluminação por detrás". 


\subsubsection{Comportamento da Onda de Choque}

Como foi visto na Seção 4.3, quanto menor a pressão da câmara, maiores são as dimensões da onda de choque. Outros gráficos representativos estão ilustrados nas Figs. 5.31 a 5.34. Em todas estas figuras, cada categoria de ensaio, com a mesma pressão e temperatura de injeção, apresentou um comportamento linear para o logaritmo das dimensões $r_{1}$ e $r_{2}$, praticamente (Fig. 5.31 a 5.34) em função do logaritmo da pressão da câmara, $P_{\infty}$. Em uma análise geral, no comportamento do raio da onda de choque, é observado que esta dimensão é menos sensível ao incremento da pressão de injeção, porém sua amplitude aumenta ainda mais quando é acrescido o valor da pressão de saturação, que é função da temperatura de injeção. Quanto à distância axial da onda de choque, $r_{2}$, ela tende a diminuir com o aumento da temperatura de injeção, mas também aumenta com o aumento da pressão de injeção.
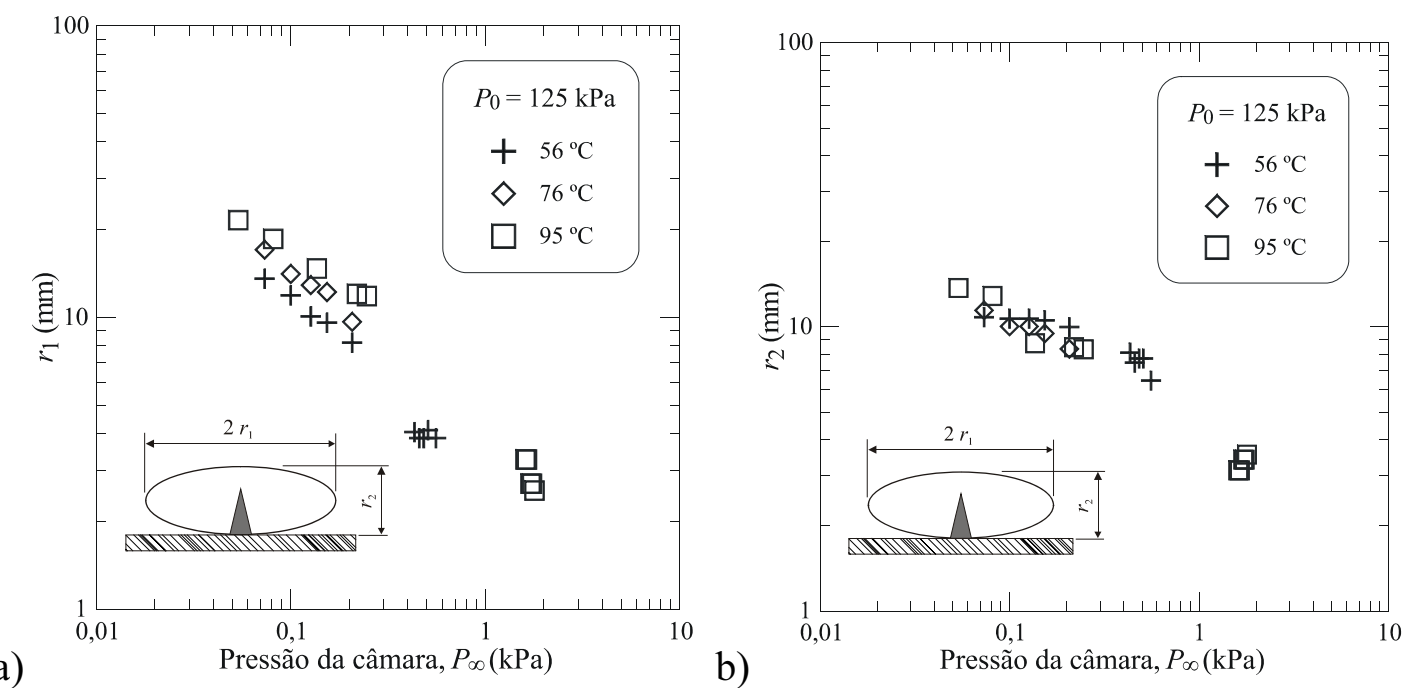

Figura 5.31 - Os comprimentos representativos $r_{1}$ (em "a") e $r_{2}$ em função da pressão da câmara. Aqui, todos com os ensaios possuem a pressão de injeção de $125 \mathrm{kPa}$ (bocal rugoso com $0,3 \mathrm{~mm}$ de diâmetro). 
a)

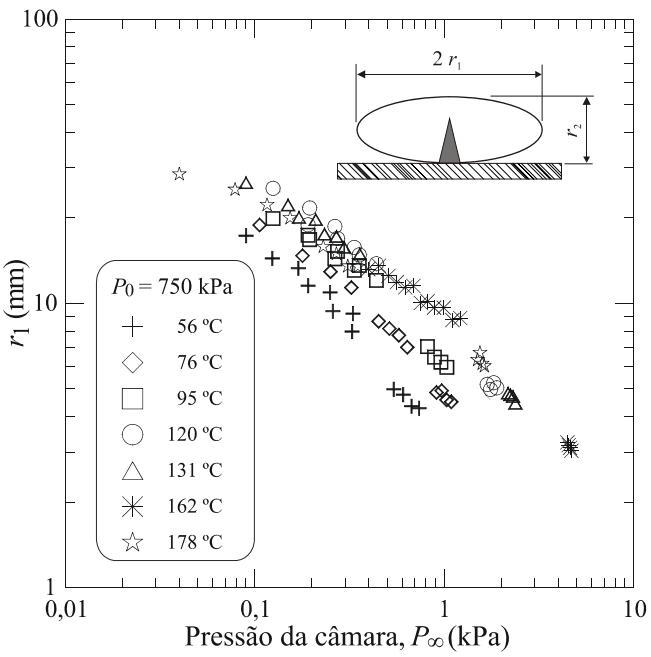

b)

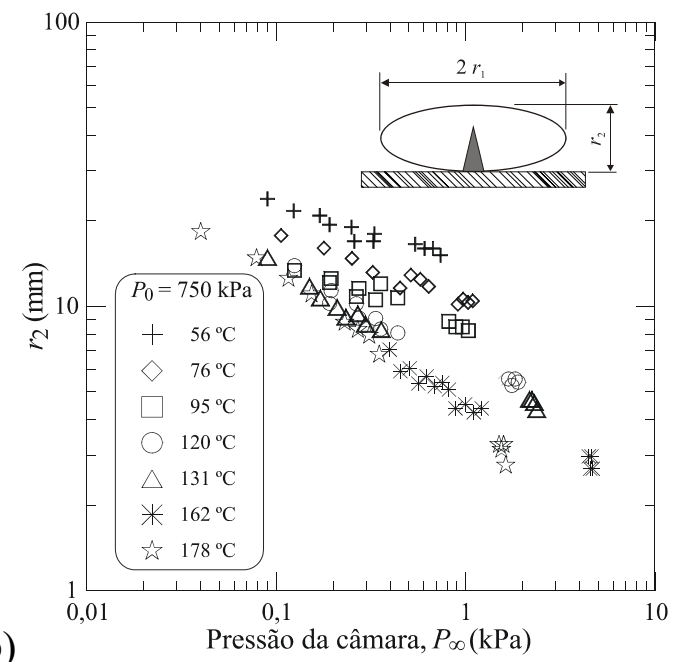

Figura 5.32 - Os comprimentos representativos $r_{1}$ (em "a") e $r_{2}$ em função da pressão da câmara. Aqui, todos com os ensaios possuem a pressão de injeção de $750 \mathrm{kPa}$ (bocal rugoso com $0,3 \mathrm{~mm}$ de diâmetro).
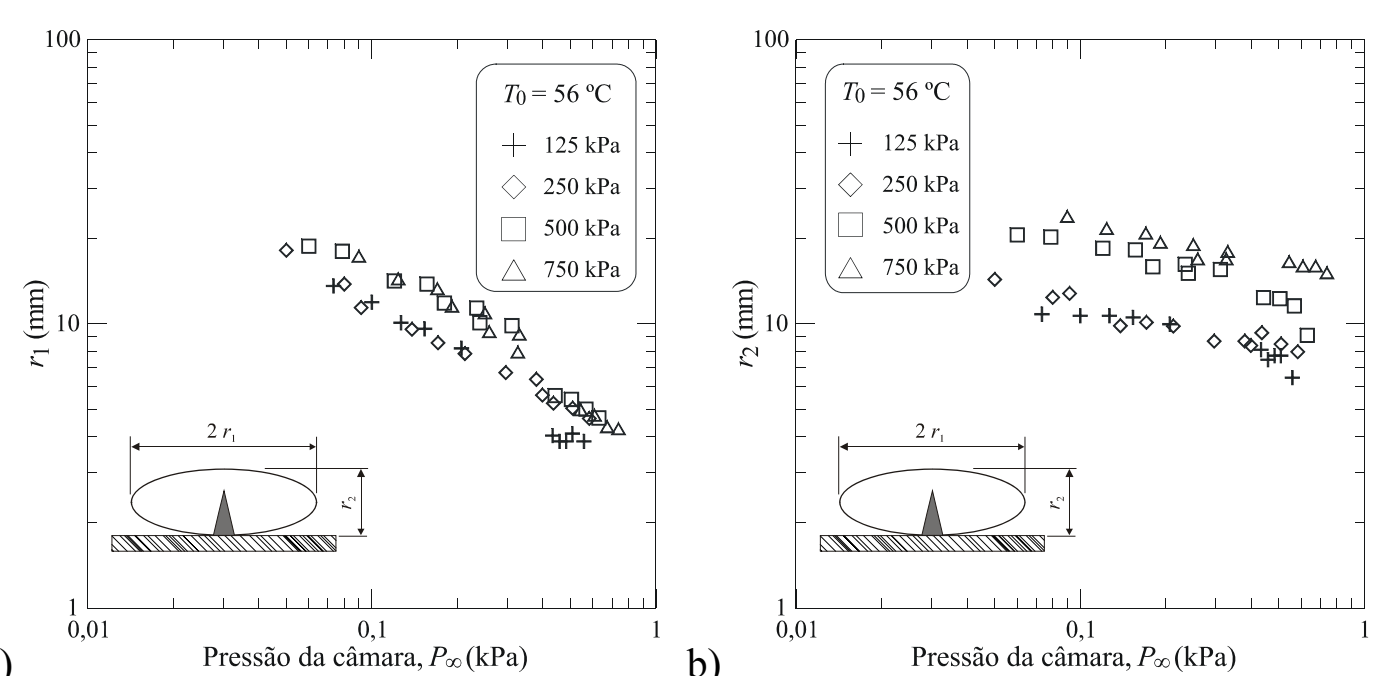

a)

b)

Figura 5.33 - Os comprimentos representativos $r_{1}$ (em "a") e $r_{2}$ em função da pressão da câmara. Aqui, todos com os ensaios possuem a temperatura de injeção de $56^{\circ} \mathrm{C}$ (bocal rugoso com $0,3 \mathrm{~mm}$ de diâmetro). 
a)

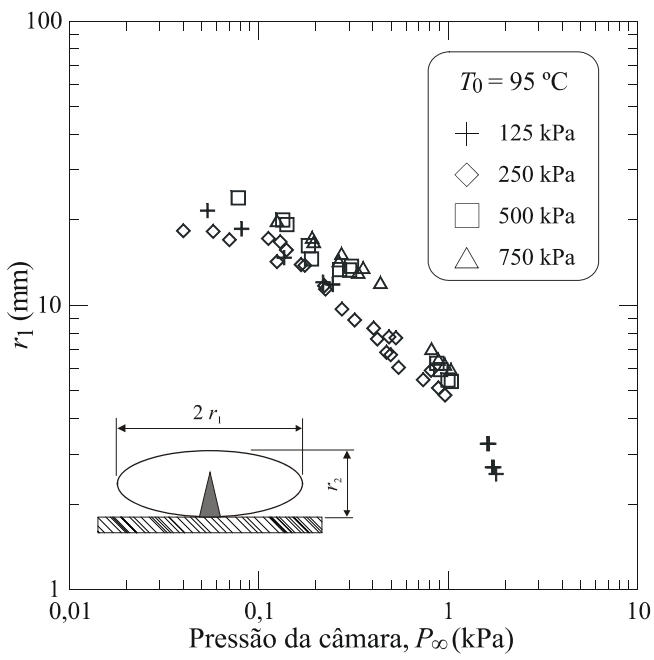

b)

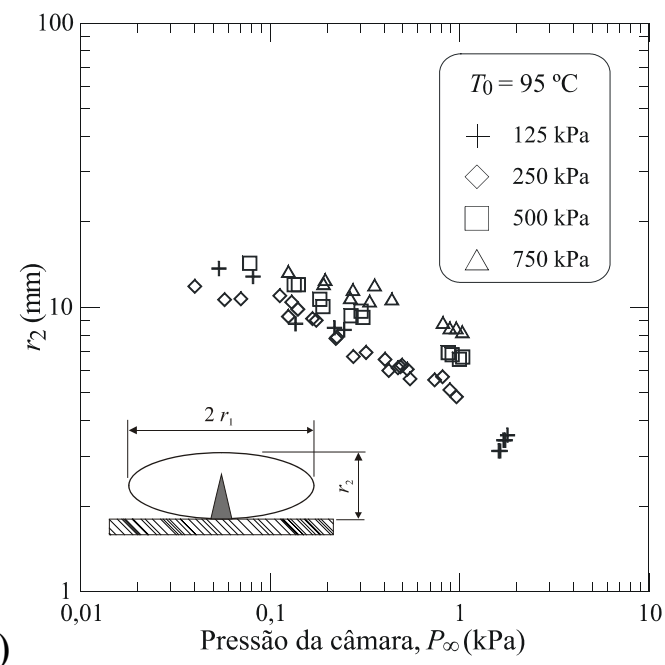

Figura 5.34 - Os comprimentos representativos $r_{1}$ (em "a") e $r_{2}$ em função da pressão da câmara. Aqui, todos com os ensaios possuem a temperatura de injeção de $95^{\circ} \mathrm{C}$ (bocal rugoso com $0,3 \mathrm{~mm}$ de diâmetro).

Uma análise dos resultados com detalhes indica o caráter bi-dimensional e axissimétrico do fenômeno evaporativo. No entanto, foi possível observar uma relação de proporcionalidade entre o comprimento do núcleo de líquido, $L_{\mathrm{E}}$, e a distância axial da onda de choque, $r_{2}$. Na Fig. 5.28 foi mostrado que o comprimento do núcleo líquido é proporcional ao seguinte fator: $\left(P_{0} / P_{s a t}\right)^{0,6}$. Por isto, neste gráfico, a pressão da câmara é multiplicada por este fator, e no eixo das ordenadas ficou indicado a razão da distância axial pelo raio do bocal, $r_{2} / r_{\mathrm{b}}$ (distância normalizada). 


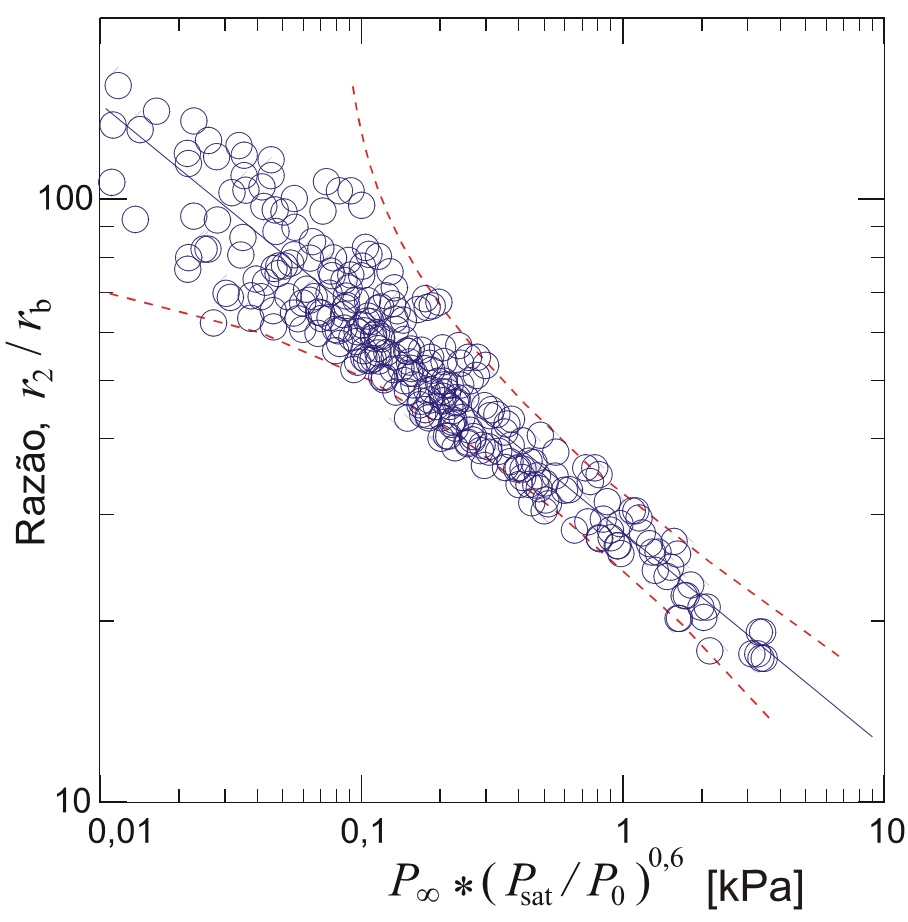

Figura 5.35 - Gráfico que mostra a influência do comprimento do núcleo líquido na distância axial da onda de choque. Nele, a razão do comprimento característico $r_{2}$ pelo raio do bocal $r_{\mathrm{b}}$ está em função da pressão da câmara corrigido pelo fator de proporcionalidade do comprimento do núcleo líquido. As linhas tracejadas são os limites de incerteza encontrados em função da incerteza na medição desta razão $(+/-3,3)$ e da pressão da câmara $(+/-0,07)$. 


\subsection{Comparação dos Jatos Evaporativos do Bocal de Aço de $0,3 \mathrm{~mm}$ de diâmetro com Bocais de Aço de $0,8 \mathrm{~mm}$ e de vidro de $0,35 \mathrm{~mm}$}

Neste capítulo, são discutidos e analisados os resultados obtidos com o bocal de $0,80 \mathrm{~mm}$ com superfície rugosa (bocal R08) e com os do bocal liso de vidro com diâmetro de 0,35 mm (bocal V03). Conforme foi visto na seção anterior, estes bocais possuem muitas características semelhantes com relação ao bocal menor de $0,3 \mathrm{~mm}$ discutido na Seção 5.1, porém algumas peculiaridades são ressaltadas. $O$ comportamento da vazão também é mostrado em função das condições de injeção e da pressão da câmara. Uma análise do comprimento do núcleo líquido é feita em função da pressão e temperatura de injeção comparada aos outros bocais. Todos os dados experimentais obtidos por estes dois bocais podem ser vistos no Anexo C.

De imediato, é importante mostrar que estes jatos, com uma pressão de saturação abaixo da pressão ambiente também possuem um perfil de filete retilíneo. Nas imagens das Fig. 5.35 são mostrados dois jatos ilustrando este fato. Apenas no jato do bocal R08, são vistas pequenas ondulações ao longo do filete que não promovem o desprendimento de gotículas no percurso mostrado na fotografia.

Em seguida, ilustrado nas Figs. 5.36 a 5.40, é feita uma comparação dos jatos obtidos pelos três bocais estudados. Estas imagens mostram que diâmetros de bocais maiores promovem um núcleo líquido maior e dimensões da onda de choque também maior. Isto retrata um comportamento proporcional tanto do comprimento do núcleo de líquido como das dimensões características da onda de choque em relação aos diâmetros dos bocais R03, R08 e V03, que possuem 0,30, 0,80 e 0,35 mm, respectivamente.

Para os jatos que não possuem ondas de choque, os perfis dos jatos destes bocais R08 e V03 são bastante similares em relação aos vistos na Seção 5.1. 


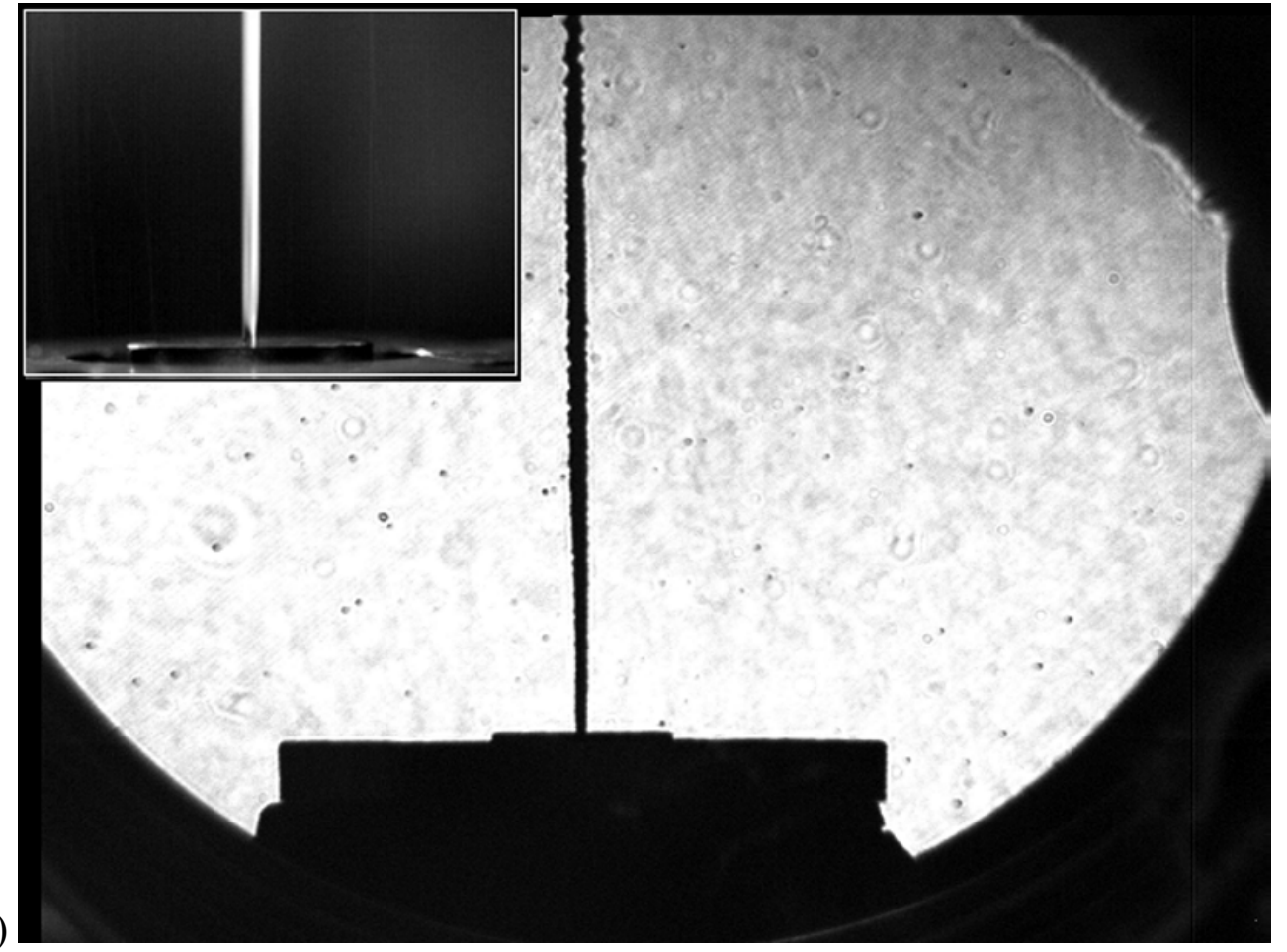

a)

b)

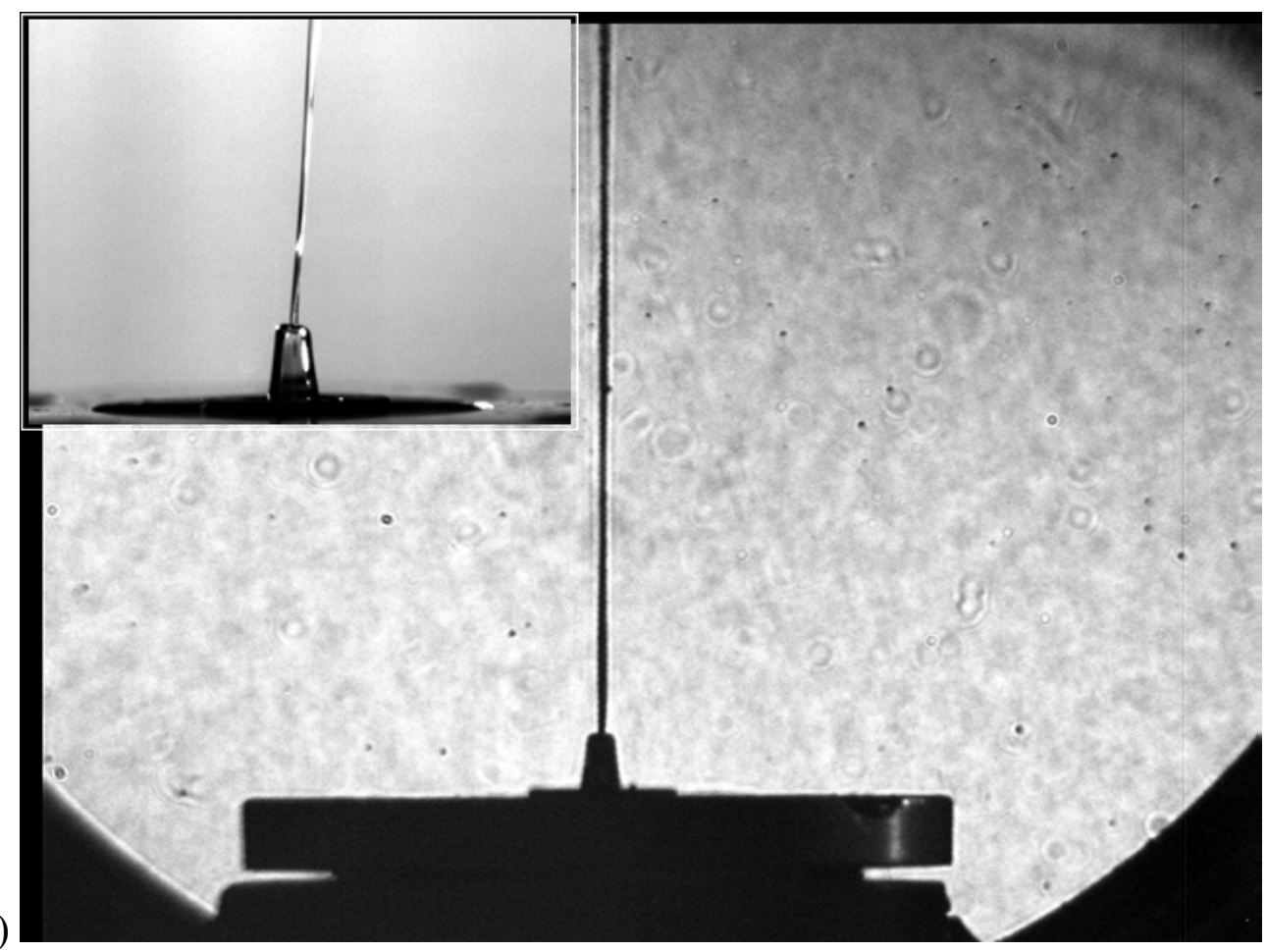

Figura 5.36 - Jatos com pressão e temperatura de injeção de $250 \mathrm{kPa}$ e $22^{\circ} \mathrm{C}$. A pressão da câmara é a atmosférica e a razão entre as pressões de saturação e câmara é igual a 0,05 . A primeira é um jato do bocal R08 e a outra do bocal de vidro V03. Os destaques nos cantos superiores das imagens são imagens adquiridas pela câmara CCD que utiliza o recurso de "iluminação por detrás". As imagens principais foram obtidas pelo método "Schlieren" (ensaios feitos na calibração do $C_{\mathrm{D}}$ ). 
a)

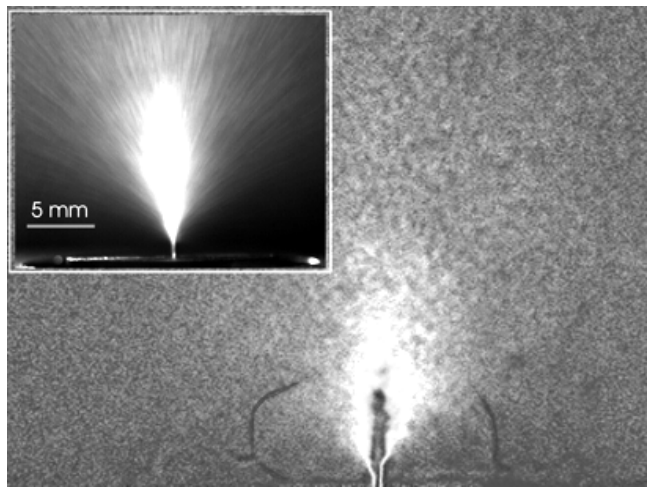

b)

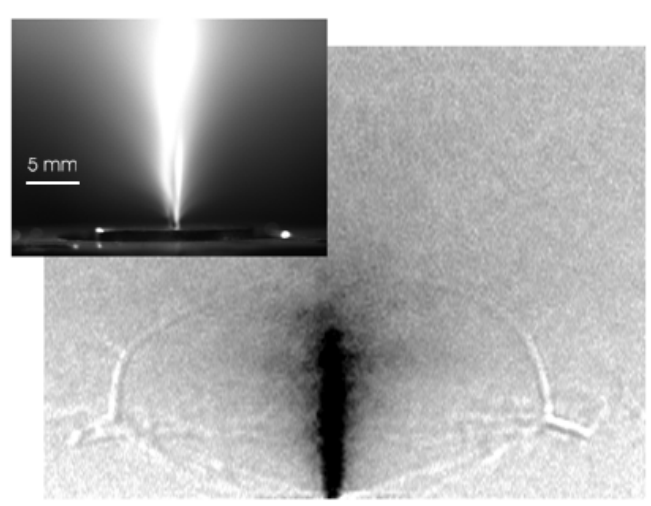

c)

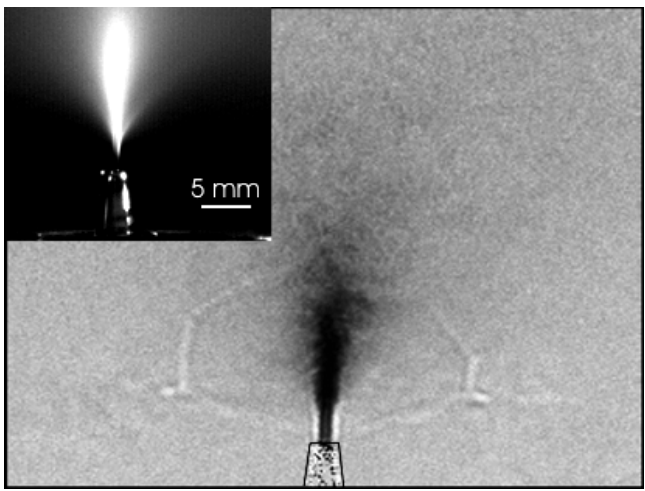

Figura 5.37 - Ensaios com as condições de injeção de $P_{0}=125 \mathrm{kPa}, T_{0}=56^{\circ} \mathrm{C}$ e $P_{\infty}=0,15 \pm 0,07 \mathrm{kPa}$. Cada imagem se refere aos bocais R03, R08 e V03, respectivamente. a)

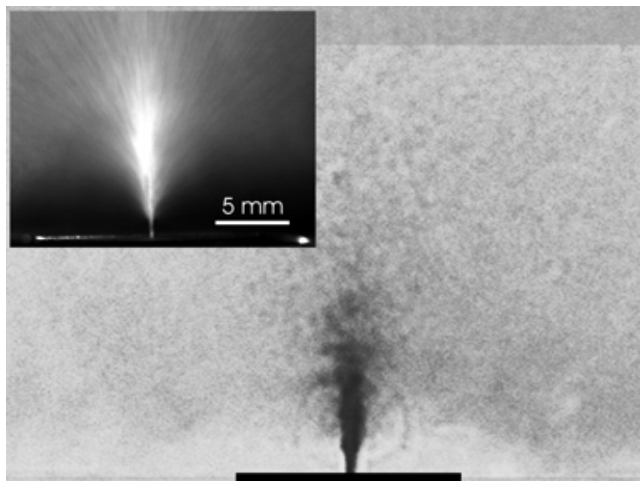

b)

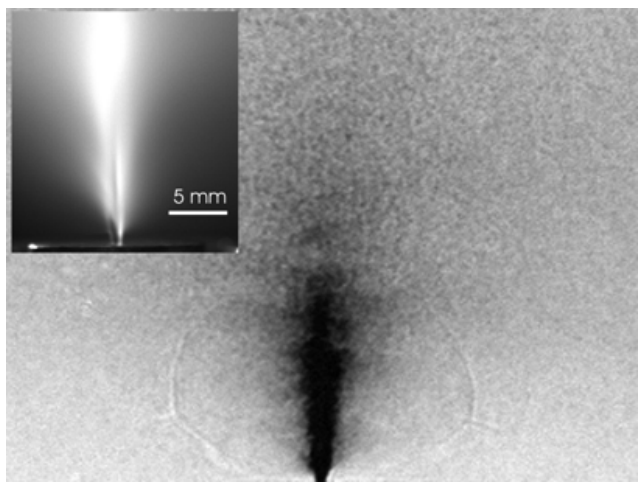

c)

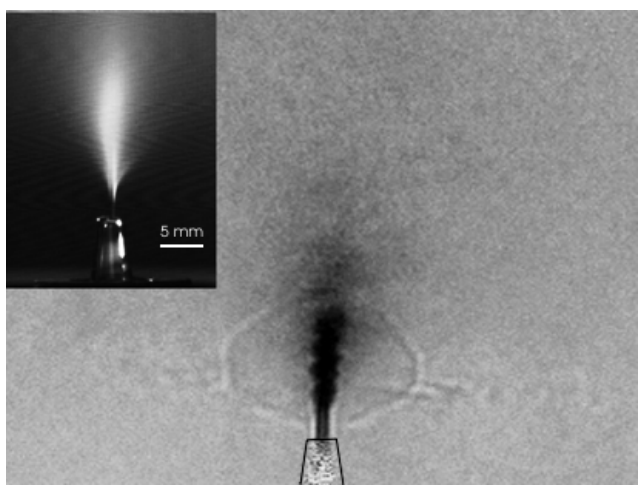

Figura 5.38 - Ensaios com as condições de injeção de $P_{0}=125 \mathrm{kPa}, T_{0}=56^{\circ} \mathrm{C}$ e $P_{\infty}=0,45 \pm 0,07 \mathrm{kPa}$. Cada imagem se refere aos bocais R03, R08 e V03, respectivamente. 
a)

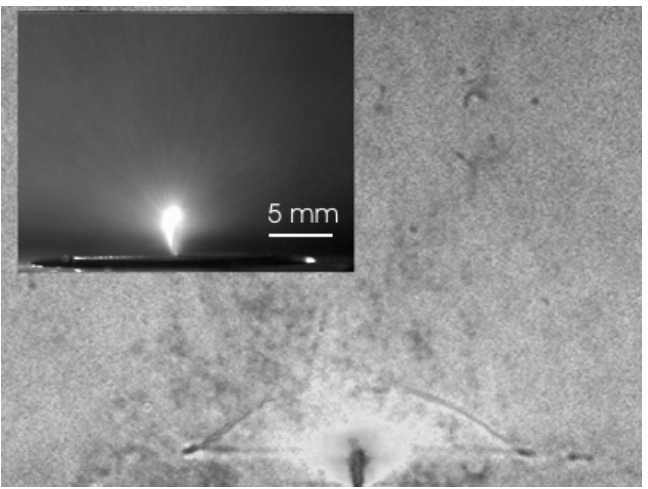

b)

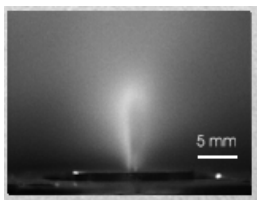

c)

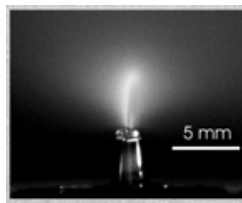

a)

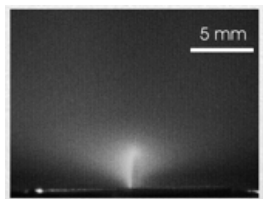

b)

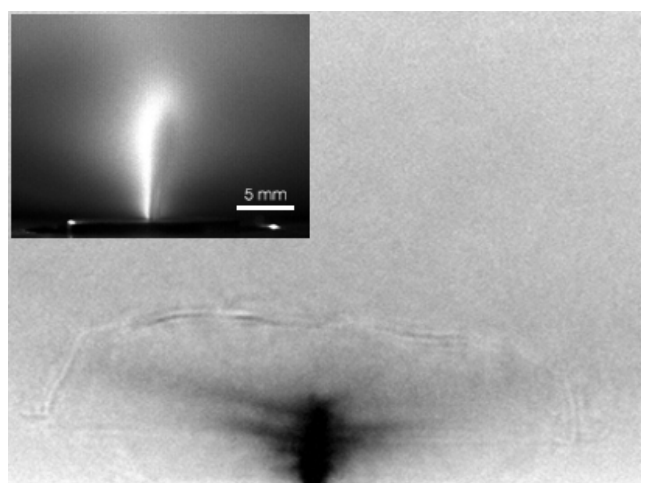

c)
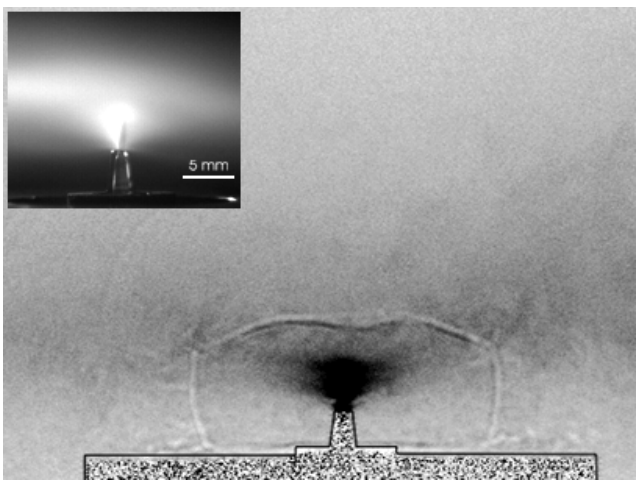

Figura 5.40 - Ensaios com as condições de injeção de $P_{0}=250 \mathrm{kPa}, T_{0}=120^{\circ} \mathrm{C}$ e $P_{\infty}=0,42 \pm 0,07 \mathrm{kPa}$. Cada imagem se refere aos bocais R03, R08 e V03, respectivamente.

\subsubsection{Comparação da Condição de Máxima Vazão}

A condição de máxima vazão obtida nestes bocais apresentou semelhante comportamento em relação ao bocal de aço de $0,3 \mathrm{~mm}$ de diâmetro, ou seja, para cada condição de injeção e temperatura, cada bocal alcançou uma vazão cuja redução da pressão da câmara não a alterava, mantendo-a neste patamar máximo. Para 
comparar as máximas vazões destes bocais, foi utilizada a vazão mássica superficial nesta condição máxima. No gráfico da Fig. 5.41, em função da razão entre as pressões de saturação e de injeção e da categoria de pressão de injeção, é feita uma comparação das vazões mássicas superficiais, na condição de blocagem. Para cada categoria de pressão de injeção de cada bocal, é observada uma queda linear desta vazão em função da razão de pressões. O bocal de vidro (V03) obteve uma menor inclinação desta curvas em relação ao bocal R03. E o bocal R08 foi o que possuiu a menor vazão superficial máxima.

Como nota, deve-se lembrar que o bocal de vidro tem sua menor seção com valor de 0,35 mm de diâmetro, sendo sua borda de saída arredondada. É difícil afirmar se o jato emerge do bocal com o diâmetro da restrição, ou sofre um aumento de diâmetro acompanhando a curvatura da borda na saída. Sem uma dimensão precisa deste diâmetro, a determinação da pressão metaestável após sair do bocal líquido pode não ser a mesma daquela inferida na menor seção através da medição da vazão.

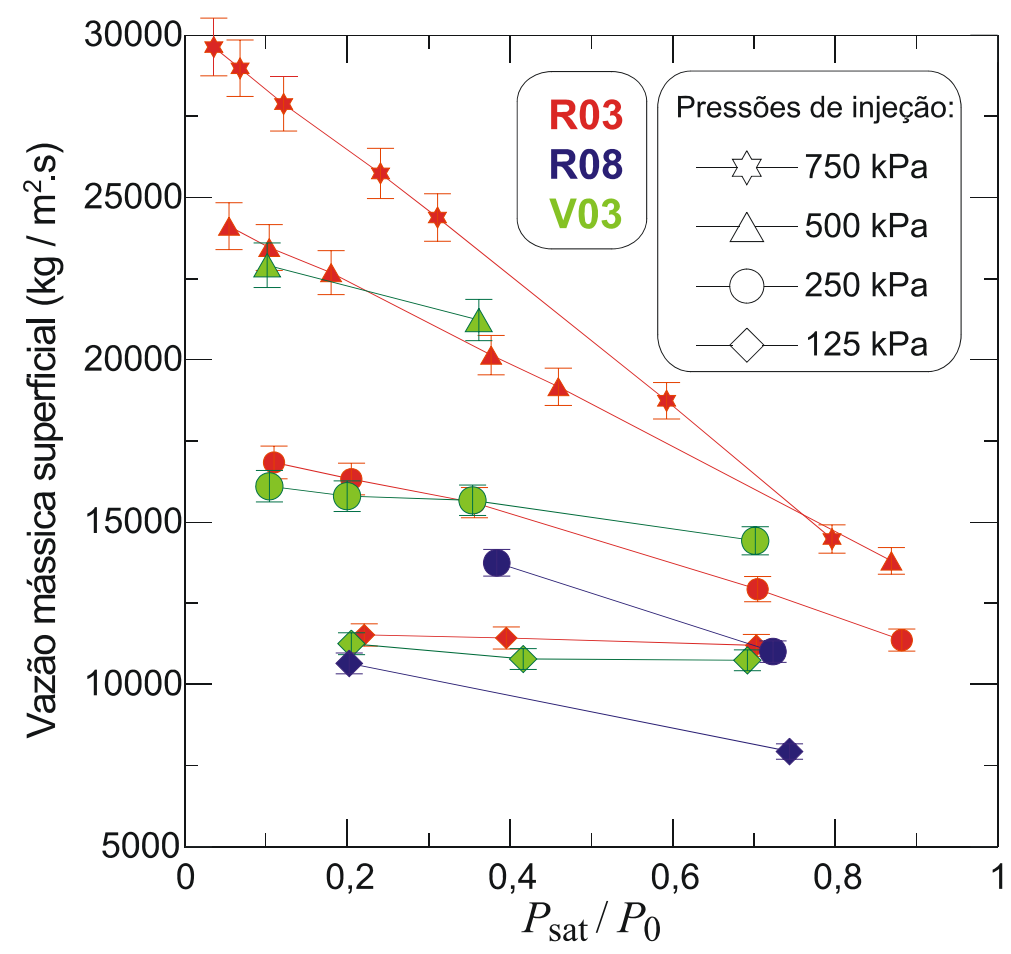

Figura 5.41 - Comparativo das máximas vazões superficiais alcançadas pelos bocais com relação à seção de saída. Os símbolos da legenda representam a pressão de injeção e a cor do símbolo se refere ao bocal experimentado. 
Como comparação, outros gráficos estão apresentados nas Figs. 5.42 e 5.43. Este primeiro ilustra quantas vezes a pressão da câmara deve ser menor que a pressão de saturação para alcançar a vazão máxima. $O$ outro mostra o grau de metaestabilidade alcançada pelo líquido quando a vazão está blocada. Tanto o bocal de vidro como o bocal R03, possuem comportamentos similares. A diferença se fez quando o enfoque foi o aumento da temperatura de injeção do bocal de vidro que alcançou um grau de metaestabilidade um pouco maior que o de aço com diâmetro aproximado. Conforme esperado pelo gráfico da Fig. 5.43 o grau de metaestabilidade dos jatos do bocal R08 possui um valor menor que os outros.

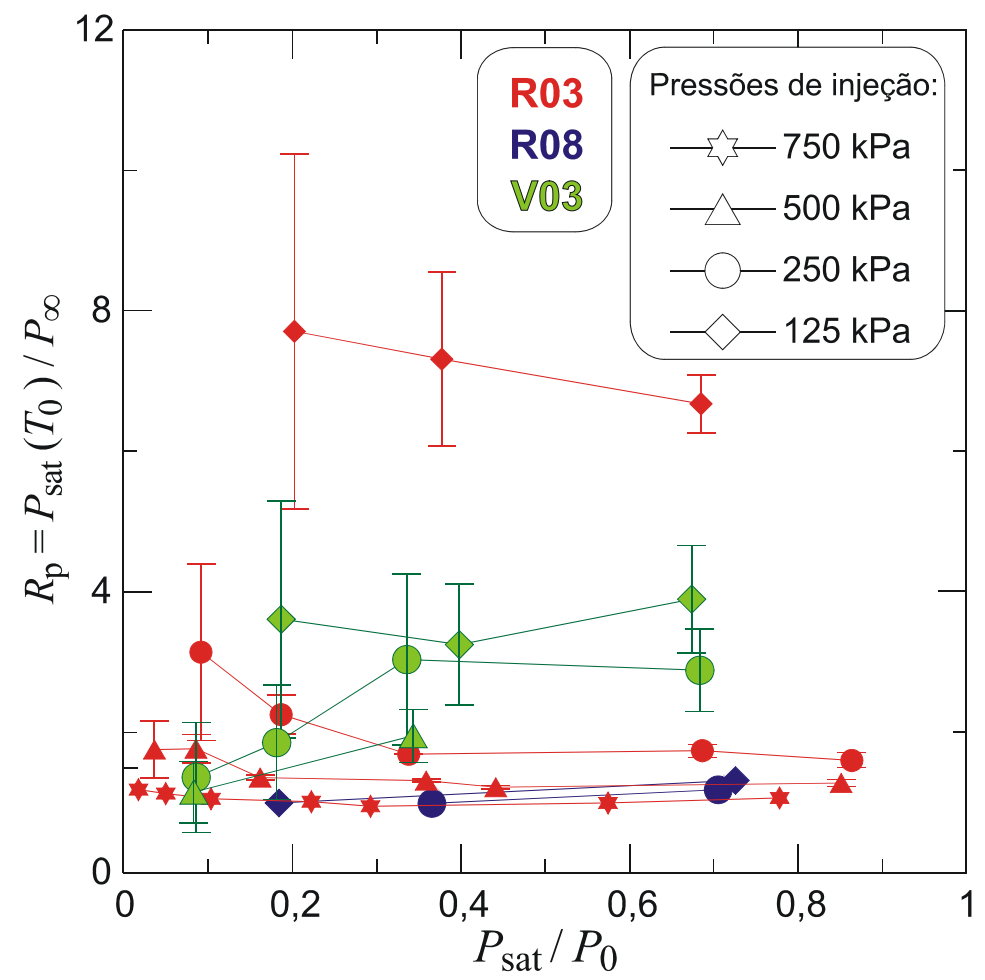

Figura 5.42 - Comparativo das máximas razões de pressão de saturação e da câmara $\left(R_{\mathrm{P}}\right)$ para alcançar a máxima vazão. Os símbolos da legenda representam a pressão de injeção e a cor do símbolo se refere ao bocal experimentado. 


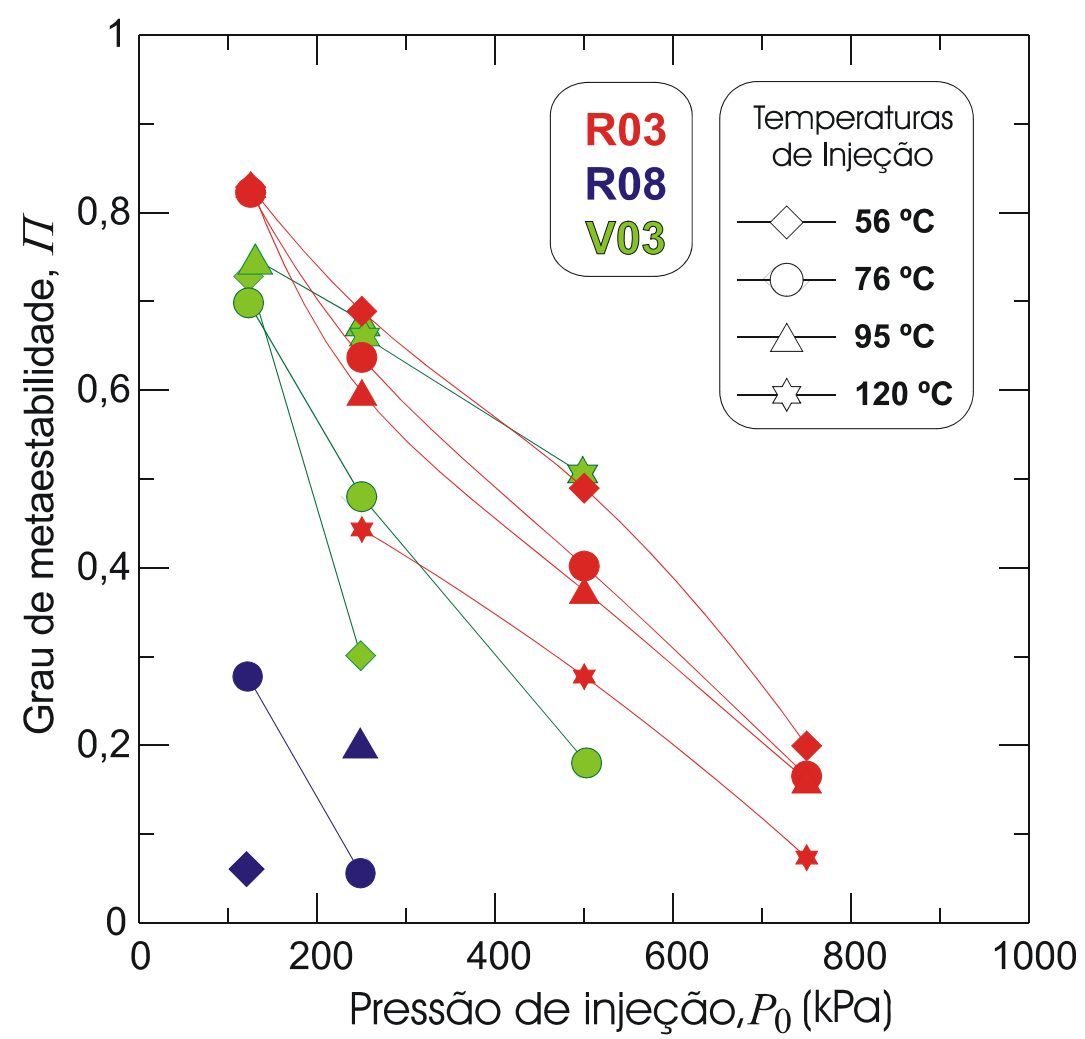

Figura 5.43 - Comparativo do grau de metaestabilidade em função da pressão de injeção. Os símbolos da legenda representam a pressão de injeção e a cor do símbolo se refere ao bocal experimentado.

\subsubsection{Comparação do Comprimento de Extinção do Líquido}

A normalização do comprimento de extinção do núcleo de líquido é uma forma de comparar dos diversos bocais. Para isto, esta dimensão foi dividida pelo diâmetro do bocal ensaiado, isto é, $L_{\mathrm{E}} / D_{\mathrm{b}}$. Esta comparação envolve experimentos dos bocais deste estudo (Tab. B.4 do Anexo B para o bocal R03 e, Tab. C. 2 e C.5 do Anexo C para os bocais R08 e V03) e os experimentos de Athans (1995) cujos dados experimentais estão na Tab. 5.5. No gráfico da Fig. 5.44 estão indicados estes comprimentos normalizados de todos os ensaios aqui apresentados, além dos ensaios de Athans, em função da razão entre a pressão de saturação e da câmara. A grande maioria dos pontos está compreendida na faixa limitada pelas linhas tracejadas. Porém, como similarmente visto na Subseção 5.1.6, além daqueles já destacados no gráfico da Fig. 5.28, neste gráfico (Fig. 5.44) é notada a extrapolação de outros pontos, referente aos ensaios do bocal de vidro. Assim como ocorreu no bocal R03 o atraso da onda de evaporação (ver Subseção 5.1.6), o bocal V03 também apresentou 
este atraso para os pontos que extrapolaram. Como exemplo do atraso que ocorre no bocal de vidro estão mostradas as imagens dos ensaios V03\1329m10, V03\2349500 e V03\2368500, na Fig.5.45 a 5.46. O ensaio V03\2393m10 da Fig. 5.47, cuja pressão de injeção é de $250 \mathrm{kPa}$, não apresentou este atraso na imagem do jato e seu resultado da razão $L_{\mathrm{E}} / D_{\mathrm{b}}$ fícou compreendida na região limitada pelas linhas tracejadas.

Tabela 5.5 - Alguns ensaios de Athans (1995) com um bocal de 0,864 mm de diâmetro utilizando iso-octano.

\begin{tabular}{cccccccr}
\hline Athans & $\boldsymbol{P}_{\mathbf{0}}$ & $\boldsymbol{T}_{\mathbf{0}}$ & $\boldsymbol{P}_{\text {sat }}$ & $\boldsymbol{P}_{\infty}$ & $\boldsymbol{m}$ & $\boldsymbol{P}_{\text {sat }} / \boldsymbol{P}_{\mathbf{0}}$ & $\boldsymbol{L}_{\mathbf{E}} / \boldsymbol{D}_{\mathbf{b}}$ \\
\hline Ensaio & $(\mathrm{kPa})$ & $\left({ }^{\circ} \mathrm{C}\right)$ & $(\mathrm{kPa})$ & $(\mathrm{kPa})$ & $(\mathrm{kg} / \mathrm{s})$ & & \\
\hline A6 - 04/01/94 & 2069 & 148 & 335,1 & 0,66 & 0,2038 & 0,162 & 14,26 \\
A8- 04/01/94 & 2097 & 200 & 893,5 & 0,65 & 0,01857 & 0,426 & 8,51 \\
A7 - 09/01/94 & 1207 & 150 & 349,6 & 0,62 & 0,01549 & 0,290 & 9,89 \\
A8 - 09/01/94 & 980 & 150 & 349,6 & 0,59 & 0,01387 & 0,357 & 9,66 \\
A9 - 09/01/94 & 773 & 150 & 349,6 & 0,59 & 0,01229 & 0,452 & 8,28 \\
A10 - 09/01/94 & 719 & 150 & 349,6 & 0,57 & 0,01189 & 0,486 & 7,13 \\
A11 - 09/01/94 & 604 & 150 & 349,6 & 0,59 & 0,01072 & 0,579 & 7,59 \\
A12 - 09/01/94 & 521 & 150 & 349,6 & 0,61 & 0,01002 & 0,671 & 5,52 \\
A13 - 09/01/94 & 451 & 150 & 349,6 & 0,61 & 0,00878 & 0,775 & 4,83 \\
A1 - 22/10/94 & 2403 & 201 & 908,8 & 1,92 & 0,02102 & 0,378 & 9,9 \\
A2 - 22/10/94 & 2529 & 206 & 988,0 & 2,47 & 0,02134 & 0,391 & 9,7 \\
A3 - 22/10/94 & 2606 & 211 & 1072,3 & 2,3 & 0,02143 & 0,411 & 9,4 \\
A4 - 22/10/95 & 2577 & 215 & 1143,8 & 2,24 & 0,02127 & 0,444 & 9,4 \\
A5 - 22/10/96 & 2608 & 221 & 1257,6 & 2,36 & 0,02085 & 0,482 & 8,7 \\
A6 - 22/10/97 & 2731 & 226 & 1359,4 & 2,3 & 0,02105 & 0,498 & 7,5 \\
A11 - 22/10/98 & 2646 & 204 & 955,7 & atm & 0,02253 & 0,361 & 13,1 \\
A12 - 22/10/99 & 2650 & 211 & 1072,3 & atm & 0,02227 & 0,405 & 12,5 \\
A17 - 22/10/100 & 2509 & 223 & 1297,6 & atm & 0,02059 & 0,517 & 10,3 \\
\hline
\end{tabular}




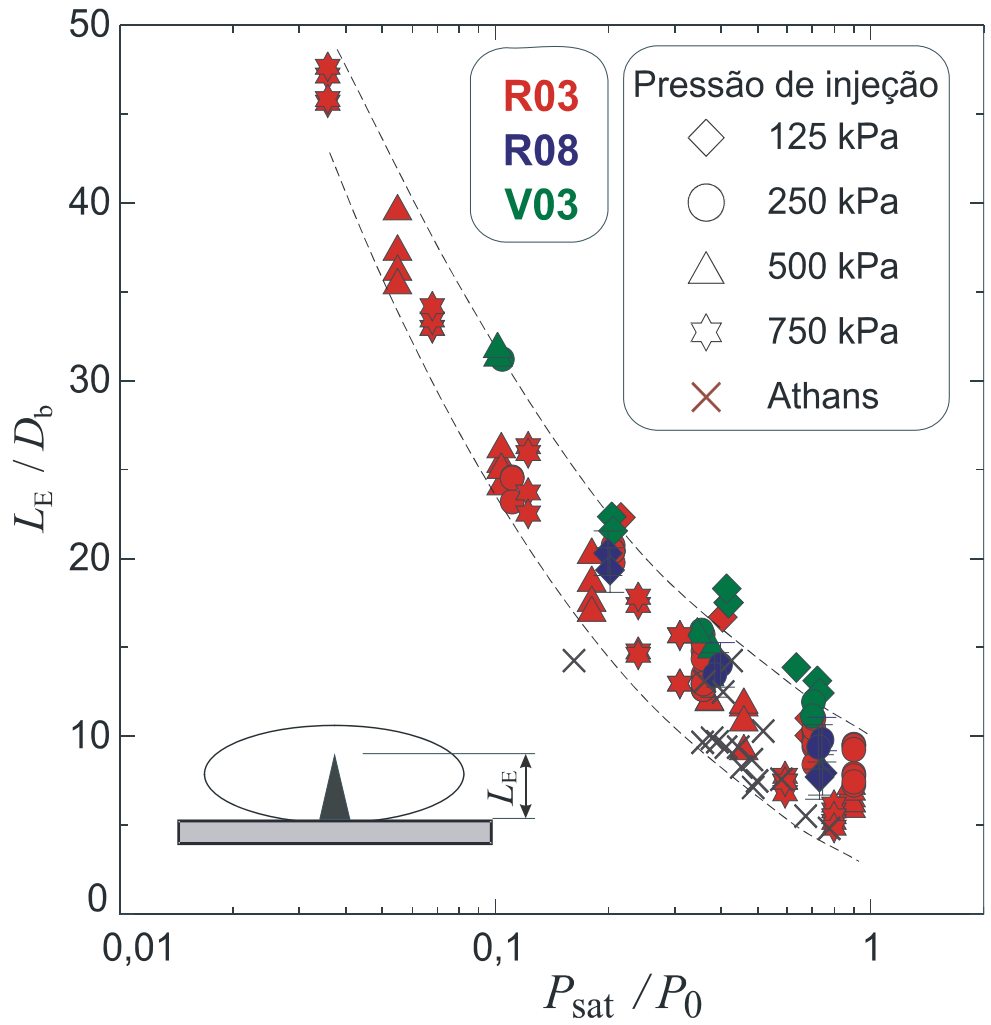

Figura 5.44 - Comparativo do comprimento de extinção do núcleo líquido normalizado em função da razão da pressão de saturação e de injeção. Uma curva de ajuste para estes dados pode ser escrita através da seguinte equação: $L_{E} / D_{b}=13,643 .\left(P_{s a t} / P_{0}\right)^{-0,607}$. O tracejado se refere ao limite inferior e superior de erro desta curva em função da precisão na medição deste comprimento que é de 3,3 para o bocal de $0,30 \mathrm{~mm}\left(\Delta L_{E} / D_{b}= \pm 1,0 / D_{b}\right)$. 


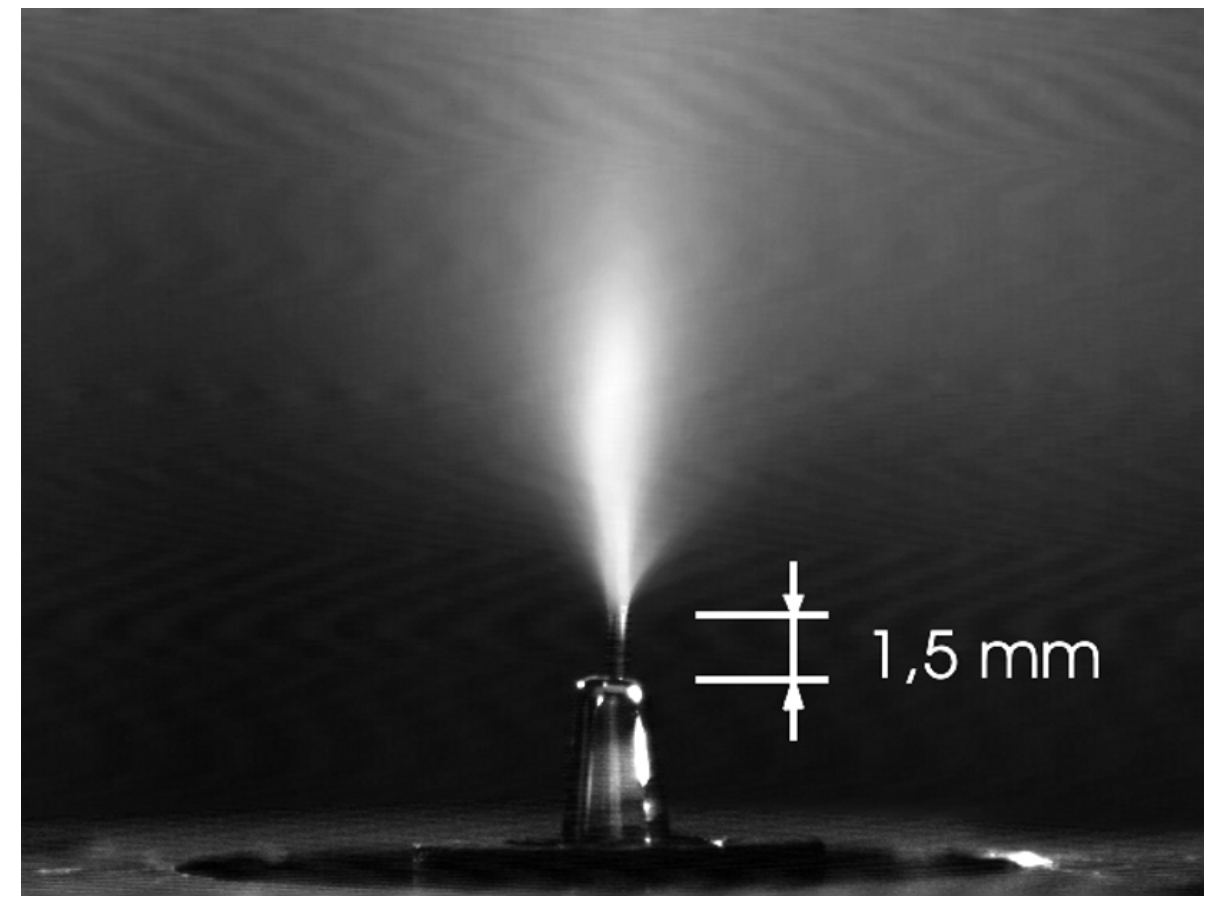

Figura 5.45 - Imagens do jato do ensaio V03 \1329m10, com condições de injeção de $121,7 \mathrm{kPa}, 56,5^{\circ} \mathrm{C}$, pressão da câmara de $0,35 \mathrm{kPa}$ e velocidade de $17,2 \mathrm{~m} / \mathrm{s}$. Nela existe a indicação do atraso da onda de evaporação, pela "Iluminação por detrás".

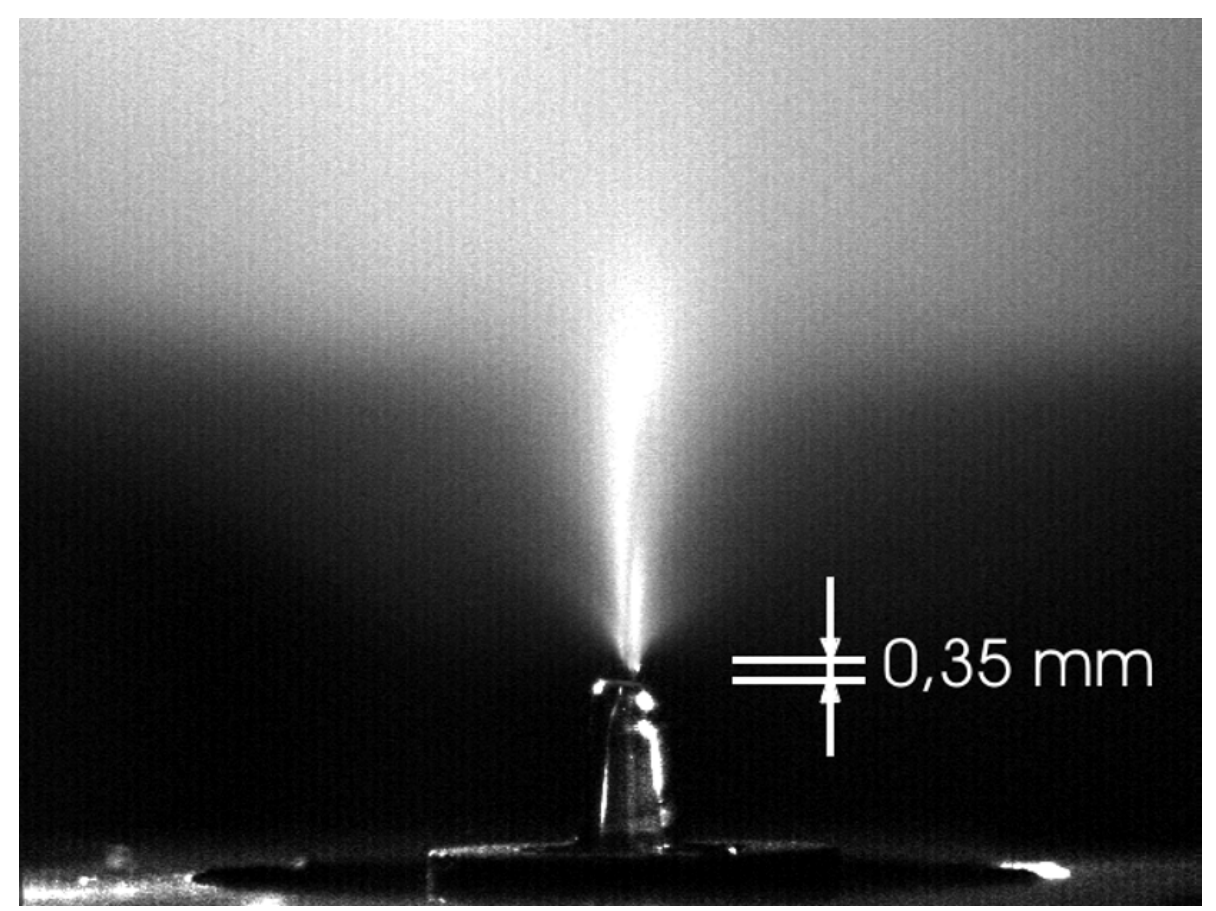

Figura 5.46 - Imagens do jato do ensaio V03\2349500, com condições de injeção de $249,9 \mathrm{kPa}, 74,8^{\circ} \mathrm{C}$, pressão da câmara de $1,70 \mathrm{kPa}$ e velocidade de $24,9 \mathrm{~m} / \mathrm{s}$. Nela existe a indicação do atraso da onda de evaporação, pela "Iluminação por detrás". 


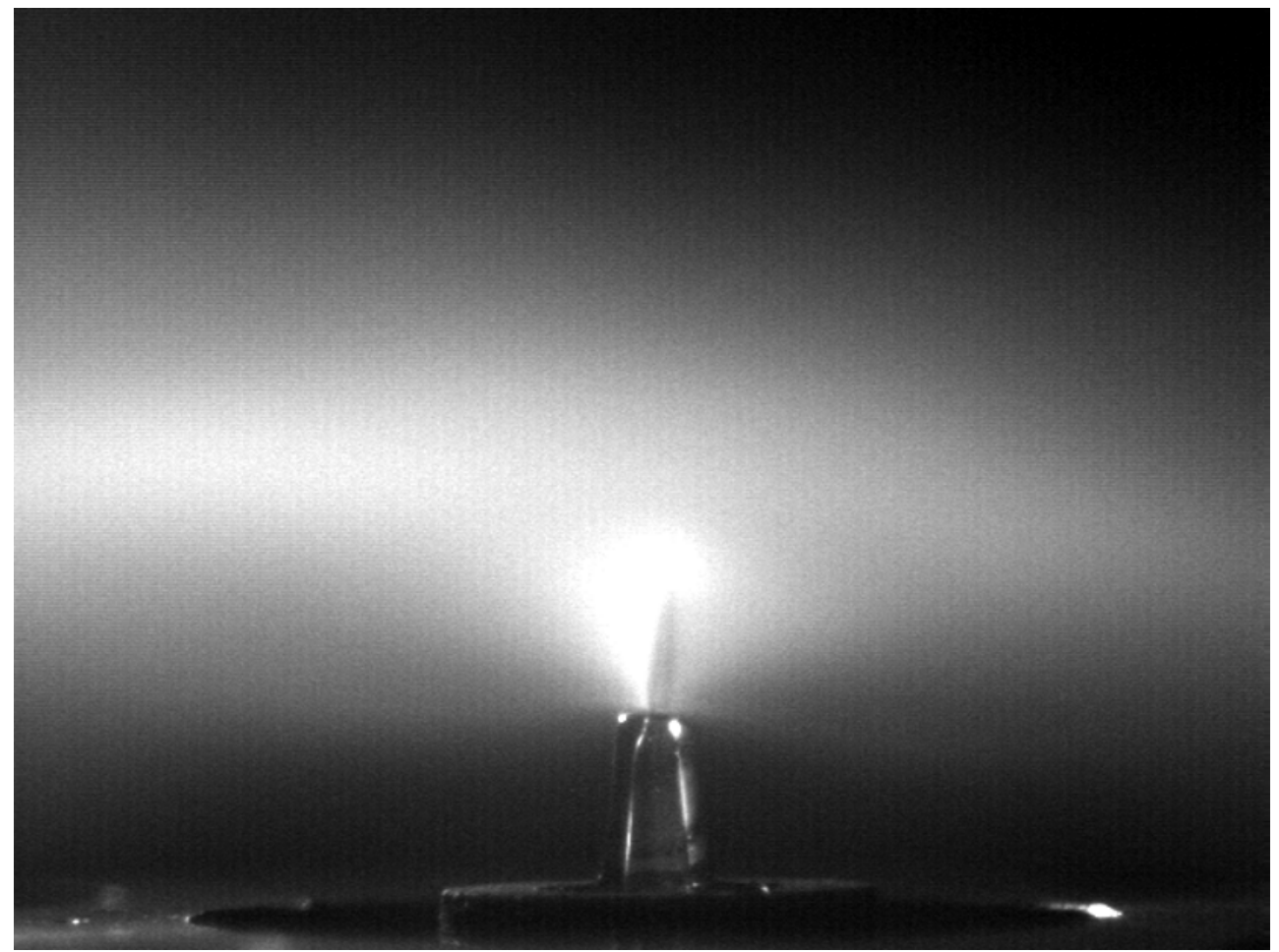

Figura 5.47 - Imagens do jato do ensaio V03 $\backslash 2393 \mathrm{~m} 10$, com condições de injeção de $250,4 \mathrm{kPa}, 120,1{ }^{\circ} \mathrm{C}$, pressão da câmara de $0,60 \mathrm{kPa}$ e velocidade de $23,8 \mathrm{~m} / \mathrm{s}$. Nela não existe um atraso da onda de evaporação perceptível.

\subsubsection{Comparação do Comportamento da Onda de Choque}

Nesta primeira análise, é mostrada a formação das ondas de choque pelos três bocais cujos experimentos estavam contidos nestas condições de injeção: $125 \mathrm{kPa}$ e $56{ }^{\circ} \mathrm{C}, 125 \mathrm{kPa}$ e $95{ }^{\circ} \mathrm{C}, 250 \mathrm{kPa}$ e $95{ }^{\circ} \mathrm{C}$ e, $250 \mathrm{kPa}$ e $120{ }^{\circ} \mathrm{C}$. Os gráficos representativos estão ilustrados nas Figs. 5.48 a 5.51. Neles é possível verificar que os ensaios, cuja pressão de injeção está mais próxima da pressão de saturação, não há grande diferenciação nas dimensões características da onda de choque em função dos diferentes bocais (Figs. 5.49 e 5.51). Estes ensaios assumem um núcleo de líquido mais curto que os demais. 
a)

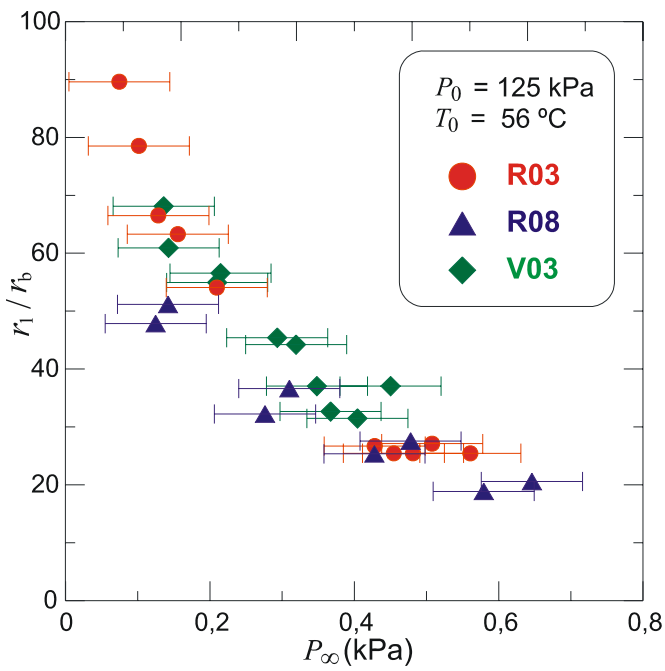

b)

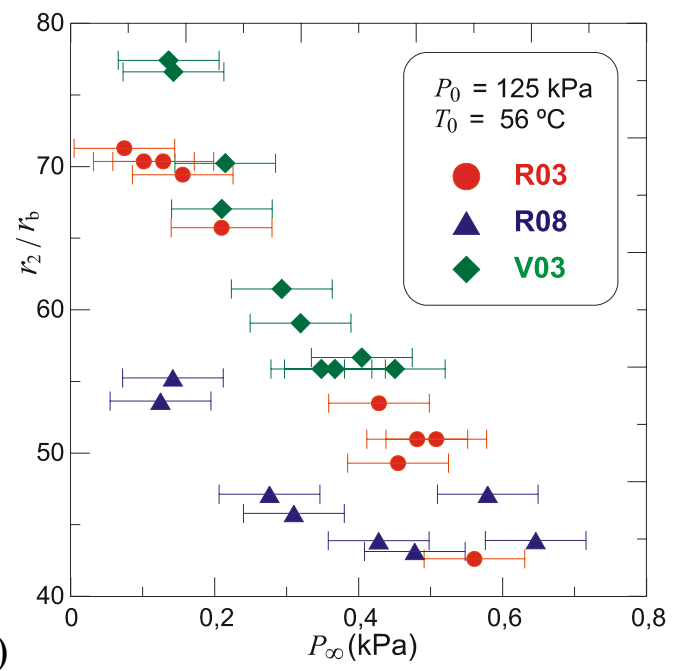

Figura 5.48 - O comprimento representativo, $r_{1}$ (a primeira imagem) e $r_{2}$ dos bocais estudados são comparados com os ensaios cuja pressão e temperatura de injeção são de $125 \mathrm{kPa}$ e $56^{\circ} \mathrm{C}$.
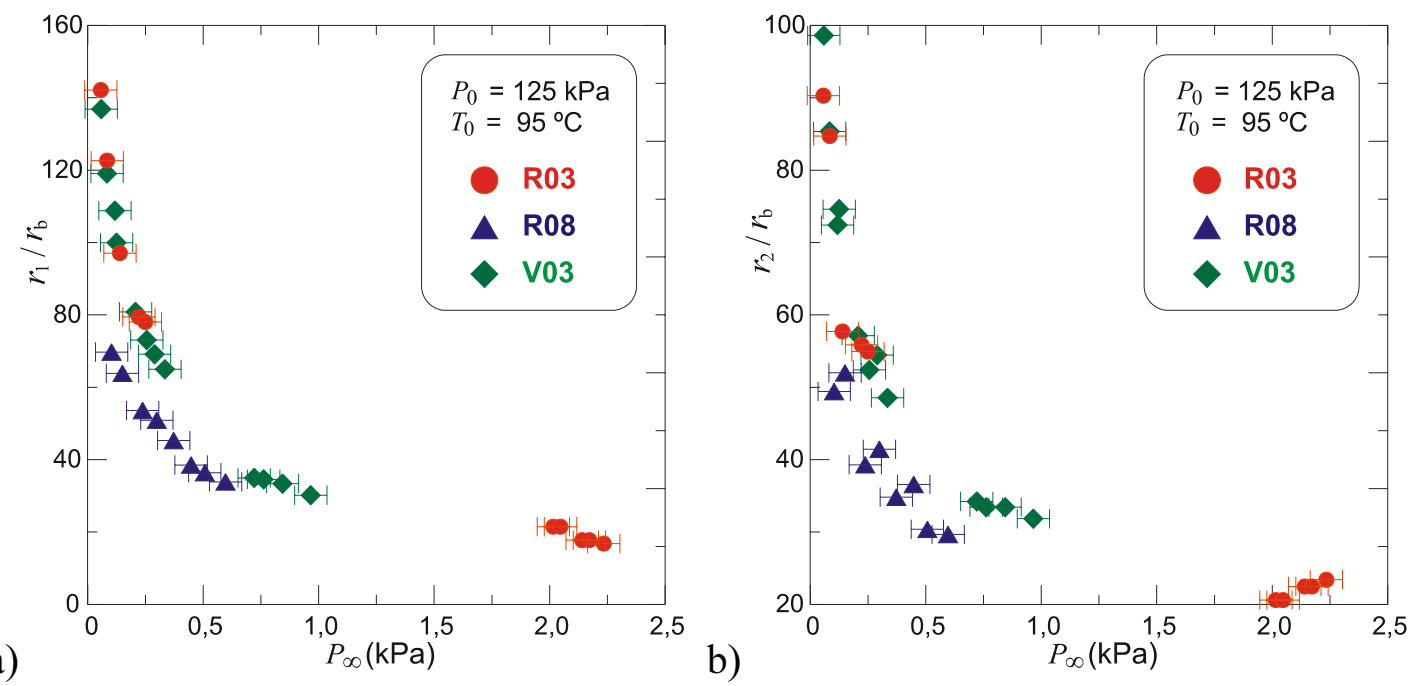

Figura 5.49 - O comprimento representativo, $r_{1}$ (a primeira imagem) e $r_{2}$ dos bocais estudados são comparados com os ensaios cuja pressão e temperatura de injeção são de $125 \mathrm{kPa}$ e $95^{\circ} \mathrm{C}$. 
a)

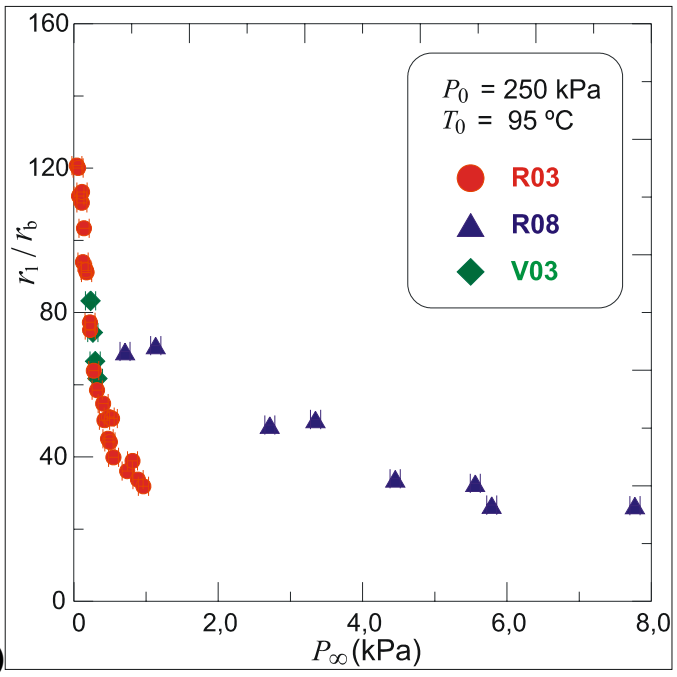

b)

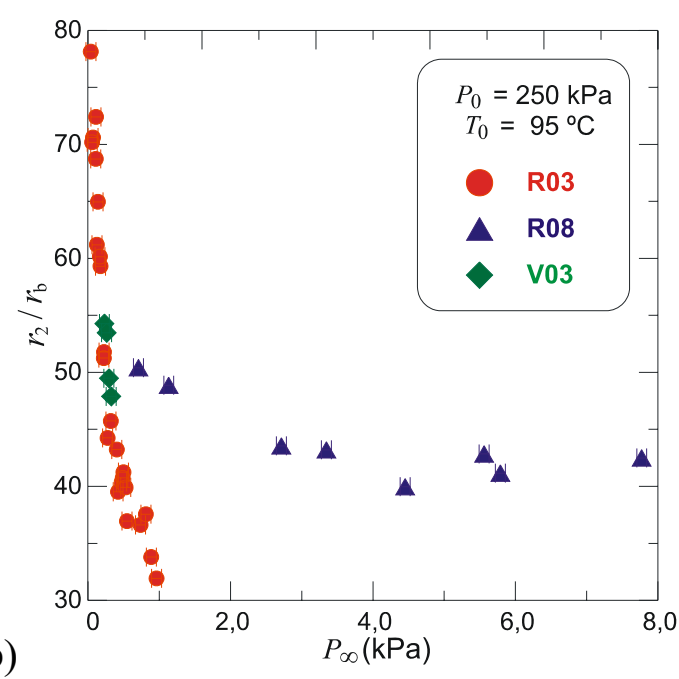

Figura 5.50 - O comprimento representativo, $r_{1}$ (a primeira imagem) e $r_{2}$ dos bocais estudados são comparados com os ensaios cuja pressão e temperatura de injeção são de $250 \mathrm{kPa}$ e $95^{\circ} \mathrm{C}$.
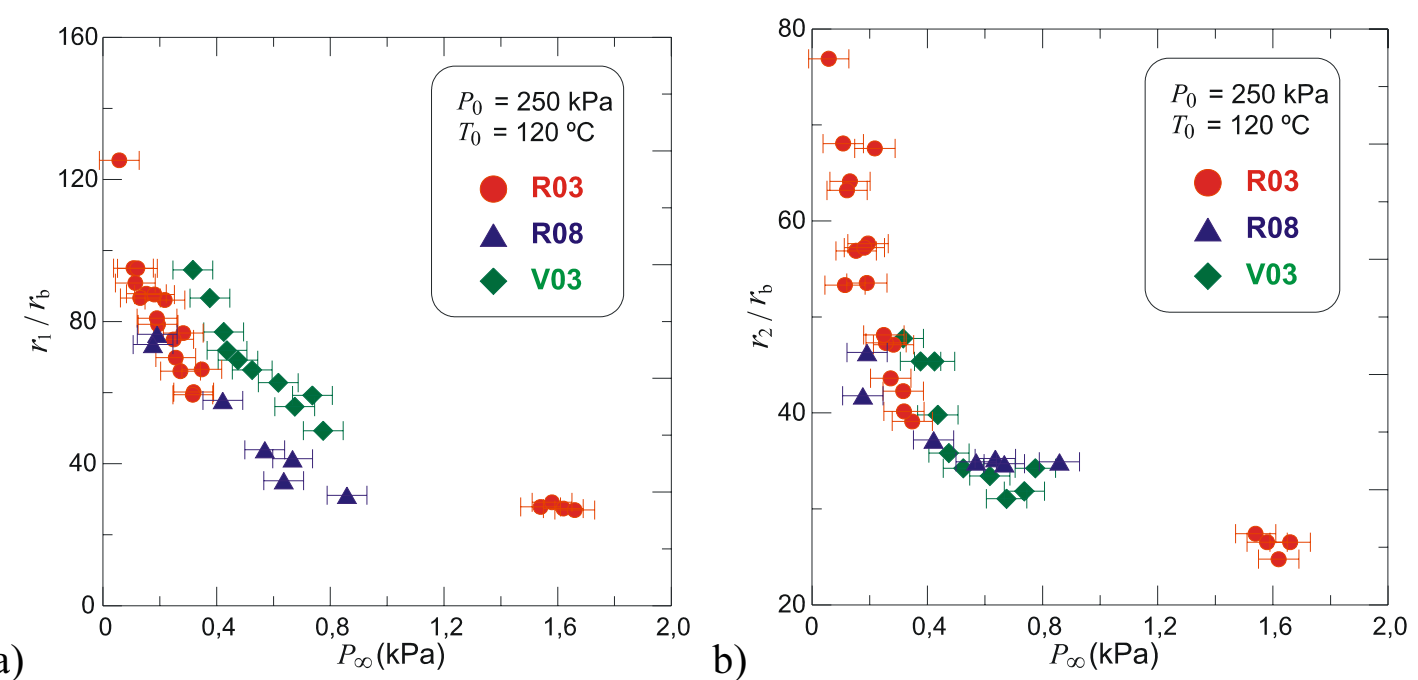

Figura 5.51 - O comprimento representativo, $r_{1}$ (a primeira imagem) e $r_{2}$ dos bocais estudados são comparados com os ensaios cuja pressão e temperatura de injeção são de $250 \mathrm{kPa}$ e $120^{\circ} \mathrm{C}$.

\subsubsection{A Influência das Condições de Injeção e do Comprimento do} Núcleo Líquido nas Dimensões da Onda de Choque

Como este trabalho lida com uma mistura líquido-vapor que parte de uma evaporação, a pressão de estagnação pode ser associada à pressão de saturação do fluido. No entanto, o termo que se refere à razão entre diâmetros pode ser convertida, 
para este caso, como a razão entre a área projetada pelo raio da onda de choque $\left(A_{1}\right)$ e a área lateral do cone de líquido $\left(A_{\mathrm{L}}\right)$ :

$$
\frac{A_{1}}{A_{L}}=\frac{\pi \cdot r_{1}^{2}}{\pi \cdot r_{b} \cdot \sqrt{r_{b}^{2}+L_{E}^{2}}} \cong \frac{r_{1}^{2}}{r_{b} \cdot L_{E}} \text {, pois. } L_{E} \gg r_{b}
$$

Como já foi visto, o comprimento do núcleo de líquido normalizado pelo diâmetro do bocal é proporcional à razão $r_{b} \cdot\left(P_{0} / P_{s a t}\right)^{0,6}, \operatorname{logo}$ :

$$
\frac{r_{1}^{2}}{r_{b} \cdot L_{E}} \propto \frac{r_{1}^{2}}{r_{b}^{2}\left(P_{0} / P_{s a t}\right)^{0,6}}
$$

Se o resultado acima é proporcional à razão entre a pressão de saturação e da câmara, $\left(P_{\text {sat }} / P_{\infty}\right)$, pode-se obter a seguinte relação:

$$
\left(\frac{r_{1}^{2}}{r_{b}^{2}\left(P_{0} / P_{s a t}\right)^{0,6}}\right) \propto\left(\frac{P_{0}}{P_{\infty}}\right) \Rightarrow\left[\frac{r_{1}^{2}}{r_{b}^{2}}\right] \propto\left[\left(\frac{P_{\text {sat }}}{P_{\infty}}\right) \cdot\left(\frac{P_{0}}{P_{\text {sat }}}\right)^{0.6}\right] .
$$

E através desta proporcionalidade (Eq. 5.3) pode-se obter o gráfico da Fig. 5.53 e verificar que, praticamente, todos os ensaios concentram-se em uma região.

Infelizmente, um gráfico semelhante que represente a distância axial normalizada, $r_{2} / r_{\mathrm{b}}$, em função das condições de injeção, independente do bocal utilizado, não foi aqui encontrado.

Tabela 5.6 - Ensaios de Athans (1995) com dimensões da onda de choque para o bocal de $0,864 \mathrm{~mm}$ de diâmetro utilizando iso-octano.

\begin{tabular}{ccccc}
\hline $\begin{array}{c}\boldsymbol{P}_{\mathbf{0}} \\
(\mathrm{kPa})\end{array}$ & $\begin{array}{c}\boldsymbol{T}_{\mathbf{0}} \\
\left({ }^{\circ} \mathrm{C}\right)\end{array}$ & $\begin{array}{c}\boldsymbol{P}_{\boldsymbol{\infty}} \\
(\mathrm{kPa})\end{array}$ & $\begin{array}{c}\boldsymbol{r}_{\mathbf{1}} \\
(\mathrm{mm})\end{array}$ & $\begin{array}{c}\boldsymbol{r}_{\mathbf{2}} \\
(\mathrm{mm})\end{array}$ \\
\hline 2397 & 204 & 5,73 & 12,5 & 15 \\
2338 & 200 & 8,25 & 7,0 & 11 \\
2293 & 200 & 9,87 & 6,5 & 12 \\
\hline
\end{tabular}




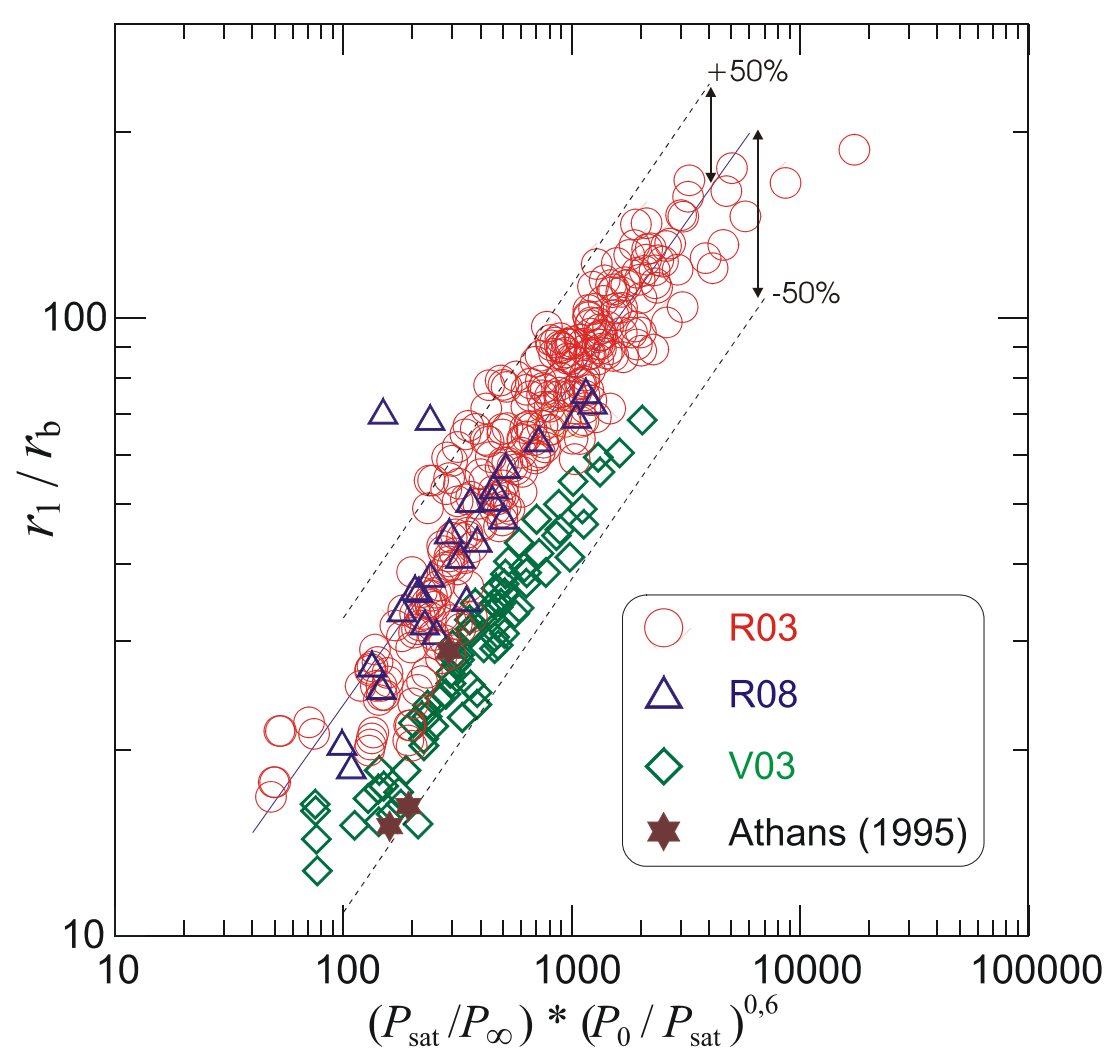

Figura 5.52 - A razão do comprimento característico $r_{1}$ pelo raio do bocal $r_{\mathrm{b}} \mathrm{em}$ função da razão da pressão de saturação e da câmara corrigido pelo fator de proporcionalidade do comprimento do núcleo líquido. As linhas tracejadas são os limites da correlação $\left(r_{1} / r_{\mathrm{b}} \pm 50 \%\right)$. No trabalho de Crist e outros (1966), para um escoamento de compressíveis de diversos gases foi obtida a correlação de $r_{1} / r_{b} \cong 0,373 *\left(P_{0} / P_{\infty}\right)^{0,523}$ enquanto a curva que melhor se ajusta para estes resultados é igual a $r_{1} / r_{b} \cong 2,152 *\left[\left(P_{\text {sat }} / P_{\infty}\right) \cdot\left(P_{0} / P_{\text {sat }}\right)^{0,6}\right]^{0,521}$.

\subsubsection{Considerações Sobre a Dimensão da Onda de Choque do Bocal de Vidro}

Ensaios com este bocal resultaram em imagens que mostram ondas de choque na parte inferior, localizada entre a saída do bocal e o início da onda de evaporação (Fig. 5.53). A onda de choque pode aumentar até a região da saída do bocal (Fig. 5.54). E, em estágios mais avançados, a sua expansão se aproxima do corpo do injetor (Fig. 5.55). 
a)

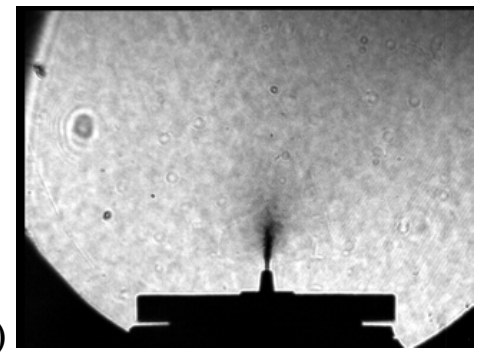

b)
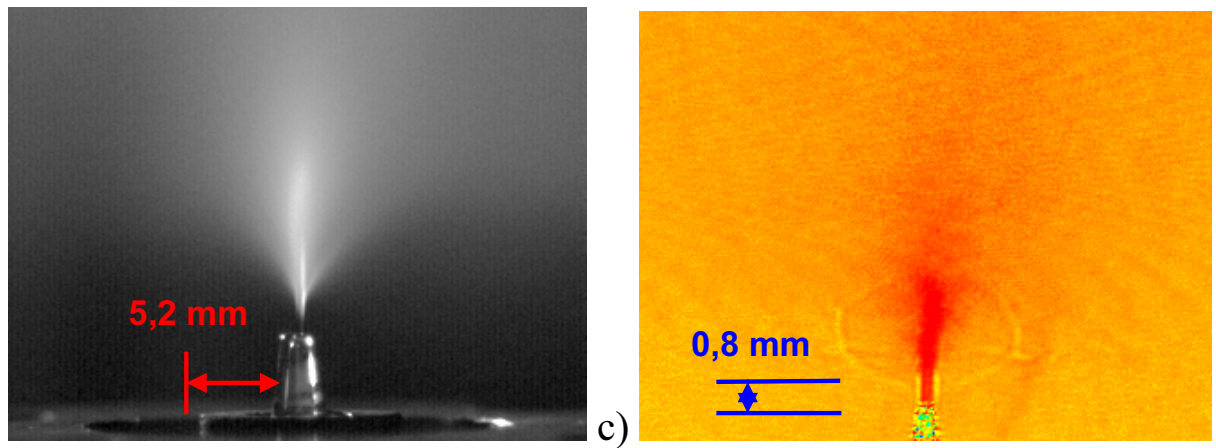

Figura 5.53 - Imagens do jato do ensaio V03\1329500 com pressão e temperatura de injeção de $123,5 \mathrm{kPa}$ e $56,7{ }^{\circ} \mathrm{C}$ e, pressão da câmara de $0,27 \mathrm{kPa}$. A primeira é a imagem original obtida pelo "Schlieren" e a segunda foi obtida pela "iluminação pro detrás". A última imagem é filtrada matematicamente da primeira e mostra a onda de choque a distância de $0,8 \mathrm{~mm}$ da saída do bocal.

a)

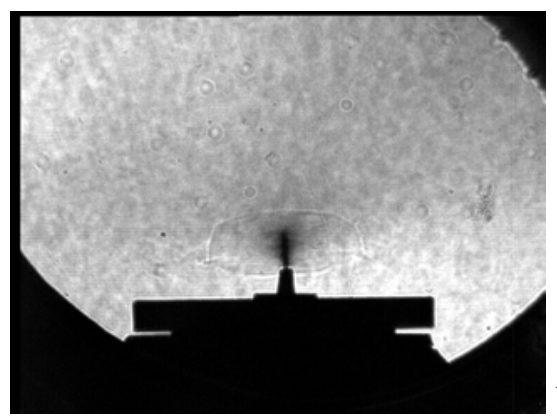

c)

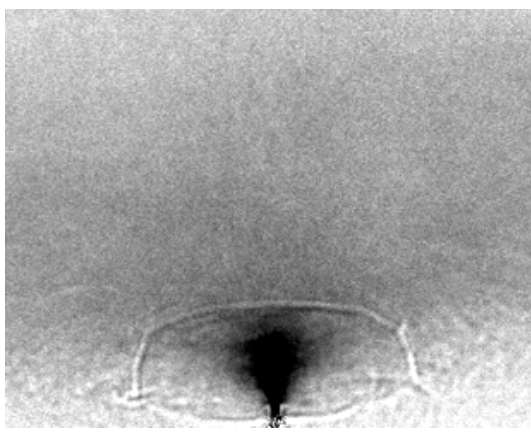

b)

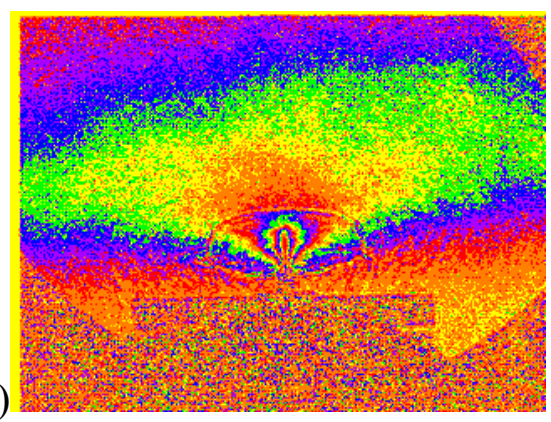

d)

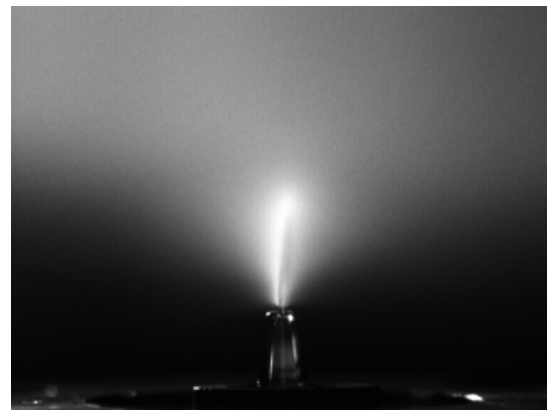

Figura 5.54 - Imagens do jato do ensaio V03\2368500 com pressão e temperatura de injeção de $250,8 \mathrm{kPa}$ e $94,4{ }^{\circ} \mathrm{C}$ e, pressão da câmara de $0,34 \mathrm{kPa}$. A primeira é a imagem original obtida pelo "Schlieren", a segunda e a terceira foram filtradas desta original. A última imagem foi obtida pela "iluminação pro detrás". 
a)
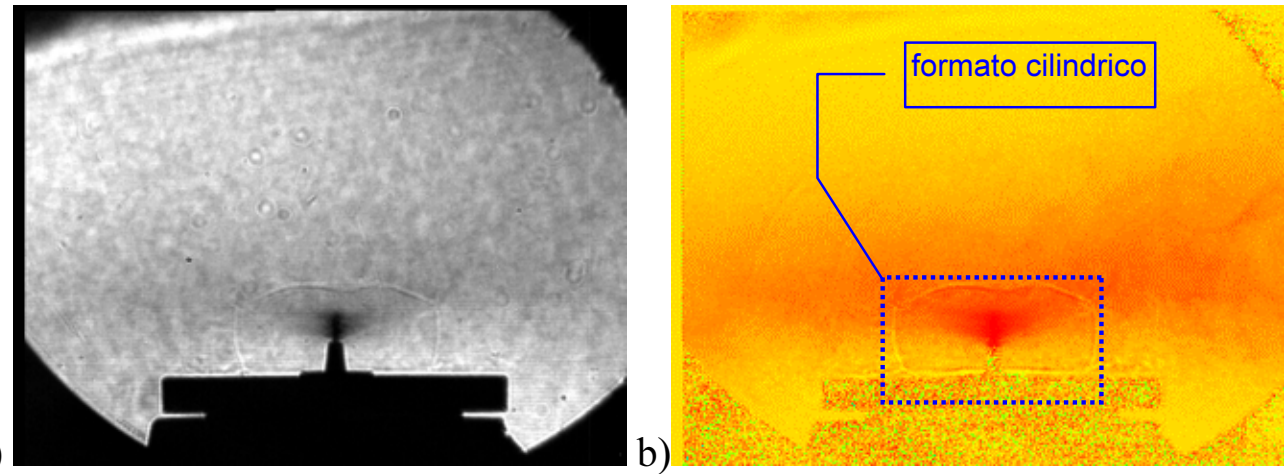

c)
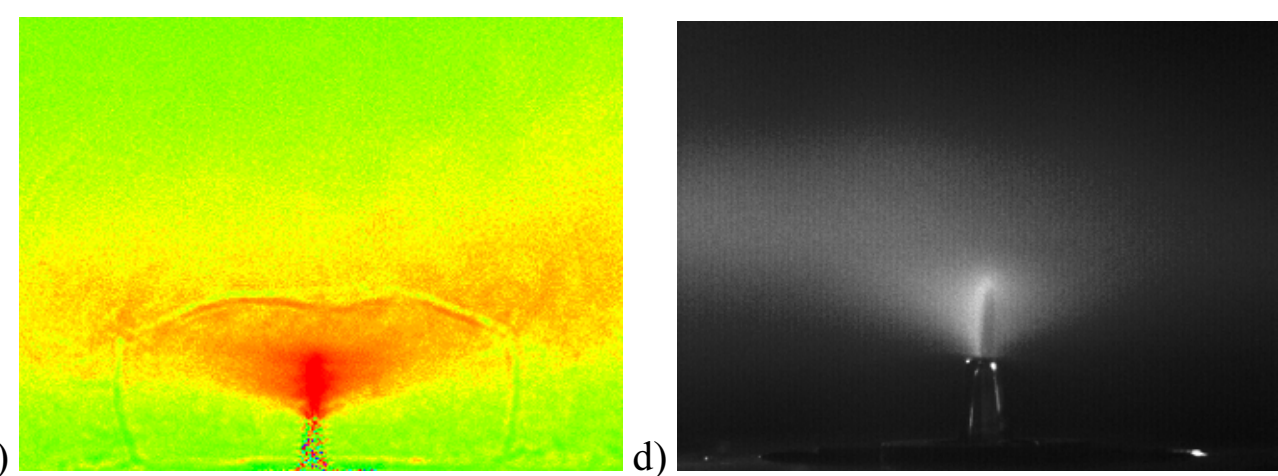

Figura 5.55 - Imagens do jato do ensaio V03\2393m10 com pressão e temperatura de injeção de $255,4 \mathrm{kPa}$ e $120,6^{\circ} \mathrm{C}$ e, pressão da câmara de $0,53 \mathrm{kPa}$. A primeira é a imagem original obtida pelo "Schlieren" e tanto a segunda como a terceira foram filtradas desta original. A última imagem foi obtida pela "iluminação pro detrás".

Tomando a imagem do primeiro caso (Fig. 5.53), se as condições de injeção se mantiverem constantes, e apenas fosse diminuído a pressão da câmara com o propósito de expandir a onda de choque, como nos casos das Figs. 5.54 e 5.55, não é possível determinar a diferença da pressão metaestável. As incertezas associadas a esta medição são maiores que as diferenças que devem ser encontradas para estas diferentes configurações. Como exemplo, são mostradas as imagens dos ensaios V03\1368100 e V03\1368500 na Fig. 5.56 que apresentaram a mesma pressão metaestável, praticamente, de 23,2 e 22,5 $\mathrm{kPa}$.

Os ensaios do bocal de vidro foram os que apresentaram uma onda de choque com um formato quase cilíndrico. Como nos casos da seção anterior, algumas imagens indicam ondas de choque reflexivas. 
a)

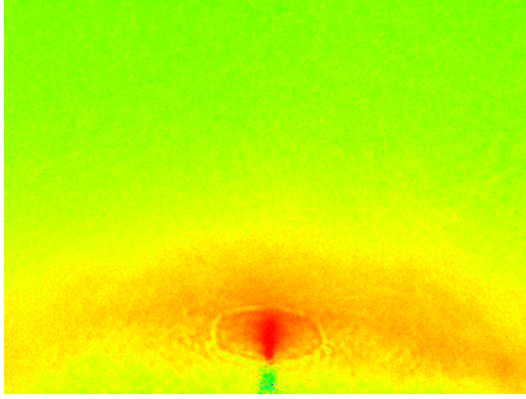

b)

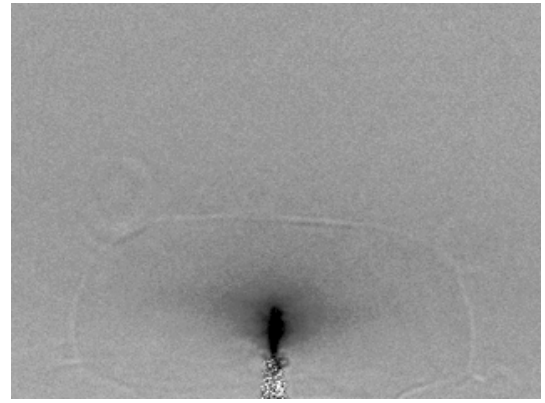

Figura 5.56 - Imagens dos jatos dos ensaios V03\1368100 e V03\1368500, respectivamente. Suas pressões de injeção eram de 123,2 e $123,7 \mathrm{kPa}$, temperatura de $94,4{ }^{\circ} \mathrm{C}$ e $95,0{ }^{\circ} \mathrm{C}$ e, pressões da câmara de 0,86 e $0,23 \mathrm{kPa}$. As pressões metaestáveis calculadas eram de 23,2 e $22,5 \mathrm{kPa}$ e a incerteza associada é de $\pm 5 \mathrm{kPa}$. 


\section{APLICAÇÃo da TEORIA da ONDA de EVAPORAÇÃo NOS JATOS}

\subsection{Cálculo do Núcleo de Líquido}

A análise do núcleo de líquido revela importantes informações sobre o fenômeno evaporativo. A modelagem do núcleo de líquido assume que a evaporação se dá por meio de uma onda oblíqua de choque de evaporação, conforme já discutido na Seção 2.4. Nesse processo, a estabilidade do núcleo e o seu comprimento de extinção, $L_{\mathrm{E}}$, são muito relevantes.

Como visto na Seção 2.6 (Fig. 2.12), o líquido parte de uma pressão e temperatura de injeção e, escoando pelo bocal, vem a se tornar metaestável, na sua seção de saída. A expansão interna ao bocal é considerada praticamente isotérmica e, portanto, admiti-se que o líquido, ao deixar o bocal, alcança uma pressão metaestável, inferida pelas medidas da vazão mássica. O líquido emergente passa então a sofrer um processo abrupto evaporativo, como uma onda de evaporação oblíqua, ou seja, a evaporação se dá na superfície do núcleo de líquido. De acordo com a modelagem física abordada por Simões-Moreira e outros (2002), a mudança de fase do líquido metaestável resulta em uma mistura bifásica sônica, com o número de Mach unitário, perfazendo a jusante da onda oblíqua evaporativa. Esta mistura bifásica expande livremente alcançando velocidades crescentes acompanhada, como de usual, por um aumento do número de Mach e rebaixamento das demais propriedades. A expansão termina com a formação de uma onda de choque, para o ajuste de pressão.

Em termos de modelagem, deve-se conhecer a temperatura e pressão de injeção e a pressão metaestável, que é calculada a partir da equação do bocal (Eq. 4.4). Com estas informações é possível calcular as propriedades a jusante da onda de evaporação (estado “2”), assumindo a condição sônica a jusante, também chamada de condição de Chapman-Jouguet (índice “CJ”). Assim, é possível obter a vazão superficial mássica da lateral do cone $\left(J_{\mathrm{CJ}}\right)$ que é constante em toda a periferia do núcleo líquido. Como já foi mostrado (Seção 2.4), através das vazões mássicas do 
bocal, $J_{\mathrm{b}}$, e do cone líquido, $J_{\mathrm{CJ}}$, determina-se o ângulo da onda, $\beta$, e o comprimento do núcleo líquido, $L_{\mathrm{E}}$ :

$$
\operatorname{sen} \beta=\frac{J_{\mathrm{CJ}}}{J_{\mathrm{b}}} \quad \Rightarrow \quad L_{E}=r_{b} \sqrt{\left(\frac{J_{\mathrm{b}}}{J_{\mathrm{CJ}}}\right)^{2}-1} .
$$

A Tab. 6.1 mostra os dados experimentais obtidos em função das condições de injeção $\left(P_{\text {inj }}\right.$ e $\left.T_{\text {inj }}\right)$. Nela estão a pressão de saturação, a pressão metaestável do líquido, o volume específico do líquido, $v_{1}$, a vazão mássica, $\dot{m}$, a vazão superficial do bocal, o comprimento do cone líquido e o ângulo de giro da mistura bifásica, $\theta$.

Tabela 6.1 - Resultados experimentais médios obtidos pelas séries de ensaios do bocal R03.

\begin{tabular}{|c|c|c|c|c|c|c|c|c|c|}
\hline $\begin{array}{c}\text { Série } \\
\text { de ensaios }\end{array}$ & $\begin{array}{c}P_{\text {inj }} \\
(\mathrm{kPa}) \\
\end{array}$ & $\begin{array}{r}T_{\text {inj }} \\
\left({ }^{\circ} \mathrm{C}\right) \\
\end{array}$ & $\begin{array}{c}P_{\text {sat }} \\
(\mathrm{kPa}) \\
\end{array}$ & $\begin{array}{c}P_{1 \mathrm{~m}} \\
(\mathrm{kPa}) \\
\end{array}$ & $\begin{array}{c}v_{1} \\
\left(\mathrm{~m}^{3} / \mathrm{kg}\right) \\
\end{array}$ & $\begin{array}{c}\dot{m} \\
(\mathrm{~g} / \mathrm{s}) \\
\end{array}$ & $\begin{array}{c}J_{\mathrm{bm}} \\
\left(\mathrm{kg} / \mathrm{m}^{2} \cdot \mathrm{s}\right)\end{array}$ & $\begin{array}{c}L_{\mathrm{E}} \\
(\mathrm{mm}) \\
\end{array}$ & $\begin{array}{r}\theta \\
(9) \\
\end{array}$ \\
\hline R03\1329 & 125 & 56 & 27,1 & 4,6 & 0,001537 & 0,8354 & 11177 & 6,2 & 39,5 \\
\hline R03\1349 & 125 & 76 & 50,5 & 8,9 & 0,001569 & 0,8287 & 11086 & 4,2 & 45,0 \\
\hline R03\1368 & 125 & 95 & 87,4 & 12,9 & 0,001596 & 0,8120 & 10863 & 2,3 & 48,0 \\
\hline R03\2329 & 250 & 56 & 27,7 & 8,6 & 0,001538 & 1,2207 & 16331 & 7,4 & 39,7 \\
\hline R03\2349 & 250 & 76 & 51,3 & 16,0 & 0,001569 & 1,1846 & 15931 & 6,3 & 30,8 \\
\hline R03\2368 & 250 & 95 & 89,5 & 36,3 & 0,001598 & 1,1263 & 15110 & 4,3 & 42,8 \\
\hline R03\2393 & 250 & 120 & 176,7 & 97,5 & 0,001643 & 0,9378 & 12584 & 3,1 & 47,4 \\
\hline R03।2404 & 250 & 131 & 222,6 & 133,0 & 0,001665 & 0,8240 & 11105 & 2,9 & 40,0 \\
\hline R03\5329 & 500 & 56 & 27,2 & 13,9 & 0,001538 & 1,7485 & 23392 & 11,5 & 36,8 \\
\hline R03\5349 & 500 & 76 & 51,5 & 30,8 & 0,001569 & 1,7009 & 22755 & 7,8 & 34,0 \\
\hline R03।5368 & 500 & 95 & 90,5 & 49,6 & 0,001598 & 1,6447 & 22176 & 5,7 & 43,0 \\
\hline R03\5393 & 500 & 120 & 183,8 & 128,3 & 0,001647 & 1,4607 & 19663 & 3,9 & 43,6 \\
\hline R03\5404 & 500 & 131 & 231,3 & 166,9 & 0,001670 & 1,3902 & 18669 & 3,6 & 45,0 \\
\hline R03।5435 & 500 & 162 & 442,1 & 334,8 & 0,001771 & 1,0008 & 13442 & 2,1 & 46,2 \\
\hline R03।7329 & 750 & 56 & 26,8 & 21,5 & 0,001537 & 2,1486 & 28744 & 14,4 & 34,3 \\
\hline R03।7349 & 750 & 76 & 51,1 & 42,7 & 0,001570 & 2,1012 & 28111 & 10,3 & 33,8 \\
\hline R03।7368 & 750 & 95 & 92,1 & 77,3 & 0,001599 & 2,0215 & 27044 & 7,6 & 32,3 \\
\hline R03।7393 & 750 & 120 & 180,3 & 167,0 & 0,001645 & 1,8664 & 24969 & 5,0 & 39,5 \\
\hline R03।7404 & 750 & 131 & 233,7 & 221,5 & 0,001671 & 1,7681 & 23654 & 4,4 & 42,8 \\
\hline R03।7435 & 750 & 162 & 443,7 & 416,4 & 0,001772 & 1,3588 & 18178 & 2,3 & 47,6 \\
\hline R03\7451 & 750 & 178 & 607,4 & 545,3 & 0,001851 & 1,0498 & 14044 & 1,7 & 47,4 \\
\hline
\end{tabular}


Tabela 6.2 - Resultados calculados das séries de ensaios do bocal R03 a jusante da onda de evaporação.

\begin{tabular}{|c|c|c|c|c|c|c|c|c|c|c|c|}
\hline $\begin{array}{c}\text { Série } \\
\text { de ensaios }\end{array}$ & $\begin{array}{c}P_{2} \\
(\mathrm{kPa})\end{array}$ & $\begin{array}{c}T_{2} \\
\left({ }^{\circ} \mathrm{C}\right)\end{array}$ & $x_{2}$ & $\begin{array}{c}v_{2} \\
\left(\mathrm{~m}^{3} / \mathrm{kg}\right)\end{array}$ & $\begin{array}{c}J_{\mathrm{CJ}} \\
\left(\mathrm{kg} / \mathrm{m}^{2} \mathrm{~s}\right)\end{array}$ & $\begin{array}{c}u_{2} \\
(\mathrm{~m} / \mathrm{s}) \\
\end{array}$ & $\operatorname{sen}(\beta)$ & $\begin{array}{c}L_{\mathrm{E}} \\
(\mathrm{mm})\end{array}$ & $\begin{array}{c}\text { erro } L_{\mathrm{E}} \\
\% \\
\end{array}$ & $\begin{array}{c}\theta \\
(9)\end{array}$ & $\begin{array}{c}\text { erro } \theta \\
\%\end{array}$ \\
\hline R03\1329 & 1,8 & 1,0 & 0,348 & 3,9755 & 20,2 & 80,46 & 0,00176 & 86,5 & 1299,6 & 77,5 & 96,2 \\
\hline R03\1349 & 3,5 & 12,2 & 0,407 & 2,5973 & 34,6 & 89,76 & 0,00302 & 50,3 & 1109,7 & 78,5 & 74,5 \\
\hline R03\1368 & 6,6 & 25,0 & 0,461 & 1,5897 & 63,3 & 100,62 & 0,00565 & 26,9 & 1090,7 & 79,6 & 65,8 \\
\hline R03\2329 & 5,0 & 19,4 & 0,242 & 1,1053 & 57,2 & 63,26 & 0,00340 & 44,7 & 501,4 & 67,5 & 70,3 \\
\hline R03\2349 & 13,2 & 40,4 & 0,247 & 0,4527 & 140,9 & 63,81 & 0,00863 & 17,6 & 180,1 & 67,6 & 119,6 \\
\hline R03।2368 & 32,2 & 63,3 & 0,231 & 0,1834 & 319,3 & 58,54 & 0,02047 & 7,4 & 71,6 & 65,8 & 53,7 \\
\hline R0312393 & 60,5 & 81,9 & 0,298 & 0,1356 & 527,8 & 71,58 & 0,04080 & 3,7 & 19,0 & 71,1 & 50,0 \\
\hline R03\2404 & 83,3 & 92,3 & 0,302 & 0,1011 & 709,0 & 71,69 & 0,06237 & 2,4 & $-15,0$ & 71,7 & 79,1 \\
\hline R03।5329 & 9,5 & 32,7 & 0,162 & 0,4059 & 116,3 & 47,19 & 0,00482 & 31,5 & 173,9 & 51,6 & 40,3 \\
\hline R03।5349 & 17,8 & 47,5 & 0,206 & 0,2833 & 191,8 & 54,31 & 0,00817 & 18,6 & 137,6 & 55,4 & 62,9 \\
\hline R03।5368 & 41,5 & 70,5 & 0,186 & 0,1196 & 430,7 & 51,50 & 0,01898 & 8,0 & 40,1 & 53,8 & 25,1 \\
\hline R03\5393 & 91,2 & 95,3 & 0,220 & 0,0681 & 807,4 & 55,00 & 0,04007 & 3,8 & $-3,6$ & 56,6 & 29,9 \\
\hline R03।5404 & 125,7 & 106,9 & 0,207 & 0,0476 & 1068,7 & 50,84 & 0,05572 & 2,7 & $-24,1$ & 54,6 & 21,4 \\
\hline R03\5435 & 223,9 & 130,0 & 0,297 & 0,0393 & 1667,5 & 65,60 & 0,12078 & 1,3 & $-40,4$ & 62,8 & 35,8 \\
\hline R03।7329 & 15,4 & 43,8 & 0,089 & 0,1418 & 206,1 & 29,23 & 0,00695 & 21,8 & 52,1 & 32,3 & $-5,8$ \\
\hline R03।7349 & 31,3 & 62,5 & 0,107 & 0,0883 & 362,6 & 32,00 & 0,01251 & 12,1 & 17,9 & 34,4 & 1,9 \\
\hline R03।7368 & 60,9 & 82,1 & 0,108 & 0,0499 & 650,0 & 32,43 & 0,02331 & 6,5 & $-14,2$ & 34,7 & 7,6 \\
\hline R03।7393 & 134,5 & 109,5 & 0,102 & 0,0229 & 1239,0 & 28,41 & 0,04812 & 3,2 & $-36,7$ & 31,1 & $-21,2$ \\
\hline R03।7404 & 202,1 & 125,4 & 0,061 & 0,0103 & 1788,6 & 18,39 & 0,07333 & 2,1 & $-53,2$ & 20,1 & $-52,9$ \\
\hline R03।7435 & 340,1 & 148,6 & 0,135 & 0,0131 & 2597,9 & 33,98 & 0,13859 & 1,1 & $-52,1$ & 38,0 & $-20,2$ \\
\hline R03।7451 & 402,9 & 156,7 & 0,221 & 0,0172 & 2839,3 & 48,95 & 0,19606 & 0,8 & $-55,2$ & 50,5 & 6,4 \\
\hline
\end{tabular}

A Tab. 6.2 contém os valores das propriedades a jusante da onda de evaporação calculados através das condições de injeção $\left(P_{\text {inj }}\right.$ e $\left.T_{\text {inj }}\right)$ e da pressão metaestável do líquido correspondentes às séries de ensaios da Tab. 6.1. Nela estão indicados a pressão $\left(P_{2}\right)$ e temperatura $\left(T_{2}\right)$ a jusante da onda, o título, $x_{2}$, o volume específico da mistura, $v_{2}$, a vazão superficial, $J_{\mathrm{CJ}}$, o seno do semi-ângulo do cone, o comprimento do cone líquido e o ângulo de giro do fluido calculados e os erros percentuais decorrentes deste cálculo.

A Fig. 6.1 ilustra graficamente os resultados desta dimensão do cone de líquido tomando os dados calculados e os encontrados experimentalmente. A faixa de incerteza do calculado é decorrente do erro existente na pressão metaestável do líquido. $\mathrm{O}$ traço vertical corresponde à faixa de confiabilidade para determinação do comprimento na imagem do jato. Similarmente, a Fig. 6.2 apresenta um gráfico que relaciona o ângulo de giro $(\theta)$ calculado e o experimental. Devido à técnica de visualização, no caso, a iluminação por detrás, não existe uma definição clara o suficiente para a obtenção correta deste ângulo nas imagens dos jatos, por isto, foi apresentado com uma faixa de erro de $\pm 20^{\circ}$. Uma representação da medição do 
ângulo de giro é feita na Fig. 6.3 do ensaio 7349500 onde é possível observar a dificuldade de se obter tal medida já que a técnica integra o escoamento por toda a volta do cone líquido. A melhor técnica seria o "laser sheet" ou lâmina de "laser" cuja iluminação passa exclusivamente no eixo central do jato.

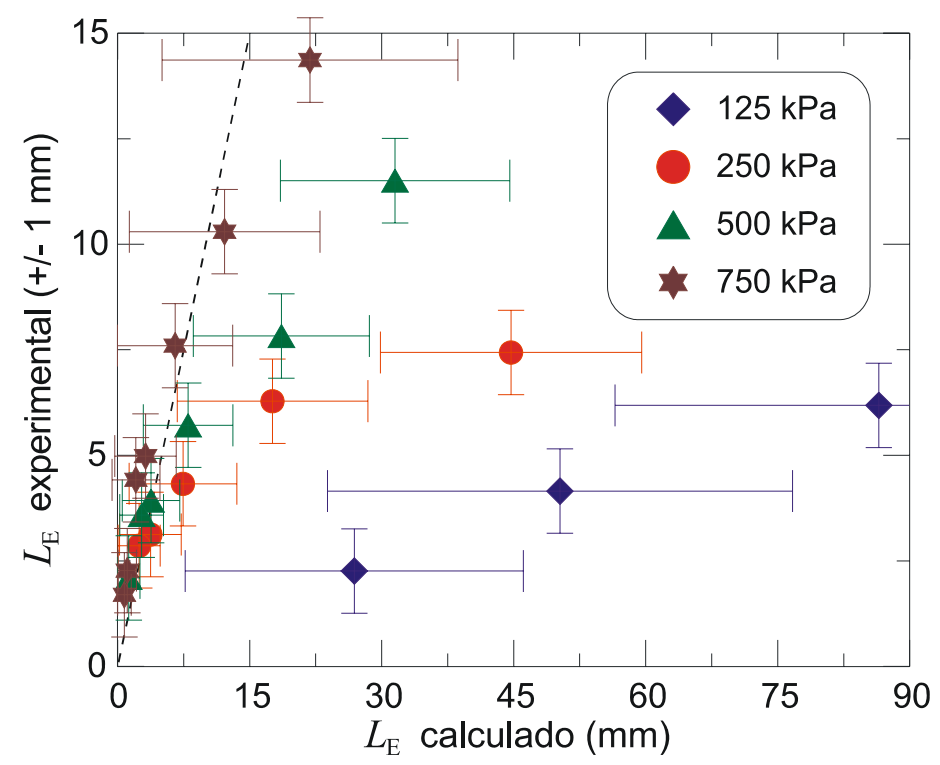

Figura 6.1 - Comparação do comprimento do núcleo de líquido experimental e o calculado do bocal R03.

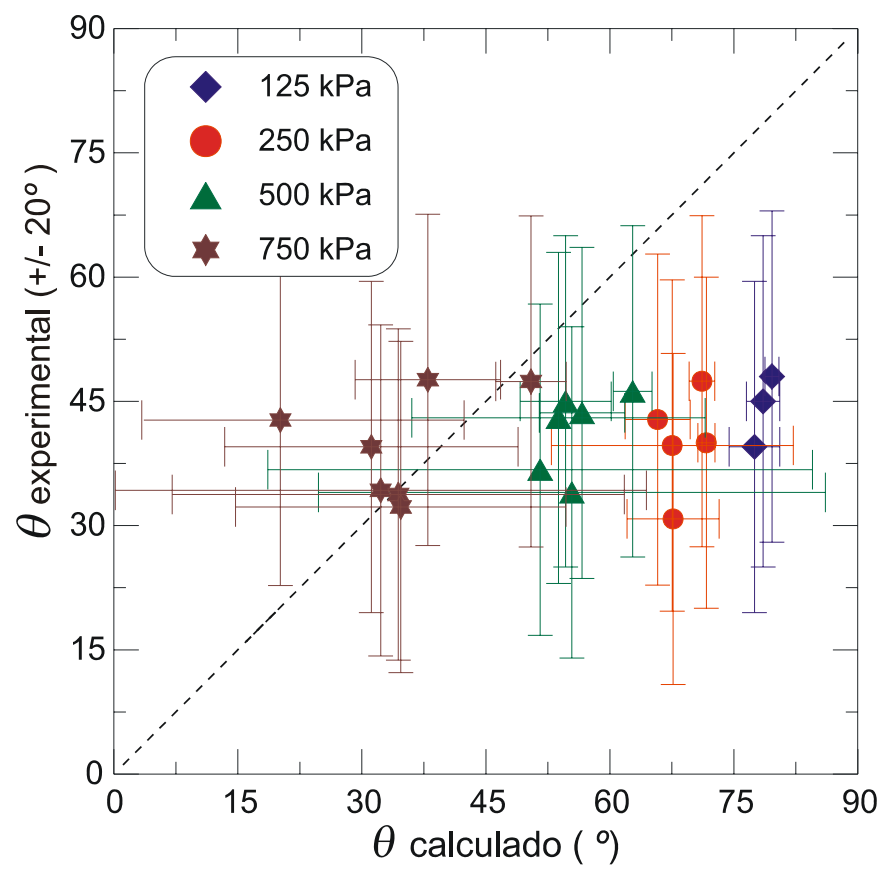

Figura 6.2 - Comparação do ângulo de giro experimental e o calculado do bocal R03. 


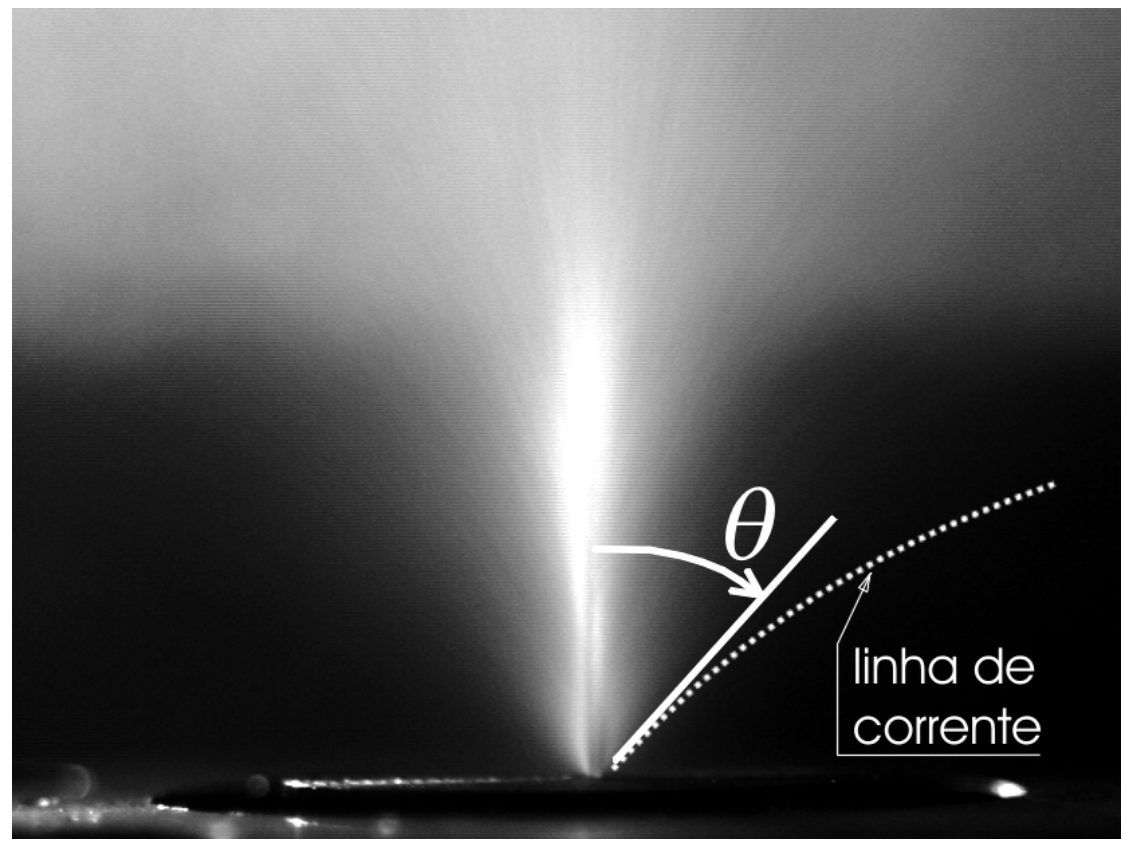

Figura 6.3 - Exemplo de medição do ângulo de giro do jato do ensaio 7349500 . Este ângulo corresponde à tangente da trajetória do fluido quando parte da onda de evaporação. Devido à técnica de "iluminação por detrás", este procedimento envolve uma grande incerteza experimental.

Também feito um levantamento do comprimento de extinção do núcleo de líquido dos outros bocais e estão apresentados nas Figs. 6.4 e 6.5 cujos dados estão indicados na Tab. 6.3 e 6.4 .

Tabela 6.3 - Resultados experimentais médios obtidos pelas séries de ensaios do bocal R08 (de aço com 0,8 mm de diâmetro) e bocal V03 (de vidro com diâmetro de $0,35 \mathrm{~mm})$.

\begin{tabular}{|c|c|c|c|c|c|c|c|c|}
\hline $\begin{array}{c}\text { Série } \\
\text { de ensaios }\end{array}$ & $\begin{array}{c}P_{\text {inj }} \\
(\mathrm{kPa})\end{array}$ & $\begin{array}{l}T_{\text {inj }} \\
\left({ }^{\circ} \mathrm{C}\right)\end{array}$ & $\begin{array}{c}P_{\text {sat }} \\
(\mathrm{kPa})\end{array}$ & $\begin{array}{c}P_{1 \mathrm{~m}} \\
(\mathrm{kPa})\end{array}$ & $\begin{array}{c}v_{1} \\
\left(\mathrm{~m}^{3} / \mathrm{kg}\right) \\
\end{array}$ & $\begin{array}{c}\dot{m} \\
(\mathrm{~g} / \mathrm{s})\end{array}$ & $\begin{array}{c}J_{\mathrm{bm}} \\
\left(\mathrm{kg} / \mathrm{m}^{2} \cdot \mathrm{s}\right)\end{array}$ & $\begin{array}{c}L_{\mathrm{E}} \\
(\mathrm{mm})\end{array}$ \\
\hline R08\1056 & 125 & 56 & 24,34 & 22,87 & 0,0015100 & 5,0227 & 10647 & 15,8 \\
\hline R08\1095 & 125 & 95 & 90,42 & 65,32 & 0,0015980 & 3,7430 & 7935 & 6,3 \\
\hline R08\2095 & 250 & 95 & 95,38 & 70,04 & 0,0015860 & 6,4849 & 13747 & 10,9 \\
\hline $\mathrm{R} 0812120$ & 250 & 120 & 179,54 & 143,18 & 0,0016500 & 5,1950 & 11013 & 7,7 \\
\hline V03\1329 & 125 & 56 & 25,2 & 6,8 & 0,001512 & 1,1586 & 11257 & 7,7 \\
\hline V03\1349 & 125 & 76 & 51,1 & 15,4 & 0,001555 & 1,1100 & 10785 & 6,2 \\
\hline V03\1368 & 125 & 95 & 90,0 & 22,7 & 0,001597 & 1,1059 & 10745 & 4,6 \\
\hline V03\2329 & 250 & 56 & 25,9 & 18,1 & 0,001514 & 1,6576 & 16105 & 10,9 \\
\hline V03\2349 & 250 & 76 & 49,9 & 26,0 & 0,001553 & 1,6262 & 15800 & 7,9 \\
\hline V03\2368 & 250 & 95 & 88,8 & 28,6 & 0,001596 & 1,6133 & 15675 & 5,6 \\
\hline V0312393 & 250 & 120 & 177,5 & 60,3 & 0,001665 & 1,4850 & 14428 & 4,0 \\
\hline V03।5349 & 500 & 76 & 51,0 & 41,8 & 0,001554 & 2,3589 & 22919 & 11,1 \\
\hline V03\5393 & 500 & 120 & 180,2 & 89,1 & 0,001667 & 2,1853 & 21233 & 5,4 \\
\hline
\end{tabular}


Tabela 6.4 - Resultados calculados, a jusante da onda de evaporação, das séries de ensaios do bocal R08 (de aço com $0,8 \mathrm{~mm}$ de diâmetro) e bocal V03 (de vidro com diâmetro de $0,35 \mathrm{~mm}$ ).

\begin{tabular}{|c|c|c|c|c|c|c|c|c|c|}
\hline $\begin{array}{c}\text { Série } \\
\text { de ensaios }\end{array}$ & $\begin{array}{r}P_{2} \\
(\mathrm{kPa}) \\
\end{array}$ & $\begin{array}{c}T_{2} \\
\left({ }^{\circ} \mathrm{C}\right) \\
\end{array}$ & $x_{2}$ & $\begin{array}{c}v_{2} \\
\left(\mathrm{~m}^{3} / \mathrm{kg}\right) \\
\end{array}$ & $\begin{array}{c}J_{\mathrm{CJ}} \\
\left.\mathrm{kg} / \mathrm{m}^{2} \mathrm{~s}\right) \\
\end{array}$ & $\begin{array}{c}u_{2} \\
(\mathrm{~m} / \mathrm{s}) \\
\end{array}$ & $\operatorname{sen}(\beta)$ & $\begin{array}{c}L_{\mathrm{E}} \\
(\mathrm{mm}) \\
\end{array}$ & $\begin{array}{c}\text { erro } L_{\mathrm{E}} \\
\% \\
\end{array}$ \\
\hline R08\1056 & 18,6 & 48,5 & 0,055 & 0,07275 & 245,5 & 17,86 & 0,0231 & 17,3 & 9,8 \\
\hline R08\1095 & 43,8 & 72,1 & 0,187 & 0,11156 & 441,7 & 49,28 & 0,0557 & 7,2 & 14,8 \\
\hline R0812095 & 47,0 & 74,1 & 0,190 & 0,10625 & 469,0 & 49,83 & 0,0341 & 11,7 & 7,5 \\
\hline R0812120 & 100,4 & 98,8 & 0,198 & 0,05576 & 888,8 & 49,56 & 0,0807 & 4,9 & $-35,4$ \\
\hline V03\1329 & 3,8 & 13,9 & 0,294 & 1,6325 & 42,9 & 69,99 & 0,0038 & 45,7 & 494,7 \\
\hline V03\1349 & 8,7 & 30,8 & 0,330 & 0,8660 & 88,3 & 76,48 & 0,0082 & 21,2 & 241,5 \\
\hline V03\1368 & 12,4 & 38,7 & 0,417 & 0,7856 & 114,5 & 89,97 & 0,0107 & 16,3 & 254,8 \\
\hline V03।2329 & 12,0 & 38,0 & 0,143 & 0,2774 & 148,6 & 41,23 & 0,0092 & 18,9 & 72,6 \\
\hline V03।2349 & 15,9 & 44,5 & 0,234 & 0,3524 & 169,7 & 59,82 & 0,0107 & 16,2 & 105,2 \\
\hline V03।2368 & 16,0 & 44,8 & 0,375 & 0,5584 & 150,1 & 83,79 & 0,0096 & 18,2 & 225,3 \\
\hline V03।2393 & 33,9 & 64,7 & 0,450 & 0,3374 & 280,9 & 94,79 & 0,0195 & 8,9 & 121,2 \\
\hline V03\5349 & 30,2 & 61,6 & 0,119 & 0,1000 & 342,9 & 34,30 & 0,0150 & 11,6 & 4,6 \\
\hline V03।5393 & 53,1 & 77,7 & 0,363 & 0,1806 & 448,4 & 80,99 & 0,0211 & 8,2 & 51,4 \\
\hline
\end{tabular}

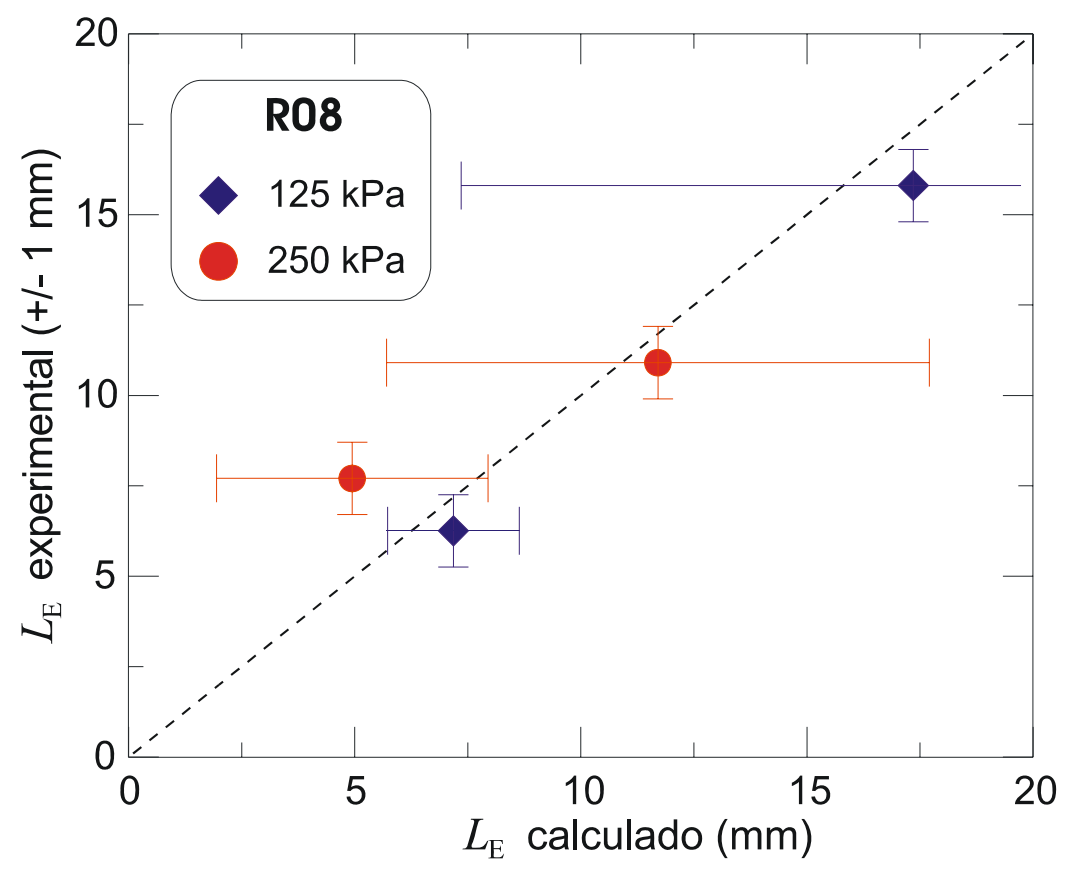

Figura 6.4 - Comparação do comprimento do núcleo de líquido experimental e o calculado do bocal R08. 


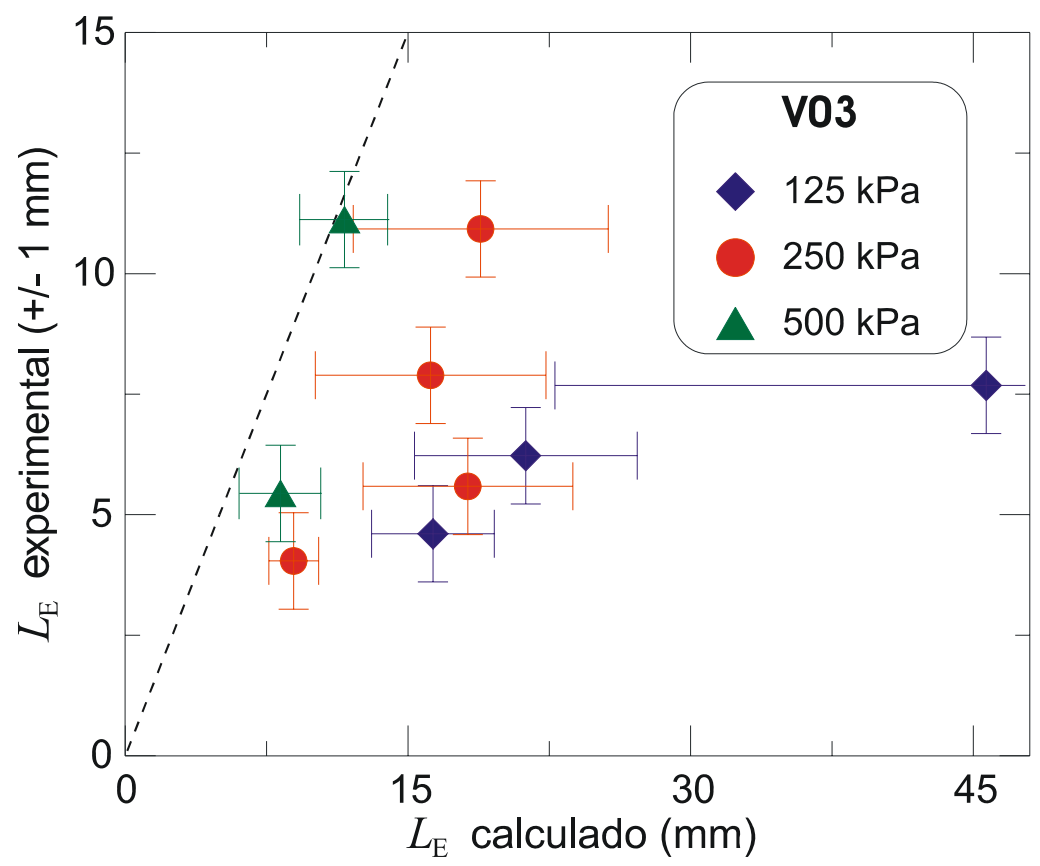

Figura 6.5 - Comparação do comprimento do núcleo de líquido experimental e o calculado do bocal V03.

\subsection{O Atraso da Onda de Evaporação}

Os comprimentos, $L_{\mathrm{E}}$, calculados que não se enquadraram com os resultados esperados, indicados nos gráficos das Figs. 6.1 e 6.5, através do cálculo da onda de evaporação, podem estar associados ao atraso da onda de evaporação, pelo menos, para o bocal R03. Deste bocal, os ensaios com a temperatura de $56{ }^{\circ} \mathrm{C}$ e pressões de $125 \mathrm{kPa}$ e $250 \mathrm{kPa}$, através da análise visual da onda de evaporação possuíam a evidência deste atraso. A este grupo, também deve ser acrescentado os ensaios que foram obtidos com pressão e temperatura de $125 \mathrm{kPa}$ e $76{ }^{\circ} \mathrm{C}$. Os outros que não apresentaram nitidamente este fenômeno através do registro fotográfico, mas que mostraram uma pequena discordância do comprimento calculado possuem respectivamente pressão e temperatura de injeção de: $125 \mathrm{kPa}$ e $95^{\circ} \mathrm{C}, 250 \mathrm{kPa}$ e 76 ${ }^{\circ} \mathrm{C}$ e, finalmente, $500 \mathrm{kPa}$ e $56{ }^{\circ} \mathrm{C}$. $\mathrm{Na}$ Fig. 6.6, os ensaios com as pressões e temperaturas de injeção testados são mostrados. Os ensaios que permitiram visualizar o atraso fotograficamente, conjuntamente, com aqueles que se suspeita possuir um atraso da onda evaporativa em virtude dos resultados obtidos pelos cálculos, são destacados nesta figura. 


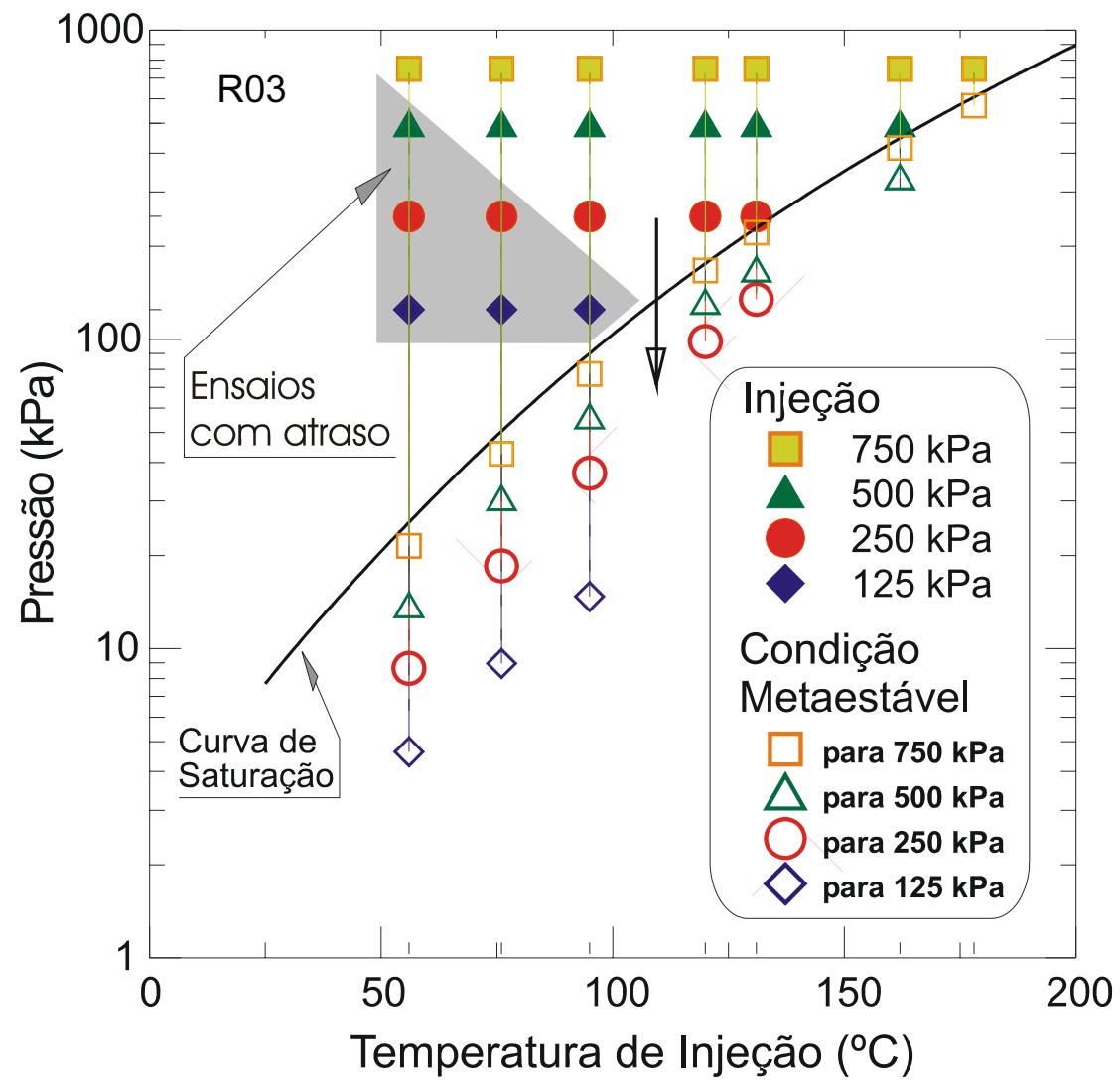

Figura 6.6 - Gráfico que mostra as condições de injeção dos ensaios feitos para o bocal de aço com 0,3 mm de diâmetro (R03) e a pressão metaestável alcançada pelo ensaio. Nele são indicados os ensaios com atraso da onda de evaporação.

Pelos registros fotográficos, o bocal R08 não apresentou atraso da onda de evaporação, com exceção dos ensaios com as condições de injeção de $125 \mathrm{kPa}$ e 56 ${ }^{\circ} \mathrm{C}$ que apresentaram um atraso 0,5 mm, aproximadamente. Mesmo assim, os cálculos do comprimento do núcleo líquido foram condizentes ao experimental (Fig. 6.4). Para os ensaios do bocal de vidro (V03), este atraso foi nitidamente visualizado nas imagens destes experimentos, como visto na Subseção 5.2.2, e teve a grande maioria dos comprimentos calculados deste núcleo fora do esperado. Como já foi dito, a borda na seção de saída do bocal é arredondada e isto também pode ter interferido no diâmetro do núcleo de líquido fazendo com que sua dimensão aumente em relação ao diâmetro de sua restrição $(0,35 \mathrm{~mm})$, colaborando para a sobrevalorização na determinação do comprimento (Fig. 6.5). 


\subsubsection{Condição do Líquido Metaestável no Atraso}

Na seção anterior, foi explicado que o cone líquido do bocal de vidro pode adquirir um diâmetro da base diferente do diâmetro da garganta do bocal e, por conseqüência, o cálculo do comprimento não condizia com o observado. Porém, quando existe o atraso, a pressão metaestável pode ser bem diferente da pressão estimada na saída do bocal. Como os resultados experimentais mostram que o comprimento é menor que o calculado, provavelmente, a pressão metaestável aumentou, ou seja, uma pressão metaestável $\left(P_{1}\right)$ maior resulta em um fluxo superficial mássico da onda $\left(J_{\mathrm{CJ}}\right)$ maior. Esta característica de incremento do fluxo pode ser comprovada na Tab. 6.2. Nela, para uma mesma temperatura de injeção, se verifica que pressões metaestáveis maiores proporcionam um fluxo maior. Isto porque a pressão de injeção pouco interfere no calculo da vazão, $J_{\mathrm{CJ}}$, e além disto, Simões-Moreira (1999) comprovou tal fato em seus cálculos. E se esta pressão se altera, considerando que a evaporação é desprezível na continuidade do filete jato, antes da onda de evaporação, pela lei da conservação de massa e pela equação de Bernoulli, é factível que aumente proporcionalmente o diâmetro da base do cone. Estes dois fatores aumentados, fluxo mássico da onda de choque e base do cone evaporativo, diminuem o comprimento do cone.

\subsubsection{Considerações sobre a Onda de Choque Formada em Jatos com Atraso da Onda Evaporativa}

É difícil ilustrar um esquema sobre a geometria das ondas de choque na região próxima do bocal, quando há este atraso da evaporação. Provavelmente, no início da onda de evaporação, esteja ocorrendo uma expansão de Prandt-Meyer, similar ao encontrado na teoria de escoamento de compressíveis (Thompson, 1988). O fluxo na onda de evaporação tem uma direção perpendicular ao jato, e este escoamento que se localiza no início da onda de evaporação se expande para a região onde não ocorreu a evaporação e, conseqüentemente, acaba resultando nesta expansão. $\mathrm{O}$ detalhe à direita da Fig. 6.7 esquematiza como seria a geometria hipotética das ondas de choque próximo ao bocal. Da figura, as indicações $L_{\mathrm{d}}, v_{\mathrm{j}}$, e $\theta$, 
correspondem à distância do atraso, ao ângulo de expansão de Prandt-Meyer, e ao ângulo de giro do fluido após a onda. É possível que a onda de choque oblíqua não se origina, necessariamente, na extremidade da saída do bocal. E entre a onda de choque gerada pela expansão de Prandt-Meyer, a onda de choque oblíqua (indicada na figura) e, o núcleo, na região mais escura da expansão bifásica, pode existir ondas de choques do tipo oblíquas e reflexivas tornando complexa a explicação da geometria dessas ondas nesta região em virtude da impossibilidade de se observar com maiores detalhes esses fenômenos pela imagem do jato.

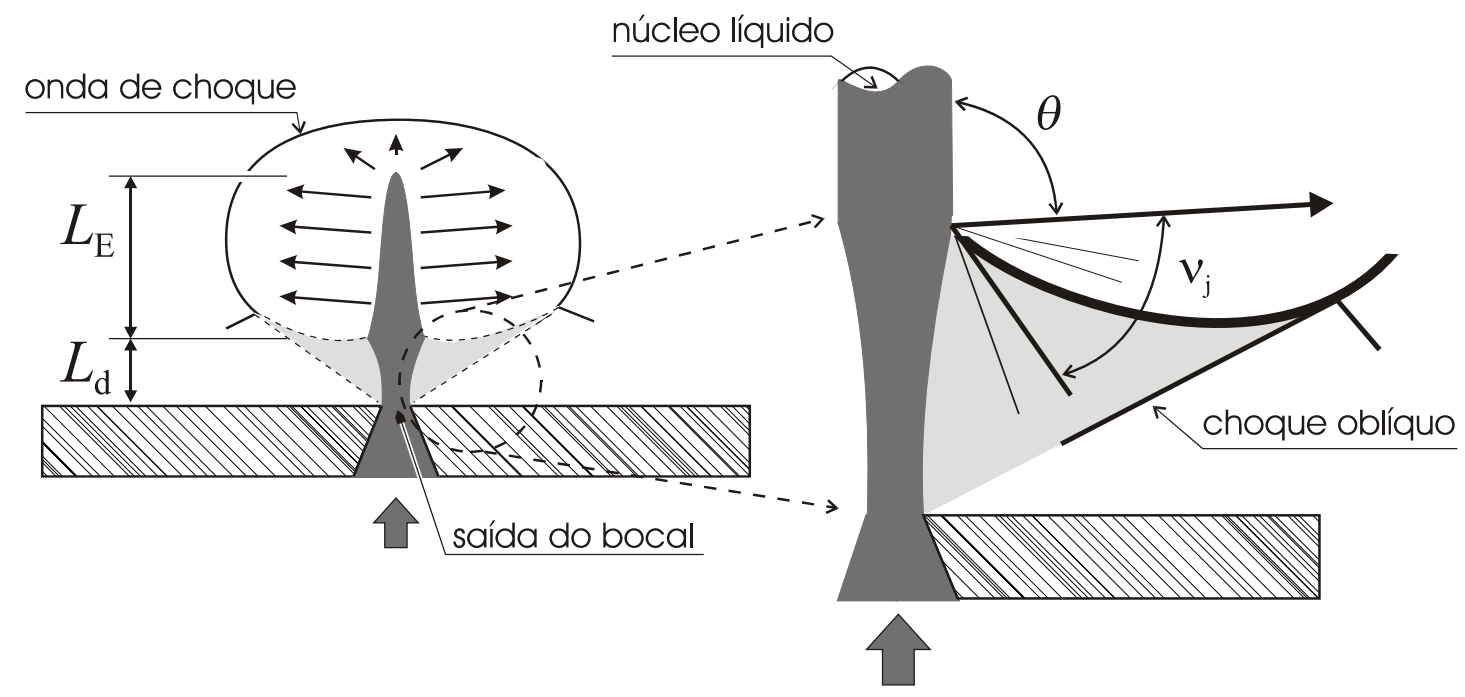

Figura 6.7 - Ilustração esquemática da geometria das ondas de choque que ocorrem próximas da saída do bocal. A parte escurecida da expansão do esquema, entre a onda de choque oblíqua e o núcleo de líquido, pode apresentar ondas de choque reflexivas e oblíquas, internamente a esta região. O diâmetro do núcleo de líquido também pode aumentar após a saída do bocal.

Para o bocal de vidro a analogia é a mesma, ou seja, também deve ocorrer a expansão de Prandt-Meyer e a onda de choque oblíqua (Fig. 6.8). A Fig. 5.52 do capítulo anterior mostra duas imagens de jato que possuem uma onda de choque que se fecha na porção líquida sem a evaporação e a outra já envolve a porção exposta do bocal de vidro. Uma forma indireta de saber se a onda de choque oblíqua se fecha na porção líquida do jato, ou no bocal de vidro, é a diferença da pressão metaestável inferida pelos dois tipos de choque observados. A onda de choque que se fecha na parte líquida teria uma pressão metaestável próxima da pressão da câmara e a onda 
de choque que envolve o bocal teria uma pressão menor, isto porque a pressão da saída do bocal assumiria a pressão antes da onda de choque visualizada. Porém estas pressões estariam na ordem da pressão da câmara (100 Pa) e a diferença mínima mensurável através da vazão experimental é de (5000 Pa), inviabilizando este estudo.

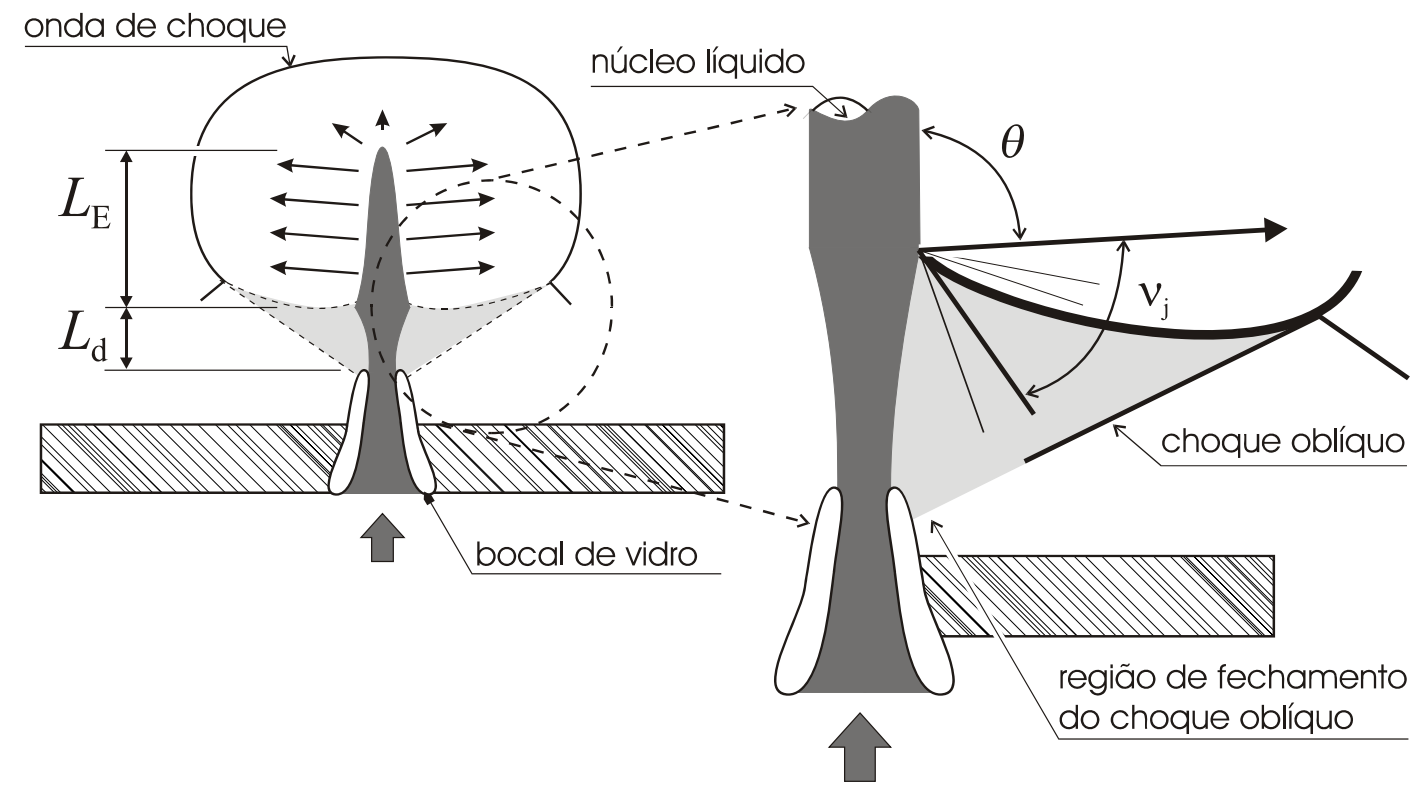

Figura 6.8 - Ilustração esquemática da geometria das ondas de choque que ocorrem próxima da saída para o bocal de vidro, semelhante ao explicado na Fig 6.7 . 


\section{Conclusões e Continuidade do Trabalho}

\subsection{Conclusões}

Foram encontrados jatos que possuíam: (1) filete contínuo, (2) fragmentado em virtude da evaporação e, em casos com baixíssimas pressões da câmara, (3) abrupta evaporação seguida por expansão com formação de ondas de choque. Todos os tipos de jatos dependiam muito da razão entre a pressão de saturação e da câmara, $R_{\mathrm{P}}$ e, conseqüentemente, da pressão metaestável alcançada na saída do bocal para a condição de máxima vazão. Já esta pressão de máxima vazão também dependia da pressão e temperatura de injeção $\left(P_{0}\right.$ e $\left.T_{0}\right)$. Basicamente, temperaturas e pressões de injeção elevadas, em relação ao conjunto de ensaios aqui apresentados, possuíam uma pressão metaestável próxima da pressão de saturação, ou seja, seu grau de metaestabilidade era menor e próximo de zero.

Caracterizando melhor os tipos de jatos, quando o líquido, a certo valor de $P_{0}$ e $T_{0}$, era descarregado na câmara com pressão menor que a pressão metaestável de máxima vazão, o jato possuía um filete contínuo. Neste estágio, o $R_{\mathrm{P}}$ máximo era próximo de 1 para pressões e temperaturas de injeção elevados e, com temperaturas e pressões menores, o $R_{\mathrm{P}}$ alcançava valores da ordem de 5. Casos com $R_{\mathrm{P}}$ iguais a 10, o jato se fragmentava e muitas vezes não tinha perfil simétrico. Em estágios mais avançados, $R_{\mathrm{P}}=50$ a 100 , o jato possuía simetria e, em uma faixa de temperatura de injeção menor, 50 a $131{ }^{\circ} \mathrm{C}$, já mostrava a presença da onda de choque. Eram ensaios que também apresentaram um núcleo de líquido cuja evaporação ocorria em sua superfície.

Como já comentado acima, cada série de ensaio com uma determinada pressão e temperatura inicial, alcançava uma pressão metaestável em uma determinada vazão máxima, ou seja, mesmo que se diminuísse a pressão da câmara, a vazão não elevava como poderia se esperar, como também não diminuía. Nesta mesma ocasião o núcleo líquido manteve a simetria e a regularidade de formato, com extensão contínua e definida, mesmo reduzindo a pressão da câmara. Estas regularidades da vazão e do núcleo de líquido mostram um forte indício de que não 
houve nucleação interna ao bocal e a evaporação se manteve na superfície do núcleo de líquido como onda de evaporação.

Nesta tese foi admitido que a expansão interna ao bocal ocorre de forma isotérmica. Em seguida, a onda de evaporação impõe um salto de propriedades termodinâmicas. A ocorrência de uma onda de choque é a comprovação de um escoamento supersônico. Na modelagem usada nesta tese, a mistura bifásica deixa a frente de evaporação com velocidade sônica. Neste instante, como a área normal ao seu escoamento tende a aumentar, e sua pressão é maior que a pressão da câmara, pela teoria de escoamento compressível, a mistura bifásica deve assumir uma velocidade supersônica crescente para depois equilibrar sua pressão de estagnação com a pressão da câmara através de uma onda de choque. Pelas imagens obtidas, ficou evidente que o fluido sofre um giro em decorrência da onda de evaporação. A utilização do iso-octano que é uma substância SCME mostrou-se favorável para a obtenção de imagens com clareza dos fenômenos envolvidos.

A análise das imagens mostra a presença de ondas de choque envolvendo o núcleo de líquido. A estrutura da onda de choque aparenta ser traspassada pelo escoamento com gotículas. Em alguns casos, cujo núcleo de líquido é mais extenso, há a formação de duas ondas de choque reflexivas e, entre elas, existe uma onda de choque paralela ao eixo do jato que deve ser quase normal ao escoamento.

A solução analítica proposta para a onda de evaporação (Cap. 2) mostrou que a razão entre as pressões a jusante e a montante da onda de evaporação $\left(P_{2} / P_{1}\right)$ são principalmente dependentes do grau de metaestabilidade e pouco possuem influência da temperatura inicial, sob a condição de Chapman-Jouguet. Através do estudo numérico e do analítico proposto, verificou-se que todas as substâncias possuem comportamento semelhante da relação $P_{2} / P_{1}$ em função do grau de metaestabilidade e que o máximo valor desta razão é de 0,5 para graus de metaestabilidade próximos do valor unitário.

A aplicação da teoria de ondas de evaporação no núcleo de líquido mostrouse compatível com os resultados experimentais. Mesmo assim, se questionou se esta teoria é aplicável aos jatos que sofrem um atraso da onda de evaporação. Estes jatos possuíam um grau de metaestabilidade elevado. Também foi visto, que os jatos com atraso da onda de evaporação, e na região próxima da saída do bocal, o escoamento 
pode ser muito complexo com relação à geometria de ondas de choque formadas.

A comparação das imagens obtidas pelas duas técnicas ópticas de visualização (método "Schlieren" e método de “iluminação por detrás") agregada ao processamento matemático das imagens foi importante para obter conclusões sobre os fenômenos ocorridos nestes jatos.

A utilização de mais dois bocais mostrou coerência nos fenômenos envolvidos como a formação do núcleo de líquido, da onda de evaporação, da onda de choque e de blocagem da vazão. Estes bocais também apresentaram os outros tipos de jatos já mencionados, que são caracterizados pela ausência do escoamento supersônico. O bocal de vidro, com diâmetro de $0,35 \mathrm{~mm}$, indicou resultados semelhantes ao bocal de aço com $0,3 \mathrm{~mm}$, em relação ao máximo fluxo superficial mássico. Na condição de máxima vazão, o bocal de aço de $0,8 \mathrm{~mm}$ obteve um fluxo superficial mássico menor que os demais, para as mesmas condições de injeção. Em todos os bocais, também houve incompatibilidade da aplicação da teoria das ondas de evaporação quando o jato apresentava um atraso da onda de evaporação. Nas imagens do bocal de aço de $0,8 \mathrm{~mm}$ não houve aparentemente um atraso na onda de evaporação e apresentou um comprimento de extinção do núcleo de líquido calculado compatível com o resultado experimental. Comparando os três bocais, para condições iniciais de injeção e pressões da câmara iguais, verificou-se que as principais dimensões da onda de choque eram proporcionais ao diâmetro da seção de saída do bocal. Na grade de ensaios pesquisada e para o fluido aqui estudado, foi verificado que a dimensão representativa do raio da onda de choque é dependente das pressões de saturação, da câmara e da dimensão do núcleo de líquido. Também foi visto que o comprimento de extinção do núcleo líquido é função da razão entre as pressões de saturação e de injeção.

\subsection{Continuidade do Trabalho}

Sugere-se que para a continuidade da investigação dos fenômenos evaporativos aqui discutidos que os seguintes testes e análises adicionais sejam conduzidos:

a. Testar outros líquidos de natureza diferente da de um 
hidrocarboneto, tais como: água, álcool e um refrigerante frigorífico;

b. aplicar outras técnicas de visualização dos jatos como a técnica de "laser sheet", ou iluminação por uma lâmina de "laser". Essa técnica permitiria resolver por completo a frente de evaporação. Além disso, em função das elevadas velocidades envolvidas, seria conveniente a utilização de uma fonte de laser pulsante, com o menor tempo de exposição possível;

c. analisar a ocorrência desse fenômeno em outros dispositivos, tais como: passagem de válvulas, tubos de orifício e orifícios de uma forma geral;

d. obter de forma analítica ou experimental um modelo que possa prever a pressão de metaestabilidade que é alcançada em experimentos dessa natureza. 


\section{Anexo A}

Tabela de propriedades de saturação do iso-octano 
Tab. A.1 - Tabela de propriedades de saturação do iso-octano $\left(\mathrm{C}_{8} \mathrm{H}_{18}\right)$.

\begin{tabular}{|c|c|c|c|c|c|c|c|}
\hline $\begin{array}{c}T \\
\left({ }^{\circ} \mathrm{C}\right)\end{array}$ & $\begin{array}{c}P \\
(\mathbf{P a})\end{array}$ & $\begin{array}{c}v_{\mathrm{L}} \\
\left(\mathbf{m}^{3} / \mathbf{k g}\right)\end{array}$ & $\begin{array}{c}v_{\mathrm{V}} \\
\left(\mathbf{m}^{3} / \mathbf{k g}\right)\end{array}$ & $\begin{array}{c}h_{\mathrm{L}} \\
(\mathrm{J} / \mathrm{kg})\end{array}$ & $\begin{array}{c}h_{\mathrm{V}} \\
(\mathrm{J} / \mathrm{kg})\end{array}$ & $\begin{array}{c}s_{\mathrm{L}} \\
(\mathrm{J} / \mathrm{kg} \cdot \mathrm{K}) \\
\end{array}$ & $\begin{array}{c}s_{\mathrm{V}} \\
(\mathrm{J} / \mathrm{kg} . \mathrm{K} \\
\end{array}$ \\
\hline$-107,38$ & 0,015 & 0,00125114 & 797950,4 & $-196008,3$ & 155756,8 & $-770,114$ & 1351,893 \\
\hline-100 & 0,057 & 0,00127400 & 222620,0 & $-187000,0$ & 160300,0 & $-714,650$ & 1303,254 \\
\hline-95 & 0,133 & 0,00127970 & 97836,1 & $-178000,0$ & 167900,0 & $-677,280$ & 1275,558 \\
\hline-90 & 0,294 & 0,00128550 & 45352,1 & $-169000,0$ & 175600,0 & $-640,077$ & 1251,269 \\
\hline-85 & 0,620 & 0,00129140 & 22073,0 & $-160000,0$ & 183200,0 & $-603,042$ & 1229,402 \\
\hline-80 & 1,252 & 0,00129740 & 11233,2 & $-151000,0$ & 190900,0 & $-566,175$ & 1210,165 \\
\hline-75 & 2,422 & 0,00130340 & 5955,76 & $-142000,0$ & 198600,0 & $-529,475$ & 1194,729 \\
\hline-70 & 4,510 & 0,00130960 & 3278,84 & $-133000,0$ & 206400,0 & $-492,942$ & 1181,683 \\
\hline-65 & 8,107 & 0,00131580 & 1868,82 & $-123000,0$ & 212200,0 & $-456,577$ & 1169,785 \\
\hline-60 & 14,107 & 0,00132220 & 1099,80 & $-114000,0$ & 222100,0 & $-420,379$ & 1160,198 \\
\hline-55 & 23,819 & 0,00132860 & 666,670 & $-105000,0$ & 229900,0 & $-384,349$ & 1153,142 \\
\hline-50 & 39,108 & 0,00133520 & 415,338 & $-95800,0$ & 237700,0 & $-348,487$ & 1148,264 \\
\hline-45 & 62,571 & 0,00134180 & 265,413 & $-86300,0$ & 245700,0 & $-312,792$ & 1143,619 \\
\hline-40 & 97,729 & 0,00134860 & 173,654 & $-76800,0$ & 253600,0 & $-277,264$ & 1141,136 \\
\hline-35 & 149,26 & 0,00135550 & 116,136 & $-67300,0$ & 261600,0 & $-241,904$ & 1140,235 \\
\hline-30 & 219,98 & 0,00136500 & 85,1531 & $-57600,0$ & 269800,0 & $-213,000$ & 1133,494 \\
\hline-25 & 343,97 & 0,00137300 & 55,5780 & $-48200,0$ & 279200,0 & $-177,500$ & 1141,863 \\
\hline-20 & 467,96 & 0,00138100 & 41,6753 & $-38800,0$ & 285300,0 & $-142,000$ & 1138,269 \\
\hline-15 & 698,61 & 0,00138850 & 28,4674 & $-29200,0$ & 293200,0 & $-106,500$ & 1161,755 \\
\hline-10 & 929,26 & 0,00139600 & 21,8161 & $-19600,0$ & 300800,0 & $-71,0000$ & 1146,55 \\
\hline-5 & 1330,55 & 0,00140400 & 15,5258 & $-9800,0$ & 317600,0 & $-35,5000$ & 1185,458 \\
\hline 0 & 1731,85 & 0,00141200 & 12,1507 & 0,0 & 317100,0 & 0,0 & 1160,901 \\
\hline 5 & 2394,43 & 0,00142030 & 8,9449298 & 9925,5 & 325175,5 & 35,6876 & 1169,069 \\
\hline 10 & 3057,00 & 0,00142860 & 7,1942446 & 19902,1 & 333302,1 & 70,9249 & 1177,759 \\
\hline 15 & 4103,60 & 0,00143643 & 5,4447623 & 29930,6 & 341330,6 & 105,734 & 1186,421 \\
\hline 20 & 5150,20 & 0,00144425 & 4,4444444 & 40012,5 & 349412,5 & 140,130 & 1195,563 \\
\hline 25 & 6578,10 & 0,00145296 & 3,4481438 & 50149,0 & 357549,0 & 174,136 & 1205,161 \\
\hline 30 & 8320,60 & 0,00146178 & 2,8571429 & 60341,7 & 365741,7 & 207,766 & $1215,18 \varepsilon$ \\
\hline 35 & 10639,8 & 0,00147059 & 2,2334694 & 70591,9 & 373941,9 & 241,042 & 1225,465 \\
\hline 40 & 12959 & 0,00147951 & 1,8587361 & 80901,5 & 382201,5 & 273,975 & 1236,133 \\
\hline 45 & 16246 & 0,00148887 & 1,490303 & 91272,3 & 390372,3 & 306,588 & 1246,710 \\
\hline 50 & 19533 & 0,00149835 & 1,2578616 & 101706,2 & 398606,2 & 338,891 & 1257,659 \\
\hline 55 & 23677 & 0,00150852 & 1,0382833 & 112205,1 & 406755,1 & 370,915 & 1268,523 \\
\hline 60 & 28535 & 0,00151883 & 0,8896797 & 122771,4 & 414971,4 & 402,660 & 1279,742 \\
\hline 65 & 34201 & 0,00152917 & 0,7435164 & 133407,1 & 423207,1 & 434,132 & 1291,149 \\
\hline 70 & 40774 & 0,00153965 & 0,6459948 & 144114,8 & 431514,8 & 465,356 & 1302,890 \\
\hline 75 & 48780 & 0,00155099 & 0,5476492 & 154897,0 & 439897,0 & 496,362 & 1314,975 \\
\hline 80 & 56786 & 0,00156250 & 0,4793864 & 165756,2 & 448356,2 & 527,147 & 1327,374 \\
\hline 85 & 67102 & 0,00157381 & 0,4062687 & 176695,3 & 456745,3 & 557,737 & 1339,672 \\
\hline 90 & 77418 & 0,00158529 & 0,3552398 & 187717,0 & 465217,0 & 588,132 & 1352,279 \\
\hline 95 & 90459 & 0,00159744 & 0,3054033 & 198824,3 & 473574,3 & 618,357 & 1364,656 \\
\hline 100 & 103500 & 0,00160979 & 0,2700513 & 210020,4 & 482020,4 & 648,415 & 1377,344 \\
\hline 105 & 119965 & 0,00162285 & 0,2332804 & 221308,4 & 490408,4 & 678,336 & 1389,958 \\
\hline 110 & 136000 & 0,00163613 & 0,2069108 & 232691,7 & 498891,7 & 708,114 & 1402,881 \\
\hline 115 & 156182 & 0,00165003 & 0,1813356 & 244173,7 & 507223,7 & 737,780 & 1415,482 \\
\hline 120 & 175850 & 0,00166417 & 0,1623377 & 255758,0 & 515658,0 & 767,329 & 1428,400 \\
\hline
\end{tabular}

continua... 
...continuação da Tab. A.1.

\begin{tabular}{|c|c|c|c|c|c|c|c|}
\hline $\begin{array}{c}\mathrm{T} \\
\left({ }^{\circ} \mathrm{C}\right) \\
\end{array}$ & $\begin{array}{c}P \\
(\mathbf{P a}) \\
\end{array}$ & $\begin{array}{c}v_{\mathrm{L}} \\
\left(\mathrm{m}^{3} / \mathrm{kg}\right)\end{array}$ & $\begin{array}{c}v_{\mathrm{V}} \\
\left(\mathrm{m}^{3} / \mathbf{k g}\right)\end{array}$ & $\begin{array}{c}h_{\mathrm{L}} \\
(\mathrm{J} / \mathrm{kg}) \\
\end{array}$ & $\begin{array}{c}h_{\mathrm{V}} \\
(\mathrm{J} / \mathbf{k g}) \\
\end{array}$ & $\begin{array}{c}s_{\mathrm{L}} \\
(\mathrm{J} / \mathrm{kg} \cdot \mathrm{K}) \\
\end{array}$ & $\begin{array}{c}s_{\mathrm{V}} \\
(\mathrm{J} / \mathrm{kg} \cdot \mathrm{K})\end{array}$ \\
\hline 125 & 200278 & 0,00167842 & 0,1428272 & 267448,3 & 524048,3 & 796,793 & 1441,273 \\
\hline 130 & 224100 & 0,00169291 & 0,1282216 & 279248,3 & 532548,3 & 826,162 & 1454,464 \\
\hline 135 & 253253 & 0,00170823 & 0,1136245 & 291161,9 & 541011,9 & 855,473 & 1467,625 \\
\hline 140 & 281700 & 0,00172384 & 0,1025957 & 303193,3 & 549593,3 & 884,712 & 1481,105 \\
\hline 145 & 316157 & 0,00174019 & 0,0915062 & 315346,5 & 558046,5 & 913,919 & 1494,332 \\
\hline 150 & 349800 & 0,00175685 & 0,0829187 & 327625,8 & 566625,8 & 943,077 & 1507,888 \\
\hline 155 & 390115 & 0,00177447 & 0,0741916 & 340035,5 & 575185,5 & 972,227 & 1521,451 \\
\hline 160 & 429500 & 0,00179244 & 0,0673854 & 352580,3 & 583880,3 & 1001,35 & 1535,35 \\
\hline 165 & 476227 & 0,00181274 & 0,0606126 & 365264,6 & 592364,6 & 1030,49 & 1548,81 \\
\hline 170 & 521900 & 0,00183352 & 0,0553097 & 378093,3 & 600993,3 & 1059,63 & 1562,62 \\
\hline 175 & 577615 & 0,00185512 & 0,0497894 & 391071,1 & 609571,1 & 1088,82 & 1576,38 \\
\hline 180 & 632100 & 0,00187723 & 0,0454545 & 404203,1 & 618303,1 & 1118,02 & 1590,49 \\
\hline 185 & 692603 & 0,00190096 & 0,0411679 & 417494,3 & 626844,3 & 1147,28 & 1604,23 \\
\hline 190 & 751800 & 0,00192530 & 0,0377358 & 430949,9 & 635549,9 & 1176,58 & 1618,34 \\
\hline 195 & 823407 & 0,00195370 & 0,0340387 & 444575,2 & 644025,2 & 1205,98 & 1632,02 \\
\hline 200 & 893500 & 0,00198295 & 0,0310463 & 458375,7 & 652675,7 & 1235,44 & 1646,09 \\
\hline 205 & 975094 & 0,00201593 & 0,0279594 & 472356,9 & 660956,9 & 1265,02 & 1659,46 \\
\hline 210 & 1055000 & 0,00205002 & 0,0254647 & 486524,6 & 669424,6 & 1294,68 & 1673,24 \\
\hline 215 & 1147440 & 0,00208681 & 0,0230029 & 500884,3 & 677384,3 & 1324,49 & 1686,06 \\
\hline 220 & 1238000 & 0,00212495 & 0,0209996 & 515442,2 & 685542,2 & 1354,40 & 1699,32 \\
\hline 225 & 1338539 & 0,00216940 & 0,0191057 & 530127,5 & 692739,1 & 1366,003 & 1692,43 \\
\hline 230 & 1445000 & 0,00221386 & 0,0173671 & 544983,2 & 700783,2 & 1392,486 & 1702,14 \\
\hline 235 & 1562140 & 0,00226835 & 0,0156202 & 560023,2 & 710150,0 & 1414,612 & 1710,05 \\
\hline 240 & 1677000 & 0,00232558 & 0,0141583 & 575221,6 & 714521,6 & 1444,725 & 1716,19 \\
\hline 245 & 1807750 & 0,00240067 & 0,0126195 & 590624,5 & 724124,5 & 1475,064 & 1732,71 \\
\hline 250 & 1936000 & 0,00248077 & 0,0113263 & 606192,8 & 725292,8 & 1496,741 & 1724,40 \\
\hline 260 & 2225000 & 0,00272702 & 0,00883392 & 638114,4 & 730134,4 & 1547,864 & 1720,46 \\
\hline 270 & 2545000 & 0,00344234 & 0,00537634 & 670945,8 & 707605,8 & 1598,316 & 1665,81 \\
\hline 271,1 & 2583000 & 0,00421941 & 0,00421941 & 674602,6 & 674602,6 & 1603,825 & 1603,83 \\
\hline
\end{tabular}




\section{Anexo B}

Resultados Experimentais

do Bocal de Aço com

0,3 mm - Bocal (R03)

(séries: Run1, Run2 e Run3) 


\section{B.1. Medição das Vazões Mássicas - Bocal R03}

Os dados de referentes a vazão estão nas Tabs. B.1, B.2 e B.3 que são relativas às séries de ensaio "Run1”, “Run2” e "Run3”, respectivamente, no entanto, a metodologia de coleta de dados das vazões não é diferente em nenhuma destas séries. Nestas tabelas, os ensaios estão apresentados em ordem cronológica com o número de aquisição, seguida do código do ensaio, dia de realização, assim como, pressão e temperatura de injeção nominal. Nas colunas seguintes, estão colocados a pressão $\left(P_{0}\right)$ e temperatura de injeção reais $\left(T_{0}\right)$, a pressão da câmara média $\left(P_{\infty}\right)$ e a razão entre a pressão de vapor e pressão da câmara $\left(R_{\mathrm{P}}\right)$. A partir da décima coluna, consta o número de Reynolds, $R e$, que é calculado através da vazão mássica medida, $\dot{m}$,depois o coeficiente de descarga, $C_{\mathrm{D}}$, calculado através da Eq. (B.1) cuja curva foi levantada experimentalmente, e a vazão mássica estimada, $\dot{m}_{e}$, que é obtida através da equação de descarga do bocal para fluidos incompressíveis representada pela Eq. (B.2). O parâmetro, $P_{1}$, corresponde à pressão do líquido superaquecido na saída do bocal e é calculado através da Eq. (B.4) e utiliza a vazão mássica medida no ensaio.

$$
\begin{aligned}
& C_{D}=0,9673-5,6682 / \sqrt{\mathrm{Re}} \\
& \dot{m}_{e}=C_{D} \cdot A_{b} \cdot \sqrt{2 \cdot \rho_{l} \cdot\left(P_{0}-P_{\infty}\right)} \\
& \operatorname{Re}=\frac{\rho_{l} \cdot u_{1} \cdot D_{b}}{\mu} \\
& P_{1}=P_{0}-\frac{1}{2 \cdot \rho_{l}}\left(\frac{\dot{m}}{C_{D} \cdot A_{b}}\right)^{2}
\end{aligned}
$$


Tabela B.1 - Tabela com os ensaios da série "RUN1" (bocal rugoso com 0,3 mm de diâmetro).

\begin{tabular}{|c|c|c|c|c|c|c|c|c|c|c|c|c|c|}
\hline & Código & Dia & $\begin{array}{c}\boldsymbol{P}_{\text {inj }} \\
(\mathrm{kPa})\end{array}$ & $\begin{array}{c}\boldsymbol{T}_{\mathbf{i n j}} \\
(\mathrm{K}) \\
\end{array}$ & $\begin{array}{c}\boldsymbol{P}_{\mathbf{0}} \\
(\mathrm{kPa})\end{array}$ & $\begin{array}{c}\boldsymbol{T}_{\mathbf{0}} \\
\left({ }^{\circ} \mathrm{C}\right) \\
\end{array}$ & $\begin{array}{c}\boldsymbol{P}_{\infty} \\
(\mathrm{kPa})\end{array}$ & $\boldsymbol{R}_{\mathbf{P}}$ & $\mathbf{R e}$ & $C_{\mathrm{D}}$ & $\begin{array}{c}\text { medido } \\
\dot{m} \\
(\mathrm{~g} / \mathrm{s}) \\
\end{array}$ & $\begin{array}{c}\text { estimado } \\
\dot{m}_{e} \\
(\mathrm{~g} / \mathrm{s}) \\
\end{array}$ & $\begin{array}{c}\boldsymbol{P}_{\mathbf{1}} \\
(\mathrm{kPa}) \\
\end{array}$ \\
\hline 1 & 2368m10 & 31-jan-01 & 250 & 368 & 250,6 & 94,7 & 0,13 & 683,4 & 19739 & 0,9269 & 1,1268 & 1,2171 & 37,4 \\
\hline 2 & 2368500 & 01-fev-01 & 250 & 368 & 251,4 & 95,2 & 0,20 & 450,8 & 19832 & 9270 & 1,1277 & 1,2188 & 37,8 \\
\hline 3 & $2406 \mathrm{~m} 17$ & 01-fev-01 & 250 & 404 & 249,5 & 130,2 & 0,13 & 1799,4 & - & - & - & - & \\
\hline 4 & 2368100 & 01-fev-01 & 250 & 368 & 246,8 & 93,9 & 0,85 & 102,1 & 19486 & 0,9266 & 1,1194 & 1,2060 & 36,4 \\
\hline 5 & 2368010 & 01-fev-01 & 250 & 368 & 250,8 & 95,0 & 9,07 & 9,9 & 19680 & 0,9268 & 1,1208 & 1,1951 & 39,8 \\
\hline 6 & $2368010 b$ & 01-fev-01 & 250 & 368 & 250,9 & 94,6 & 9,27 & 9,6 & 19670 & 0,9268 & 1,1237 & 1,1951 & 38,8 \\
\hline 7 & $2368010 c$ & 01-fev-01 & 250 & 368 & 250,4 & 95,2 & 9,40 & 9,6 & 19693 & 0,9269 & 1,1198 & 1,1932 & 39,7 \\
\hline 8 & $2368010 d$ & 01-fev-01 & 250 & 368 & 250,5 & 94,7 & 9,93 & 8,9 & 19638 & 0,9268 & 1,1210 & 1,1923 & 39,4 \\
\hline 9 & 2368002 & 01-fev-01 & 250 & 368 & 250,3 & 95,3 & 45,33 & 2,0 & 19236 & 0,9264 & 1,0929 & 1,0981 & 49,3 \\
\hline 10 & 2368001 & 01-fev-01 & 250 & 368 & 250,0 & 94,6 & 89,99 & 1,0 & 16875 & 0,9236 & 0,9641 & 0,9648 & 92,3 \\
\hline 11 & $2406 m 10$ & 12-fev-01 & 250 & 404 & 251,4 & 125,0 & 0,18 & 1135,5 & 16890 & 0,9236 & 0,7653 & 1,1936 & 147,8 \\
\hline 12 & 2406500 & 12-fev-01 & 250 & 404 & 250,1 & 129,0 & 0,38 & 583,1 & - & - & - & - & \\
\hline 13 & $2406 \mathrm{~m} 10 \mathrm{~b}$ & $15-f e v-01$ & 250 & 404 & 248,6 & 128,0 & 0,23 & 949,0 & - & - & - & - & \\
\hline 14 & $2406500 \mathrm{~b}$ & 15 -fev-01 & 250 & 404 & 250,0 & 132,8 & 0,48 & 503,2 & 20832 & 0,9280 & 0,8904 & 1,1882 & 110,1 \\
\hline 15 & 2349500 & $15-f e v-01$ & 250 & 349 & 251,7 & 76,2 & 0,16 & 330,6 & 18086 & 0,9251 & 1,1992 & 1,2281 & 13,7 \\
\hline 16 & 2349100 & 15-fev-01 & 250 & 349 & 251,5 & 76,7 & 0,53 & 98,9 & 17963 & 0,9250 & 1,1860 & 1,2262 & 18,5 \\
\hline 17 & 2349010 & 15-fev-01 & 250 & 349 & 249,1 & 76,2 & 6,67 & 7,7 & 17627 & 0,9246 & 1,1687 & 1,2046 & 22,7 \\
\hline 18 & 2349005 & 15-fev-01 & 250 & 349 & 250,2 & 76,1 & 10,07 & 5,1 & 17632 & 0,9246 & 1,1700 & 1,1988 & 23,3 \\
\hline 19 & $2404 \mathrm{~m} 10$ & 16-fev-01 & 250 & 404 & 250,6 & 131,8 & 0,22 & 1086,1 & 15026 & 0,9210 & 0,6471 & 1,1823 & 174,8 \\
\hline 20 & 2404500 & 16-fev-01 & 250 & 404 & 250,7 & 130,8 & 0,48 & 480,3 & 22090 & & 0,9584 & 1,1932 & 89,8 \\
\hline 21 & 2404100 & 16-fev-01 & 250 & 404 & 251,3 & 131,1 & 3,30 & 9,6 & 20846 & & 0,9024 & 1,1861 & 108,1 \\
\hline 22 & 2404010 & $16-f e$ & 250 & 404 & 249,6 & 130,7 & 24,00 & 9,5 & 21364 & & 0,9276 & 1,1313 & 98,6 \\
\hline 23 & 2404005 & $16-f e$ & 250 & 404 & 252,6 & 129,8 & 43,73 & 1 & 18791 & & 0,8214 & 1,0855 & 133,3 \\
\hline 24 & $2404 \mathrm{~m} 10 \mathrm{~b}$ & 21-fev-01 & 250 & 404 & 256,2 & 130,2 & 0,22 & 1046,2 & 17961 & 0,9250 & 0,7828 & 1,2022 & 147,4 \\
\hline 25 & $2404500 \mathrm{~b}$ & 21-fev-01 & 250 & 404 & 257,1 & 130,9 & 0,48 & 481,4 & 18687 & 0,9258 & 0,8102 & 1,2042 & 140,8 \\
\hline 26 & $2404010 b$ & 21-fev-01 & 250 & 404 & 265,7 & 129,4 & 24,00 & 9,2 & 21290 & 0,9284 & 0,9334 & 1,1727 & 113,1 \\
\hline 27 & 2349001 & 21-fev-01 & 250 & 349 & 250,1 & 76,2 & 48,00 & 1,1 & 16668 & 0,9233 & 1,1051 & 1,0965 & 46,9 \\
\hline 28 & $5435 \mathrm{~m} 10$ & 22-fev-01 & 500 & 435 & 543,3 & 161,9 & 0,45 & 991,6 & 28987 & 0,9340 & 0,9954 & 1,7213 & 361,1 \\
\hline 29 & 5435500 & 22-fev-01 & 500 & 435 & 504,1 & 159,9 & 0,94 & 458,4 & 27263 & 0,9329 & 0,9505 & 1,6589 & 338,2 \\
\hline 30 & 5435100 & 22-fev-01 & 500 & 435 & 502,5 & 160,8 & 8,67 & 50,3 & 28035 & 0,9334 & 0,9708 & 1,6424 & 329,4 \\
\hline 31 & 5435010 & 22-fev-01 & 500 & 435 & 501,9 & 162,6 & 44,93 & 10,1 & 31009 & & 1,0592 & 1,5787 & 296,0 \\
\hline 32 & 5435005 & 22-fev-01 & 500 & 435 & 501,5 & 161,9 & 90,00 & 5,0 & 34246 & 0,9366 & 1,1760 & 1,5012 & 249,4 \\
\hline 33 & $5404 \mathrm{~m} 10$ & 22-fev-01 & 500 & 404 & 500,5 & 131,2 & 0,26 & 903,0 & 30447 & 0,9348 & 1,3170 & 1,7038 & 202,0 \\
\hline 34 & $5435 \mathrm{~m} 10 \mathrm{~b}$ & 22-fev-01 & 500 & 435 & 502,1 & 162,1 & 0,55 & 814,6 & 27083 & 0,9328 & 0,9286 & 1,6516 & 342,8 \\
\hline 35 & 5404500 & 22-fev-01 & 500 & 404 & 501,7 & 131,4 & 0,55 & 420,6 & 31668 & 0,9354 & 1,3678 & 1,7062 & 180,2 \\
\hline 36 & 5404100 & 22-fev-01 & 500 & 404 & 501,1 & 131,0 & 2,45 & 93,5 & 32969 & 0,9360 & 1,4283 & 1,7036 & 151,4 \\
\hline 37 & 5404010 & 22-fev-01 & 500 & 404 & 499,2 & 131,1 & 24,00 & 9,6 & 32608 & 0,9359 & 1,4116 & 1,6623 & 157,4 \\
\hline 38 & 5404005 & 22-fev-01 & 500 & 404 & 500,7 & 131,0 & 48,00 & 4,8 & 33633 & 0,9363 & 1,4570 & 1,6231 & 137,1 \\
\hline 39 * & 5404002 & 22-fev-01 & 500 & 404 & 501,4 & 130,8 & 95,99 & 2,4 & 32429 & 0,9358 & 1,4070 & 1,5345 & 161,9 \\
\hline
\end{tabular}

* depois do ensaio 39, foi feita a reposição do tubo de vidro graduado. A escala dos sensores ópticos de nível deste tubo que antes era de $2 \mathrm{ml}$, passa a ser de 1,90 $\mathrm{ml}$. 
Continuação da Tab. B.1 que possuem os ensaios da série "RUN1" (bocal rugoso com 0,3 mm de diâmetro).

\begin{tabular}{|c|c|c|c|c|c|c|c|c|c|c|c|c|c|}
\hline & Código & Dia & $\begin{array}{c}\boldsymbol{P}_{\text {inj }} \\
(\mathrm{kPa})\end{array}$ & $\begin{array}{c}T_{\text {inj }} \\
(\mathrm{K}) \\
\end{array}$ & $\begin{array}{c}\boldsymbol{P}_{\mathbf{0}} \\
(\mathrm{kPa}) \\
\end{array}$ & $\begin{array}{c}\boldsymbol{T}_{\mathbf{0}} \\
\left({ }^{\circ} \mathrm{C}\right) \\
\end{array}$ & $\begin{array}{c}\boldsymbol{P}_{\infty} \\
(\mathrm{kPa})\end{array}$ & $\boldsymbol{R}_{\mathbf{P}}$ & $\mathbf{R e}$ & $C_{\mathrm{D}}$ & $\begin{array}{c}\text { medido } \\
\dot{m} \\
(\mathrm{~g} / \mathrm{s}) \\
\end{array}$ & $\begin{array}{c}\text { estimado } \\
\dot{m}_{e} \\
(\mathrm{~g} / \mathrm{s}) \\
\end{array}$ & $\begin{array}{c}\boldsymbol{P}_{\mathbf{1}} \\
(\mathrm{kPa}) \\
\end{array}$ \\
\hline 40 & $5404500 b$ & 15 -mar-01 & 500 & 404 & 500,0 & 131,0 & 0,45 & 509,3 & 31754 & 0,9354 & 1,3757 & 1,7041 & 175,1 \\
\hline 41 & $2368 \mathrm{~m} 10 \mathrm{~b}$ & 16-mar-01 & 250 & 368 & 251,3 & 95,5 & 0,14 & 649,6 & 19811 & 0,9270 & 1,1238 & 1,2184 & 39,1 \\
\hline 42 & $2349500 b$ & 16-mar-01 & 250 & 349 & 251,8 & 76,6 & 0,18 & 296,0 & 17966 & 0,9250 & 1,1872 & 1,2279 & 18,4 \\
\hline 43 & $2349001 b$ & $16-m a r-01$ & 250 & 349 & 250,7 & 75,7 & 54,00 & 0,9 & 16438 & 0,9230 & 1,0945 & 1,0813 & 51,3 \\
\hline 44 & $2368001 b$ & $16-m a r-01$ & 250 & 368 & 249,8 & 95,0 & 87,06 & 1,0 & 17352 & 0,9242 & 0,9882 & 0,9737 & 84,3 \\
\hline 45 & 2349_05 & 16-mar-01 & 250 & 349 & 251,3 & 76,5 & 107,99 & 0,5 & 13933 & 0,9192 & 0,9215 & 0,9151 & 108,1 \\
\hline 46 & 2368_05 & 16-mar-01 & 250 & 368 & 250,0 & 94,5 & 173,99 & 0,5 & 11708 & 0,9149 & 0,6694 & 0,6491 & 171,5 \\
\hline 47 & $2393 m 10$ & 17-mar-01 & 250 & 393 & 248,7 & 119,7 & 0,19 & 918,6 & 20796 & 0,9279 & 0,9805 & 1,1969 & 82,6 \\
\hline 48 & 2393500 & 17-mar-01 & 250 & 393 & 249,6 & 120,2 & 0,25 & 706,9 & 21371 & 0,9285 & 1,0038 & 1,1992 & 75,7 \\
\hline 49 & 2393100 & 17-mar-01 & 250 & 393 & 249,6 & 120,2 & 1,60 & 110,5 & 20132 & 0,9273 & 0,9456 & 1,1944 & 94,7 \\
\hline 50 & 2393010 & 17-mar-01 & 250 & 393 & 249,9 & 120,2 & 18,00 & 9,8 & 19573 & 0,9267 & 0,9193 & 1,1536 & 103,2 \\
\hline 51 & 2393005 & 17-mar-01 & 250 & 393 & 250,0 & 119,7 & 36,00 & 4,8 & 20012 & 0,9272 & 0,9435 & 1,1083 & 95,8 \\
\hline 52 & 2393002 & 17-mar-01 & 250 & 393 & 250,3 & 119,8 & 89,90 & 1,9 & 19147 & 0,9263 & 0,9021 & 0,9554 & 108,9 \\
\hline 53 & $2393 \mathrm{~m} 10 \mathrm{~b}$ & 22-mar-01 & 250 & 393 & 251,3 & 120,6 & 0,22 & 830,1 & 19944 & 0,9271 & 0,9340 & 1,2014 & 100,0 \\
\hline 54 & 2393800 & 22-mar-01 & 250 & 393 & 257,3 & 119,7 & 0,23 & 775,7 & 17430 & 0,9243 & 0,8218 & 1,2129 & 139,1 \\
\hline 55 & $5435 \mathrm{~m} 10 \mathrm{c}$ & 26-mar-01 & 500 & 435 & 500,9 & 162,0 & 0,40 & 1117,8 & 26295 & 0,9323 & 0,9023 & 1,6492 & 350,3 \\
\hline
\end{tabular}

Tabela B.2 - Tabela com os ensaios da série "RUN2" (bocal rugoso com 0,3 mm de diâmetro).

\begin{tabular}{|c|c|c|c|c|c|c|c|c|c|c|c|c|c|}
\hline & Código & Dia & $\begin{array}{c}\boldsymbol{P}_{\text {inj }} \\
(\mathrm{kPa})\end{array}$ & $\begin{array}{c}\boldsymbol{T}_{\text {inj }} \\
(\mathrm{K})\end{array}$ & $\begin{array}{c}\boldsymbol{P}_{\mathbf{0}} \\
(\mathrm{kPa})\end{array}$ & $\begin{array}{c}\boldsymbol{T}_{\mathbf{0}} \\
\left({ }^{\circ} \mathrm{C}\right)\end{array}$ & $\begin{array}{c}\boldsymbol{P}_{\infty} \\
(\mathrm{kPa})\end{array}$ & $\boldsymbol{R}_{\mathbf{P}}$ & $\mathbf{R e}$ & $C_{\mathrm{D}}$ & $\begin{array}{c}\text { medido } \\
\dot{m} \\
(\mathrm{~g} / \mathrm{s})\end{array}$ & $\begin{array}{c}\text { estimado } \\
\dot{m}_{e} \\
\text { (g/s) }\end{array}$ & $\begin{array}{c}\boldsymbol{P}_{\mathbf{1}} \\
(\mathrm{kPa})\end{array}$ \\
\hline 56 & 2368200 & 11-mar-03 & 250 & 368 & 250,0 & 94,4 & 0,49 & 181,6 & 19822 & 0,9270 & 1,1342 & 1,2151 & 34,1 \\
\hline 57 & $2368100 b$ & 11-mar-03 & 250 & 368 & 250,0 & 95,0 & 0,50 & 179,2 & - & - & - & - & . \\
\hline 58 & $2368200 b$ & 20-mar-03 & 250 & 368 & 252,2 & 95,4 & 0,43 & 213,3 & 20101 & 0,9273 & 1,1412 & 1,2204 & 33,6 \\
\hline 59 & 2393050 & 24-mar-03 & 250 & 393 & 249,5 & 119,7 & 3,80 & 45,9 & 20507 & 0,9277 & 0,9669 & 1,1896 & 87,8 \\
\hline 60 & $2349001 c$ & 27-mar-03 & 250 & 349 & 250,0 & 75,7 & 61,86 & 0,8 & 15836 & 0,9222 & 1,0544 & 1,0561 & 64,5 \\
\hline 61 & 2368001c & 27-mar-03 & 250 & 368 & 250,4 & 94,8 & 89,62 & 1,0 & 17144 & 0,9240 & 0,9779 & 0,9675 & 88,3 \\
\hline 62 & $2393 \mathrm{~m} 10 \mathrm{c}$ & 03-jun-03 & 250 & 393 & 251,8 & 121,7 & 0,11 & 1746,5 & 20366 & 0,9275 & 0,9459 & 1,2025 & 96,5 \\
\hline 63 & 2329100 & 03-jun-03 & 250 & 329 & 250,2 & 56,5 & 0,28 & 100,6 & 15405 & 0,9216 & 1,2168 & 1,2316 & 8,2 \\
\hline 64 & 2329500 & 06-jun-03 & 250 & 329 & 249,0 & 56,9 & 0,08 & 352,0 & 15381 & 0,9215 & 1,2103 & 1,2287 & 9,4 \\
\hline 65 & 2329050 & 06-jun-03 & 250 & 329 & 257,2 & 56,3 & 0,49 & 55,8 & 15605 & 0,9219 & 1,2350 & 1,2490 & 8,2 \\
\hline 66 & $5393 \mathrm{~m} 10$ & 26-jun-03 & 500 & 393 & 503,3 & 120,6 & 0,26 & 686,5 & 31651 & 0,9354 & 1,4822 & 1,7226 & 131,8 \\
\hline 67 & 5393010 & 01-jul-03 & 500 & 393 & 476,5 & 122,8 & 17,73 & 10,6 & 31893 & 0,9355 & 1,4691 & 1,6422 & 110,6 \\
\hline 68 & 5393100 & 01-jul-03 & 500 & 393 & 485,3 & 122,6 & 1,70 & 110,6 & 30722 & 0,9349 & 1,4173 & 1,6856 & 144,3 \\
\hline 69 & 5393500 & 01-jul-03 & 500 & 393 & 502,5 & 122,2 & 0,33 & 562,5 & 31638 & 0,9354 & 1,4639 & 1,7193 & 139,3 \\
\hline 70 & $5393 \mathrm{~m} 10 \mathrm{~b}$ & 01-jul-03 & 500 & 393 & 501,6 & 123,2 & 0,21 & 928,0 & 31497 & 0,9353 & 1,4465 & 1,7166 & 146,4 \\
\hline 71 & 5368010 & 03-jul-03 & 500 & 368 & 501,9 & 95,4 & 9,20 & 9,9 & 28859 & 0,9339 & 1,6384 & 1,7263 & 59,7 \\
\hline 72 & 5368100 & 03-jul-03 & 500 & 368 & 503,4 & 95,4 & 0,96 & 94,9 & 28868 & 0,9339 & 1,6389 & 1,7434 & 61,0 \\
\hline 73 & 5368500 & 03-jul-03 & 500 & 368 & 500,2 & 95,1 & 0,23 & 399,5 & 28917 & 0,9339 & 1,6455 & 1,7394 & 54,4 \\
\hline 74 & $5368 \mathrm{~m} 10$ & 03-jul-03 & 500 & 368 & 501,3 & 95,2 & 0,19 & 474,5 & 28160 & 0,9335 & 1,6012 & 1,7405 & 78,6 \\
\hline
\end{tabular}


Tabela B.3 - Tabela com os ensaios da série "RUN3" (bocal rugoso com 0,3 mm de diâmetro).

\begin{tabular}{|c|c|c|c|c|c|c|c|c|c|c|c|c|c|}
\hline & & & $\begin{array}{c}\boldsymbol{P}_{\text {inj }} \\
(\mathrm{kPa})\end{array}$ & $\begin{array}{l}\boldsymbol{T}_{\mathbf{i n j}} \\
(\mathrm{K}) \\
\end{array}$ & $\begin{array}{c}\boldsymbol{P}_{\mathbf{0}} \\
(\mathrm{kPa}) \\
\end{array}$ & $\begin{array}{c}\boldsymbol{T}_{\mathbf{0}} \\
\left({ }^{\circ} \mathrm{C}\right) \\
\end{array}$ & $\begin{array}{c}\boldsymbol{P}_{\infty} \\
(\mathrm{kPa}) \\
\end{array}$ & $\boldsymbol{R}_{\mathbf{P}}$ & & & $\begin{array}{c}\text { medido } \\
\dot{m} \\
(\mathrm{~g} / \mathrm{s}) \\
\end{array}$ & $\begin{array}{c}\dot{m}_{e} \\
(\mathrm{~g} / \mathrm{s}) \\
\end{array}$ & $\begin{array}{c}\boldsymbol{P}_{\mathbf{1}} \\
(\mathrm{kPa}) \\
\end{array}$ \\
\hline 75 & & & 500 & 349 & 497,6 & 76,9 & 0,11 & 474,8 & & & ,6993 & .,7538 & 30 \\
\hline 76 & 5349100 & -set-03 & 500 & 349 & 496,3 & 76,7 & 0,48 & 108,2 & 25679 & ,9319 & ,6955 & 1,7509 & 31,4 \\
\hline 77 & 53400 & & 500 & 349 & 496,8 & 77,3 & 5,07 & 10,4 & 26125 &, 9322 & ,7163 & 1,7437 & 20,4 \\
\hline 78 & 5220 & & 500 & 329 & 501,6 & 56,6 & 0,20 & 137,7 & & &, 7455 & 1,7735 & 15,9 \\
\hline 79 & 5329500 & & 500 & 329 & 504,1 & 57,1 & 0,15 & 185,6 & 22221 & & 1,7453 & 1,7777 & 18,4 \\
\hline 80 & 53290 & & 500 & 329 & 501,6 & 56,6 & 0,54 & 50,7 & 22215 & & 1,7531 & 1,7731 & 11,8 \\
\hline 81 & 5329010 & & 500 & 329 & 500,3 & 56,4 & 2,53 & 10,7 & 22095 & & 1,7469 & 1,7673 & 13,9 \\
\hline 82 & $7451 m 45$ & t-03 & 750 & 451 & 751,6 & 178,1 & 0,13 & 4551,5 & 32378 & 0,9357 & 0,9809 & 1,9923 & 69,5 \\
\hline 83 & $7451 \mathrm{~m} 20$ & -out-03 & 750 & 451 & 752,4 & 178,9 & 0,29 & 2161,2 & 35370 & 71 & 1,0648 & 1,9936 & 37,9 \\
\hline 84 & 7451500 & -out-03 & 750 & 451 & 756,6 & 177,6 & 2,35 & 257,6 & 35663 & 32 & 1,0846 & 2,0006 & 534,9 \\
\hline 85 & 7451100 & 1-out-03 & 750 & 451 & 754,6 & 177,6 & 6,97 & 86,7 & 38541 & &, 1722 & 1,9943 & 196,3 \\
\hline 86 & 7451 & 2 & 750 & 451 & 753,8 & 176,9 & 13,74 & 43,4 & 34949 & & 1,0688 & 1,9831 & 538,9 \\
\hline 87 & 745 & & 750 & 451 & 750,1 & 173,7 & & 9 & & & 1684 & & 96,1 \\
\hline 88 & & & 750 & 435 & 749,2 & 161,8 & & & & & & & \\
\hline 89 & 10 & & 750 & 435 & 747,7 & 161,3 & 0,72 & & & & 1,3720 & 2,0385 & 409,4 \\
\hline 90 & 1400 & & 750 & 435 & 749,5 & 161,7 & 1,05 & 423,1 & & & 1,3561 & 2,0393 & 418,5 \\
\hline 91 & 7435 & & 750 & 435 & 749,3 & 161,8 & 4,60 & 96,8 & & & 1,3635 & 2,0341 & 414,7 \\
\hline 92 & 7435010 & & 750 & 435 & 747,4 & 161,6 & 45,13 & 9,8 & & & 1,3277 & 1,9750 & 430,0 \\
\hline 93 & $7404 r$ & & 750 & 404 & 751,9 & 131,7 & 0,18 & 277,6 & 40148 & & 1,7302 & 2,1056 & 244,3 \\
\hline 94 & 74045 & 24-out-03 & 750 & 404 & 749,6 & 131,9 & 0,27 & 872,5 & 40897 & & 1,7599 & 2,1025 & 224,6 \\
\hline 95 & 74041 & 24-out-03 & 750 & 404 & 753,0 & 131,7 & 2,28 & 102,5 & 41217 & & 1,7763 & 2,1050 & 218,5 \\
\hline 96 & 7404010 & 24-out-03 & 750 & 404 & 748,9 & 131,7 & 23,00 & 10,1 & 40556 & & 1,7478 & 2,0694 & 231,1 \\
\hline 97 & 7404002 & 24-ou & 750 & 404 & 752,7 & 131,1 & 126,16 & 1,8 & 40437 & 0,9391 & 1,7505 & 1,9234 & 233,8 \\
\hline 98 & 7393002 & & 750 & 393 & 753,6 & 120,4 & 93,33 & 1,9 & & & 1,8596 & 1,9891 & 1765 \\
\hline 99 & 7368001 & & 750 & 368 & 752,8 & 96,0 & 93,33 & 1,0 & & &, 9682 & 2,0115 & 121,4 \\
\hline 100 & 7368002 & & 750 & 368 & & 96,3 & & & & & & & 61,6 \\
\hline & & & 750 & 393 & 750,6 & 121,4 & 17,94 & & & & & & 167,4 \\
\hline 102 & & & 750 & 393 & & 21,1 & & & & & 833 & 237 & 61,0 \\
\hline 103 & & & 750 & 393 & & 21,3 & & & & & & 224 & $.73,8$ \\
\hline 104 & 7 & & 750 & 393 & 749,9 & 121,0 & 1,80 & 0,2 & & & & & 166,4 \\
\hline 105 & 7368100 & 29-out-03 & 750 & 368 & 752,3 & 96,4 & 0,93 & 101,0 & 36024 & 0,9374 & 2,0292 & 2,1477 & 81,6 \\
\hline 106 & 7368010 & 29-out-03 & 750 & 368 & 750,1 & 95,7 & 9,00 & 10,2 & 35994 & 0,9374 & 2,0387 & 2,1337 & 73,6 \\
\hline 107 & $7368 m 10$ & 30 -out-03 & 750 & 368 & 750,9 & 95,2 & 0,23 & 391,4 & 35705 & 0,9373 & 2,0302 & 2,1477 & 80,1 \\
\hline 108 & 7368500 & 30 -out-03 & 750 & 368 & 748,4 & 95,3 & 0,31 & 288,6 & 35398 & 0,9371 & 2,0112 & 2,1436 & 89,9 \\
\hline 109 & $7393100 \mathrm{~b}$ & 30 -out-03 & 750 & 393 & 751,9 & 120,9 & 1,79 & 100,5 & 40082 & & 1,8728 & 2,1197 & 166,4 \\
\hline 110 & & & 750 & 349 & 750,7 & 77,1 & & & & & & & 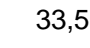 \\
\hline 111 & & & 750 & 349 & 752,5 & 77,0 & & & & & 2,0910 & 2,1641 & U, \\
\hline 112 & & 30 -out-03 & 750 & 349 & 749,2 & 76,8 & 0,90 & 57,0 & 31825 & 0,9355 & 2,0995 & 2,1591 & 41,6 \\
\hline 113 & 73490 & & 750 & 349 & 753,0 & 76,2 & & 10,2 & 31681 & & 2,1005 & 2,1593 & 45,1 \\
\hline 114 & 7349002 & & 750 & 349 & 747,8 & 76,0 & 24,93 & 2,0 & 31346 & & 0818 & ,1224 & 52,3 \\
\hline 115 & 7329200 & & 750 & 329 & 751,1 & 56,4 & & & 27326 & & 1605 & 1795 & 13,3 \\
\hline 116 & 7329500 & 31-out-03 & 750 & 329 & 752,0 & 56,4 & 0,21 & 130,1 & 27419 & 0,9330 & 2,1679 & 2,1810 & 9,2 \\
\hline
\end{tabular}


Continuação da Tab. B.3 que possuem os ensaios da série "RUN3" (bocal rugoso com 0,3 mm de diâmetro).

\begin{tabular}{|c|c|c|c|c|c|c|c|c|c|c|c|c|c|}
\hline & Código & Dia & $\begin{array}{c}\boldsymbol{P}_{\text {inj }} \\
(\mathrm{kPa}) \\
\end{array}$ & $\begin{array}{c}\boldsymbol{T}_{\text {inj }} \\
(\mathrm{K}) \\
\end{array}$ & $\begin{array}{c}\boldsymbol{P}_{\mathbf{0}} \\
(\mathrm{kPa}) \\
\end{array}$ & $\begin{array}{c}T_{0} \\
\left({ }^{\circ} \mathrm{C}\right) \\
\end{array}$ & $\begin{array}{c}\boldsymbol{P}_{\infty} \\
(\mathrm{kPa}) \\
\end{array}$ & $\boldsymbol{R}_{\mathbf{P}}$ & $\mathbf{R e}$ & $C_{\mathrm{D}}$ & $\begin{array}{c}\text { medido } \\
\dot{m} \\
(\mathrm{~g} / \mathrm{s}) \\
\end{array}$ & $\begin{array}{c}\text { estimado } \\
\dot{m}_{e} \\
(\mathrm{~g} / \mathrm{s}) \\
\end{array}$ & $\begin{array}{c}\boldsymbol{P}_{\mathbf{1}} \\
(\mathrm{kPa}) \\
\end{array}$ \\
\hline 117 & 7329050 & 31-out-03 & 750 & 329 & 751,6 & 56,1 & 0,64 & 41,6 & 26920 & 0,9327 & 2,1345 & 2,1794 & 31,3 \\
\hline 118 & 7329010 & 31-out-03 & 750 & 329 & 751,2 & 56,3 & 2,13 & 12,6 & 26952 & 0,9327 & 2,1330 & 2,1765 & 31,8 \\
\hline 119 & 7329002 & 31-out-03 & 750 & 329 & 750,4 & 56,1 & 12,40 & 2,1 & 27078 & 0,9328 & 2,1471 & 2,1608 & 21,7 \\
\hline 120 & 5349050 & 31-out-03 & 500 & 349 & 501,9 & 76,2 & 0,93 & 54,2 & 25759 & 0,9319 & 1,7079 & 1,7605 & 30,4 \\
\hline 121 & 1368500 & 07-nov-03 & 125 & 368 & 123,5 & 94,8 & 0,15 & 582,8 & 14065 & 0,9195 & 0,8022 & 0,8543 & 14,7 \\
\hline 122 & 1368050 & 07-nov-03 & 125 & 368 & 125,1 & 93,4 & 2,13 & 40,3 & 14250 & 0,9198 & 0,8218 & 0,8538 & 11,2 \\
\hline 123 & 1368002 & 07-nov-03 & 125 & 368 & 123,5 & 92,6 & 44,00 & 1,9 & 11960 & 0,9154 & 0,6941 & 0,6836 & 41,5 \\
\hline 124 & $1368002 b$ & 07-nov-03 & 125 & 368 & 122,9 & 92,7 & 44,66 & 1,9 & 11715 & 0,9149 & 0,6794 & 0,6777 & 44,3 \\
\hline 125 & $1368002 c$ & 07-nov-03 & 125 & 368 & 124,5 & 93,8 & 44,66 & 1,9 & 11831 & 0,9151 & 0,6802 & 0,6844 & 45,6 \\
\hline 126 & 1329500 & 07-nov-03 & 125 & 329 & 123,0 & 56,5 & 0,14 & 191,0 & 10801 & 0,9127 & 0,8532 & 0,8624 & 2,8 \\
\hline 127 & 1329050 & 07-nov-03 & 125 & 329 & 122,1 & 56,4 & 0,49 & 54,6 & 10683 & 0,9124 & 0,8447 & 0,8578 & 4,2 \\
\hline 128 & 1329002 & 07-nov-03 & 125 & 329 & 121,3 & 56,3 & 12,47 & 2,2 & 10215 & 0,9112 & 0,8084 & 0,8105 & 13,0 \\
\hline 129 & 1349002 & 07-nov-03 & 125 & 349 & 128,0 & 76,3 & 24,47 & 2,1 & 11648 & 0,9147 & 0,7716 & 0,7855 & 28,1 \\
\hline 130 & 1349500 & 07-nov-03 & 125 & 349 & 122,7 & 75,2 & 0,14 & 359,6 & 12473 & 0,9165 & 0,8340 & 0,8568 & 6,6 \\
\hline 131 & 1349100 & 20-jan-04 & 125 & 349 & 124,7 & 76,9 & 0,45 & 114,1 & 12492 & 0,9165 & 0,8234 & 0,8620 & 11,3 \\
\hline 132 & $1349100 \mathrm{~b}$ & 20-jan-04 & 125 & 349 & 124,0 & 77,3 & 0,53 & 98,0 & - & - & - & - & - \\
\hline
\end{tabular}

\section{B.2. Medição do Comprimento de Extinção do Núcleo Líquido}

Na Tab. B.4, do Anexo B, são vistos os ensaios com os valores nominais de pressão e temperatura de injeção $\left(P_{0}\right.$ e $\left.T_{0}\right)$, seguida da pressão de saturação $\left(P_{\text {sat }}\right)$ à temperatura de injeção $\left(T_{0}\right)$, pressão da câmara $\left(P_{\infty}\right)$ e a razão entre a pressão de saturação e a pressão de injeção $\left(P_{\text {sat }} / P_{0}\right)$. O comprimento de extinção $\left(L_{\mathrm{E}}\right)$ é a próxima coluna e depois, está a razão entre a comprimento de extinção do líquido e o diâmetro do bocal $\left(L_{\mathrm{E}} / D_{\mathrm{b}}\right)$. 
Tabela B.4 - Relação do comprimento do núcleo líquido de cada ensaio (bocal rugoso com 0,3 mm de diâmetro).

\begin{tabular}{|c|c|c|c|c|c|c|c|}
\hline Ensaio & $\begin{array}{c}P_{0} \\
(\mathrm{kPa})\end{array}$ & $\begin{array}{c}T_{0} \\
\left({ }^{\circ} \mathrm{C}\right) \\
\end{array}$ & $\begin{array}{c}P_{\text {sat }} \\
(\mathrm{kPa})\end{array}$ & $\begin{array}{c}P_{\infty} \\
(\mathrm{kPa})\end{array}$ & $P_{\text {sat }} / P_{0}$ & $\begin{array}{c}L_{\mathrm{E}} \\
(+/-1 \mathrm{~mm}) \\
\end{array}$ & $L_{\mathrm{E}} / D_{\mathrm{b}}$ \\
\hline run3\1329500 & 125 & 56 & 27,0 & 0,14 & 0,216 & 6,9 & 22,3 \\
\hline run3\1329050 & 125 & 56 & 27,0 & 0,50 & 0,216 & 7,5 & 24,2 \\
\hline run3\1349500 & 125 & 76 & 50,4 & 0,14 & 0,403 & 5,2 & 16,7 \\
\hline run3\1368050 & 125 & 95 & 85,8 & 1,70 & 0,686 & 3,4 & 11,0 \\
\hline run3\1368500 & 125 & 95 & 85,8 & 0,15 & 0,686 & 3,1 & 10,0 \\
\hline run2\2329500 & 250 & 56 & 27,7 & 0,08 & 0,111 & 7,6 & 24,6 \\
\hline run2\2329100 & 250 & 56 & 27,7 & 0,28 & 0,111 & 7,2 & 23,2 \\
\hline run2\2329050 & 250 & 56 & 27,7 & 0,49 & 0,111 & 7,6 & 24,5 \\
\hline run1/2349500 & 250 & 76 & 51,5 & 0,16 & 0,206 & 6,1 & 19,8 \\
\hline run1 $12349500 b$ & 250 & 76 & 51,5 & 0,18 & 0,206 & 6,4 & 20,7 \\
\hline run1\2349100 & 250 & 76 & 51,5 & 0,53 & 0,206 & 6,3 & 20,4 \\
\hline run1\2349010 & 250 & 76 & 51,5 & 6,67 & 0,206 & 6,3 & 20,4 \\
\hline run1\2349005 & 250 & 76 & 51,5 & 10,07 & 0,206 & 6,3 & 20,4 \\
\hline run1|2368m10 & 250 & 95 & 89,4 & 0,13 & 0,358 & 4,9 & 15,7 \\
\hline run1 $12368 m 10 b$ & 250 & 95 & 89,4 & 0,14 & 0,358 & 4,7 & 15,3 \\
\hline run1|2368500 & 250 & 95 & 89,4 & 0,20 & 0,358 & 4,6 & 14,8 \\
\hline run2\2368200b & 250 & 95 & 89,4 & 0,43 & 0,358 & 4,2 & 13,5 \\
\hline run2\2368200 & 250 & 95 & 89,4 & 0,49 & 0,358 & 4,4 & 14,4 \\
\hline run1\2368100 & 250 & 95 & 89,4 & 0,85 & 0,358 & 4,7 & 15,2 \\
\hline run1|2368010 & 250 & 95 & 89,4 & 9,07 & 0,358 & 3,9 & 12,6 \\
\hline run112368010b & 250 & 95 & 89,4 & 9,27 & 0,358 & 4,0 & 13,0 \\
\hline run1 $\mid 2368010 c$ & 250 & 95 & 89,4 & 9,40 & 0,358 & 3,9 & 12,6 \\
\hline run1|2368010d & 250 & 95 & 89,4 & 9,93 & 0,358 & 4,0 & 13,0 \\
\hline run $2 \backslash 2393 m 10 \mathrm{c}$ & 250 & 120 & 176,5 & 0,11 & 0,706 & 3,0 & 9,7 \\
\hline run1|2393m10 & 250 & 120 & 176,5 & 0,19 & 0,706 & 2,9 & 9,4 \\
\hline run1 $\mid 2393 m 10 b$ & 250 & 120 & 176,5 & 0,22 & 0,706 & 3,2 & 10,2 \\
\hline run1\2393800 & 250 & 120 & 176,5 & 0,23 & 0,706 & 3,2 & 10,4 \\
\hline run1\2393500 & 250 & 120 & 176,5 & 0,25 & 0,706 & 3,0 & 9,6 \\
\hline run1 $\backslash 2393100$ & 250 & 120 & 176,5 & 1,60 & 0,706 & 3,2 & 10,4 \\
\hline run2\2393050 & 250 & 120 & 176,5 & 3,80 & 0,706 & 2,6 & 8,4 \\
\hline run1\2393005 & 250 & 120 & 176,5 & 36,0 & 0,706 & 3,4 & 11,0 \\
\hline run1/2406m10 & 250 & 131 & 225,4 & 0,18 & 0,902 & 2,9 & 9,5 \\
\hline run1|2404m10 & 250 & 131 & 225,4 & 0,22 & 0,902 & 2,2 & 7,3 \\
\hline run1/2404m10b & 250 & 131 & 225,4 & 0,22 & 0,902 & 2,9 & 9,5 \\
\hline run1/2404500b & 250 & 131 & 225,4 & 0,48 & 0,902 & 2,4 & 7,9 \\
\hline run1 12404500 & 250 & 131 & 225,4 & 0,48 & 0,902 & 2,4 & 7,8 \\
\hline run1\2404100 & 250 & 131 & 225,4 & 3,30 & 0,902 & 2,3 & 7,4 \\
\hline run1\2404005 & 250 & 131 & 225,4 & 43,7 & 0,902 & 2,9 & 9,3 \\
\hline run3\5329500 & 500 & 56 & 27,4 & 0,15 & 0,055 & 12,3 & 39,8 \\
\hline run3\5329100 & 500 & 56 & 27,4 & 0,20 & 0.055 & 11,6 & 37,5 \\
\hline run3\5329050 & 500 & 56 & 27,4 & 0,54 & 0,055 & 11,2 & 36,4 \\
\hline run3\5329010 & 500 & 56 & 27,4 & 2,53 & 0,055 & 11,0 & 35,6 \\
\hline run3\5349500 & 500 & 76 & 51,8 & 0,11 & 0,104 & 7,9 & 25,6 \\
\hline run3\5349100 & 500 & 76 & 51,8 & 0,48 & 0,104 & 8,1 & 26,4 \\
\hline run3\5349050 & 500 & 76 & 51,8 & 0,93 & 0,104 & 7,5 & 24,3 \\
\hline run3\5349010 & 500 & 76 & 51,8 & 5,07 & 0,104 & 7,8 & 25,2 \\
\hline run2 $25368 \mathrm{~m} 10$ & 500 & 95 & 90,3 & 0,19 & 0,181 & 5,8 & 18,9 \\
\hline run2\5368500 & 500 & 95 & 90,3 & 0,23 & 0,181 & 6,3 & 20,4 \\
\hline run2 15368100 & 500 & 95 & 90,3 & 0,96 & 0,181 & 5,5 & 17,7 \\
\hline run2\5368010 & 500 & 95 & 90,3 & 9,20 & 0,181 & 5,3 & 17,2 \\
\hline run215393m10b & 500 & 120 & 186,0 & 0,21 & 0,372 & 3,8 & 12,2 \\
\hline run215393m10 & 500 & 120 & 186,0 & 0,26 & 0,372 & 4,2 & 13,6 \\
\hline
\end{tabular}

continua... 
Continuação da Tab. B.4 (bocal rugoso com 0,3 mm de diâmetro).

\begin{tabular}{|c|c|c|c|c|c|c|c|}
\hline Ensaio & $\begin{array}{c}P_{0} \\
(\mathrm{kPa}) \\
\end{array}$ & $\begin{array}{c}T_{0} \\
\left({ }^{\circ} \mathrm{C}\right) \\
\end{array}$ & $\begin{array}{c}P_{\text {sat }} \\
(\mathrm{kPa}) \\
\end{array}$ & $\begin{array}{c}P_{\infty} \\
(\mathrm{kPa}) \\
\end{array}$ & $P_{\text {sat }} / P_{0}$ & $\begin{array}{c}L_{\mathrm{E}} \\
(+/-1 \mathrm{~mm}) \\
\end{array}$ & $L_{\mathrm{E}} / D_{\mathrm{b}}$ \\
\hline run215393500 & 500 & 120 & 186,0 & 0,33 & 0,372 & 3,8 & 12,2 \\
\hline run2\5393100 & 500 & 120 & 186,0 & 1,70 & 0,372 & 3,8 & 12,2 \\
\hline run2\5393010 & 500 & 120 & 186,0 & 17,7 & 0,372 & 4,2 & 13,6 \\
\hline run1/5404m10 & 500 & 131 & 229,6 & 0,26 & 0,459 & 3,7 & 11,9 \\
\hline run115404500b & 500 & 131 & 229,6 & 0,45 & 0,459 & 3,7 & 12,0 \\
\hline run115404100 & 500 & 131 & 229,6 & 2,45 & 0,459 & 2,9 & 9,4 \\
\hline run1 $\mid 5404010$ & 500 & 131 & 229,6 & 24,0 & 0,459 & 3,4 & 11,0 \\
\hline run $115435 \mathrm{~m} 10 \mathrm{c}$ & 500 & 162 & 443,6 & 0,40 & 0,887 & 2,1 & 6,8 \\
\hline run115435m10 & 500 & 162 & 443,6 & 0,45 & 0,887 & 2,0 & 6,5 \\
\hline run115435m10b & 500 & 162 & 443,6 & 0,55 & 0,887 & 1,9 & 6,2 \\
\hline run115435500 & 500 & 162 & 443,6 & 0,94 & 0,887 & 2,0 & 6,5 \\
\hline run1|5435010 & 500 & 162 & 443,6 & 44,9 & 0,887 & 2,2 & 7,1 \\
\hline run1/5435005 & 500 & 162 & 443,6 & 90,0 & 0,887 & 2,3 & 7,5 \\
\hline run317329500 & 750 & 56 & 26,8 & 0,21 & 0,036 & 14,5 & 47,2 \\
\hline run3।7329200 & 750 & 56 & 26,8 & 0,23 & 0,036 & 14,1 & 45,6 \\
\hline run317329050 & 750 & 56 & 26,8 & 0,64 & 0,036 & 14,1 & 45,8 \\
\hline run3।7329010 & 750 & 56 & 26,8 & 2,14 & 0,036 & 14,7 & 47,6 \\
\hline run3\7349500 & 750 & 76 & 50,9 & 0,22 & 0,068 & 10,2 & 33,0 \\
\hline run3।7349100 & 750 & 76 & 50,9 & 0,55 & 0,068 & 10,2 & 33,0 \\
\hline run3\7349050 & 750 & 76 & 50,9 & 1,00 & 0,068 & 10,3 & 33,4 \\
\hline run3\7349010 & 750 & 76 & 50,9 & 4,90 & 0,068 & 10,5 & 34,2 \\
\hline run3\7368m10 & 750 & 95 & 91,7 & 0,23 & 0,122 & 8,1 & 26,3 \\
\hline run3\7368500 & 750 & 95 & 91,7 & 0,32 & 0,122 & 8,0 & 25,9 \\
\hline run3\7368100 & 750 & 95 & 91,7 & 0,93 & 0,122 & 7,3 & 23,7 \\
\hline run3\7368010 & 750 & 95 & 91,7 & 9,00 & 0,122 & 6,9 & 22,5 \\
\hline run3ı7393m10 & 750 & 120 & 180,3 & 0,23 & 0,240 & 5,4 & 17,4 \\
\hline run317393500 & 750 & 120 & 180,3 & 0,32 & 0,240 & 5,5 & 17,8 \\
\hline run317393100b & 750 & 120 & 180,3 & 1,79 & 0,240 & 4,6 & 14,8 \\
\hline run317393010 & 750 & 120 & 180,3 & 17,94 & 0,240 & 4,5 & 14,6 \\
\hline run3\7404m10 & 750 & 131 & 232,7 & 0,18 & 0,310 & 4,8 & 15,7 \\
\hline run3ı7404500 & 750 & 131 & 232,7 & 0,27 & 0,310 & 4,8 & 15,7 \\
\hline run3\7404100 & 750 & 131 & 232,7 & 2,28 & 0,310 & 4,0 & 13,0 \\
\hline run3\7404010 & 750 & 131 & 232,7 & 23,00 & 0,310 & 4,0 & 13,0 \\
\hline run317435m20 & 750 & 162 & 443,7 & 0,48 & 0,592 & 2,3 & 7,5 \\
\hline run315435m10 & 750 & 162 & 443,7 & 0,72 & 0,592 & 2,3 & 7,5 \\
\hline run3\7435500 & 750 & 162 & 443,7 & 1,05 & 0,592 & 2,4 & 7,8 \\
\hline run3\} 1 7 4 3 5 1 0 0 $&{750} &{162} &{443,7} &{4,58} &{0,592} &{2,1} &{6,8} \\
{\hline \text { run3।7435010 }} &{750} &{162} &{443.7} &{45,13} &{0,592} &{2.3} &{7,5} \\
{\hline \text { run317451m45 }} &{750} &{178} &{599,1} &{0,14} &{0,799} &{1,6} &{5,2} \\
{\hline \text { run317451m20 }} &{750} &{178} &{599,1} &{0,29} &{0,799} &{1,8} &{5,8} \\
{\hline \text { run3।7451500 }} &{750} &{178} &{599,1} &{1,57} &{0,799} &{1,9} &{6,2} \\
{\hline \text { run3\7451100 }} &{750} &{178} &{599,1} &{6,97} &{0,799} &{1,7} &{5,5} \\
{\hline \text { run3।7451010 }} &{750} &{178} &{599,1} &{70,59} &{0,799} &{1,5} &{4,9} \\
$\hline
\end{tabular}




\section{B.3. Medição das Dimensões da Estrutura da Onda de Choque}

A dimensão radial da onda de choque, $r_{1}$, e sua distância axial em relação à saída do bocal, $r_{2}$, foram as principais medidas tomadas para análises do comportamento da onda de choque. Os valores destas dimensões estão apresentados na Tab. B.5, cujas imagens estão expostas na seção seguinte. Nesta tabela estão apresentados os ensaios seguidos da série, categoria da pressão e temperatura de injeção. Logo após estão os valores exatos da pressão e temperatura de injeção. São adquiridas várias imagens de um único ensaio e, para cada uma delas, estão correlacionadas a pressão da câmara e a razão entre as pressões de saturação e da câmara com as dimensões do raio e da distância axial da onda de choque formada naquele instante. 
Tabela B.5 - Relação das dimensões da onda de choque formada como o raio, $r_{1}$ e a distancia axial, $r_{2}$ (bocal rugoso com $0,3 \mathrm{~mm}$ de diâmetro).

\begin{tabular}{|c|c|c|c|c|c|c|c|c|c|c|}
\hline Ensaio & Série & $\begin{array}{c}P_{\text {inj }} \\
(\mathrm{kPa})\end{array}$ & $\begin{array}{l}T_{\text {inj }} \\
\left({ }^{\circ} \mathrm{C}\right)\end{array}$ & $\begin{array}{c}P_{0} \\
(\mathrm{kPa})\end{array}$ & $\begin{array}{c}T_{0} \\
\left({ }^{\circ} \mathrm{C}\right)\end{array}$ & Imagem & $R_{\mathrm{p}}$ & $\begin{array}{c}P_{\infty} \\
(\mathrm{kPa})\end{array}$ & $\begin{array}{c}r_{1} \\
(\mathrm{~mm})\end{array}$ & $\begin{array}{c}r_{2} \\
(\mathrm{~mm})\end{array}$ \\
\hline 1329050 & run3 & 125 & 56 & 122,1 & 56,4 & 6 & 0,43 & 62,8 & 4,0 & 8,1 \\
\hline 1329050 & run3 & 125 & 56 & 122,1 & 56,4 & 4 & 0,46 & 58,7 & 3,9 & 7,5 \\
\hline 1329050 & run3 & 125 & 56 & 122,1 & 56,4 & 3 & 0,48 & 56,2 & 3,9 & 7,7 \\
\hline 1329050 & run3 & 125 & 56 & 122,1 & 56,4 & 2 & 0,51 & 52,9 & 4,1 & 7,7 \\
\hline 1329050 & run3 & 125 & 56 & 122,1 & 56,4 & 1 & 0,56 & 48,2 & 3,9 & 6,5 \\
\hline 1329500 & run3 & 125 & 56 & 123,0 & 56,5 & 6 & 0,07 & 387,4 & 13,6 & 10,8 \\
\hline 1329500 & run3 & 125 & 56 & 123,0 & 56,5 & 4 & 0,10 & 271,2 & 11,9 & 10,7 \\
\hline 1329500 & run3 & 125 & 56 & 123,0 & 56,5 & 3 & 0,13 & 208,6 & 10,1 & 10,7 \\
\hline 1329500 & run3 & 125 & 56 & 123,0 & 56,5 & 2 & 0,15 & 180,8 & 9,6 & 10,5 \\
\hline 1329500 & run3 & 125 & 56 & 123,0 & 56,5 & 1 & 0,21 & 129,1 & 8,2 & 10,0 \\
\hline 1349500 & run3 & 125 & 76 & 122,7 & 75,2 & 6 & 0,07 & 693,6 & 17,1 & 11,4 \\
\hline 1349500 & run3 & 125 & 76 & 122,7 & 75,2 & 4 & 0,10 & 485,5 & 14,1 & 10,0 \\
\hline 1349500 & run3 & 125 & 76 & 122,7 & 75,2 & 3 & 0,13 & 373,5 & 12,9 & 10,0 \\
\hline 1349500 & run3 & 125 & 76 & 122,7 & 75,2 & 2 & 0,15 & 323,7 & 12,2 & 9,5 \\
\hline 1349500 & run3 & 125 & 76 & 122,7 & 75,2 & 1 & 0,21 & 231,2 & 9,7 & 8,4 \\
\hline 1368050 & run3 & 125 & 95 & 123,5 & 94,8 & 8 & 0,08 & 1070,0 & 18,6 & 12,9 \\
\hline 1368050 & run3 & 125 & 95 & 123,5 & 94,8 & 6 & 0,22 & 389,1 & 12,1 & 8,5 \\
\hline 1368050 & run3 & 125 & 95 & 125,1 & 93,4 & 5 & 1,61 & 53,2 & 3,3 & 3,1 \\
\hline 1368050 & run3 & 125 & 95 & 125,1 & 93,4 & 2 & 1,64 & 52,2 & 3,3 & 3,1 \\
\hline 1368050 & run3 & 125 & 95 & 125,1 & 93,4 & 1 & 1,71 & 50,1 & 2,7 & 3,4 \\
\hline 1368500 & run3 & 125 & 95 & 123,5 & 94,8 & 8 & 0,05 & 1783,4 & 21,6 & 13,7 \\
\hline 1368500 & run3 & 125 & 95 & 123,5 & 94,8 & 7 & 0,14 & 636,9 & 14,7 & 8,8 \\
\hline 1368500 & run3 & 125 & 95 & 123,5 & 94,8 & 4 & 0,25 & 356,7 & 11,8 & 8,3 \\
\hline 1368500 & run3 & 125 & 95 & 125,1 & 93,4 & 2 & 1,74 & 51,2 & 2,7 & 3,4 \\
\hline 1368500 & run3 & 125 & 95 & 125,1 & 93,4 & 1 & 1,79 & 49,8 & 2,6 & 3,6 \\
\hline 2329050 & run2 & 250 & 56 & 257,2 & 56,3 & 6 & 0,40 & 68,3 & 5,6 & 8,4 \\
\hline 2329050 & run2 & 250 & 56 & 257,2 & 56,3 & 4 & 0,44 & 62,1 & 5,3 & 9,3 \\
\hline 2329050 & run2 & 250 & 56 & 257,2 & 56,3 & 2 & 0,51 & 53,6 & 5,0 & 8,5 \\
\hline 2329050 & run2 & 250 & 56 & 257,2 & 56,3 & 1 & 0,58 & 47,1 & 4,6 & 8,0 \\
\hline 2329100 & run2 & 250 & 56 & 250,2 & 56,5 & 6 & 0,17 & 162,8 & 8,6 & 10,1 \\
\hline 2329100 & run2 & 250 & 56 & 250,2 & 56,5 & 4 & 0,21 & 131,8 & 7,9 & 9,8 \\
\hline 2329100 & run2 & 250 & 56 & 250,2 & 56,5 & 2 & 0,30 & 92,2 & 6,7 & 8,7 \\
\hline 2329100 & run2 & 250 & 56 & 250,2 & 56,5 & 1 & 0,38 & 72,8 & 6,4 & 8,7 \\
\hline 2329500 & run2 & 250 & 56 & 249,0 & 56,9 & 6 & 0,05 & 563,2 & 18,1 & 14,3 \\
\hline 2329500 & run2 & 250 & 56 & 249,0 & 56,9 & 4 & 0,08 & 352,0 & 13,8 & 12,4 \\
\hline 2329500 & run2 & 250 & 56 & 249,0 & 56,9 & 2 & 0,09 & 312,9 & 11,4 & 12,8 \\
\hline 2329500 & run2 & 250 & 56 & 249,0 & 56,9 & 1 & 0,14 & 201,1 & 9,6 & 9,8 \\
\hline 2349100 & run1 & 250 & 76 & 251,5 & 76,7 & 4 & 0,43 & 120,8 & 6,8 & 7,2 \\
\hline 2349100 & run1 & 250 & 76 & 251,5 & 76,7 & 3 & 0,49 & 106,0 & 6,5 & 7,0 \\
\hline 2349100 & run1 & 250 & 76 & 251,5 & 76,7 & 2 & 0,56 & 92,8 & 5,2 & 7,0 \\
\hline 2349100 & run1 & 250 & 76 & 251,5 & 76,7 & 1 & 0,62 & 83,8 & 5,0 & 6,7 \\
\hline 2349500 & run1 & 250 & 76 & 251,7 & 76,2 & 4 & 0,07 & 732,0 & 14,7 & 9,7 \\
\hline 2349500 & run1 & 250 & 76 & 251,8 & 76,6 & 3 & 0,07 & 732,0 & 16,4 & 12,8 \\
\hline 2349500 & run1 & 250 & 76 & 251,7 & 76,2 & 2 & 0,21 & 244,0 & 9,8 & 9,4 \\
\hline 2349500 & run1 & 250 & 76 & 251.8 & 76.6 & 1 & 0.21 & 244.0 & 10.9 & 8,9 \\
\hline $2349500 b$ & run1 & 250 & 76 & 2518 & 76.6 & 4 & 0.11 & 470.9 & 15.0 & 11.3 \\
\hline $2349500 b$ & run1 & 250 & 76 & 251.7 & 76.2 & 3 & 0.12 & 431.7 & 13.8 & 9.5 \\
\hline $2349500 b$ & run1 & 250 & 76 & 2517 & 76.2 & 2 & 0.27 & 1919 & 7.9 & 9.4 \\
\hline $2349500 b$ & run1 & 250 & 76 & 251,8 & 76,6 & 1 & 0,28 & 185,0 & 7,7 & 8,4 \\
\hline 2368100 & run1 & 250 & 95 & 246.8 & 93,9 & 4 & 0.74 & 117,3 & 5,5 & 5,6 \\
\hline
\end{tabular}

continua... 
...continuação de Tab. B.5.

\begin{tabular}{|c|c|c|c|c|c|c|c|c|c|c|}
\hline Ensaio & Série & $\begin{array}{c}P_{\text {inj }} \\
(\mathrm{kPa})\end{array}$ & $\begin{array}{l}T_{\text {inj }} \\
\left({ }^{\circ} \mathrm{C}\right)\end{array}$ & $\begin{array}{c}P_{0} \\
(\mathrm{kPa})\end{array}$ & $\begin{array}{c}T_{0} \\
\left({ }^{\circ} \mathrm{C}\right)\end{array}$ & Imagem & $R_{\mathrm{p}}$ & $\begin{array}{c}P_{\infty} \\
(\mathrm{kPa})\end{array}$ & $\begin{array}{c}r_{1} \\
(\mathrm{~mm})\end{array}$ & $\begin{array}{c}r_{2} \\
(\mathrm{~mm})\end{array}$ \\
\hline 2368100 & run1 & 250 & 95 & 246,8 & 93,9 & 3 & 0,81 & 107,1 & 5,9 & 5,7 \\
\hline 2368100 & run1 & 250 & 95 & 246,8 & 93,9 & 2 & 0,89 & 97,5 & 5,1 & 5,1 \\
\hline 2368100 & run1 & 250 & 95 & 246,8 & 93,9 & 1 & 0,96 & 90,4 & 4,8 & 4,8 \\
\hline 2368200 & run2 & 250 & 95 & 250,0 & 94,4 & 6 & 0,47 & 187,4 & 6,8 & 6,1 \\
\hline 2368200 & run2 & 250 & 95 & 252,2 & 95,4 & 4 & 0,49 & 179,7 & 7,7 & 6,2 \\
\hline 2368200 & run2 & 250 & 95 & 252,2 & 95,4 & 3 & 0,53 & 166,2 & 7,7 & 6,1 \\
\hline 2368200 & run2 & 250 & 95 & 250,0 & 94,4 & 1 & 0,55 & 160,1 & 6,0 & 5,6 \\
\hline 2368200b & run2 & 250 & 95 & 252,2 & 95,4 & 6 & 0,32 & 283,3 & 8,9 & 6,9 \\
\hline 2368200b & run2 & 250 & 95 & 252,2 & 95,4 & 5 & 0,40 & 226,7 & 8,3 & 6,6 \\
\hline 2368200b & run2 & 250 & 95 & 250,0 & 94,4 & 3 & 0,42 & 215,9 & 7,6 & 6,0 \\
\hline 2368200b & run2 & 250 & 95 & 250,0 & 94,4 & 1 & 0,50 & 181,3 & 6,7 & 6,3 \\
\hline 2368500 & run1 & 250 & 95 & 250,6 & 94,7 & 4 & 0,04 & 2253,8 & 18,3 & 11,9 \\
\hline 2368500 & run1 & 250 & 95 & 250,6 & 94,7 & 3 & 0,14 & 643,9 & 15,7 & 9,9 \\
\hline 2368500 & run1 & 250 & 95 & 251,4 & 95,2 & 2 & 0,23 & 392,0 & 11,4 & 7,9 \\
\hline 2368500 & run1 & 250 & 95 & 251,4 & 95,2 & 1 & 0,28 & 322,0 & 9,7 & 6,7 \\
\hline 2368m10 & run1 & 250 & 95 & 251,3 & 95,5 & 4 & 0,06 & 1480,7 & 18,2 & 10,6 \\
\hline $2368 m 10$ & run1 & 250 & 95 & 250,6 & 94,7 & 3 & 0,07 & 1269,1 & 17,0 & 10,7 \\
\hline 2368m10 & run1 & 250 & 95 & 251,4 & 95,2 & 2 & 0,13 & 683,4 & 14,3 & 9,3 \\
\hline 2368m10 & run1 & 250 & 95 & 251,3 & 95,5 & 1 & 0,17 & 522,6 & 13,9 & 9,1 \\
\hline 2368m10b & run1 & 250 & 95 & 251,3 & 95,5 & 4 & 0,11 & 826,7 & 17,2 & 11,0 \\
\hline 2368m10b & run1 & 250 & 95 & 250,6 & 94,7 & 3 & 0,13 & 699,5 & 16,7 & 10,4 \\
\hline 2368m10b & run1 & 250 & 95 & 251,4 & 95,2 & 2 & 0,18 & 505,2 & 13,8 & 9,0 \\
\hline 2368m10b & run1 & 250 & 95 & 251,3 & 95,5 & 1 & 0,22 & 413,4 & 11,7 & 7,8 \\
\hline 2393100 & run1 & 250 & 120 & 249,6 & 120,2 & 4 & 1,54 & 114,8 & 4,2 & 4,2 \\
\hline 2393100 & run1 & 250 & 120 & 249,6 & 120,2 & 3 & 1,58 & 111,8 & 4,4 & 4,0 \\
\hline 2393100 & run1 & 250 & 120 & 249,6 & 120,2 & 2 & 1,62 & 109,1 & 4,1 & 3,8 \\
\hline 2393100 & run1 & 250 & 120 & 249,6 & 120,2 & 1 & 1,66 & 106,5 & 4,1 & 4,0 \\
\hline 2393500 & run1 & 250 & 120 & 257,3 & 119,7 & 4 & 0,13 & 1359,4 & 13,1 & 9,7 \\
\hline 2393500 & run1 & 250 & 120 & 249,6 & 120,2 & 3 & 0,15 & 1178,1 & 13,3 & 8,6 \\
\hline 2393500 & run1 & 250 & 120 & 251,3 & 120,6 & 2 & 0,32 & 552,3 & 9,0 & 6,4 \\
\hline 2393500 & run1 & 250 & 120 & 249,6 & 120,2 & 1 & 0,35 & 504,9 & 10,1 & 5,9 \\
\hline 2393800 & run1 & 250 & 120 & 251,3 & 120,6 & 4 & 0,25 & 698,1 & 11,4 & 7,3 \\
\hline 2393800 & run1 & 250 & 120 & 257,3 & 119,7 & 3 & 0,26 & 671,3 & 10,6 & 7,2 \\
\hline 2393800 & run1 & 250 & 120 & 248,7 & 119,7 & 2 & 0,27 & 646,4 & 10,0 & 6,6 \\
\hline 2393800 & run1 & 250 & 120 & 249,6 & 120,2 & 1 & 0,28 & 623,3 & 11,6 & 7,1 \\
\hline 2393m10 & run2 & 250 & 120 & 251,8 & 121,7 & 4 & 0,12 & 1454,4 & 14,4 & 9,6 \\
\hline 2393m10 & run1 & 250 & 120 & 248,7 & 119,7 & 3 & 0,19 & 918,6 & 12,3 & 8,1 \\
\hline 2393m10 & run1 & 250 & 120 & 257,3 & 119,7 & 1 & 0,32 & 545,4 & 9,1 & 6,1 \\
\hline 2393m10b & run1 & 250 & 120 & 248,7 & 119,7 & 4 & 0,11 & 1622,5 & 14,4 & 10,3 \\
\hline 2393m10b & run1 & 250 & 120 & 251,3 & 120,6 & 3 & 0,11 & 1622,5 & 13,8 & 8,1 \\
\hline 2393m10b & run1 & 250 & 120 & 257,3 & 119,7 & 2 & 0,19 & 939,4 & 12,0 & 8,7 \\
\hline 2393m10b & run1 & 250 & 120 & 249,6 & 120,2 & 1 & 0,22 & 811,3 & 13,1 & 10,2 \\
\hline 2393m10c & run2 & 250 & 120 & 251,8 & 121,7 & 4 & 0,06 & 3056,3 & 19,0 & 11,7 \\
\hline 2393m10c & run1 & 250 & 120 & 251,3 & 120,6 & 2 & 0,18 & 1018,8 & 13,3 & 8,7 \\
\hline 2404100 & run1 & 250 & 131 & 251,3 & 131,1 & 4 & 3,26 & 70,5 & 3,2 & 2,7 \\
\hline 2404100 & run1 & 250 & 131 & 251,3 & 131,1 & 2 & 3,43 & 67,0 & 3,4 & 2,7 \\
\hline 2404500 & run1 & 250 & 131 & 250,7 & 130,8 & 4 & 0,49 & 465,6 & 8,7 & 5,4 \\
\hline 2404500 & run1 & 250 & 131 & 257,1 & 130,9 & 3 & 0,49 & 465,6 & 7,4 & 5,2 \\
\hline $2404500 b$ & run1 & 250 & 131 & 250,7 & 130,8 & 4 & 0,53 & 431,4 & 8,0 & 4,9 \\
\hline 2404500b & run1 & 250 & 131 & 257,1 & 130,9 & 3 & 0,53 & 431,4 & 7,5 & 4,7 \\
\hline $2404 \mathrm{~m} 10 \mathrm{~b}$ & run1 & 250 & 131 & 256,2 & 130,2 & 4 & 0,24 & 937,2 & 11,4 & 6,7 \\
\hline 2406m10 & run1 & 250 & 131 & 251,4 & 125,0 & 4 & 0,16 & 1242,0 & 13,5 & 10,1 \\
\hline $2406 \mathrm{~m} 10$ & run1 & 250 & 131 & 251,4 & 125,0 & 3 & 0,19 & 1045,9 & 11,6 & 8,7 \\
\hline
\end{tabular}

continua... 
...continuação de Tab. B.5.

\begin{tabular}{|c|c|c|c|c|c|c|c|c|c|c|}
\hline Ensaio & Série & $\begin{array}{c}P_{\text {inj }} \\
(\mathrm{kPa})\end{array}$ & $\begin{array}{r}T_{\text {inj }} \\
\left({ }^{\circ} \mathrm{C}\right) \\
\end{array}$ & $\begin{array}{c}P_{0} \\
(\mathrm{kPa})\end{array}$ & $\begin{array}{c}T_{0} \\
\left({ }^{\circ} \mathrm{C}\right) \\
\end{array}$ & Imagem & $R_{\mathrm{p}}$ & $\begin{array}{c}P_{\infty} \\
(\mathrm{kPa})\end{array}$ & $\begin{array}{c}r_{1} \\
(\mathrm{~mm}) \\
\end{array}$ & $\begin{array}{c}r_{2} \\
(\mathrm{~mm})\end{array}$ \\
\hline $2406 \mathrm{~m} 10$ & run1 & 250 & 131 & 251,4 & 125,0 & 2 & 0,23 & 864,0 & 11,6 & 7,4 \\
\hline 5329050 & run3 & 500 & 56 & 501,6 & 56,6 & 4 & 0,44 & 62,0 & 5,6 & 12,4 \\
\hline 5329050 & run3 & 500 & 56 & 501,6 & 56,6 & 3 & 0,50 & 54,6 & 5,4 & 12,3 \\
\hline 5329050 & run3 & 500 & 56 & 501,6 & 56,6 & 2 & 0,57 & 47,9 & 5,0 & 11,6 \\
\hline 5329050 & run3 & 500 & 56 & 501,6 & 56,6 & 1 & 0,63 & 43,3 & 4,7 & 9,1 \\
\hline 5329100 & run3 & 500 & 56 & 504,1 & 57,1 & 4 & 0,12 & 227,2 & 14,2 & 18,5 \\
\hline 5329100 & run3 & 500 & 56 & 501,6 & 56,6 & 3 & 0,16 & 170,4 & 13,8 & 18,2 \\
\hline 5329100 & run3 & 500 & 56 & 504,1 & 57,1 & 2 & 0,24 & 113,6 & 10,1 & 15,1 \\
\hline 5329100 & run3 & 500 & 56 & 501,6 & 56,6 & 1 & 0,31 & 87,9 & 9,9 & 15,5 \\
\hline 5329500 & run3 & 500 & 56 & 504,1 & 57,1 & 4 & 0,06 & 465,7 & 18,8 & 20,6 \\
\hline 5329500 & run3 & 500 & 56 & 501,6 & 56,6 & 3 & 0,08 & 349,3 & 18,0 & 20,2 \\
\hline 5329500 & run3 & 500 & 56 & 504,1 & 57,1 & 2 & 0,18 & 155,2 & 11,8 & 15,9 \\
\hline 5329500 & run3 & 500 & 56 & 501,6 & 56,6 & 1 & 0,23 & 121,5 & 11,4 & 16,2 \\
\hline 5349050 & run3 & 500 & 76 & 501,9 & 76,2 & 4 & 0,86 & 58,3 & 4,1 & 7,6 \\
\hline 5349050 & run3 & 500 & 76 & 501,9 & 76,2 & 3 & 0,90 & 55,8 & 3,9 & 7,1 \\
\hline 5349050 & run3 & 500 & 76 & 501,9 & 76,2 & 2 & 0,95 & 52,8 & 3,8 & 7,6 \\
\hline 5349050 & run3 & 500 & 76 & 501,9 & 76,2 & 1 & 0,99 & 50,7 & 3,6 & 7,2 \\
\hline 5349100 & run3 & 500 & 76 & 496,3 & 76,7 & 4 & 0,41 & 126,7 & 10,1 & 10,5 \\
\hline 5349100 & run3 & 500 & 76 & 496,3 & 76,7 & 3 & 0,46 & 112,9 & 9,1 & 10,3 \\
\hline 5349100 & run3 & 500 & 76 & 496,3 & 76,7 & 2 & 0,51 & 101,8 & 8,5 & 10,4 \\
\hline 5349100 & run3 & 500 & 76 & 496,3 & 76,7 & 1 & 0,56 & 92,8 & 7,8 & 9,8 \\
\hline 5349500 & run3 & 500 & 76 & 497,6 & 76,9 & 4 & 0,04 & 1305,8 & 24,4 & 16,5 \\
\hline 5349500 & run3 & 500 & 76 & 497,6 & 76,9 & 3 & 0,09 & 580,3 & 18,2 & 14,5 \\
\hline 5349500 & run3 & 500 & 76 & 497,6 & 76,9 & 2 & 0,13 & 401,8 & 15,4 & 12,5 \\
\hline 5349500 & run3 & 500 & 76 & 497,6 & 76,9 & 1 & 0,18 & 290,2 & 13,5 & 11,9 \\
\hline 5368100 & run2 & 500 & 95 & 503,4 & 95,4 & 5 & 0,87 & 104,2 & 6,2 & 6,9 \\
\hline 5368100 & run2 & 500 & 95 & 503,4 & 95,4 & 4 & 0,91 & 99,6 & 5,9 & 6,8 \\
\hline 5368100 & run2 & 500 & 95 & 503,4 & 95,4 & 2 & 1,00 & 90,7 & 5,5 & 6,6 \\
\hline 5368100 & run2 & 500 & 95 & 503,4 & 95,4 & 1 & 1,04 & 87,2 & 5,4 & 6,7 \\
\hline 5368500 & run2 & 500 & 95 & 500,2 & 95,1 & 5 & 0,18 & 499,3 & 16,2 & 10,7 \\
\hline 5368500 & run2 & 500 & 95 & 501,3 & 95,2 & 4 & 0,19 & 473,1 & 14,6 & 10,1 \\
\hline 5368500 & run2 & 500 & 95 & 501,3 & 95,2 & 2 & 0,30 & 299,6 & 13,3 & 9,7 \\
\hline 5368500 & run2 & 500 & 95 & 500,2 & 95,1 & 1 & 0,31 & 289,9 & 13,7 & 9,2 \\
\hline 5368m10 & run2 & 500 & 95 & 501,3 & 95,2 & 5 & 0,08 & 1126,9 & 23,9 & 14,3 \\
\hline $5368 \mathrm{~m} 10$ & run2 & 500 & 95 & 501,3 & 95,2 & 3 & 0,13 & 693,5 & 20,0 & 12,0 \\
\hline 5368m10 & run2 & 500 & 95 & 500,2 & 95,1 & 2 & 0,14 & 643,9 & 19,2 & 12,0 \\
\hline $5368 \mathrm{~m} 10$ & run2 & 500 & 95 & 500,2 & 95,1 & 1 & 0,27 & 333,9 & 13,4 & 9,3 \\
\hline 5393100 & run2 & 500 & 120 & 485,3 & 122,6 & 5 & 1,67 & 112,3 & 3,1 & 4,1 \\
\hline 5393100 & run2 & 500 & 120 & 485,3 & 122,6 & 4 & 1,68 & 111,6 & 3,3 & 4,1 \\
\hline 5393100 & run2 & 500 & 120 & 485,3 & 122,6 & 2 & 1,71 & 109,6 & 3,3 & 4,5 \\
\hline 5393100 & run2 & 500 & 120 & 485,3 & 122,6 & 1 & 1,72 & 109,0 & 3,1 & 4,0 \\
\hline 5393500 & run2 & 500 & 120 & 503,3 & 120,6 & 5 & 0,25 & 742,6 & 13,8 & 7,4 \\
\hline 5393500 & run2 & 500 & 120 & 502,5 & 122,2 & 4 & 0,37 & 501,7 & 13,3 & 7,6 \\
\hline 5393500 & run2 & 500 & 120 & 503,3 & 120,6 & 2 & 0,37 & 501,7 & 12,2 & 6,2 \\
\hline 5393500 & run2 & 500 & 120 & 502,5 & 122,2 & 1 & 0,42 & 442,0 & 14,0 & 7,3 \\
\hline $5393 m 10$ & run2 & 500 & 120 & 501,6 & 123,2 & 5 & 0,16 & 1115,5 & 19,7 & 11,0 \\
\hline 5393m10 & run2 & 500 & 120 & 502,5 & 122,2 & 4 & 0,24 & 743,7 & 17,5 & 9,8 \\
\hline $5393 m 10$ & run2 & 500 & 120 & 501,6 & 123,2 & 2 & 0,25 & 713,9 & 14,3 & 8,1 \\
\hline 5393m10 & run2 & 500 & 120 & 502,5 & 122,2 & 1 & 0,29 & 615,4 & 15,3 & 7,6 \\
\hline 5393m10b & run2 & 500 & 120 & 501,6 & 123,2 & 4 & 0,11 & 1729,4 & 22,3 & 12,4 \\
\hline 5393m10b & run2 & 500 & 120 & 503,3 & 120,6 & 3 & 0,20 & 951,2 & 15,3 & 8,4 \\
\hline 5393m10b & run2 & 500 & 120 & 501,6 & 123,2 & 2 & 0,21 & 905,9 & 15,8 & 8,6 \\
\hline 5393m10b & run2 & 500 & 120 & 503,3 & 120,6 & 1 & 0,32 & 594,5 & 12,9 & 6,8 \\
\hline 5404100 & run1 & 500 & 131 & 501,1 & 131,0 & 4 & 2,34 & 97,9 & 3,9 & 3,7 \\
\hline 5404100 & run1 & 500 & 131 & 501,1 & 131,0 & 3 & 2,41 & 95,1 & 3,7 & 3,8 \\
\hline 5404100 & run1 & 500 & 131 & 501,1 & 131,0 & 2 & 2,49 & 92,0 & 3,7 & 4,2 \\
\hline
\end{tabular}

continua... 
...continuação de Tab. B.5.

\begin{tabular}{|c|c|c|c|c|c|c|c|c|c|c|}
\hline Ensaio & Série & $\begin{array}{c}P_{\text {inj }} \\
(\mathrm{kPa}) \\
\end{array}$ & $\begin{array}{r}T_{\text {inj }} \\
\left({ }^{\circ} \mathrm{C}\right) \\
\end{array}$ & $\begin{array}{c}P_{0} \\
(\mathrm{kPa}) \\
\end{array}$ & $\begin{array}{c}T_{0} \\
\left({ }^{\circ} \mathrm{C}\right) \\
\end{array}$ & Imagem & $R_{\mathrm{p}}$ & $\begin{array}{c}P_{\infty} \\
(\mathrm{kPa}) \\
\end{array}$ & $\begin{array}{c}r_{1} \\
(\mathrm{~mm}) \\
\end{array}$ & $\begin{array}{c}r_{2} \\
(\mathrm{~mm}) \\
\end{array}$ \\
\hline 5404100 & run1 & 500 & 131 & 501,1 & 131,0 & 1 & 2,56 & 89,5 & 3,7 & 4,5 \\
\hline 5404500b & run1 & 500 & 131 & 500,0 & 131,0 & 4 & 0,34 & 674,1 & 14,0 & 7,4 \\
\hline 5404500b & run1 & 500 & 131 & 500,0 & 131,0 & 3 & 0,41 & 559,0 & 13,7 & 7,7 \\
\hline 5404500b & run1 & 500 & 131 & 500,0 & 131,0 & 2 & 0,49 & 467,7 & 10,9 & 5,9 \\
\hline 5404500b & run1 & 500 & 131 & 500,0 & 131,0 & 1 & 0,56 & 409,3 & 10,2 & 5,6 \\
\hline $5404 m 10$ & run1 & 500 & 131 & 500,5 & 131,2 & 4 & 0,28 & 822,4 & 13,0 & 7,4 \\
\hline $5404 \mathrm{~m} 10$ & run1 & 500 & 131 & 500,5 & 131,2 & 3 & 0,33 & 697,8 & 11,9 & 6,3 \\
\hline 5435500 & run1 & 500 & 162 & 504,1 & 159,9 & 4 & 0,89 & 481,6 & 7,5 & 4,3 \\
\hline 5435500 & run1 & 500 & 162 & 504,1 & 159,9 & 3 & 0,92 & 465,9 & 7,5 & 4,6 \\
\hline 5435500 & run1 & 500 & 162 & 504,1 & 159,9 & 2 & 0,95 & 451,2 & 7,2 & 4,9 \\
\hline 5435500 & run1 & 500 & 162 & 504,1 & 159,9 & 1 & 0,98 & 437,4 & 7,0 & 4,3 \\
\hline $5435 \mathrm{~m} 10$ & run1 & 500 & 162 & 543,3 & 161,9 & 4 & 0,41 & 1088,4 & 11,2 & 5,7 \\
\hline $5435 \mathrm{~m} 10$ & run1 & 500 & 162 & 500,9 & 162,0 & 3 & 0,43 & 1037,8 & 10,4 & 5,2 \\
\hline $5435 \mathrm{~m} 10$ & run1 & 500 & 162 & 502,1 & 162,1 & 2 & 0,44 & 1014,2 & 10,3 & 6,2 \\
\hline $5435 \mathrm{~m} 10$ & run1 & 500 & 162 & 502,1 & 162,1 & 1 & 0,59 & 756,3 & 10,3 & 5,9 \\
\hline $5435 \mathrm{~m} 10 \mathrm{~b}$ & run1 & 500 & 162 & 543,3 & 161,9 & 4 & 0,44 & 1018,3 & 10,9 & 5,5 \\
\hline $5435 \mathrm{~m} 10 \mathrm{~b}$ & run1 & 500 & 162 & 543,3 & 161,9 & 3 & 0,46 & 974,0 & 9,7 & 5,5 \\
\hline $5435 \mathrm{~m} 10 \mathrm{~b}$ & run1 & 500 & 162 & 543,3 & 161,9 & 2 & 0,49 & 914,3 & 9,0 & 5,2 \\
\hline $5435 \mathrm{~m} 10 \mathrm{~b}$ & run1 & 500 & 162 & 502,1 & 162,1 & 1 & 0,51 & 878,5 & 10,3 & 6,3 \\
\hline $5435 \mathrm{~m} 10 \mathrm{c}$ & run1 & 500 & 162 & 500,9 & 162,0 & 4 & 0,33 & 1354,9 & 10,9 & 6,0 \\
\hline $5435 \mathrm{~m} 10 \mathrm{c}$ & run1 & 500 & 162 & 500,9 & 162,0 & 3 & 0,38 & 1176,7 & 10,5 & 6,4 \\
\hline $5435 \mathrm{~m} 10 \mathrm{c}$ & run1 & 500 & 162 & 500,9 & 162,0 & 2 & 0,48 & 931,5 & 9,7 & 4,9 \\
\hline $5435 \mathrm{~m} 10 \mathrm{c}$ & run1 & 500 & 162 & 502,1 & 162,1 & 1 & 0,66 & 677,5 & 9,2 & 5,1 \\
\hline 7329050 & run3 & 750 & 56 & 751,6 & 56,1 & 4 & 0,54 & 49,2 & 5,0 & 16,6 \\
\hline 7329050 & run3 & 750 & 56 & 751,6 & 56,1 & 3 & 0,61 & 43,6 & 4,8 & 16,0 \\
\hline 7329050 & run3 & 750 & 56 & 751,6 & 56,1 & 2 & 0,67 & 39,7 & 4,3 & 16,0 \\
\hline 7329050 & run3 & 750 & 56 & 751,6 & 56,1 & 1 & 0,74 & 35,9 & 4,3 & 15,1 \\
\hline 7329200 & run3 & 750 & 56 & 752,0 & 56,4 & 4 & 0,17 & 158,8 & 13,3 & 20,9 \\
\hline 7329200 & run3 & 750 & 56 & 751,1 & 56,4 & 3 & 0,19 & 142,1 & 11,5 & 19,4 \\
\hline 7329200 & run3 & 750 & 56 & 751,1 & 56,4 & 2 & 0,26 & 103,8 & 9,4 & 16,9 \\
\hline 7329200 & run3 & 750 & 56 & 752,0 & 56,4 & 1 & 0,33 & 81,8 & 9,2 & 18,0 \\
\hline 7329500 & run3 & 750 & 56 & 752,0 & 56,4 & 4 & 0,09 & 299,9 & 17,3 & 23,9 \\
\hline 7329500 & run3 & 750 & 56 & 751,1 & 56,4 & 3 & 0,12 & 224,9 & 14,4 & 21,7 \\
\hline 7329500 & run3 & 750 & 56 & 752,0 & 56,4 & 2 & 0,25 & 108,0 & 10,9 & 19,0 \\
\hline 7329500 & run3 & 750 & 56 & 751,1 & 56,4 & 1 & 0,33 & 81,8 & 8,0 & 16,9 \\
\hline 7349050 & run3 & 750 & 76 & 749,2 & 76,8 & 4 & 0,91 & 56,2 & 4,9 & 10,2 \\
\hline 7349050 & run3 & 750 & 76 & 749,2 & 76,8 & 3 & 0,97 & 52,8 & 4,9 & 10,6 \\
\hline 7349050 & run3 & 750 & 76 & 749,2 & 76,8 & 2 & 1,03 & 49,7 & 4,6 & 10,3 \\
\hline 7349050 & run3 & 750 & 76 & 749,2 & 76,8 & 1 & 1,09 & 47,0 & 4,5 & 10,5 \\
\hline 7349100 & run3 & 750 & 76 & 752,5 & 77,0 & 4 & 0,45 & 114,5 & 8,6 & 11,6 \\
\hline 7349100 & run3 & 750 & 76 & 752,5 & 77,0 & 3 & 0,51 & 101,0 & 8,1 & 12,9 \\
\hline 7349100 & run3 & 750 & 76 & 752,5 & 77,0 & 2 & 0,58 & 88,8 & 7,7 & 12,5 \\
\hline 7349100 & run3 & 750 & 76 & 752,5 & 77,0 & 1 & 0,64 & 80,5 & 7,0 & 11,7 \\
\hline 7349500 & run3 & 750 & 76 & 750,7 & 77,1 & 4 & 0,11 & 469,9 & 18,9 & 17,8 \\
\hline 7349500 & run3 & 750 & 76 & 750,7 & 77,1 & 3 & 0,18 & 287,2 & 14,7 & 16,0 \\
\hline 7349500 & run3 & 750 & 76 & 750,7 & 77,1 & 2 & 0,25 & 206,8 & 12,9 & 14,8 \\
\hline 7349500 & run3 & 750 & 76 & 750,7 & 77,1 & 1 & 0,32 & 161,5 & 11,4 & 13,2 \\
\hline 7368100 & run3 & 750 & 95 & 752,3 & 96,4 & 4 & 0,82 & 113,9 & 7,0 & 8,9 \\
\hline 7368100 & run3 & 750 & 95 & 752,3 & 96,4 & 3 & 0,89 & 104,9 & 6,5 & 8,5 \\
\hline 7368100 & run3 & 750 & 95 & 752,3 & 96,4 & 2 & 0,96 & 97,3 & 6,2 & 8,5 \\
\hline 7368100 & run3 & 750 & 95 & 752,3 & 96,4 & 1 & 1,03 & 90,7 & 6,0 & 8,2 \\
\hline 7368500 & run3 & 750 & 95 & 748,4 & 95,3 & 4 & 0,19 & 476,2 & 17,4 & 12,1 \\
\hline 7368500 & run3 & 750 & 95 & 750,9 & 95,2 & 3 & 0,20 & 452,4 & 16,8 & 12,5 \\
\hline 7368500 & run3 & 750 & 95 & 748,4 & 95,3 & 2 & 0,36 & 251,3 & 13,6 & 12,0 \\
\hline 7368500 & run3 & 750 & 95 & 748,4 & 95,3 & 1 & 0,44 & 205,6 & 12,0 & 10,7 \\
\hline
\end{tabular}

continua... 
...continuação de Tab. B.5.

\begin{tabular}{|c|c|c|c|c|c|c|c|c|c|c|}
\hline Ensaio & Série & $\begin{array}{c}P_{\text {inj }} \\
(\mathrm{kPa}) \\
\end{array}$ & $\begin{array}{r}T_{\text {inj }} \\
\left({ }^{\circ} \mathrm{C}\right) \\
\end{array}$ & $\begin{array}{c}P_{0} \\
(\mathrm{kPa}) \\
\end{array}$ & $\begin{array}{c}T_{0} \\
\left({ }^{\circ} \mathrm{C}\right) \\
\end{array}$ & Imagem & $R_{\mathrm{p}}$ & $\begin{array}{c}P_{\infty} \\
(\mathrm{kPa}) \\
\end{array}$ & $\begin{array}{c}r_{1} \\
(\mathrm{~mm}) \\
\end{array}$ & $\begin{array}{c}r_{2} \\
(\mathrm{~mm}) \\
\end{array}$ \\
\hline 7368m10 & run3 & 750 & 95 & 750,9 & 95,2 & 4 & 0,13 & 693,9 & 19,9 & 13,4 \\
\hline 7368m10 & run3 & 750 & 95 & 748,4 & 95,3 & 3 & 0,27 & 334,1 & 15,3 & 11,6 \\
\hline 7368m10 & run3 & 750 & 95 & 750,9 & 95,2 & 2 & 0,27 & 334,1 & 14,4 & 10,8 \\
\hline 7368m10 & run3 & 750 & 95 & 750,9 & 95,2 & 1 & 0,34 & 265,3 & 13,1 & 10,5 \\
\hline 7393100b & run3 & 750 & 120 & 751,9 & 120,9 & 4 & 1,69 & 106,4 & 5,2 & 5,6 \\
\hline 7393100b & run3 & 750 & 120 & 751,9 & 120,9 & 3 & 1,76 & 102,2 & 5,0 & 5,3 \\
\hline 7393100b & run3 & 750 & 120 & 751,9 & 120,9 & 2 & 1,83 & 98,3 & 5,3 & 5,6 \\
\hline 7393100b & run3 & 750 & 120 & 751,9 & 120,9 & 1 & 1,90 & 94,6 & 5,0 & 5,4 \\
\hline 7393500 & run3 & 750 & 120 & 752,8 & 121,3 & 4 & 0,19 & 955,8 & 18,9 & 10,2 \\
\hline 7393500 & run3 & 750 & 120 & 753,2 & 121,1 & 3 & 0,20 & 908,1 & 21,7 & 11,4 \\
\hline 7393500 & run3 & 750 & 120 & 752,8 & 121,3 & 2 & 0,36 & 504,5 & 14,8 & 8,3 \\
\hline 7393500 & run3 & 750 & 120 & 752,8 & 121,3 & 1 & 0,44 & 412,8 & 13,8 & 8,1 \\
\hline 7393m10 & run3 & 750 & 120 & 753,2 & 121,1 & 4 & 0,13 & 1390,1 & 25,4 & 13,9 \\
\hline 7393m10 & run3 & 750 & 120 & 752,8 & 121,3 & 3 & 0,27 & 669,3 & 16,9 & 9,1 \\
\hline 7393m10 & run3 & 750 & 120 & 753,2 & 121,1 & 2 & 0,27 & 669,3 & 18,7 & 10,2 \\
\hline 7393m10 & run3 & 750 & 120 & 753,2 & 121,1 & 1 & 0,34 & 531,5 & 15,7 & 9,1 \\
\hline 7404100 & run3 & 750 & 131 & 753,0 & 131,7 & 4 & 2,17 & 107,5 & 4,8 & 4,7 \\
\hline 7404100 & run3 & 750 & 131 & 753,0 & 131,7 & 3 & 2,24 & 104,1 & 4,8 & 4,7 \\
\hline 7404100 & run3 & 750 & 131 & 753,0 & 131,7 & 2 & 2,31 & 100,9 & 4,7 & 4,6 \\
\hline 7404100 & run3 & 750 & 131 & 753,0 & 131,7 & 1 & 2,38 & 98,0 & 4,4 & 4,3 \\
\hline 7404500 & run3 & 750 & 131 & 749,6 & 131,9 & 4 & 0,17 & 1378,0 & 20,1 & 10,7 \\
\hline 7404500 & run3 & 750 & 131 & 751,9 & 131,7 & 3 & 0,21 & 1115,5 & 19,7 & 9,9 \\
\hline 7404500 & run3 & 750 & 131 & 749,6 & 131,9 & 2 & 0,30 & 780,9 & 15,8 & 8,7 \\
\hline 7404500 & run3 & 750 & 131 & 749,6 & 131,9 & 1 & 0,36 & 650,7 & 14,9 & 8,3 \\
\hline 7404m10 & run3 & 750 & 131 & 751,9 & 131,7 & 4 & 0,09 & 2590,8 & 26,6 & 14,9 \\
\hline 7404m10 & run3 & 750 & 131 & 751,9 & 131,7 & 3 & 0,15 & 1554,5 & 22,2 & 11,8 \\
\hline 7404m10 & run3 & 750 & 131 & 749,6 & 131,9 & 2 & 0,23 & 1013,8 & 17,5 & 9,2 \\
\hline $7404 \mathrm{~m} 10$ & run3 & 750 & 131 & 751,9 & 131,7 & 1 & 0,27 & 863,6 & 17,2 & 9,4 \\
\hline 7435100 & run3 & 750 & 162 & 749,3 & 161,8 & 4 & 4,47 & 99,6 & 3,2 & 3,0 \\
\hline 7435100 & run3 & 750 & 162 & 749,3 & 161,8 & 3 & 4,54 & 98,0 & 3,2 & 2,7 \\
\hline 7435100 & run3 & 750 & 162 & 749,3 & 161,8 & 2 & 4,62 & 96,3 & 3,1 & 3,0 \\
\hline 7435100 & run3 & 750 & 162 & 749,3 & 161,8 & 1 & 4,69 & 94,9 & 3,0 & 2,7 \\
\hline 7435500 & run3 & 750 & 162 & 749,5 & 161,7 & 4 & 0,89 & 499,2 & 9,7 & 4,4 \\
\hline 7435500 & run3 & 750 & 162 & 749,5 & 161,7 & 3 & 1,00 & 444,3 & 9,7 & 4,5 \\
\hline 7435500 & run3 & 750 & 162 & 749,5 & 161,7 & 2 & 1,11 & 400,2 & 8,7 & 4,2 \\
\hline 7435500 & run3 & 750 & 162 & 749,5 & 161,7 & 1 & 1,22 & 364,1 & 8,9 & 4,4 \\
\hline $7435 \mathrm{~m} 10$ & run3 & 750 & 162 & 747,7 & 161,3 & 4 & 0,62 & 710,9 & 11,4 & 5,7 \\
\hline $7435 \mathrm{~m} 10$ & run3 & 750 & 162 & 747,7 & 161,3 & 3 & 0,69 & 638,8 & 11,5 & 5,2 \\
\hline $7435 \mathrm{~m} 10$ & run3 & 750 & 162 & 747,7 & 161,3 & 2 & 0,75 & 587,7 & 10,0 & 5,4 \\
\hline $7435 \mathrm{~m} 10$ & run3 & 750 & 162 & 747,7 & 161,3 & 1 & 0,82 & 537,5 & 10,2 & 5,1 \\
\hline $7435 m 20$ & run3 & 750 & 162 & 749,2 & 161,8 & 4 & 0,40 & 1112,8 & 13,2 & 7,0 \\
\hline $7435 \mathrm{~m} 20$ & run3 & 750 & 162 & 749,2 & 161,8 & 3 & 0,45 & 989,2 & 13,6 & 5,9 \\
\hline $7435 m 20$ & run3 & 750 & 162 & 749,2 & 161,8 & 2 & 0,51 & 872,8 & 12,5 & 6,1 \\
\hline $7435 \mathrm{~m} 20$ & run3 & 750 & 162 & 749,2 & 161,8 & 1 & 0,56 & 794,9 & 11,9 & 5,4 \\
\hline 7451500 & run3 & 750 & 178 & 756,6 & 177,6 & 4 & 1,50 & 402,8 & 6,3 & 3,3 \\
\hline 7451500 & run3 & 750 & 178 & 756,6 & 177,6 & 3 & 1,54 & 392,3 & 6,7 & 3,1 \\
\hline 7451500 & run3 & 750 & 178 & 756,6 & 177,6 & 2 & 1,59 & 380,0 & 6,1 & 3,3 \\
\hline 7451500 & run3 & 750 & 178 & 756,6 & 177,6 & 1 & 1,63 & 370,7 & 6,0 & 2,8 \\
\hline $7451 \mathrm{~m} 20$ & run3 & 750 & 178 & 752,4 & 178,9 & 4 & 0,23 & 2692,1 & 15,8 & 8,8 \\
\hline $7451 \mathrm{~m} 20$ & run3 & 750 & 178 & 752,4 & 178,9 & 3 & 0,27 & 2293,3 & 15,0 & 8,3 \\
\hline $7451 \mathrm{~m} 20$ & run3 & 750 & 178 & 752,4 & 178,9 & 2 & 0,31 & 1997,4 & 13,5 & 7,9 \\
\hline $7451 \mathrm{~m} 20$ & run3 & 750 & 178 & 752,4 & 178,9 & 1 & 0,35 & 1769,1 & 13,5 & 6,8 \\
\hline $7451 m 45$ & run3 & 750 & 178 & 751,6 & 178,1 & 4 & 0,04 & 15247,5 & 28,5 & 18,3 \\
\hline $7451 \mathrm{~m} 45$ & run3 & 750 & 178 & 751,6 & 178,1 & 3 & 0,08 & 7623,8 & 25,2 & 14,8 \\
\hline $7451 \mathrm{~m} 45$ & run3 & 750 & 178 & 751,6 & 178,1 & 2 & 0,12 & 5082,5 & 22,2 & 12,5 \\
\hline $7451 \mathrm{~m} 45$ & run3 & 750 & 178 & 751,6 & 178,1 & 1 & 0,15 & 4066,0 & 20,0 & 11,0 \\
\hline
\end{tabular}




\section{B.4. Imagens dos Ensaios Realizados com Iso-octano}

A seguir são mostradas as imagens dos ensaios realizados utilizando a mesma substância iso-octano. A primeira, da seqüência de imagens apresentada em cada ensaio, refere-se a uma das originais adquiridas através do método "Schlieren" e a escala dimensional de 50 mm (ver Fig. B.1) é tomada através da plataforma que está na saída do bocal, conforme também foi exemplificado neste primeiro ensaio (2349_05). Apenas poucas imagens têm uma escala indicativa. Isto deve ocorrer quando a onda de choque pouco se destaca, não permitindo ao leitor comparar visualmente o tamanho da onda de choque com a referência dimensional que é o corpo do injetor (indicada na Fig. B.1). Para um valor mais exato do tamanho da onda de choque, a Tab. B.5, seção anterior, mostra estes valores de forma mais detalhada.

Dentro de cada ensaio, existem outras imagens que são aquelas tratadas matematicamente com filtro subtrativo e submetidas ao mapa de cor que melhor realça os fenômenos envolvidos. As informações de pressão $\left(P_{0}\right)$ e temperatura $\left(T_{0}\right)$ de injeção do ensaio, assim como, a pressão média da câmara $\left(P_{\infty}\right)$ onde é descarregado o jato e a razão entre pressões de saturação e pressão média da câmara $\left(R_{\mathrm{p}}\right)$. A vazão mássica ( $\left.\dot{m}\right)$ também é acrescentado em cada ensaio, seguido da velocidade do jato $\left(u_{1}\right)$ na saída do bocal, assim como sua pressão de líquido metaestável $\left(P_{1}\right)$ calculada através da vazão obtida, considerando como incompressível. 


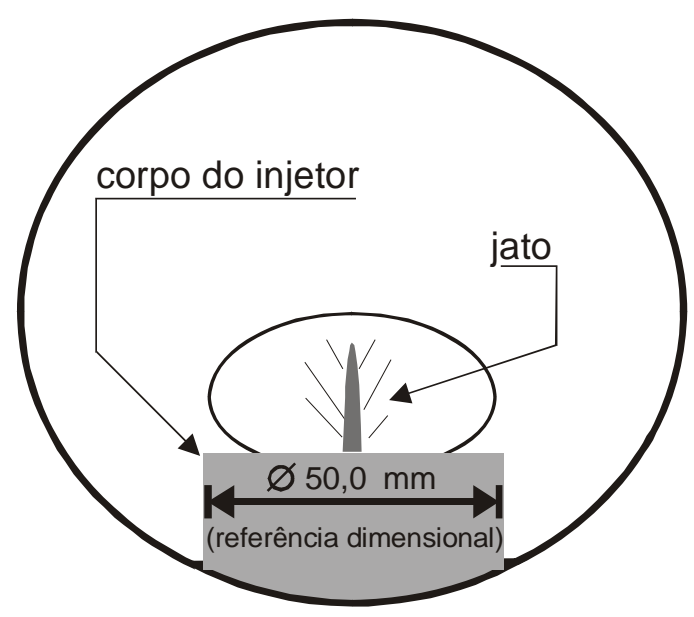

Figura B.1 - Ilustração da referência dimensional para todos os ensaios.

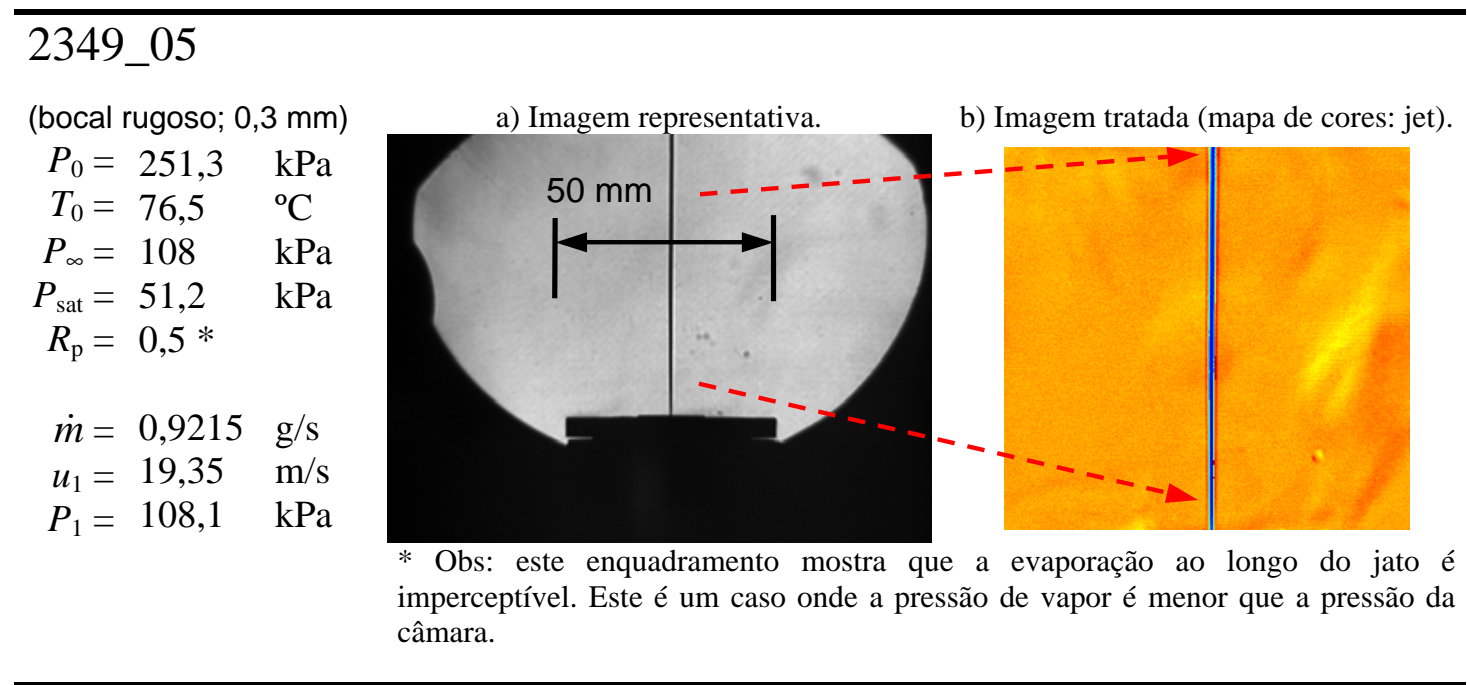

\section{1}

(bocal rugoso; 0,3 $\mathrm{mm}$ )

$P_{0}=250,1 \quad \mathrm{kPa}$

$T_{0}=76,2 \quad{ }^{\circ} \mathrm{C}$

$P_{\infty}=48,00 \mathrm{kPa}$

$P_{\text {sat }}=51,2 \quad \mathrm{kPa}$

$R_{\mathrm{p}}=1,1 *$

$\dot{m}=1,1051 \mathrm{~g} / \mathrm{s}$

$u_{1}=23,19 \mathrm{~m} / \mathrm{s}$

$P_{1}=46,9 \quad \mathrm{kPa}$

a) Imagem representativa.

b) Imagem tratada (mapa de cores: jet).
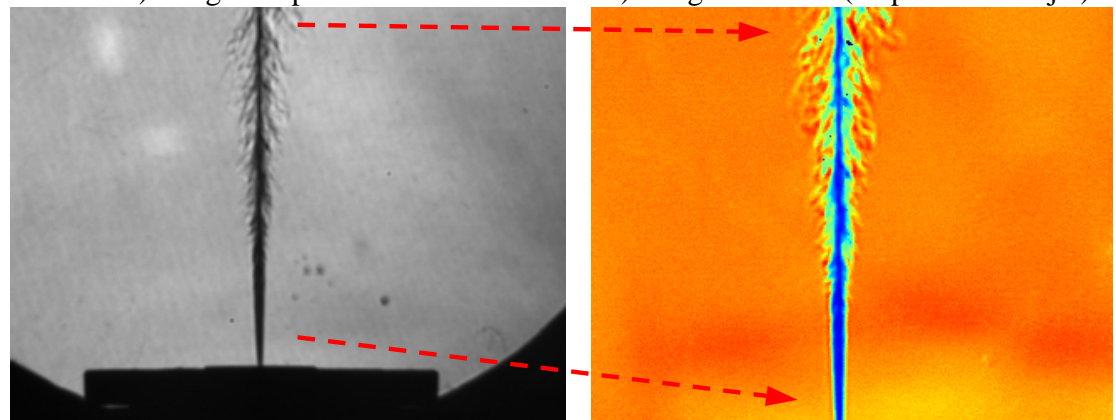

* Obs: este enquadramento mostra que já existe uma evaporação ao longo do jato. Este é um caso onde a pressão de vapor é igual à pressão da câmara. 

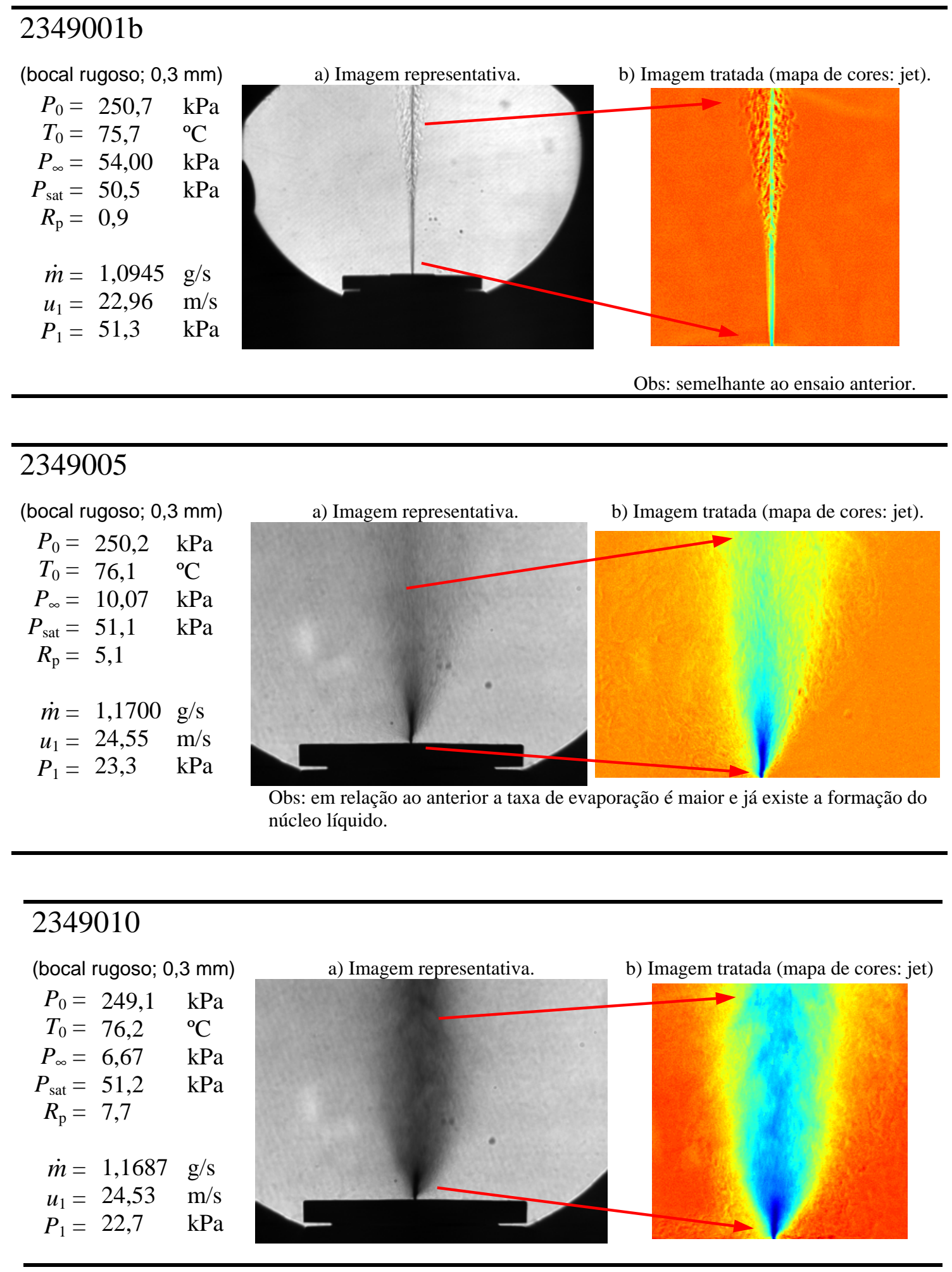


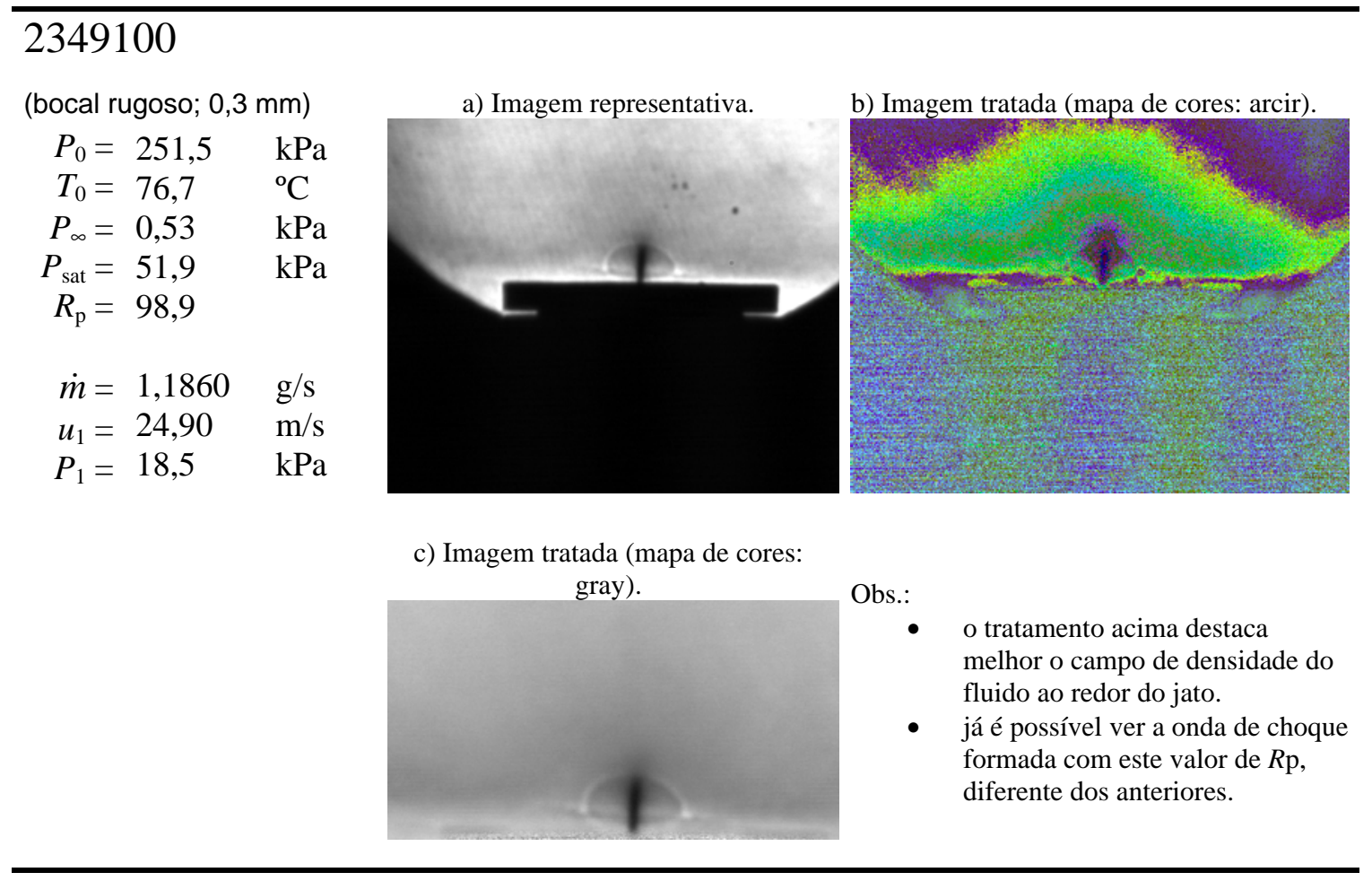

\section{0}

(bocal rugoso; 0,3 $\mathrm{mm}$ )

a) Imagem representativa.

$\begin{array}{rlr}P_{0} & =251,7 & \mathrm{kPa} \\ T_{0} & =76,2 & { }^{\circ} \mathrm{C} \\ P_{\infty} & =0,16 & \mathrm{kPa} \\ P_{\text {sat }} & =51,2 & \mathrm{kPa} \\ R_{\mathrm{p}} & =330,6 & \\ \dot{m} & =1,1992 & \mathrm{~g} / \mathrm{s} \\ u_{1}=25,17 & \mathrm{~m} / \mathrm{s} \\ P_{1}=13,7 & \mathrm{kPa}\end{array}$

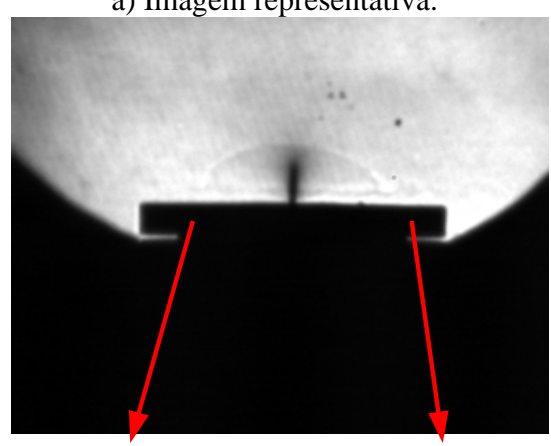

b) Imagem tratada (mapa de cores: gray). c) Imagem tratada (mapa de cores: arcir).

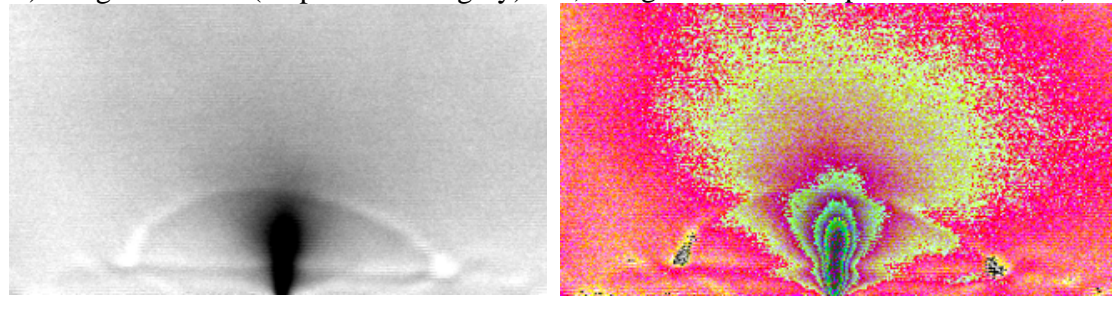



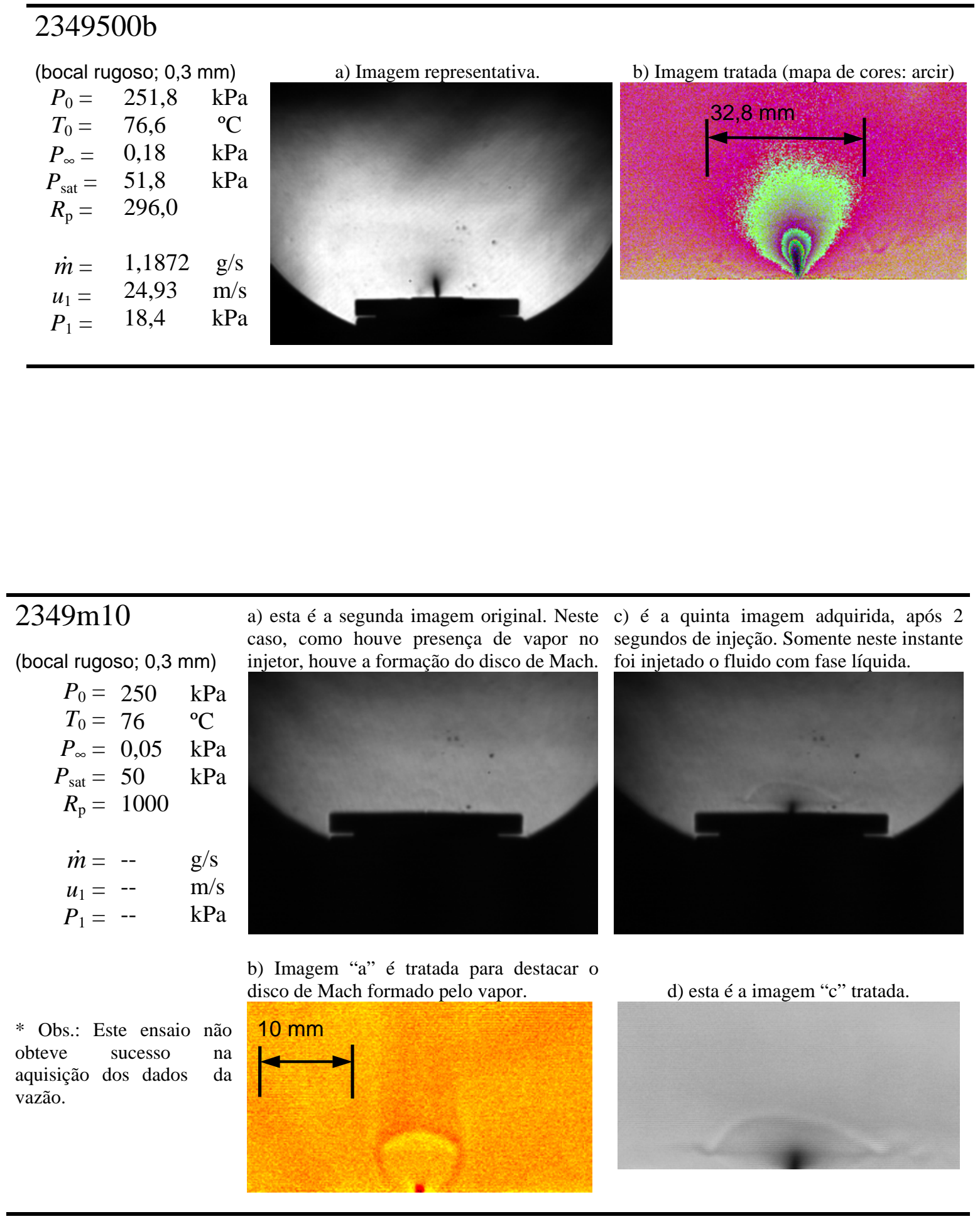


\section{8_05}

(bocal rugoso; 0,3 mm)

$P_{0}=250,0 \quad \mathrm{kPa}$

$T_{0}=94,5 \quad{ }^{\circ} \mathrm{C}$

$P_{\infty}=174,0 \quad \mathrm{kPa}$

$P_{\text {sat }}=88,3 \quad \mathrm{kPa}$

$R_{\mathrm{p}}=0,5 *$

$\dot{m}=0,6694 \mathrm{~g} / \mathrm{s}$

$u_{1}=14,30 \mathrm{~m} / \mathrm{s}$

$P_{1}=171,5 \quad \mathrm{kPa}$

b) Imagem tratada (mapa de cores:
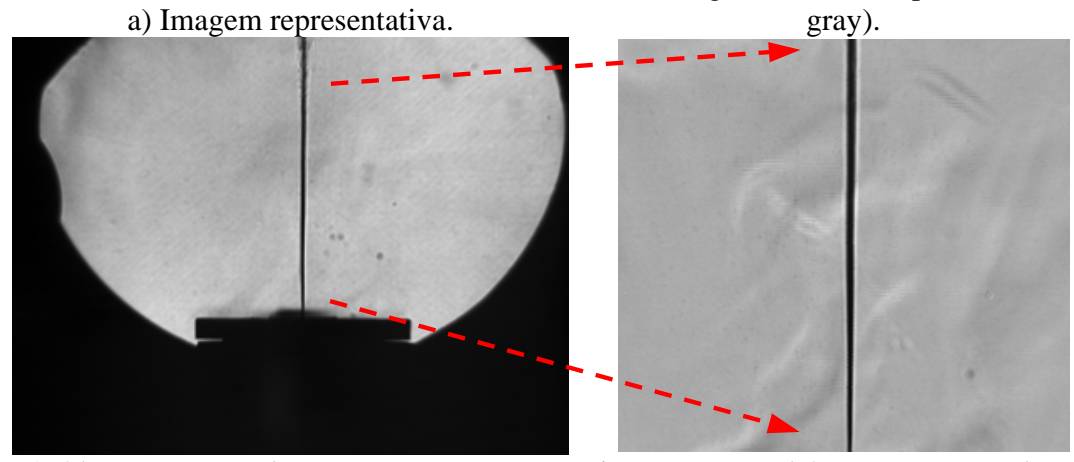

* Obs: este enquadramento mostra que, praticamente, não há evaporação ao longo do jato. Este é um caso onde a pressão de vapor é menor que a pressão da câmara.

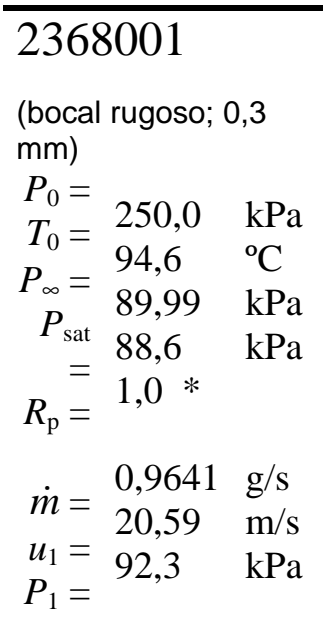

a) Imagem representativa. Esta imagem b) Imagem representativa. Imagem após 0,5 registrou a fase inicial do jato. s da imagem anterior.

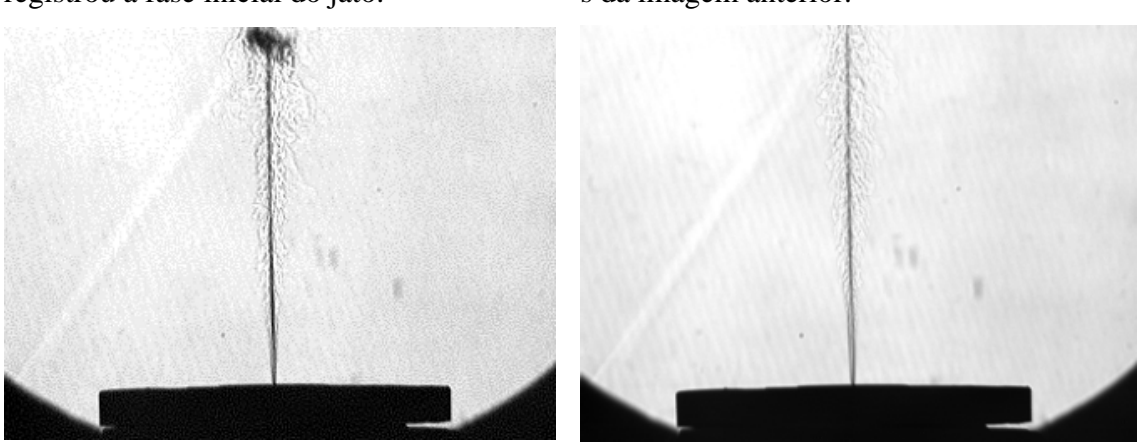

* A pressão de vapor é igual à pressão da câmara proporcionando uma evaporação ao redor do jato.

\section{1b}

(bocal rugoso; 0,3 $\mathrm{mm}$ ) a) Imagem representativa.

$P_{0}=249,8 \quad \mathrm{kPa}$

$T_{0}=95,0 \quad{ }^{\circ} \mathrm{C}$

$P_{\infty}=87,06 \quad \mathrm{kPa}$

$P_{\text {sat }}=89,6 \quad \mathrm{kPa}$

$R_{\mathrm{p}}=1,0$

$\dot{m}=0,9882 \mathrm{~g} / \mathrm{s}$

$u_{1}=21,12 \mathrm{~m} / \mathrm{s}$

$P_{1}=84,3 \quad \mathrm{kPa}$ b) Imagem tratada (mapa de cores: gray).
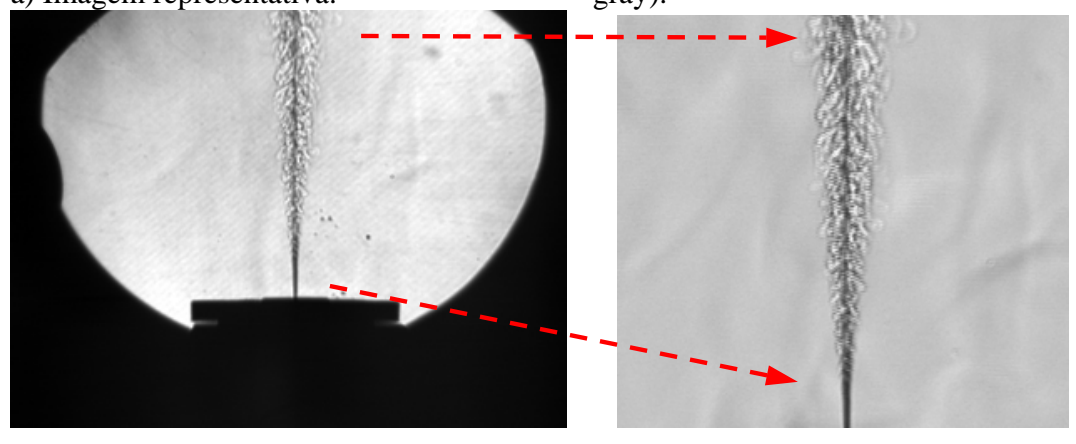

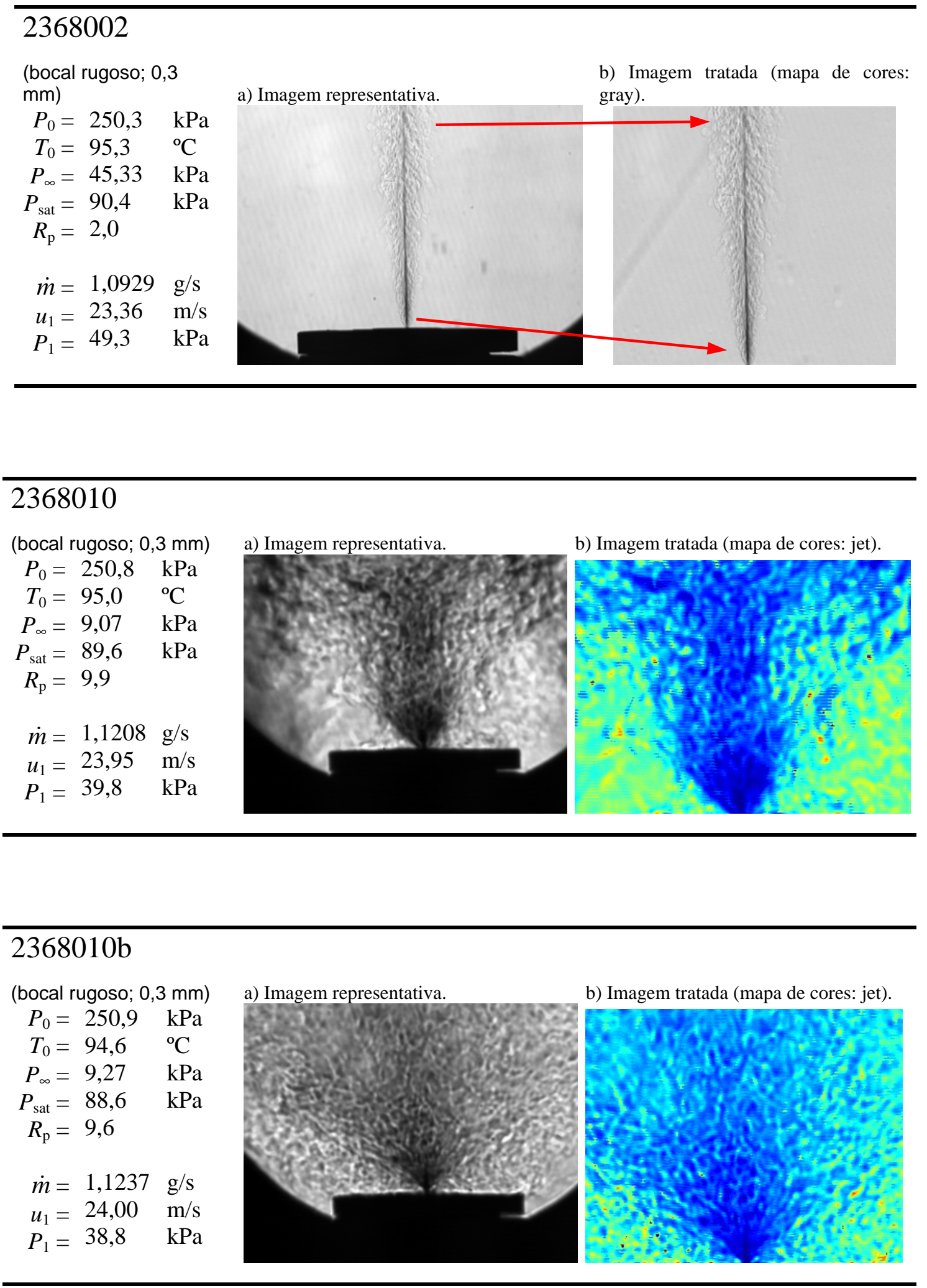


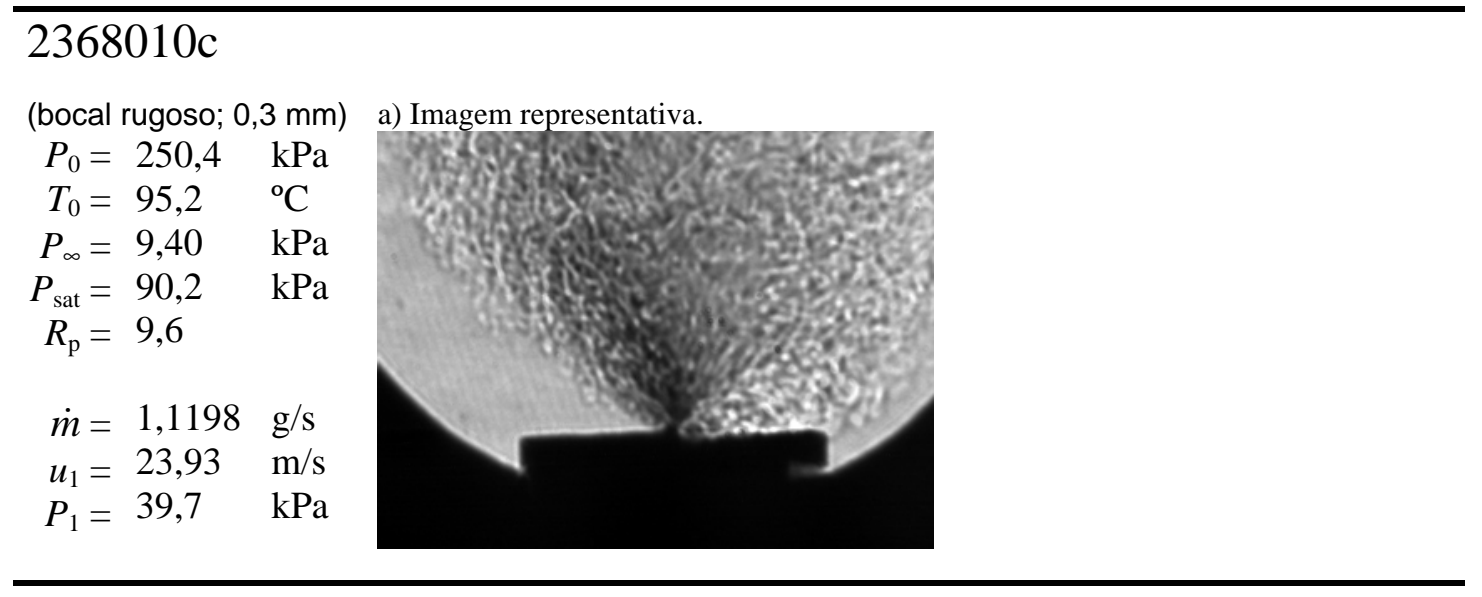

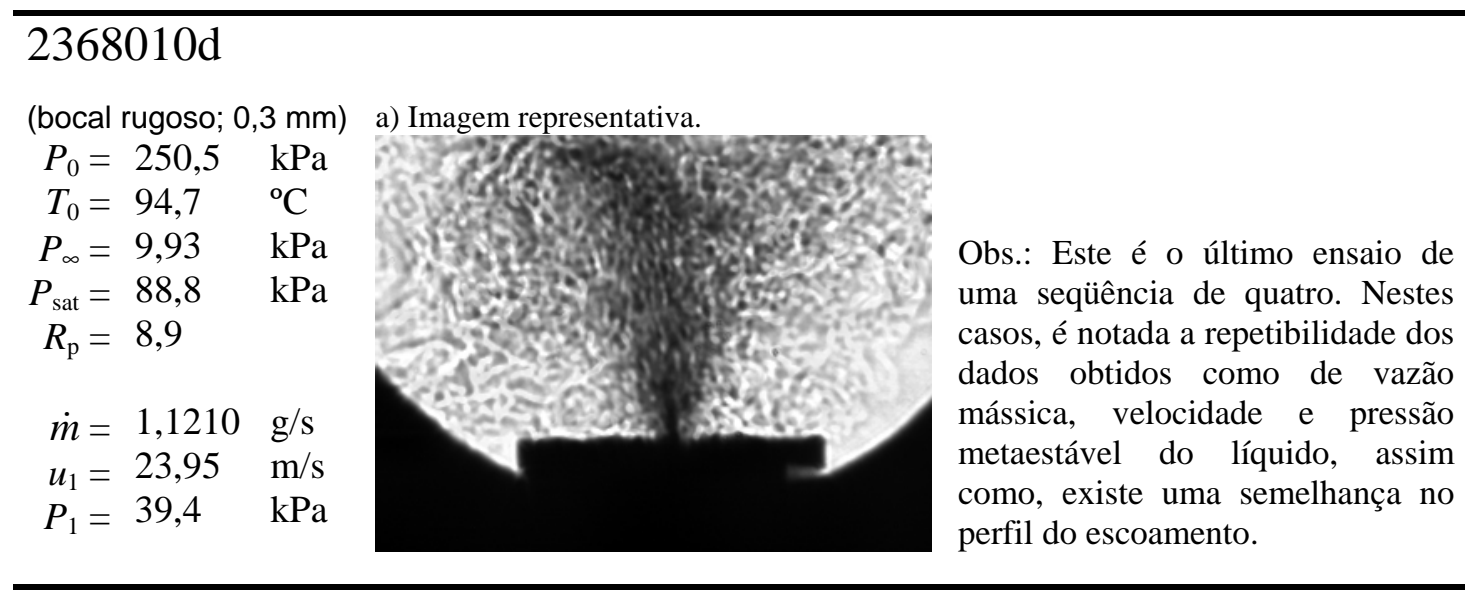

\begin{tabular}{rll}
\hline 2368100 & & \\
(bocal rugoso; $0,3 \mathrm{~mm}$ ) & a) Imagem representativa. & b) Imagem tratada (mapa de cores: hsv). \\
$P_{0}$ & $=246,8 \quad \mathrm{kPa}$ & \\
$T_{0}$ & $=93,9 \quad{ }^{\circ} \mathrm{C}$ \\
$P_{\infty}$ & $=0,85$ & $\mathrm{kPa}$ \\
$P_{\text {sat }}$ & 86,8 & $\mathrm{kPa}$ \\
& $=102,1$
\end{tabular}




\begin{tabular}{|c|c|c|}
\hline 23685 & 00 & \\
\hline (bocal r & Igoso; 0, & \\
\hline$P_{0}=$ & 251,4 & \\
\hline$T_{0}=$ & 95,2 & ${ }^{\circ} \mathrm{C}$ \\
\hline$P_{\infty}=$ & 0,20 & $\mathrm{kF}$ \\
\hline$P_{\text {sat }}=$ & 90,2 & \\
\hline$R_{\mathrm{p}}=$ & 450,8 & \\
\hline$\dot{m}=$ & 1,1277 & $g / s$ \\
\hline$u_{1}=$ & 24,10 & \\
\hline$P_{1}=$ & 37,8 & \\
\hline
\end{tabular}

a) Imagem representativa.

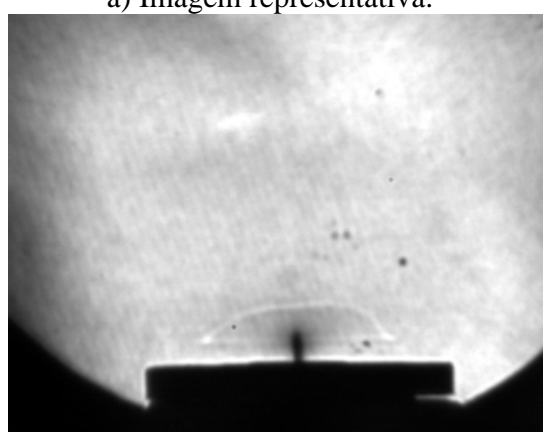

c) Imagem tratada (mapa de cores: jet) b) Imagem tratada (mapa de cores: prism).

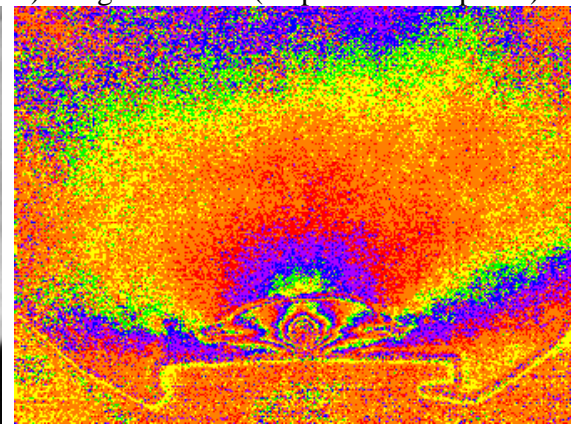

Obs.: A imagem ao lado melhor destaca a onda de choque e o núcleo de líquido.

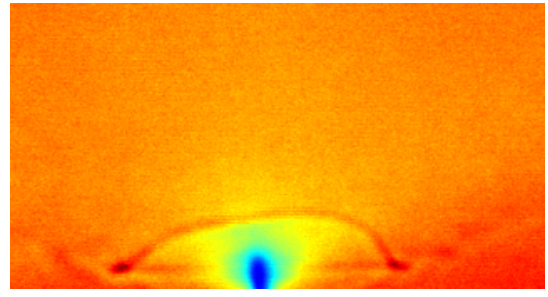

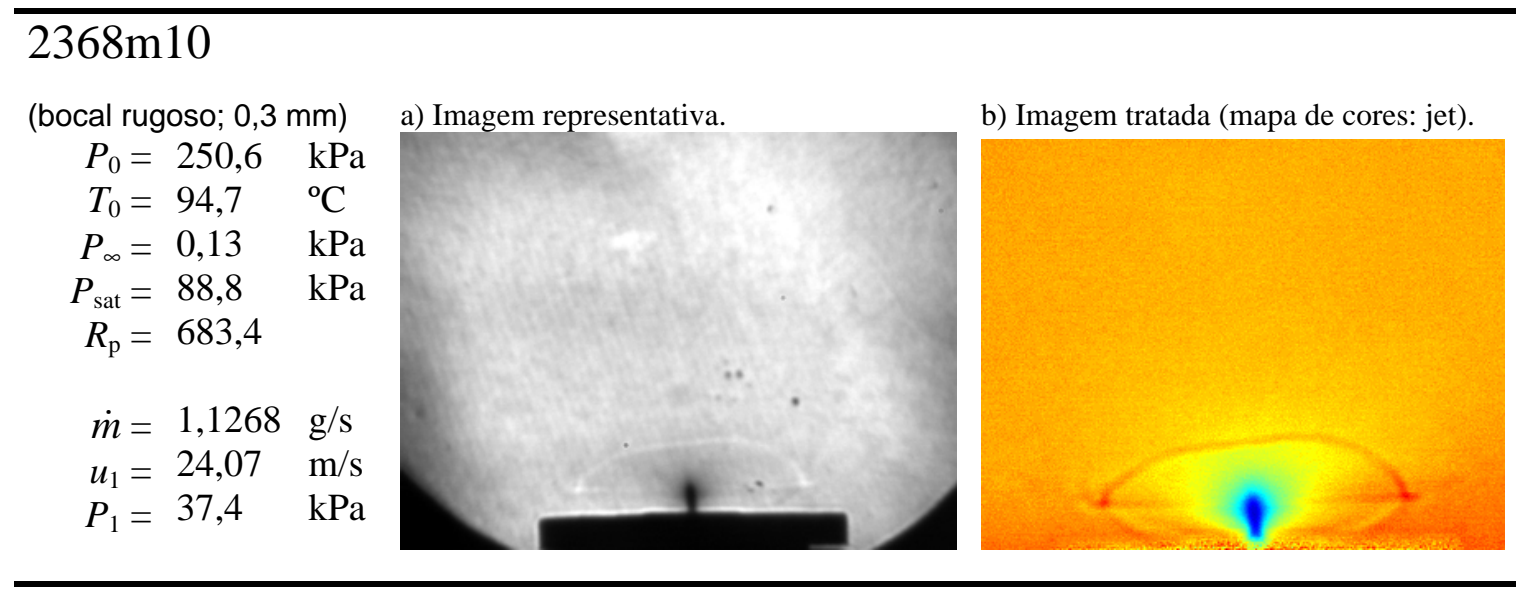

\section{8m10b}

\begin{tabular}{|c|c|c|}
\hline ocal & & \\
\hline$P_{0}=$ & 251,3 & $\mathrm{kP}$ \\
\hline$T_{0}=$ & 95,5 & ${ }^{\circ} \mathrm{C}$ \\
\hline$P_{\infty}=$ & 0,1 & $\mathrm{kP}$ \\
\hline$P_{\mathrm{sat}}=$ & 90,9 & $\mathrm{kP}$ \\
\hline$R_{\mathrm{p}}=$ & 649,6 & \\
\hline & 1,12 & $\mathrm{~g} / \mathrm{s}$ \\
\hline & 24,03 & $\mathrm{~m} / \mathrm{s}$ \\
\hline$P_{1}=$ & 39,1 & \\
\hline
\end{tabular}

a) Imagem representativa.

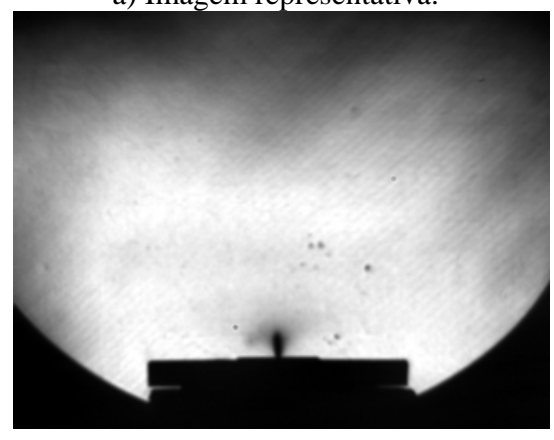

b) Imagem tratada (mapa de cores: gray).

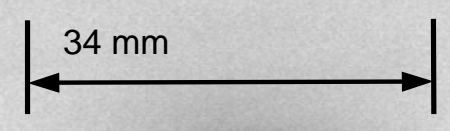



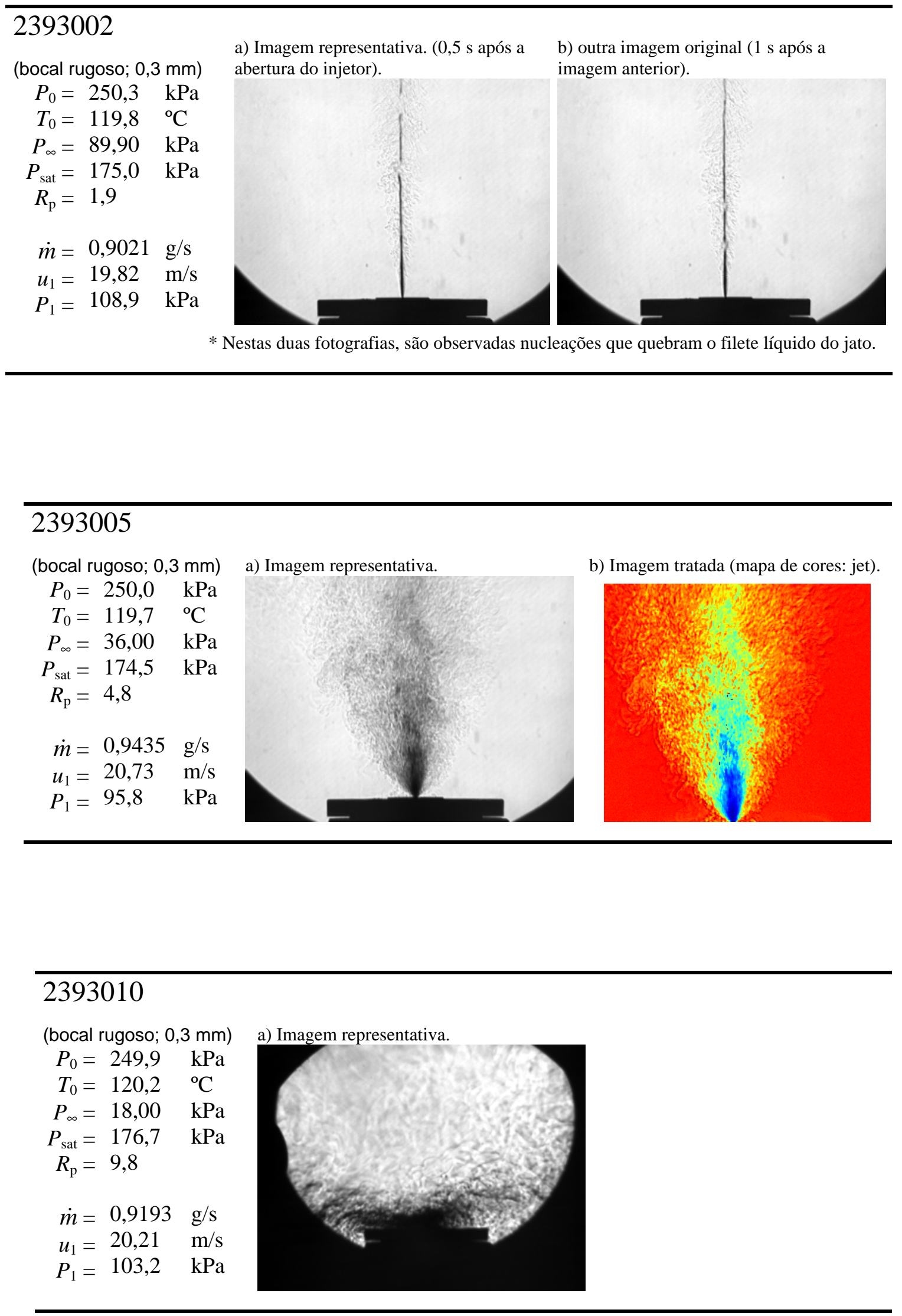

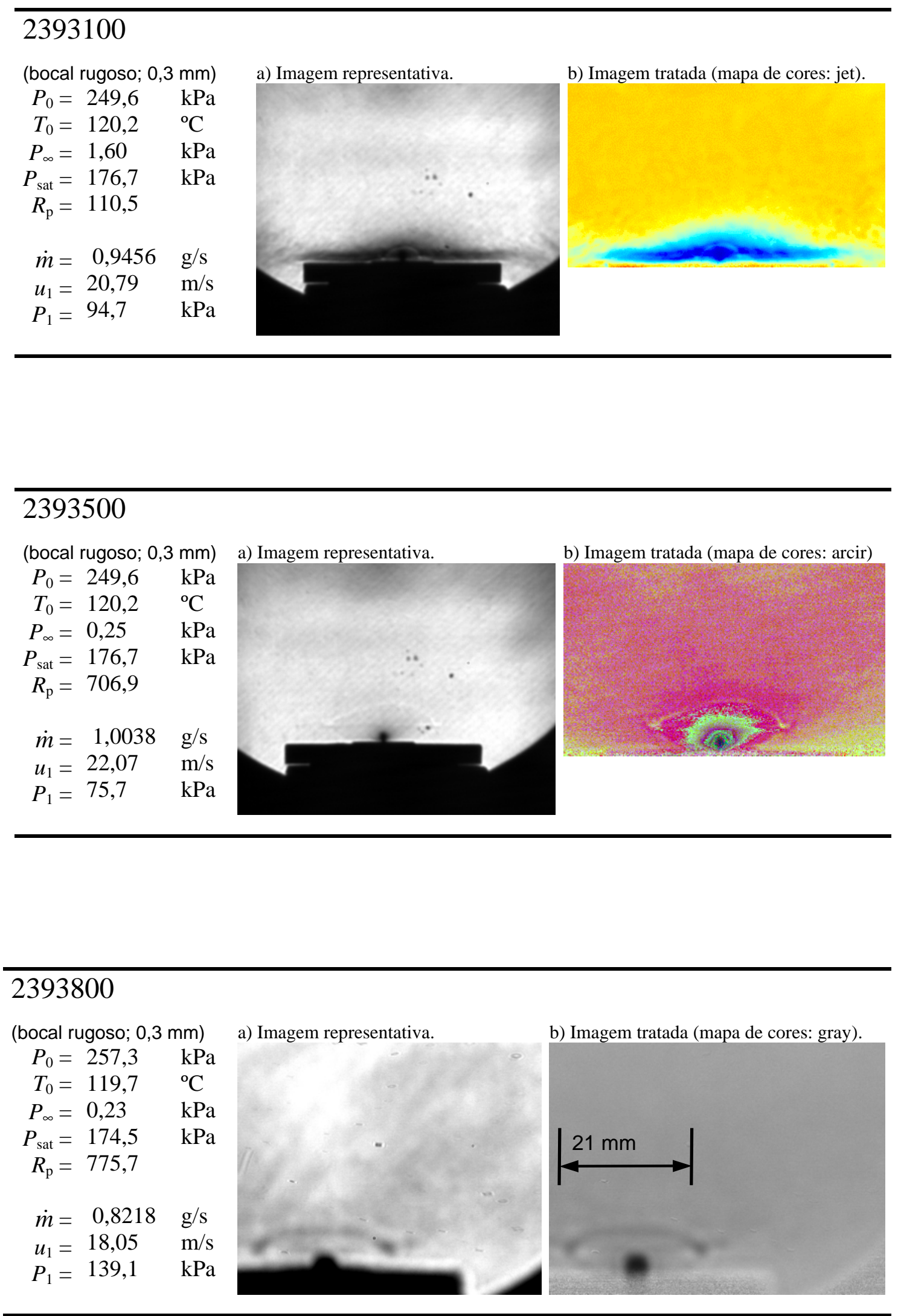


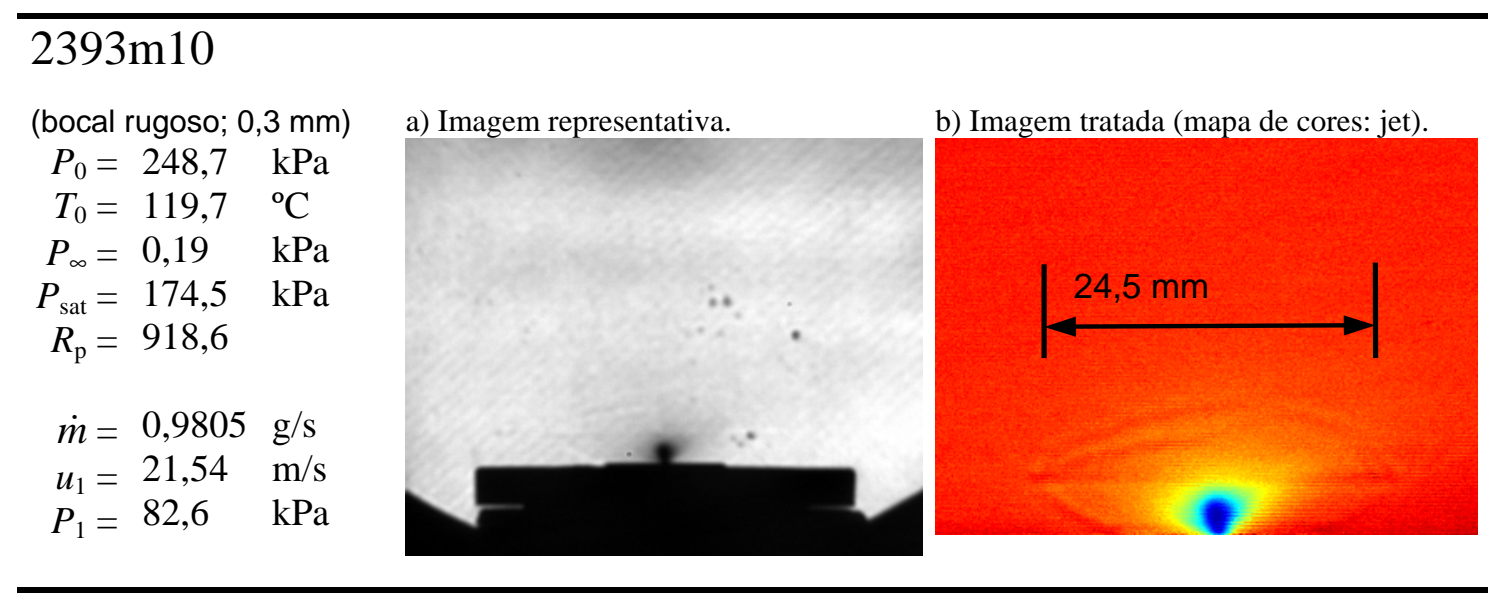

\section{3m10b}

(bocal rugoso; $0,3 \mathrm{~mm}$ )
$P_{0}=251,3 \quad \mathrm{kPa}$
$T_{0}=120,6 \quad{ }^{\circ} \mathrm{C}$
$P_{\infty}=0,22 \quad \mathrm{kPa}$
$P_{\text {sat }}=178,5 \mathrm{kPa}$
$R_{\mathrm{p}}=830,1$
$\dot{m}=0,9340 \mathrm{~g} / \mathrm{s}$
$u_{1}=20,54 \mathrm{~m} / \mathrm{s}$
$P_{1}=100,0 \mathrm{kPa}$

a) Imagem representativa.

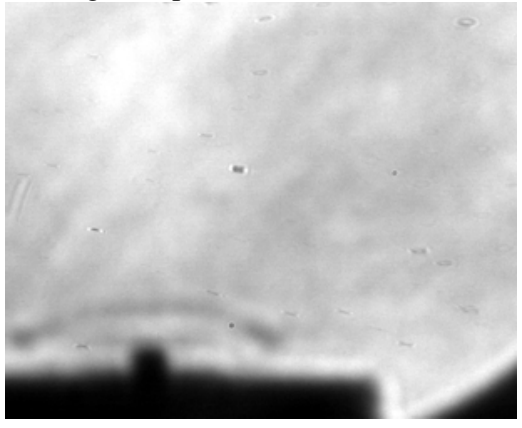

* Obs.: este ensaio ocorreu na etapa inicial, onde era necessário ajustes da bancada. b) Imagem tratada (mapa de cores: gray).
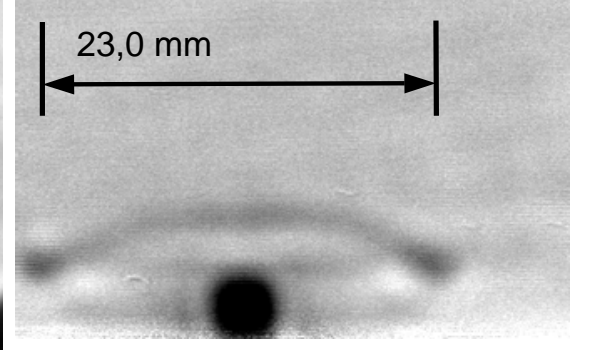

. 

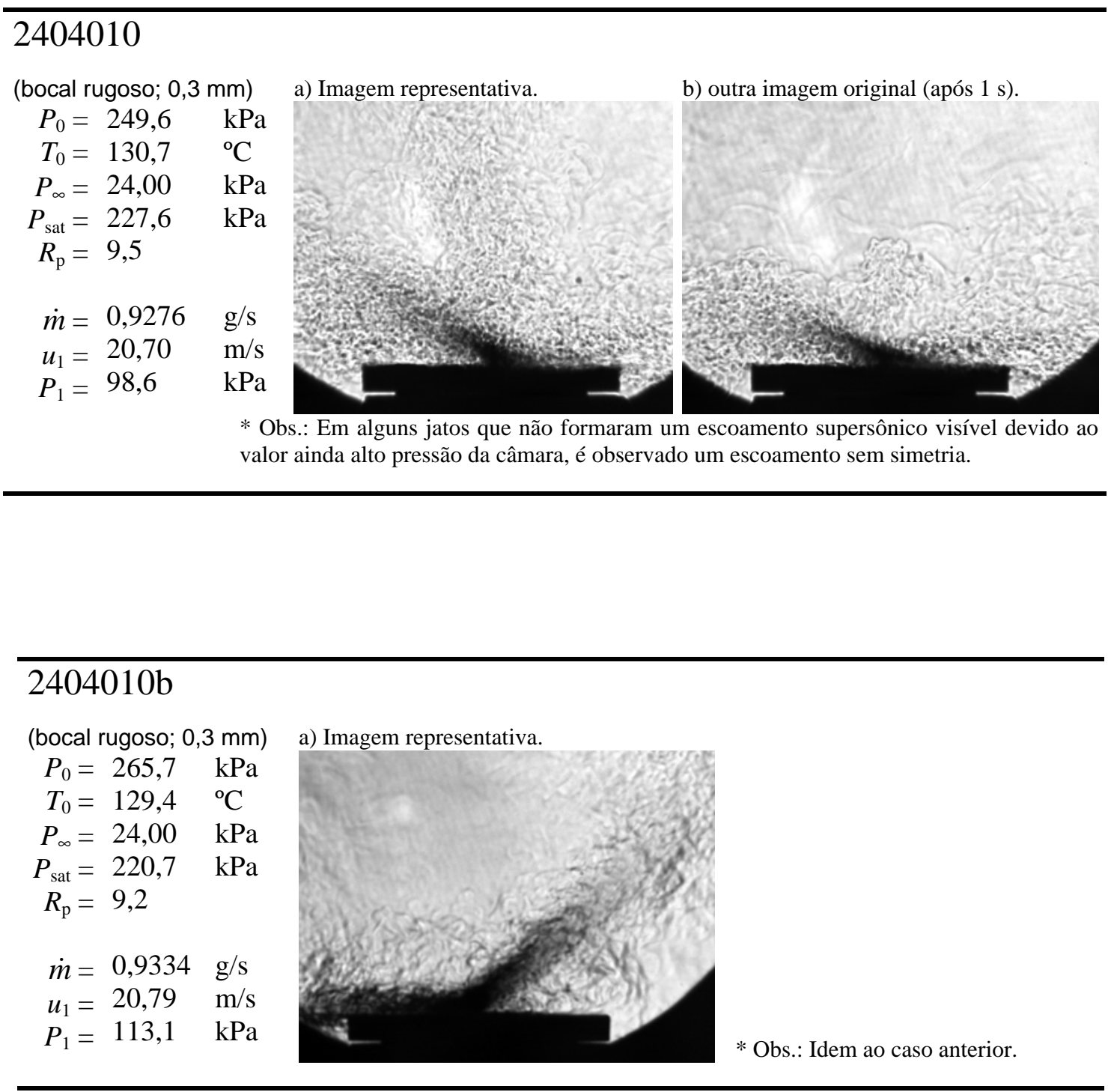

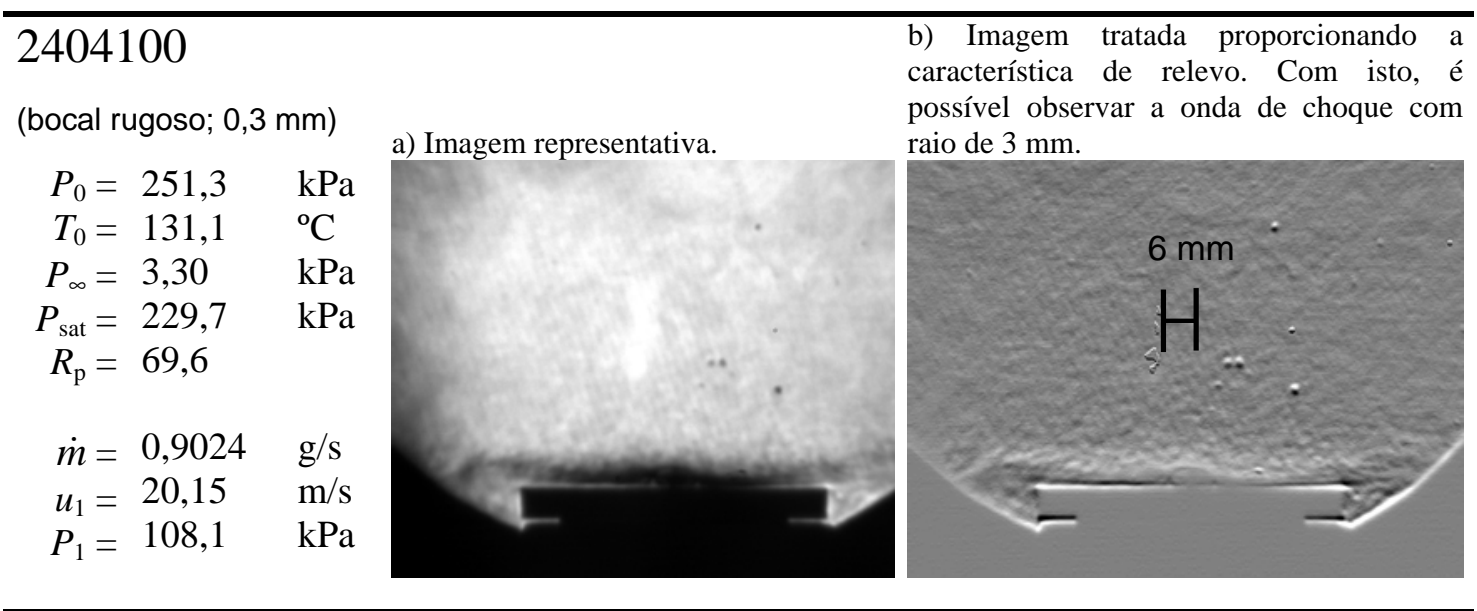



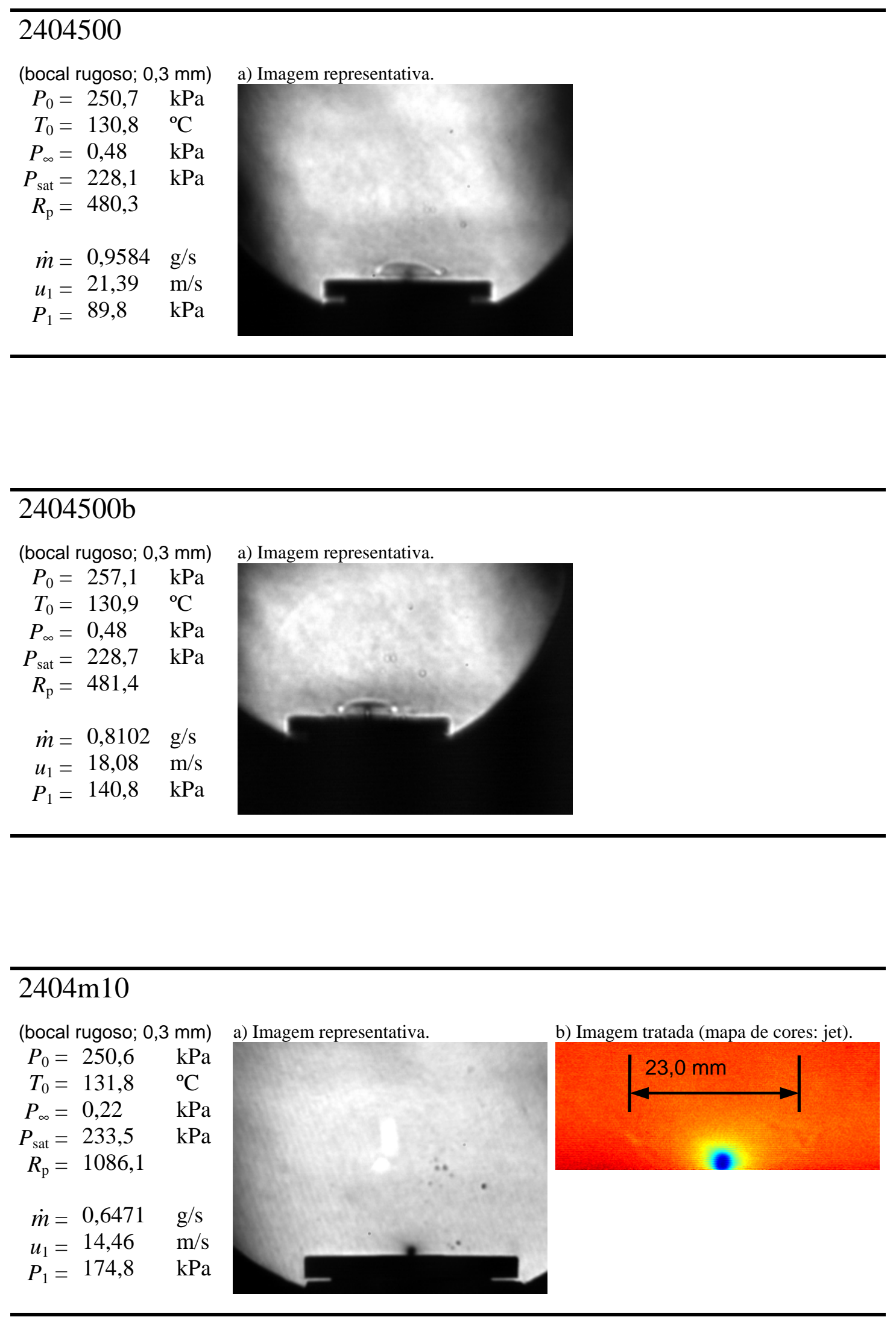


\section{4m10b}

(bocal rugoso; 0,3 mm)

a) Imagem representativa.

$$
\begin{aligned}
& P_{0}=256,2 \quad \mathrm{kPa} \\
& T_{0}=130,2 \quad{ }^{\circ} \mathrm{C} \\
& P_{\infty}=0,22 \quad \mathrm{kPa} \\
& P_{\text {sat }}=224,9 \quad \mathrm{kPa} \\
& R_{\mathrm{p}}=1046,2 \\
& \dot{m}=0,7828 \mathrm{~g} / \mathrm{s} \\
& u_{1}=17,45 \mathrm{~m} / \mathrm{s} \\
& P_{1}=147,4 \quad \mathrm{kPa}
\end{aligned}
$$

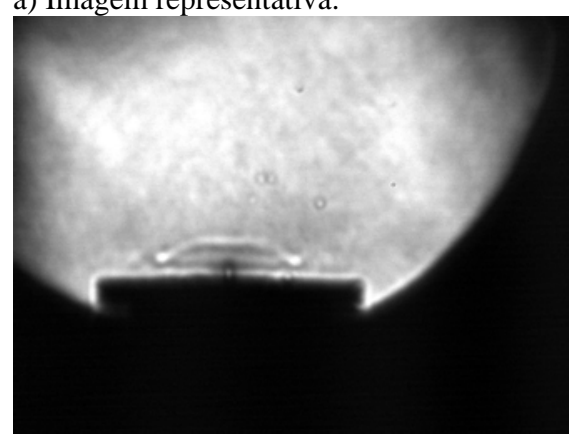

\section{0}

(bocal rugoso; 0,3 mm)

$P_{0}=250,1 \mathrm{kPa}$

$T_{0}=129,0{ }^{\circ} \mathrm{C}$

$P_{\infty}=0,38 \quad \mathrm{kPa}$

$P_{\text {sat }}=218,7 \mathrm{kPa}$

$R_{\mathrm{p}}=583,1$

$$
\begin{array}{lll}
\dot{m}=-- & \mathrm{g} / \mathrm{s} \\
u_{1}=-- & \mathrm{m} / \mathrm{s} \\
P_{1}=-- & \mathrm{kPa}
\end{array}
$$

Observações:

- Não foi obtido sucesso neste ensaio. O fluido começou a vaporizar internamente na câmara do injetor, antes da injeção. A temperatura de injeção (linha vermelha) não mantém um patamar constante.

- Também não há registro fotográfico do jato. 


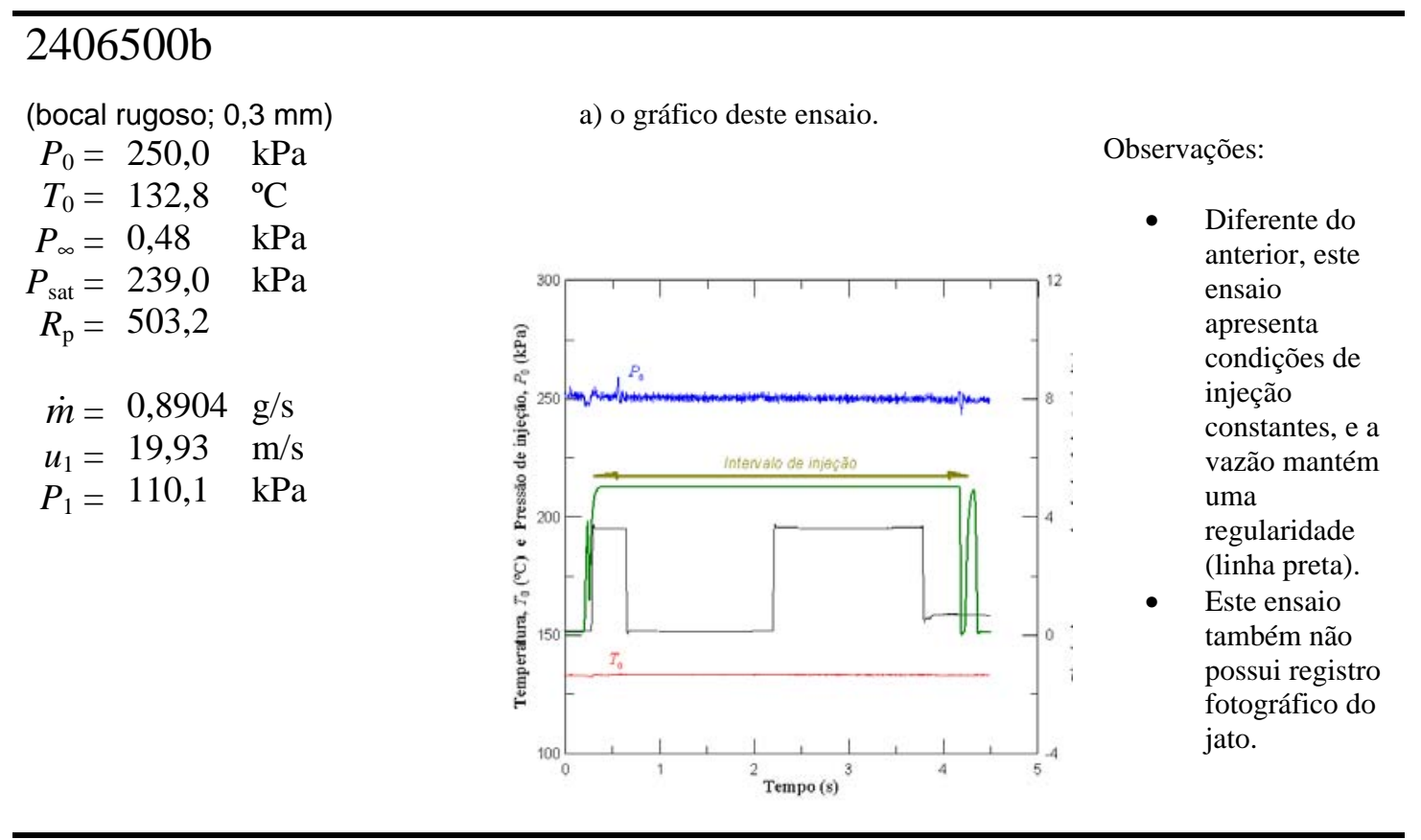

$$
\begin{array}{rll}
P_{0} & =251,4 & \mathrm{kPa} \\
T_{0} & =125,0 & { }^{\circ} \mathrm{C} \\
P_{\infty} & =0,18 & \mathrm{kPa} \\
P_{\text {sat }} & =198,7 & \mathrm{kPa} \\
R_{\mathrm{p}} & =1135,5 & \\
\dot{m} & =0,7653 \mathrm{~g} / \mathrm{s} \\
u_{1} & =16,93 & \mathrm{~m} / \mathrm{s} \\
P_{1}=147,8 & \mathrm{kPa}
\end{array}
$$

a) Imagem representativa.

b) Imagem tratada (mapa de cores: jet).
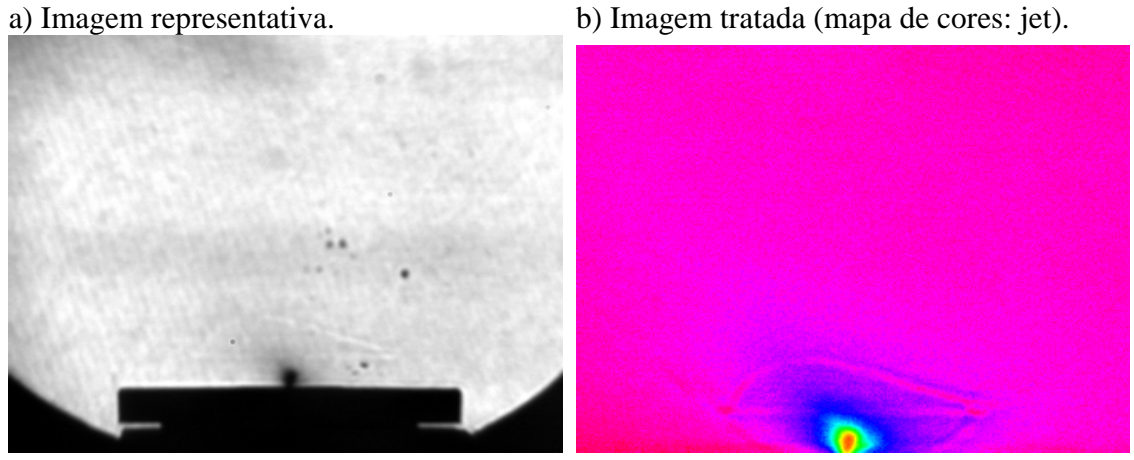

c) Imagem da abertura do injetor.

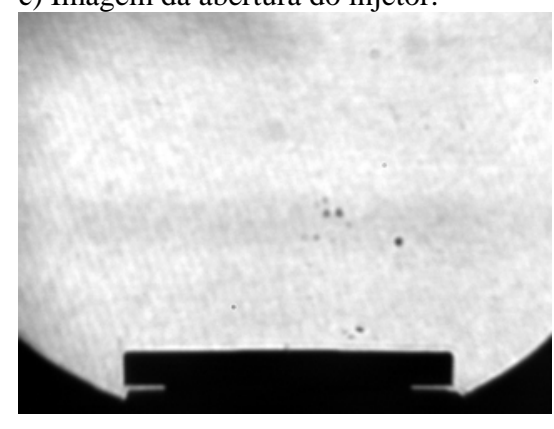

d) Imagem "c" tratada.

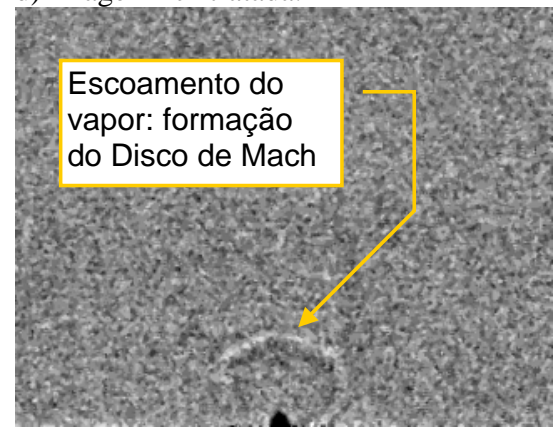

*Obs.: Neste caso (imagem “c”), foi possível registrar uma fotografia do instante inicial do jato. Neste momento o vapor formado pelo recuo da haste do injetor está sendo expulso. A imagem "a" mostra o jato em regime permanente e foi adquirida $0,5 \mathrm{~s}$ após este transitório. 

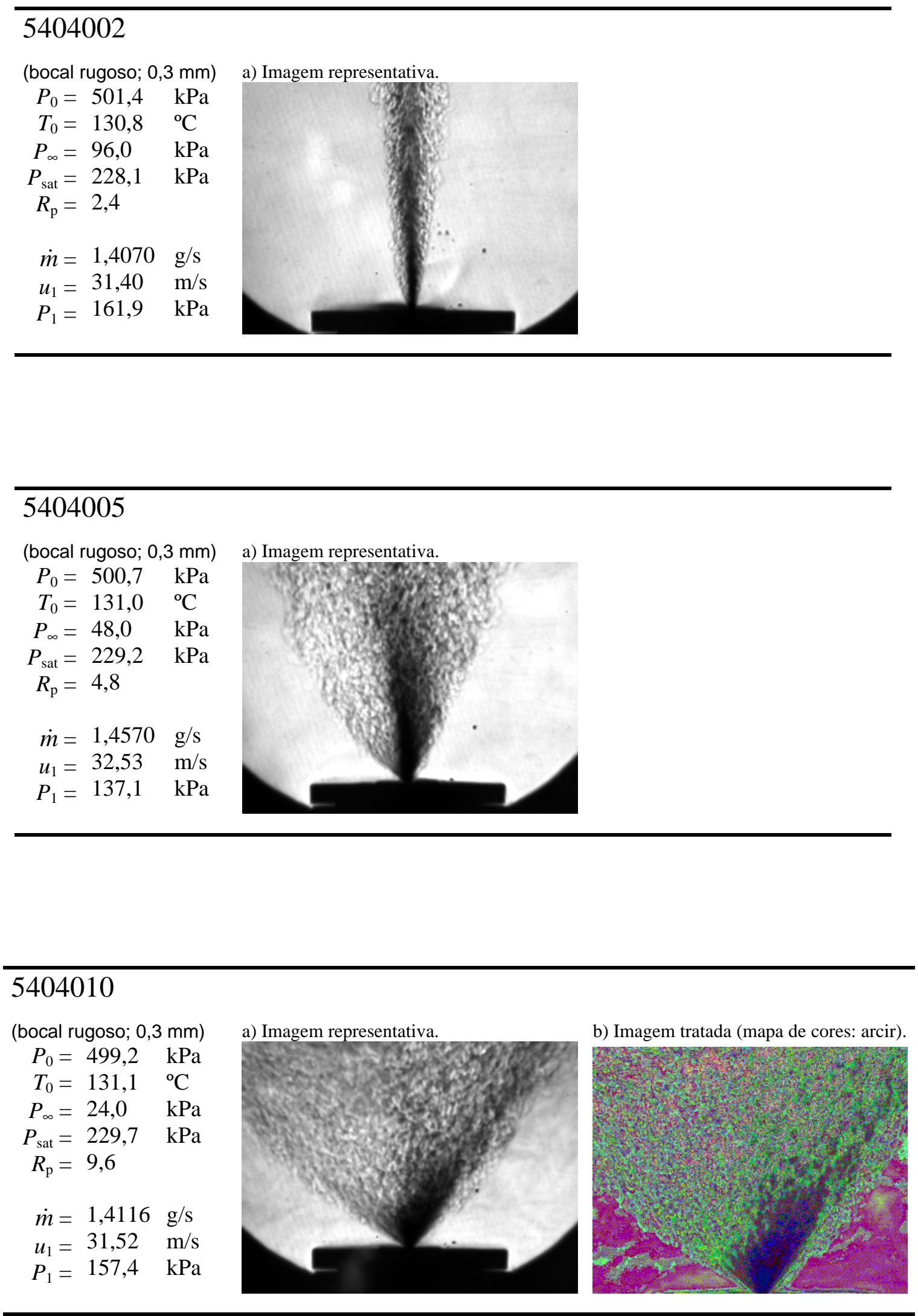

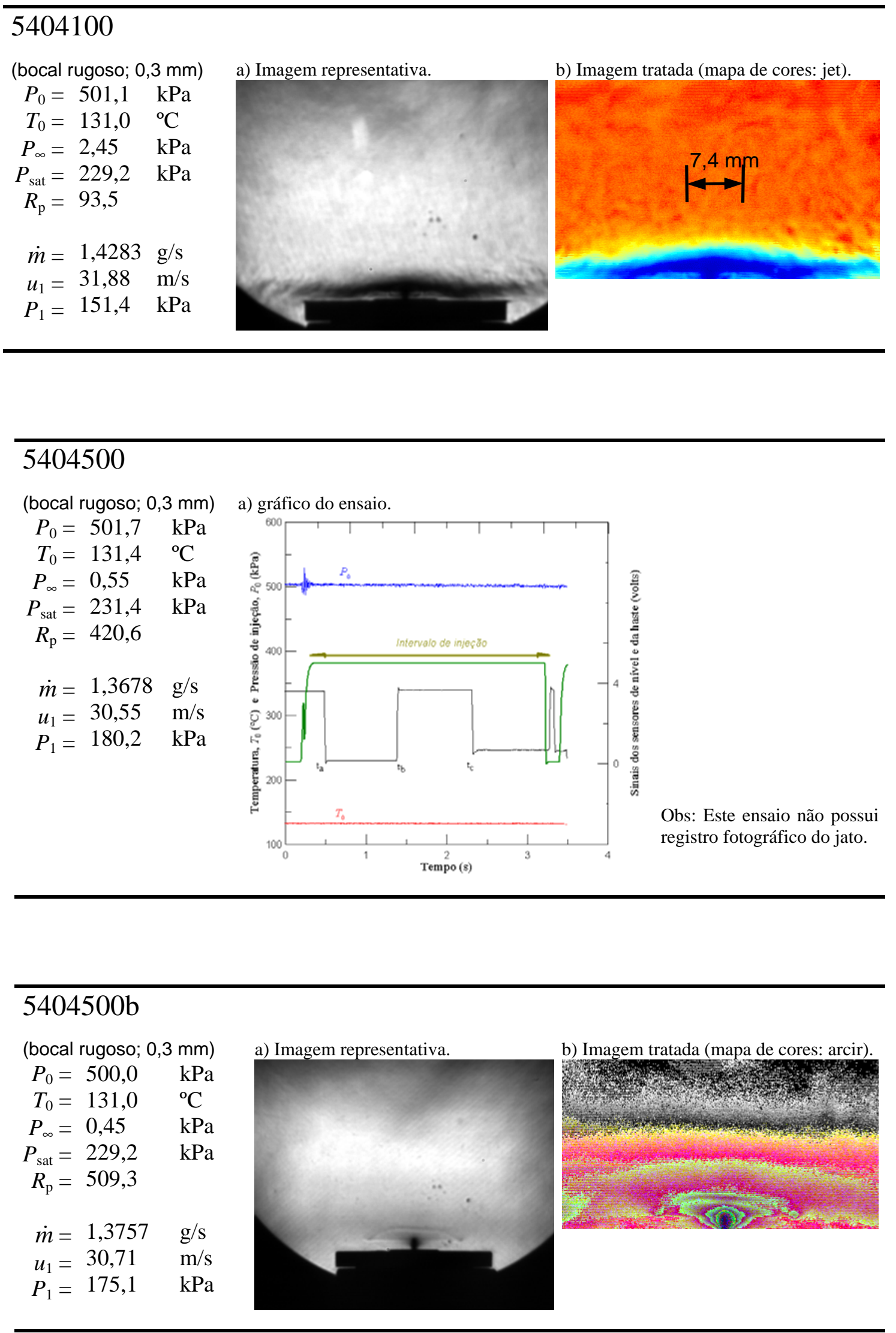

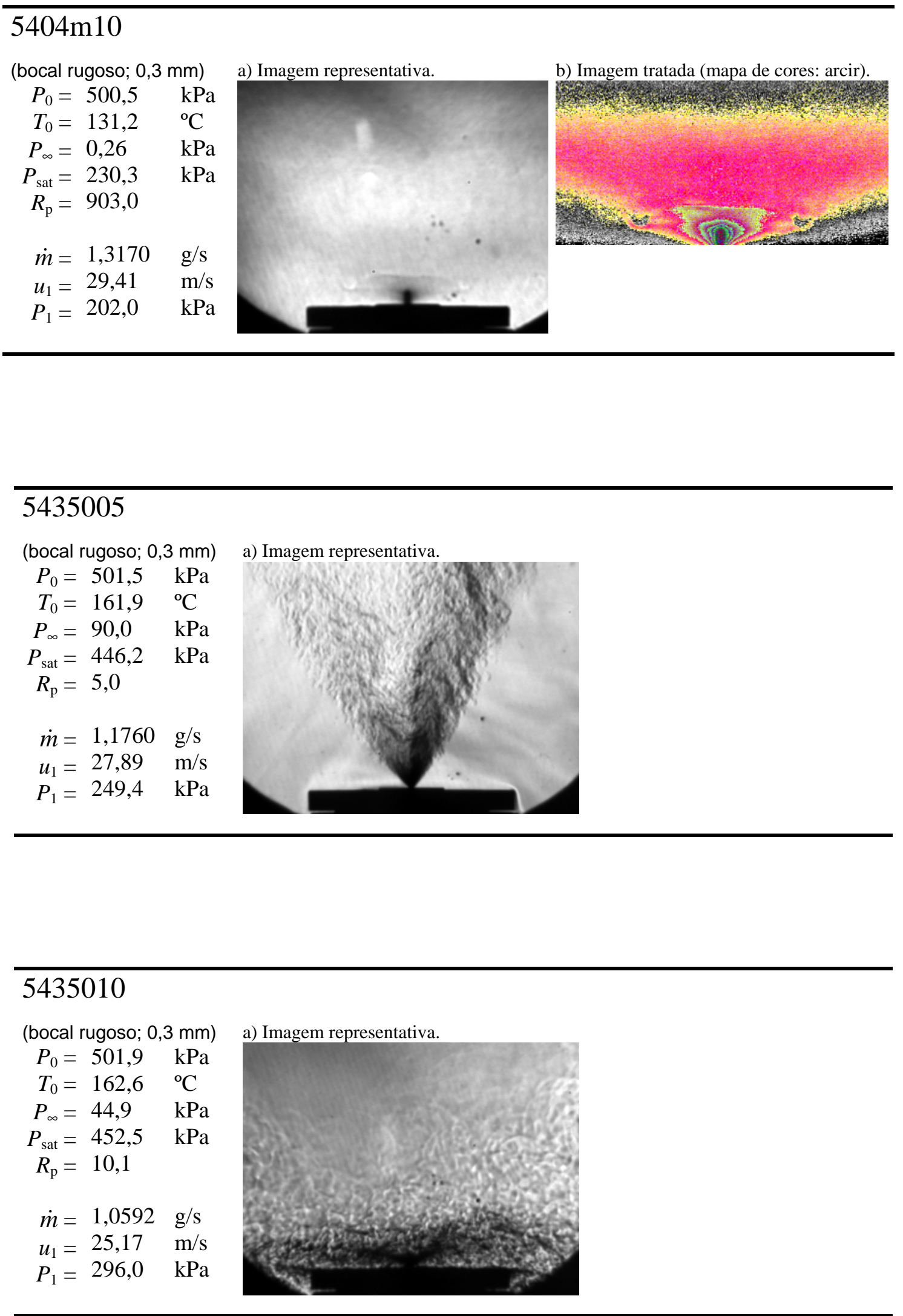

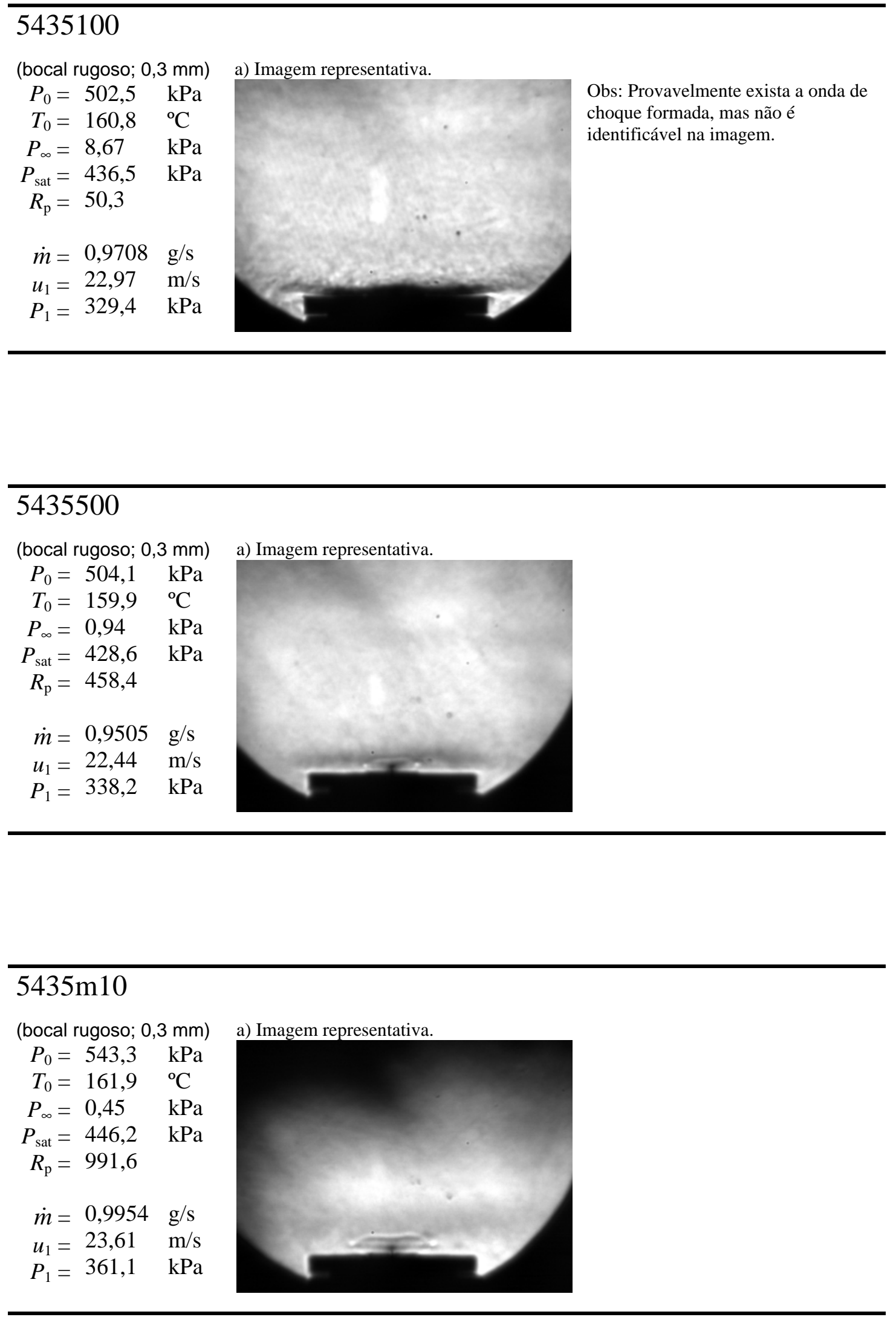

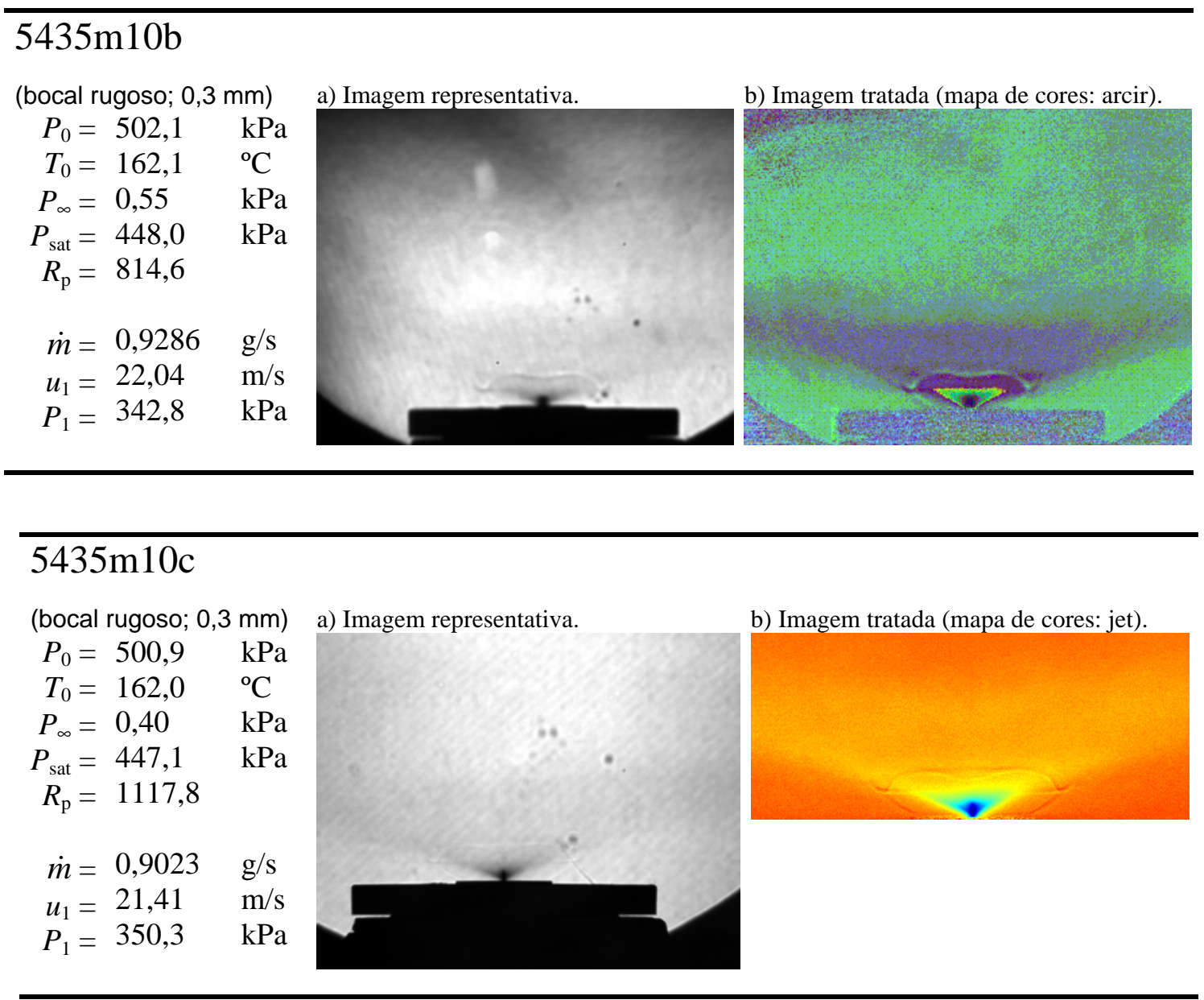

\section{Série de ensaios: RUN2}

Nesta série de ensaio de ensaios, foi implementada a utilização da lâmpada de “flash” para o método "Schlieren” e a utilização da segunda câmara de CCD onde a iluminação era feita por detrás do fenômeno. Logo, esta série de ensaios teve o objetivo de fazer um ajuste deste segundo método óptico. 

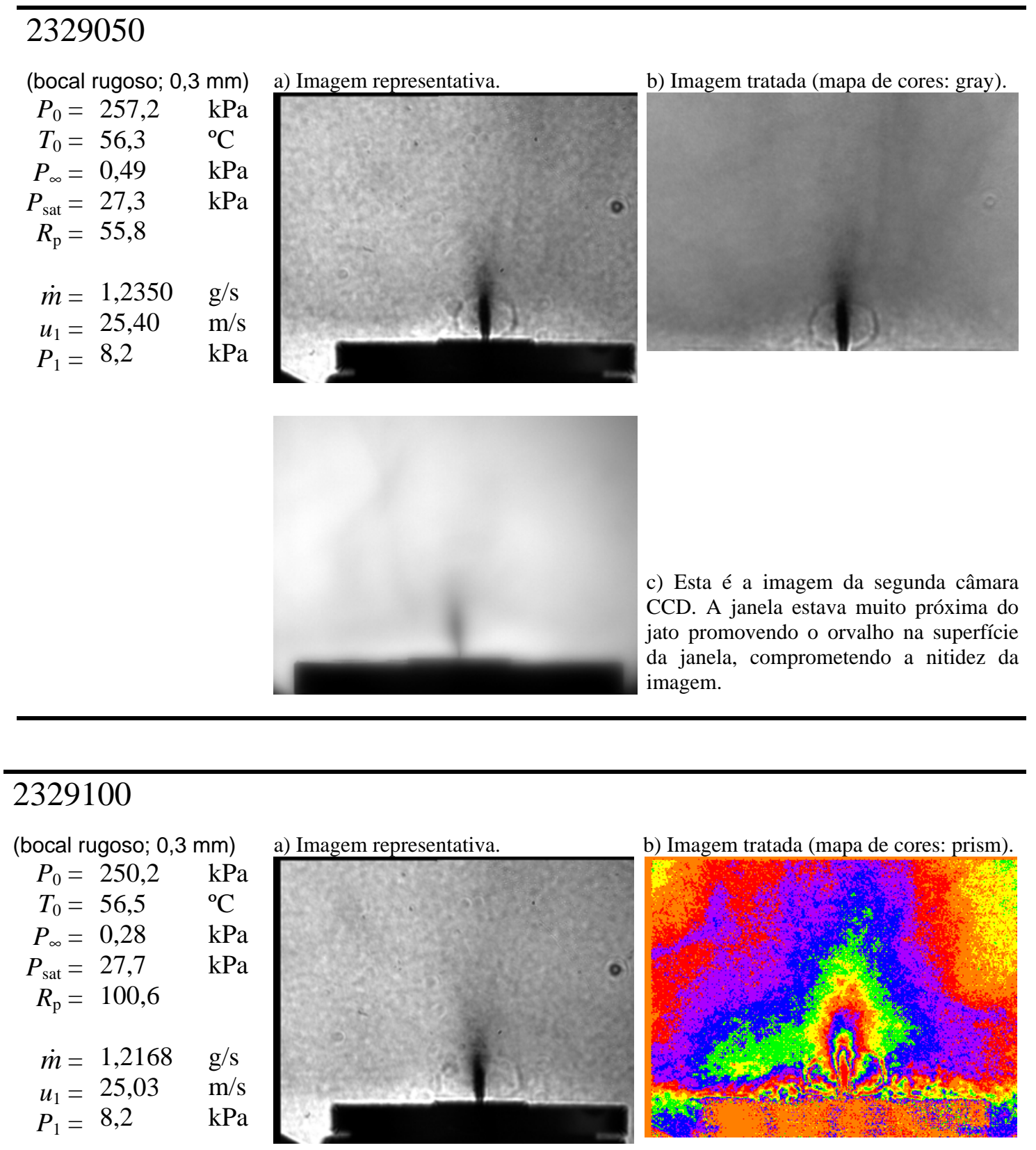

c) Imagem tratada (mapa de cores: hsv).

b) Imagem tratada (mapa de cores: prism).

$\begin{array}{rlrl}P_{0} & =250,2 & \mathrm{kPa} \\ T_{0} & =56,5 & & { }^{\circ} \mathrm{C} \\ P_{\infty} & =0,28 & \mathrm{kPa} \\ P_{\text {sat }} & =27,7 & \mathrm{kPa} \\ R_{\mathrm{p}} & =100,6 & & \\ \dot{m} & =1,2168 & \mathrm{~g} / \mathrm{s} \\ u_{1}=25,03 & \mathrm{~m} / \mathrm{s} \\ P_{1}=8,2 & \mathrm{kPa}\end{array}$

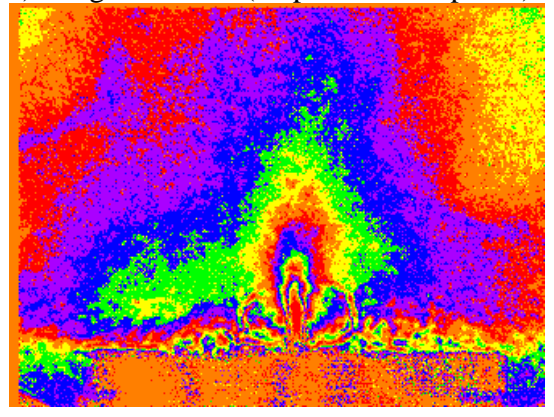

d) Conforme a imagem "c" do caso

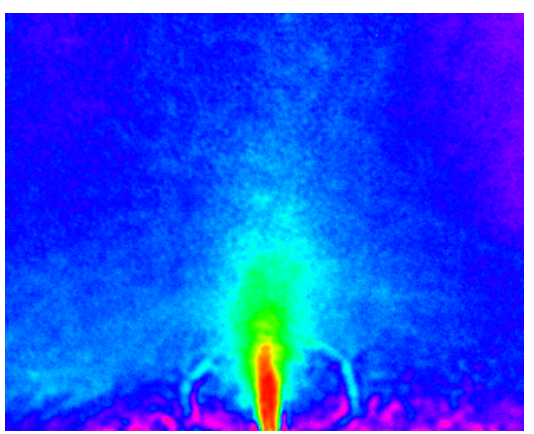
anterior.

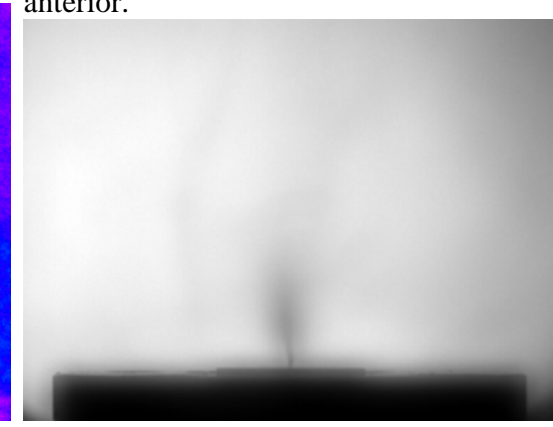




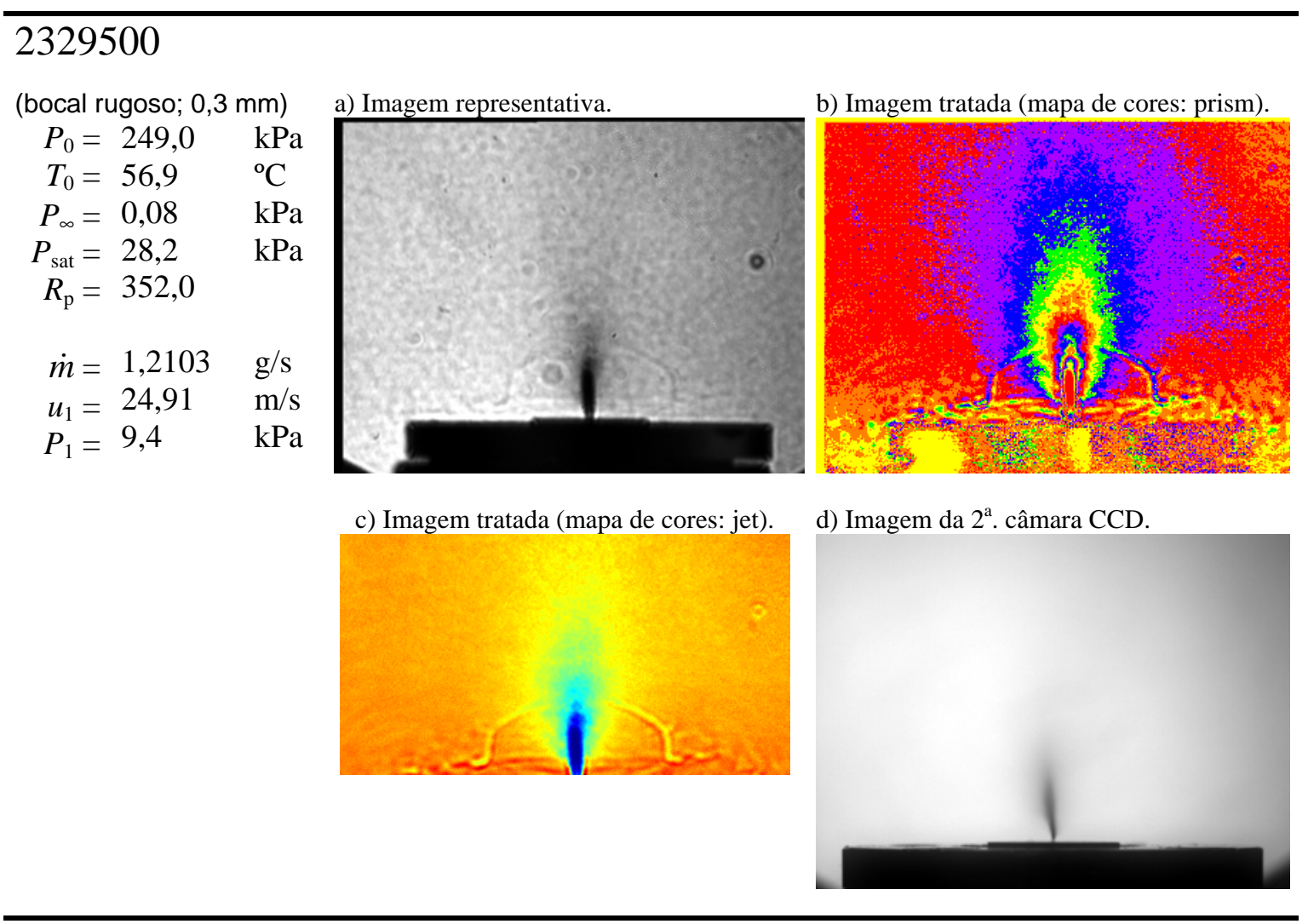

\section{1c}

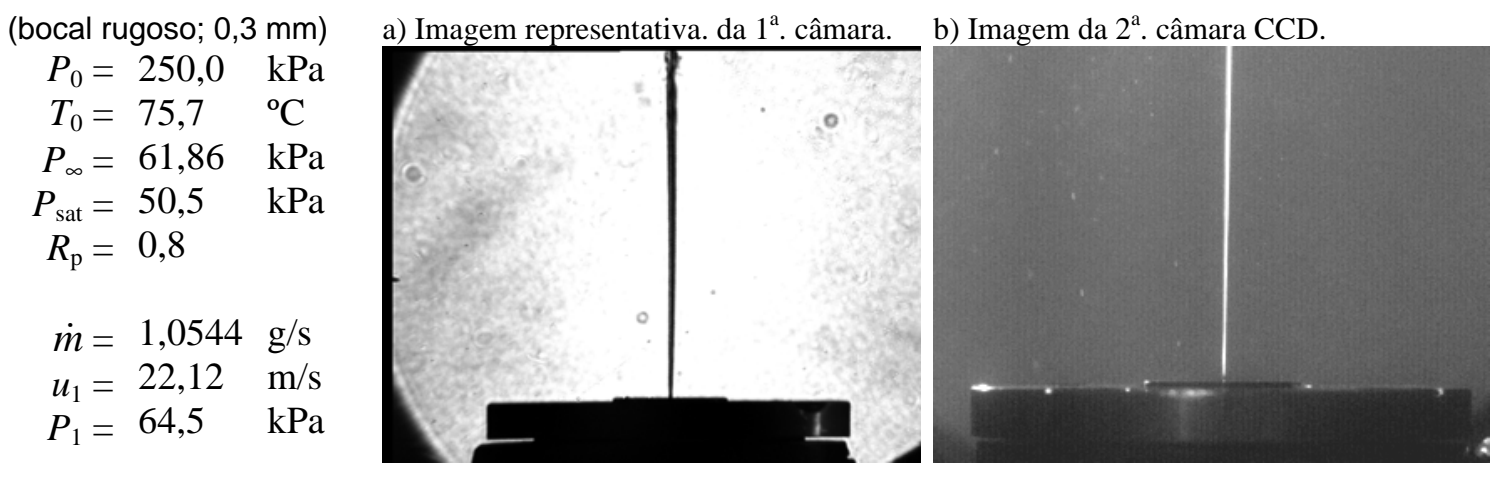




\section{1c}

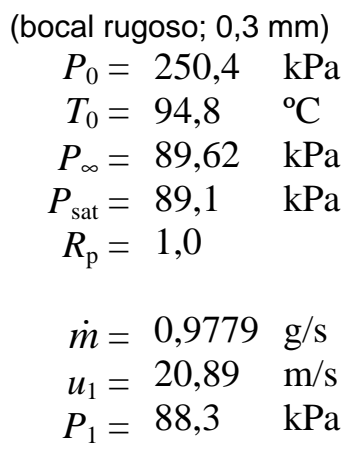

a) Imagem representativa. da $1^{\text {a }}$. câmara.

b) Imagem da $2^{\mathrm{a}}$. câmara CCD.
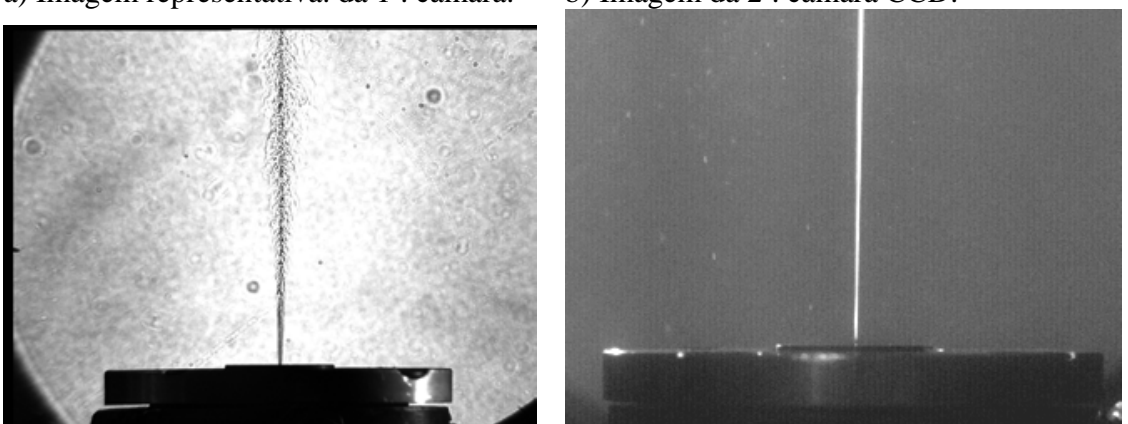

* Obs.: Embora a $1^{\mathrm{a}}$. câmara CCD, pertencente ao sistema "Schlieren", oferece uma imagem com um jato quase fragmentando em seu filete devido a evaporação ao longo do jato. A outra comprova que o jato é contínuo.
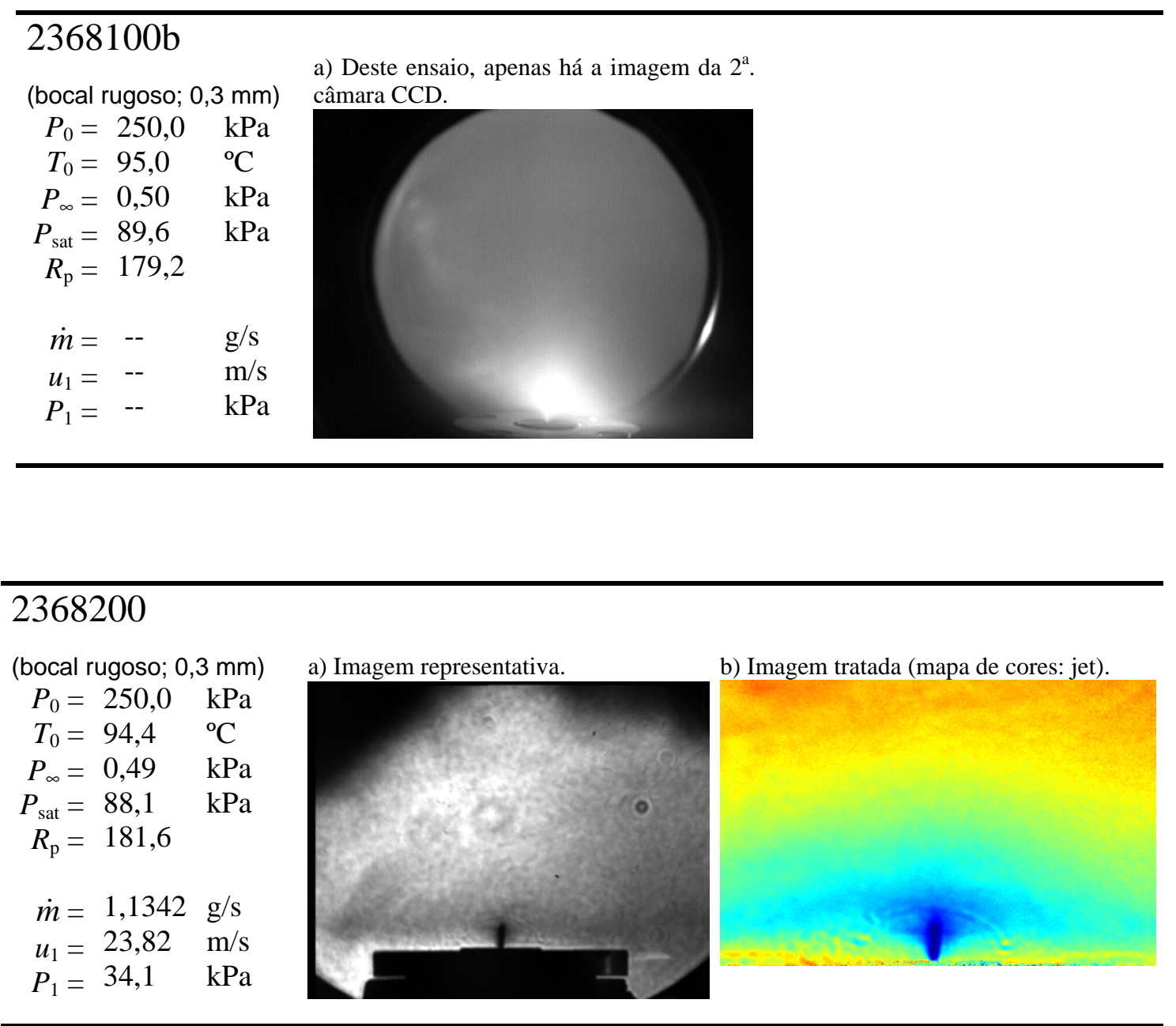


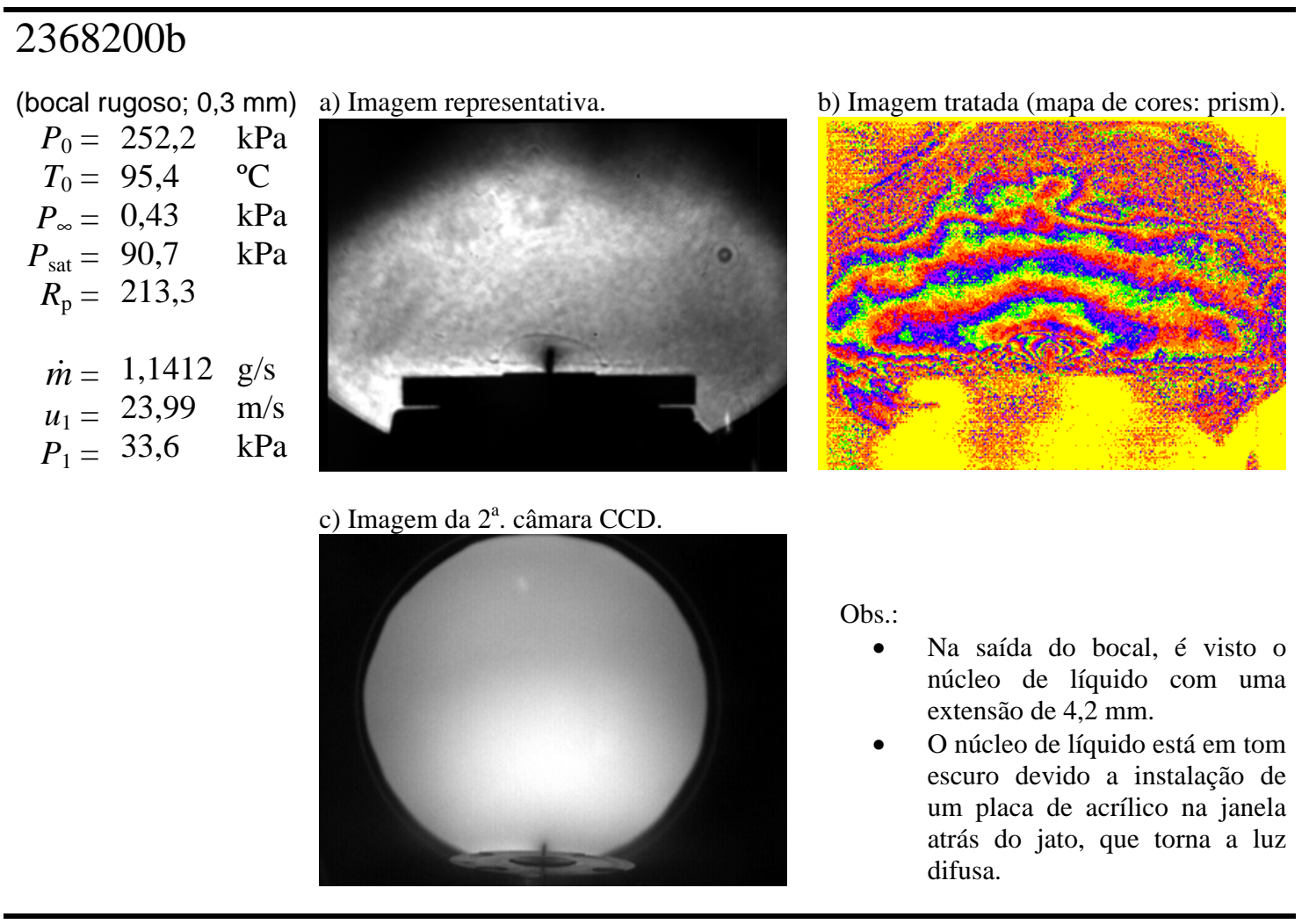

\section{0}

(bocal rugoso; 0,3 $\mathrm{mm}$ ) CCD

$$
\begin{array}{rlr}
P_{0} & =249,5 & \mathrm{kPa} \\
T_{0} & =119,7 & { }^{\circ} \mathrm{C} \\
P_{\infty} & =3,80 & \mathrm{kPa} \\
P_{\text {sat }} & =174,5 & \mathrm{kPa} \\
R_{\mathrm{p}} & =45,9 & \\
\dot{m} & =0,9669 & \mathrm{~g} / \mathrm{s} \\
u_{1}=21,24 & \mathrm{~m} / \mathrm{s} \\
P_{1}=87,8 & \mathrm{kPa}
\end{array}
$$

b) Imagem tratada (mapa de cores: prism).

Onúcleo de líquido está em tom devido a instalação de difusa. a) Imagem representativa. $1^{\text {a }}$. câmara

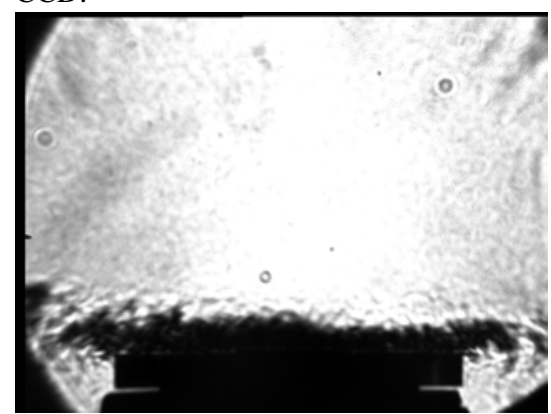

b) Imagem da $2^{\text {a }}$. câmara CCD.

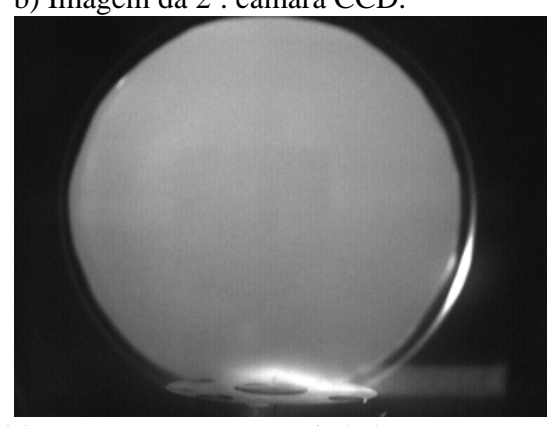

* Ensaios que possuem um núcleo de líquido pouco extenso (aqui é de 2,6 mm) e valores de $R$ p desta ordem de valor limitam um detalhamento visual pelo "Schlieren". 


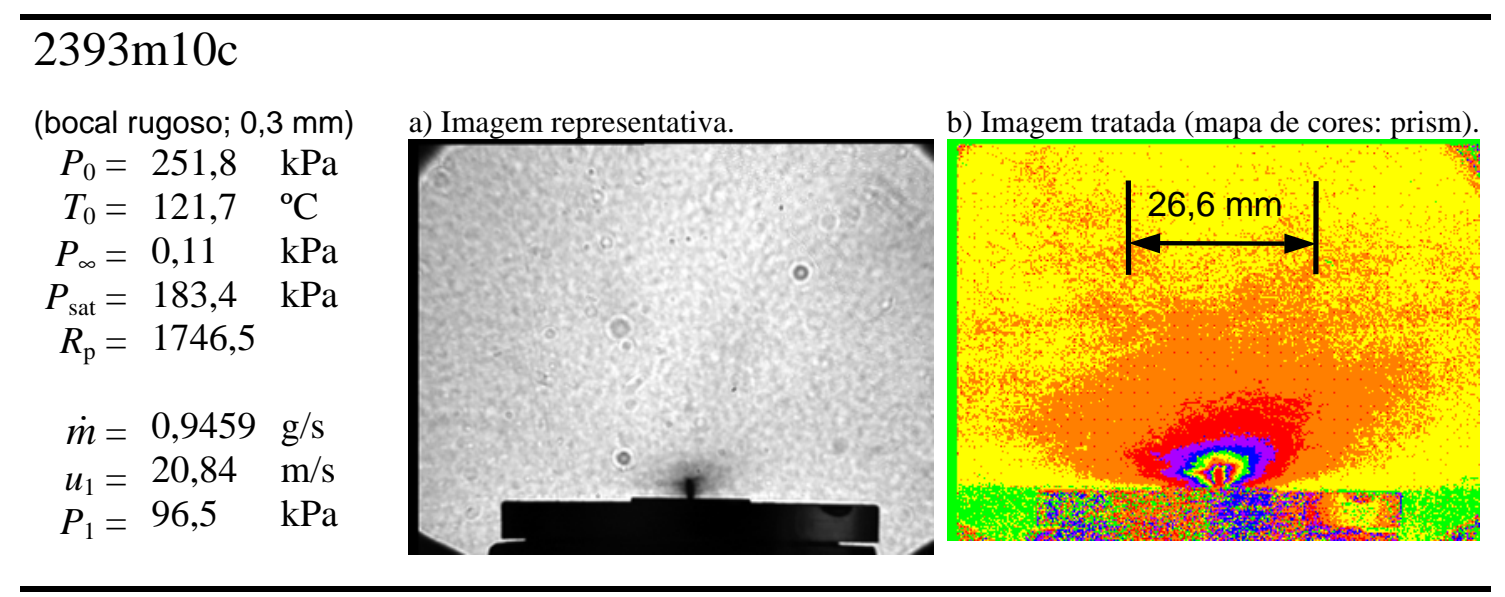

\section{0}

(bocal rugoso; 0,3 mm) a) Imagem representativa.

$$
\begin{array}{rlr}
P_{0} & =501,9 & \mathrm{kPa} \\
T_{0} & =95,4 & { }^{\circ} \mathrm{C} \\
P_{\infty} & =9,20 & \mathrm{kPa} \\
P_{\text {sat }} & =90,7 & \mathrm{kPa} \\
R_{\mathrm{p}} & =9,9 & \\
\dot{m} & =1,6523 & \mathrm{~g} / \mathrm{s} \\
u_{1}=35,32 & \mathrm{~m} / \mathrm{s} \\
P_{1}=52,4 & \mathrm{kPa}
\end{array}
$$

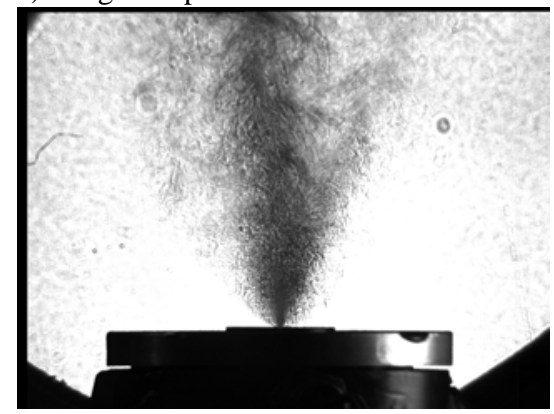

b) Imagem da $2^{\mathrm{a}}$. câmara CCD.

* a segunda imagem destaca bem o núcleo de líquido.

\section{0}

(bocal rugoso; 0,3 $\mathrm{mm}$ )

$$
\begin{array}{rlr}
P_{0} & =503,4 & \mathrm{kPa} \\
T_{0} & =95,4 & { }^{\circ} \mathrm{C} \\
P_{\infty} & =0,96 & \mathrm{kPa} \\
P_{\text {sat }} & =90,7 & \mathrm{kPa} \\
R_{\mathrm{p}} & =94,9 & \\
\dot{m} & =1,6528 & \mathrm{~g} / \mathrm{s} \\
u_{1}=35,33 & \mathrm{~m} / \mathrm{s} \\
P_{1}=53,6 & \mathrm{kPa}
\end{array}
$$

a) Imagem representativa.

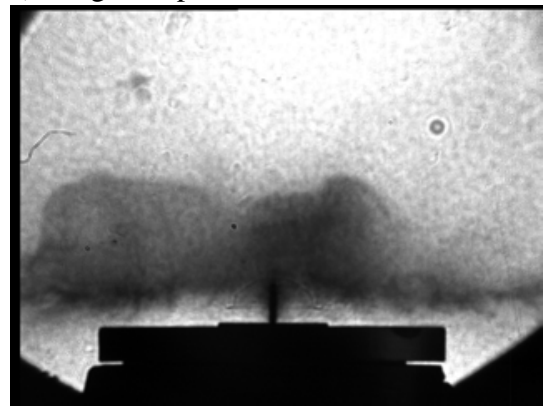

b) Imagem da $2^{\mathrm{a}}$. câmara CCD.

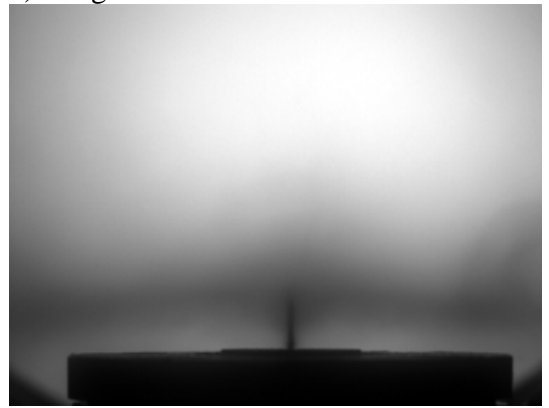

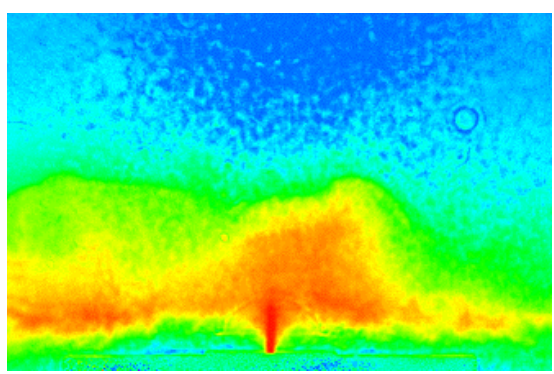

c) Imagem "a” tratada (mapa de cores: hsv). 


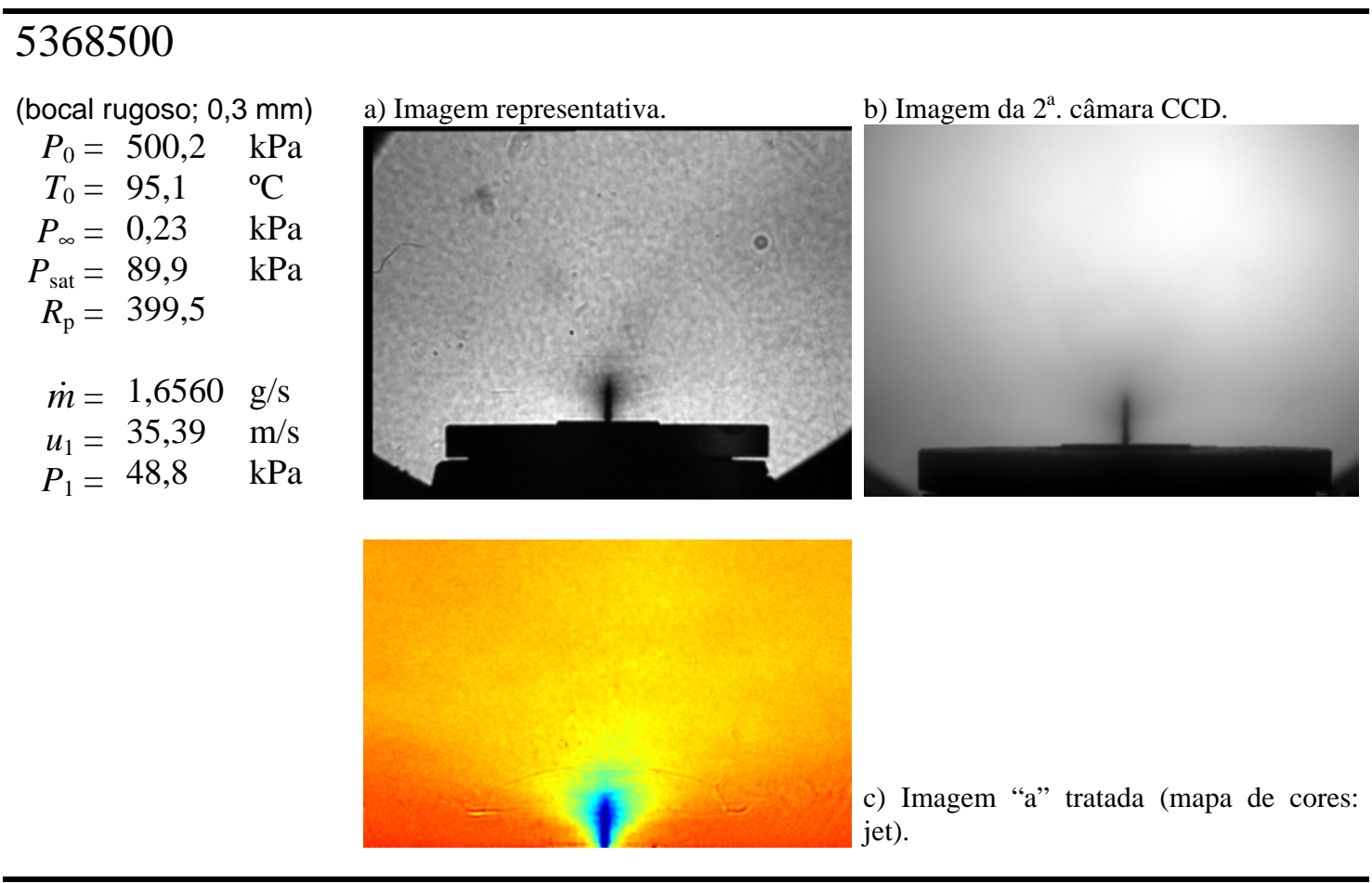

\section{$5368 \mathrm{~m} 10$}

(bocal rugoso; 0,3 $\mathrm{mm}$ )

$P_{0}=501,3 \quad \mathrm{kPa}$

$T_{0}=95,2 \quad{ }^{\circ} \mathrm{C}$

$P_{\infty}=0,19 \quad \mathrm{kPa}$

$P_{\text {sat }}=90,2 \quad \mathrm{kPa}$

$R_{\mathrm{p}}=474,5$

$\dot{m}=1,6012 \mathrm{~g} / \mathrm{s}$

$u_{1}=34,22 \mathrm{~m} / \mathrm{s}$

$P_{1}=78,6 \quad \mathrm{kPa}$

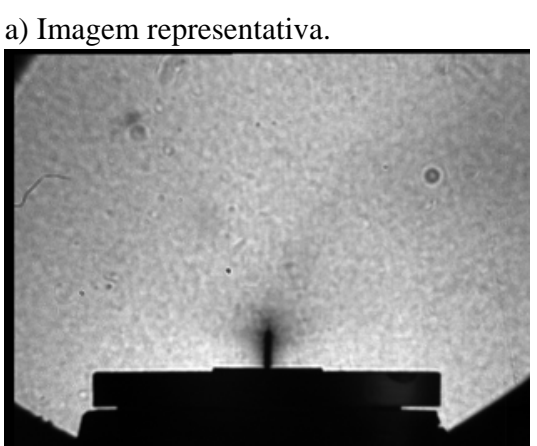

b) Imagem da $2^{\mathrm{a}}$. câmara CCD.

c) Imagem "a” tratada (mapa de cores: gray).

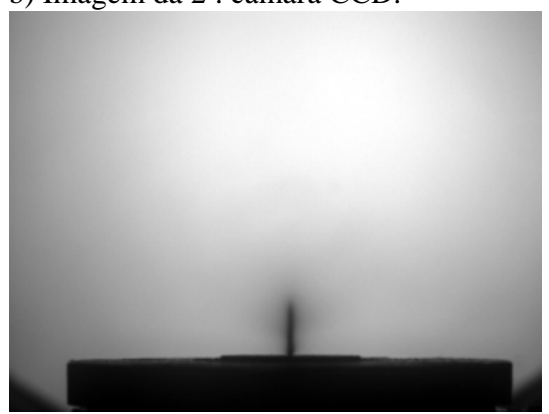

d) Imagem "a” tratada (mapa de cores: arcir).

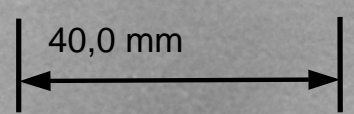

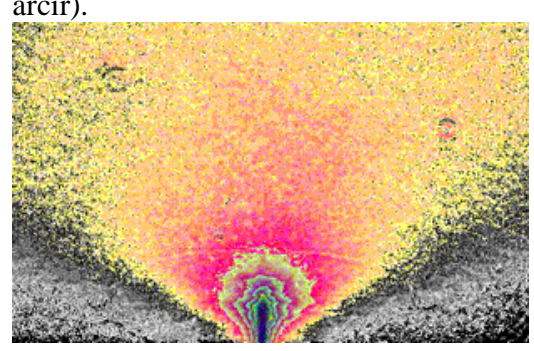




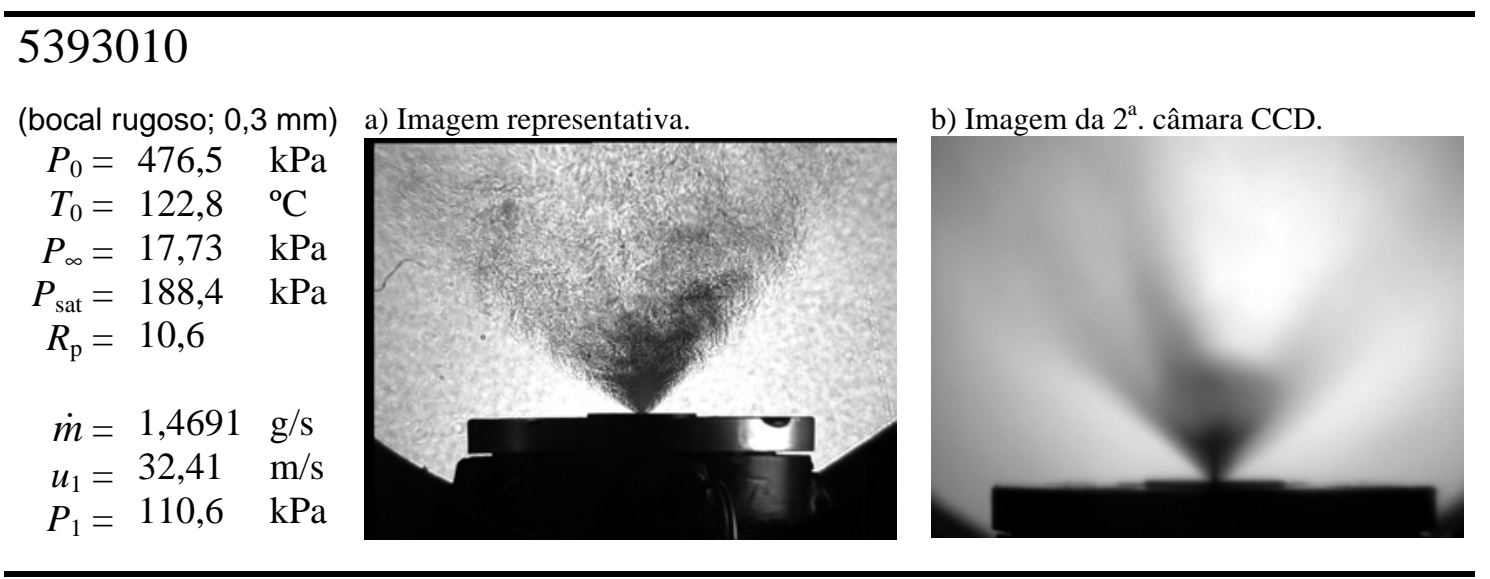

\section{0}

(bocal rugoso; 0,3 $\mathrm{mm}$ ) a) Imagem representativa.

$$
\begin{array}{rlrl}
P_{0} & =485,3 & \mathrm{kPa} \\
T_{0} & =122,6 & { }^{\circ} \mathrm{C} \\
P_{\infty} & =1,70 & \mathrm{kPa} \\
P_{\text {sat }} & =187,5 & \mathrm{kPa} \\
R_{\mathrm{p}} & =110,6 & \\
\dot{m} & =1,4173 & \mathrm{~g} / \mathrm{s} \\
u_{1}=31,26 & \mathrm{~m} / \mathrm{s} \\
P_{1}=144,3 & \mathrm{kPa}
\end{array}
$$
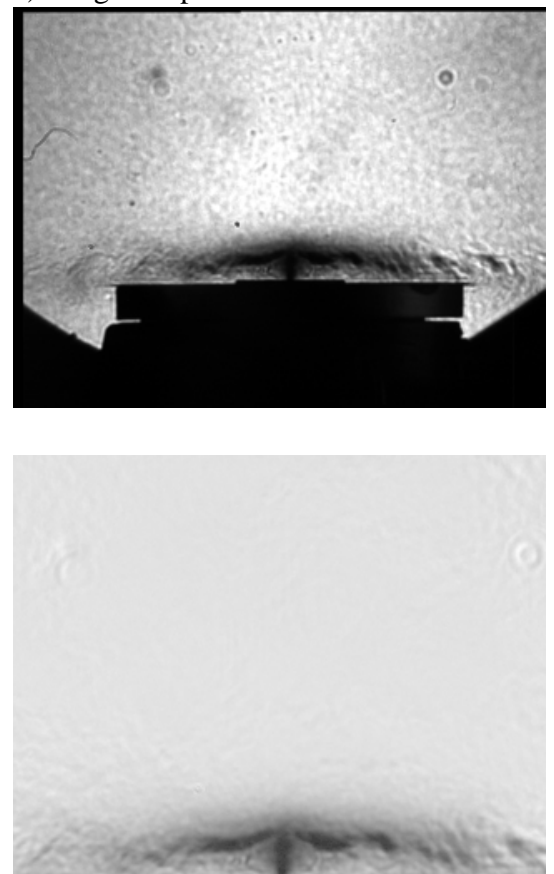

b) Imagem da $2^{\mathrm{a}}$. câmara CCD.

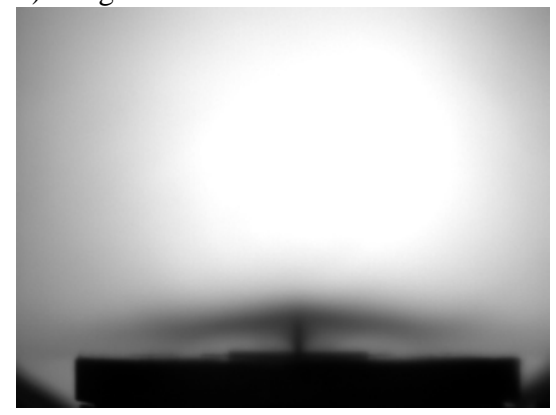

c) Imagem tratada (mapa de cores: gray). 

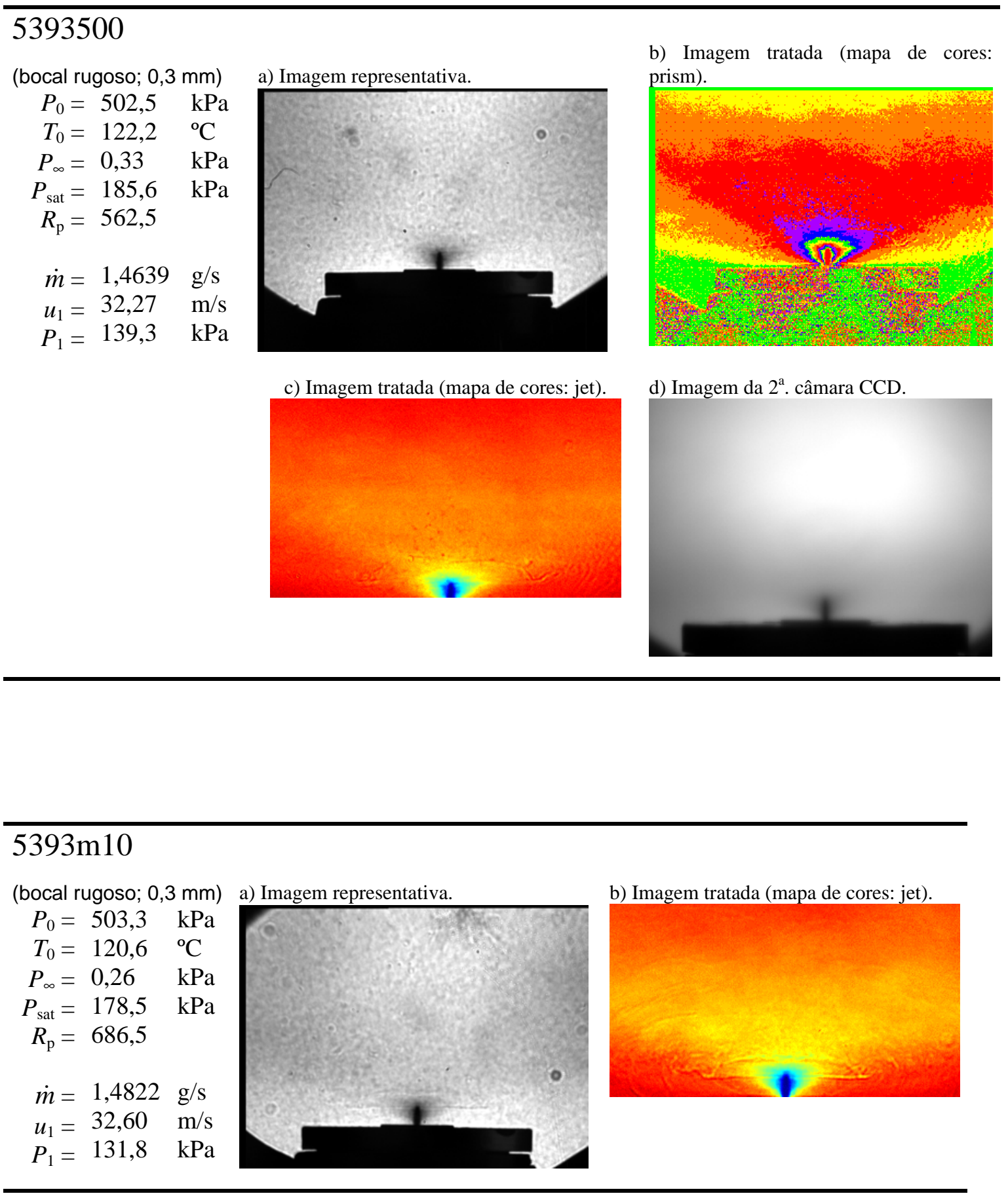


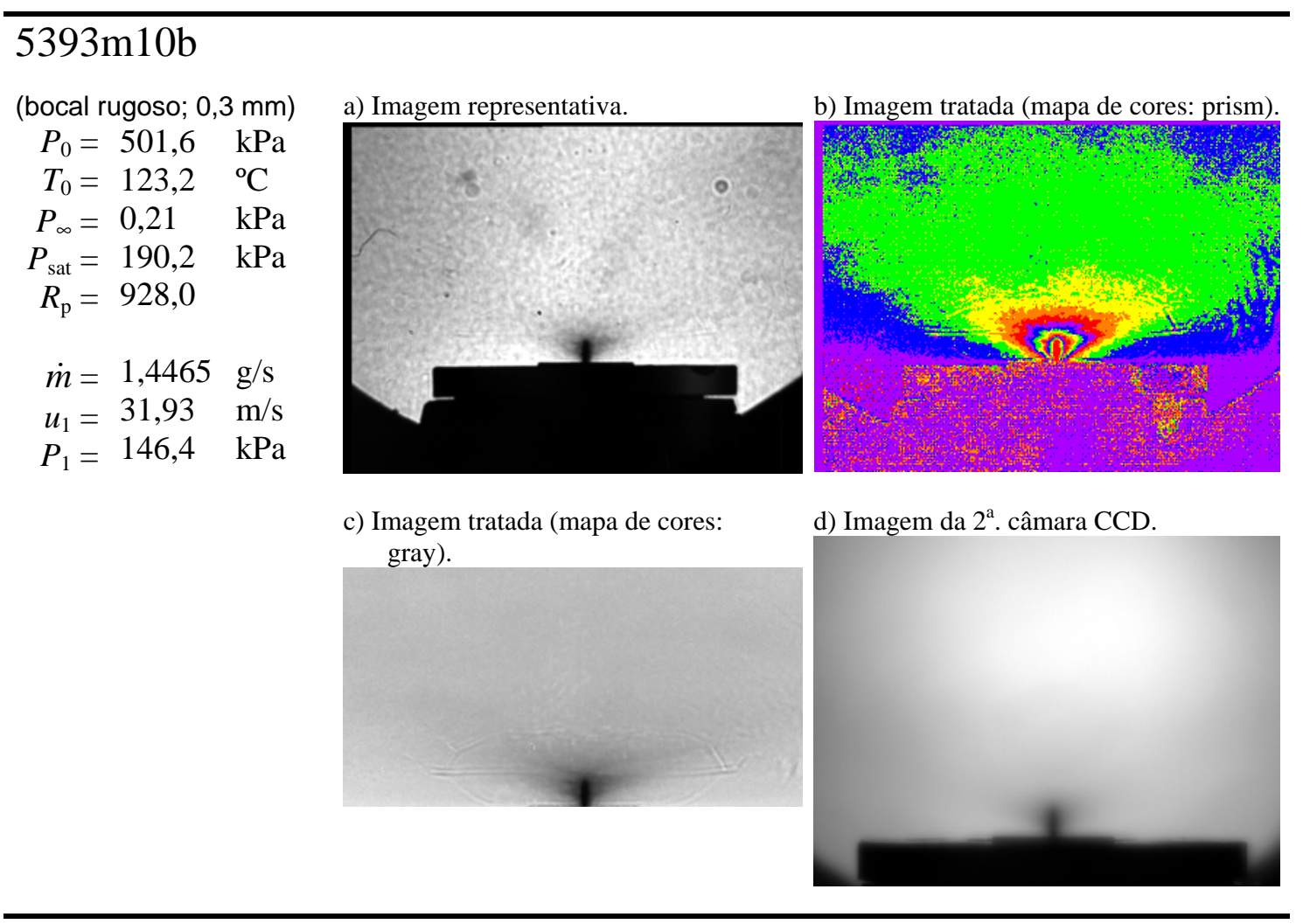

\section{Série de ensaios: RUN3}

Esta série de ensaio se destaca pela padronização da iluminação da segunda câmara cuja fonte é uma lâmpada dicróica de 250 W, e que fica atrás do ponto de observação à distância de 500 mm. Também foi feita a implantação de um adaptador que afasta a janela em $100 \mathrm{~mm}$ do injetor e proporcionou imagens muito mais nítidas deste ponto de observação, pois havia uma condensação de gotículas nesta janela. Além disso, foi implementada a utilização do sensor de vácuo que proporcionou o registro através da placa de aquisição de dados. 
Quanto ao método de iluminação por detrás, foi feito um aumento do foco do jato e foi retirada a placa de acrílico leitosa que tornava difusa a iluminação. Isto proporcionou uma tonalidade clara ao núcleo líquido. Neste método óptico, a referência da escala dimensional da imagem da segunda câmara ficou na distância que existe entre a borda do bocal até o seu centro, na saída do jato, conforme é exemplificado no ensaio 1329002, a seguir.

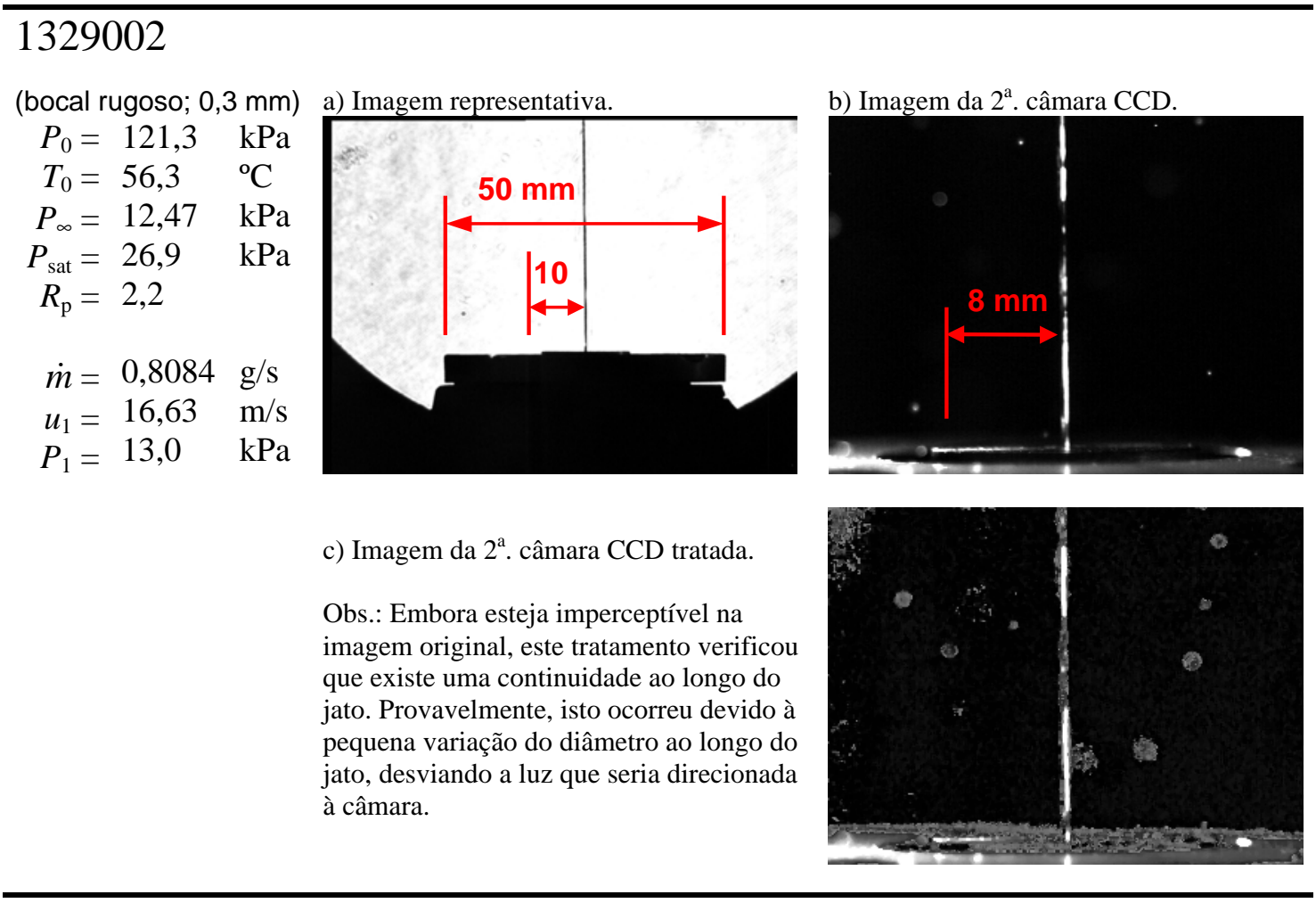




\section{0}

(bocal rugoso; 0,3 $\mathrm{mm}$ )

a) Imagem representativa.

$$
\begin{array}{rlrl}
P_{0} & =122,1 & \mathrm{kPa} \\
T_{0} & =56,4 & & { }^{\circ} \mathrm{C} \\
P_{\infty} & =0,49 & \mathrm{kPa} \\
P_{\text {sat }} & =27,0 & \mathrm{kPa} \\
R_{\mathrm{p}} & =54,6 & & \\
\dot{m} & =0,8447 & \mathrm{~g} / \mathrm{s} \\
u_{1}=17,37 & \mathrm{~m} / \mathrm{s} \\
P_{1}=4,2 & \mathrm{kPa}
\end{array}
$$

Obs: A imagem da $2^{\mathrm{a}}$. câmara mostra que a onda de evaporação ocorre 1,5 mm após sair do bocal. $\mathrm{Na}$ imagem tratada ao lado, é observado que a onda de choque inicia no local da formação da onda de evaporação e, praticamente paralela à parede externa do bocal.

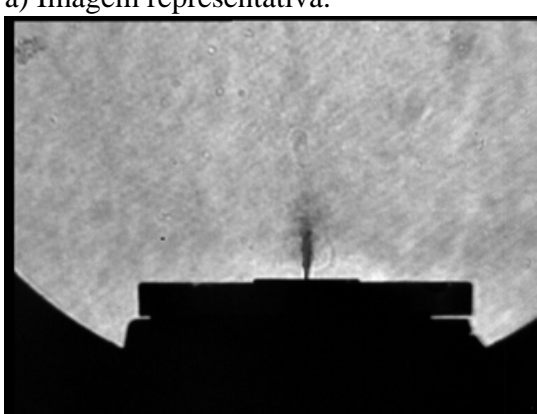

c) Imagem tratada (mapa de cores: gray).

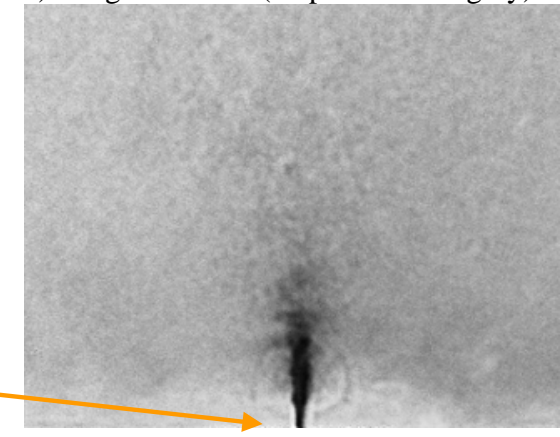

b) Imagem da $2^{a}$. câmara CCD.

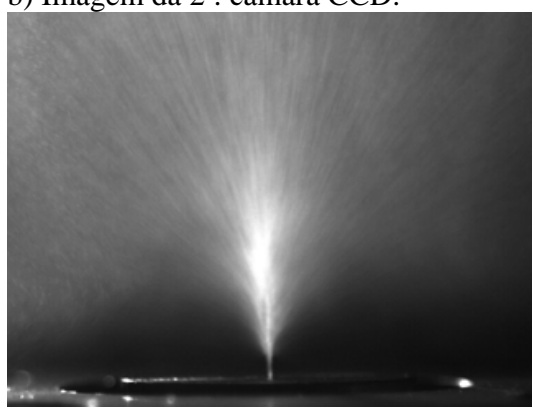

d) Combinação das imagens "b” e "c".

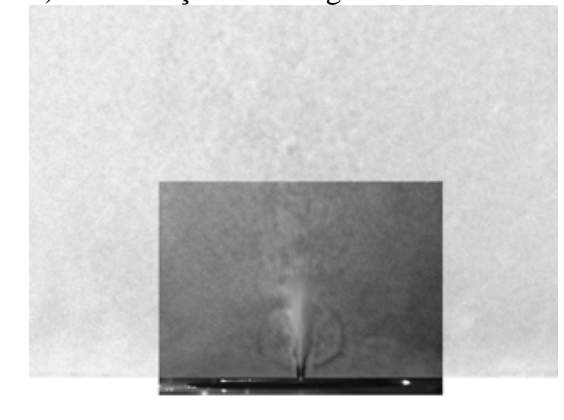

\section{0}

$\begin{array}{rll}\text { (bocal rugoso; } 0,3 \mathrm{~mm} \text { ) } \\ P_{0}=123,0 & \mathrm{kPa} \\ T_{0}=56,5 & { }^{\circ} \mathrm{C} \\ P_{\infty} & =0,14 & \mathrm{kPa} \\ P_{\text {sat }} & =27,1 & \mathrm{kPa} \\ R_{\mathrm{p}} & =191,0 & \\ & & \\ \dot{m} & =0,8532 & \mathrm{~g} / \mathrm{s} \\ u_{1} & =17,55 & \mathrm{~m} / \mathrm{s} \\ P_{1} & =2,8 & \mathrm{kPa}\end{array}$

a) Imagem representativa.

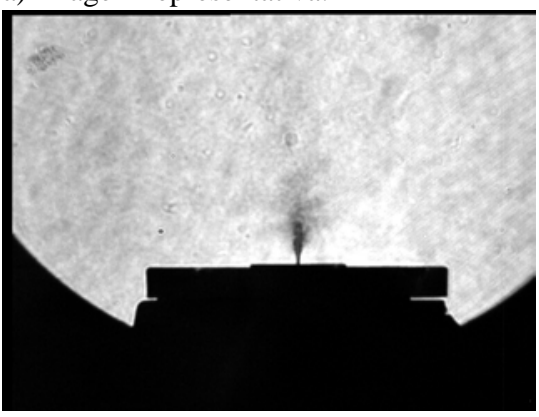

b) Imagem da 2a . câmara CCD.

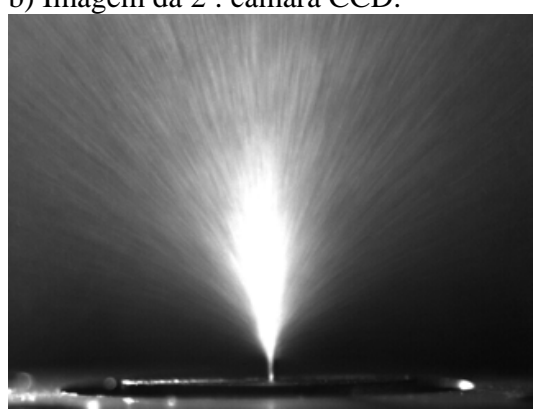

c) Imagem tratada (mapa de cores: gray).

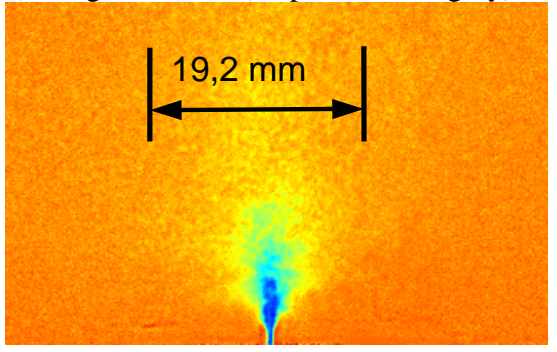




$$
\begin{array}{rlr}
P_{0} & =128,0 & \mathrm{kPa} \\
T_{0}=76,3 & { }^{\circ} \mathrm{C} \\
P_{\infty}=24,47 & \mathrm{kPa} \\
P_{\text {sat }}=50,4 & \mathrm{kPa} \\
R_{\mathrm{p}}=2,1 & \\
\dot{m}=0,7716 & \mathrm{~g} / \mathrm{s} \\
u_{1}=16,20 & \mathrm{~m} / \mathrm{s} \\
P_{1}=28,1 & \mathrm{kPa}
\end{array}
$$

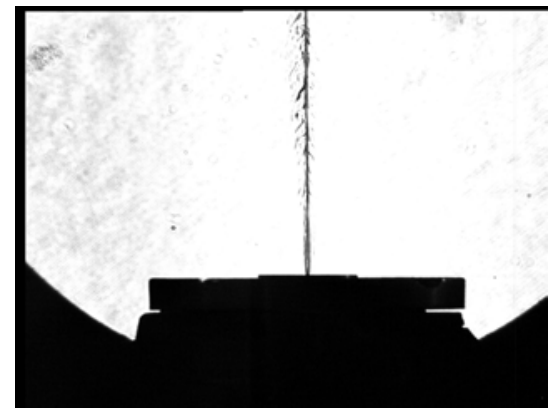

\begin{tabular}{|c|c|c|}
\hline 1349100 & & \\
\hline (bocal rugoso; 0 & $3 \mathrm{~mm})$ & \\
\hline$P_{0}=124,7$ & $\mathrm{kPa}$ & \\
\hline$T_{0}=76,9$ & ${ }^{\circ} \mathrm{C}$ & \\
\hline$P_{\infty}=0,45$ & $\mathrm{kPa}$ & \\
\hline$P_{\text {sat }}=51,4$ & $\mathrm{kPa}$ & \\
\hline$R_{\mathrm{p}}=114,1$ & & $\begin{array}{l}\text { - Não foi obtido sucesso na } \\
\text { aquisição das imagens. }\end{array}$ \\
\hline$\dot{m}=0,8234$ & $\mathrm{~g} / \mathrm{s}$ & \\
\hline$u_{1}=17,29$ & $\mathrm{~m} / \mathrm{s}$ & \\
\hline$P_{1}=11,3$ & $\mathrm{kPa}$ & \\
\hline
\end{tabular}

c) Imagem da $2^{\mathrm{a}}$. câmara CCD tratada. Neste caso, também foi possível processada matematicamente a imagem para realçar que o filete do jato que não sofre descontinuidade.
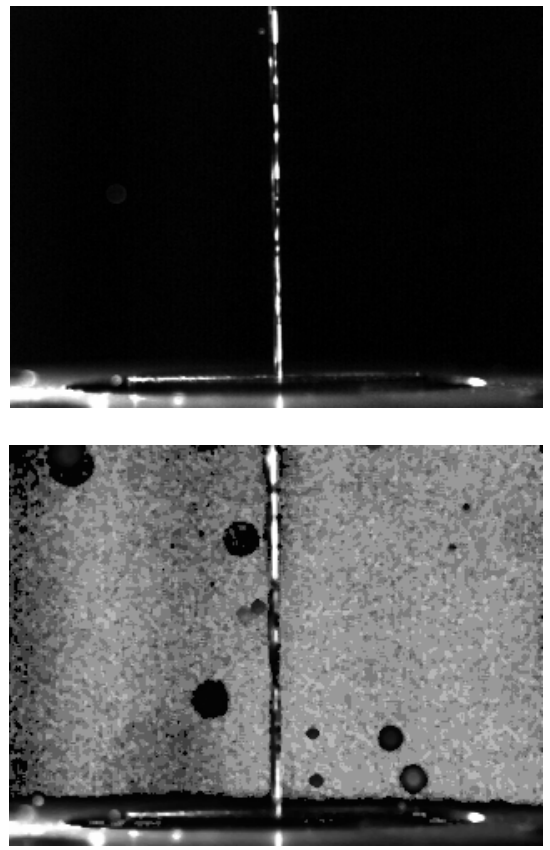

\section{0b}

(bocal rugoso; 0,3 $\mathrm{mm}$ )

a) Imagem representativa.

b) Imagem tratada (mapa de cores: rand). 


$$
\begin{array}{rlrl}
P_{0} & =124,0 & \mathrm{kPa} \\
T_{0} & =77,3 & { }^{\circ} \mathrm{C} \\
P_{\infty} & =0,53 & \mathrm{kPa} \\
P_{\text {sat }} & =52,0 & \mathrm{kPa} \\
R_{\mathrm{p}} & =98,0 & \\
\dot{m}=-- & \mathrm{g} / \mathrm{s} \\
u_{1}=-- & \mathrm{m} / \mathrm{s} \\
P_{1}=-- & \mathrm{kPa}
\end{array}
$$
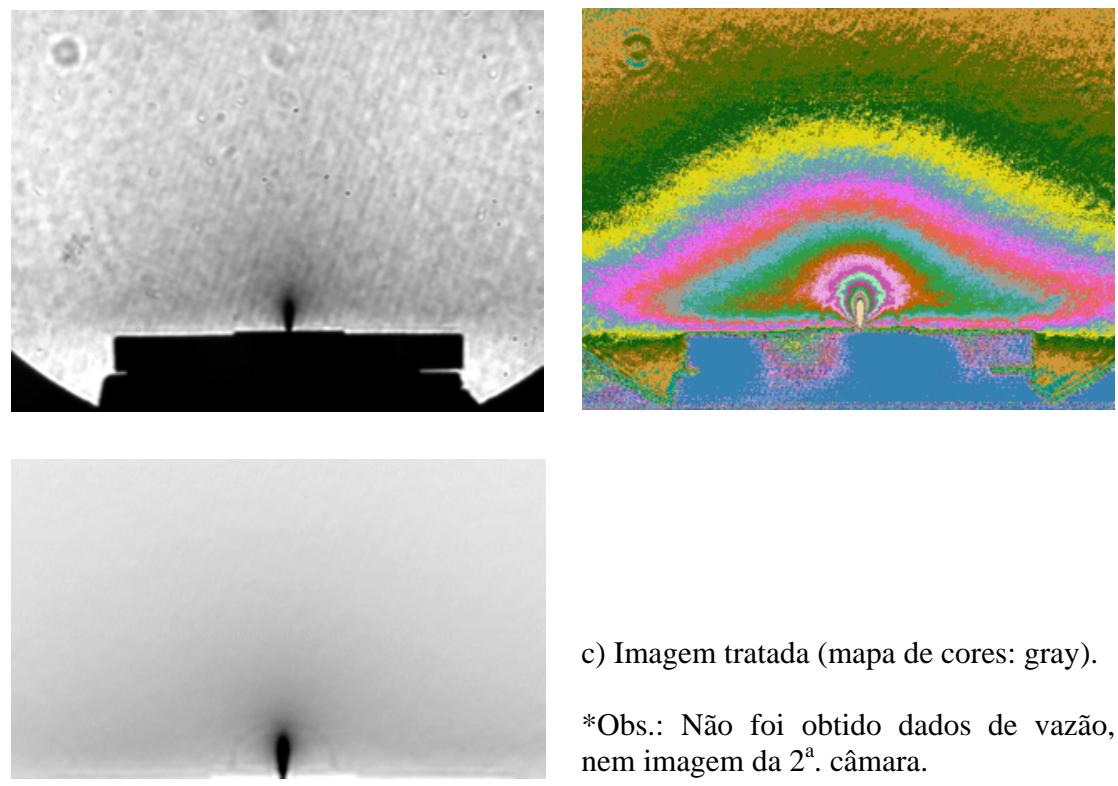

c) Imagem tratada (mapa de cores: gray).

*Obs.: Não foi obtido dados de vazão, nem imagem da $2^{\mathrm{a}}$. câmara.

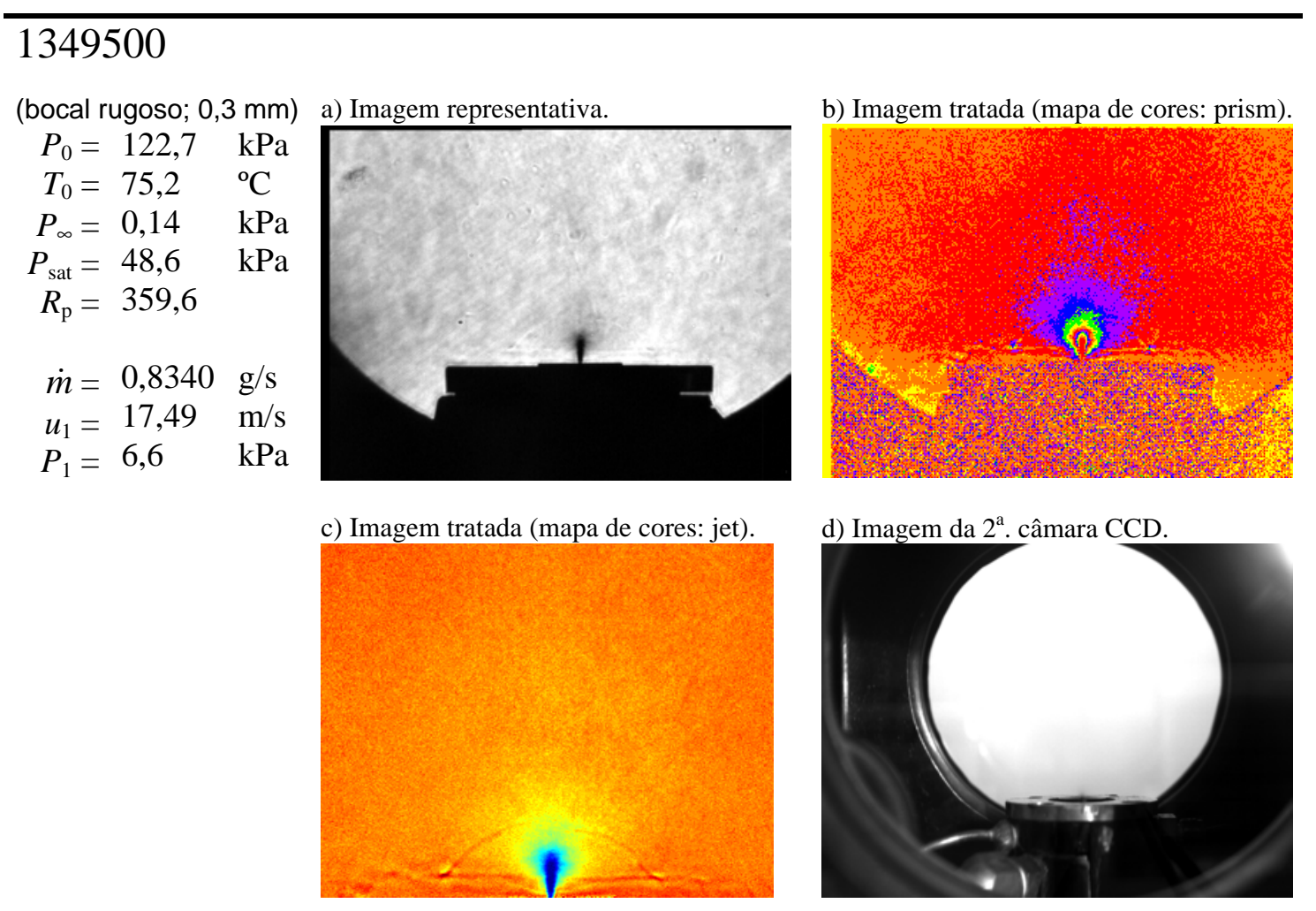

1368002

(bocal rugoso; 0,3 mm) a) Imagem representativa.

b) Imagem da $2^{\mathrm{a}}$. câmara CCD. 


$$
\begin{array}{rlr}
P_{0} & =123,5 & \mathrm{kPa} \\
T_{0} & =92,6 & { }^{\circ} \mathrm{C} \\
P_{\infty} & =44,00 & \mathrm{kPa} \\
P_{\text {sat }} & =83,6 & \mathrm{kPa} \\
R_{\mathrm{p}} & =1,9 & \\
\dot{m} & =0,6941 & \mathrm{~g} / \mathrm{s} \\
u_{1} & =14,80 & \mathrm{~m} / \mathrm{s} \\
P_{1} & =41,5 & \mathrm{kPa}
\end{array}
$$
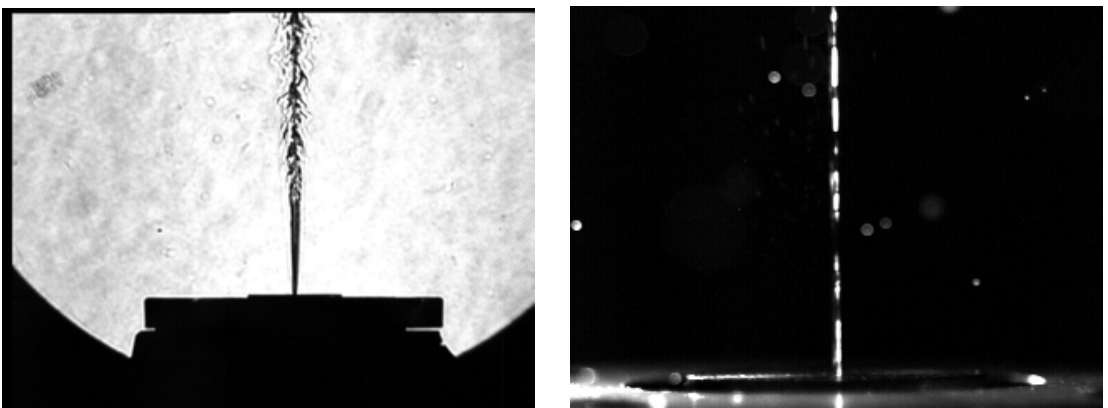

c) Imagem da $2^{\mathrm{a}}$. câmara CCD tratada.

Obs.: Embora esteja imperceptível na imagem original, este tratamento verificou que existe uma continuidade ao longo do jato.

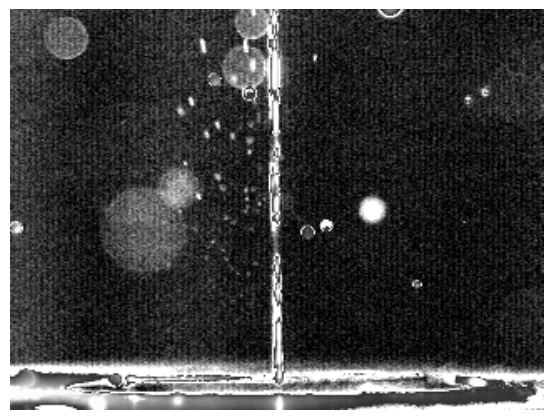

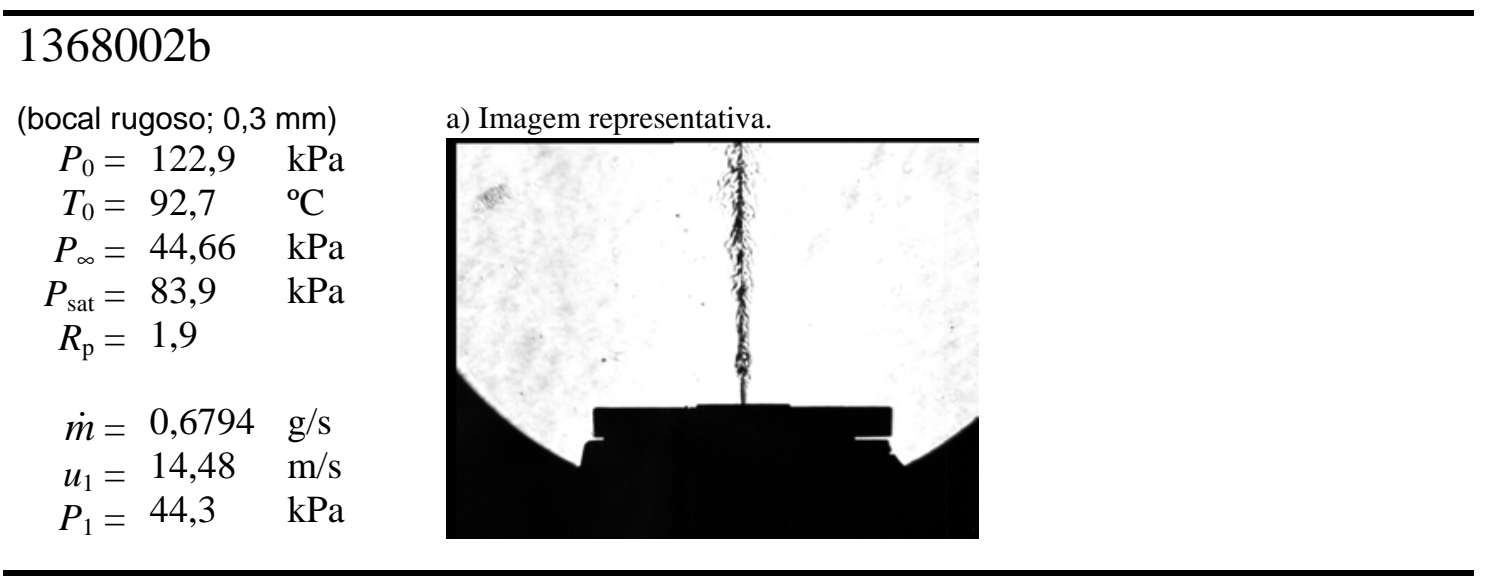

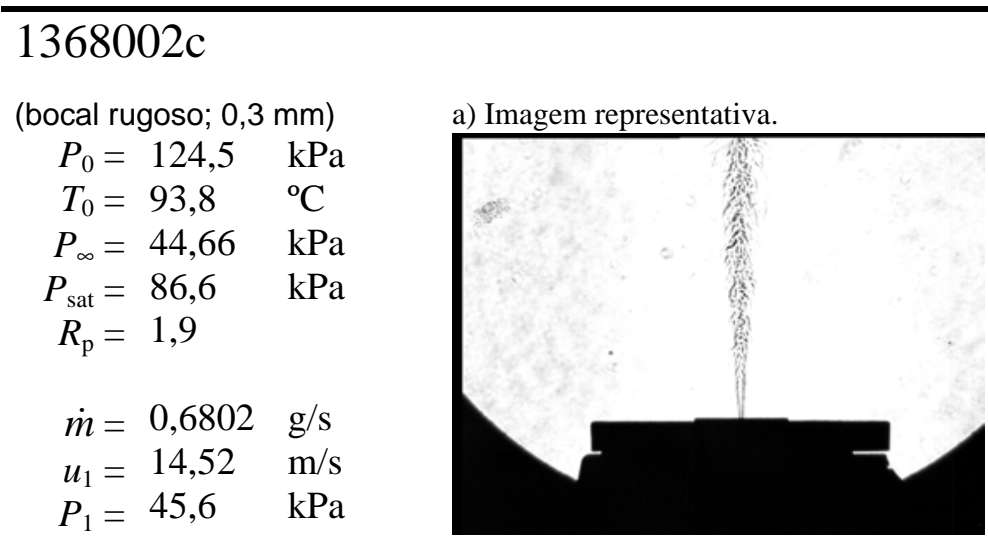




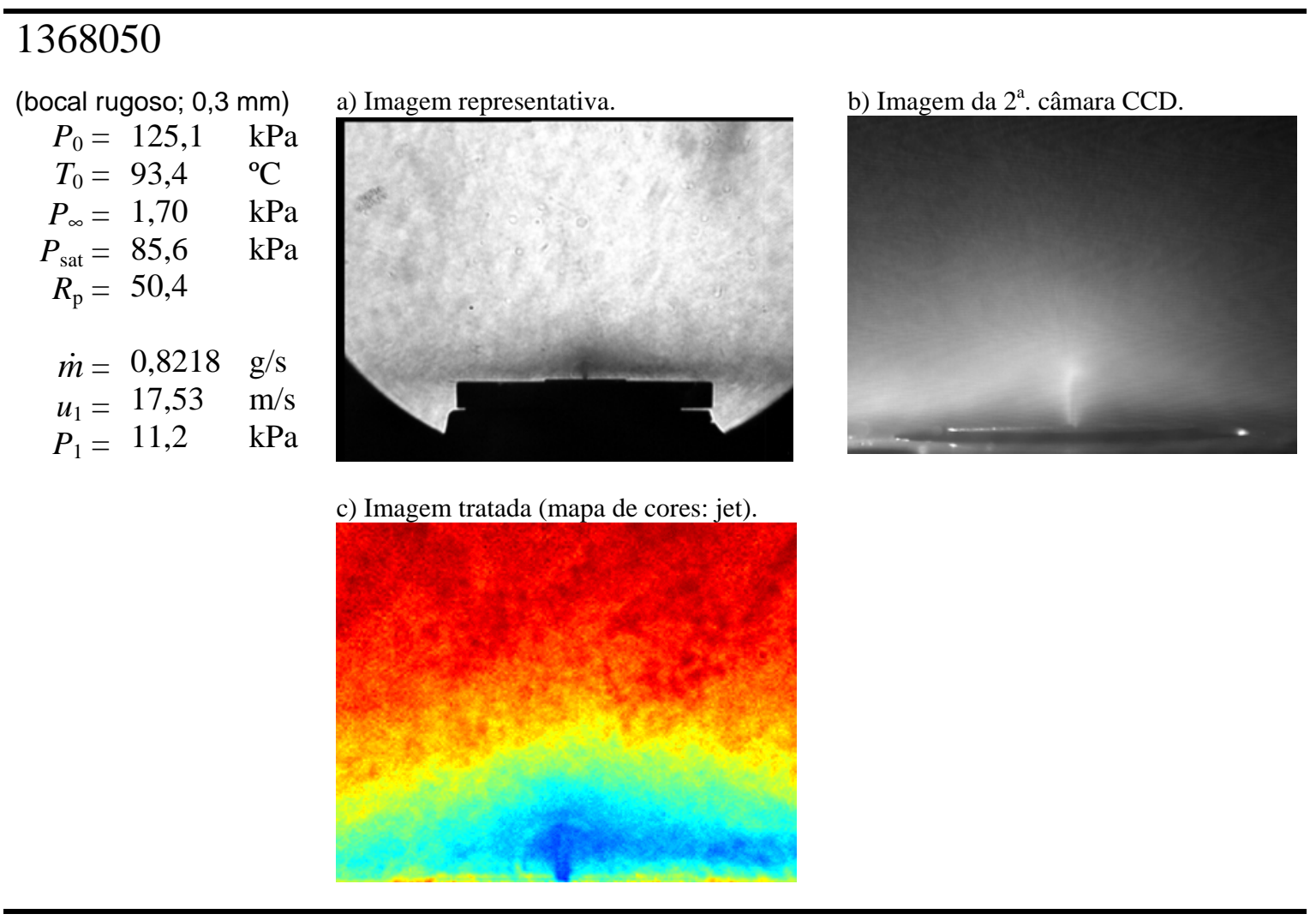

\section{0}

(bocal rugoso; 0,3 $\mathrm{mm}$ ) a) Imagem representativa. $P_{0}=123,5 \quad \mathrm{kPa}$

$T_{0}=94,8 \quad{ }^{\circ} \mathrm{C}$

$P_{\infty}=0,15 \quad \mathrm{kPa}$

$P_{\text {sat }}=89,2 \quad \mathrm{kPa}$

$R_{\mathrm{p}}=582,8$

$\dot{m}=0,8022 \mathrm{~g} / \mathrm{s}$

$u_{1}=17,14$

$P_{1}=14,7$

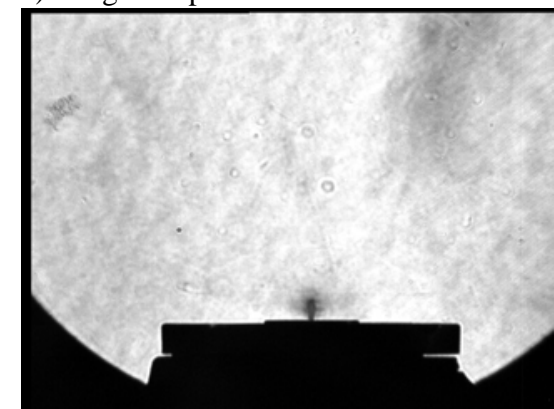

b) Imagem da $2^{\mathrm{a}}$. câmara CCD.

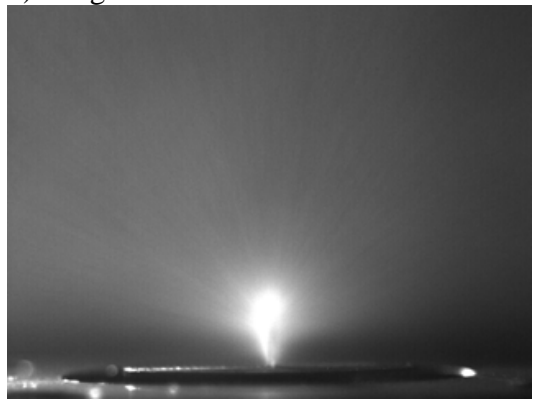

c) Imagem tratada (mapa de cores: jet).

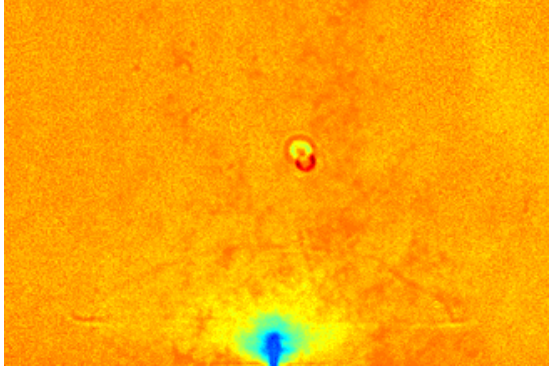



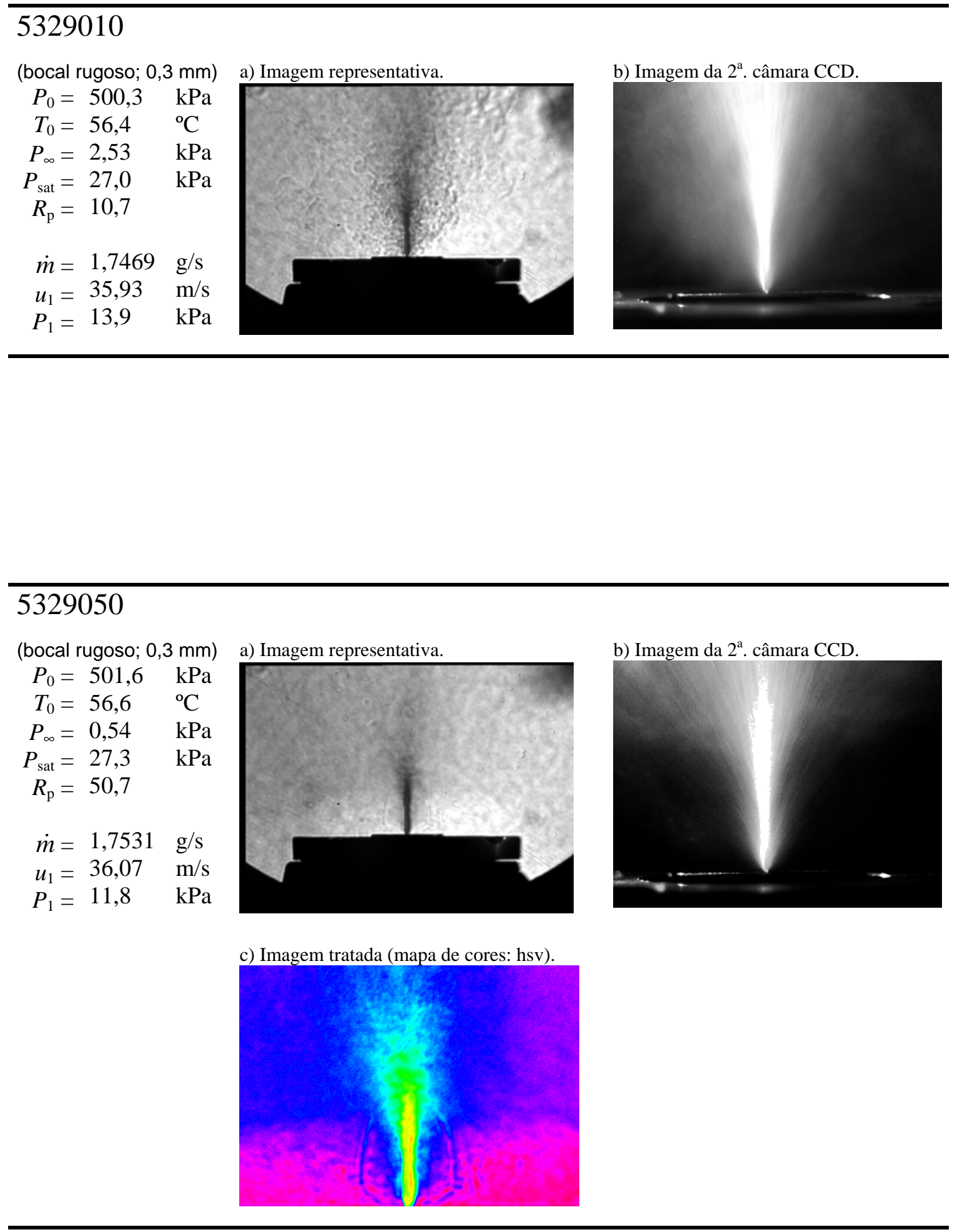


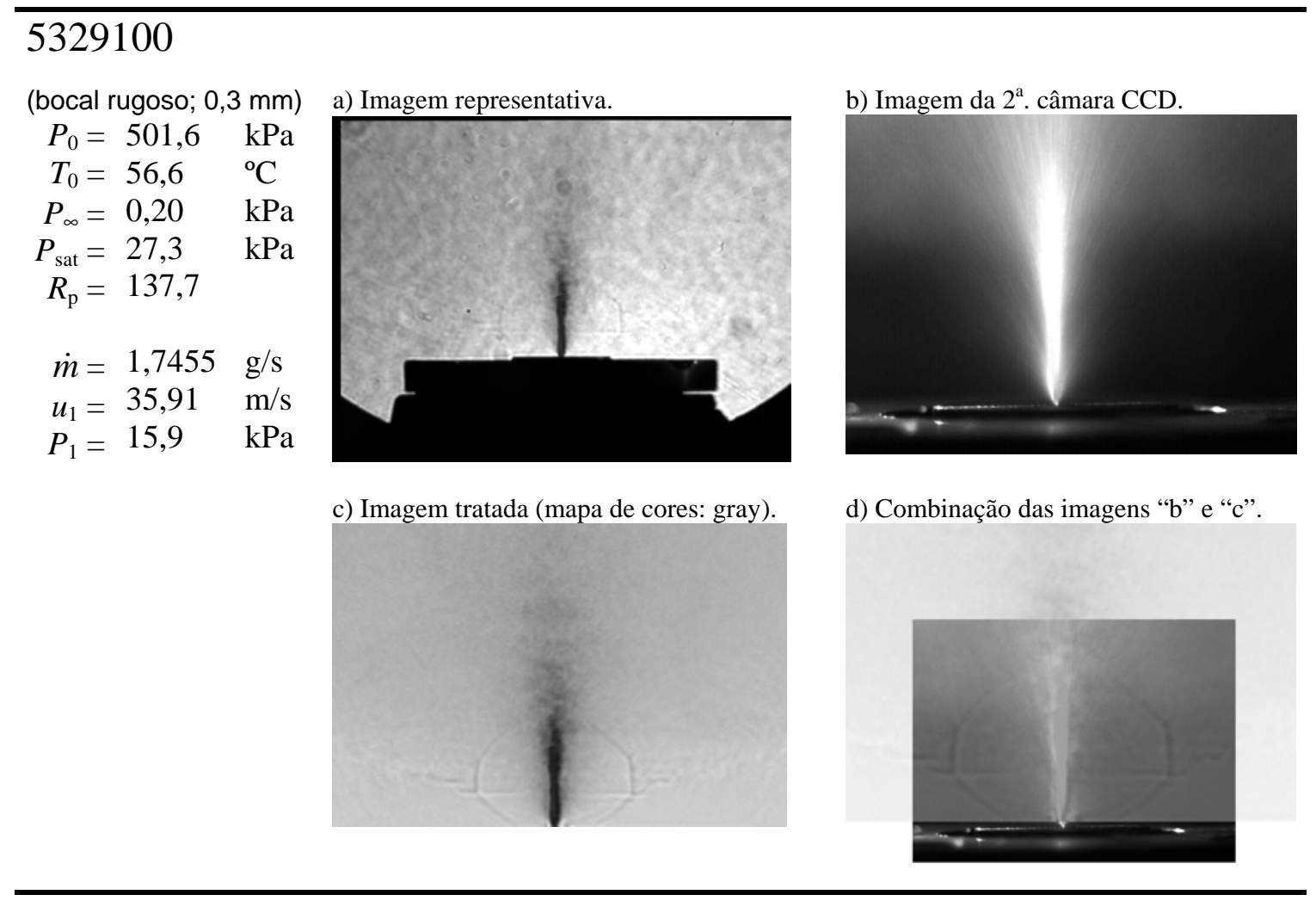

\begin{tabular}{rl}
\hline 5329500 & \\
(bocal rugoso; $0,3 \mathrm{~mm}$ ) \\
$P_{0}=504,1 \quad \mathrm{kPa}$ \\
$T_{0}=57,1 \quad{ }^{\circ} \mathrm{C}$ \\
$P_{\infty}=0,15$ & $\mathrm{kPa}$ \\
$P_{\text {sat }}=27,9$ & $\mathrm{kPa}$ \\
$R_{\mathrm{p}}=185,6$ & \\
$\dot{m}=1,7453$ & $\mathrm{~g} / \mathrm{s}$ \\
$u_{1}=35,93$ & $\mathrm{~m} / \mathrm{s}$ \\
$P_{1}=18,4$ & $\mathrm{kPa}$
\end{tabular}

a) Imagem representativa.

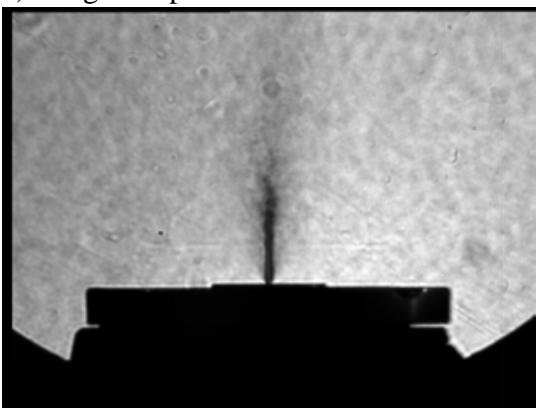

c) Imagem tratada (mapa de cores: hsv).

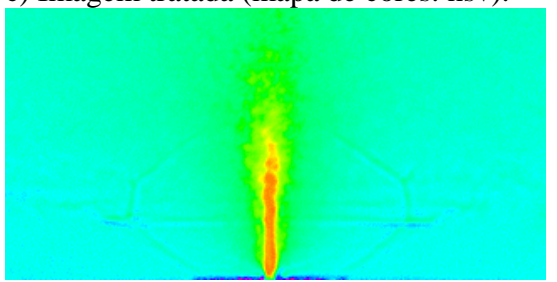

b) Imagem tratada (mapa de cores: prism).

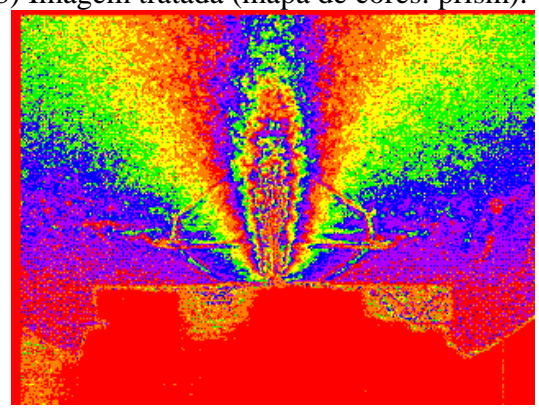

d) Imagem da $2^{a}$. câmara CCD.

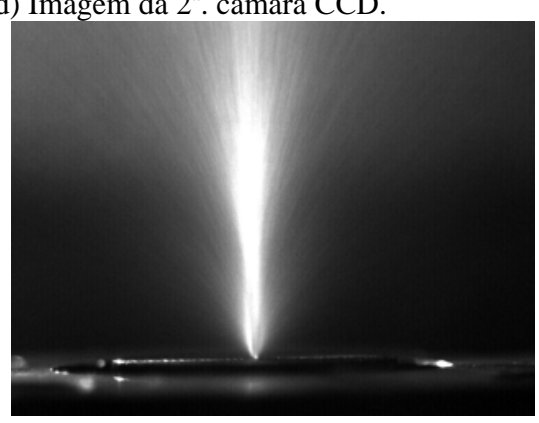




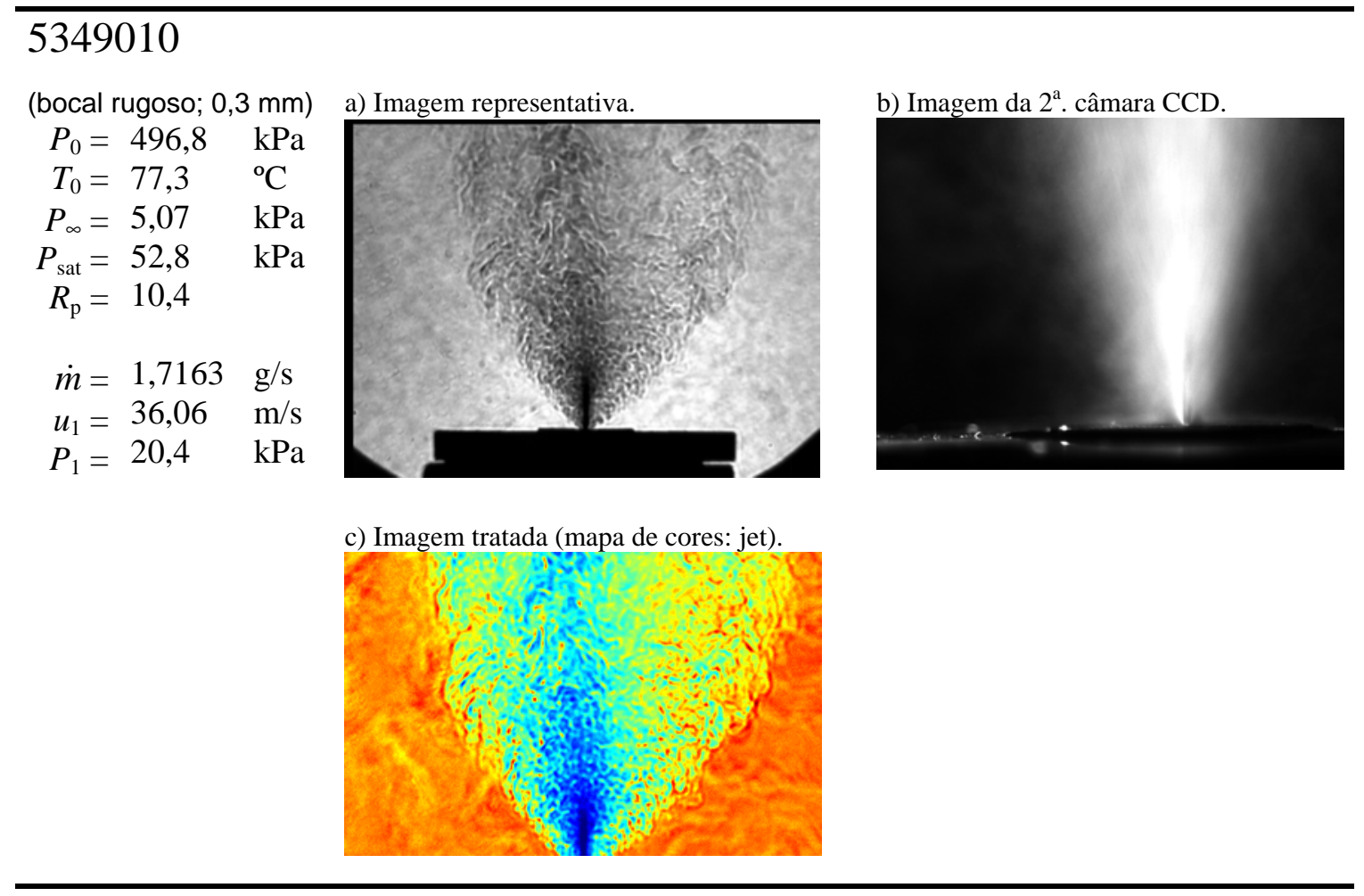

\section{0}

(bocal rugoso; 0,3 $\mathrm{mm}$ )

a) Imagem representativa.

$\begin{array}{rlrl}P_{0} & =501,9 & \mathrm{kPa} \\ T_{0} & =76,2 & { }^{\circ} \mathrm{C} \\ P_{\infty} & =0,93 & \mathrm{kPa} \\ P_{\text {sat }} & =50,2 & \mathrm{kPa} \\ R_{\mathrm{p}} & =54,2 & & \\ \dot{m} & =1,7079 & \mathrm{~g} / \mathrm{s} \\ u_{1}=35,85 & \mathrm{~m} / \mathrm{s} \\ P_{1}=30,4 & \mathrm{kPa}\end{array}$

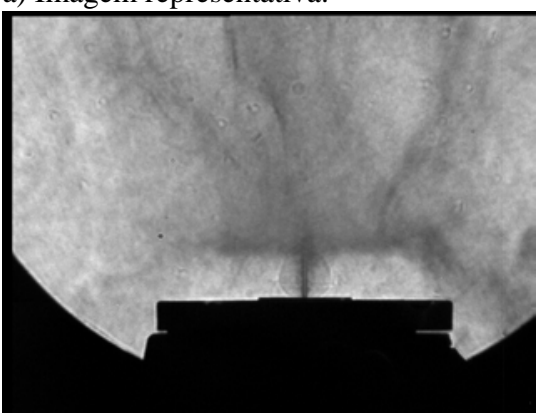

b) Imagem tratada (mapa de cores: prism).

b) Imagem tratada (mapa de cores: gray).
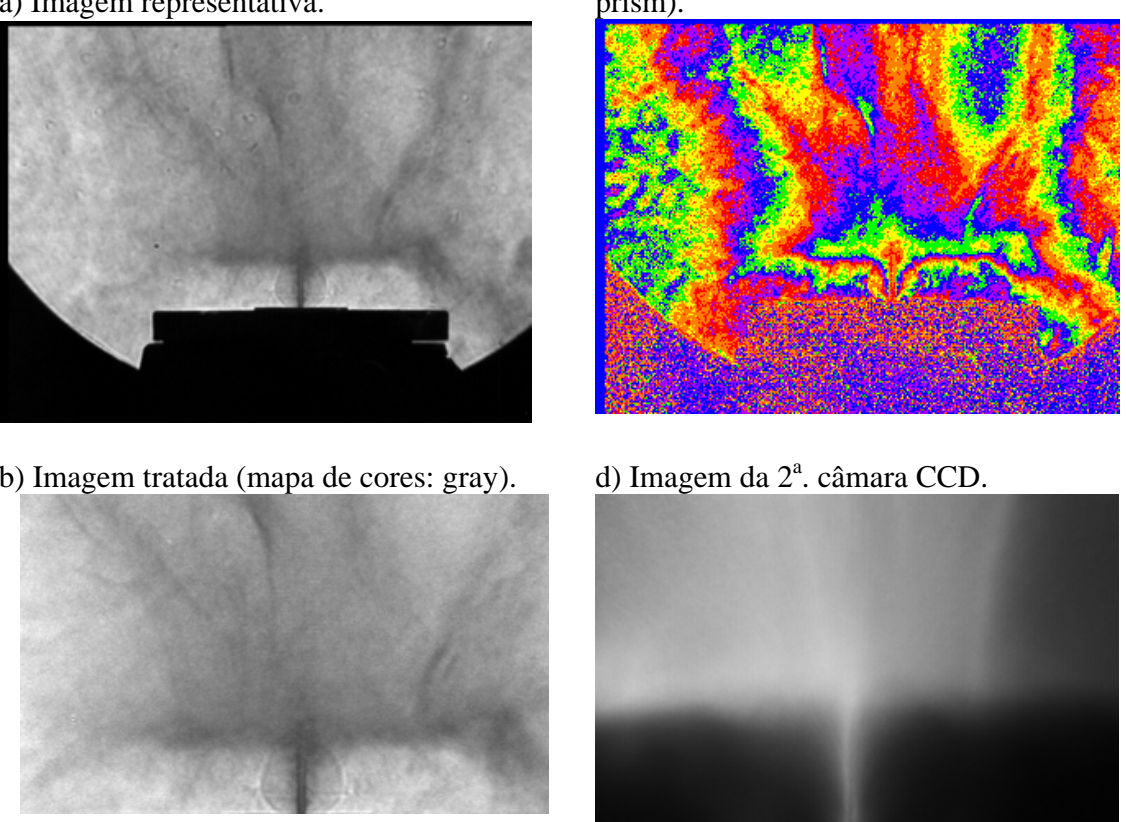

d) Imagem da $2^{\mathrm{a}}$. câmara CCD.

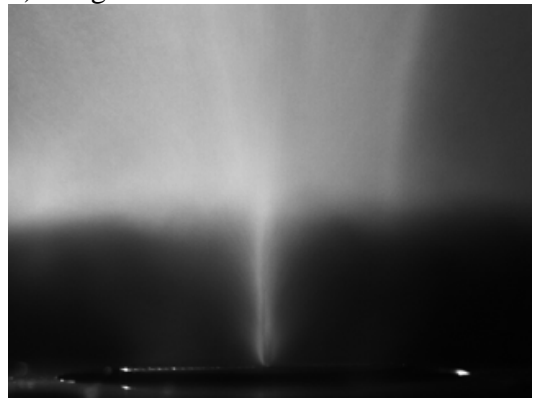



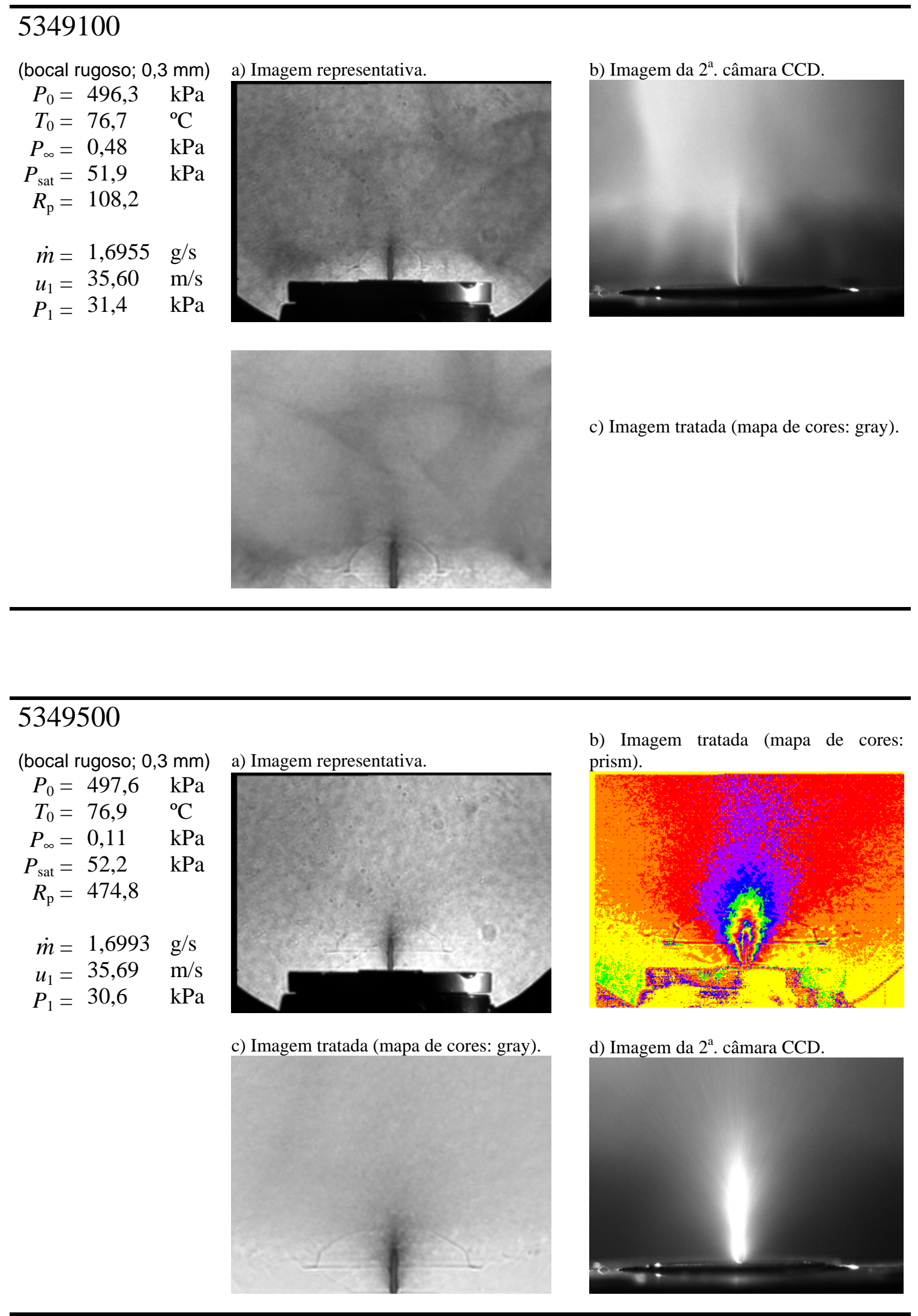

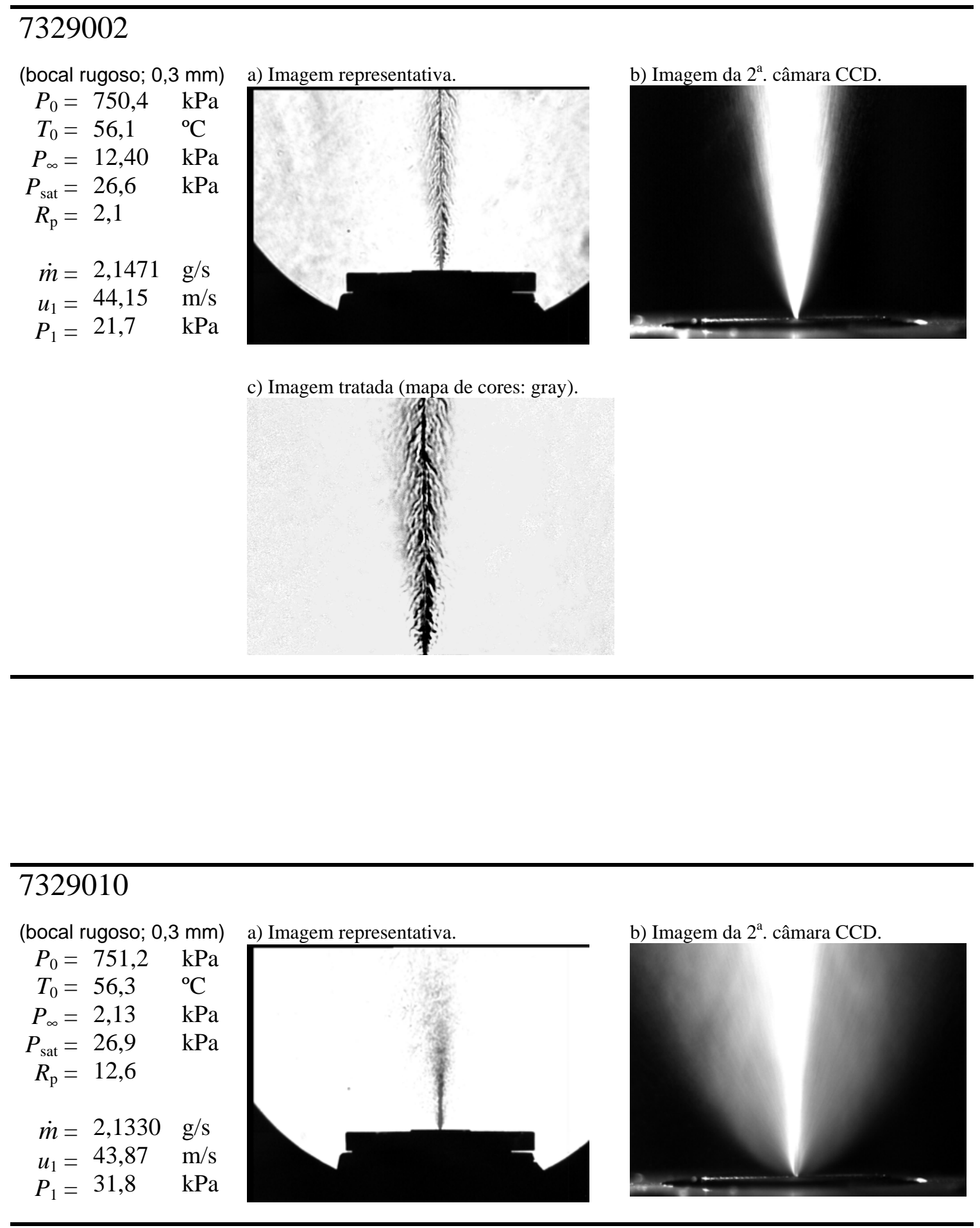


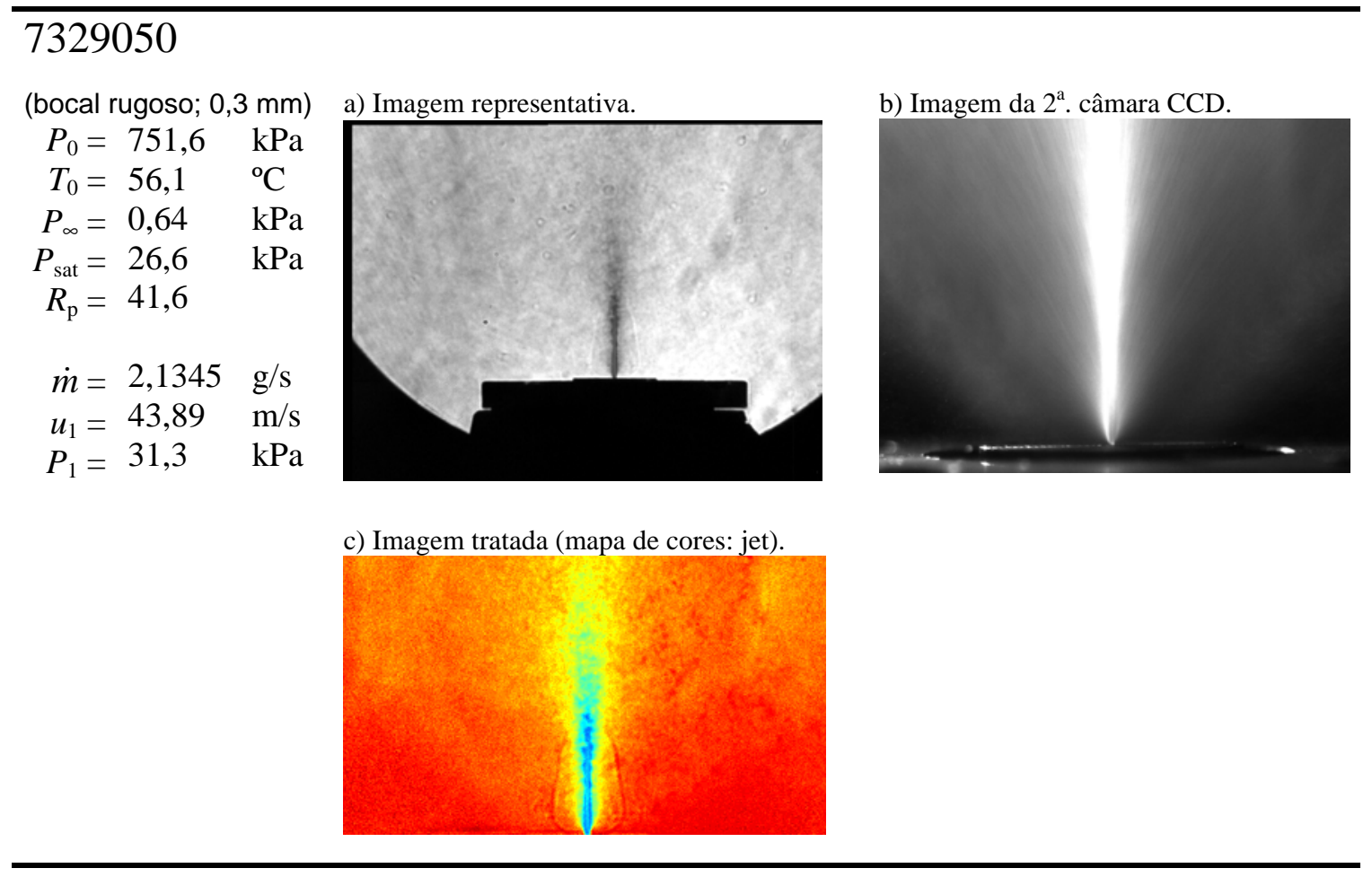

\section{0}

(bocal rugoso; 0,3 $\mathrm{mm}$ ) $P_{0}=751,1 \quad \mathrm{kPa}$

$T_{0}=56,4 \quad{ }^{\circ} \mathrm{C}$

$P_{\infty}=0,22 \quad \mathrm{kPa}$

$P_{\text {sat }}=27,0 \quad \mathrm{kPa}$

$R_{\mathrm{p}}=120,2$

$\dot{m}=2,1605 \mathrm{~g} / \mathrm{s}$

$u_{1}=44,44$

$P_{1}=13,3$

$\mathrm{m} / \mathrm{s}$

$\mathrm{kPa}$

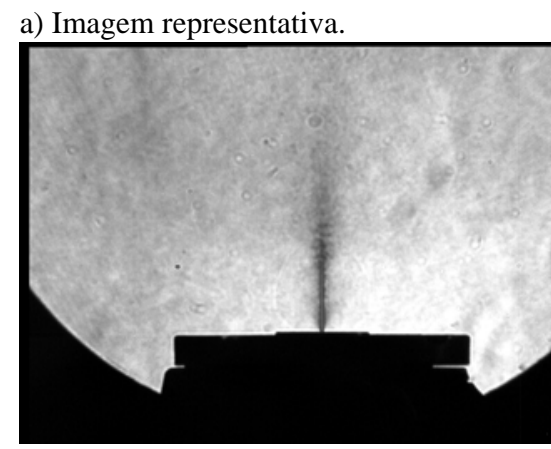

c) Imagem tratada (mapa de cores: jet). b) Imagem tratada (mapa de cores: prism).

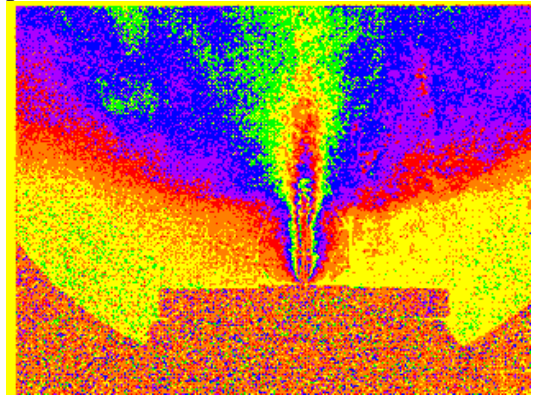

d) Imagem da $2^{\mathrm{a}}$. câmara CCD.
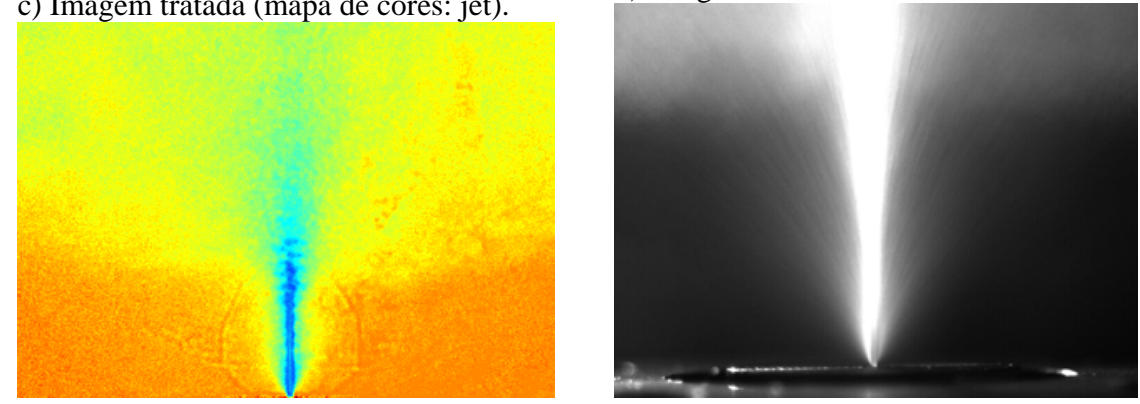


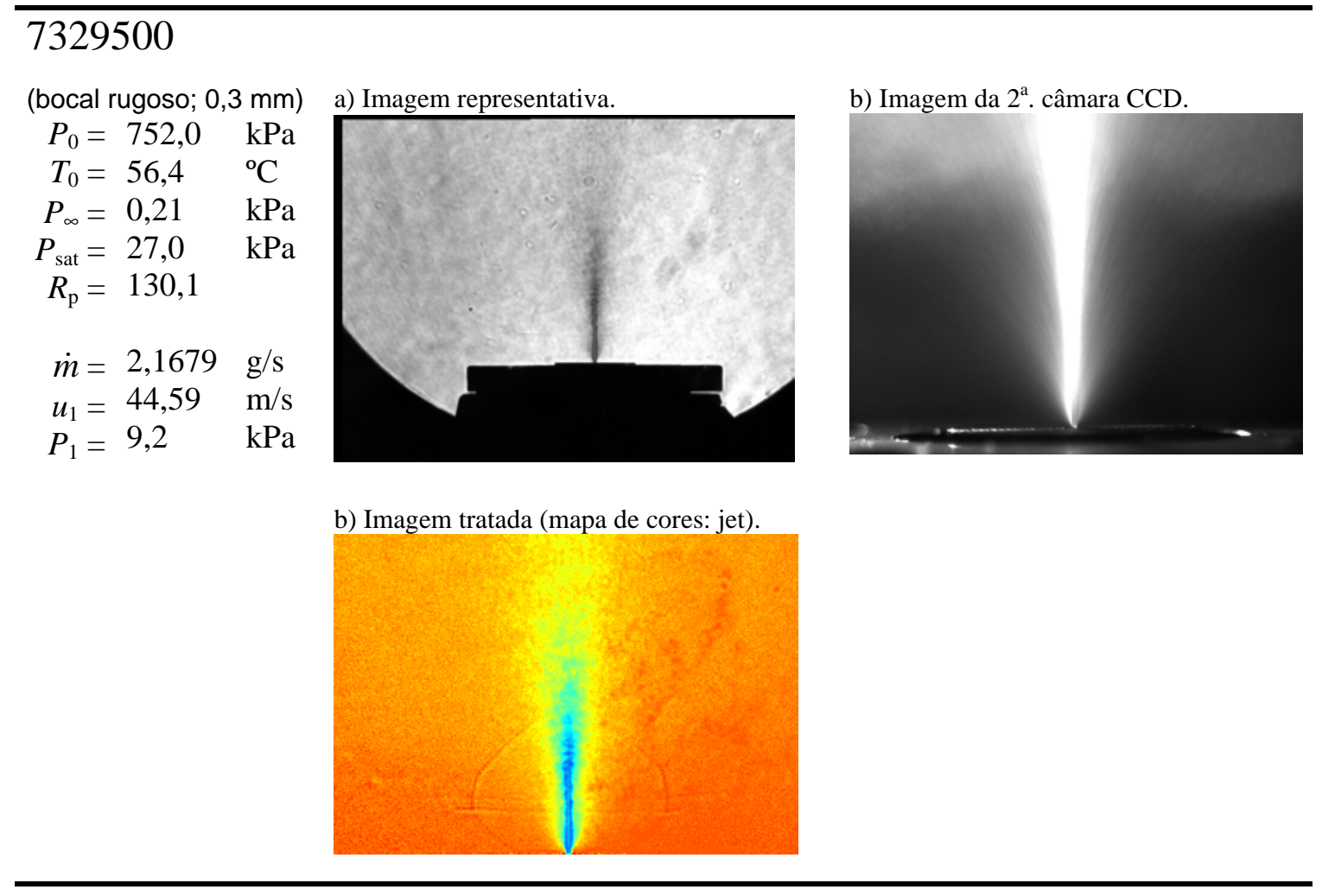

\section{2}

(bocal rugoso; 0,3 mm)

a) Imagem representativa.

$\begin{array}{rlr}P_{0} & =747,8 & \mathrm{kPa} \\ T_{0} & =76,0 & { }^{\circ} \mathrm{C} \\ P_{\infty} & =24,93 & \mathrm{kPa} \\ P_{\text {sat }} & =49,9 & \mathrm{kPa} \\ R_{\mathrm{p}} & =2,0 & \\ \dot{m} & =2,0818 & \mathrm{~g} / \mathrm{s} \\ u_{1} & =43,69 & \mathrm{~m} / \mathrm{s} \\ P_{1} & =52,3 & \mathrm{kPa}\end{array}$

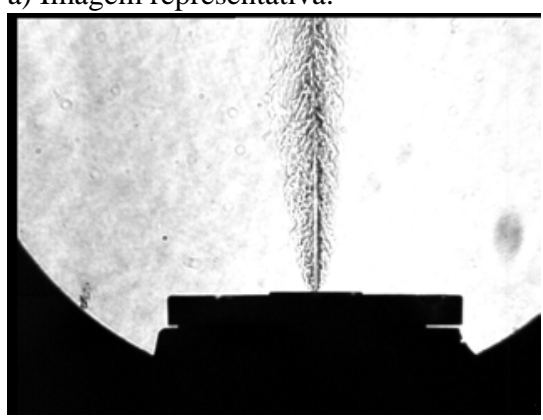

b) Imagem da $2^{\mathrm{a}}$. câmara CCD.

c) Imagem tratada (mapa de cores: gray).
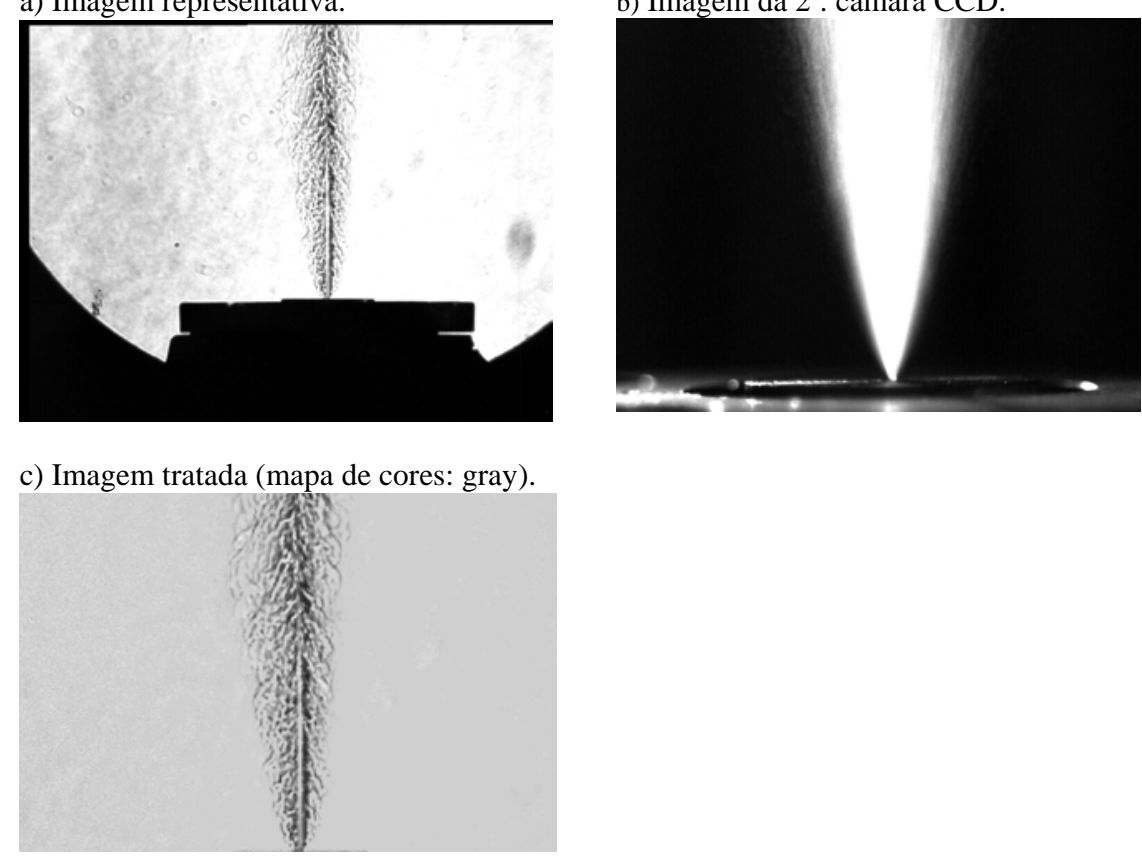


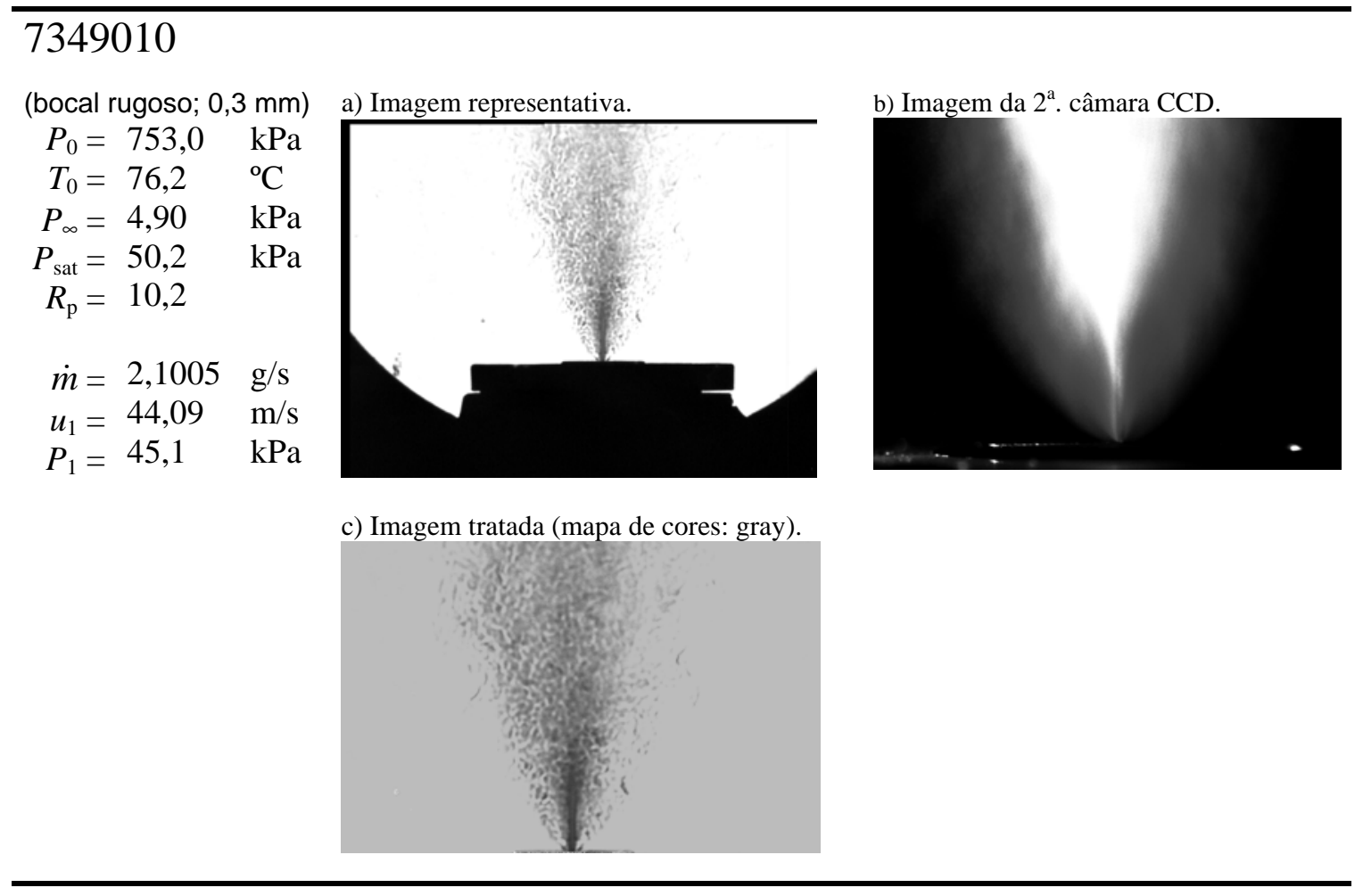

\section{0}

(bocal rugoso; 0,3 $\mathrm{mm}$ ) a) Imagem representativa.

$\begin{array}{rlrl}P_{0} & =749,2 & \mathrm{kPa} \\ T_{0} & =76,8 & & { }^{\circ} \mathrm{C} \\ P_{\infty} & =1,00 & \mathrm{kPa} \\ P_{\text {sat }} & =51,2 & \mathrm{kPa} \\ R_{\mathrm{p}} & =51,3 & & \\ \dot{m} & =2,0995 & \mathrm{~g} / \mathrm{s} \\ u_{1}=44,09 & \mathrm{~m} / \mathrm{s} \\ P_{1}=41,6 & \mathrm{kPa}\end{array}$

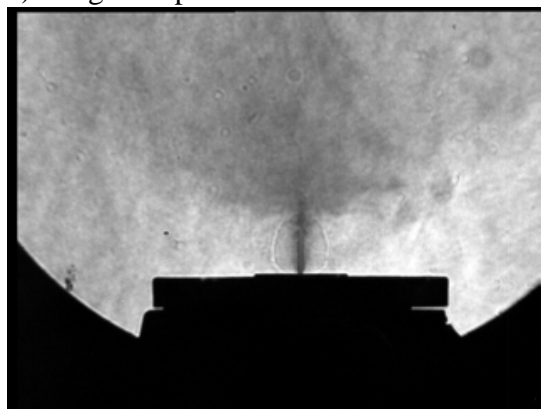

c) Imagem tratada (mapa de cores: jet).

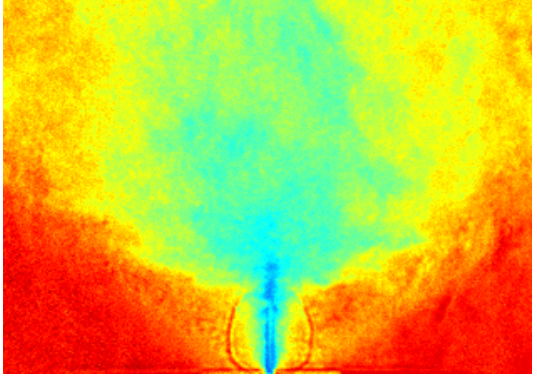

b) Imagem tratada (mapa de cores: prism).

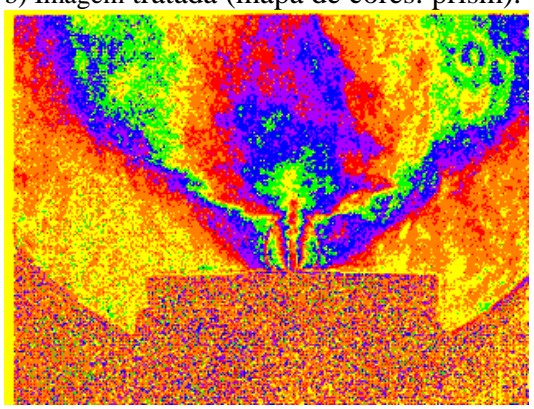

d) Imagem da $2^{\mathrm{a}}$. câmara CCD.

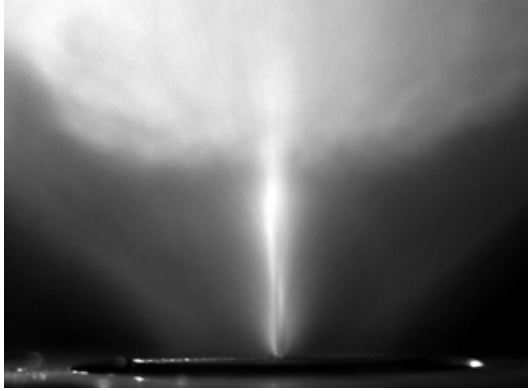




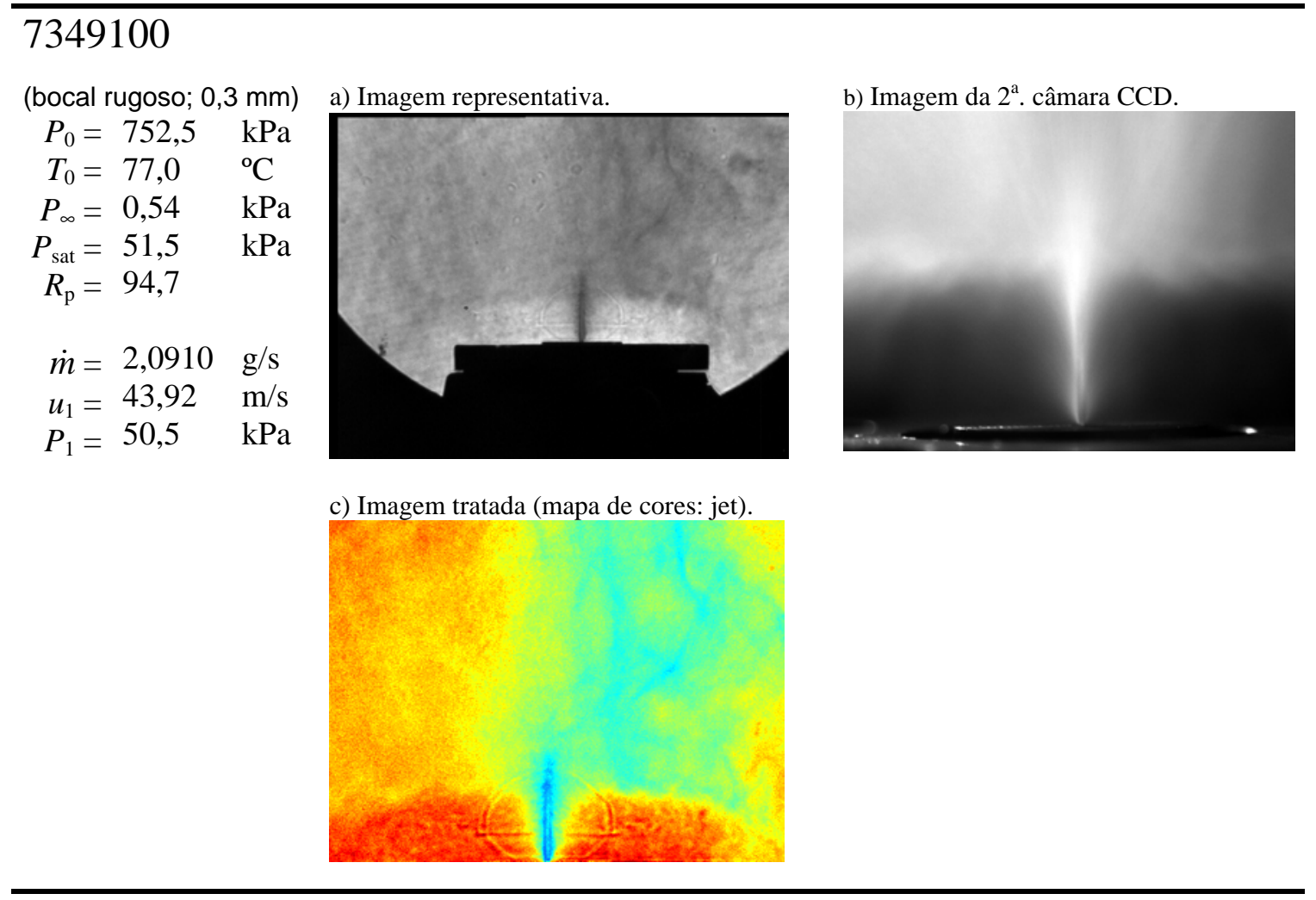

\section{0}

(bocal rugoso; 0,3 $\mathrm{mm}$ )

a) Imagem representativa.

$P_{0}=750,7 \quad \mathrm{kPa}$

$T_{0}=77,1 \quad{ }^{\circ} \mathrm{C}$

$P_{\infty}=0,21$

$P_{\text {sat }}=51,7$

$R_{\mathrm{p}}=241,5$

$\dot{m}=2,1138$

$u_{1}=44,40$

$P_{1}=33,5$

g/s

$\mathrm{m} / \mathrm{s}$

$\mathrm{kPa}$

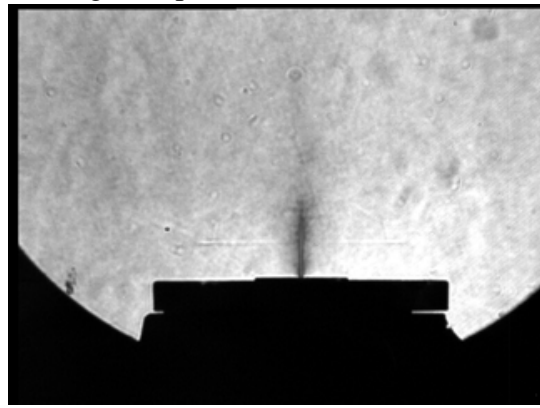

c) Imagem tratada (mapa de cores: gray).

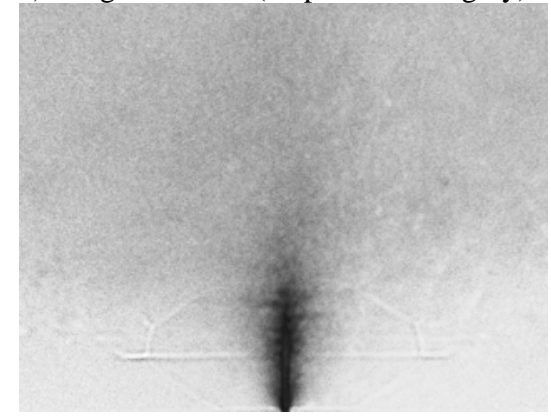

b) Imagem tratada (mapa de cores: prism).

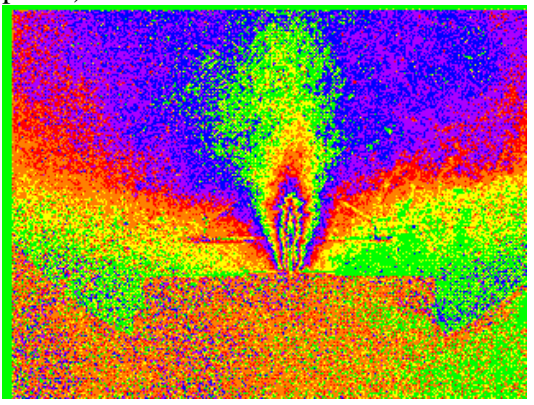

d) Imagem da 2a . câmara CCD.

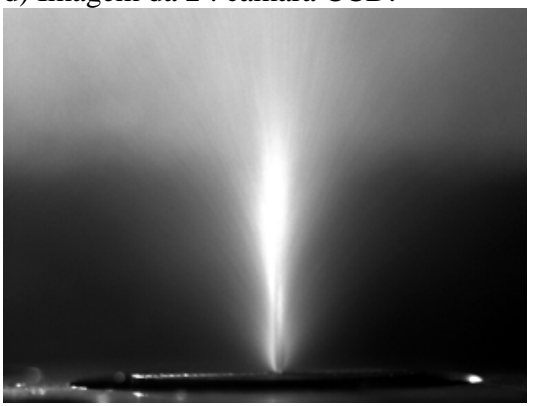



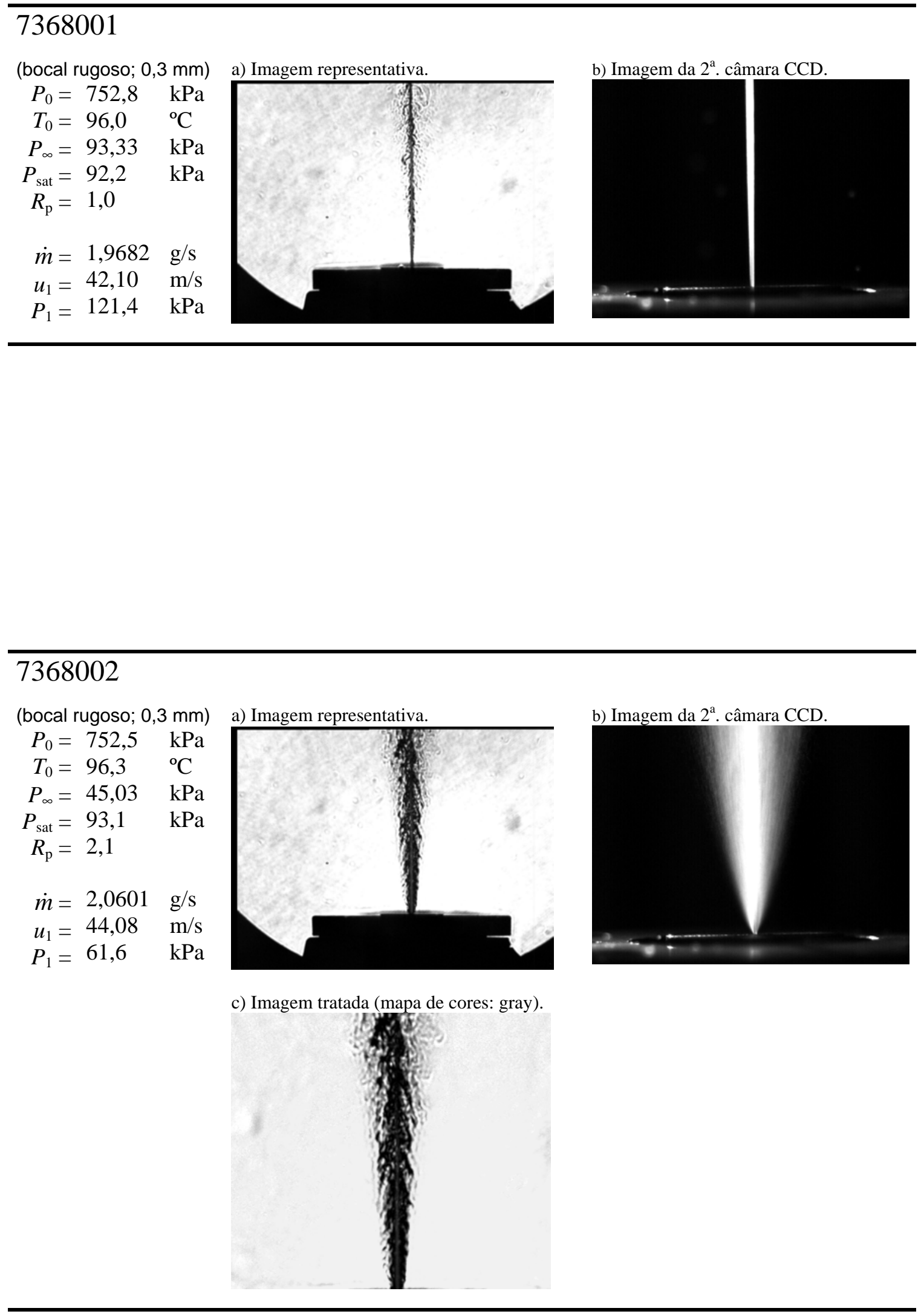


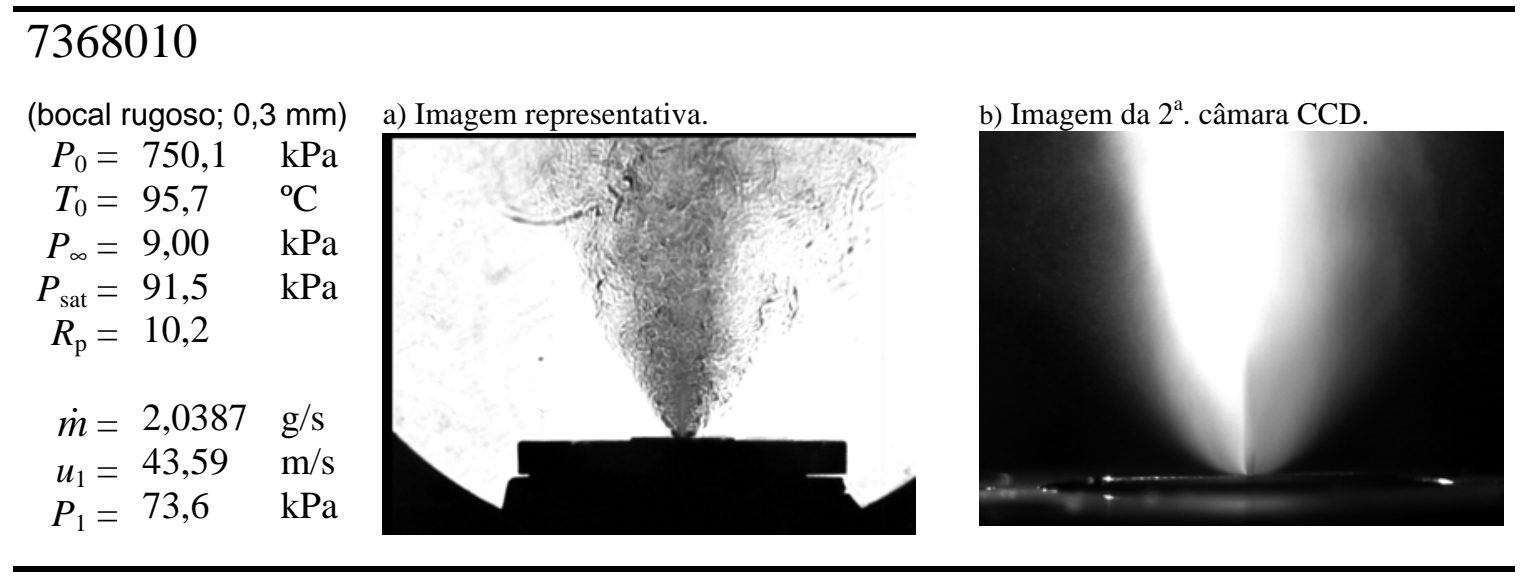

\section{0}

(bocal rugoso; 0,3 $\mathrm{mm}$ ) a) Imagem representativa. $P_{0}=752,3 \quad \mathrm{kPa}$ $T_{0}=96,4 \quad{ }^{\circ} \mathrm{C}$

$P_{\infty}=0,93 \quad \mathrm{kPa}$

$P_{\text {sat }}=93,4 \quad \mathrm{kPa}$

$R_{\mathrm{p}}=101,0$

$\dot{m}=2,0292 \mathrm{~g} / \mathrm{s}$

$u_{1}=43,42$

$P_{1}=81,6$

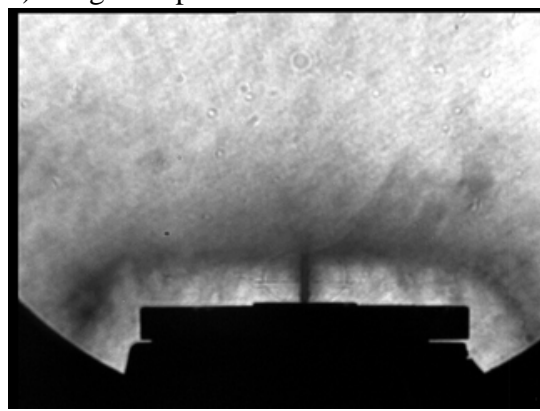

c) Imagem tratada (mapa de cores: gray). b) Imagem da $2^{\mathrm{a}}$. câmara CCD.

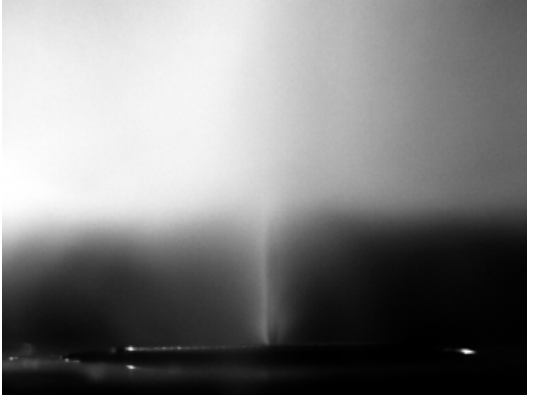

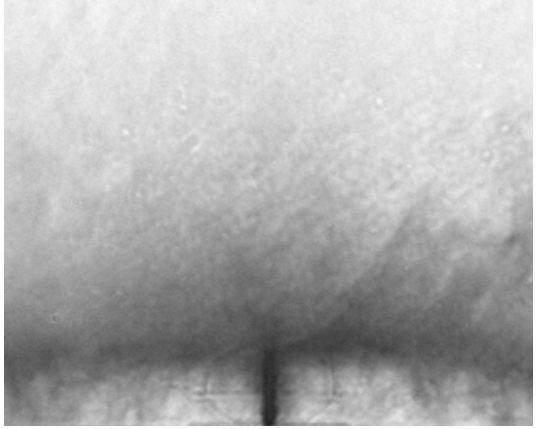




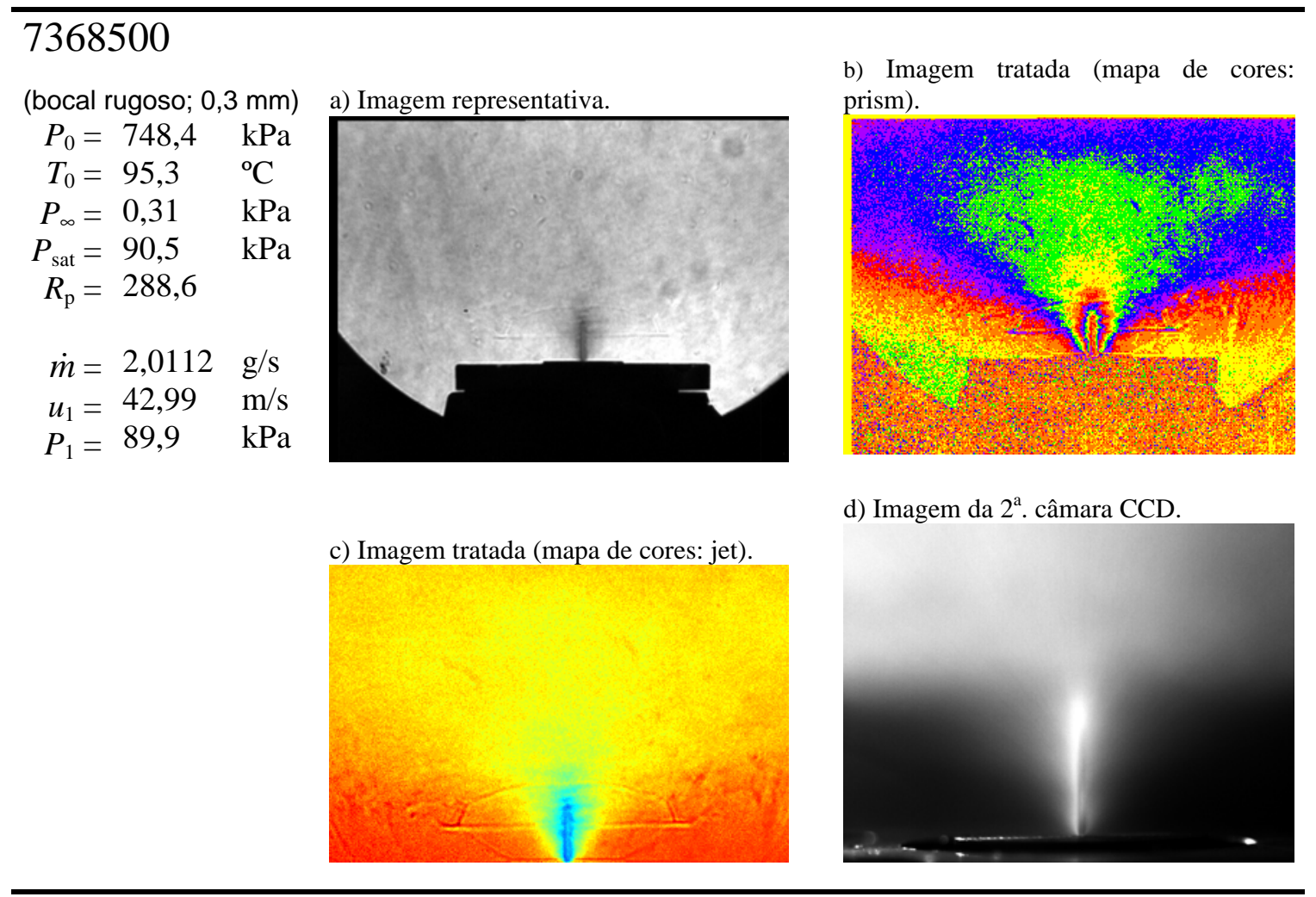

\section{$7368 \mathrm{~m} 10$}

$\begin{array}{rlr}\text { (bocal rugoso; } & 0,3 \mathrm{~mm} \text { ) } \\ P_{0} & =750,9 & \mathrm{kPa} \\ T_{0} & =95,2 & { }^{\circ} \mathrm{C} \\ P_{\infty} & =0,23 & \mathrm{kPa} \\ P_{\text {sat }} & =90,2 & \mathrm{kPa} \\ R_{\mathrm{p}}=391,4 & \\ \dot{m}=2,0302 & \mathrm{~g} / \mathrm{s} \\ u_{1}=43,39 & \mathrm{~m} / \mathrm{s} \\ P_{1}=80,1 & \mathrm{kPa}\end{array}$

a) Imagem representativa.

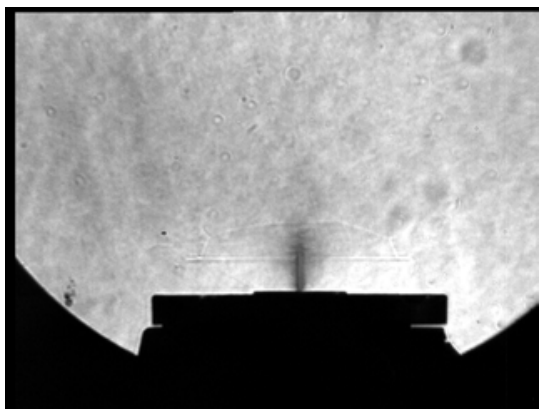

c) Imagem tratada (mapa de cores: prism).

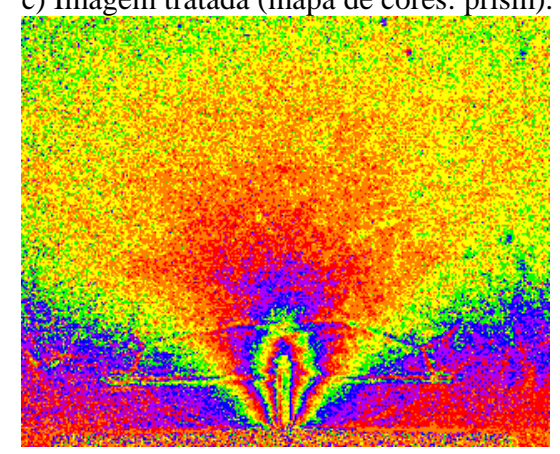

b) Imagem tratada (mapa de cores: gray).

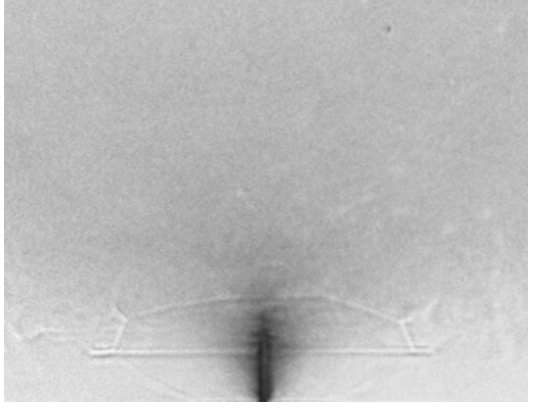

d) Imagem da 2a . câmara CCD.

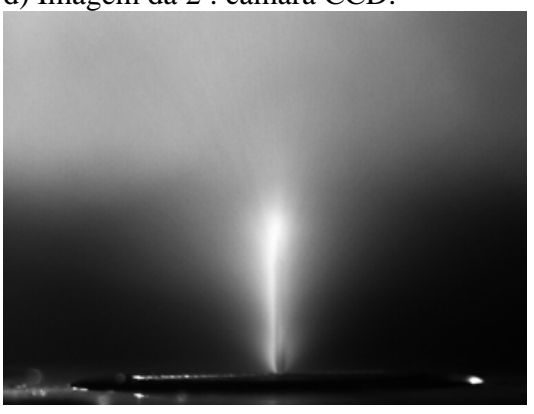



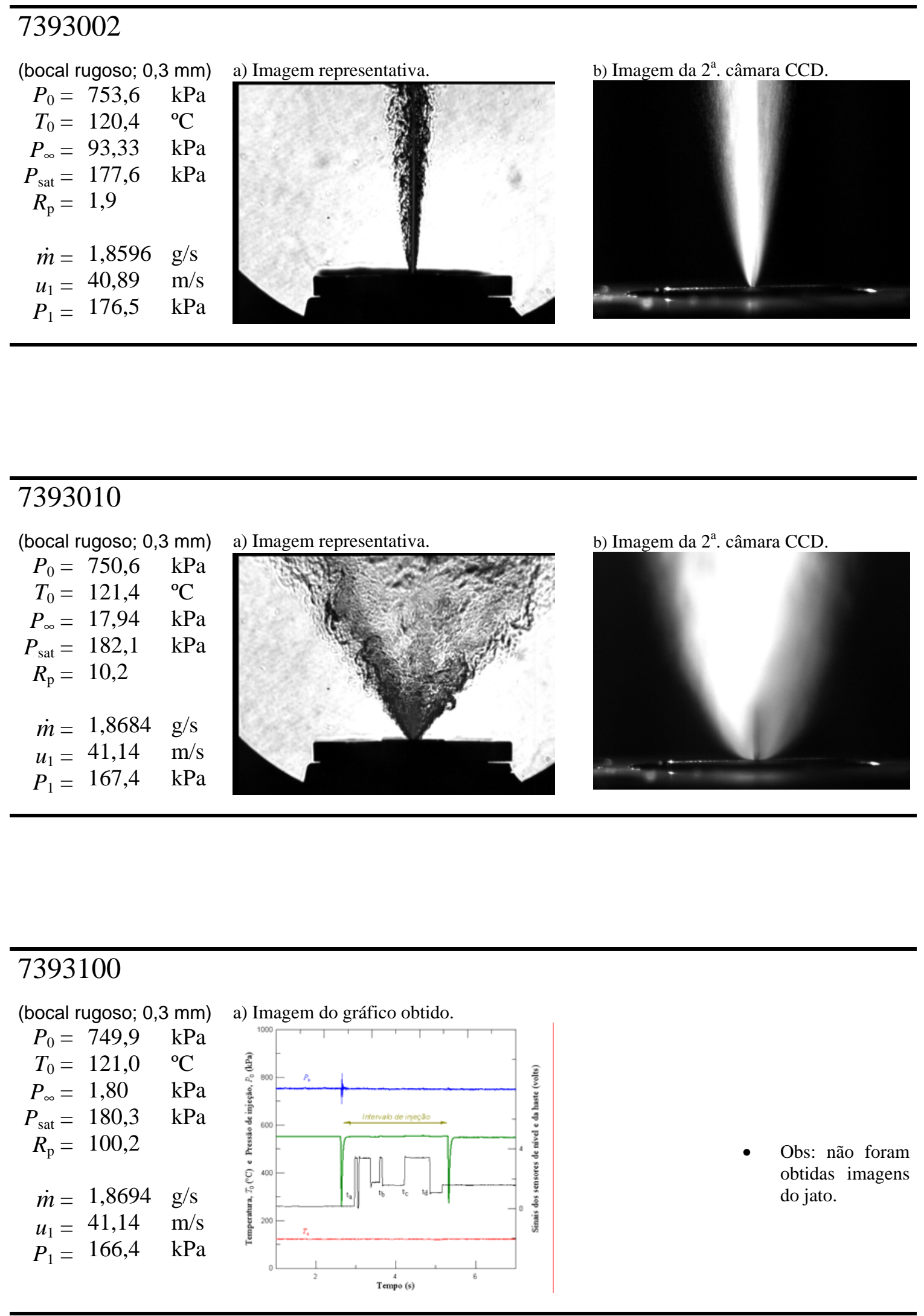

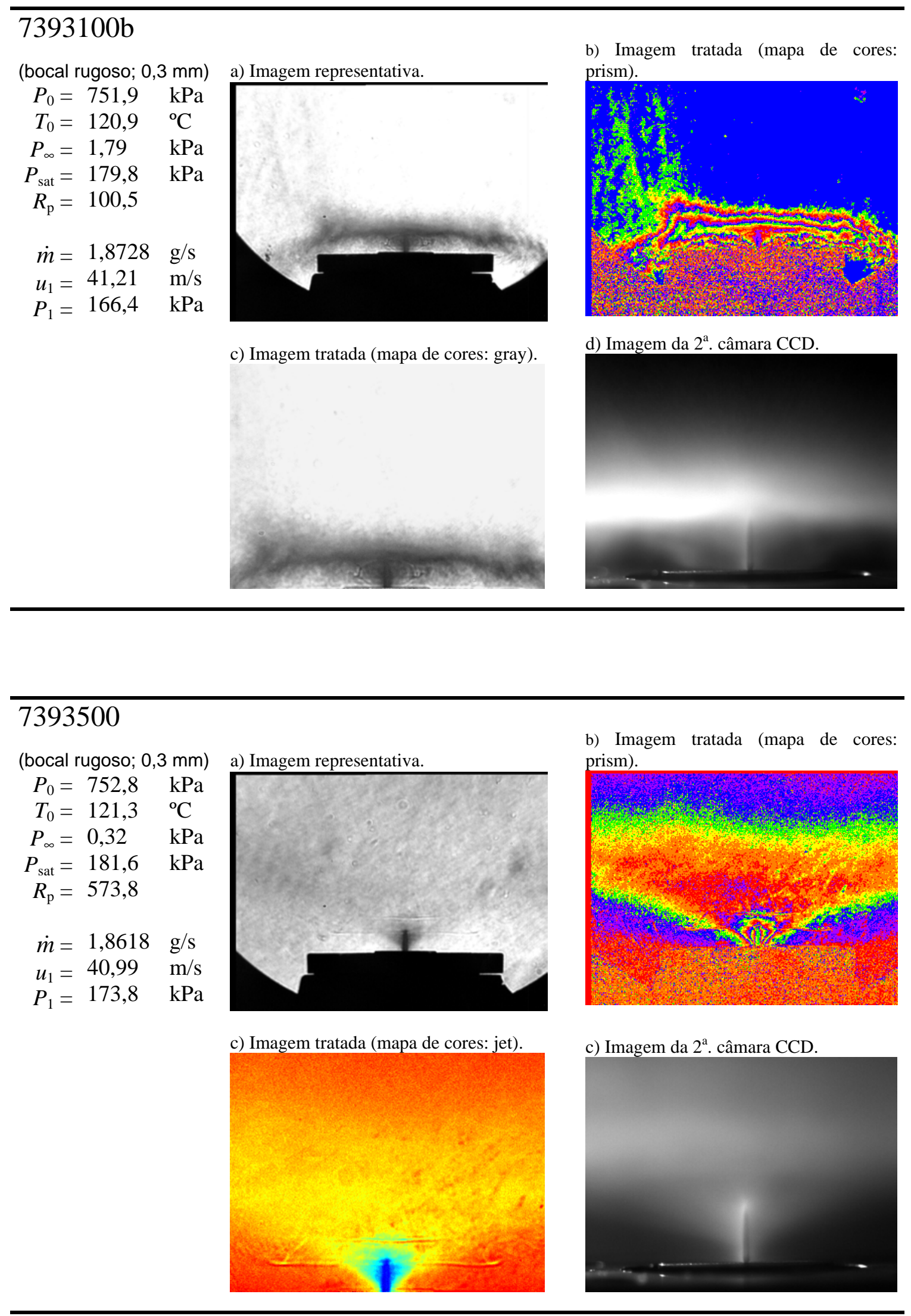

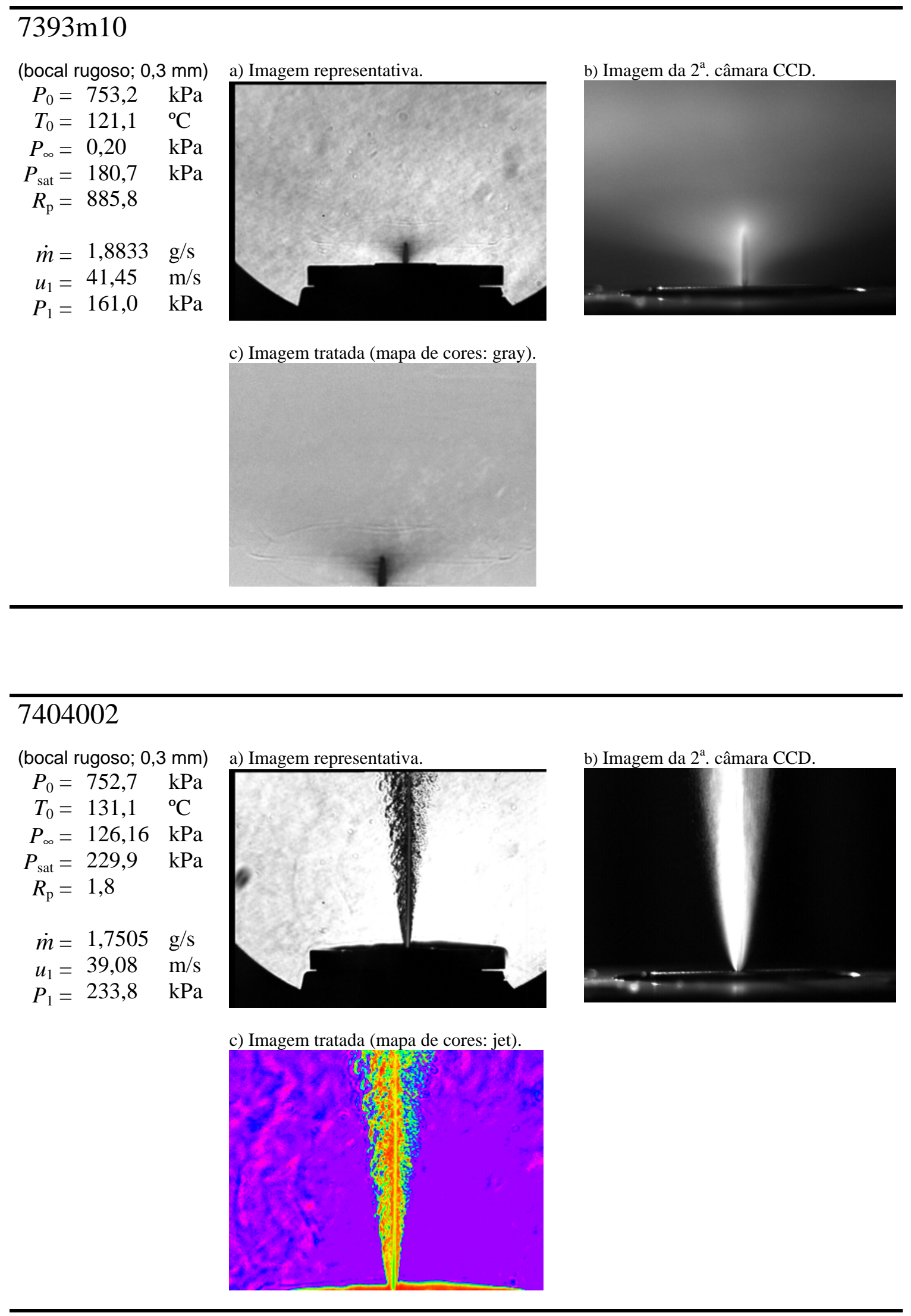

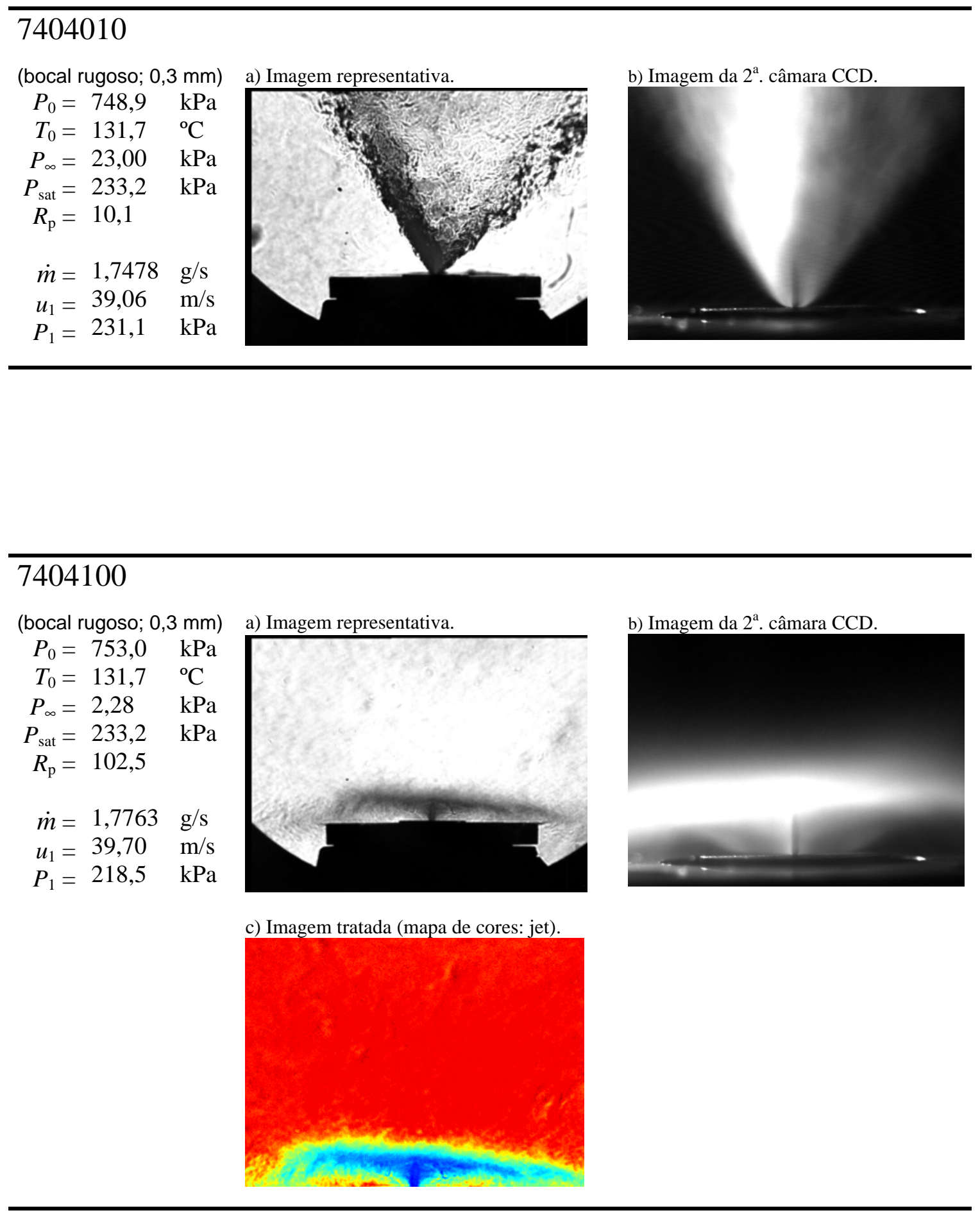


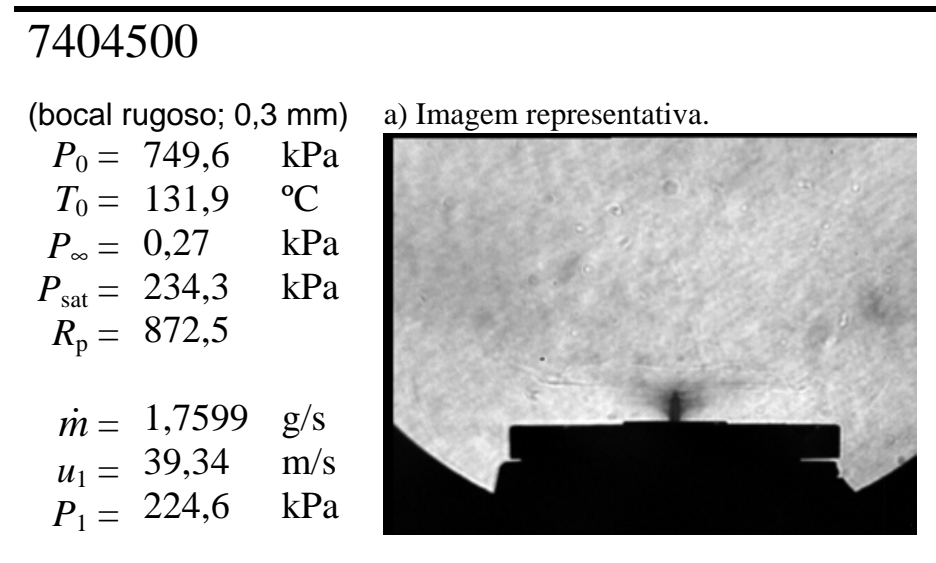

c) Imagem tratada (mapa de cores: gray).

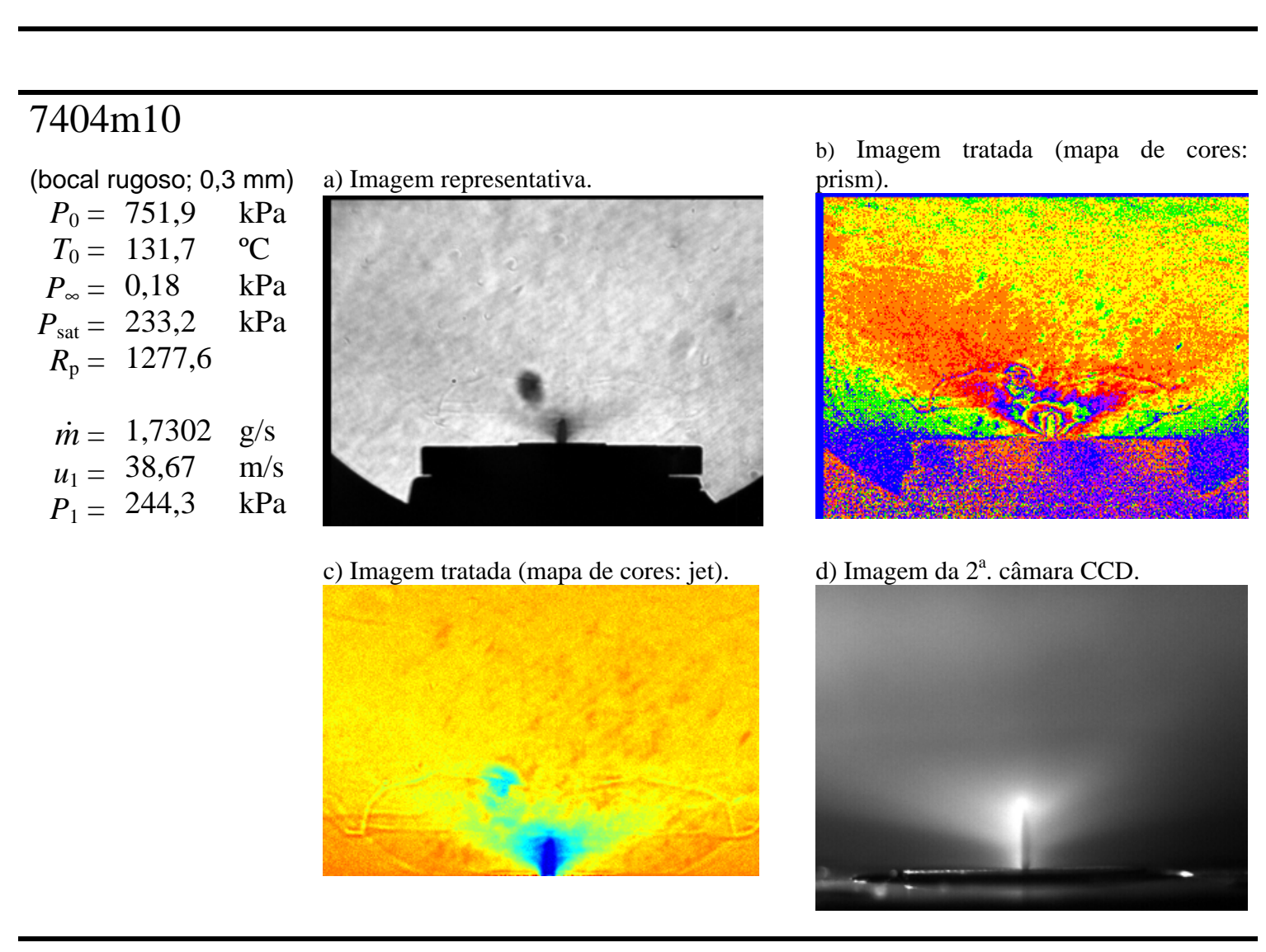

b) Imagem tratada (mapa de cores: prism).

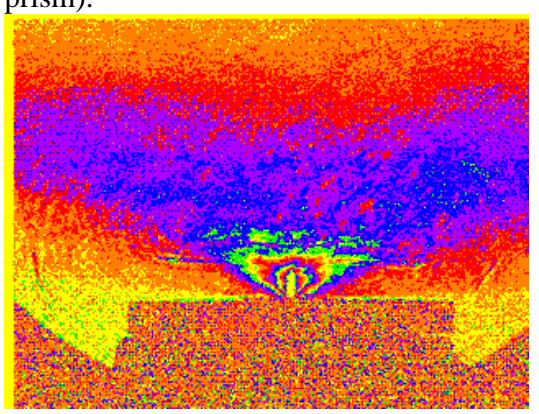

c) Imagem da $2^{\mathrm{a}}$. câmara CCD.

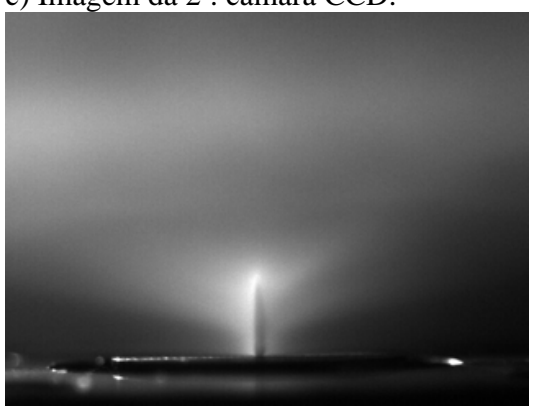



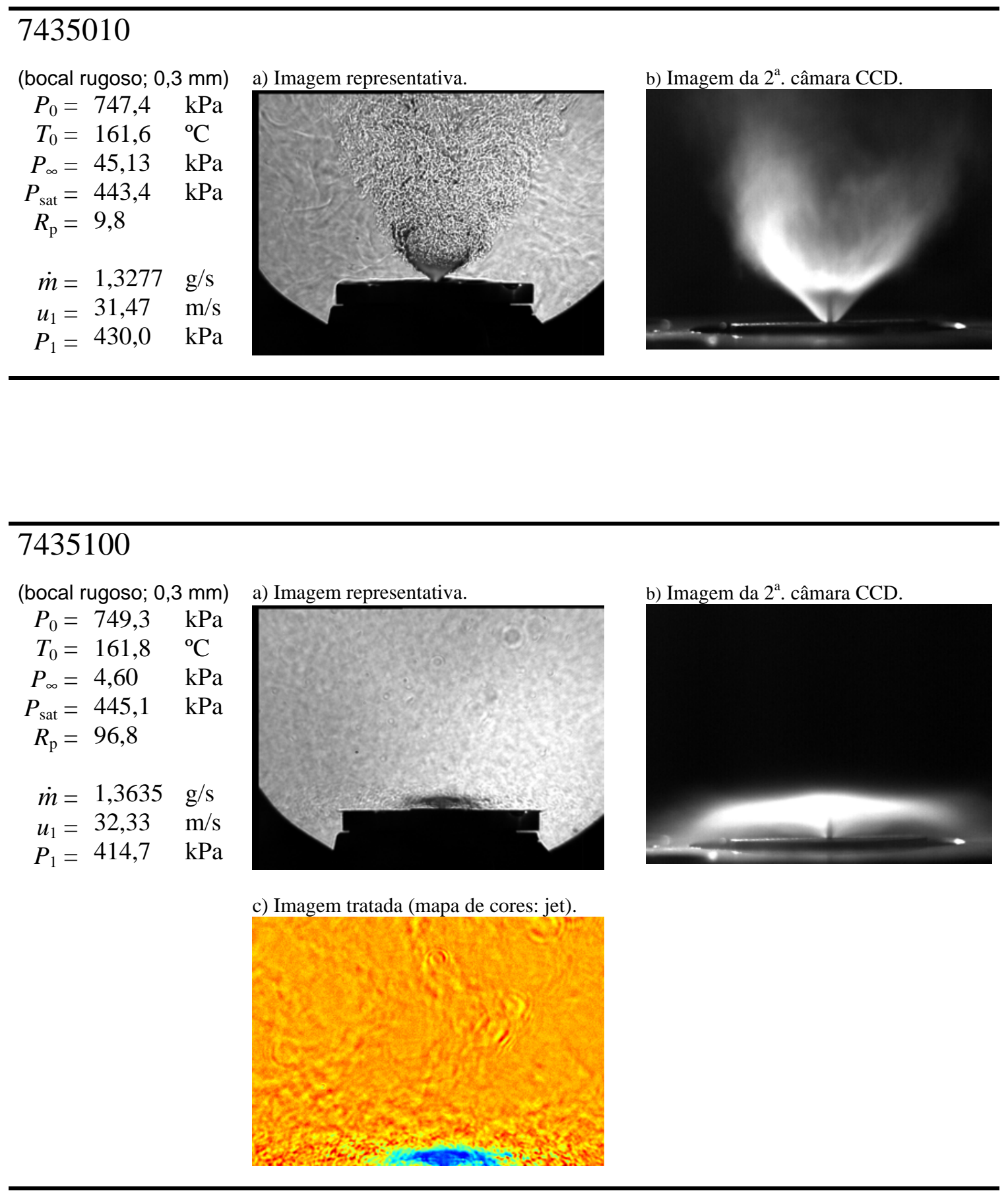


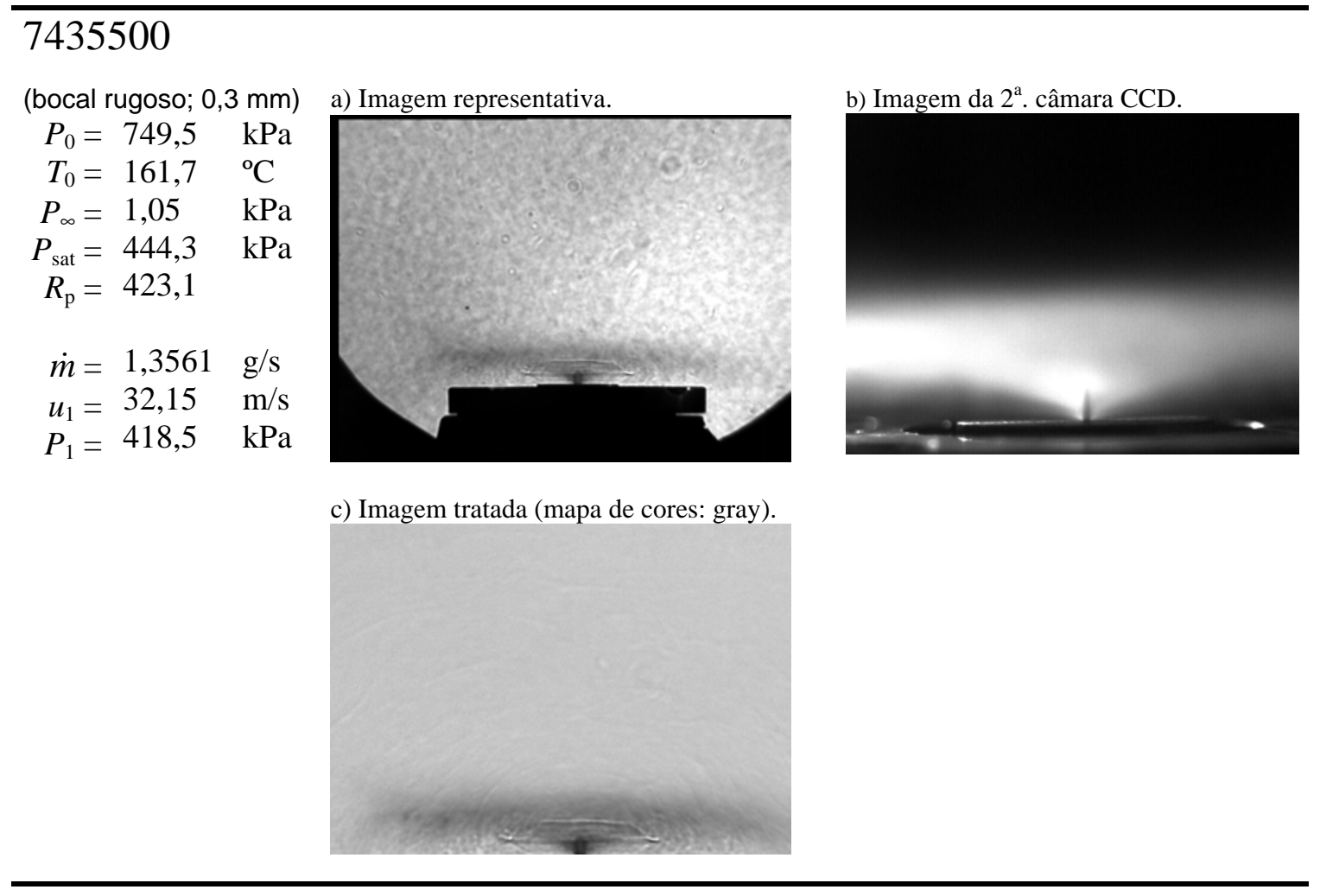

\section{$7435 \mathrm{~m} 10$}

(bocal rugoso; 0,3 $\mathrm{mm}$ )

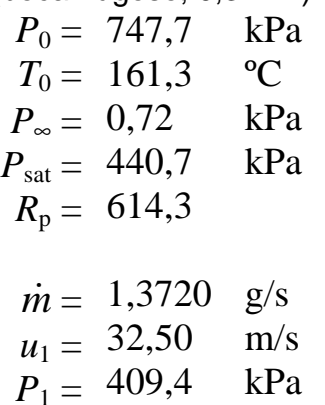

a) Imagem representativa.

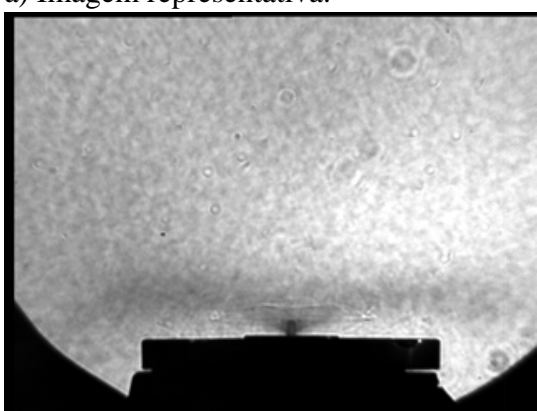

c) Imagem tratada (mapa de cores: gray).

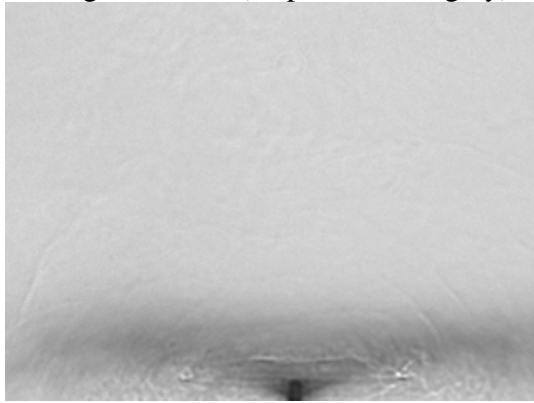

b) Imagem tratada (mapa de cores: jet).

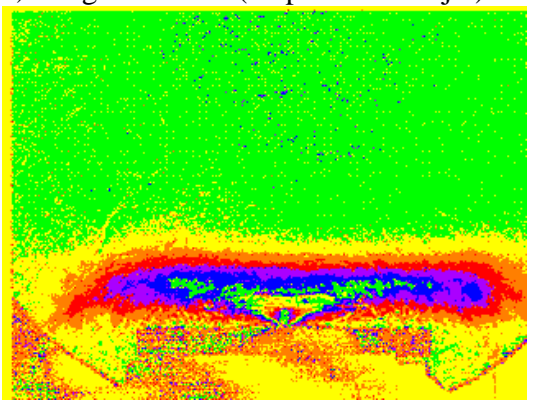

d) Imagem da $2^{\mathrm{a}}$. câmara CCD.

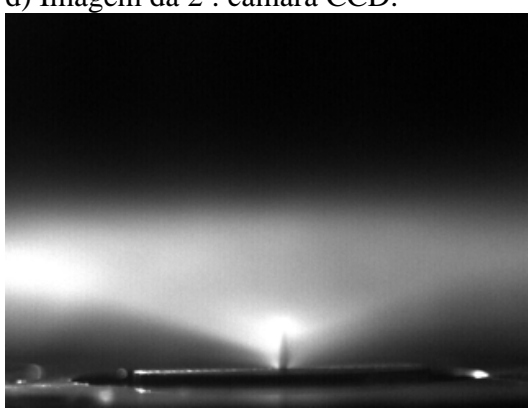



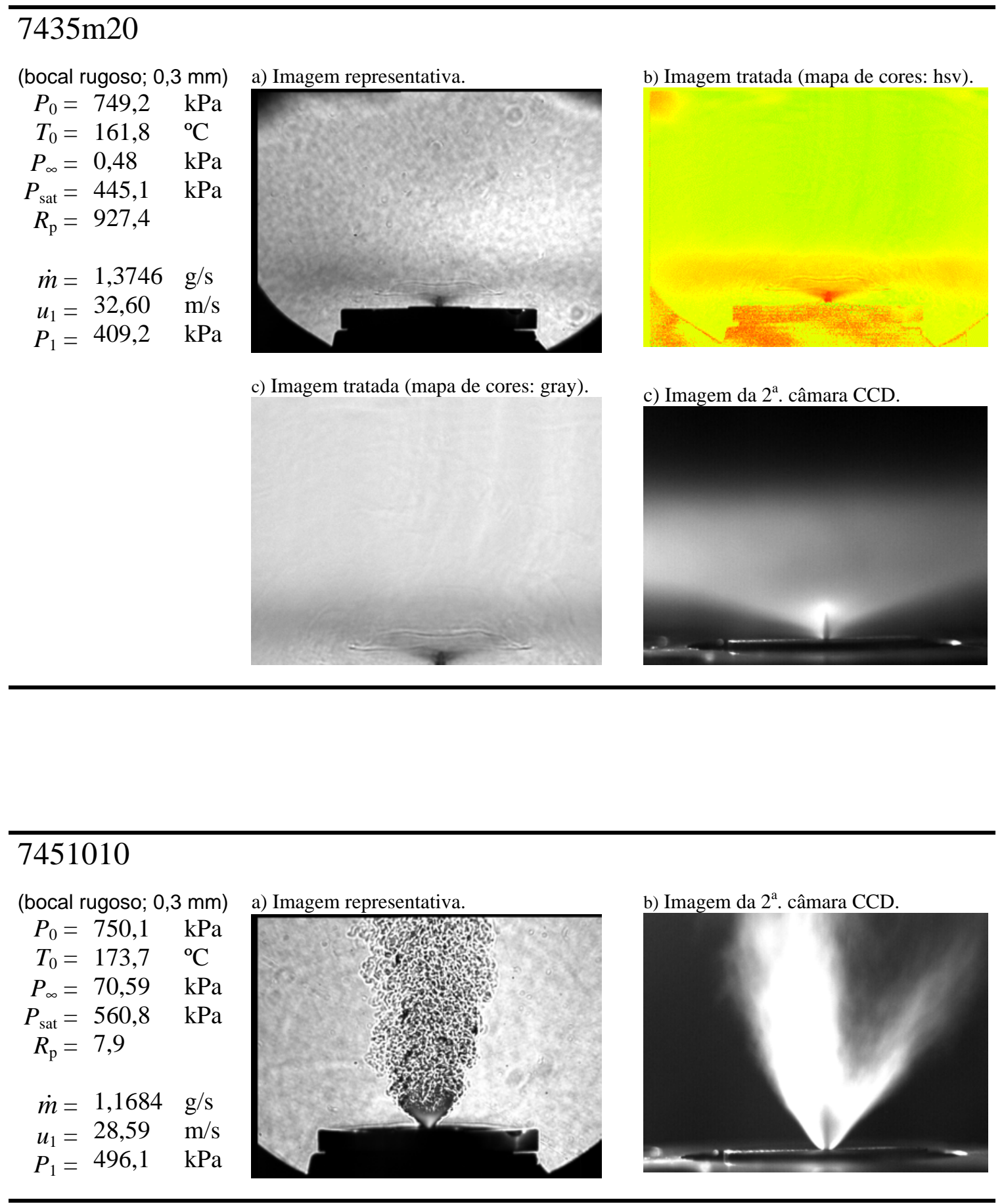

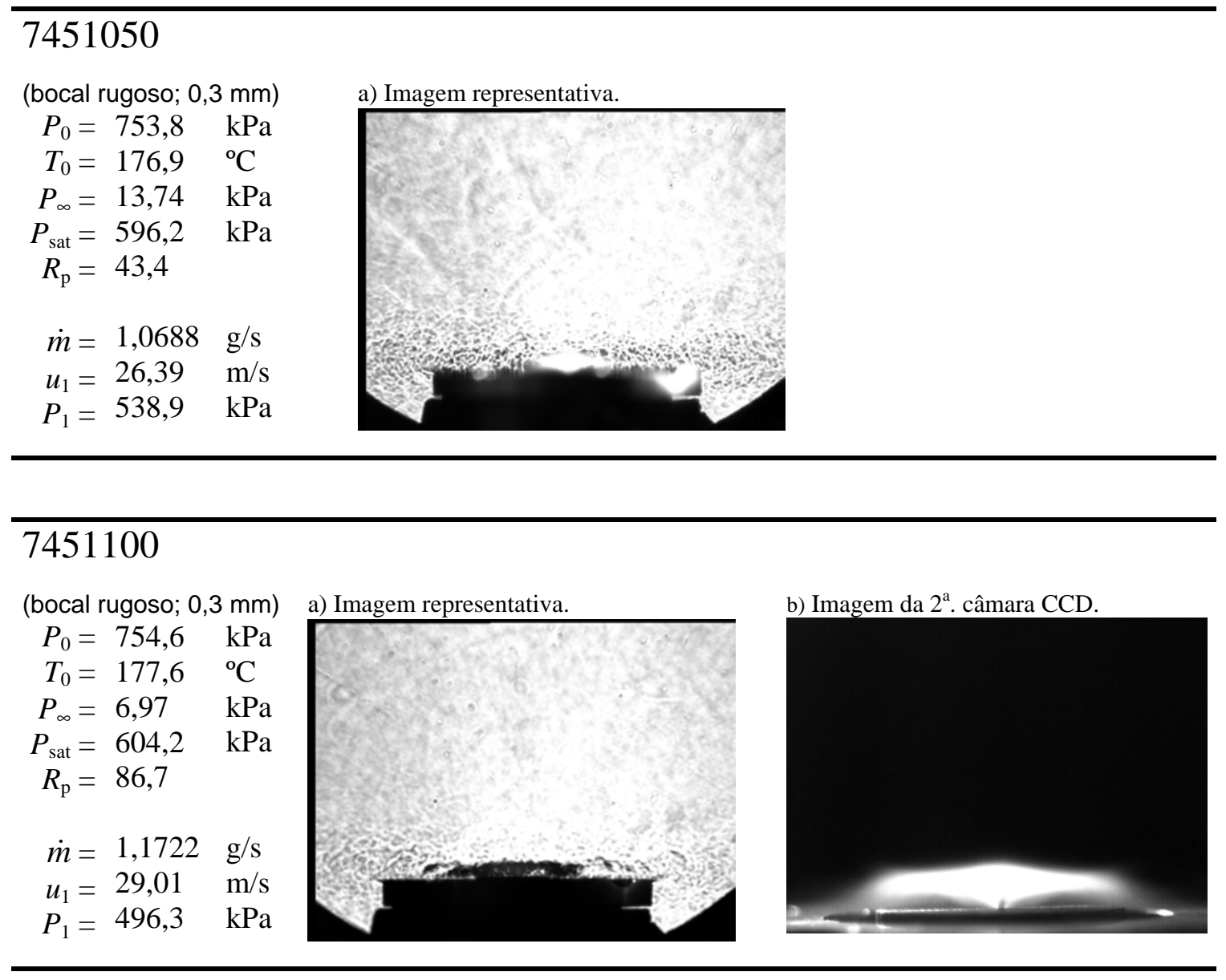

\section{0}

\begin{tabular}{|c|c|c|}
\hline (bocal & ugoso; 0 , & $3 \mathrm{~mm})$ \\
\hline$P_{0}=$ & 756,6 & $\mathrm{kPa}$ \\
\hline$T_{0}=$ & 177,6 & ${ }^{\circ} \mathrm{C}$ \\
\hline$P_{\infty}=$ & 1,57 & $\mathrm{kPa}$ \\
\hline$P_{\text {sat }}=$ & 604,2 & $\mathrm{kPa}$ \\
\hline$R_{\mathrm{p}}=$ & 386,0 & \\
\hline$\dot{m}=$ & 1,0846 & $\mathrm{~g} / \mathrm{s}$ \\
\hline$u_{1}=$ & 26,84 & $\mathrm{~m} / \mathrm{s}$ \\
\hline$P_{1}=$ & 534,9 & $\mathrm{kPa}$ \\
\hline
\end{tabular}

a) Imagem representativa.

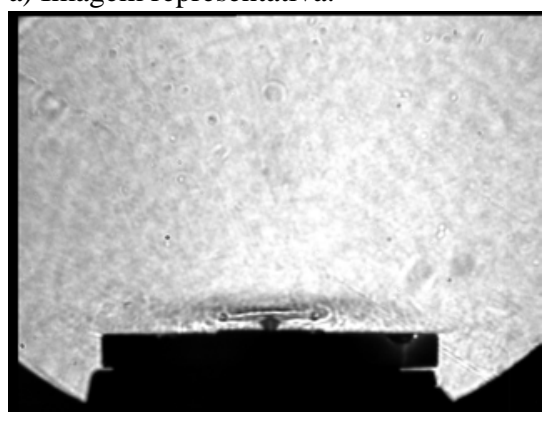

c) Imagem tratada (mapa de cores: jet). b) Imagem da $2^{\mathrm{a}}$. câmara CCD

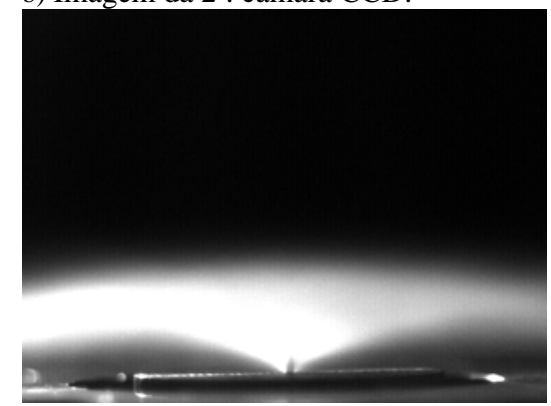

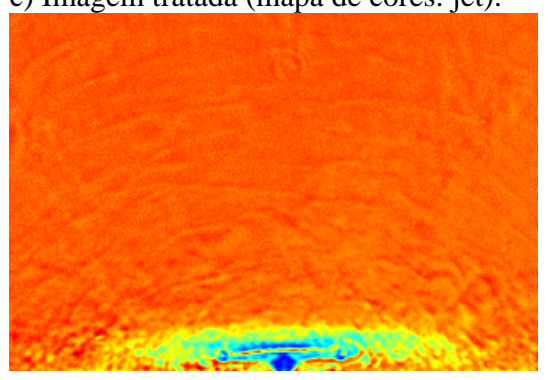



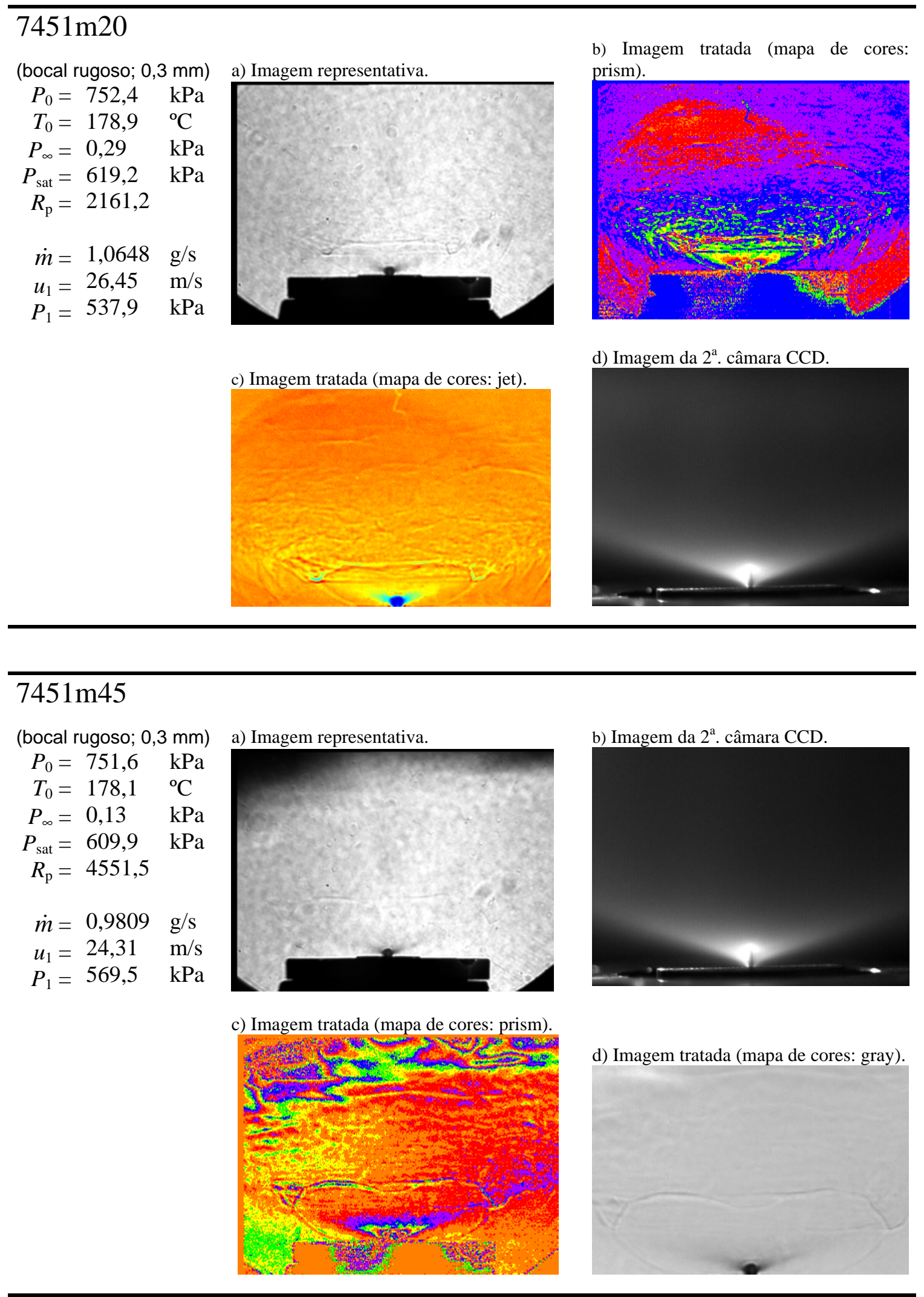


\section{Anexo C}

Resultados Experimentais

do Bocal de Aço com

$0,8 \mathrm{~mm}$ e do

Bocal de Vidro de

$0,35 \mathrm{~mm}$

(R08 e V03) 


\section{C.1. Medição das Vazões Mássicas - Série R08}

Na Tab. C.1, os ensaios estão apresentados, primeiramente com o código do ensaio, dia de realização, seguido da pressão e temperatura de injeção que estão classificados $\left(P_{\text {inj }}\right.$ e $\left.T_{\text {inj }}\right)$. Nas colunas seguintes, estão colocados a pressão e temperatura de injeção medidas ( $P_{0}$ e $\left.T_{0}\right)$, a pressão da câmara média $\left(P_{\infty}\right)$ e a razão entre a pressão de vapor e pressão da câmara $\left(R_{\mathrm{P}}\right)$. Em seguida está o número de Reynolds, $R e$, a vazão mássica, $\dot{m}$, o coeficiente de descarga, $C_{\mathrm{D}}$, calculado através da Eq. (C.1) cuja curva foi levantada experimentalmente, e a vazão mássica estimada, $\dot{m}_{e}$, que é obtida através da equação de descarga do bocal para fluidos incompressíveis representada pela Eq. (B.2). O parâmetro, $P_{1}$, é calculado através da Eq. (B.4) e se refere à pressão do líquido superaquecido na saída do bocal e depende da vazão mássica medida no ensaio.

$$
C_{D}=0,9954-16,827 / \sqrt{\mathrm{Re}}
$$

Tabela C.1 - Tabela com os ensaios da série "R08" (bocal rugoso com 0,8 mm de diâmetro).

\begin{tabular}{|c|c|c|c|c|c|c|c|c|c|c|c|c|}
\hline Código & dia & $\begin{array}{c}\boldsymbol{P}_{\text {inj }} \\
(\mathrm{kPa})\end{array}$ & $\begin{array}{l}T_{\text {inj }} \\
\left({ }^{\circ} \mathrm{C}\right) \\
\end{array}$ & $\begin{array}{c}\boldsymbol{P}_{\mathbf{0}} \\
(\mathrm{kPa}) \\
\end{array}$ & $\begin{array}{c}\boldsymbol{T}_{\mathbf{0}} \\
\left({ }^{\circ} \mathrm{C}\right) \\
\end{array}$ & $\begin{array}{c}\boldsymbol{P}_{\infty} \\
(\mathrm{kPa})\end{array}$ & $\boldsymbol{R}_{\mathbf{P}}$ & $\mathbf{R e}$ & $C_{\mathrm{D}}$ & $\begin{array}{l}\text { medido } \\
\qquad \dot{m} \\
(\mathrm{~g} / \mathrm{s})\end{array}$ & $\begin{array}{l}m_{\mathrm{e}} \\
(\mathrm{g} / \mathrm{s}) \\
\end{array}$ & $\begin{array}{c}\boldsymbol{P}_{\mathbf{1}} \\
(\mathrm{kPa})\end{array}$ \\
\hline R08\1056002 & 26-out-04 & 125 & 56 & 120,5 & 56,2 & 22,93 & 1,1 & 24617 & 0,9443 & 4,8989 & 5,0190 & 27,5 \\
\hline & & 125 & 56 & 121 & 55,6 & 0,39 & & & & 5,0462 & 5,5999 & 23,1 \\
\hline R08\1056m10 & $26-0$ & 125 & 56 & 119,0 & 55,4 & 0,35 & 68 & 25547 & 0,9465 & 5,1230 & 5,5503 & 17,9 \\
\hline 02 & 2 & 25 & 95 & 120,7 & 95,4 & 63,66 & 1,4 & 235 & & 3,3555 & 528 & 75,1 \\
\hline R08\10s & -04 & 125 & 95 & 121, & 94,9 & 0,37 & 241,4 & 2725 & & 3,9018 & 5,5146 & 60,7 \\
\hline R08\1095m10 & 26-out-04 & 125 & 95 & 122,7 & 94,7 & 0,31 & 293,9 & 27695 & 0,9513 & 3,9716 & 5,5562 & 60,2 \\
\hline R08|20 & & 250 & 95 & 250,8 & 95,9 & 30,17 & 3,1 & 465 & & 6,6063 & 7,6614 & 86,7 \\
\hline & & 250 & 95 & & 97,6 & & & & & 6,4541 & 720 & 92,7 \\
\hline R0812095 & & 250 & 95 & 244 & 97,8 & 4,4 & 21 & 458 & & 6,4170 & 752 & 89,0 \\
\hline R0812095m10 & 23-set-04 & 250 & 95 & 249,0 & 97,2 & 4,05 & 23,6 & 45951 & 0,9770 & 6,4621 & 8,0629 & 91 \\
\hline & & & & & & 89,4 & & & & & & 136,0 \\
\hline R08\2120500 & & 250 & 120 & 247 & 121,7 & 0,52 & 349,7 & 428 & & 5,0000 & 7,9553 & 149, \\
\hline R08\2120m10 & 06-out-04 & 250 & 120 & 246,5 & 120,7 & 0,42 & 424,5 & 43747 & 0,9748 & 5,1428 & 7,9555 & 143,7 \\
\hline
\end{tabular}




\section{C.2. Medição do Comprimento de Extinção do Núcleo Líquido - Série R08}

Na Tab. C.2, são vistos os ensaios com os valores nominais de pressão e temperatura de injeção ( $P_{\text {inj }}$ e $T_{\text {inj}}$ ), seguida da pressão de saturação $\left(P_{\text {sat }}\right)$ à temperatura de injeção $\left(T_{0}\right)$, pressão da câmara $\left(P_{\infty}\right)$ e a razão entre a pressão de saturação e a pressão de injeção $\left(P_{\text {sat }} / P_{0}\right)$. O comprimento de extinção $\left(L_{\mathrm{E}}\right)$ é a próxima coluna e depois, está a razão entre a comprimento de extinção do líquido e o diâmetro do bocal $\left(L_{\mathrm{E}} / D_{\mathrm{b}}\right)$.

Tabela C.2 - Relação do comprimento do núcleo líquido de cada ensaio - Série R08 (bocal rugoso com 0,8 mm de diâmetro).

\begin{tabular}{|c|c|c|c|c|c|c|c|c|c|}
\hline Ensaio & $\begin{array}{c}P_{\text {inj }} \\
(\mathrm{kPa})\end{array}$ & $\begin{array}{c}T_{\text {inj }} \\
\left({ }^{\circ} \mathrm{C}\right)\end{array}$ & $\begin{array}{c}P_{0} \\
(\mathrm{kPa})\end{array}$ & $\begin{array}{c}T_{0} \\
\left({ }^{\circ} \mathrm{C}\right) \\
\end{array}$ & $\begin{array}{c}P_{\text {sat }} \\
(\mathrm{kPa})\end{array}$ & $\begin{array}{c}P_{\infty} \\
(\mathrm{kPa})\end{array}$ & $P_{\text {sat }} / P_{0}$ & $\begin{array}{c}L_{\mathrm{E}} \\
(\mathrm{mm})\end{array}$ & $L_{\mathrm{E}} / D_{\mathrm{b}}$ \\
\hline R08\1056002 & 125 & 56 & 120,5 & 56,2 & 24,8 & 22,93 & 0,206 & - & - \\
\hline R08\1056500 & 125 & 56 & 121,4 & 55,6 & 24,2 & 0,39 & 0,200 & 16,2 & 20,29 \\
\hline R08\1056m10 & 125 & 56 & 119,0 & 55,4 & 24,0 & 0,35 & 0,202 & 15,4 & 19,35 \\
\hline R08\1095002 & 125 & 95 & 120,7 & 95,4 & 91,5 & 63,66 & 0,758 & - & - \\
\hline R08\1095500 & 125 & 95 & 121,2 & 94,9 & 90,2 & 0,37 & 0,744 & 6,3 & 7,94 \\
\hline R08\1095m10 & 125 & 95 & 122,7 & 94,7 & 89,6 & 0,31 & 0,730 & 6,2 & 7,71 \\
\hline R0812095003 & 250 & 95 & 250,8 & 95,9 & 92,1 & 30,17 & 0,367 & - & - \\
\hline R08I2095500 & 250 & 95 & 249,7 & 97,6 & 96,7 & 4,14 & 0,387 & - & - \\
\hline R08\2095500b & 250 & 95 & 244,3 & 97,8 & 97,2 & 4,45 & 0,398 & 11,2 & 14,02 \\
\hline R08\2095m10 & 250 & 95 & 249,0 & 97,2 & 95,6 & 4,05 & 0,384 & 10,7 & 13,45 \\
\hline R08\2120002 & 250 & 120 & 250,5 & 120,1 & 176,3 & 89,46 & 0,704 & - & - \\
\hline R0812120500 & 250 & 120 & 247,4 & 121,7 & 183,4 & 0,52 & 0,741 & 7,8 & 9,82 \\
\hline R0812120m10 & 250 & 120 & 246,5 & 120,7 & 178,9 & 0,42 & 0,726 & 7,5 & 9,41 \\
\hline
\end{tabular}




\section{C.3. Medição das Dimensões da Estrutura da Onda de Choque - Série R08}

Na Tab. C.3, estão a dimensão radial da onda de choque, $r_{1}$, e sua distância axial em relação à saída do bocal, $r_{2}$, todos obtidos através de ensaios deste bocal de 0,8 mm. Nela estão apresentados os ensaios seguidos da série, categoria da pressão e temperatura de injeção ( $P_{\text {inj }}$ e $T_{\text {inj }}$ ). Logo após estão os valores experimentais da pressão e temperatura de injeção $\left(P_{0}\right.$ e $\left.T_{0}\right)$. De um único ensaio são adquiridas várias imagens e, para cada uma delas, são correlacionadas a pressão da câmara $\left(P_{\infty}\right)$ e a razão entre as pressões de saturação e da câmara $\left(R_{\mathrm{p}}\right)$ com as dimensões do raio e da distância axial da onda de choque formada neste devido instante. As imagens principais de cada ensaio com as ondas de choque estão inseridas na seção seguinte. 
Tabela C.3 - Relação das dimensões da onda de choque formada como o raio, $r_{1}$ e a distancia axial, $r_{2}$ (bocal rugoso com 0,8 mm de diâmetro).

\begin{tabular}{|c|c|c|c|c|c|c|c|c|c|}
\hline Ensaio & $\begin{array}{c}P_{\text {inj }} \\
(\mathrm{kPa}) \\
\end{array}$ & $\begin{array}{c}T_{\text {inj }} \\
\left({ }^{\circ} \mathrm{C}\right) \\
\end{array}$ & $\begin{array}{c}P_{0} \\
(\mathrm{kPa})\end{array}$ & $\begin{array}{c}T_{0} \\
\left({ }^{\circ} \mathrm{C}\right) \\
\end{array}$ & Imagem & $\begin{array}{c}R_{\mathrm{P}} \\
(\mathrm{kPa}) \\
\end{array}$ & $\begin{array}{c}P_{\infty} \\
(\mathrm{kPa})\end{array}$ & $\begin{array}{c}r_{1} \\
(\mathrm{~mm}) \\
\end{array}$ & $\begin{array}{c}r_{2} \\
(\mathrm{~mm}) \\
\end{array}$ \\
\hline R08\1056002 & 125 & 56 & 120,5 & 56,2 & 1 & - & - & - & - - \\
\hline R08\1056500 & 125 & 56 & 121,4 & 55,6 & 1 & 170,6 & 0,14 & 20,5 & 22,1 \\
\hline R08\1056500 & 125 & 56 & 121,4 & 55,6 & 2 & 78,1 & 0,31 & 14,7 & 18,3 \\
\hline R08\1056500 & 125 & 56 & 121,4 & 55,6 & 3 & 50,7 & 0,48 & 11,0 & 17,3 \\
\hline R08\1056500 & 125 & 56 & 121,4 & 55,6 & 4 & 37,5 & 0,65 & 8,2 & 17,6 \\
\hline R08\1056m10 & 125 & 56 & 119,0 & 55,4 & 1 & 192,7 & 0,12 & 19,1 & 21,5 \\
\hline R08\1056m10 & 125 & 56 & 119,0 & 55,4 & 2 & 87,0 & 0,28 & 12,9 & 18,9 \\
\hline R08|1056m10 & 125 & 56 & 119,0 & 55,4 & 3 & 56,2 & 0,43 & 10,1 & 17,6 \\
\hline R08I1056m10 & 125 & 56 & 119,0 & 55,4 & 4 & 41,5 & 0,58 & 7,5 & 18,9 \\
\hline R08\1095002 & 125 & 95 & 120,7 & 95,4 & 1 & - & - & - & - - \\
\hline R08\1095500 & 125 & 95 & 121,2 & 94,9 & 1 & 599,7 & 0,15 & 25,5 & 20,8 \\
\hline R08\1095500 & 125 & 95 & 121,2 & 94,9 & 2 & 301,5 & 0,30 & 20,4 & 16,6 \\
\hline R08\1095500 & 125 & 95 & 121,2 & 94,9 & 3 & 201,4 & 0,45 & 15,4 & 14,6 \\
\hline R08\1095500 & 125 & 95 & 121,2 & 94,9 & 4 & 151,2 & 0,60 & 13,5 & 11,9 \\
\hline R08|1095m10 & 125 & 95 & 122,7 & 94,7 & 1 & 868,1 & 0,10 & 27,9 & 19,8 \\
\hline R08\1095m10 & 125 & 95 & 122,7 & 94,7 & 2 & 377,0 & 0,24 & 21,4 & 15,7 \\
\hline R08\1095m10 & 125 & 95 & 122,7 & 94,7 & 3 & 240,8 & 0,37 & 18,1 & 13,9 \\
\hline R08\1095m10 & 125 & 95 & 122,7 & 94,7 & 4 & 176,9 & 0,51 & 14,5 & 12,1 \\
\hline R08\2095003 & 250 & 95 & 250,8 & 95,9 & 1 & - & - & - & - - \\
\hline R08\2095500 & 250 & 95 & 249,7 & 97,6 & 1 & -- & - & - & - \\
\hline R08\209 & 250 & 95 & 244,3 & 97,8 & 1 & 85,8 & 1,13 & 28,3 & 19,5 \\
\hline R08\2095500b & 250 & 95 & 244,3 & 97,8 & 2 & 29,1 & 3,35 & 20,1 & 17,3 \\
\hline R08\2095500b & 250 & 95 & 244,3 & 97,8 & 3 & 17,5 & 5,56 & 13,1 & 17,1 \\
\hline R08\2095500b & 250 & 95 & 244,3 & 97,8 & 4 & 12,5 & 7,77 & 10,6 & 17,0 \\
\hline R08I2095m10 & 250 & 95 & 249,0 & 97,2 & 1 & 134,9 & 0,71 & 27,7 & 20,2 \\
\hline R0812095m10 & 250 & 95 & 249,0 & 97,2 & 3 & 35,2 & 2,71 & 19,5 & 17,4 \\
\hline R08|2095m10 & 250 & 95 & 249,0 & 97,2 & 4 & 21,5 & 4,45 & 13,6 & 16,0 \\
\hline R08I2095m10 & 250 & 95 & 249,0 & 97,2 & 5 & 16,5 & 5,79 & 10,7 & 16,5 \\
\hline R08\2120002 & 250 & 120 & 250,5 & 120,1 & 1 & - & - & - & \\
\hline R08\2120500 & 250 & 120 & 247,4 & 121,7 & 1 & 963,4 & 0,19 & 30,6 & 18,5 \\
\hline R08\2120500 & 250 & 120 & 247,4 & 121,7 & 2 & 322,3 & 0,57 & 17,6 & 14,0 \\
\hline R08\2120500 & 250 & 120 & 247,4 & 121,7 & 3 & 288,4 & 0,64 & 14,1 & 14,1 \\
\hline R08\2120500 & 250 & 120 & 247,4 & 121,7 & 4 & 213,6 & 0,86 & 12,4 & 14,0 \\
\hline R08|2120m10 & 250 & 120 & 246,5 & 120,7 & 1 & 1017,6 & 0,18 & 29,4 & 16,7 \\
\hline R08I2120m10 & 250 & 120 & 246,5 & 120,7 & 2 & 424,5 & 0,42 & 23,1 & 14,9 \\
\hline R08I2120m10 & 250 & 120 & 246,5 & 120,7 & 3 & 268,2 & 0,67 & 16,5 & 13,9 \\
\hline
\end{tabular}




\section{C.4. Imagens dos Ensaios da Série R08}

Em cada ensaio, são colocados as condições de temperatura de injeção, $T_{0}$, pressão de injeção, $P_{0}$, pressão de saturação à temperatura de injeção, $P_{\text {sat }}$, e a razão entre pressão de vapor e pressão da câmara, $R_{\mathrm{P}}$. A primeira, da seqüência de imagens de cada ensaio, refere-se a uma das imagens típicas adquiridas através do método “Schlieren” e a escala dimensional de $50 \mathrm{~mm}$ é tomada através da plataforma que está na saída do bocal, conforme também é realçado apenas neste primeiro ensaio (1056002)

Dentro de cada ensaio, existem outras imagens que são aquelas tratadas matematicamente com filtro subtrativo e submetidas ao mapa de cor que melhor realça os fenômenos envolvidos assim como, a imagem obtida pela segunda câmara CCD, que utiliza o método de iluminação por detrás. Outras informações como vazão mássica $(\dot{m})$ também é acrescentado em cada ensaio, seguido da velocidade do jato $\left(u_{1}\right)$ na saída do bocal, assim como sua pressão de líquido metaestável $\left(P_{1}\right)$ calculada através da vazão obtida, considerando como incompressível. 

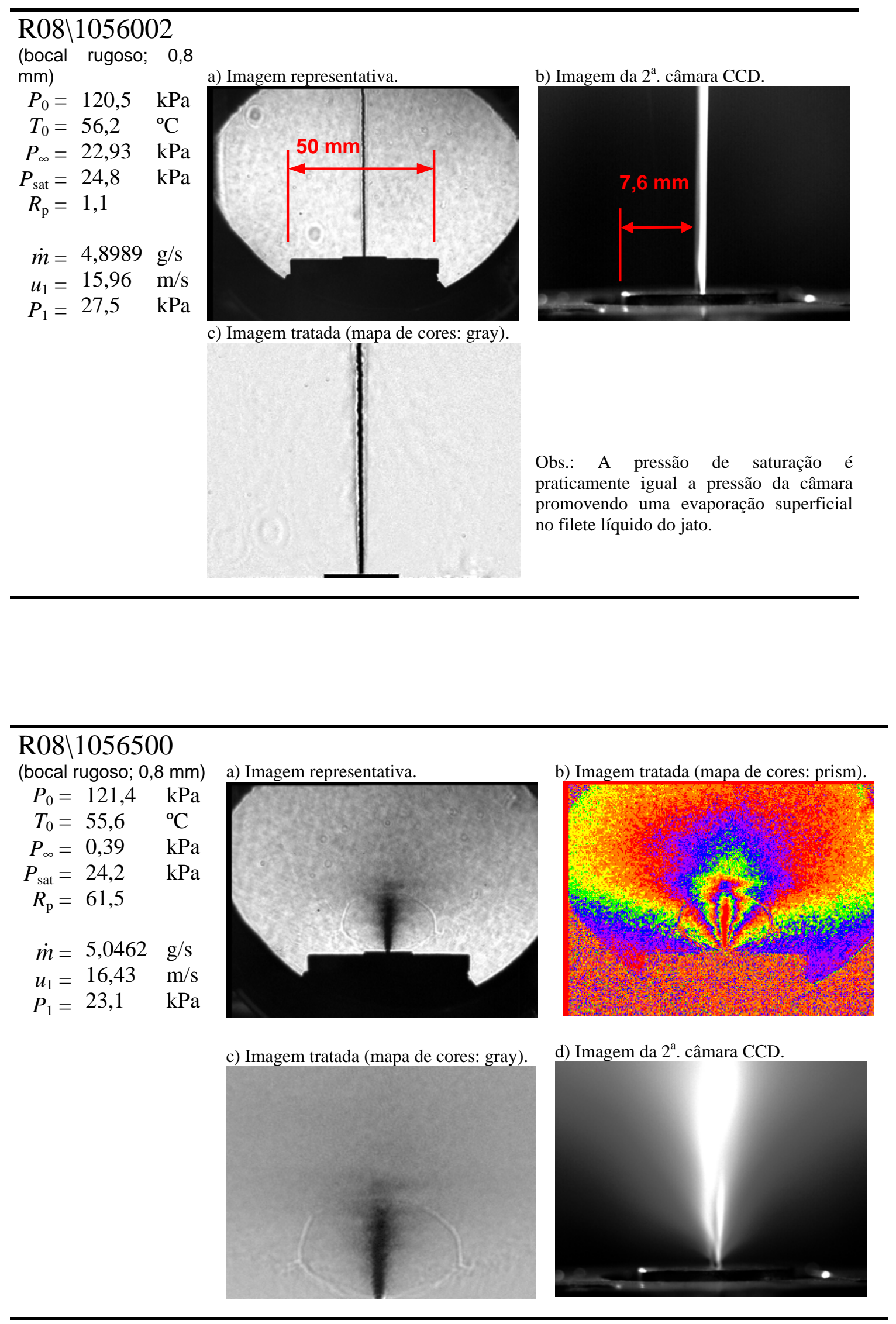

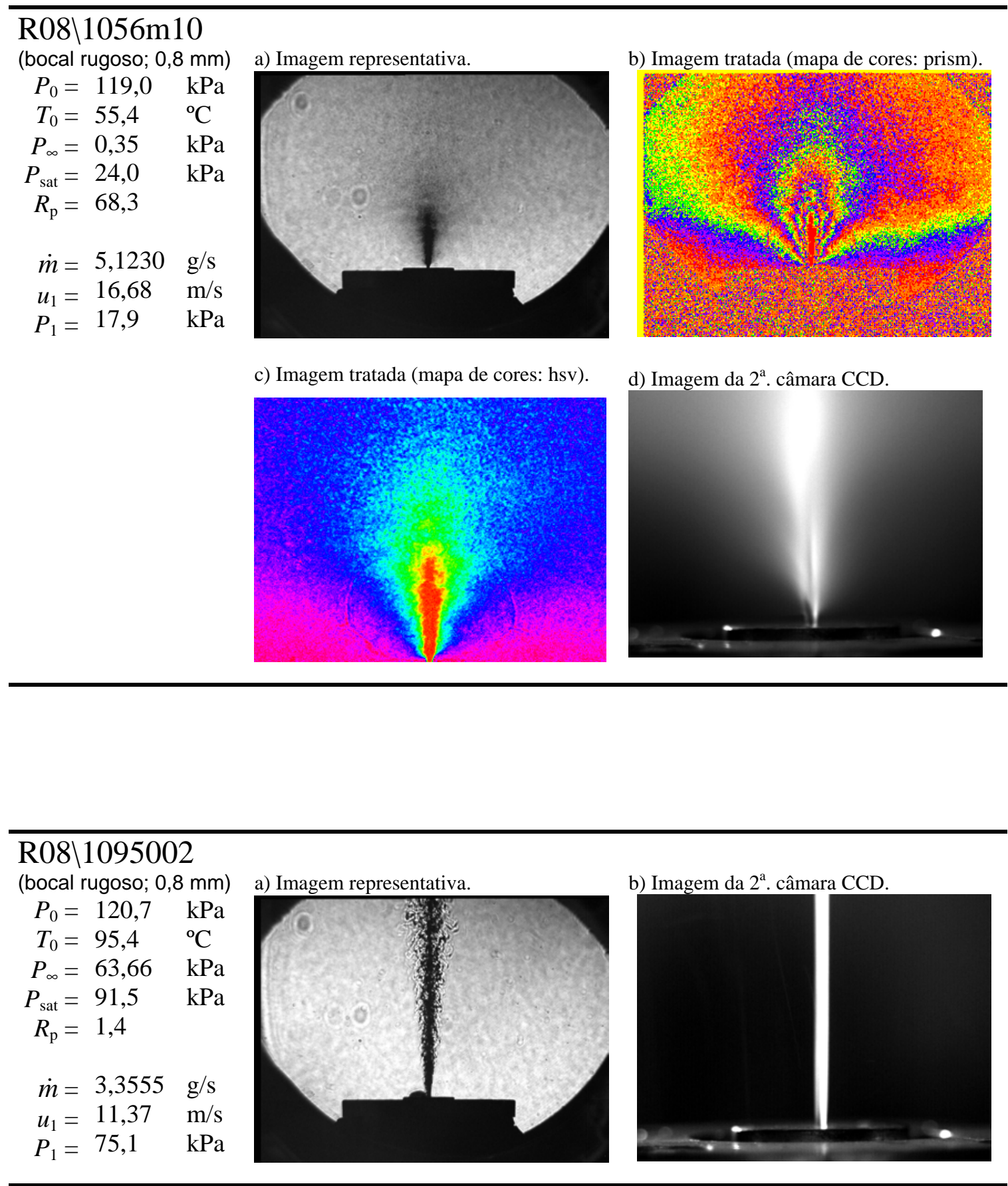


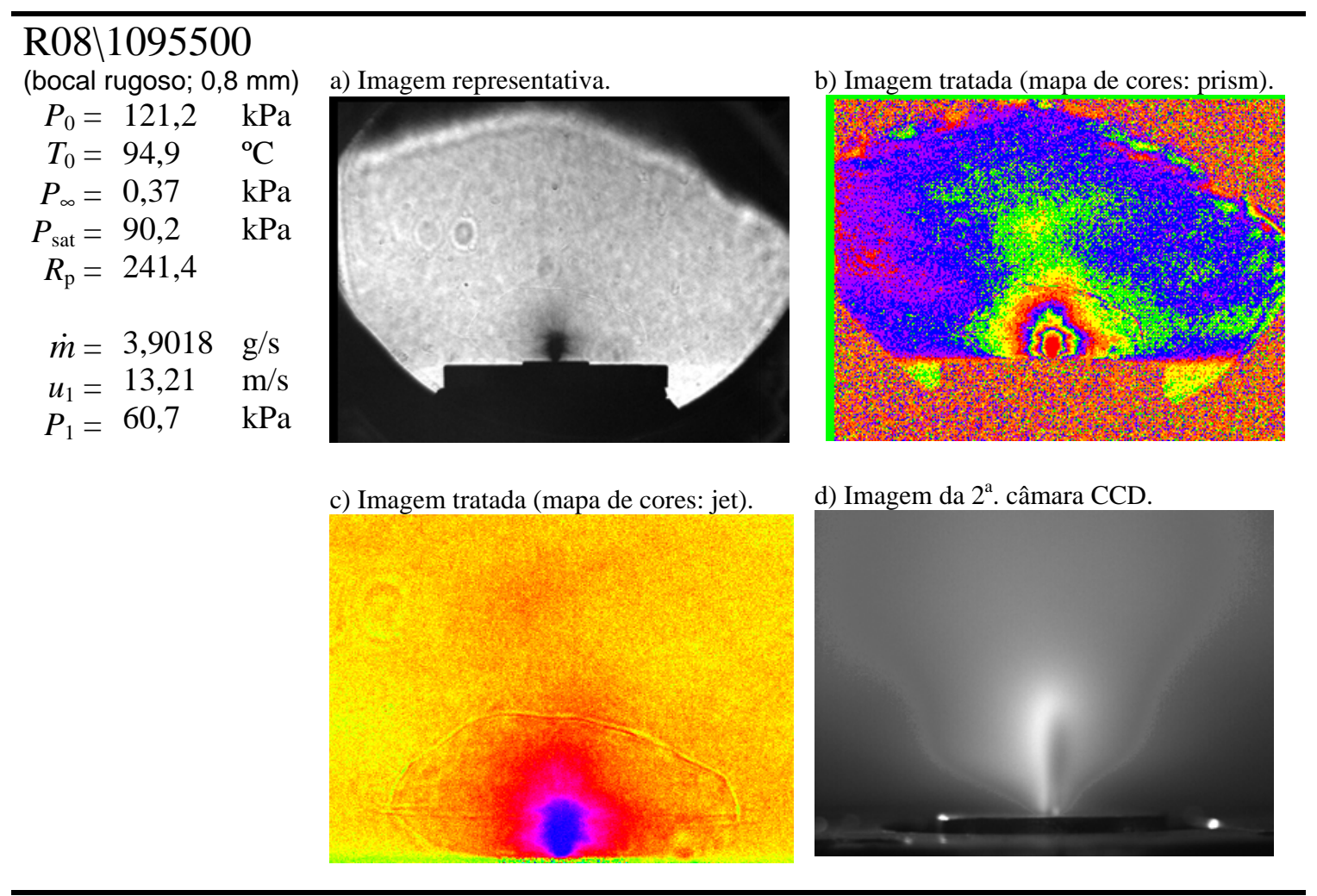

\begin{tabular}{|c|c|c|}
\hline \multicolumn{3}{|c|}{$\begin{array}{l}\mathrm{R} 08 \backslash 1095 \mathrm{~m} 10 \\
\text { (bocal rugoso; 0,8 mm) }\end{array}$} \\
\hline$P_{0}=$ & 122,7 & $\mathrm{kPa}$ \\
\hline$T_{0}=$ & 94,7 & ${ }^{\circ} \mathrm{C}$ \\
\hline$P_{\infty}=$ & 0,31 & $\mathrm{kPa}$ \\
\hline $\begin{aligned} P_{\text {sat }} & = \\
R_{\mathrm{p}} & =\end{aligned}$ & $\begin{array}{l}89,6 \\
293,9\end{array}$ & $\mathrm{kPa}$ \\
\hline$\dot{m}=$ & 3,9716 & $\mathrm{~g} / \mathrm{s}$ \\
\hline$u_{1}=$ & $\begin{array}{l}13,44 \\
602\end{array}$ & $\mathrm{~m} / \mathrm{s}$ \\
\hline$P_{1}=$ & 60,2 & $\mathrm{kPa}$ \\
\hline
\end{tabular}

a) Imagem representativa.

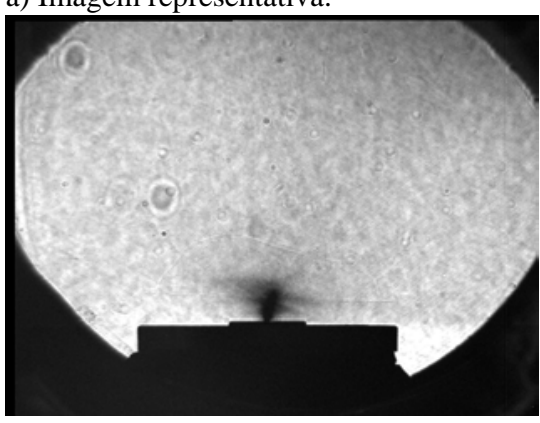

c) Imagem tratada (mapa de cores: jet).

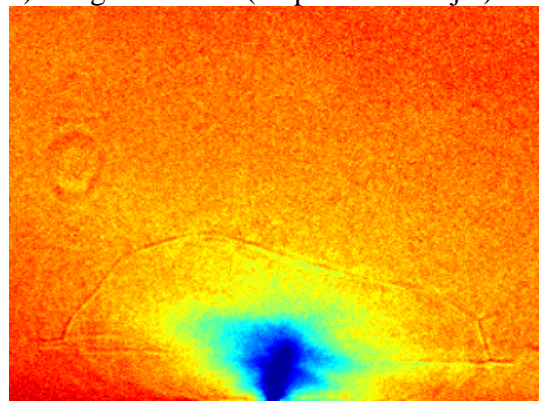

b) Imagem tratada (mapa de cores: prism).

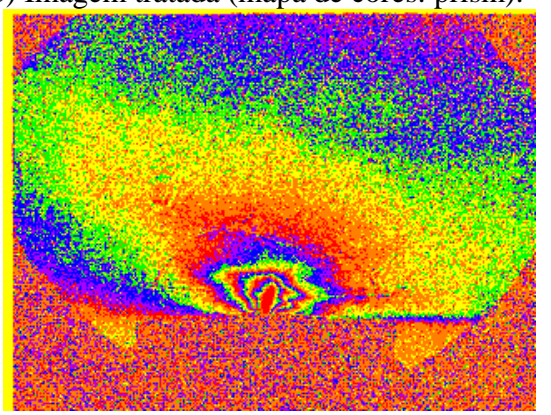

d) Imagem da $2^{\mathrm{a}}$. câmara CCD.

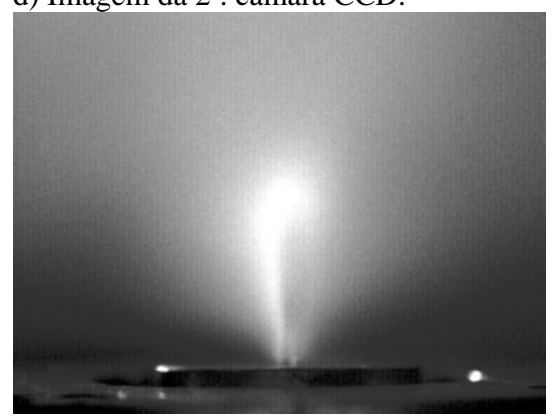



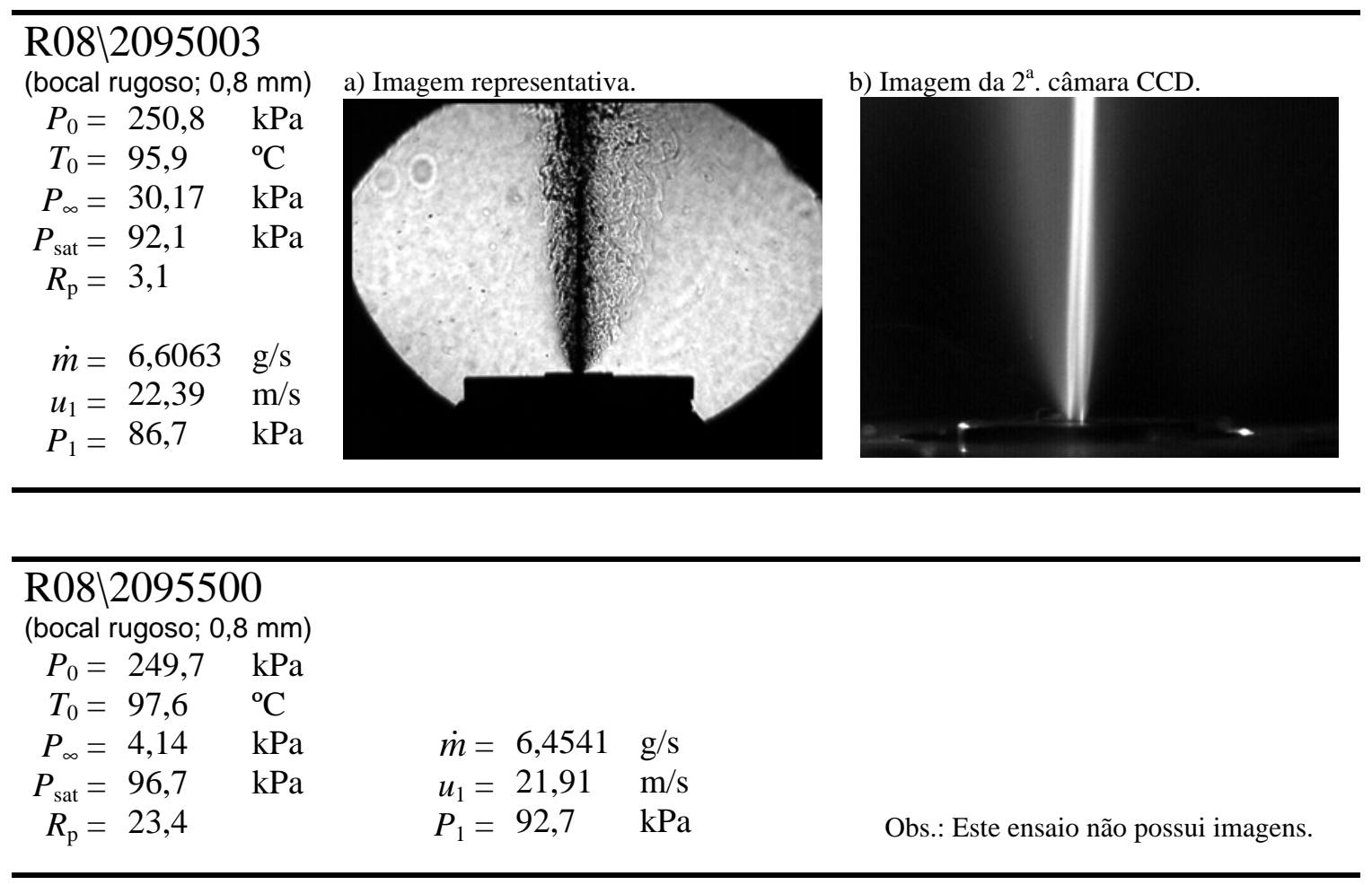

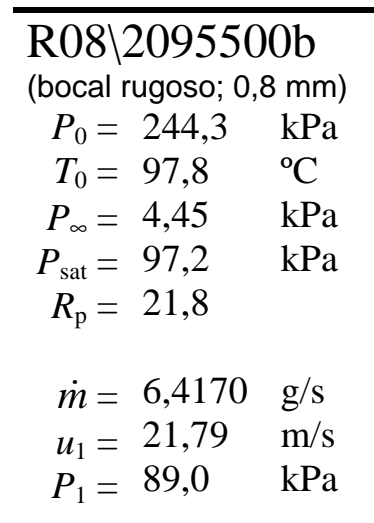

a) Imagem representativa.

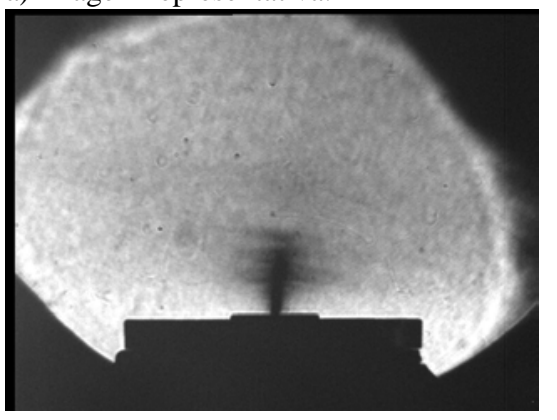

b) Imagem da $2^{\mathrm{a}}$. câmara CCD.

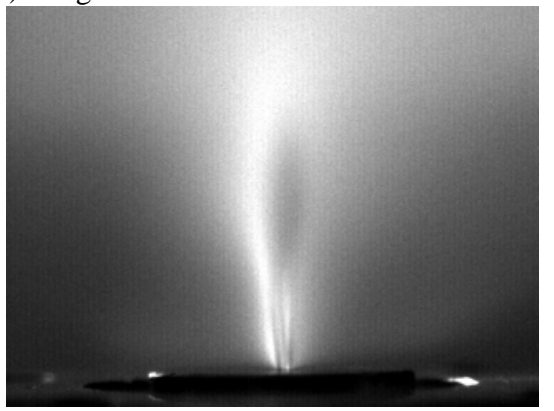

c) Imagem tratada (mapa de cores: gray). 

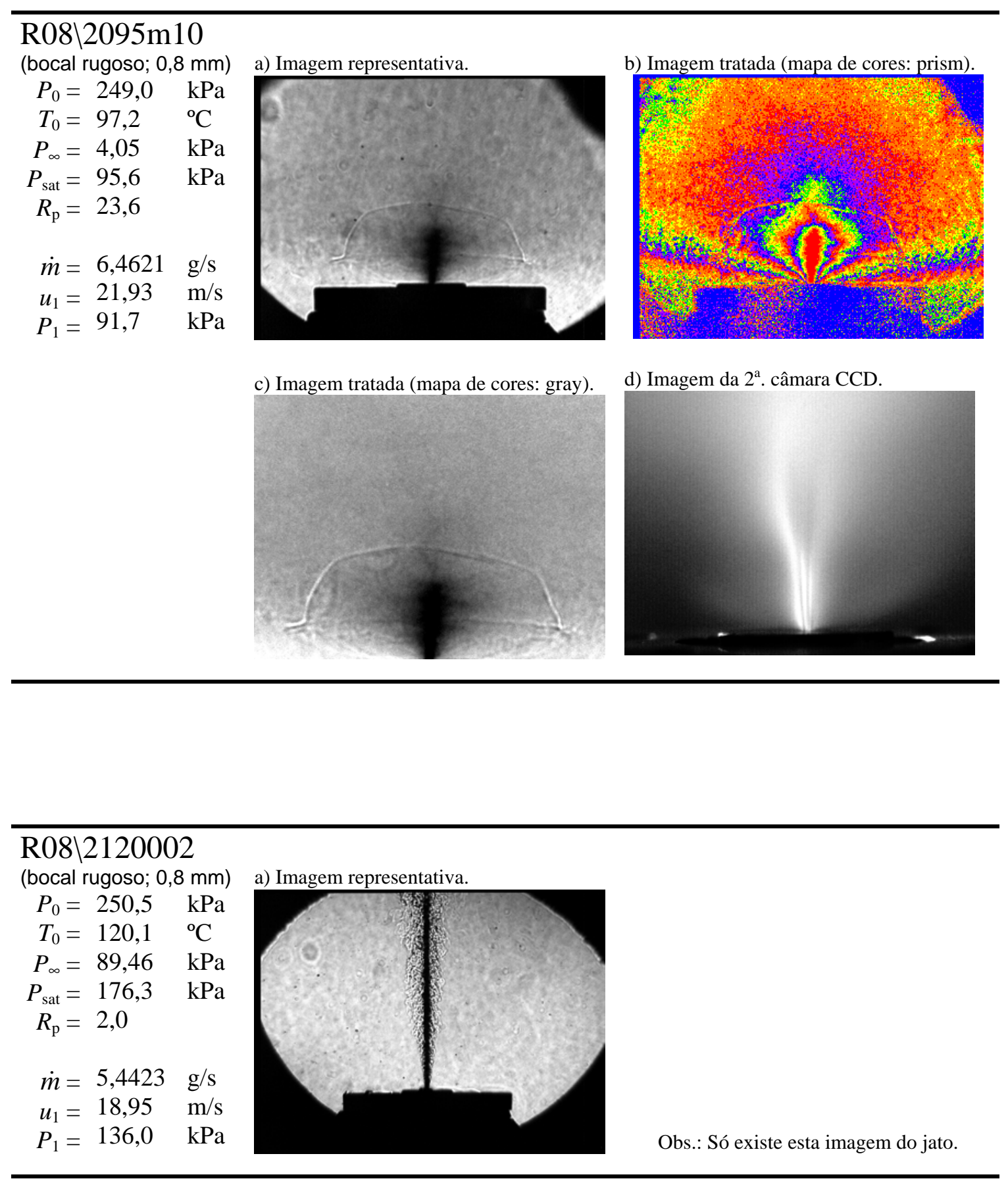


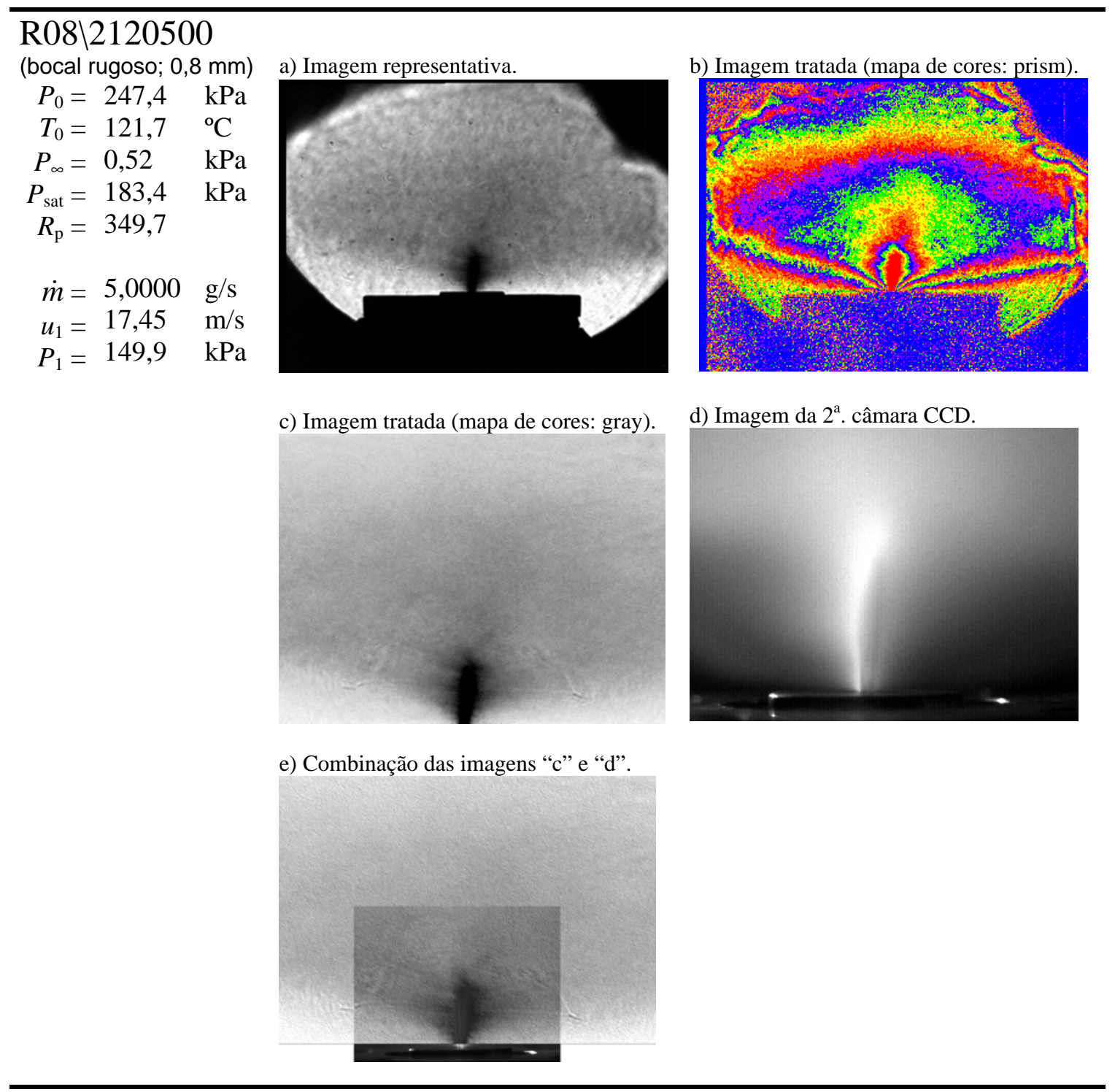




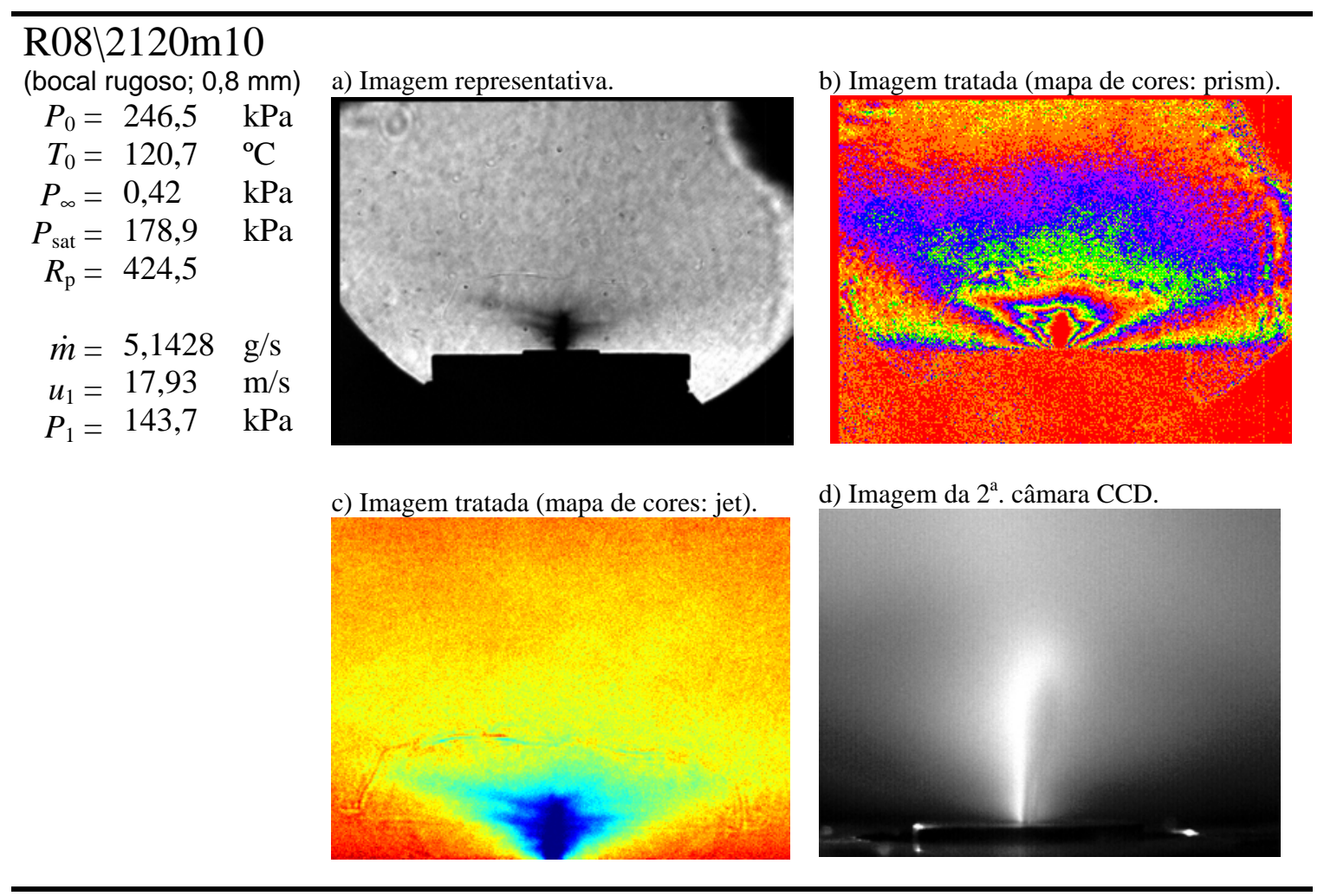

(bocal rugoso; $0.8 \mathrm{~mm}$ )

$P_{0}=246,5 \mathrm{kPa}$

$T_{0}=120,7 \quad{ }^{\circ} \mathrm{C}$

$P_{\infty}=0,42 \quad \mathrm{kPa}$

$P_{\text {sat }}=178,9 \quad \mathrm{kPa}$

$R_{\mathrm{p}}=424,5$

$\dot{m}=5,1428 \mathrm{~g} / \mathrm{s}$

$u_{1}=17,93 \mathrm{~m} / \mathrm{s}$

$P_{1}=143,7 \quad \mathrm{kPa}$

c) Imagem tratada (mapa de cores: jet). b) Imagem tratada (mapa de cores: prism)

d) Imagem da $2^{a}$. câmara CCD. 


\section{C.5. Medição das Vazões Mássicas - Série V03}

Na Tab. C.4, os ensaios estão apresentados com o código do ensaio, dia de realização, seguido da pressão e temperatura de injeção nominais ( $P_{\text {inj }}$ e $\left.T_{\text {inj }}\right)$. Nas colunas seguintes, estão colocados a pressão e temperatura de injeção medidas $\left(P_{0} \mathrm{e}\right.$ $\left.T_{0}\right)$, a pressão da câmara média $\left(P_{\infty}\right)$ e a razão entre a pressão de vapor e pressão da câmara $\left(R_{\mathrm{P}}\right)$. A partir da nona coluna, consta o número de Reynolds, $R e$, que é calculado através da vazão mássica medida, $\dot{m}$, depois o coeficiente de descarga, $C_{\mathrm{D}}$, cuja curva foi levantada experimentalmente (Eq. C.2), e a vazão mássica estimada, $\dot{m}_{e}$, é obtida através da equação de descarga do bocal (Eq. B.2). O parâmetro, $P_{1}$, corresponde à pressão do líquido metaestável na saída do bocal e é determinada pela equação Eq. (B.4).

$$
C_{D}=0,9963-8,8247 / \sqrt{\operatorname{Re}}
$$

Tabela C.4 - Tabela com os ensaios da série "V03” (bocal de vidro com 0,35 mm de diâmetro).

\begin{tabular}{|c|c|c|c|c|c|c|c|c|c|c|c|c|}
\hline Código & dia & $\begin{array}{c}\boldsymbol{P}_{\text {inj }} \\
(\mathrm{kPa})\end{array}$ & $\begin{array}{l}T_{\text {inj }} \\
\left({ }^{\circ} \mathrm{C}\right) \\
\end{array}$ & $\begin{array}{c}\boldsymbol{P}_{\mathbf{0}} \\
(\mathrm{kPa}) \\
\end{array}$ & $\begin{array}{c}\boldsymbol{T}_{\mathbf{0}} \\
\left({ }^{\circ} \mathrm{C}\right) \\
\end{array}$ & $\begin{array}{c}\boldsymbol{P}_{\infty} \\
(\mathrm{kPa})\end{array}$ & $\boldsymbol{R}_{\mathbf{P}}$ & $\mathbf{R e}$ & $\mathbf{C}_{\mathbf{D}}$ & $\begin{array}{c}\text { medido } \\
\dot{m} \\
(\mathrm{~g} / \mathrm{s}) \\
\end{array}$ & $\begin{array}{c}\text { estimado } \\
m_{\mathrm{e}} \\
(\mathrm{g} / \mathrm{s}) \\
\end{array}$ & $\begin{array}{c}\boldsymbol{P}_{\mathbf{1}} \\
(\mathrm{kPa}) \\
\end{array}$ \\
\hline V03\1329500 & 16-nov-04 & 125 & 56 & 123,5 & 56,7 & 0,27 & 92,3 & 12579 & 0,9176 & 1,1637 & 1,1955 & 6,7 \\
\hline V03।1329m10 & 16-nov-04 & 125 & 56 & 121,7 & 56,5 & 0,35 & 72,5 & 12444 & 0,9172 & 1,1534 & 1,1860 & 6,9 \\
\hline V03\1349100 & 05-nov-04 & 125 & 76 & 122,8 & 76,6 & 0,48 & 107,3 & 14339 & 0,9226 & 1,1119 & 1,1856 & 15,2 \\
\hline V03\1349500 & 05-nov-04 & 125 & 76 & 121,2 & 76,3 & 0,23 & 219,3 & 14143 & 0,9221 & 1,0995 & 1,1785 & 15,9 \\
\hline V03\1349m10 & 05-nov-04 & 125 & 76 & 123,9 & 76,6 & 0,24 & 215,3 & 14426 & 0,9228 & 1,1186 & 1,1923 & 15,1 \\
\hline V03।1368100 & 05-nov-04 & 125 & 95 & 123,2 & 94,4 & 0,86 & 102,8 & 15892 & 0,9263 & 1,0670 & 1,1803 & 23,2 \\
\hline V03\1368500 & 05-nov-04 & 125 & 95 & 123,7 & 95,0 & 0,23 & 397,6 & 16064 & 0,9267 & 1,0735 & 1,1859 & 22,5 \\
\hline V03\1368m10 & 05-nov-04 & 125 & 95 & 143,2 & 95,1 & 0,20 & 461,6 & 17631 & 0,9299 & 1,1773 & 1,2806 & 22,3 \\
\hline V03|2329100 & 15-dez-04 & 250 & 56 & 248,6 & 57,4 & 0,41 & 63,2 & 18036 & 0,9306 & 1,6576 & 1,7200 & 18,1 \\
\hline V0312349500 & 15-dez-04 & 250 & 76 & 249,9 & 74,8 & 1,70 & 28,5 & 20739 & 0,9350 & 1,6326 & 1,7130 & 24,4 \\
\hline V03\2349m10 & 15-dez-04 & 250 & 76 & 249,7 & 76,7 & 0,52 & 98,3 & 20906 & 0,9353 & 1,6197 & 1,7153 & 27,5 \\
\hline V03।2368500 & 22-dez-04 & 250 & 95 & 250,8 & 94,4 & 0,34 & 259,6 & 24028 & 0,9394 & 1,6133 & 1,7127 & 28,6 \\
\hline V0312393500 & 15-dez-04 & 250 & 120 & 250,4 & 120,1 & 0,60 & 293,9 & 27051 & 0,9427 & 1,4921 & 1,6918 & 56,1 \\
\hline V03।2393m10 & 15-dez-04 & 250 & 120 & 255,4 & 120,6 & 0,53 & 339,3 & 26895 & 0,9425 & 1,4779 & 1,7081 & 64,6 \\
\hline V03।5349500 & 22-dez-04 & 500 & 76 & 504,3 & 76,6 & 0,58 & 88,5 & 30522 & 0,9458 & 2,3667 & 2,4663 & 40,4 \\
\hline V03।5349m10 & 22-dez-04 & 500 & 76 & 501,0 & 76,3 & 0,46 & 110,1 & 30244 & 0,9456 & 2,3511 & 2,4583 & 43,2 \\
\hline V03।5393500 & 16-dez-04 & 500 & 120 & 496,5 & 122,5 & 0,75 & 252,0 & 40063 & 0,9522 & 2,1703 & 2,4037 & 92,3 \\
\hline V03।5393m10 & 16-dez-04 & 500 & 120 & 499,6 & 119,2 & 0,36 & 486,1 & 39622 & 0,9520 & 2,2003 & 2,4168 & 85,8 \\
\hline
\end{tabular}




\section{C.6. Medição do Comprimento de Extinção do Núcleo Líquido - Série V03}

$\mathrm{Na}$ Tab. C.5, são vistos os valores obtidos dos ensaios com os valores nominais de pressão e temperatura de injeção $\left(P_{\text {inj }}\right.$ e $\left.T_{\text {inj }}\right)$, seguida da pressão de saturação $\left(P_{\text {sat }}\right)$ à temperatura de injeção $\left(T_{0}\right)$, pressão da câmara $\left(P_{\infty}\right)$ e a razão entre a pressão de saturação e a pressão de injeção $\left(P_{\text {sat }} / P_{0}\right)$. O comprimento de extinção $\left(L_{\mathrm{E}}\right)$ é a próxima coluna e depois, está a razão entre a comprimento de extinção do líquido e o diâmetro do bocal $\left(L_{\mathrm{E}} / D_{\mathrm{b}}\right)$.

Tabela C.5 - Relação do comprimento do núcleo líquido de cada ensaio - Série V03 (bocal de vidro com 0,35 mm de diâmetro).

\begin{tabular}{|c|c|c|c|c|c|c|c|}
\hline Ensaio & $\begin{array}{c}P_{\text {inj }} \\
(\mathrm{kPa}) \\
\end{array}$ & $\begin{array}{l}T_{\text {inj }} \\
\left({ }^{\circ} \mathrm{C}\right) \\
\end{array}$ & $\begin{array}{c}P_{\text {sat }} \\
(\mathrm{kPa}) \\
\end{array}$ & $\begin{array}{c}P_{\infty} \\
(\mathrm{kPa}) \\
\end{array}$ & $P_{\text {sat }} / P_{0}$ & $\begin{array}{c}L_{\mathrm{E}} \\
(\mathrm{mm}) \\
\end{array}$ & $L_{\mathrm{E}} / D_{\mathrm{b}}$ \\
\hline V03\1329500 & 125 & 56 & 25,2 & 0,27 & 0,204 & 7,8 & 22,35 \\
\hline V03\1329m10 & 125 & 56 & 25,1 & 0,35 & 0,206 & 7,5 & 21,55 \\
\hline V03\1349100 & 125 & 76 & 51,2 & 0,48 & 0,417 & 6,1 & 17,51 \\
\hline V03\1349500 & 125 & 76 & 50,8 & 0,23 & 0,419 & 6,1 & 17,51 \\
\hline V03।1349m10 & 125 & 76 & 51,2 & 0,24 & 0,413 & 6,4 & 18,31 \\
\hline V03\1368100 & 125 & 95 & 88,8 & 0,86 & 0,721 & 4,6 & 13,13 \\
\hline V03\1368500 & 125 & 95 & 90,5 & 0,23 & 0,731 & 4,4 & 12,44 \\
\hline V03\1368m10 & 125 & 95 & 90,7 & 0,20 & 0,633 & 4,9 & 13,87 \\
\hline V03\2329100 & 250 & 56 & 25,9 & 0,41 & 0,104 & 10,9 & 31,21 \\
\hline V0312349500 & 250 & 76 & 48,4 & 1,70 & 0,194 & 7,8 & 22,35 \\
\hline V03।2349m10 & 250 & 76 & 51,4 & 0,52 & 0,206 & 8,0 & 22,75 \\
\hline V0312368500 & 250 & 95 & 88,8 & 0,34 & 0,354 & 5,6 & 15,96 \\
\hline V03।2393500 & 250 & 120 & 176,3 & 0,60 & 0,704 & 4,2 & 11,94 \\
\hline V03।2393m10 & 250 & 120 & 178,7 & 0,53 & 0,699 & 3,9 & 11,14 \\
\hline V03\5349500 & 500 & 76 & 51,2 & 0,58 & 0,102 & 11,0 & 31,53 \\
\hline V03\5349m10 & 500 & 76 & 50,8 & 0,46 & 0,101 & 11,2 & 32,01 \\
\hline V03\5393500 & 500 & 120 & 187,7 & 0,75 & 0,378 & 5,3 & 15,12 \\
\hline V03।5393m10 & 500 & 120 & 172,6 & 0,36 & 0,345 & 5,6 & 15,96 \\
\hline
\end{tabular}

\section{C.7. Medição das Dimensões da Estrutura da Onda de Choque - Série V03}

Na Tab. C.6 estão apresentados os ensaios seguidos da série, categoria da pressão e temperatura de injeção. Logo após estão os valores exatos da pressão e temperatura de injeção. São adquiridas várias imagens de um único ensaio e, para cada uma delas, é correlacionada a pressão da câmara e a razão entre as pressões de saturação e da câmara com as dimensões do raio e da distância axial da onda de 
choque formada neste devido instante. Na seção seguinte estão as imagens destes ensaios.

Tabela C.6 - Relação das dimensões da onda de choque formada como o raio, $r_{1}$ e a distancia axial, $r_{2}$ (bocal de vidro com 0,35 mm de diâmetro).

\begin{tabular}{|c|c|c|c|c|c|c|c|c|c|}
\hline Ensaio & $\begin{array}{r}P_{\text {inj }} \\
(\mathrm{kPa})\end{array}$ & $\begin{array}{r}T_{\mathrm{inj}} \\
\left({ }^{\circ} \mathrm{C}\right) \\
\end{array}$ & $\begin{array}{c}P_{0} \\
(\mathrm{kPa})\end{array}$ & $\begin{array}{c}T_{0} \\
\left({ }^{\circ} \mathrm{C}\right) \\
\end{array}$ & Imagem & $\begin{array}{c}R_{\mathrm{P}} \\
(\mathrm{kPa})\end{array}$ & $\begin{array}{c}P_{\infty} \\
(\mathrm{kPa})\end{array}$ & $\begin{array}{c}r_{1} \\
(\mathrm{~mm})\end{array}$ & $\begin{array}{c}r_{2} \\
(\mathrm{~mm})\end{array}$ \\
\hline V03\1329500 & 125 & $\begin{array}{l}56 \\
\end{array}$ & 123,5 & 56,7 & $\overline{l 1}$ & $\begin{array}{l}177 \\
\end{array}$ & $\begin{array}{l}0,14 \\
\end{array}$ & 10,7 & 13,4 \\
\hline V03।1329500 & 125 & 56 & 123,5 & 56,7 & 3 & 120 & 0,21 & 9,6 & 11,7 \\
\hline V03l1329500 & 125 & 56 & 123,5 & 56,7 & 6 & 72 & 0,35 & 6,5 & 9,8 \\
\hline V03\1329500 & 125 & 56 & 123,5 & 56,7 & 7 & 69 & 0,37 & 5,7 & 9,8 \\
\hline V03\1329500 & 125 & 56 & 123,5 & 56,7 & 8 & 62 & 0,40 & 5,5 & 9,9 \\
\hline V03\1329m10 & 125 & 56 & 121,7 & 56,5 & 1 & 184 & 0,14 & 11,9 & 13,5 \\
\hline V03\1329m10 & 125 & 56 & 121,7 & 56,5 & 2 & 117 & 0,21 & 9,9 & 12,3 \\
\hline V03\1329m10 & 125 & 56 & 121,7 & 56,5 & 4 & 85 & 0,29 & 7,9 & 10,8 \\
\hline V03\1329m10 & 125 & 56 & 121,7 & 56,5 & 5 & 78 & 0,32 & 7,7 & 10,3 \\
\hline V03\1329m10 & 125 & 56 & 121,7 & 56,5 & 7 & 56 & 0,45 & 6,5 & 9,8 \\
\hline V03\1349100 & 125 & 76 & 122,8 & 76,6 & 1 & 147 & 0,35 & 7,6 & 8,2 \\
\hline V03\1349100 & 125 & 76 & 122,8 & 76,6 & 2 & 133 & 0,39 & 7,3 & 7,8 \\
\hline V03\1349100 & 125 & 76 & 122,8 & 76,6 & 5 & 103 & 0,50 & 6,0 & 7,1 \\
\hline V03\1349100 & 125 & 76 & 122,8 & 76,6 & 8 & 84 & 0,61 & 5,4 & 7,0 \\
\hline V03\1349500 & 125 & 76 & 121,2 & 76,3 & 1 & 527 & 0,10 & 15,9 & 12,4 \\
\hline V03\1349500 & 125 & 76 & 121,2 & 76,3 & 2 & 376 & 0,13 & 13,6 & 11,3 \\
\hline V03\1349500 & 125 & 76 & 121,2 & 76,3 & 6 & 175 & 0,29 & 9,0 & 8,4 \\
\hline V03\1349500 & 125 & 76 & 121,2 & 76,3 & 8 & 138 & 0,37 & 8,3 & 8,4 \\
\hline V03\1349m10 & 125 & 76 & 123,9 & 76,6 & 1 & 505 & 0,10 & 15,6 & 11,8 \\
\hline V03\1349m10 & 125 & 76 & 123,9 & 76,6 & 2 & 365 & 0,14 & 13,8 & 10,6 \\
\hline V03\1349m10 & 125 & 76 & 123,9 & 76,6 & 6 & 173 & 0,30 & 9,3 & 9,6 \\
\hline V03\1349m10 & 125 & 76 & 123,9 & 76,6 & 8 & 137 & 0,37 & 7,9 & 8,2 \\
\hline V03\1368100 & 125 & 95 & 123,2 & 94,4 & 1 & 123 & 0,72 & 6,1 & 6,0 \\
\hline V03\1368100 & 125 & 95 & 123,2 & 94,4 & 2 & 117 & 0,76 & 6,0 & 5,9 \\
\hline V03\1368100 & 125 & 95 & 123,2 & 94,4 & 4 & 105 & 0,84 & 5,8 & 5,9 \\
\hline V03\1368100 & 125 & 95 & 123,2 & 94,4 & 7 & 92 & 0,97 & 5,3 & 5,6 \\
\hline V03\1368500 & 125 & 95 & 123,7 & 95,0 & 1 & 1083 & 0,08 & 20,8 & 14,9 \\
\hline V03\1368500 & 125 & 95 & 123,7 & 95,0 & 2 & 725 & 0,12 & 17,5 & 13,1 \\
\hline V03\1368500 & 125 & 95 & 123,7 & 95,0 & 4 & 437 & 0,21 & 14,1 & 10,0 \\
\hline V03\1368500 & 125 & 95 & 123,7 & 95,0 & 6 & 313 & 0,29 & 12,1 & 9,5 \\
\hline V03\1368m10 & 125 & 95 & 143,2 & 95,1 & 1 & 1546 & 0,06 & 24,0 & 17,3 \\
\hline V03l1368m10 & 125 & 95 & 143,2 & 95,1 & 2 & 770 & 0,12 & 19,0 & 12,7 \\
\hline V03\1368m10 & 125 & 95 & 143,2 & 95,1 & 6 & 355 & 0,26 & 12,8 & 9,2 \\
\hline V03\1368m10 & 125 & 95 & 143,2 & 95,1 & 8 & 271 & 0,33 & 11,4 & 8,5 \\
\hline V03।2329100 & 250 & 56 & 248,6 & 57,4 & 1 & 99 & 0,26 & 8,7 & 12,9 \\
\hline V0312329100 & 250 & 56 & 248,6 & 57,4 & 2 & 85 & 0,30 & 7,9 & 12,9 \\
\hline V03।2329100 & 250 & 56 & 248,6 & 57,4 & 4 & 67 & 0,39 & 5,3 & 12,5 \\
\hline V0312329100 & 250 & 56 & 248,6 & 57,4 & 6 & 55 & 0,47 & 5,3 & 11,9 \\
\hline V0312349500 & 250 & 76 & 249,9 & 74,8 & 1 & 29 & 1,67 & 5,7 & 9,2 \\
\hline V0312349500 & 250 & 76 & 249,9 & 74,8 & 2 & 29 & 1,68 & 5,6 & 8,7 \\
\hline V0312349500 & 250 & 76 & 249,9 & 74,8 & 4 & 29 & 1,69 & 5,0 & 8,7 \\
\hline V0312349500 & 250 & 76 & 249,9 & 74,8 & 6 & 28 & 1,71 & 4,5 & 8,5 \\
\hline
\end{tabular}

continua... 
...continuação da Tab. C.6.

\begin{tabular}{|c|c|c|c|c|c|c|c|c|c|}
\hline Ensaio & $\begin{array}{c}P_{\text {inj }} \\
(\mathrm{kPa}) \\
\end{array}$ & $\begin{array}{l}T_{\text {inj }} \\
\left({ }^{\circ} \mathrm{C}\right) \\
\end{array}$ & $\begin{array}{c}P_{0} \\
(\mathrm{kPa}) \\
\end{array}$ & $\begin{array}{c}T_{0} \\
\left({ }^{\circ} \mathrm{C}\right) \\
\end{array}$ & Imagem & $\begin{array}{c}R_{\mathrm{P}} \\
(\mathrm{kPa}) \\
\end{array}$ & $\begin{array}{c}P_{\infty} \\
(\mathrm{kPa}) \\
\end{array}$ & $\begin{array}{c}r_{1} \\
(\mathrm{~mm}) \\
\end{array}$ & $\begin{array}{c}r_{2} \\
(\mathrm{~mm}) \\
\end{array}$ \\
\hline V0312349m10 & 250 & 76 & 249,7 & 76,7 & 1 & 140 & 0,37 & 10,8 & 10,3 \\
\hline V03।2349m10 & 250 & 76 & 249,7 & 76,7 & 2 & 125 & 0,41 & 10,0 & 10,2 \\
\hline V03\2349m10 & 250 & 76 & 249,7 & 76,7 & 4 & 103 & 0,50 & 8,5 & 10,1 \\
\hline V03।2349m10 & 250 & 76 & 249,7 & 76,7 & 6 & 87 & 0,59 & 7,1 & 8,8 \\
\hline V03।2368500 & 250 & 95 & 250,8 & 94,4 & 1 & 386 & 0,23 & 14,6 & 9,5 \\
\hline V03।2368500 & 250 & 95 & 250,8 & 94,4 & 2 & 339 & 0,26 & 13,0 & 9,4 \\
\hline V03\2368500 & 250 & 95 & 250,8 & 94,4 & 3 & 302 & 0,29 & 11,6 & 8,7 \\
\hline V03\2368500 & 250 & 95 & 250,8 & 94,4 & 4 & 272 & 0,33 & 10,8 & 8,4 \\
\hline V0312393500 & 250 & 120 & 250,4 & 120,1 & 1 & 415 & 0,43 & 13,5 & 7,9 \\
\hline V03।2393500 & 250 & 120 & 250,4 & 120,1 & 2 & 371 & 0,48 & 12,1 & 6,3 \\
\hline V0312393500 & 250 & 120 & 250,4 & 120,1 & 3 & 336 & 0,53 & 11,6 & 6,0 \\
\hline V0312393500 & 250 & 120 & 250,4 & 120,1 & 6 & 261 & 0,68 & 9,8 & 5,4 \\
\hline V0312393500 & 250 & 120 & 250,4 & 120,1 & 8 & 227 & 0,78 & 8,6 & 6,0 \\
\hline V03\2393m10 & 250 & 120 & 255,4 & 120,6 & 1 & 565 & 0,32 & 16,5 & 8,4 \\
\hline V03।2393m10 & 250 & 120 & 255,4 & 120,6 & 2 & 475 & 0,38 & 15,2 & 7,9 \\
\hline V03\2393m10 & 250 & 120 & 255,4 & 120,6 & 3 & 409 & 0,44 & 12,6 & 7,0 \\
\hline V03\2393m10 & 250 & 120 & 255,4 & 120,6 & 6 & 290 & 0,62 & 11,0 & 5,9 \\
\hline V03।2393m10 & 250 & 120 & 255,4 & 120,6 & 8 & 242 & 0,74 & 10,4 & 5,6 \\
\hline V03।5349500 & 500 & 76 & 504,3 & 76,6 & 1 & 112 & 0,46 & 11,6 & 15,9 \\
\hline V03\5349500 & 500 & 76 & 504,3 & 76,6 & 2 & 104 & 0,49 & 10,2 & 13,8 \\
\hline V03।5349500 & 500 & 76 & 504,3 & 76,6 & 3 & 97 & 0,53 & 8,3 & 13,0 \\
\hline V03।5349500 & 500 & 76 & 504,3 & 76,6 & 4 & 91 & 0,56 & 8,9 & 13,3 \\
\hline V03।5349m10 & 500 & 76 & 501,0 & 76,3 & 1 & 282 & 0,18 & 17,2 & 16,7 \\
\hline V03।5349m10 & 500 & 76 & 501,0 & 76,3 & 2 & 195 & 0,26 & 13,6 & 15,7 \\
\hline V03\5349m10 & 500 & 76 & 501,0 & 76,3 & 3 & 149 & 0,34 & 11,9 & 14,4 \\
\hline V03।5349m10 & 500 & 76 & 501,0 & 76,3 & 4 & 121 & 0,42 & 10,3 & 13,3 \\
\hline V03।5393500 & 500 & 120 & 496,5 & 122,5 & 1 & 282 & 0,67 & 13,0 & 7,8 \\
\hline V03।5393500 & 500 & 120 & 496,5 & 122,5 & 2 & 273 & 0,69 & 12,1 & 7,7 \\
\hline V03।5393500 & 500 & 120 & 496,5 & 122,5 & 3 & 264 & 0,71 & 11,2 & 7,4 \\
\hline V03।5393500 & 500 & 120 & 496,5 & 122,5 & 4 & 256 & 0,73 & 10,2 & 7,4 \\
\hline V03।5393m10 & 500 & 120 & 499,6 & 119,2 & 1 & 855 & 0,20 & 21,2 & 13,1 \\
\hline V03।5393m10 & 500 & 120 & 499,6 & 119,2 & 2 & 703 & 0,25 & 19,7 & 10,8 \\
\hline V03।5393m10 & 500 & 120 & 499,6 & 119,2 & 3 & 596 & 0,29 & 16,2 & 10,1 \\
\hline V03।5393m10 & 500 & 120 & 499,6 & 119,2 & 4 & 518 & 0,33 & 14,4 & 8,4 \\
\hline
\end{tabular}




\section{C.8. Imagens dos Ensaios da Série V03}

A seguir são mostradas as imagens dos ensaios realizados utilizando a mesma substância iso-octano. Para cada ensaio são colocados as condições de temperatura de injeção, $T_{0}$, pressão de injeção, $P_{0}$, e a razão entre pressão de vapor e pressão da câmara, $R_{\mathrm{P}}=P_{\text {sat }} / P_{\infty}$. A primeira, da seqüência de imagens de cada ensaio, refere-se a uma das imagens originais adquiridas através do método "Schlieren” e a escala dimensional de $50 \mathrm{~mm}$ também é tomada através da plataforma que está na saída do bocal, conforme também é realçado apenas neste primeiro ensaio (1329500). Além disso, nas imagens da $2^{\mathrm{a}}$. câmara CCD, este ensaio apresenta uma escala dimensional de 5,2 mm que se refere a distância da linha de centro do jato até o canto do bocal, indicado na imagem. Apenas poucas imagens têm uma escala indicativa. Isto deve ocorrer quando a onda de choque pouco se destaca, não permitindo ao leitor este comparativo dimensional na imagem representativa.

Dentro de cada ensaio, existem outras imagens que são aquelas tratadas matematicamente com filtro subtrativo e submetidas ao mapa de cor que melhor realça os fenômenos envolvidos. As informações de pressão $\left(P_{0}\right)$ e temperatura $\left(T_{0}\right)$ de injeção do ensaio, assim como, a pressão média da câmara $\left(P_{\infty}\right)$ onde é descarregado o jato e a razão entre pressões de saturação e pressão média da câmara $\left(R_{\mathrm{p}}\right)$. A vazão mássica ( $\left.\dot{m}\right)$ também é acrescentado em cada ensaio, seguido da velocidade do jato $\left(u_{1}\right)$ na saída do bocal, assim como sua pressão de líquido metaestável $\left(P_{1}\right)$ calculada através da vazão obtida, considerando como incompressível. 


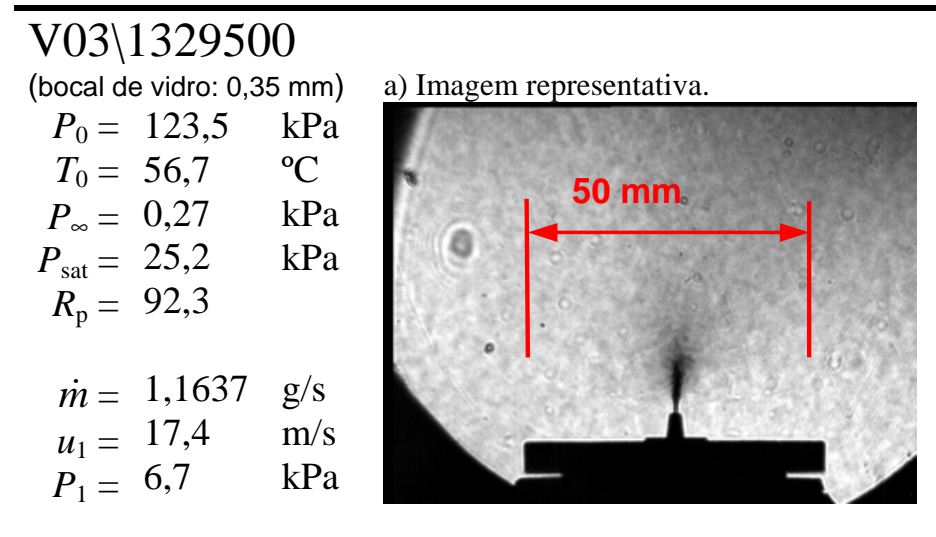

c) Imagem tratada (mapa de cores: jet).

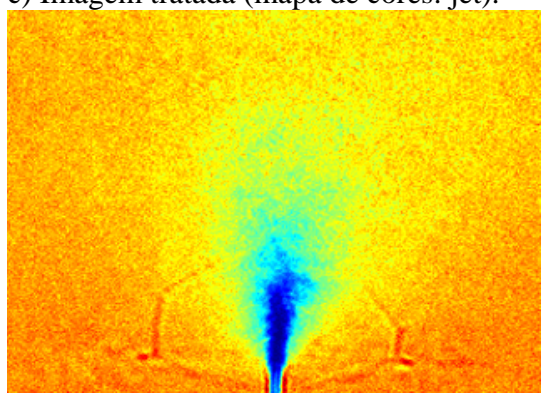

e) Imagem representativa (3 s após abertura do injetor).
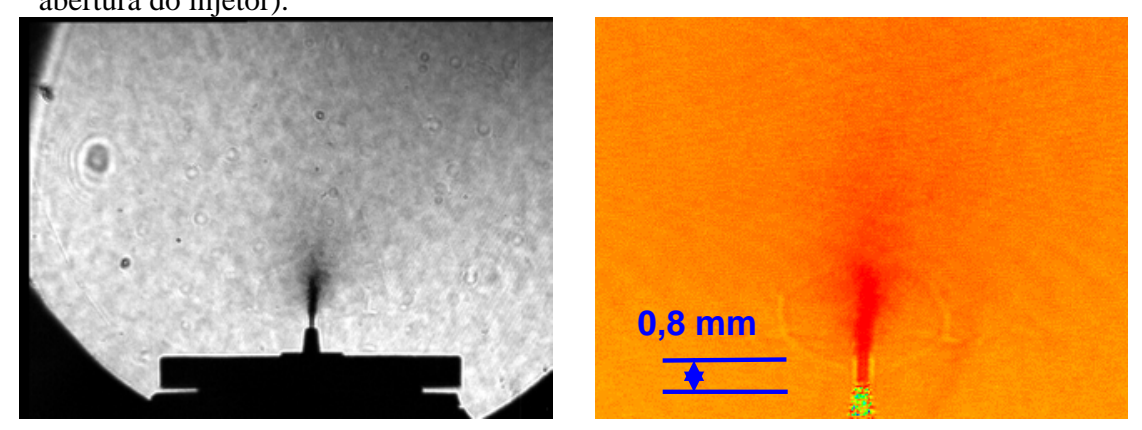

Obs.: o "fechamento" inferior da onda de choque ocorre à $0,8 \mathrm{~mm}$ após a saída do bocal, quando a pressão da câmara aumenta para 0,35 kPa, relativo à imagem "e". Esta posição coincide com o local onde inicia a onda de evaporação vista na imagem "b". No entanto, quando o jato era descarregado em uma pressão da câmara menor, como na imagem "a” que é de $0,21 \mathrm{kPa}$, este "fechamento" ocorreu rente à saída do bocal. c) Imagem “e” tratada (mapa de cores: hsv).

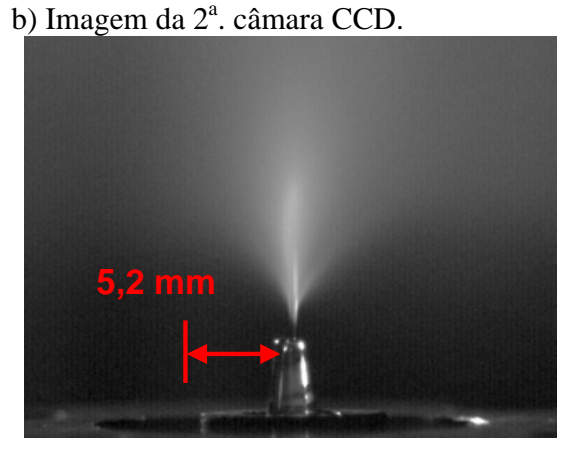

d) Combinação das imagens "b” e "c".

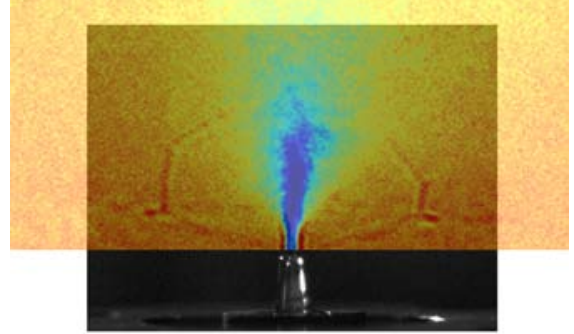




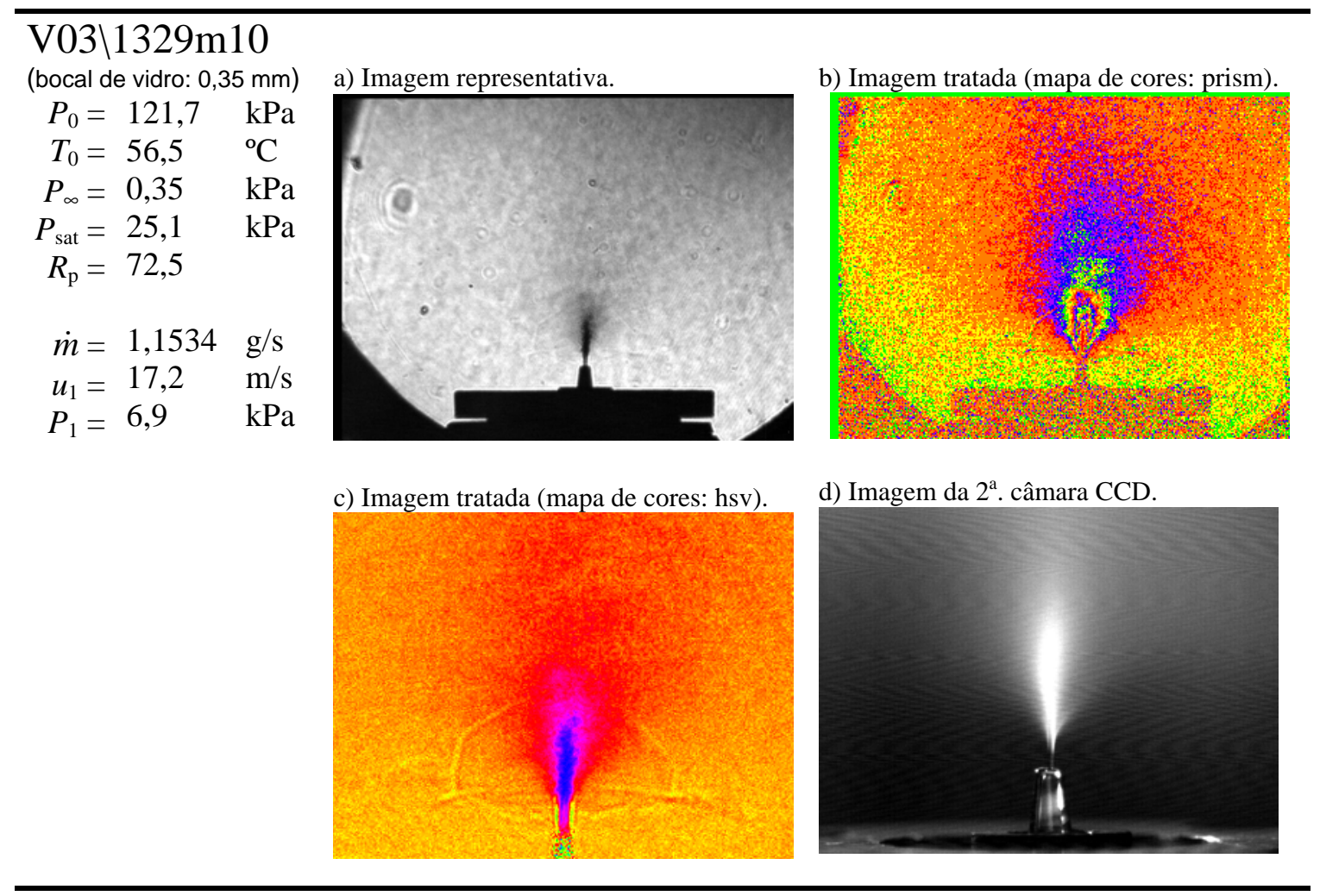

\section{V03 $\backslash 1349100$}

(bocal de vidro: 0,35 mm)

$\begin{array}{rlrl}P_{0} & =122,8 & \mathrm{kPa} \\ T_{0} & =76,6 & { }^{\circ} \mathrm{C} \\ P_{\infty} & =0,48 & \mathrm{kPa} \\ P_{\text {sat }} & =51,2 & \mathrm{kPa} \\ R_{\mathrm{p}} & =107,3 & & \\ \dot{m} & =1,1119 & \mathrm{~g} / \mathrm{s} \\ u_{1} & =17,0 & \mathrm{~m} / \mathrm{s} \\ P_{1} & =15,2 & \mathrm{kPa}\end{array}$

a) Imagem representativa.

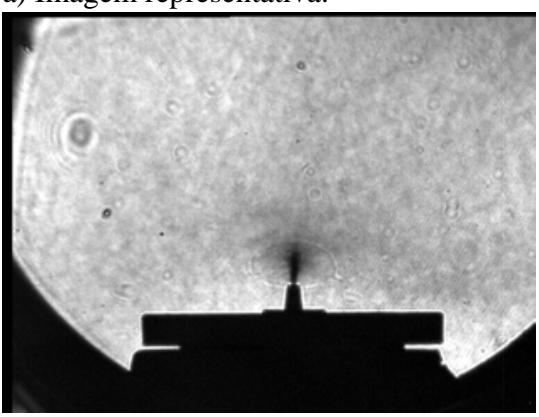

c) Imagem tratada (mapa de cores: gray).

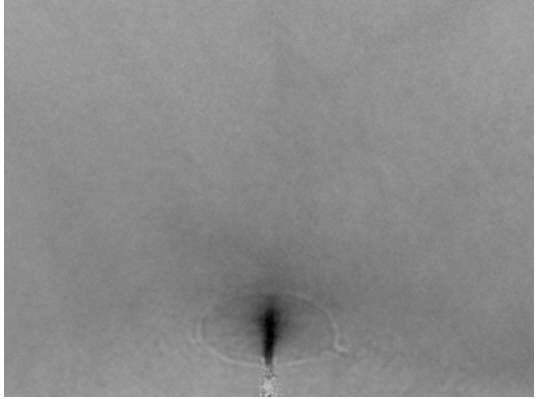

d) Imagem da 2a . câmara CCD.

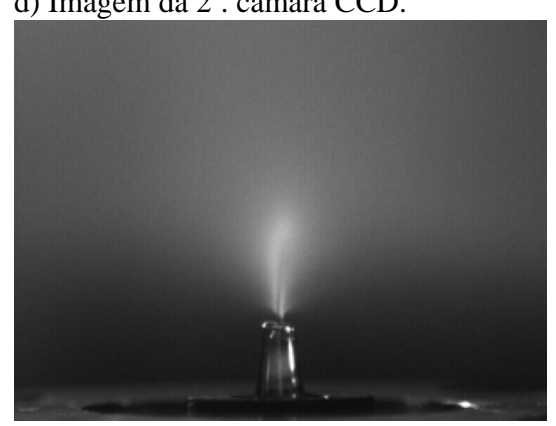

Obs.: comparando com os ensaios anteriores, o aumento da temperatura de injeção
diminuiu a distância onde ocorre a onda de evaporação para 0,4 mm. Obs.: comparando com os ensaios anteriores, o aumento da temperat
diminuiu a distância onde ocorre a onda de evaporação para $\sim 0,4 \mathrm{~mm}$.

b) Imagem tratada (mapa de cores: prism).

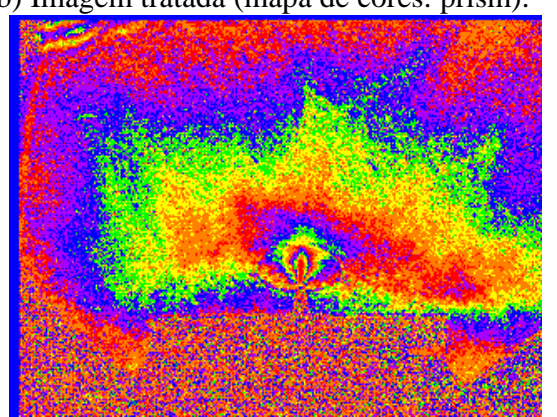




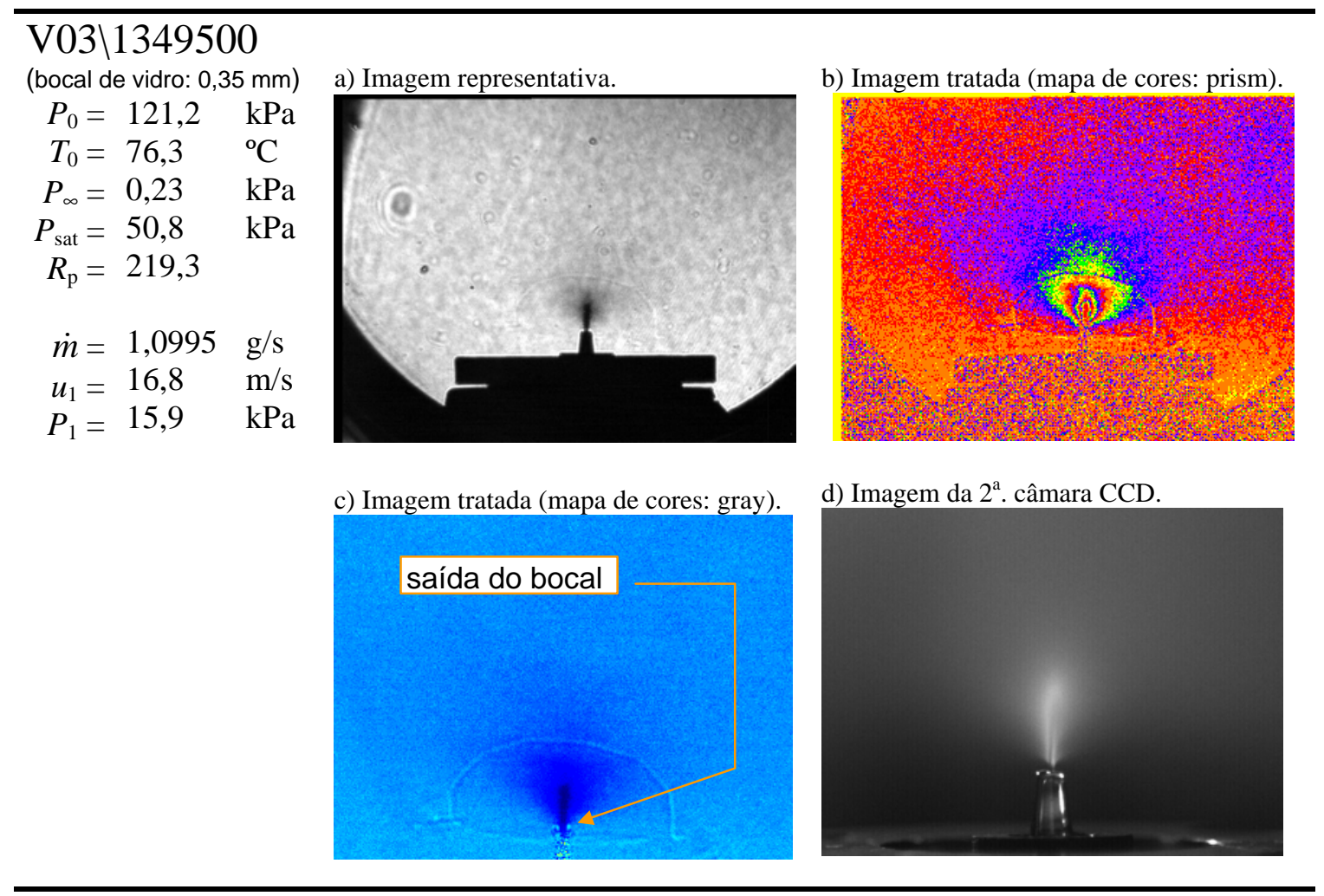




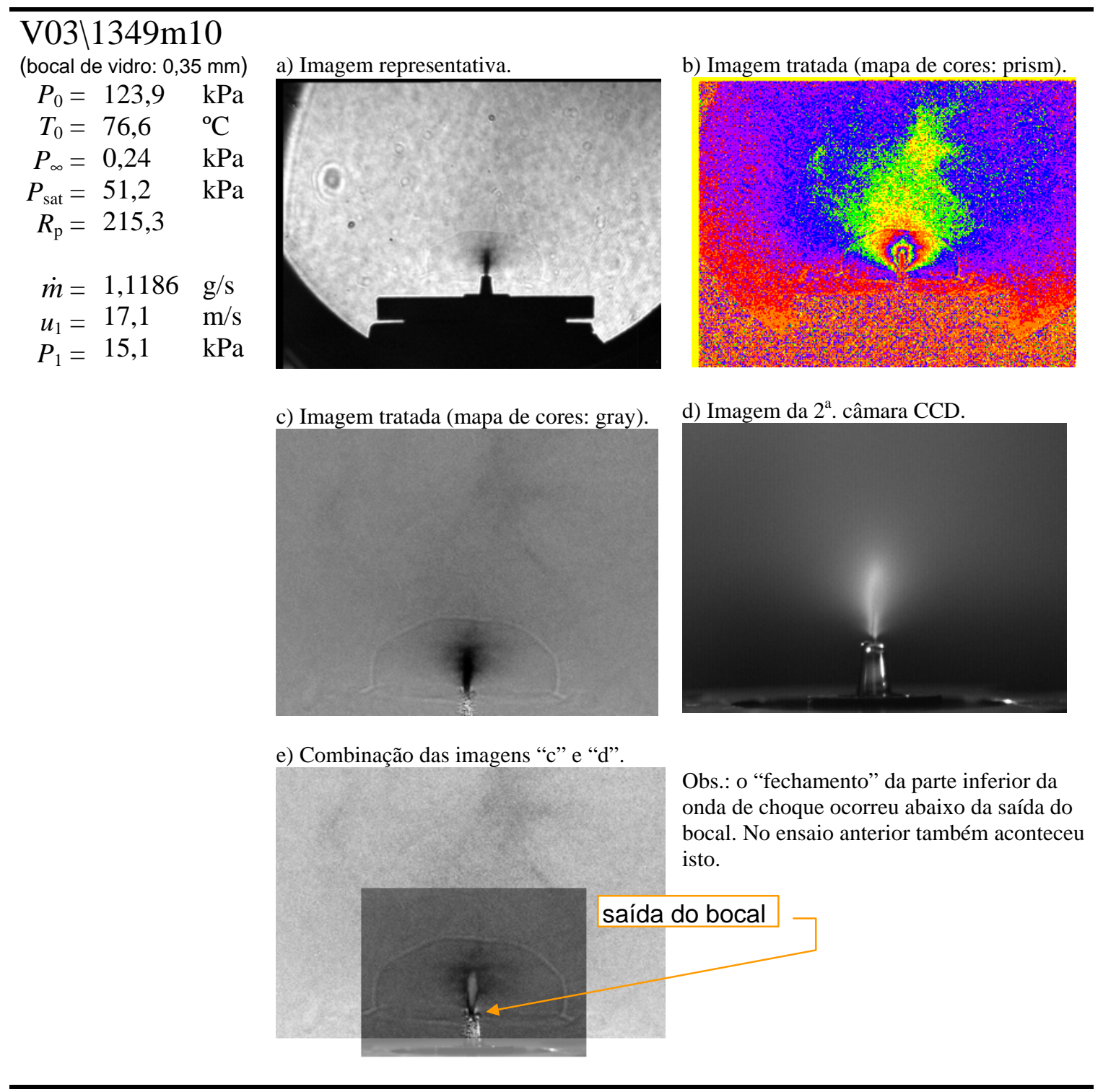




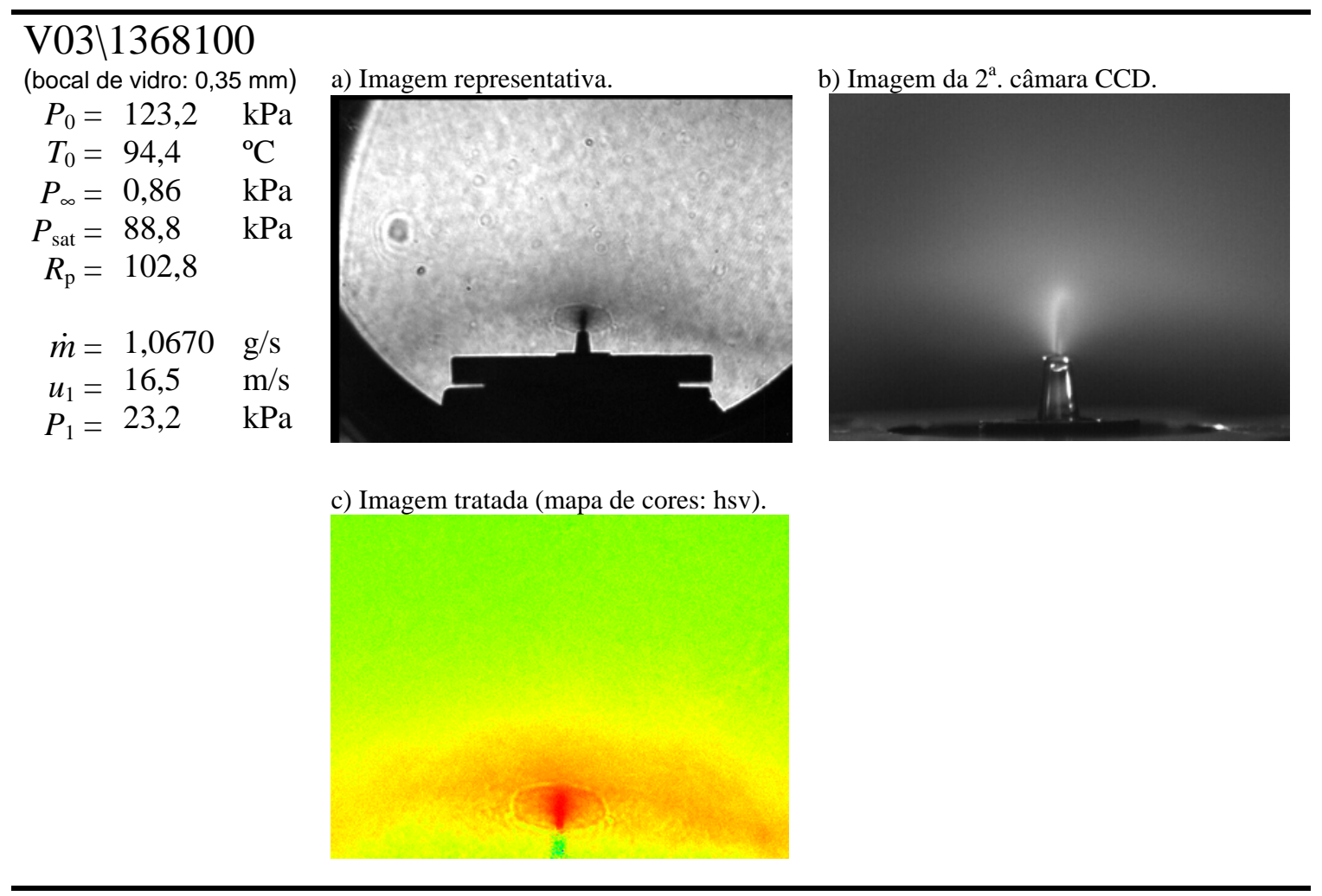

\section{V03\1368500}

(bocal de vidro: $0,35 \mathrm{~mm}$ )

$\begin{array}{rlrl}P_{0} & =123,7 & \mathrm{kPa} \\ T_{0} & =95,0 & { }^{\circ} \mathrm{C} \\ P_{\infty} & =0,23 & \mathrm{kPa} \\ P_{\text {sat }} & =90,5 & \mathrm{kPa} \\ R_{\mathrm{p}} & =397,6 & & \\ \dot{m} & =1,0735 & \mathrm{~g} / \mathrm{s} \\ u_{1}=16,7 & \mathrm{~m} / \mathrm{s} \\ P_{1}=22,5 & \mathrm{kPa}\end{array}$

a) Imagem representativa.

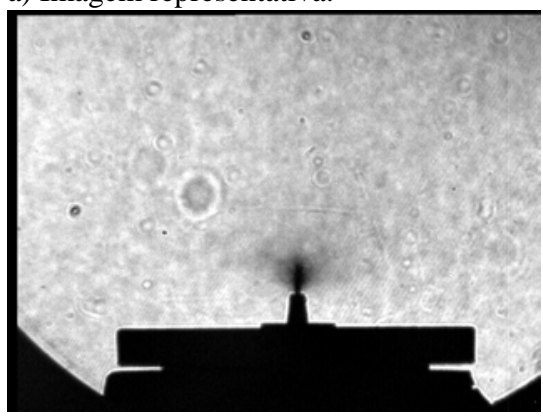

c) Imagem tratada (mapa de cores: gray).

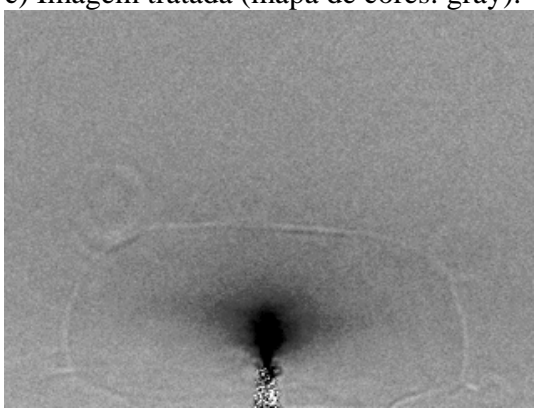

d) Imagem da $2^{\mathrm{a}}$. câmara CCD.

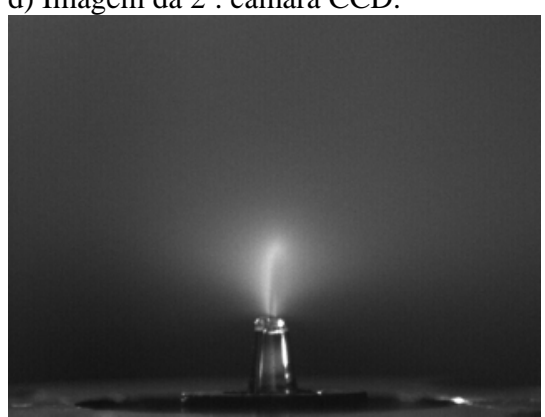

b) Imagem tratada (mapa de cores: prism).

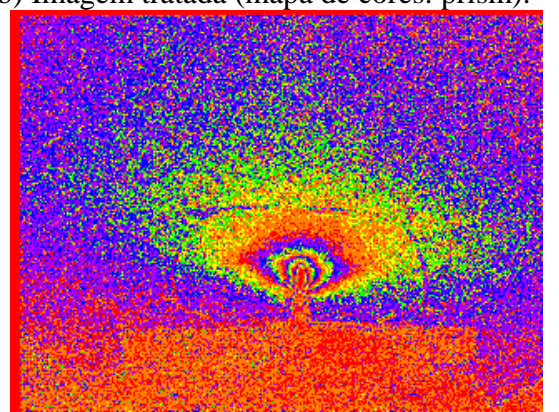

Obs.: A onda de choque se expandiu tanto que se aproximou da parede externa do bocal, ou seja, na plataforma superior do injetor. 


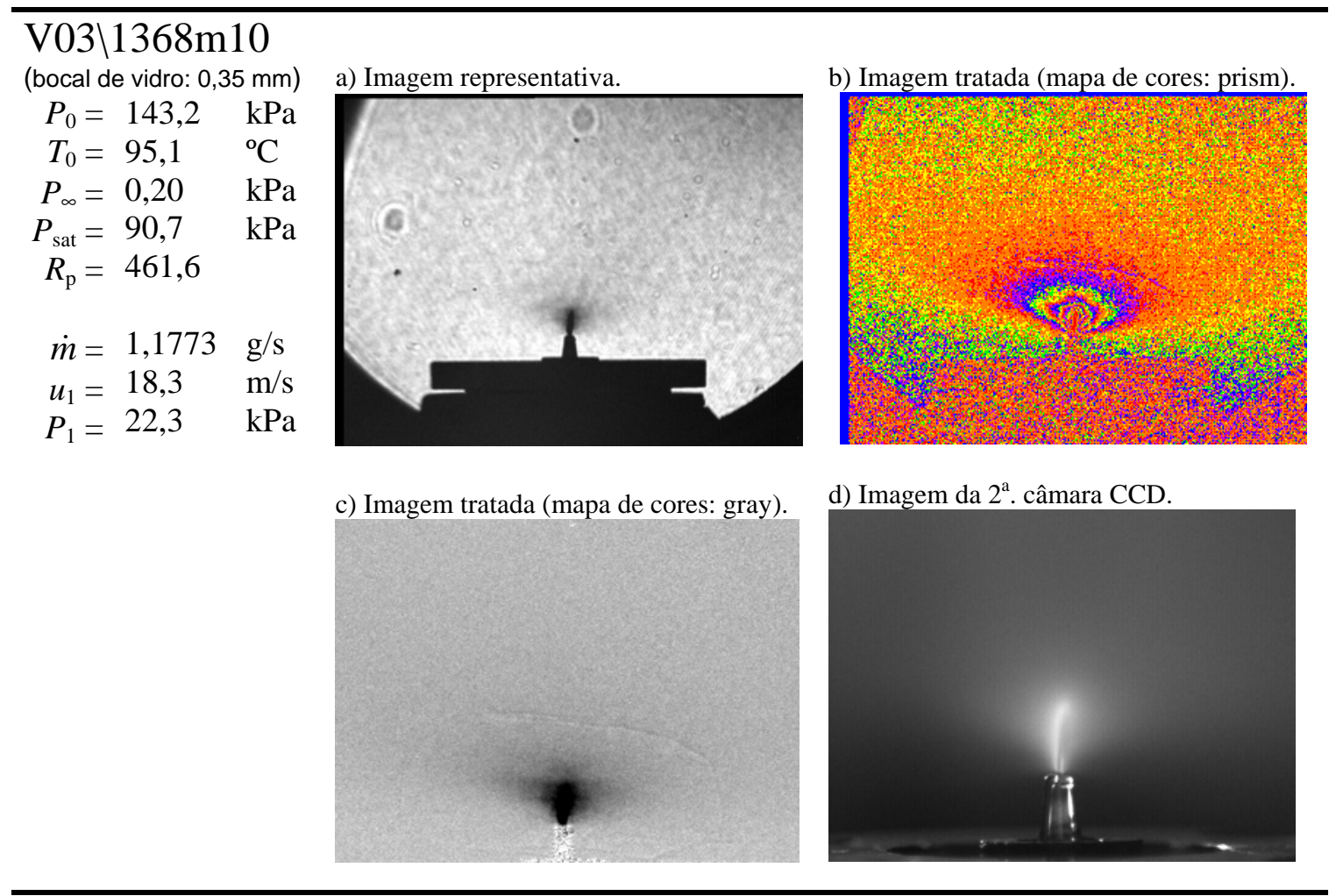

(bocal de vidro: 0,35 mm)

$P_{0}=143,2 \quad \mathrm{kPa}$

$T_{0}=95,1$

$P_{\text {sat }}=90,7$

$R_{\mathrm{p}}=461,6$

$\dot{m}=1,1773$

$u_{1}=18,3$

$P_{1}=22,3$

$\mathrm{m} / \mathrm{s}$

c) Imagem tratada (mapa de cores: gray) 


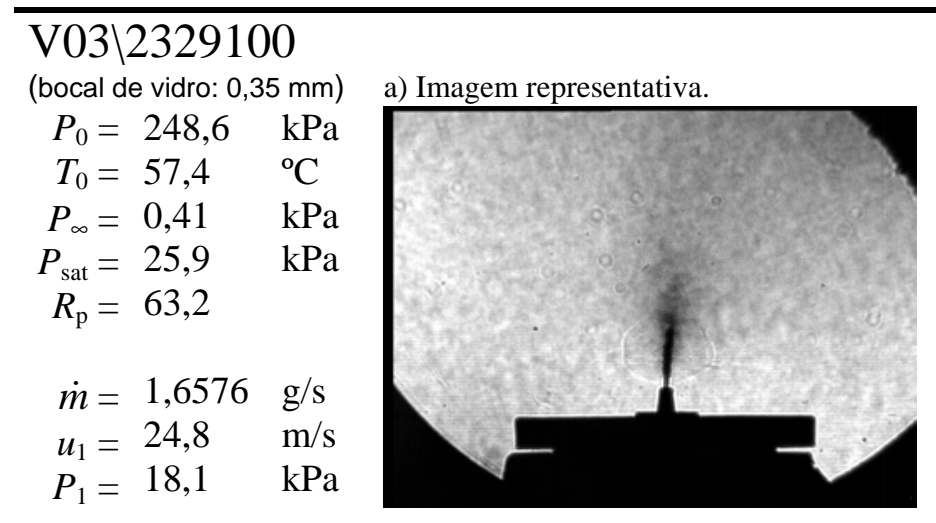

c) Imagem tratada (mapa de cores: gray).

Obs.: A onda de choque tem seu "fechamento" à $\sim 0,5 \mathrm{~mm}$ acima da saída do jato do bocal, enquanto que a onda de evaporação iniciou à $2 \mathrm{~mm}$ desta saída. b) Imagem da $2^{\mathrm{a}}$. câmara CCD.

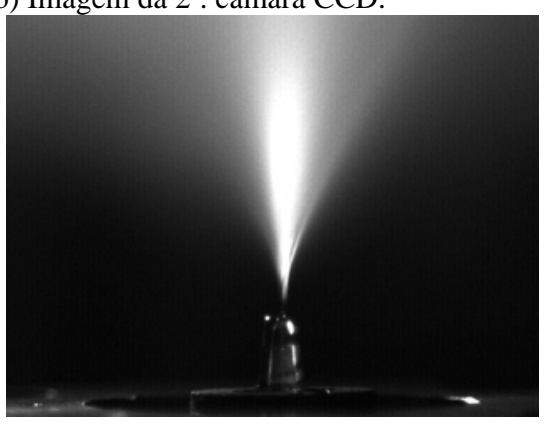

d) Combinação das imagens "b” e "c".

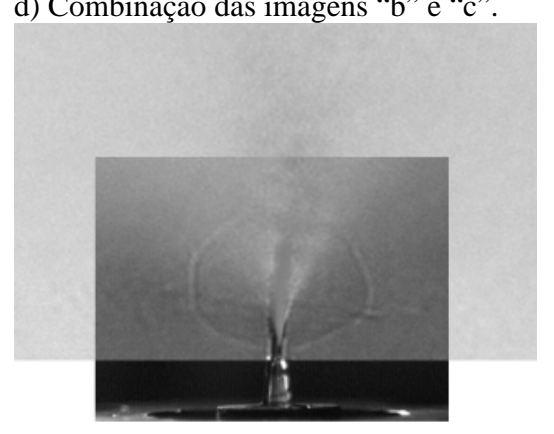

f) Imagem tratada $2^{\mathrm{a}}$. câmara CCD.

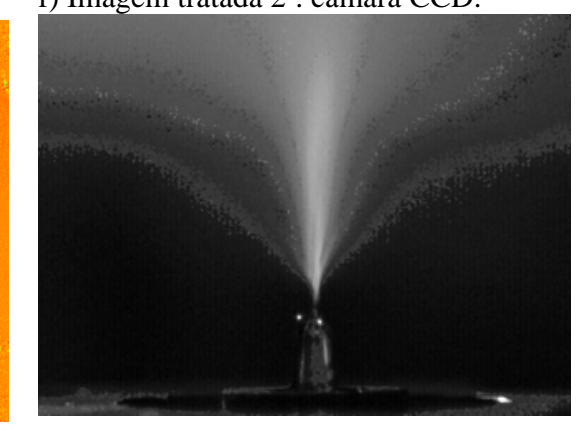

e) Imagem tratada (mapa de cores: hsv).

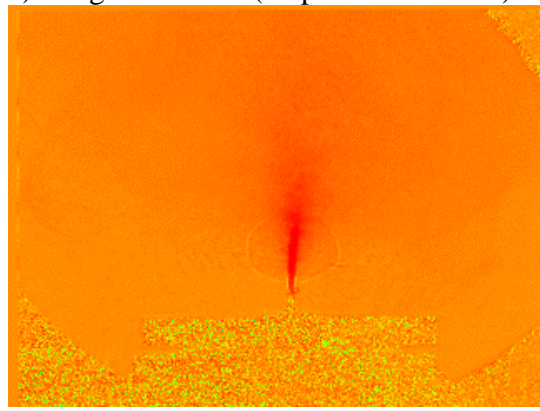



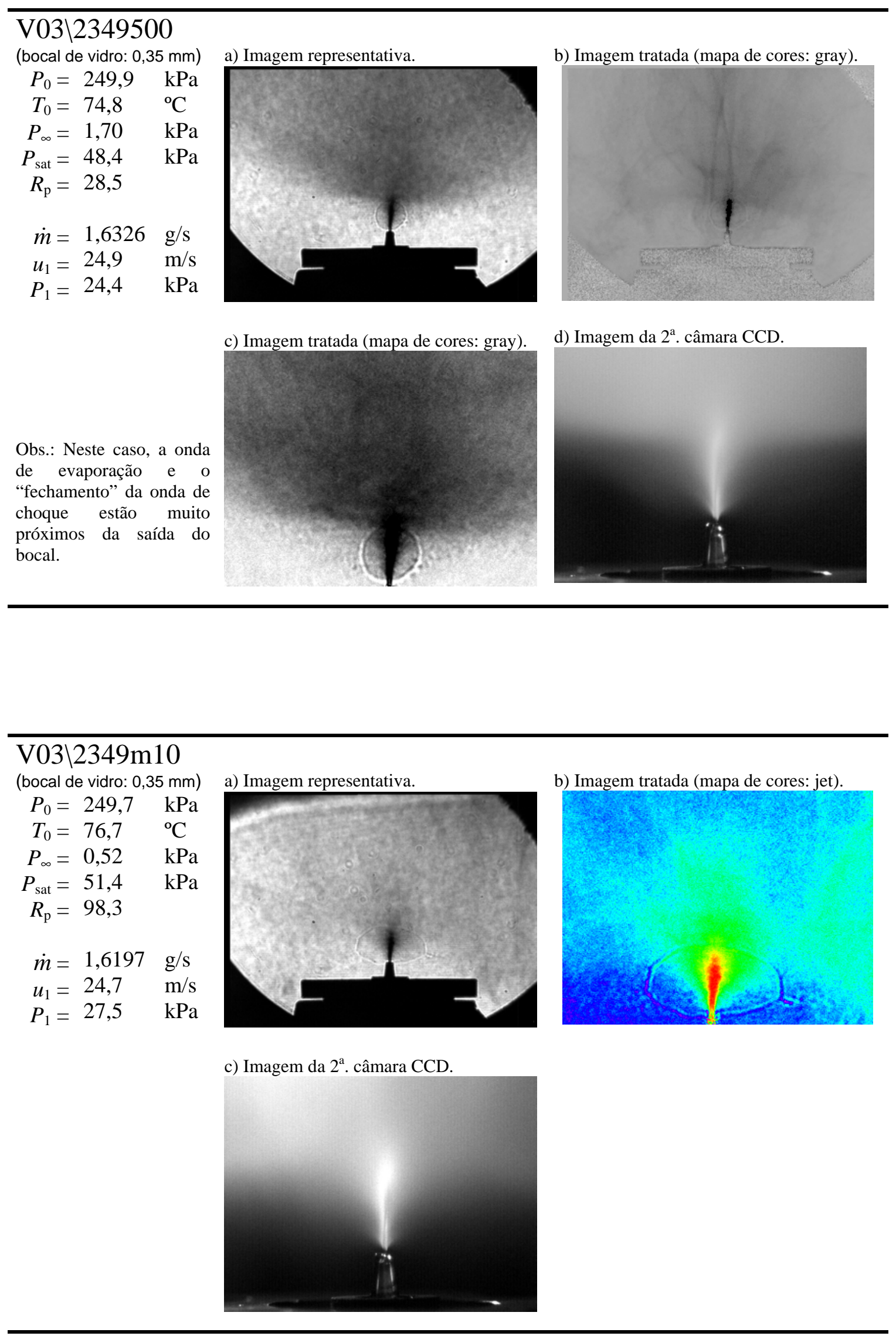


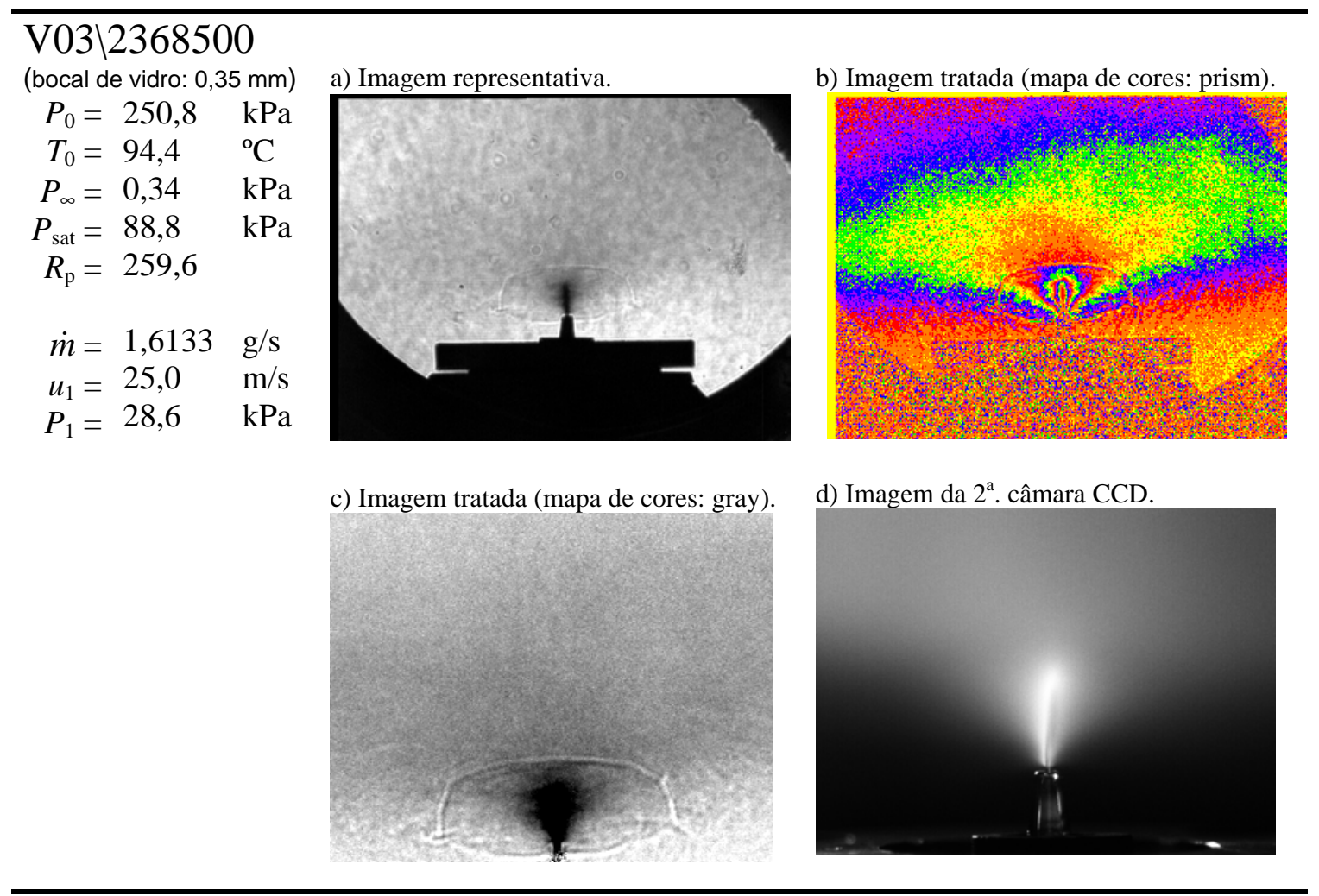

\begin{tabular}{rl}
\hline $\mathrm{V} 03 \backslash 2393500$ \\
(bocal de vidro: $0,35 \mathrm{~mm}$ ) \\
$P_{0}=250,4$ & $\mathrm{kPa}$ \\
$T_{0}=120,1$ & ${ }^{\circ} \mathrm{C}$ \\
$P_{\infty}=0,60$ & $\mathrm{kPa}$ \\
$P_{\text {sat }}=176,3$ & $\mathrm{kPa}$ \\
$R_{\mathrm{p}}=293,9$ & \\
& \\
$\dot{m}=1,4921$ & $\mathrm{~g} / \mathrm{s}$ \\
$u_{1}=23,8$ & $\mathrm{~m} / \mathrm{s}$ \\
$P_{1}=56,1$ & $\mathrm{kPa}$
\end{tabular}

a) Imagem representativa.

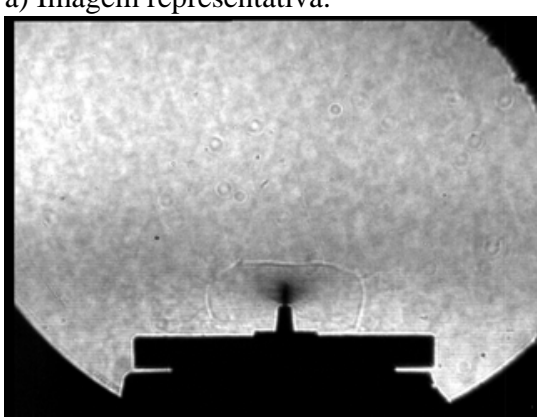

b) Imagem tratada (mapa de cores: prism).

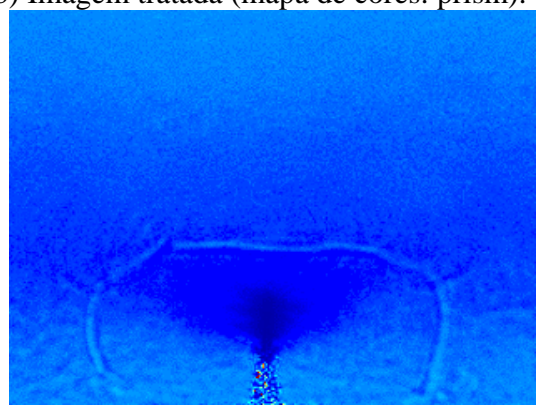

d) Sexta imagem obtida em 3 s após a

c) Imagem tratada (mapa de cores: gray). imagem "a".

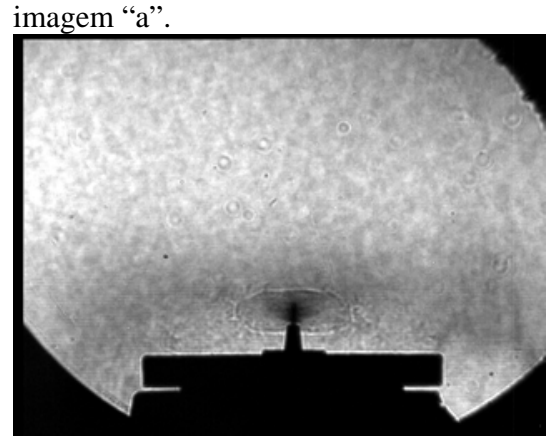

Obs.: Após 3 s, é comprovado que a onda de choque formada se contrai. Neste intervalo, a pressão da câmara aumentou de 0,43 para $0,68 \mathrm{kPa}$.

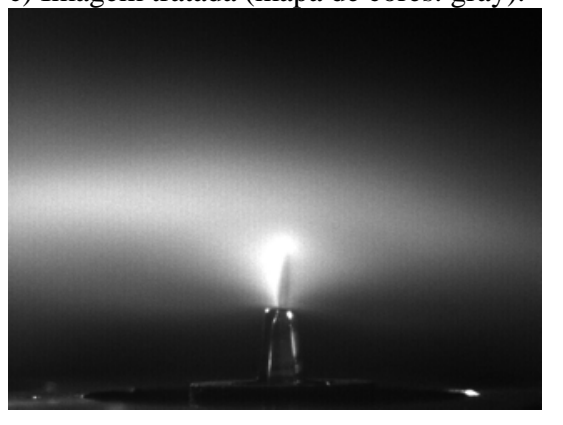

d) Imagem da $2^{\mathrm{a}}$. câmara CCD. 


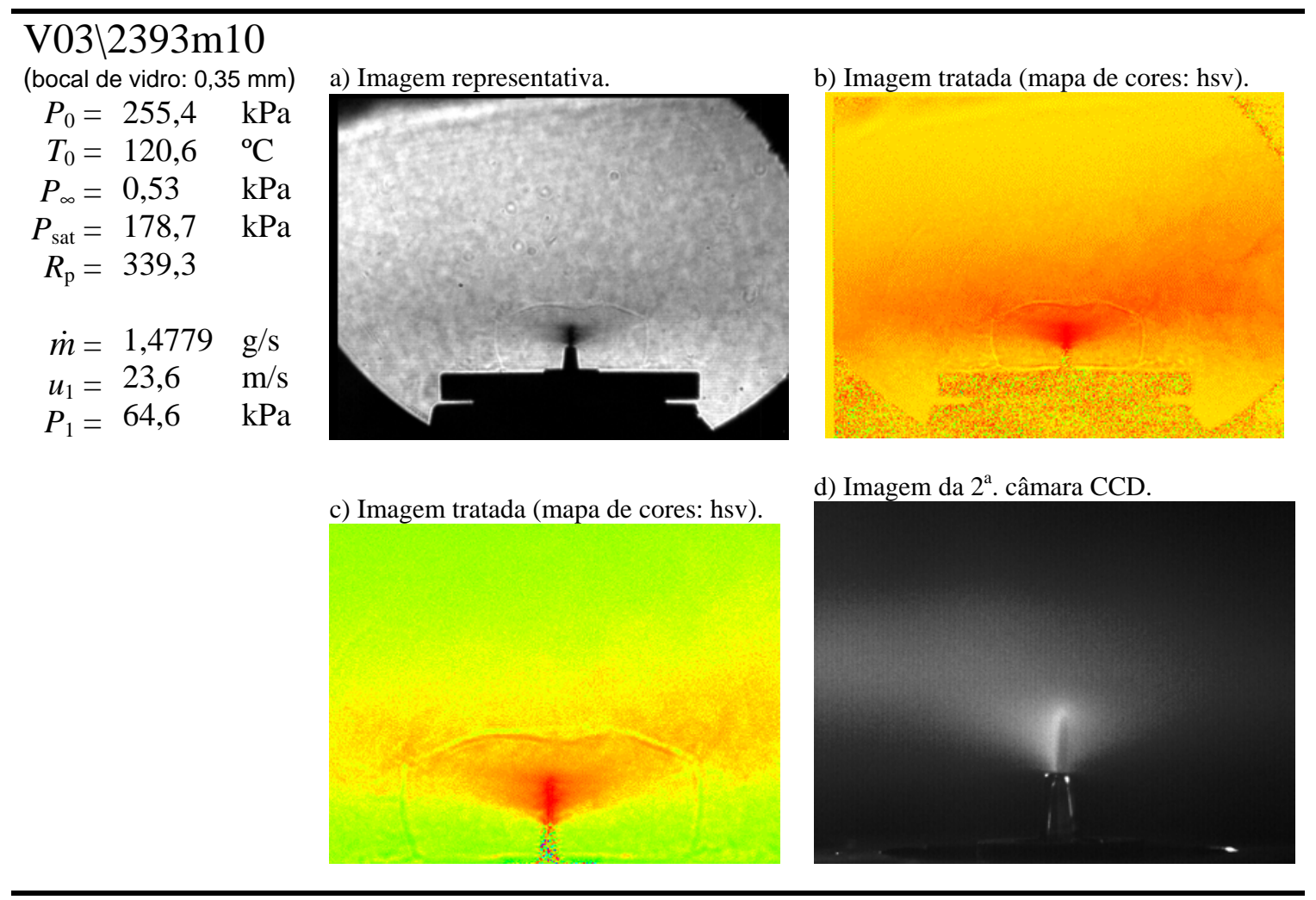




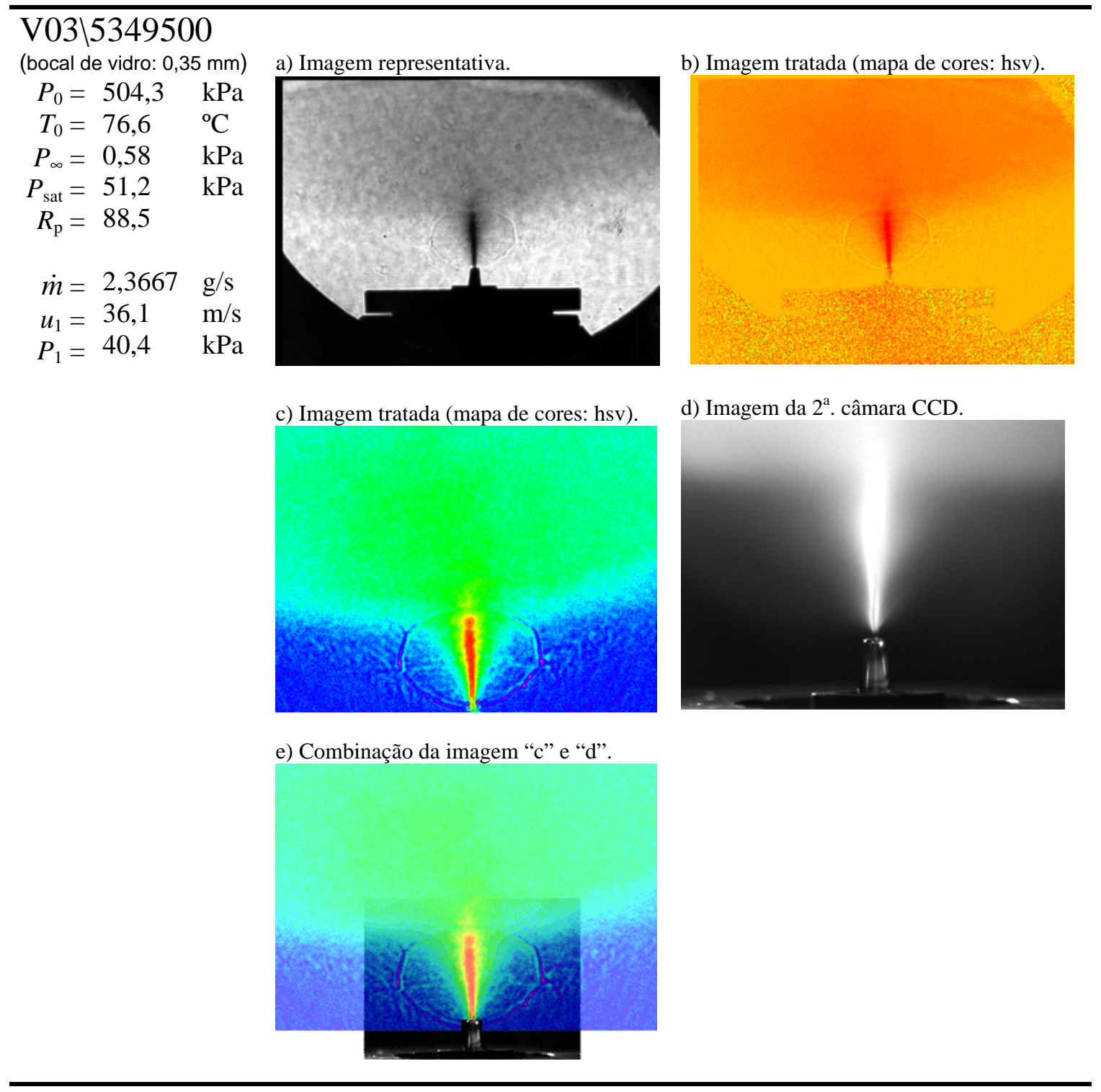



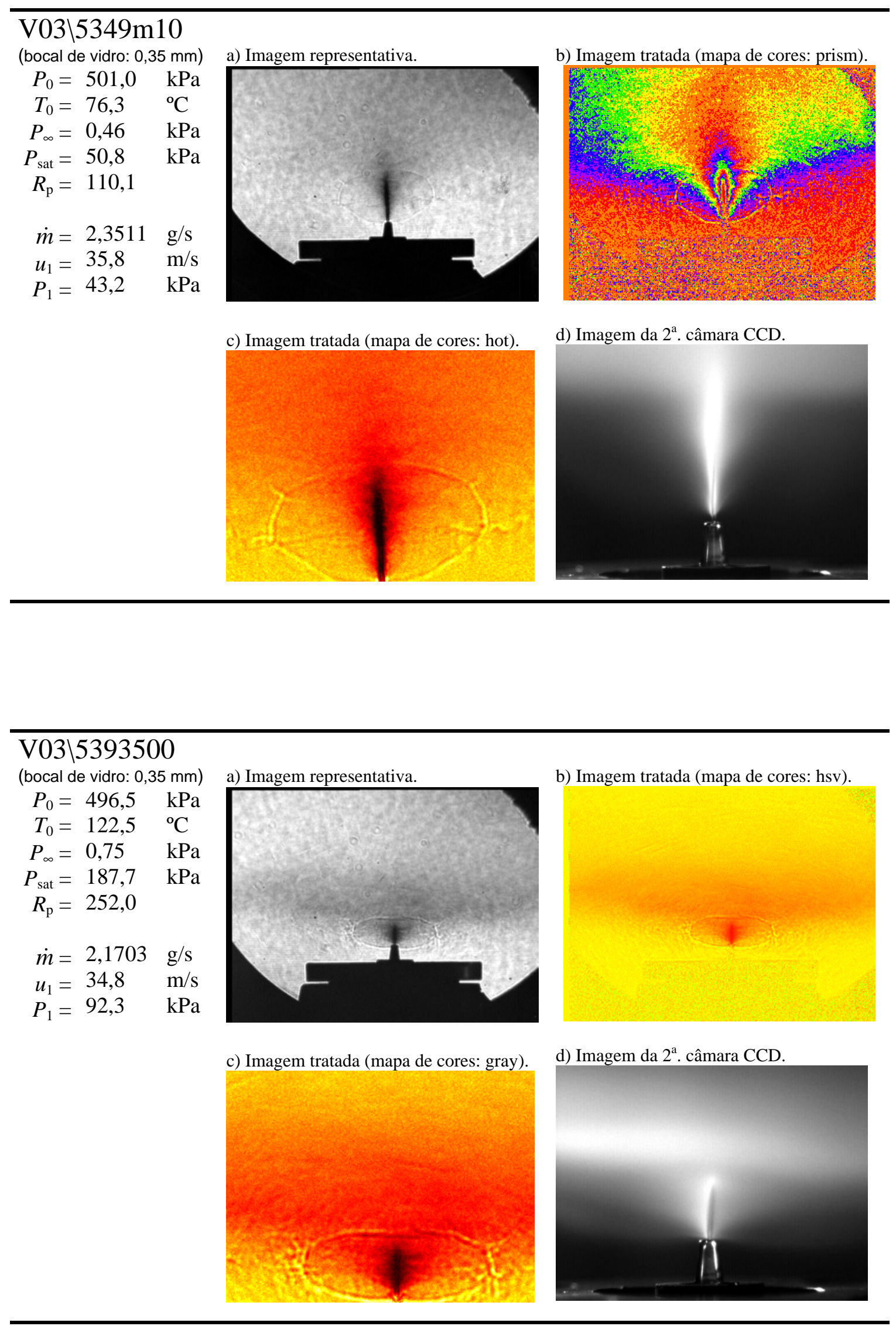


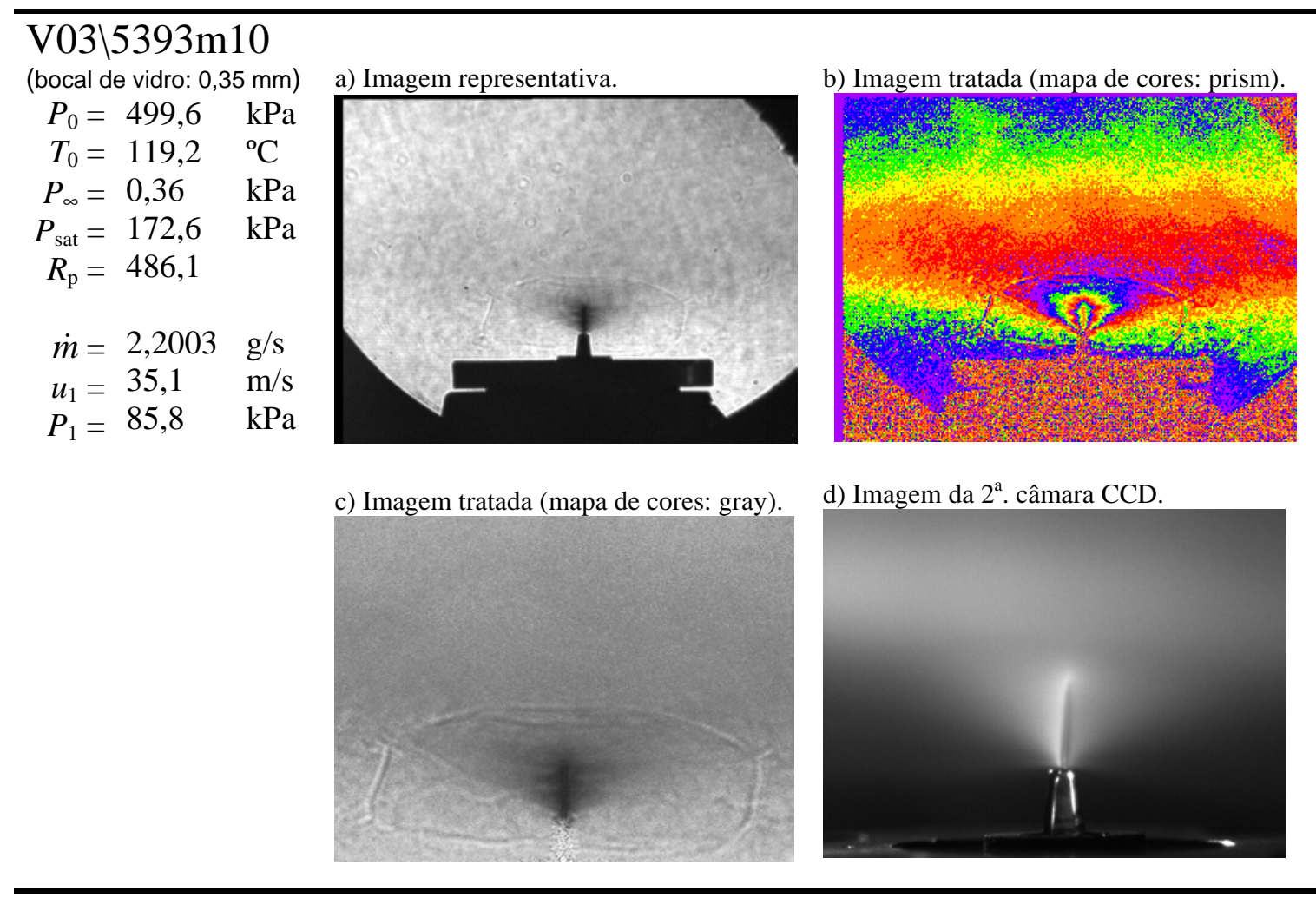




\section{LISTA DE REFERÊNCIAS}

Abbott, M. M. e Van Ness, H. C., 1989, Schaum's Outline of Theory and Problems of Thermodynamics, $2^{\circ}$ ed., McGraw-Hill.

Alamgir, Md. e Lienhard, J. H., 1981, Correlation of Undershoot During Hot-Water Depressurization, Journal of Heat Transfer, Transactions of the ASME, Vol. 103, pp. 52-55.

Angelo, E., 2004, Análise Numérica da Dinâmica da Expansão de Líquidos Superaquecidos em Evaporação Rápida, tese de doutorado apresentada à Escola Politécnica da Universidade de São Paulo, São Paulo, Brasil.

Angelo, E. e Simões-Moreira, J. R., 2004, Liquid Jets Expanding into a LowPressure Environment - Numerical Solution, artigo n. ${ }^{\circ}$ AP-8, Third International Symposium of Two-Phase Flow Modeling and Experimentation, Pisa, Italia.

ANSI/ASME, Norma PTC 19.1-1985, Measurement Uncertainty.

Arcoumanis, C., Gavaises, M., Flora, H., Roth, H., 2001, Visualisation of cavitation in diesel engine injectors, Mec. Ind., Vol. 2, pp. 375-381.

Attou, A.; Bolle, L.; Seynhaeve, J.M., 2000, Experimental study of the critical flashing flow through a relief line: evidence of the double-choked flow phenomenon. International Journal of Multiphase Flow, Vol. 26, p.921-947.

Athans, R. E., 1994, The Rapid Expansion of Near-Critical Retrograde Fluid, tese de doutorado apresentada ao Rensselaer Polytechnic Institute, Nova York, EUA.

Athans, R. E. e Hirsa, A., 1995, A Photographic Study of a Small Flashing Jets, Flow Visualization and Image Processing of Multiphase System, ASME, Vol. 209, pp. 201-206. 
Badock, C., Wirth, R., Fath, A., Leipertz, A., 1999, Investigation of cavitation in real size diesel injection nozzles, International Journal of Heat and Fluid Flow, Vol. 20, pp. 538-544.

Baumann, H. D., 1963, The Introduction of a Critical Flow Factor for Valve Sizing, ISA Transactions, Vol. 2, n 2, pp. 107-111.

Benjamin, M.W. e Miller, J. G., 1941, The Flow of Saturated Water through Throttling Orifices, Transaction of the A.S.M.E., July, pp. 419-429.

Burnell, J. G., 1947, Flow of Boiling Water through Nozzles, Engineering, December 12, pp. 1109-1116.

Carey, V. P., 1992, Liquid-Vapor Phase-Change Phenomena, Hemisphere Publishing Corporation.

Crist, S., Sherman, P. M., and Glass, D. R., 1966, Study of the Highly Underexpanded Sonic Jet, AIAA Journal, Vol. 3, nº 1, pp. 68-71.

Darby, R., 2004, On two-phase frozen and flashing flows in safety relief values Recommended calculation method and the proper use of the discharge coefficient, Journal of Loss Prevention in the Process Industries, Vol. 17, pp. 255-259.

Dettlef, G., Thompson, P. A., Meier, G. E. A. e Speckmann, H. D., 1979, An Experimental Study of Liquefaction Shock Waves, Journal of Fluid Mechanics, Vol. 95, pp. 279-304.

Edwards High Vacuum International, 1996, Instruction Manual - CG 16K Capsule Dial Gauge. 
Emrich, R. J., 1985, Radial Flow of Metastable Liquid, Proceedings of the $15^{\text {th }}$ International Symposium on Shock Waves and Shock Tubes, July 28 - Aug 2, Stanford University, Berkeley, California, EUA, pp. 745-752.

Faeth, G. M., Hsiang, L. -P. e, Wu, P. -K., 1995, Structure and Breakup Properties of Spray, International Journal of Multiphase Flow, Vol. 21, Suppl., pp. 99-127.

Ferro, E., Ghiazza, E., Bosio, B., Costa, P., 2002, Modelling of flash and stripping Phenomena in deaerators for seawater desalination, Desalination, Vol. 142, pp.171-180.

Fox, R. W. e McDonalds, A. T., 1995, Introdução à Mecânica dos Fluidos, Ed. Guanabara.

Fuchs, H. e Legge, H., 1979, Flow of a water jet into vacuum, Acta Astronautica, Pergamon Press Ltd., Vol. 6, pp. 1213-1226.

Guimarães, M. S. e Simões Moreira, J. R., 1999, Arranjo Óptico para a Visualização de Jatos Evaporativos de Líquidos Altamente Superaquecidos, Trabalho de Formatura, Escola Politécnica, Universidade de São Paulo e, Relatório Final de bolsa de iniciação científica FAPESP, processo nº 97/01188-9.

Hill, L. G. e Sturtevant, B., 1990, An Experimental Study of Evaporation Waves in a Superheated Liquid, Adiabatics Waves in Liquid-Vapor Systems, eds. Meier, G. E. A. e Thompson, P. A., Springer-Verlag, pp. 25-37.

ISA, 1995, Flow Equations for Sizing Control Valves, Norma ISA-S75.01-1985 (R1995).

Kitamura, Y., Morimitsu, H. e, Takahashi, T., 1986, Critical Superheated for Flashing of Superheated Liquid Jets, Industrial \& Engineering Chemistry Fundamentals, Vol. 25, n 2, pp. 205-211. 
Kurschat, Th., Chaves, H. e Meier, G. E. A., 1992, Complete Adiabatic Evaporation of Highly Superheated Liquid Jets, Journal of Fluid Mechanics, Vol. 236, pp. 4359.

Jernqvist, A., Jernqvist, M., Aly, G., 2001, Simulation of thermal desalination processes, Desalination, Vol.134, pp.187-193.

Labuntsov, D. A. e Avdeev, A. A., 1982, Mechanism of Flow Blockage Involving Shock Boiling of Liquid, Teplofizica Vysokich Temperatur, Vol. 20, nº 1, pp. 8895.

Labuntsov, D. A. e Avdeev, A. A., 1982, Mechanism of Transient Blowdown of a Flashing Liquid, Teplofizica Vysokich Temperatur, Vol. 20, nº 2, pp. 288-295.

Lacerda, N. L., 1986, On the Start Up of Supersonic Under Expanded Jets, tese de doutorado apresentada ao California Institute of Technology, California, EUA.

Lambrakis, K, C., 1972, Negative $\Gamma$ Fluids, Dissertação, Rensselaer Polytechnic Institute, Nova York, EUA.

Lasheras, J. C. e Hopfinger, E. J., 2000, Liquid Jet Instability and Atomization in a Coaxial Gas Stream, Annual Reviews Fluid Mechanics, Vol. 32, pp.275-308.

Leung, J. C., 2004, A theory on the discharge coefficient for safety relief valve, Journal of Loss Prevention in the Process Industries, Vol. 17, pp. 301-313.

Lenzing, T., Friedel, L. Cremers, J. Alhusein, M., 1998, Prediction of the maximum full lift safety valve two-phase flow capacity, Journal of Loss Prevention in the Process Industries, Vol. 11, pp. 307-321.

Lienhart, J. H. e Day, J. B., 1970, The Breakup of Superheated Liquid Jets, Transaction of the ASME - Journal of Basic Engineering, Vol. 92, pp. 515-521. 
Lin, S. P. e Reitz, R. D., 1998, Drop and Spray Formation From a Liquid Jet, Annual Reviews Fluid Mechanics, Vol. 30, pp. 85-105.

Okuyama, K., Tsukahara, S., Morita, N., I., Yoshihiro, 2004, Transient behavior of boiling bubbles generated on the small heater of a thermal ink jet printhead, Experimental Thermal and Fluid Science, Vol. 28, pp. 825-834.

Khoo, B.C., Klaseboer, E. e Hung K.C., 2005, A collapsing bubble-induced micropump using the jetting effect, Sensors and Actuators A, Vol. 118, pp. 152-161.

Ogle, R. A., Megerle, M. V., Morrison III, D. R., Carpenter, A. R., 2004, Explosion caused by flashing liquid in a process vessel, Journal of Hazardous Materials, Vol. 115, pp. 133-140.

Omega Engineering, Inc., 1993, Thermocouple Reference Tables.

Oza, R. D., 1984, On the Mechanism of Flashing Injection of Initially Subcooled Fuels, Journal Fluid Engineering, Transactions of the ASME, Vol. 106, pp. 105109.

Oza, R. D. e Sinnamon, J. F., 1983, An Experimental and Analitycal Study of FlashBoiling Fuel Injection, SAE International Congress \& Exposition, artigo n. ${ }^{\circ}$ 830590, Detroit, Michigan, 28 fevereiro-4 março.

Peter, E. M., Takimoto, A. e Hashiro, Y., 1994, Flashing and Shattering Phenomena of Superheated Liquid Jets, JSME International Journal, Série B, Vol. 37, n 2, pp. 313-321.

Pianthong, K., Zakrzewski, S., Behnia, M. e, Milton, B.E., 2002, Supersonic Liquid Jets: Their Generation and Shock Wave Characteristic, Shock Wave Journal, Vol. 11, $n^{\circ}$ 6, pp. 457-466. 
Pinti, D. L., Marty, B., 1998, Separation of noble gas mixtures from petroleum and their isotopic analysis by mass spectrometry, Journal of Chromatography A, Vol. 824, pp. 109-117.

Ramamurthi, K. e Nandakumar, K., 1994, Disintegration of Liquid Jets From SharpEdged Nozzles, “Atomization and Spray”, Vol. 4, pp. 551-564.

Reid, R. C., 1976, Superheated Liquids, American Scientist, Vol. 64, pp. 146-56.

Reitz, R. D., 1990, A Study Photographic of Flash-Boiling Atomization, Aerosol Science and Technology, Vol. 12, pp. 561-569.

Shepherd, J. E., McCahan, S. e Cho, J., 1989, Evaporation Waves Model for Superheated Liquid, Adiabatics Waves in Liquid-Vapor Systems, eds. Meier, G. E. A. e Thompson, P. A., Springer-Verlag, pp. 3-12.

Simões-Moreira, J. R., e Bullard, C. W., 2003, Pressure Drop and Flashing Mechanisms in Refrigerant Expansion Devices, International Journal of Refrigeration, Vol. 26, $n^{0} 7$.

Simões-Moreira, J. R., Vieira, M. M. e, Angelo, E., 2002, Highly Expanded Flashing Liquid Jets, Journal of Thermophysics and Heat Transfer, Vol. 16, $\mathrm{n}^{\mathrm{o}}$ 3, pp. 415424.

Simões-Moreira, J. R., 2000, Oblique Evaporation Waves, Shock Waves - An International Journal on Shock Waves, Detonations and Explosions, Vol. 10, $\mathrm{n}^{\circ} 4$, pp. 229-234.

Simões-Moreira, J. R. 1999, Aplicação da Teoria das Ondas de Evaporação aos jatos evaporativos, tese de livre docência apresentada, Escola Politécnica, Universidade de São Paulo. 
Simões-Moreira, J. R. e Shepherd, J. E., 1999, Evaporation Waves in Superheated Dodecane, Journal of Fluid Mechanics, Vol. 382, pp. 63-86.

Simões-Moreira, J. R., 1994, Adiabatic Evaporation Waves, tese de doutorado apresentada ao Rensselaer Polytechnic Institute, Nova Iorque, EUA.

Simões-Moreira, J. R., McCahan S., e Shepherd, J. E., 1993, Complete Evaporation Waves, artigo n. ${ }^{\circ}$ 93-FE-7, ASME - Fluids Engineering Conference, EUA.

Stawczyk, J., 2003, Experimental evaluation of LPG tank explosion hazards, Journal of Hazardous Materials, Vol. B 96, pp. 189-200.

Skripov, V. P., 1974, Metastable Liquids, John Wiley \& Sons.

Thompson, P. A., 1988, Compressible-Fluid Dynamics.

Thompson, P. A. e Sullivan, D. A., 1975, On the Possibility of Complete Condensation Shock Waves in Retrograde Fluids, Journal of Fluid Mechanics, Vol. 95, pp. 279-304.

van den Berg, A.C., van der Voort, M.M., Weerheijm, J. e Versloot, N.H.A, 2004, Expansion-controlled evaporation: a safe approach to BLEVE blast, Journal of Loss Prevention in the Process Industries, Vol. 17, pp. 397-405.

Vieira, M. M., 1999, Estudo Experimental de Jatos Evaporativos, Dissertação de Mestrado apresentada à Escola Politécnica da Universidade de São Paulo.

Villani, E. e Simões Moreira, J. R., 1997, Proditer - Programa Computacional Didático de Termodinâmica, Trabalho de Formatura, Escola Politécnica, Universidade de São Paulo e, Relatório Final de bolsa de iniciação científica FAPESP, processo n ${ }^{\circ}$ 96/02070-9. 
Wang, X., Zhub, C., Ahluwalia, R., 2004, Numerical simulation of evaporating spray jets in concurrent gas-solids pipe flows, Powder Technology, Vol. 140, pp. 5667.

Wildgen, A. e Straub, J., 1989, The Boiling Mechanism in Superheated Free Jets, International Journal of Multiphase Flow, Vol. 15, No. 2, pp. 193-207.

Witlox, H. W. M. e Bowen, P. J., 2002, Flashing Liquid Jets and Two-phase Dispersion, HSE - Health and Safety Executive, \#403/2002.

Yildiz, D., Rambaud, P., Van Beeck, J.P.A.J., Buchlin, J-M., 2003, Thermal characterization of a R134A two-phase flashing jet, ICLASS 2003 - 9th International Conference on Liquid Atomization and Spray Systems, Sorrento, Italia, Julho 13-18.

Yu, Z., Garcia, A. S., Johnston, K. P. e Williams, R. O., 2004, Spray freezing into liquid nitrogen for highly stable protein nanostructured microparticles, European Journal of Pharmaceutics and Biopharmaceutics, Vol. 58, pp. 529-537. 


\section{Apêndice I}

Análise de Incerteza e Calibrações 


\section{APÊNDICE I}

\section{ANÁLISE DE INCERTEZAS, INSTRUMENTAÇÃO E CALIBRAÇÕES}

\section{I.1. A Análise de Incerteza}

Nesta seção são apresentados alguns procedimentos e termos de forma genérica e resumida que são utilizados na análise de incerteza da leitura das medidas aqui mencionadas.

Inicialmente, para a análise da incerteza de uma leitura, é necessário verificar os erros associados desta medida como: o limite de desvio e o limite de precisão. O limite de desvio é considerado um erro sistemático $(B)$ que está associado a acurácia do equipamento, enquanto, o limite de precisão $(P)$ está associado ao dobro do erro aleatório da leitura da medição, para uma confiabilidade de 95\%. Este erro aleatório, na leitura de um equipamento, se refere à metade da menor escala legível. Desta forma, a incerteza total de uma certa leitura $(U)$ pode ser escrita como:

$$
U=\sqrt{B^{2}+P^{2}} .
$$

No entanto, se o erro aleatório provém de uma análise estatística de uma determinada medida, pode-se associá-lo ao desvio padrão da amostra $(\sigma)$. Geralmente, nas análises a seguir, este procedimento é feito através de um levantamento de curva de ajuste em função dos dados obtidos experimentalmente. Neste caso, para uma confiabilidade de 95\%, é necessário multiplicar este desvio por dois para obter o limite de precisão total deste parâmetro.

$$
U=\sqrt{B^{2}+(2 * \sigma)^{2}} .
$$

Se existem medições independentes no procedimento, as incertezas associadas à calibração são obtidas pela raiz da soma dos quadrados da incerteza de cada equipamento envolvido na calibração. 
A partir da incerteza verificada em uma leitura, é possível conferir a sua propagação de erro em outros parâmetros dependentes desta. No estudo feito neste trabalho, a propagação do erro em determinado parâmetro (no caso, como exemplificação genérica, o parâmetro $X$, dependente das leituras $A_{\mathrm{x}}, B_{\mathrm{x}}, C_{\mathrm{x}}$, etc.), pode ser obtida através de:

$$
U_{X}^{2}=\left(\frac{\partial X}{\partial A_{x}}\right)^{2} U_{A x}^{2}+\left(\frac{\partial X}{\partial B_{x}}\right)^{2} U_{B x}^{2}+\left(\frac{\partial X}{\partial C_{x}}\right)^{2} U_{C X}^{2}+\ldots
$$

onde,

$$
X=f\left(A_{x}, B_{x}, C_{x}, \ldots\right) .
$$

Outros termos e procedimentos no estudo da propagação de erro também são necessários nesta análise, porém serão oportunamente explicados na seção onde estão sendo apresentados. É importante ressalvar que esta pequena explanação se baseia na norma ANSI/ASME PTC 19.1 Parte I, e foi resumida para apresentar o escopo da análise de incerteza aqui feita.

\section{I.2. Medição da vazão}

A medição da vazão experimental $(Q)$ é obtida pela medição do deslocamento do nível volumétrico da pipeta $(\Delta V)$, como descrito na Seção 3.3 e o intervalo de injeção $(\Delta t)$.

$$
Q=\frac{\Delta V}{\Delta t}
$$

Na leitura do deslocamento volumétrico existe um limite de desvio $\left(B_{\Delta V}\right)$ desprezível em relação ao limite de precisão $\left(P_{\Delta V}\right)$ igual a $0,050 \mathrm{ml}$, que é o dobro da menor escala do instrumento. Desta forma, a incerteza desta medida $\left(U_{\Delta V}\right)$ continua sendo igual a $0,050 \mathrm{ml}$.

Quanto à medição do intervalo de tempo da injeção, a incerteza está somente associada ao limite de precisão para identificação do transitório identificado nos dados da pressão de injeção (ver gráfico da Fig. 3.10), ou seja, quando a injeção dá início, a pressão diminui em média 1000 Pa em 0,002 s e quando fecha, a pressão aumenta em média 1000 Pa em 0,002 s, aproximadamente. Desta forma, pode-se 
colocar com segurança um valor de $0,004 \mathrm{~s}$ de incerteza $\left(U_{\Delta t}\right)$. Conhecendo as incertezas do deslocamento volumétrico e do instante, a análise da propagação destes erros na leitura da vazão, obtida pelas Eqs. (I.2 e I.3), pode ser vista na equação a seguir:

$$
\frac{B_{Q}}{Q}=\sqrt{\left(\frac{U_{\Delta V}}{\Delta V}\right)^{2}+(-1)^{2} \cdot\left(\frac{U_{\Delta t}}{\Delta t}\right)^{2}}=\sqrt{\left(\frac{0,050}{6,00}\right)^{2}+\left(\frac{0,004}{3,000}\right)^{2}}=0,00844
$$

Tomando como base que os líquidos injetados tiveram um volume de injeção médio de $6,00 \mathrm{ml}$ em um tempo de injeção efetivo de 3,00 s, tem-se uma razão do desvio sistemático da vazão de $0,844 \%$.

No entanto, além da medição do volume total, existe uma medição das vazões através dos sensores. A média das leituras destas vazões corresponde ao valor da vazão real tomada no experimento, conseqüentemente, deste valor médio deve se agregar um desvio da média. De 114 ensaios, a média dos desvios da média destas medições corresponde ao valor de $0,018 \mathrm{ml} / \mathrm{s}$. A associação deste erro aleatório com o erro sistemático obtido na Eq. (I.4), fornece a incerteza total da leitura da vazão, aqui exposto na forma percentual.

$$
\frac{U_{Q}}{Q}=\sqrt{\left(\frac{B_{Q}}{Q}\right)^{2}+\left(\frac{2 * S_{Q}}{Q}\right)^{2}}=\sqrt{\left(\frac{0,0169}{2,00}\right)^{2}+\left(\frac{2 * 0,018}{2,00}\right)^{2}}=0,0199 \text { ou } 1,99 \%
$$

\section{I.3. Medição da pressão do sistema de vácuo}

Neste sistema, a medição é feita após 5 minutos do desligamento da bomba de vácuo a fim de se alcançar o equilíbrio. Como foi visto na Seção 3.1, dois instrumentos fazem a medição de pressão: (1) vacuômetro analógico e (2) manovacuômetro de mercúrio. A seguir estão identificados na Tab. I.1 os desvios das leituras de cada um e o valor da incerteza, correspondendo sempre com um intervalo de $95 \%$ de confiabilidade.

O limite do desvio $(B)$ do vacuômetro analógico é de $2 \%$ do fundo de escala, segundo o manual do instrumento (manual do fabricante Boc-Edwards do vacuômetro analógico, escala de 0 a 25 mbar), e o limite de precisão $(P)$ é a 
identificação da menor escala possível de se visualizar, que neste caso, é menor que a metade de sua resolução. A resolução é de 0,10 mbar.

Tabela I.1 - Incerteza da medição do sistema de vácuo (valores em mbar).

\begin{tabular}{ccccc}
\hline Equipamento & $\begin{array}{c}\text { Intervalo de } \\
\text { medição }\end{array}$ & $\begin{array}{c}\text { Limite de } \\
\text { Desvio }(B)\end{array}$ & $\begin{array}{c}\text { Limite de } \\
\text { Precisão }(P)\end{array}$ & $\begin{array}{c}\text { Incerteza } \\
(U)\end{array}$ \\
\hline \hline Vacuômetro analógico & 0 a 2,5 kPa & 0,50 & 0,20 & 0,54 mbar ou 0,054 kPa \\
Mano-vacuômetro de Hg & 2,5 a $200 \mathrm{kPa}$ & 0,00 & 0,94 & 0,94 mbar ou 0,094 kPa \\
\hline
\end{tabular}

Para o mano-vacuômetro de mercúrio, o limite de desvio (B) é desprezível. Quanto ao limite de precisão $(P)$, que é um erro aleatório, é a metade da menor escala de leitura, portanto é de 0,5 mmHg ou 0,667 mbar, como essa medição também é associada a medição no barômetro com o mesmo limite de precisão, temse que o valor total deste erro é a raiz quadrada da soma dos quadrados dos limites de precisão resultando em 0,943 mbar.

Além destes instrumentos, foi implantado a partir da série de ensaios “RUN2” um sensor para baixíssimas pressões, o modelo APGX-16 de fabricação da BOC-Edwards. Possui uma melhor qualidade de precisão e suas medições são registradas eletronicamente pelo sistema de aquisição de dados. No entanto, a cada imagem obtida em um ensaio, quando ela é relacionada com o tempo em que foi adquirida, existe um erro de $0,5 \mathrm{~s}$, aproximadamente, correspondendo a uma variação de 0,05 kPa em média. Desta forma, o erro associado a esta leitura fica muito próximo do vacuômetro CGK16, não modificando a incerteza desta leitura nesta escala de pressão mais baixa, conseqüentemente, mantendo o mesmo valor no quadro da Tab I.1, praticamente. 


\section{I.4. Medição da pressão de injeção}

A medição da pressão de injeção é feita através do transdutor, modelo XTE 190-250A, com escala de 0 a $1000 \mathrm{kPa}$, da marca Kulite. O procedimento de calibração é feito pressurizando a linha de injeção da bancada experimental onde é feita a leitura de valores da pressão da linha através do manômetro padrão da marca Heise (0 a $1000 \mathrm{kPa}$ ), com escala mínima de 0,5 kPa. Os dados da leitura do manômetro são comparados com os dados feitos pelo sistema de aquisição de dados que é utilizado na bancada experimental.

A Tab. I.2 apresenta as características básicas dos equipamentos envolvidos. Nesta tabela, o erro sistemático confere a acurácia do equipamento que seria $0,1 \%$ do fundo de escala, e o erro aleatório está associado à precisão de leitura que é a metade da escala. O primeiro erro se refere ao limite de desvio, enquanto que o dobro do erro aleatório equivale ao limite de precisão, basicamente. A raiz quadrada da soma dos quadrados dos limites de desvio e de precisão determina a incerteza de cada equipamento.

Os valores medidos e estimados pelo ajuste de curva encontrado pelo método dos mínimos quadrados estão na Tab. I.3 e estão representados no gráfico da Fig. I.2.

Tabela I.2 - Descrição e desvios dos equipamentos.

\begin{tabular}{lcc}
\hline Equipamento & Manômetro Padrão & Sist. aquisição de dados \\
\hline \hline Tipo & analógico & Condicionador de sinais + Conversor \\
Escala & 0 a $1000[\mathrm{kPa}]$ & A/D \\
Fabricante & Heise & 0 a 5 [V] -12 bits \\
Modelo & - & Lynx \\
Resolução & $0,50[\mathrm{kPa}]$ & MSC1000 e CAD1236 \\
Erro Sistemático & $1,00[\mathrm{kPa}]$ & $0,61035[\mathrm{mV}]$ \\
Erro Aleatório & $0,25[\mathrm{kPa}]$ & - \\
Lim. desvio: $\quad B$ & $1,00[\mathrm{kPa}]$ & $0,61035[\mathrm{mV}]=>0,197[\mathrm{kPa}]^{*}$ \\
Lim. precisão: $P$ & $0,50[\mathrm{kPa}]$ & $0,394[\mathrm{kPa}]$ \\
\hline Incerteza: $U$ & $1,118[\mathrm{kPa}]$ & $0,394[\mathrm{kPa}]$ \\
\hline
\end{tabular}


A equação de conversão linear da leitura no transdutor, $V$ em volts, para a medida $P$, em kiloPascal, é:

$$
P=322,65^{*} V+0,6104
$$

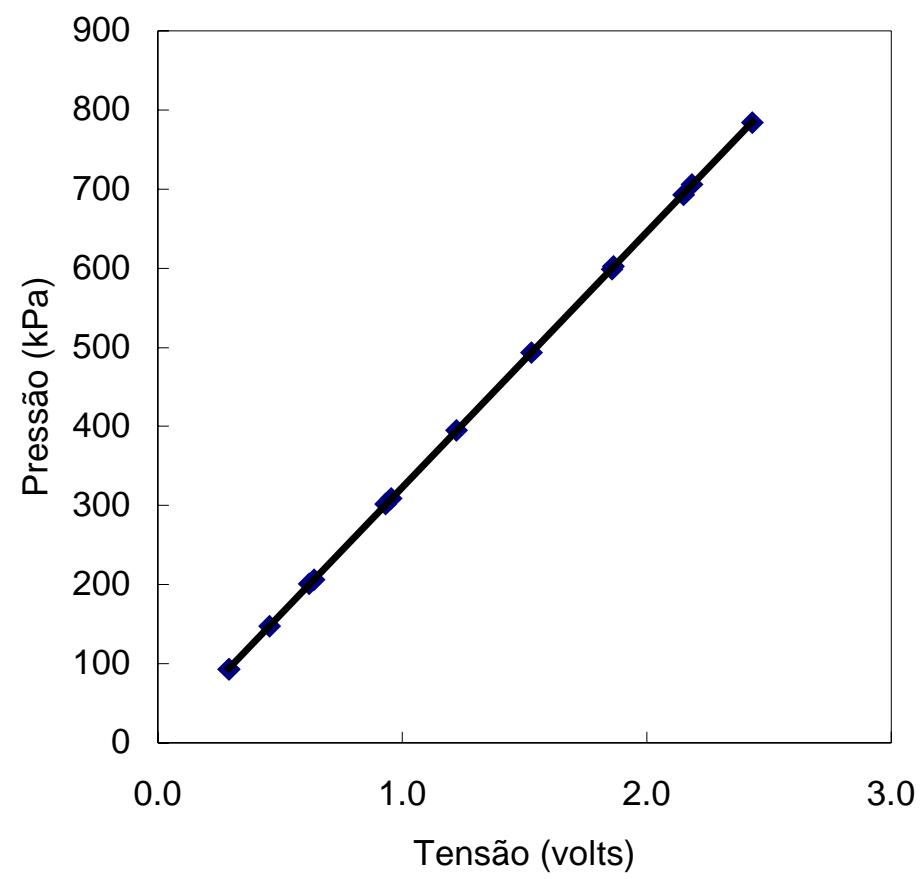

Figura I.1 - Gráfico da curva de calibração do transdutor de pressão.

O valor SEE ("Standard Error of Estimate"), representado na Tab. I.3, é o desvio padrão devido a correção dos valores estimados pela curva dada pela Eq. I.6, e pode ser calculado segundo a Eq. I.7, conforme determina a norma da ANSI/ASME PTC 19.1 Parte I,

$$
S E E=\sqrt{\frac{\sum(\text { Erro })^{2}}{N-2}}
$$

onde, $\Sigma(E r r o)^{2}$ é a somatória das diferenças dos valores estimados com os valores lidos em tal procedimento e, $N$ é o números de amostras. 
Tabela I.3 - Calibração do transdutor de pressão.

\begin{tabular}{cccc}
\hline $\begin{array}{c}\text { Leitura do } \\
\text { conversor A/D } \\
\text { [volts] }\end{array}$ & $\begin{array}{c}\text { Pressão } \\
\text { medida } \\
{[\mathrm{kPa}]}\end{array}$ & $\begin{array}{c}\text { Ajuste } \\
\text { Eq. I.5 }\end{array}$ & Erro \\
{$[\mathrm{kPa}]$} & {$[\mathrm{kPa}]$} \\
\hline \hline 0,2906 & 93,200 & 94,372 & $-1,172$ \\
0,2913 & 93,450 & 94,598 & $-1,148$ \\
0,4570 & 147,500 & 148,061 & $-0,561$ \\
0,6202 & 201,000 & 200,718 & 0,282 \\
0,6379 & 206,700 & 206,429 & 0,271 \\
0,9323 & 302,300 & 301,417 & 0,883 \\
0,9541 & 308,800 & 308,451 & 0,349 \\
1,2209 & 395,500 & 394,534 & 0,966 \\
1,5270 & 493,600 & 493,297 & 0,303 \\
1,8567 & 599,200 & 599,675 & $-0,475$ \\
1,8639 & 602,500 & 601,998 & 0,502 \\
2,1493 & 693,100 & 694,082 & $-0,982$ \\
2,1860 & 706,000 & 705,923 & 0,077 \\
2,4307 & 784,000 & 784,876 & $-0,876$ \\
& & $\Sigma(\text { Erro })^{2}=$ & 7,3036 \\
& & SEE $=$ & 0,7802 \\
\hline
\end{tabular}

Sendo assim, o valor de +/- 2*SEE corresponde ao intervalo de confiança de 95\% nos valores da curva estimada e convertida em Pascal é de 1,560 kPa.

Desta forma, combinando as incertezas do manômetro de precisão $\left(U_{\text {mano }}\right)$, do sistema de aquisição de dados $\left(U_{a q}\right)$ e da curva de ajuste (2*SEE), tem-se o valor da incerteza da primeira etapa igual a 1,959 kPa, conforme a Eq. I.8:

$$
U_{1}=\sqrt{\left(U_{\text {mano }}\right)^{2}+\left(U_{a q}\right)^{2}+(2 * S E E)^{2}}=\sqrt{(1,118)^{2}+(0,394)^{2}+(1,560)^{2}}=1,959 \mathrm{kPa}
$$

Cabe ressalvar que o transdutor de pressão está na linha de injeção a $40 \mathrm{~cm}$ do injetor e sua temperatura praticamente não se diferencia da temperatura ambiente, portanto, não sofre desvios devido à temperatura.

\section{I.5. Medição da temperatura de injeção}

A calibração da temperatura do sistema de injeção segue o mesmo procedimento da calibração do transdutor de pressão, que foi calibrado 
conjuntamente com o condicionador de sinal e com o computador que possui a placa de aquisição de dados cujos equipamentos são utilizados na bancada experimental. Durante a calibração, o termopar esteve instalado na posição de funcionamento do injetor (ver Fig. 3.7). Onde estaria o fluido de teste, é utilizado um banho de óleo com um termômetro padrão para a devida calibração. O registro da leitura do termopar compete ao sistema de aquisição de dados que está associado aos equipamentos de conversão analógico-digital e condicionamento de sinais. O condicionador de sinal está ajustado no canal "2" para um ganho nominal de 300 vezes. Desta forma, foram levantados os dados indicados na Tab. I.4, onde a primeira coluna é a tensão medida pelo conversor A/D, seguida da leitura feita pelo termômetro padrão. Na terceira coluna está a temperatura estimada através do ajuste de curva (Eq. I.9) seguido do desvio estimado quando é feita a correção por regressão linear e, finalmente, estão apresentados os instrumentos padrões utilizados.

$$
T=-10,9409 * V^{2}+95,8553 * V-0,3296
$$

Esta curva de calibração está representada na Fig. I.2. No caso, $T$ é a temperatura estimada em função da tensão elétrica lida pelo sistema que agrega o termopar, o condicionador de sinais e o conversor A/D. 
Tabela I.4 - Calibração do Termopar.

\begin{tabular}{|c|c|c|c|c|}
\hline $\begin{array}{l}\text { Tensão } \\
\text { x } 300 \\
\text { (volts) }\end{array}$ & $\begin{array}{c}\text { Temperatura } \\
\text { Medida } \\
\left({ }^{\circ} \mathrm{C}\right)\end{array}$ & $\begin{array}{c}\text { Temperatura } \\
\text { Estimada } \\
\left({ }^{\circ} \mathrm{C}\right)\end{array}$ & $\begin{array}{l}\text { Diferença } \\
\text { pelo ajuste } \\
\left({ }^{\circ} \mathrm{C}\right)\end{array}$ & Instrumento de Aferição \\
\hline 1,7892 & 136,0 & 136,15 & 0,15 & termômetro 0-150 (escala $1^{\circ} \mathrm{C}$ ) \\
\hline 1,8009 & 137,0 & 136,81 & $-0,19$ & termômetro 0-150 (escala $1^{\circ} \mathrm{C}$ ) \\
\hline 1,5522 & 122,0 & 122,10 & 0,10 & termômetro 0-150 (escala $1^{\circ} \mathrm{C}$ ) \\
\hline 1,5347 & 121,0 & 121,01 & 0,01 & termômetro 0-150 (escala $1^{\circ} \mathrm{C}$ ) \\
\hline 1,5059 & 119,0 & 119,21 & 0,21 & termômetro 0-150 (escala $1^{\circ} \mathrm{C}$ ) \\
\hline 1,1771 & 97,0 & 97,34 & 0,34 & termômetro $80-100$ (escala $0,1^{\circ} \mathrm{C}$ ) \\
\hline 1,1471 & 95,4 & 95,23 & $-0,17$ & termômetro $80-100$ (escala $0,1^{\circ} \mathrm{C}$ ) \\
\hline 1,1419 & 95,0 & 94,86 & $-0,14$ & termômetro $80-100$ (escala $0,1^{\circ} \mathrm{C}$ ) \\
\hline 1,0286 & 87,1 & 86,69 & $-0,41$ & termômetro $80-100$ (escala $0,1^{\circ} \mathrm{C}$ ) \\
\hline 0,9513 & 81,5 & 80,96 & $-0,54$ & termômetro $80-100$ (escala $0,1^{\circ} \mathrm{C}$ ) \\
\hline 0,5288 & 46,7 & 47,30 & 0,60 & termômetro $40-60$ (escala $0,1^{\circ} \mathrm{C}$ ) \\
\hline 0,4899 & 43,5 & 44,00 & 0,50 & termômetro 40-60 (escala $0,1^{\circ} \mathrm{C}$ ) \\
\hline 0,3558 & 32,7 & 32,39 & $-0,31$ & termômetro $20-40$ (escala $0,1^{\circ} \mathrm{C}$ ) \\
\hline 0,3474 & 31,7 & 31,65 & $-0,05$ & termômetro 20-40 (escala $0,1^{\circ} \mathrm{C}$ ) \\
\hline 0,1775 & 16,2 & 16,34 & 0,14 & termômetro 0 -20 (escala $0,1^{\circ} \mathrm{C}$ ) \\
\hline 0,1876 & 17,1 & 17,27 & 0,17 & termômetro 0-20 (escala $0,1^{\circ} \mathrm{C}$ ) \\
\hline 0,1880 & 17,3 & 17,30 & 0,00 & termômetro 0-20 (escala $0,1^{\circ} \mathrm{C}$ ) \\
\hline 0,2014 & 18,6 & 18,53 & $-0,07$ & termômetro 0-20 (escala $0,1^{\circ} \mathrm{C}$ ) \\
\hline 0,2085 & 19,2 & 19,18 & $-0,02$ & termômetro 0-20 (escala $0,1^{\circ} \mathrm{C}$ ) \\
\hline \multirow[t]{2}{*}{0} & 0 & $-0,33$ & $-0,33$ & \\
\hline & & SEE: & 0,299 & \\
\hline
\end{tabular}


I. 10

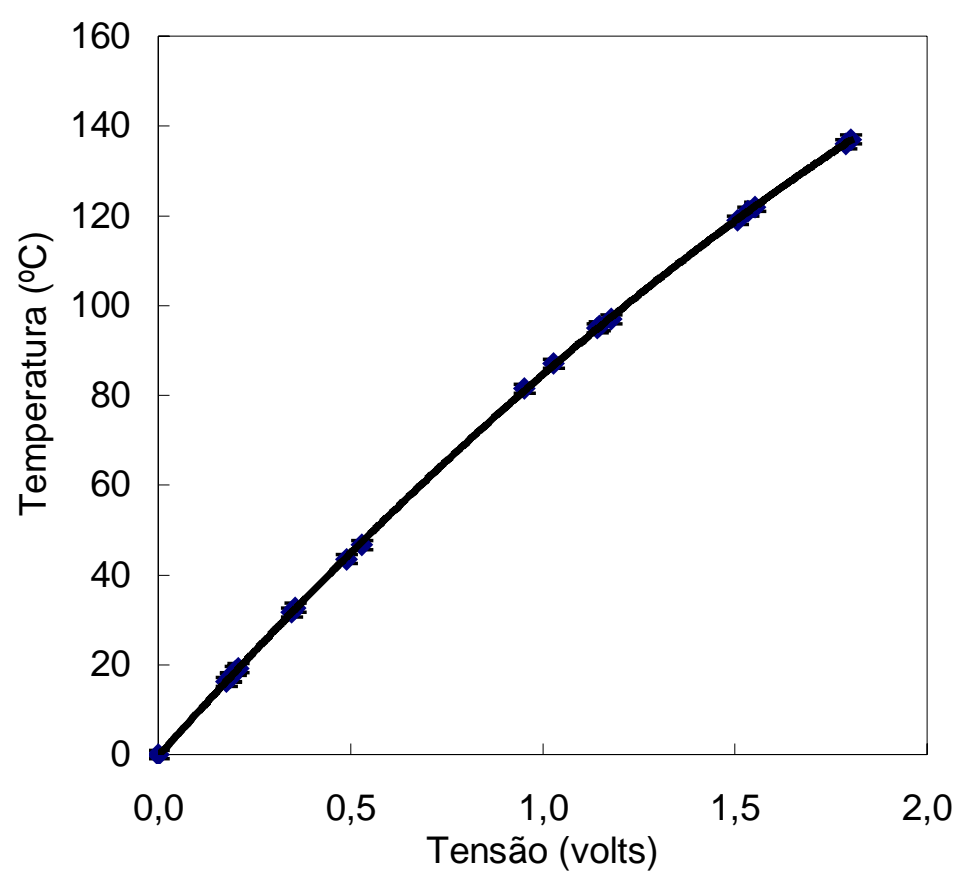

Fig. I.2 - Curva de calibração do termopar.

Tabela I.7 - Calibração do condicionador e da placa de aquisição de sinais.

\begin{tabular}{lcc}
\hline Equipamento & $\begin{array}{c}\text { Condicionador de } \\
\text { sinais }\end{array}$ & Placa de aquisição \\
\hline \hline Tipo & 8 canais & 16 canais \\
Escala & 0 a $5[\mathrm{~V}]$ & 0 a $5[\mathrm{~V}]$ \\
Ganho nominal & 300 & - \\
Fabricante & Lynx & Lynx \\
Modelo & Msc1000 & Cad 1236 \\
Resolução & - & 12 bits \\
\hline Erro sistemático & - & - \\
Erro aleatório & $0,00061035[\mathrm{~V}]=>0,05\left[{ }^{\circ} \mathrm{C}\right]$ \\
Limite de desvio & $\left(B_{T}\right):$ & \multicolumn{3}{c}{$0,10\left[{ }^{\circ} \mathrm{C}\right]$} \\
Limite de precisão $\left(P_{T}\right):$ & \multicolumn{3}{c}{$0,10\left[{ }^{\circ} \mathrm{C}\right]$} \\
\hline Incerteza $\left(U_{a q}\right):$ & \multicolumn{3}{c}{} \\
\hline
\end{tabular}

Na Tab. I.5, são expostas as especificações dos equipamentos do sistema de aquisição de dados. Nestes equipamentos apenas existem os erros aleatórios. A 
associação destes erros aleatório, que é determinado pela precisão do sistema de aquisição de dados é de $0,10^{\circ} \mathrm{C}$.

A associação da incerteza do termômetro padrão associado com as incertezas do sistema de aquisição de dados e da curva de ajuste é:

$$
U_{1}=\sqrt{\left(U_{\text {termo }}\right)^{2}+\left(U_{a q}\right)^{2}+(2 * S E E)^{2}}=\sqrt{(1,00)^{2}+(0,10)^{2}+(2 * 0,30)^{2}}=1,17^{\circ} \mathrm{C} \text { (I.10) }
$$

Desta forma, a incerteza total da temperatura de injeção é de $1,2{ }^{\circ} \mathrm{C}$.

\section{I.6. Determinação da incerteza do coeficiente de descarga}

Para determinação do coeficiente de descarga $\left(C_{D}\right)$ foi utilizado como fluido de teste a própria substância iso-octano, que era injetado no injetor da bancada, com pressões de injeção $\left(P_{0}\right)$ previamente determinadas e medidas pelo transdutor. Cabe lembrar que, no levantamento do $C_{\mathrm{D}}$, a pressão da câmara sempre foi maior que a pressão de vapor do líquido. A vazão experimental $(Q)$ foi obtida através do deslocamento do nível na pipeta volumétrica $(\Delta V)$ e pelo intervalo de tempo de injeção $(\Delta t)$ destacados pelo transitório que ocorre na pressão de injeção, e estava programado para durar em média 4,25 $\mathrm{s}$, com um deslocamento médio de 8,5 $\mathrm{ml}$. Seguindo o mesmo procedimento de cálculo da Seção I.2, o desvio sistemático da vazão é de $0,0119 \mathrm{ml}$ ou $0,0060 \%$, para uma vazão de $2 \mathrm{ml} / \mathrm{s}$. O volume específico $\left(v_{l}\right)$ do iso-octano utilizado na calibração era de $0,001456 \mathrm{~m}^{3} / \mathrm{kg}$ a uma temperatura ambiente de $25^{\circ} \mathrm{C}$. Os limites de variação desta densidade, conforme erro de ajuste de curva é de $\pm 0,000003 \mathrm{~m}^{3} / \mathrm{kg}$. O diâmetro do bocal $\left(D_{b}\right)$ é de $0,3085 \mathrm{~mm}$, com precisão de 0,001 mm, assim a área $(A)$ do bocal é de $0,074748 \mathrm{~mm}^{2}$, com uma incerteza de $0,0004846 \mathrm{~mm}^{2}$. A pressão da câmara $\left(P_{\infty}\right)$ era atmosférica e seu valor correspondia à 93,46 kPa. Conforme a equação que determina o coeficiente de descarga baseada na Equação de Bernoulli, se tem:

$$
C_{D}=\frac{Q}{A_{b} * \sqrt{2 * v_{l} *\left(P_{0}-P_{\infty}\right)}}
$$

e a área, $\quad A_{b}=\frac{\pi^{*} D_{b}{ }^{2}}{4}$. 
O erro do valor do coeficiente de descarga $\left(C_{\mathrm{D}}\right)$, por causa dos desvios de cada termo da Eq. I.11, é considerado um erro sistemático $\left(B_{C D}\right)$. Com isso, podemos escrever que o erro sistemático do coeficiente de descarga é obtido pela Eq. I.12, onde os termos com $U$ são as incertezas das respectivas medições obtidas nas seções anteriores. No caso do erro de leitura da vazão, aqui é apenas considerado o desvio sistemático, pois na etapa seguinte, será acrescentado o erro aleatório incluso no levantamento da curva de calibração do $C_{\mathrm{D}}$.

$$
\left(\frac{B_{C_{D}}}{C_{D}}\right)^{2}=(1)^{2} \cdot\left(\frac{B_{Q}}{Q}\right)^{2}+(-1)^{2}\left(\frac{U_{A b}}{A_{b}}\right)^{2}+\left(\frac{-1}{2}\right)^{2}\left(\frac{U_{v l}}{v_{l}}\right)^{2}+\left(\frac{-1}{2}\right)^{2}\left(\frac{U_{p}}{\left(P_{0}-P_{\infty}\right)}\right)^{2}
$$

Resolvendo esta equação, encontra-se a variação máxima $\left(B_{C_{D}} / C_{D}\right)$ de 1,32 \%. Logo, para um valor médio de $C_{\mathrm{D}}$ igual a 0,922 , tem-se o desvio $B_{\mathrm{CD}}$ igual a 0,01217 .

Para determinação do erro aleatório, foram realizados 25 ensaios que estão mostrados na Tab. I.8 e ilustrados na Fig. I.3, graficamente. Através dos dados experimentais, o cálculo do $C_{\mathrm{D}}$ foi ajustado pela curva que se encontra a seguir onde,

$$
C_{D}=0,9673-\frac{5,6682}{\sqrt{\operatorname{Re}}} .
$$

Desta forma, é possível determinar o erro aleatório de tal coeficiente. Para uma confiabilidade de 95\% deve-se tomar o SEE do ajuste da curva do $C_{\mathrm{D}}$ (ver Tab. I.8 onde é visto que o SEE é igual a 0,00633) e multiplicá-lo por 2 para obter o limite de precisão $\left(P_{C D}\right)$ de 0,01266 .

Como o limite de desvio $\left(B_{C D}\right)$ do coeficiente de descarga é de 0,01217 e o limite de precisão é de 0,01266, pode-se obter a incerteza do coeficiente de descarga pelo seguinte cálculo:

$$
U_{C d}=\sqrt{\left(B_{C_{D}}\right)^{2}+(2 * . S E E)^{2}}=\sqrt{\left(B_{C_{D}}\right)^{2}+\left(P_{C_{D}}\right)^{2}}=0,01756
$$

Tabela I.8 - Ensaios para determinação do coeficiente de descarga $\left(C_{D}\right)$ do bocal de aço de 0,3 mm de diâmetro. 


\begin{tabular}{cccccc}
\hline Ensaio & $\begin{array}{c}\text { Diferença de } \\
\text { pressões }\left(P_{0}-P_{\infty}\right) \\
{[\mathrm{kPa}]}\end{array}$ & $\dot{m}$ & $R e$ & $C_{D}$ & Ajuste $C_{D}$ \\
\hline 1 & 496,0 & $1,825 \mathrm{E}-03$ & 15741 & 0,935 & 0,922 \\
2 & 449,4 & $1,718 \mathrm{E}-03$ & 14811 & 0,925 & 0,921 \\
3 & 409,8 & $1,634 \mathrm{E}-03$ & 14087 & 0,921 & 0,919 \\
4 & 394,1 & $1,593 \mathrm{E}-03$ & 13737 & 0,916 & 0,919 \\
5 & 380,4 & $1,574 \mathrm{E}-03$ & 13577 & 0,921 & 0,919 \\
6 & 314,5 & $1,439 \mathrm{E}-03$ & 12411 & 0,926 & 0,916 \\
7 & 303,1 & $1,413 \mathrm{E}-03$ & 12181 & 0,926 & 0,916 \\
8 & 269,6 & $1,316 \mathrm{E}-03$ & 11352 & 0,915 & 0,914 \\
9 & 215,2 & $1,172 \mathrm{E}-03$ & 10107 & 0,912 & 0,911 \\
10 & 207,5 & $1,144 \mathrm{E}-03$ & 9868 & 0,907 & 0,910 \\
11 & 200,0 & $1,125 \mathrm{E}-03$ & 9700 & 0,908 & 0,910 \\
12 & 99,2 & $7,816 \mathrm{E}-04$ & 6740 & 0,896 & 0,898 \\
13 & 95,8 & $7,641 \mathrm{E}-04$ & 6589 & 0,891 & 0,897 \\
14 & 86,4 & $7,310 \mathrm{E}-04$ & 6304 & 0,898 & 0,896 \\
15 & 488,5 & $1,784 \mathrm{E}-03$ & 15388 & 0,921 & 0,922 \\
16 & 473,7 & $1,751 \mathrm{E}-03$ & 15096 & 0,918 & 0,921 \\
17 & 752,7 & $2,218 \mathrm{E}-03$ & 19124 & 0,923 & 0,926 \\
18 & 706,7 & $2,154 \mathrm{E}-03$ & 18572 & 0,925 & 0,926 \\
19 & 819,8 & $2,324 \mathrm{E}-03$ & 20044 & 0,927 & 0,927 \\
20 & 200,0 & $1,094 \mathrm{E}-03$ & 16417 & 0,917 & 0,923 \\
21 & 194,6 & $1,083 \mathrm{E}-03$ & 16182 & 0,920 & 0,923 \\
22 & 157,5 & $9,576 \mathrm{E}-04$ & 16723 & 0,912 & 0,923 \\
23 & 160,7 & $9,812 \mathrm{E}-04$ & 17135 & 0,925 & 0,924 \\
24 & 141,2 & $9,095 \mathrm{E}-04$ & 13677 & 0,907 & 0,919 \\
25 & 73,9 & $6,652 \mathrm{E}-04$ & 11571 & 0,925 & 0,915 \\
& & & & SEE= & 0,00633 \\
\hline & & & & &
\end{tabular}




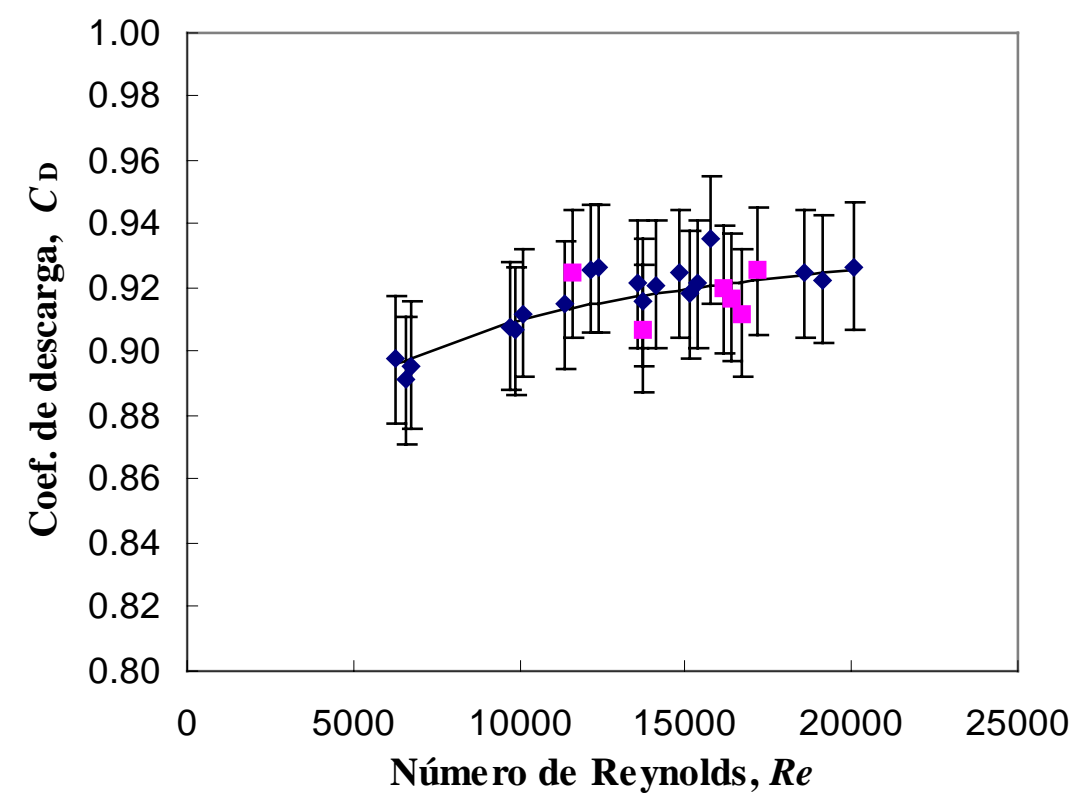

Figura I.3 - Gráfico do coeficiente de descarga em função do $C_{\mathrm{D}}$, para o bocal de aço de $0,3 \mathrm{~mm}$ de diâmetro.

A incerteza obtida pela Eq. I.14 foi vinculada a uma diferença de pressão de $100 \mathrm{kPa}$. Esta diferença de pressão resulta na maior propagação do desvio do coeficiente de descarga. Para outras diferenças de pressão, segue a Tab. I.9, com valores mais exatos desta incerteza. Nela se encontra os valores das diferenças de pressão seguida da respectiva vazão esperada. Depois estão os valores dos limites sistemáticos e de precisão. A incerteza corresponde à associação dos dois limites.

Tabela I.9 - Incertezas relacionadas à medição do coeficiente de descarga em função da diferença entre a pressão de injeção e a pressão da câmara.

\begin{tabular}{cccccc}
\hline $\begin{array}{c}\text { Diferença de } \\
\text { pressões }\left(P_{0}-P_{\infty}\right) \\
{[\mathrm{kPa}]}\end{array}$ & $\begin{array}{c}Q \\
{[\mathrm{ml} / \mathrm{s}]}\end{array}$ & $\begin{array}{c}B_{\mathrm{Cd}} \\
{[-]}\end{array}$ & $\begin{array}{c}P_{\mathrm{Cd}} \\
{[-]}\end{array}$ & $\begin{array}{c}U_{\mathrm{Cd}} \\
{[-]}\end{array}$ & $\begin{array}{c}U_{\mathrm{Cd}} / C_{\mathrm{D}} \\
{[\%]}\end{array}$ \\
\hline 100 & 1,24 & 0,01217 & 0,01266 & 0,01756 & 1,90 \\
200 & 1,75 & 0,00933 & 0,01266 & 0,01573 & 1,71 \\
300 & 2,15 & 0,00870 & 0,01266 & 0,01536 & 1,67 \\
400 & 2,48 & 0,00847 & 0,01266 & 0,01523 & 1,65 \\
500 & 2,77 & 0,00836 & 0,01266 & 0,01517 & 1,65 \\
600 & 3,04 & 0,00830 & 0,01266 & 0,01514 & 1,64 \\
700 & 3,28 & 0,00826 & 0,01266 & 0,01512 & 1,64 \\
\hline
\end{tabular}


A seguir são apresentados os levantamentos experimentais do $C_{\mathrm{D}}$ do bocal de aço de 0,798 $\mathrm{mm}$ (ou simplesmente, 0,8 $\mathrm{mm}$ ) de diâmetro e do bocal de vidro com 0,348 mm de diâmetro (ou simplesmente, 0,35 mm). O procedimento de levantamento das curvas destes bocais é o mesmo do bocal de aço de 0,3085 mm de diâmetro.

Tabela I.10 - Ensaios para determinação do coeficiente de descarga $\left(C_{D}\right)$ do bocal de aço de 0,798 mm de diâmetro.

\begin{tabular}{cccccc}
\hline Ensaio & $\begin{array}{c}\text { Diferença de } \\
\text { pressões }\left(P_{0}-P_{\infty}\right) \\
{[\mathrm{kPa}]}\end{array}$ & $\dot{m}$ & $R e$ & $C_{D}$ & Ajuste $C_{D}$ \\
\hline \hline 1 & 544,0 & $1,245 \mathrm{E}-02$ & 39095 & 0,910 & 0,910 \\
2 & 495,7 & $1,202 \mathrm{E}-02$ & 37753 & 0,920 & 0,909 \\
3 & 477,1 & $1,171 \mathrm{E}-02$ & 36788 & 0,914 & 0,908 \\
4 & 444,0 & $1,107 \mathrm{E}-02$ & 34755 & 0,895 & 0,905 \\
5 & 392,9 & $1,053 \mathrm{E}-02$ & 33064 & 0,905 & 0,903 \\
6 & 367,3 & $1,021 \mathrm{E}-02$ & 32081 & 0,909 & 0,901 \\
7 & 329,4 & $9,595 \mathrm{E}-03$ & 30135 & 0,901 & 0,899 \\
8 & 317,4 & $9,421 \mathrm{E}-03$ & 29588 & 0,902 & 0,898 \\
9 & 297,1 & $9,037 \mathrm{E}-03$ & 28383 & 0,894 & 0,896 \\
10 & 249,5 & $8,223 \mathrm{E}-03$ & 25828 & 0,888 & 0,891 \\
11 & 203,1 & $7,392 \mathrm{E}-03$ & 23216 & 0,884 & 0,885 \\
12 & 164,2 & $6,587 \mathrm{E}-03$ & 20689 & 0,876 & 0,878 \\
13 & 145,8 & $6,196 \mathrm{E}-03$ & 19459 & 0,875 & 0,875 \\
14 & 115,2 & $5,462 \mathrm{E}-03$ & 17156 & 0,868 & 0,867 \\
15 & 97,7 & $5,019 \mathrm{E}-03$ & 15764 & 0,866 & 0,861 \\
16 & 466,2 & $1,129 \mathrm{E}-02$ & 35464 & 0,914 & 0,906 \\
17 & 449,3 & $1,093 \mathrm{E}-02$ & 34328 & 0,898 & 0,905 \\
18 & 433,6 & $1,075 \mathrm{E}-02$ & 33767 & 0,897 & 0,904 \\
19 & 417,8 & $1,061 \mathrm{E}-02$ & 33331 & 0,901 & 0,903 \\
20 & 365,5 & $9,802 \mathrm{E}-03$ & 30785 & 0,887 & 0,900 \\
21 & 342,5 & $9,410 \mathrm{E}-03$ & 29556 & 0,896 & 0,898 \\
& & & & SEE $=$ & 0,00612 \\
\hline
\end{tabular}

A Tab. I.10 indica os valores obtidos no levantamento do $C_{\mathrm{D}}$ do bocal de aço de $0,8 \mathrm{~mm}$ de diâmetro (ou 0,798 mm, precisamente). A curva levantada através destes valores é:

$$
C_{D}=0,9954-\frac{16,827}{\sqrt{\operatorname{Re}}} .
$$

Da mesma forma, para o bocal de vidro de 0,3 mm de diâmetro (ou 0,348 mm, precisamente), a Tab. I.11 apresenta os valores do levantamento do $C_{\mathrm{D}}$ e a equação que representa o comportamento do $C_{\mathrm{D}}$ em função do número de Reynolds é: 


$$
C_{D}=0,9963-\frac{8,8247}{\sqrt{\operatorname{Re}}} .
$$

As faixas de incerteza calculados no bocal de aço de 0,3 mm serão as mesmas para estes bocais.

Tabela I.11 - Ensaios para determinação do coeficiente de descarga $\left(C_{D}\right)$ do bocal de vidro de $0,348 \mathrm{~mm}$ de diâmetro.

\begin{tabular}{cccccc}
\hline Ensaio & $\begin{array}{c}\text { Diferença de } \\
\text { pressões }\left(P_{0}-P_{\infty}\right) \\
{[\mathrm{kPa}]}\end{array}$ & $\dot{m}$ & $R e$ & $C_{D}$ & Ajuste $C_{D}$ \\
\hline \hline 1 & 111,7 & $1,153 \mathrm{E}-03$ & 8476 & 0,903 & 0,900 \\
2 & 104,0 & $1,104 \mathrm{E}-03$ & 8112 & 0,896 & 0,898 \\
3 & 87,7 & $1,009 \mathrm{E}-03$ & 7418 & 0,892 & 0,894 \\
4 & 71,3 & $9,061 \mathrm{E}-04$ & 6659 & 0,888 & 0,888 \\
5 & 68,8 & $8,895 \mathrm{E}-04$ & 6537 & 0,887 & 0,887 \\
6 & 51,2 & $7,614 \mathrm{E}-04$ & 5595 & 0,880 & 0,873 \\
7 & 161,0 & $1,369 \mathrm{E}-03$ & 20189 & 0,936 & 0,934 \\
8 & 199,1 & $1,529 \mathrm{E}-03$ & 19309 & 0,931 & 0,933 \\
& & & & SEE $=$ & 0,00216 \\
\hline
\end{tabular}

\section{I.7. Determinação da pressão do líquido metaestável}

Antes de iniciar com o procedimento de cálculo da incerteza deste parâmetro, é necessário recapitular os limites de erros e incertezas já calculados. Na Tab. I.12, são mostrados as leituras de volume, de tempo, de vazão, pressão de injeção, temperatura de injeção, volume específico, diâmetro de saída do bocal, área na saída do bocal e, coeficiente de descarga. Na coluna seguinte, estão expostas as unidades destas leituras, com exceção do coeficiente de descarga que é um adimensional. A seguir, tem-se a grandeza das medidas envolvidas. Com relação ao coeficiente de descarga, cada pressão de injeção resultará em um valor deste coeficiente, assim como, incertezas e limites sistemáticos e de precisão associados. Isto porque a vazão é proporcional à raiz da diferença de pressões e, o coeficiente de descarga também é proporcional a diferença de pressões por causa da influência da vazão em cima do número de Reynolds. 
Tabela I.12 - Quadro das incertezas e limites envolvidos na medição da pressão do líquido na saída do bocal.

\begin{tabular}{|c|c|c|c|c|c|c|}
\hline Leitura & Unidade & $\begin{array}{c}\text { Grandeza } \\
(X) \\
\end{array}$ & $\begin{array}{c}\text { Limite } \\
\text { Sistemático } \\
(B) \\
\end{array}$ & $\begin{array}{c}\text { Limite de } \\
\text { Precisão } \\
(P) \\
\end{array}$ & $\begin{array}{c}\text { Incerteza } \\
(U) \\
\end{array}$ & $\begin{array}{r}\text { Relação } \\
(U / X) \\
\end{array}$ \\
\hline Volume & {$[\mathrm{ml}]$} & 6,00 & - & 0,050 & 0,0500 & 0,0083 \\
\hline Tempo & {$[\mathrm{s}]$} & 3,00 & - & 0,004 & 0,0040 & 0,0013 \\
\hline Vazão & {$[\mathrm{ml} / \mathrm{s}]$} & 2,000 & 0,01688 & 0,036 & 0,0398 & 0,0199 \\
\hline $\begin{array}{l}\text { Pressão de } \\
\text { Injeção }\left(P_{0}\right)\end{array}$ & [kPa] & $\begin{array}{l}100 \\
200 \\
300 \\
400 \\
500 \\
600 \\
700\end{array}$ & \begin{tabular}{l|}
1,1854 \\
1,1854 \\
1,1854 \\
1,1854 \\
1,1854 \\
1,1854 \\
1,1854
\end{tabular} & $\begin{array}{l}1,560 \\
1,560 \\
1,560 \\
1,560 \\
1,560 \\
1,560 \\
1,560\end{array}$ & $\begin{array}{l}1,959 \\
1,959 \\
1,959 \\
1,959 \\
1,959 \\
1,959 \\
1,959\end{array}$ & \begin{tabular}{l|}
0,0196 \\
0,0098 \\
0,0065 \\
0,0049 \\
0,0039 \\
0,0033 \\
0,0028
\end{tabular} \\
\hline $\begin{array}{l}\text { Temperatura } \\
\text { de injeção }\end{array}$ & {$\left[{ }^{\circ} \mathrm{C}\right]$} & 120 & 1,0050 & 0,600 & 1,17 & \\
\hline $\begin{array}{c}\text { Volume } \\
\text { específico }\end{array}$ & {$\left[\mathrm{m}^{3} / \mathrm{kg}\right]$} & 0,001620 & 0,000003 & - & 0,000003 & 0,0019 \\
\hline $\begin{array}{c}\text { Diâmetro } \\
\text { do bocal }\end{array}$ & [mm] & 0,3085 & 0,001 & - & 0,0010 & 0,0032 \\
\hline Área & {$\left[\mathrm{mm}^{2}\right]$} & 0,074748 & 0,0004846 & - & 0,0005 & 0,0065 \\
\hline$C_{\mathrm{D}}$ & $\begin{array}{l}P_{0}=100 \mathrm{kPa} \\
P_{0}=200 \mathrm{kPa} \\
P_{0}=300 \mathrm{kPa} \\
P_{0}=400 \mathrm{kPa} \\
P_{0}=500 \mathrm{kPa} \\
P_{0}=600 \mathrm{kPa} \\
P_{0}=700 \mathrm{kPa}\end{array}$ & $\begin{array}{l}0,923 \\
0,930 \\
0,934 \\
0,936 \\
0,938 \\
0,939 \\
0,940\end{array}$ & $\begin{array}{l}0,01217 \\
0,00933 \\
0,00870 \\
0,00847 \\
0,00836 \\
0,00830 \\
0,00826\end{array}$ & $\begin{array}{l}0,01266 \\
0,01266 \\
0,01266 \\
0,01266 \\
0,01266 \\
0,01266 \\
0,01266\end{array}$ & $\begin{array}{l}0,01756 \\
0,01573 \\
0,01536 \\
0,01523 \\
0,01517 \\
0,01514 \\
0,01512\end{array}$ & $\begin{array}{l}0,0190 \\
0,0171 \\
0,0167 \\
0,0165 \\
0,0165 \\
0,0164 \\
0,0164\end{array}$ \\
\hline
\end{tabular}

Neste parâmetro, é necessário tomar a hipótese de que o escoamento é incompressível na expansão do bocal, e que não existe a evaporação internamente a ele. Através da equação clássica de Bernoulli adaptada para determinação da vazão em bocais e, utilizando o coeficiente de descarga, a diferença entre a pressão a montante e a jusante, que é a pressão metaestável do líquido $\left(P_{1}\right)$ pode ser escrita como:

$$
D P=\left(P_{0}-P_{1}\right)=\frac{Q^{2}}{2 * v_{l} * C_{D}^{2} * A_{b}^{2}}
$$

Desta equação, existem leituras cujas incertezas correlacionam entre si, como os limites sistemáticos do $C_{\mathrm{D}}$ e da área do bocal. Uma forma de avaliar esta 
correlação, evitando redundância de erros que comprometeria a incerteza total da determinação da diferença de pressão é utilizar a seguinte fórmula sugerida pela norma da ASME e reformulada para este caso específico.

$$
\begin{aligned}
& \Delta D P^{2}=\left(\frac{\partial D P}{\partial Q}\right)^{2} \cdot \Delta Q^{2}+\left(\frac{\partial D P}{\partial v}\right)^{2} \cdot \Delta v^{2}+\left(\frac{\partial D P}{\partial A_{b}}\right)^{2} \cdot \Delta A_{b}^{2}+\left(\frac{\partial D P}{\partial C_{D}}\right)^{2} \cdot \Delta C_{D}^{2}+ \\
+ & 2 \rho_{Q, v} \cdot\left(\frac{\partial D P}{\partial Q}\right) \cdot\left(\frac{\partial D P}{\partial v}\right) \cdot \Delta Q^{\prime} \cdot \Delta v^{\prime}+2 \rho_{Q, A} \cdot\left(\frac{\partial D P}{\partial Q}\right) \cdot\left(\frac{\partial D P}{\partial A_{b}}\right) \cdot \Delta Q^{\prime} \cdot \Delta A_{b}^{\prime}+2 \rho_{Q, C d} \cdot\left(\frac{\partial D P}{\partial Q}\right) \cdot\left(\frac{\partial D P}{\partial C_{D}}\right) \cdot \Delta Q^{\prime} \cdot \Delta C_{D}^{\prime}+ \\
+ & 2 \rho_{A, v} \cdot\left(\frac{\partial D P}{\partial A_{b}}\right) \cdot\left(\frac{\partial D P}{\partial v}\right) \cdot \Delta A_{b}^{\prime} \cdot \Delta v^{\prime}+2 \rho_{A, C d} \cdot\left(\frac{\partial D P}{\partial A_{b}}\right) \cdot\left(\frac{\partial D P}{\partial C_{D}}\right) \cdot \Delta A_{b}^{\prime} \cdot \Delta C_{D}^{\prime}+ \\
+ & 2 \rho_{v, C d} \cdot\left(\frac{\partial D P}{\partial v}\right) \cdot\left(\frac{\partial D P}{\partial C_{D}}\right) \cdot \Delta v^{\prime} \cdot \Delta C_{D}^{\prime}
\end{aligned}
$$

Desta equação, existe um índice de correlação que se refere ao símbolo $\rho$. De todas as leituras, como já foi dito, as únicas que tem uma correlação com os erros sistemáticos é a medida da área, $A_{\mathrm{b}}$, e o valor do $C_{\mathrm{D}}$. Portanto $\rho_{\mathrm{A}, \mathrm{Cd}}$ é igual a um e as outras correlações têm valores nulos. Logo a equação se resume a

$$
\begin{aligned}
\Delta D P^{2}=\left(\frac{\partial D P}{\partial Q}\right)^{2} \cdot \Delta Q^{2} & +\left(\frac{\partial D P}{\partial v}\right)^{2} \cdot \Delta v^{2}+\left(\frac{\partial D P}{\partial A_{b}}\right)^{2} \cdot \Delta A_{b}^{2}+\left(\frac{\partial D P}{\partial C_{D}}\right)^{2} \cdot \Delta C_{D}^{2}+ \\
& +2 \rho_{A, C d} \cdot\left(\frac{\partial D P}{\partial A_{b}}\right) \cdot\left(\frac{\partial D P}{\partial C d}\right) \cdot \Delta A_{b}^{\prime} \cdot \Delta C d^{\prime}
\end{aligned}
$$

Sabendo que, pela Eq. (I.17),

$$
\begin{aligned}
& \frac{\partial D P}{\partial Q}=\frac{Q}{v \cdot C_{D}^{2} \cdot A_{b}^{2}}, \\
& \frac{\partial D P}{\partial v}=\frac{-Q^{2}}{4 v^{2} \cdot C_{D}^{2} \cdot A_{b}^{2}}, \\
& \frac{\partial D P}{\partial A_{b}}=\frac{-Q^{2}}{v \cdot C_{D}^{2} \cdot A_{b}^{3}}, \\
& \frac{\partial D P}{\partial C_{D}}=\frac{-Q^{2}}{v \cdot C_{D}^{3} \cdot A_{b}^{2}} .
\end{aligned}
$$

E também, 


$$
\frac{\partial C_{D}}{\partial A_{b}}=\frac{\partial}{\partial A_{b}}\left(\frac{Q}{A_{b} \cdot \sqrt{2 v \cdot D P}}\right)=\frac{-Q}{A_{b}^{2} \cdot \sqrt{2 v \cdot D P}}=\frac{-C_{D}}{A_{b}} \Rightarrow \frac{\Delta C_{D}^{\prime}}{C_{D}}=\frac{-\Delta A^{\prime}}{A}
$$

Utilizando as expressões acima e substituindo os termos de variação da leitura onde:

$\Delta Q=B_{Q}, \quad \Delta v=U_{v}=B_{A}, \quad \Delta C_{D}=B_{C d}, \quad \Delta A_{b}=U_{A b}=B_{A b}, \quad \Delta A^{\prime}=B_{A} \quad$ e conseqüentemente, $\frac{\Delta C_{D}{ }^{\prime}}{C_{D}}=\frac{-B_{A b}}{A_{b}}=\frac{-U_{A b}}{A_{b}}$, pode se reescrever a Eq. I.19 como:

$$
\frac{B_{D P}^{2}}{D P^{2}}=\frac{1}{4}\left(\frac{B_{v}}{v}\right)^{2}+4 \cdot\left[\left(\frac{B_{Q}}{Q}\right)^{2}+\left(\frac{B_{C d}}{C_{D}}\right)^{2}-\left(\frac{B_{A_{b}}}{A_{b}}\right)^{2}\right]
$$

ou,

$$
\frac{B_{D P}}{P_{0}-P_{1}}=\sqrt{\frac{1}{4}\left(\frac{B_{v}}{v}\right)^{2}+4 .\left[\left(\frac{B_{Q}}{Q}\right)^{2}+\left(\frac{B_{C d}}{C_{D}}\right)^{2}-\left(\frac{B_{A_{b}}}{A_{b}}\right)^{2}\right]}
$$

Da equação acima, foi obtido o erro sistemático. O erro aleatório da medida da diferença de pressão está associado apenas ao erro aleatório da vazão. Pela Eq. (I.17), é verificado que a vazão está elevada ao quadrado, este limite de precisão da vazão se propagará pelo dobro do valor no limite de precisão das diferenças de pressões logo,

$$
\frac{P_{D P}}{P_{0}-P}=2 .\left(\frac{P_{Q}}{Q}\right)
$$

Com a associação destes dois limites, pode-se determinar a incerteza total deste parâmetro onde,

$$
U_{D P}=\sqrt{B_{D P}^{2}+P_{D P}^{2}}
$$

Finalmente, a incerteza da pressão do líquido na saída do bocal pode ser obtida através da associação da incerteza da pressão de injeção. Esta associação mostra que a incerteza deste parâmetro é basicamente dependente da diferença entre a pressão de injeção e a pressão metaestável calculada

$$
U_{P 1}=\sqrt{U_{D P}^{2}+U_{P 0}^{2}}
$$

A tabela a seguir ilustrada os limites e incertezas da diferença das pressões. Como na Tab. I.13, esta tabela mostra os limites de precisão e sistemáticos e as 
incertezas associadas respectivas às grandezas das diferenças de pressão de injeção e pressão na saída do bocal $\left(P_{0}-P_{1}\right)$, assim como, apenas à pressão metaestável do líquido $\left(P_{1}\right)$.

Tabela I.13 - Quadro das incertezas e limites envolvidos na medição da pressão do líquido na saída do bocal.

\begin{tabular}{|c|c|c|c|c|c|c|}
\hline Leitura & Unidade & $\begin{array}{c}\text { Grandeza } \\
(X)\end{array}$ & $\begin{array}{c}\text { Limite } \\
\text { Sistemático } \\
(B)\end{array}$ & $\begin{array}{c}\text { Limite de } \\
\text { Precisão } \\
(P)\end{array}$ & $\begin{array}{c}\text { Incerteza } \\
(U) \\
\end{array}$ & $\begin{array}{l}\text { Relação } \\
(U / X) \\
\end{array}$ \\
\hline$P_{0}-P_{1}$ & {$[\mathrm{kPa}]$} & $\begin{array}{l}100 \\
200 \\
300 \\
400 \\
500 \\
600 \\
700\end{array}$ & $\begin{array}{c}4,594 \\
8,539 \\
12,621 \\
16,739 \\
20,871 \\
25,012 \\
29,157\end{array}$ & $\begin{array}{l}- \\
- \\
- \\
- \\
- \\
- \\
-\end{array}$ & $\begin{array}{c}4,594 \\
8,539 \\
12,621 \\
16,739 \\
20,871 \\
25,012 \\
29,157\end{array}$ & $\begin{array}{l}0,0459 \\
0,0427 \\
0,0421 \\
0,0418 \\
0,0417 \\
0,0417 \\
0,0417\end{array}$ \\
\hline$P_{1}$ & {$[\mathrm{kPa}]$} & $\begin{array}{c}\text { para }\left(P_{0}-P_{1}\right) \\
100 \\
200 \\
300 \\
400 \\
500 \\
600 \\
700\end{array}$ & $\begin{array}{c}4,995 \\
8,761 \\
12,772 \\
16,853 \\
20,963 \\
25,089 \\
29,223\end{array}$ & $\begin{array}{l}- \\
- \\
- \\
- \\
- \\
- \\
-\end{array}$ & $\begin{array}{c}4,995 \\
8,761 \\
12,772 \\
16,853 \\
20,963 \\
25,089 \\
29,223\end{array}$ & $\begin{array}{l}- \\
- \\
- \\
- \\
- \\
- \\
-\end{array}$ \\
\hline
\end{tabular}

\section{I.8. Precisão dimensional da imagem}

Para determinar as dimensões da onda de choque, ou o comprimento da parte líquida do jato, é utilizada a relação de equivalência métrica do tamanho do "pixel”. Geralmente, é da ordem de 6 “pixels” por milímetro, dependendo da regulagem da lente objetiva da câmara. A distância tomada como referência é o diâmetro do corpo do injetor, que é de 50,7 mm e está esquematizado na Fig. I.3 e uma fotografia desta verificação se encontra na Fig. I.4. Para comprovar tal procedimento de análise de medições, colocou-se um tubo de ensaio de vidro, totalmente transparente, com diâmetro externo de 15,85 mm nas posições horizontal e vertical, sendo que, a medida de referência era de 50,70 mm correspondia a 342 “pixels”. O resultado 
esperado do diâmetro do tubo de ensaio comparado com o valor real se encontra na Tab. I.14, a seguir.

Tabela I.14 - Comparativo das dimensões encontradas.

\begin{tabular}{ccc}
\hline & Diâmetro encontrado & Diferença \\
\hline \hline Posição horizontal & $15,93 \mathrm{~mm}$ (ou 109 “pixels”) & $0.08 \mathrm{~mm}$ \\
Posição vertical & $15,92 \mathrm{~mm}$ (ou 108 “pixels”) & $0,07 \mathrm{~mm}$
\end{tabular}

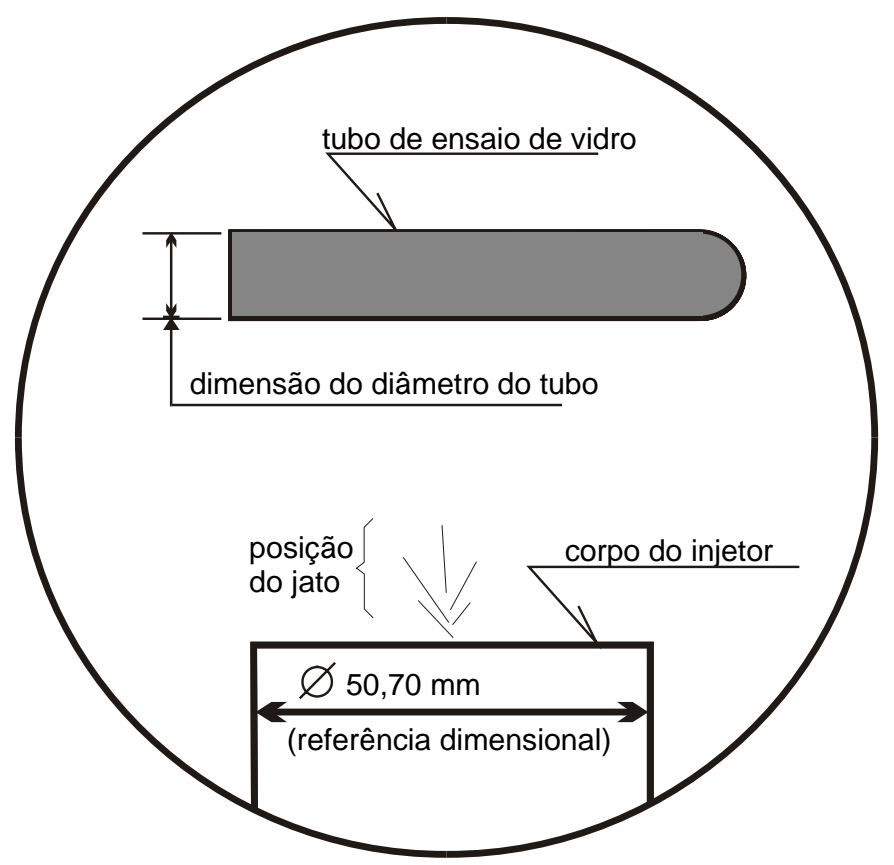

Fig. I.3 - Esquema do procedimento da análise dimensional

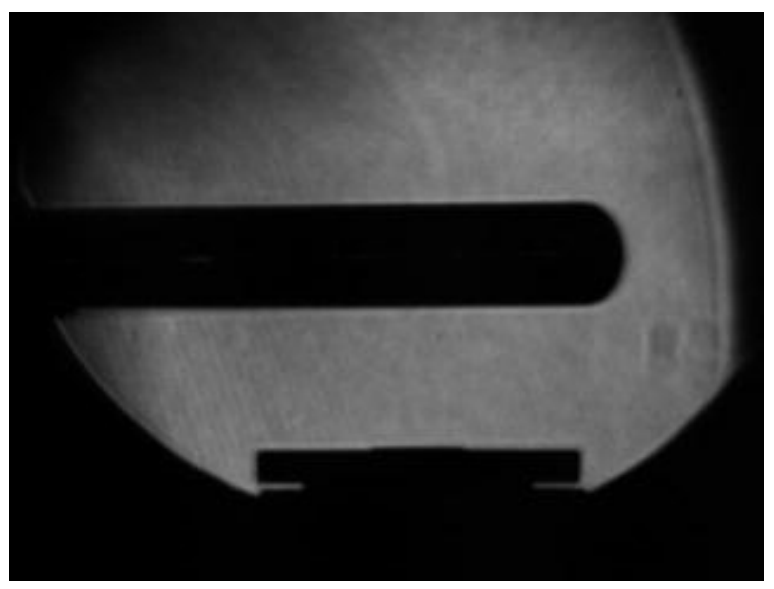

Fig. I.4 - Imagem do tubo de ensaio. 


\section{Apêndice II}

\section{Processamento}

Matemático das Imagens 


\section{Processamento Matemático das Imagens}

Existe uma primeira imagem que é obtida com a câmara de CCD, no instante imediatamente anterior ao jato. As seguintes, em intervalos de 0,50 s, no mínimo, 4 quadros são obtidas durante a injeção. No exemplo a seguir, têm-se duas imagens, em que a primeira, Fig. II.1a, foi realizada antes do jato e a outra, na Fig. II.1b, durante a injeção.

a)

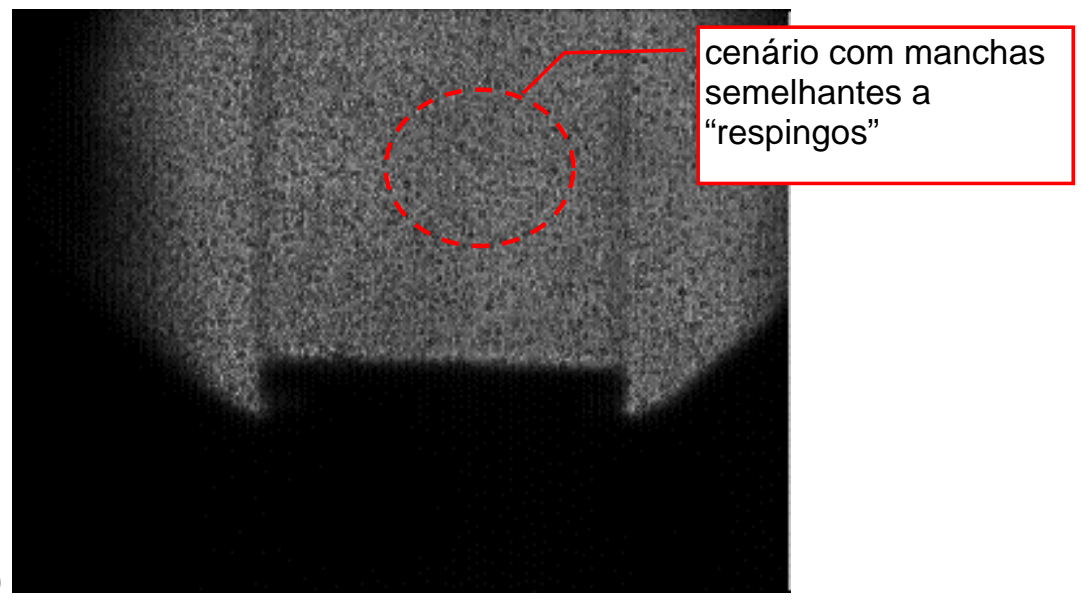

b)

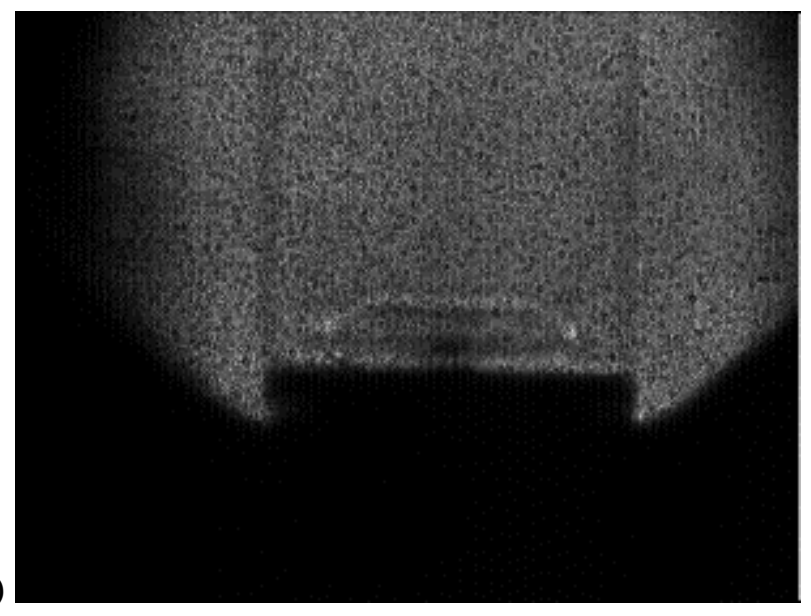

Figura II.1 - a) Fotografia obtida antes do jato (referência) e b) é uma das fotografias adquiridas durante o jato.

Para filtrar a imagem, destacando apenas o jato, a segunda imagem é subtraída da primeira imagem de referência. Para isto, na imagem existe o "pixel” (ponto de menor resolução da imagem). Todas as imagens são obtidas com uma 
disposição matricial de 640 x 480 "pixels". O filtro opera com a subtração de cada "pixel" da imagem que contém o jato, pelo "pixel" de mesma coordenada existente na imagem de referência, ou seja, a primeira imagem sem o jato. Depois, a matriz da imagem filtrada é normalizada onde o seu menor valor da matriz terá o valor nulo e o maior possuirá o valor 255 (256 tons de cinza, ou seja, 8 bits) dando um melhor contraste da imagem. Este cálculo foi programado no "MATLAB" e foi desenvolvido por Guimarães (1999). O filtro subtrativo constitui a divisão entre os valores dos "pixels" porque a magnitude deles está em escala logarítmica e a câmara CCD tem sensibilidade linear. Na Fig. II.2 tem-se a imagem filtrada do jato.

Como observação, estas fotografias, assim como outras fotografias de jatos deste trabalho, possuem um aglomerado de pequenas manchas ou "respingos" (Fig. II.1). Neste caso, elas apareceram por causa de um defeito que ocorreu no sensor CCD da câmara e com o processamento matemático foi possível subtraí-las da imagem.

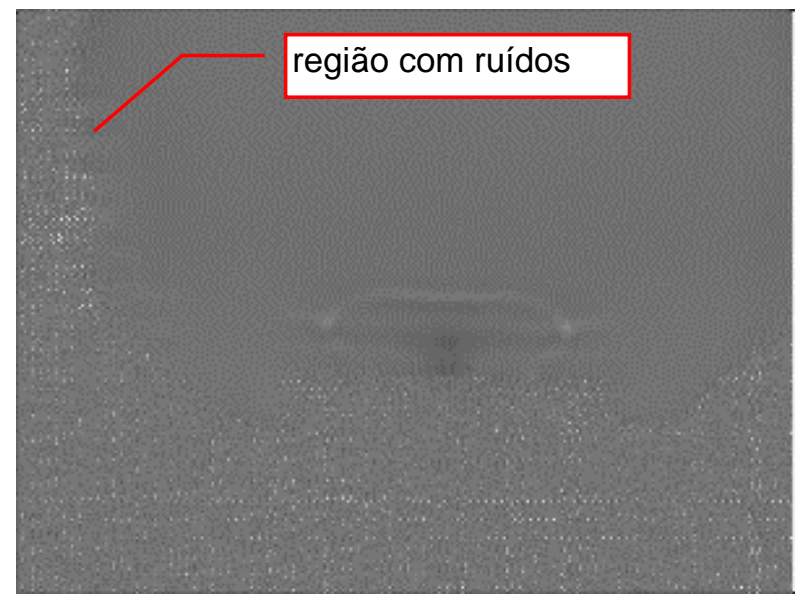

Figura II.2 - Imagem filtrada (mapa de cores "gray").

Em decorrência de vibrações das mesas ópticas e do injetor, outros ruídos de amplitude moderada nas regiões que circundam o injetor e a janela, são identificados na subtração das imagens (Fig. II.2). Para minimizar este problema, e destacar ainda mais o jato, é mudada a paleta de cores da imagem, pois é uma opção do tipo "toolbox" do Matlab. Por exemplo, os mapas de cores do tipo, "gray", "hot", "pink", "bone", e "copper", são mapas que delineiam certas linhas do sistema RGB (iniciais de "red", "green" e "blue", significando respectivamente vermelho, verde e azul) de 
cores onde, o "gray" trabalha com tons de cinza, o "hot" com tons de amarelo e vermelho, o "pink" com tons cor de rosa e marrom claro, "bone" com tons de azul, e "copper" com tons de cobre, e todos estes mapas, tendem ao tom preto para os “pixels” próximos do valor zero. Os outros mapas de cores, "jet", "cool" e "hsv", trabalham no sistema de cores que se baseiam nos valores de matiz, luminosidade e saturação.

Tabela II.1 - Exemplo ilustrativo de equivalência em mapas de cores.

\begin{tabular}{|c|c|c|c|c|c|}
\hline $\begin{array}{l}\text { Cor } \\
\text { Intervalo }\end{array}$ & $\begin{array}{c}\text { preto } \\
(0 \text { até } 4)\end{array}$ & & $\begin{array}{r}\text { tons de cinz } \\
(5 \text { até } 250)\end{array}$ & & $\begin{array}{c}\text { branco } \\
\text { (251 até 255) }\end{array}$ \\
\hline $\begin{array}{l}\text { Cor } \\
\text { Intervalo }\end{array}$ & $\begin{array}{c}\text { preto } \\
(0 \text { até } 4)\end{array}$ & $\begin{array}{c}\text { tons de } \\
\text { marrom } \\
\text { (5 até } 85)\end{array}$ & $\begin{array}{c}\text { tons de } \\
\text { vermelho } \\
\text { (86 até 170) }\end{array}$ & $\begin{array}{c}\text { tons de } \\
\text { amarelo } \\
\text { (171 até } 250)\end{array}$ & $\begin{array}{c}\text { branco } \\
\text { (251 até 255) }\end{array}$ \\
\hline
\end{tabular}

É ilustrado na Tab. II.1, em forma de exemplo, um esquema de como funciona a transformação entre os mapa de cores em uma imagem 8 bits. Este caso é um caso imaginário que muito se assemelha ao mapa de cores "hot".

Na Fig. II.3, é mostrada uma fotografia no mapa de cores "hsv", que melhor destacou o perfil do jato e a formação da onda de choque. Praticamente, todos estes mapas de cores exercem a mesma função, mas, no entanto, apenas alguns mapas de cores oferecem melhor nitidez. Neste exemplo, com o mapa "hsv", a imagem destacou melhor o jato. Com o "gray" não existia clareza.

Outros mapas de cores que destacam o gradiente de tonalidade de uma cor na imagem, é o "prism", o "flag", o "arcir" e o "rand". Estes mapas são importantes porque trabalham na imagem com um tom de cor e dividem-na em várias cores como um prisma, mas repetindo estas mesmas cores em outros tons. Na Tab. II.2 são ilustrados estes mapas de cores. 


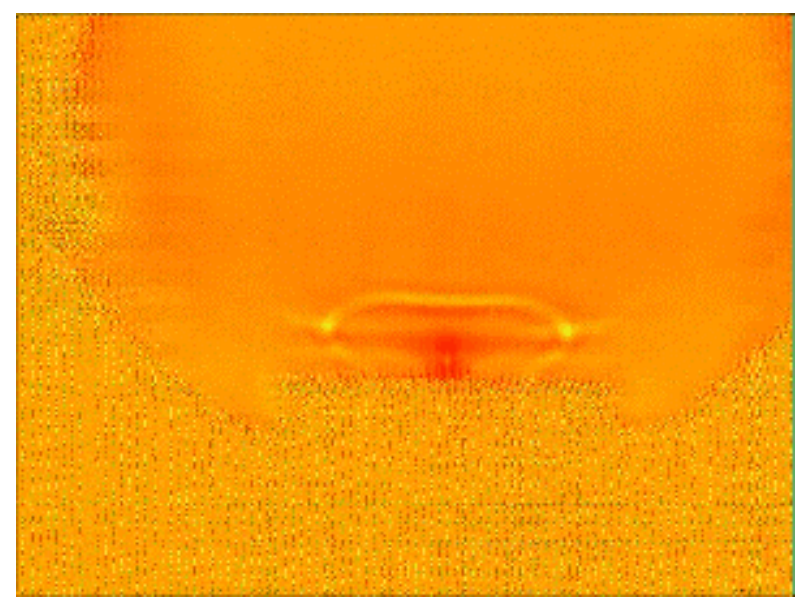

Figura II.3 - Imagem do jato no mapa de cores "hsv".

Tabela II.2 - Apresentação de um outro exemplo ilustrativo de equivalência em mapas de cores.

\begin{tabular}{|c|c|c|c|c|c|c|c|c|c|c|}
\hline Preto & \multicolumn{9}{|c|}{ Tons de cinza } & $\begin{array}{c}\text { Branco } \\
251 \text { até } 255\end{array}$ \\
\hline $\begin{array}{l}\text { Preto } \\
0 \text { até } 4\end{array}$ & \multicolumn{3}{|c|}{$\begin{array}{c}\text { Tons de marrom } \\
7 \text { até } 75\end{array}$} & \multicolumn{3}{|c|}{$\begin{array}{c}\text { Tons de vermelho } \\
76 \text { até } 175\end{array}$} & \multicolumn{3}{|c|}{$\begin{array}{c}\text { Tons de amarelo } \\
176 \text { até } 250\end{array}$} & $\begin{array}{c}\text { Branco } \\
251 \text { até } 255\end{array}$ \\
\hline Preto & $\mathrm{R}$ & G & B & $\mathrm{R}$ & G & B & $\mathrm{R}$ & G & $B$ & Branco \\
\hline 0 até 4 & $4-25$ & $26-50$ & $51-75$ & $76-109$ & $110-140$ & $141-175$ & $176-200$ & $201-225$ & $226-250$ & 251 até 255 \\
\hline
\end{tabular}

* Onde, "R" significa tons de vermelho, "G", tons de verde e "B", tons de azul.

Exemplificando isto, a Fig. II.4 mostra uma imagem com o mapa de cores "prism" que, se comparado à imagem anterior (Fig. II.3), e enfocando para a região do escoamento dos gases após a onda de choque, é possível observar que o mapa "prism" oferece uma boa noção do gradiente de densidade e escoamento nesta região. Muitas vezes, quando existe grande variação do gradiente de tonalidades em determinadas regiões da imagem, mapas de cores como o "prism", "flag", "arcir" e "rand" não oferecem nitidez na imagem. É o caso da região compreendida pelas ondas de choque.

É importante salientar que a mudança do mapa de cores, ou paleta de cores, não modifica a matriz numérica da imagem. 


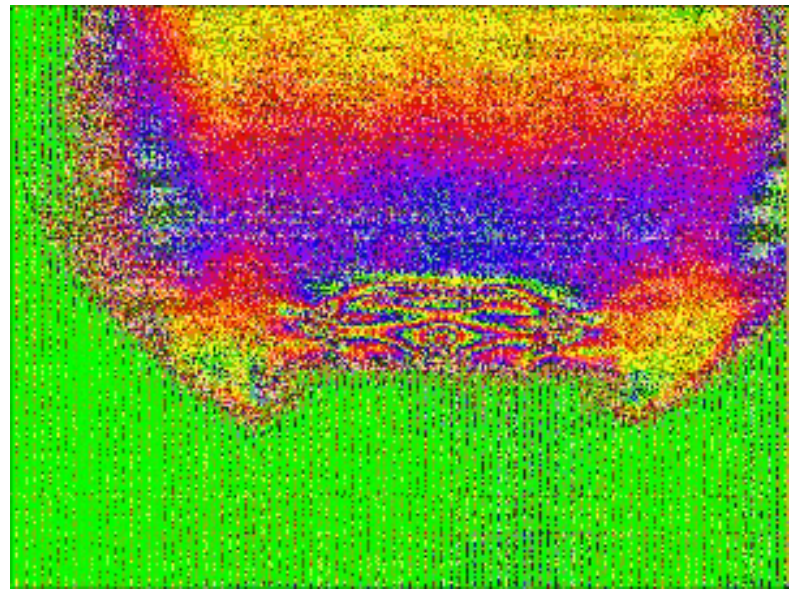

Figura II.4 - Imagem do jato no mapa de cores "prism". Com este mapa foi possível observar o gradiente de densidade que ocorre após passar pela onda de choque.

A seguir, na Tab. II.3, estão representados todos os mapas de cores que são utilizados neste trabalho.

Tabela II.3 - Tonalidade dos mapas de cores do Matlab.

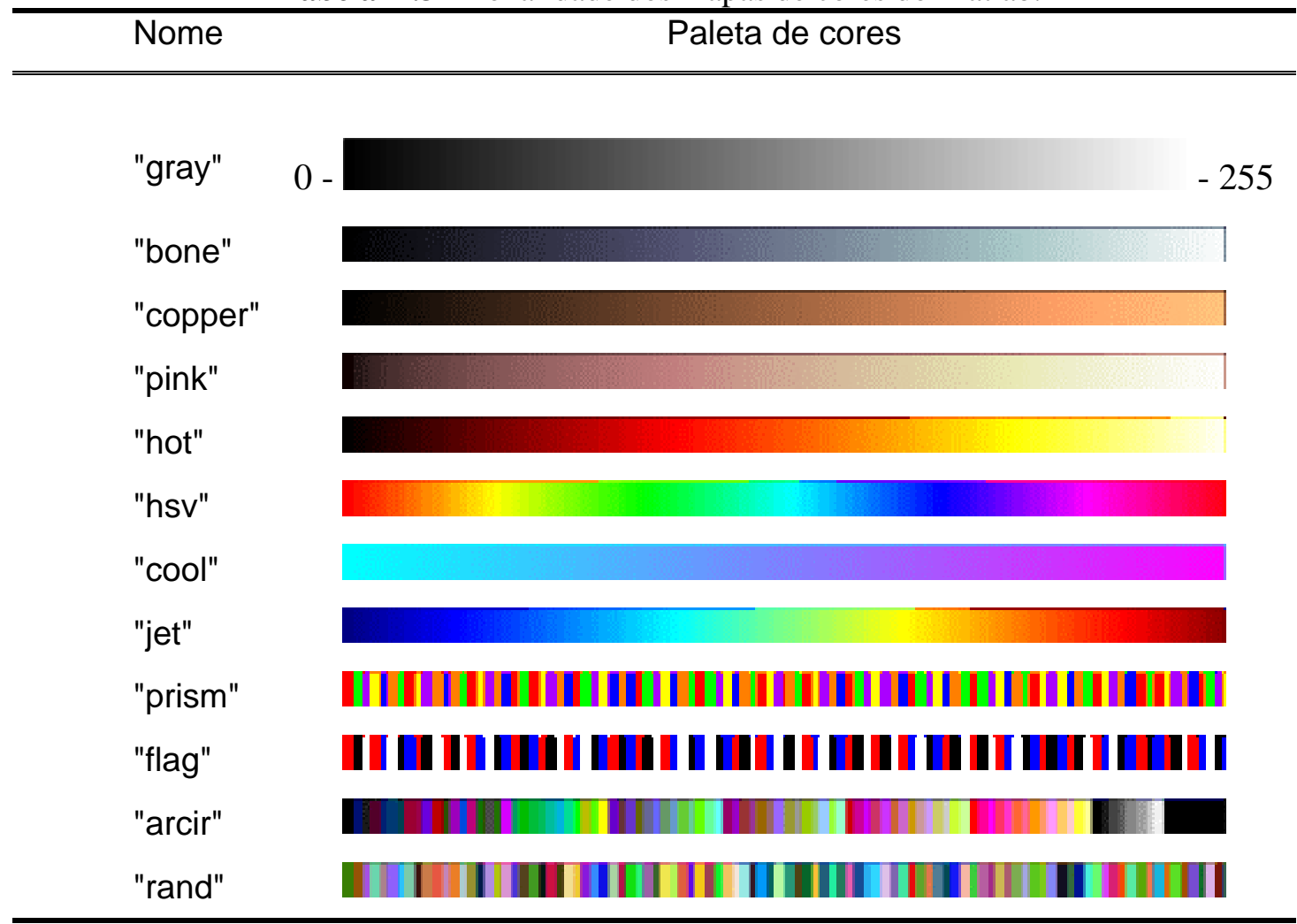

Muitas das imagens filtradas não estão apresentadas de maneira proporcional quando são expostas neste trabalho. Neste caso, é aplicado outro recurso na filtragem 
das imagens que faz o enquadramento do jato apenas, desprezando o cenário restante da fotografia. Com isto, não existe a interferência de muitos ruídos que estão na adjacência do escoamento do jato, tornando mais nítido o fenômeno estudado. Um exemplo pode ser visto na Fig. II.5.

a)

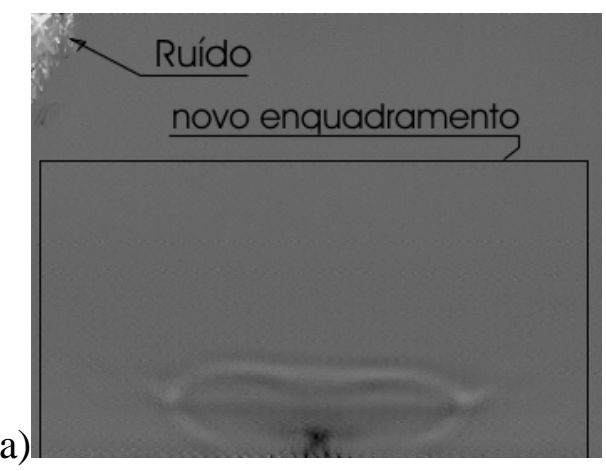

b)

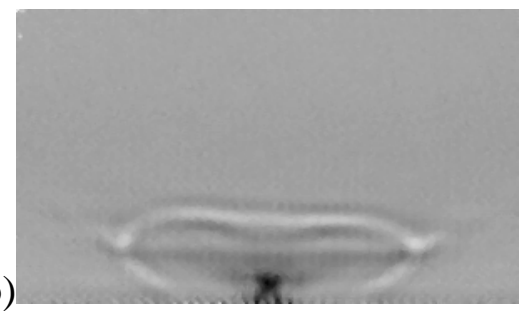

Figura II.5 - A primeira imagem ilustra um realce de um ruído decorrente da filtragem. Para retirá-lo, é feito um novo enquadramento da imagem subtraindo do cenário o local desta ocorrência. Isto também proporciona uma melhor nitidez dos fenômenos envolvidos no escoamento. 


\section{Apêndice III}

Solução Proposta para a Onda de Evaporação 


\title{
III. SOLUÇÃo PROPOSTA PARA A ONDA DE EVAPORAÇÃo
}

\author{
Marcelo Mendes Vieira \\ abril/2005 \\ (desenvolvido no "software” Maple 7)
}

\section{Condição de Chapman-Jouguet dentro da Zona de Saturação}

Este apêndice é parte suplementar da Seção 2.3 e o objetivo é mostrar o roteiro do cálculo desenvolvido para a solução proposta da onda de evaporação. O modelo aqui discutido admite que o fluido, com pressão e temperatura iniciais ( $P 0$ e T0), sofre uma queda da pressão $(P 1)$ de forma isotérmica, abaixo de sua pressão de saturação, assumindo a condição de metaestabilidade. Após alcançar, P1, o liquido metaestável expande em uma mistura líquido-vapor (índice 2) através de uma onda de evaporação. Portanto, para a solução do problema, são conhecidos os parâmetros: $P 0$, T0 e $P 1$, falta determinar as propriedades termodinâmicas do estado “2”, admitindo que o fluido evapora sob a condição de Chapman-Jouguet e, à jusante da onda, o fluido está na zona de saturação.

Como observação, as linhas que iniciam com o sinal ">” indicam os comandos utilizados no "Maple”. Em seguida, centralizado à pagina, as equações, ou resultados numéricos ou gráficos, são os resultados obtidos por estes comandos.

\section{Equação de Rankine-Hugoniot $\left(R \_H\right)$ :}

$>\mathrm{R} H:=\mathrm{h} 2-\mathrm{h} 1=1 / 2$ * (P2-P1) * ( $2+\mathrm{v} 1)$;

$$
\begin{array}{r}
R \_H:=h 2-h 1=\frac{1}{2}(P 2-P 1)(v 2+v 1) \\
>\text { R_H : = h2 - h1 }=1 / 2 *(\mathrm{P} 2-\mathrm{P} 1) *(\mathrm{v} 2+\mathrm{v} 1) ; \\
R \_H:=h 2-h 1=\frac{1}{2}(P 2-P 1)(v 2+v 1)
\end{array}
$$

Determinação da entalpia da mistura líquido-vapor, $h 2$ :

$$
\begin{gathered}
h 2=>h 2 L+x 2 *(h V 2-h L 2)=h 2 L+(v 2-v 2 L) *(h V 2-h L 2) /(v V 2-v L 2): \\
>h 2:=h 2 L+(v 2-v 2 L) *\left[\operatorname{Delta}\left[\mathrm{h} \_L V\right] / \operatorname{Delta}\left[\mathrm{v} \_L V\right]\right] ; \\
h 2:=h 2 L+(v 2-v 2 L)\left[\frac{\Delta_{h \_L V}}{\Delta_{v_{L} L V}}\right]
\end{gathered}
$$

Utilizando a Eq. de Clapeyron ("dP/dT=(hV-hL)/T( $v V-v L)$ ") e a Eq. de Antoine simplificada (com $A$ e $B$ constantes), a expressão "[( $h V 2-h L 2) /(v V 2-v L 2)]$ ” pode ser escrita como:

$$
\begin{gathered}
>\mathrm{dP} / \mathrm{dT}=\operatorname{Delta}\left[\mathrm{h} \_\mathrm{LV}\right] / \operatorname{Delta}\left[\mathrm{v}_{\mathrm{L}} \mathrm{LV}\right] / \mathrm{T} ; \mathrm{LN}(\mathrm{P})=\mathrm{A}-\mathrm{B} / \mathrm{T} ; \\
\mathrm{dP} / \mathrm{dT}=\mathrm{B} \cdot \mathrm{P} / \mathrm{T}^{\wedge} 2 ; \quad\left[\left(\operatorname{Delta}\left[\mathrm{L} \_\mathrm{LV}\right] / \operatorname{Del} \mathrm{ta}\left[\mathrm{v}_{-} \mathrm{LV}\right]\right)\right]=\mathrm{B} * \mathrm{P} 2 / \mathrm{T} 2 ; \\
\frac{d P}{d T}=\frac{\Delta_{h_{-} L V}}{\Delta_{V_{-} L V} T}
\end{gathered}
$$




$$
\begin{aligned}
& \mathrm{LN}(P)=A-\frac{B}{T} \quad \Rightarrow \quad \frac{d P}{d T}=\frac{B \cdot P}{T^{2}} \\
& >\left[\frac{\Delta_{h \_L V}}{\Delta_{V \_L V}}\right]=\frac{B P 2}{T 2} \\
& >\mathrm{R}_{-} \mathrm{H} \text {; } \\
& h 2 L+(v 2-v 2 L)\left[\frac{\Delta_{h \_L V}}{\Delta_{v \_L V}}\right]-h 1=\frac{1}{2}(P 2-P 1)(v 2+v 1)
\end{aligned}
$$

Substituindo:

$$
\begin{aligned}
& >\mathrm{R} \_\mathrm{H}:=\mathrm{h} 2 \mathrm{~L}+(\mathrm{v} 2-\mathrm{v} 2 \mathrm{~L}) *[\mathrm{~B} * \mathrm{P} 2 / \mathrm{T} 2]-\mathrm{h} 1=1 / 2 *(\mathrm{P} 2-\mathrm{P} 1) *(\mathrm{v} 2+\mathrm{v} 1) ; \\
& R \_H:=h 2 L+(v 2-v 2 L)\left[\frac{B P 2}{T 2}\right]-h 1=\frac{1}{2}(P 2-P 1)(v 2+v 1)
\end{aligned}
$$

Admitindo que a diferença entre as entalpias do líquido pode ser escrita como: (h2L - h1) $=C p^{*}(T 0-T 2)$, onde $C p$ é o calor específico para o líquido saturado, temse:

$>\mathrm{h} 1:=\mathrm{Cp} * \mathrm{~T} 0: \mathrm{h} 2 \mathrm{~L}:=\mathrm{Cp} * \mathrm{~T} 2:$

Sabendo também que $\operatorname{Ln} P=A-B / T$ :

$>\mathrm{T} 0:=\mathrm{B} /(\mathrm{A}-\ln (\mathrm{Pv})): \mathrm{T} 2:=\mathrm{B} /(\mathrm{A}-\ln (\mathrm{P} 2)):$

E considerando que os dois volumes específicos do líquido são iguais, $v 2 L=v 1$;

$>\mathrm{v} 2 \mathrm{~L}:=\mathrm{v} 1$;

$$
v 2 L:=v 1
$$

Substituindo os termos acima na expressão $R \_H$, têm-se:

$>\mathrm{R} H$;

$$
\frac{\overline{C p B}}{A-\ln (P 2)}+(v 2-v 1)[P 2(A-\ln (P 2))]-\frac{C p B}{A-\ln (P v)}=\frac{1}{2}(P 2-P 1)(v 2+v 1)
$$

Isolando $v 2$ :

$$
\begin{aligned}
& >\mathrm{Cp} * \mathrm{~B} /(\mathrm{A}-\ln (\mathrm{P} 2))+(\mathrm{v} 2-\mathrm{v} 1) * \mathrm{P} 2 *(\mathrm{~A}-\ln (\mathrm{P} 2))-\mathrm{Cp} * \mathrm{~B} /(\mathrm{A}-\ln (\mathrm{Pv}))- \\
& 1 / 2 \text { * ( P2 - P1) * ( } 2+\mathrm{v} 1)=0 \text {; } \\
& \frac{C p B}{A-\ln (P 2)}+(v 2-v 1) P 2(A-\ln (P 2))-\frac{C p B}{A-\ln (P v)}-\frac{1}{2}(P 2-P 1)(v 2+v 1)=0 \\
& >\operatorname{collect}(\%,[v 2, \mathrm{v} 1], \text { distributed) ; } \\
& \left(P 2(A-\ln (P 2))-\frac{1}{2} P 2+\frac{1}{2} P 1\right) v 2+\frac{C p B}{A-\ln (P 2)}-\frac{C p B}{A-\ln (P v)} \\
& +\left(-P 2(A-\ln (P 2))-\frac{1}{2} P 2+\frac{1}{2} P 1\right) v 1=0 \\
& >\mathrm{v} 2=[\mathrm{Cp} * \mathrm{~B} *(1 /(\mathrm{A}-\ln (\mathrm{Pv}))-1 /(\mathrm{A}-\ln (\mathrm{P} 2)))+(\mathrm{P} 2 *(\mathrm{~A}- \\
& \ln (\mathrm{P} 2))+1 / 2 * \mathrm{P} 2-1 / 2 * \mathrm{P} 1) * \mathrm{~V} 1] /[\mathrm{P} 2 *(\mathrm{~A}-\ln (\mathrm{P} 2))-1 / 2 * \mathrm{P} 2+1 / 2 * \mathrm{P} 1] \text {; } \\
& v 2=\frac{\left[C p B\left(\frac{1}{A-\ln (P v)}-\frac{1}{A-\ln (P 2)}\right)+\left(P 2(A-\ln (P 2))+\frac{1}{2} P 2-\frac{1}{2} P 1\right) v 1\right]}{\left[P 2(A-\ln (P 2))-\frac{1}{2} P 2+\frac{1}{2} P 1\right]} \\
& >\mathrm{v} 2=[\mathrm{Cp} * \mathrm{~B} *((\ln (\mathrm{Pv})-\ln (\mathrm{P} 2)) /(\mathrm{A}-\ln (\mathrm{Pv})) /(\mathrm{A}- \\
& \ln (\mathrm{P} 2)))+(\mathrm{P} 2 *(\mathrm{~A}-\ln (\mathrm{P} 2))+1 / 2 * \mathrm{P} 2-1 / 2 * \mathrm{P} 1) * \mathrm{~V} 1] /[\mathrm{P} 2 *(\mathrm{~A}-
\end{aligned}
$$




$$
\begin{aligned}
& \ln (\mathrm{P} 2))-1 / 2 * \mathrm{P} 2+1 / 2 * \mathrm{P} 1] ; \\
& \left.\qquad \mathrm{P} 2(A-\ln (P 2))-\frac{1}{2} P 2+\frac{1}{2} P 1\right]
\end{aligned}
$$

Nesta equação, o volume à jusante é apenas dependente da pressão, $P 2$. As outras variáveis são conhecidas.

EQUAÇÃO ( $I^{\prime}$ ), determinada pela equação de Rankine-Hugoniot:

$>$ v2 $(\mathrm{P} 2):=\mathrm{Cp} * \mathrm{~B} *(\ln (\mathrm{Pv})-\ln (\mathrm{P} 2)) /(\mathrm{A}-\ln (\mathrm{Pv})) /(\mathrm{A}-$ $\ln (\mathrm{P} 2)) / \mathrm{P} 2 /((\mathrm{A}-\ln (\mathrm{P} 2))-1 / 2+1 / 2 * \mathrm{P} 1 / \mathrm{P} 2)+((\mathrm{A}-\ln (\mathrm{P} 2))+1 / 2-$ $1 / 2 * \mathrm{P} 1 / \mathrm{P} 2) * \mathrm{v} 1 /((\mathrm{A}-\ln (\mathrm{P} 2))-1 / 2+1 / 2 * \mathrm{P} 1 / \mathrm{P} 2)$;

$$
\begin{gathered}
\mathrm{v} 2(P 2):=\frac{C p B(\ln (P v)-\ln (P 2))}{(A-\ln (P v))(A-\ln (P 2)) P 2\left(A-\ln (P 2)-\frac{1}{2}+\frac{\frac{1}{2} P 1}{P 2}\right)} \\
+\frac{\left(A-\ln (P 2)+\frac{1}{2}-\frac{1}{2} \frac{P 1}{P 2}\right) v 1}{A-\ln (P 2)-\frac{1}{2}+\frac{\frac{1}{2} P 1}{P 2}}
\end{gathered}
$$

\section{Estudo do termo que é multiplicado pelo volume inicial, $v 1$}

Objetivo deste estudo: considerar que este termo pode ser igualado a 1. Pelas soluções numéricas é sabido que: $\mathbf{1 / 2}<(\mathbf{P} 2 / \mathbf{P 1})<\mathbf{1}$. Isto pode simplificar a equação acima nos termos:

Como P2/P1 está contido no intervalo 0,5..1,0, pode-se calcular o comportamento deste termo que multiplica $v 1$ adotando valores de $P 2 / P 1$ iguais a 1/2, 3/4 e 1, como segue:

$$
\begin{aligned}
& >\mathrm{P} 1:=\mathrm{P} 2 ; \quad(\mathrm{A}-\ln (\mathrm{P} 2)+1 / 2-1 / 2 * \mathrm{P} 1 / \mathrm{P} 2) /(\mathrm{A}-\ln (\mathrm{P} 2)- \\
& 1 / 2+1 / 2 * \mathrm{P} 1 / \mathrm{P} 2) \text {; } \\
& \mathrm{P} 1:=4 / 3 * \mathrm{P} 2 ; \quad(\mathrm{A}-\ln (\mathrm{P} 2)+1 / 2-1 / 2 * \mathrm{P} 1 / \mathrm{P} 2) /(\mathrm{A}-\ln (\mathrm{P} 2)- \\
& 1 / 2+1 / 2 * \mathrm{P} 1 / \mathrm{P} 2) \text {; } \\
& \mathrm{P} 1:=2 / 1 * \mathrm{P} 2 ; \quad(\mathrm{A}-\ln (\mathrm{P} 2)+1 / 2-1 / 2 * \mathrm{P} 1 / \mathrm{P} 2) /(\mathrm{A}-\ln (\mathrm{P} 2)- \\
& 1 / 2+1 / 2 * \mathrm{P} 1 / \mathrm{P} 2) \text {; } \\
& \text { unassign ('P1', 'P2'); } \\
& P 1:=P 2=>1 \\
& P 1:=\frac{4}{3} P 2=>\frac{A-\ln (P 2)-\frac{1}{6}}{A-\ln (P 2)+\frac{1}{6}}
\end{aligned}
$$




$$
P 1:=2 P 2=>\frac{A-\ln (P 2)-\frac{1}{2}}{A-\ln (P 2)+\frac{1}{2}}
$$

Quando $P 1$ é igual a $P 2$, o numerador e o denominador do segundo termo da soma são exatamente iguais. Quando a razão $P 2 / P 1$ é igual a 3/4, a diferença é de 2/6. Para um grau de metaestabilidade elevado, $P 2 / P 1$ é igual a 0,5 , e a diferença entre os dois termos é igual a 1. Para a iso-octano, a constante "A" (para pressão em Pa e temperatura em K) tem um valor igual a 22. O erro introduzido por esta simplificação com relação a constante "A-ln(P2)" é praticamente desprezível, caso P1 fosse próximo do ponto crítico. Conferindo, a expressão "A-Ln(Pc) = (21$\operatorname{Ln}(2583000))$ " é igual a 7,23, ainda assim, este termo tem uma magnitude 20 vezes maior que o erro introduzido para $\mathrm{P} 2 / \mathrm{P} 1=3 / 4$. Quando esta razão assume esta magnitude, $\mathrm{P} 2 / \mathrm{P} 1=3 / 4$, v2 é muito maior que $v 1$, e isto torna o segundo termo menos expressivo na somatória da expressão. A seguir tem um exemplo de uma onda com pressão de saturação próxima do ponto crítico $(90 \%$ Pc):

$>\mathrm{Pv}:=0.9 * 2583000: \mathrm{P} 1:=0.8 * \mathrm{Pv}: \mathrm{P} 2:=0.75 * \mathrm{P} 1:$

$>\mathrm{Cp}:=2400: \mathrm{A}:=22: \mathrm{B}:=4000:$

$>\mathrm{Cp} * \mathrm{~B} *(\ln (\mathrm{Pv})-\ln (\mathrm{P} 2)) /(\mathrm{A}-\ln (\mathrm{Pv})) /(\mathrm{A}-\ln (\mathrm{P} 2)) / \mathrm{P} 2 /(\mathrm{A}-$ $\ln (\mathrm{P} 2)-1 / 2+1 / 2 * \mathrm{P} 1 / \mathrm{P} 2)+(\mathrm{A}-\ln (\mathrm{P} 2)+1 / 2-1 / 2 * \mathrm{P} 1 / \mathrm{P} 2) * \mathrm{v} 1 /(\mathrm{A}-$ $\ln (\mathrm{P} 2)-1 / 2+1 / 2 * \mathrm{P} 1 / \mathrm{P} 2)$;

$$
.007607190395+.9584288989 v 1
$$

$>$ " vol. especif. do liquido"; v1:=0.002; Cp*B*(ln (Pv) $\ln (\mathrm{P} 2)) /(\mathrm{A}-\ln (\mathrm{Pv})) /(\mathrm{A}-\ln (\mathrm{P} 2)) / \mathrm{P} 2 /(\mathrm{A}-\ln (\mathrm{P} 2)-$

$1 / 2+1 / 2 * \mathrm{P} 1 / \mathrm{P} 2)+(\mathrm{A}-\ln (\mathrm{P} 2)+1 / 2-1 / 2 * \mathrm{P} 1 / \mathrm{P} 2) * \mathrm{v} 1 /(\mathrm{A}-\ln (\mathrm{P} 2)-$ $1 / 2+1 / 2 * \mathrm{P} 1 / \mathrm{P} 2)$;

$$
v 1:=.002
$$

.009524048193

Para o volume específico inicial de $0,002 \mathrm{~m} 3 / \mathrm{kg}$ (condição próxima do ponto crítico), o erro entre o valor verdadeiro e o valor do volume obtido através da aproximação do segundo termo igualado a 1 é de $-0,87 \%$ (resultado abaixo):

$>(\%-(\mathrm{CP} * \mathrm{~B} *(\ln (\mathrm{Pv})-\ln (\mathrm{P} 2)) /(\mathrm{A}-\ln (\mathrm{Pv})) /(\mathrm{A}-\ln (\mathrm{P} 2)) / \mathrm{P} 2 /(\mathrm{A}-$ $\ln (\mathrm{P} 2)-1 / 2+1 / 2 * \mathrm{P} 1 / \mathrm{P} 2)+\mathrm{v} 1)) / \%$; $-.008729712441$

> unassign ('Pv' ' 'P1' ' 'P2 ' ' 'Cp' ', A' ', 'B' , 'v1') ;

O gráfico a seguir mostra o comportamento do termo que multiplica o volume inicial, $v 1$, em função do grau de metaestabilidade, $\boldsymbol{G}$. Nele é possível observar que este fator ficou compreendido entre 0,91 e 1,00, para este caso da temperatura inicial próxima do ponto crítico. Se diminuir esta temperatura, o menor valor do intervalo tende a elevar. 


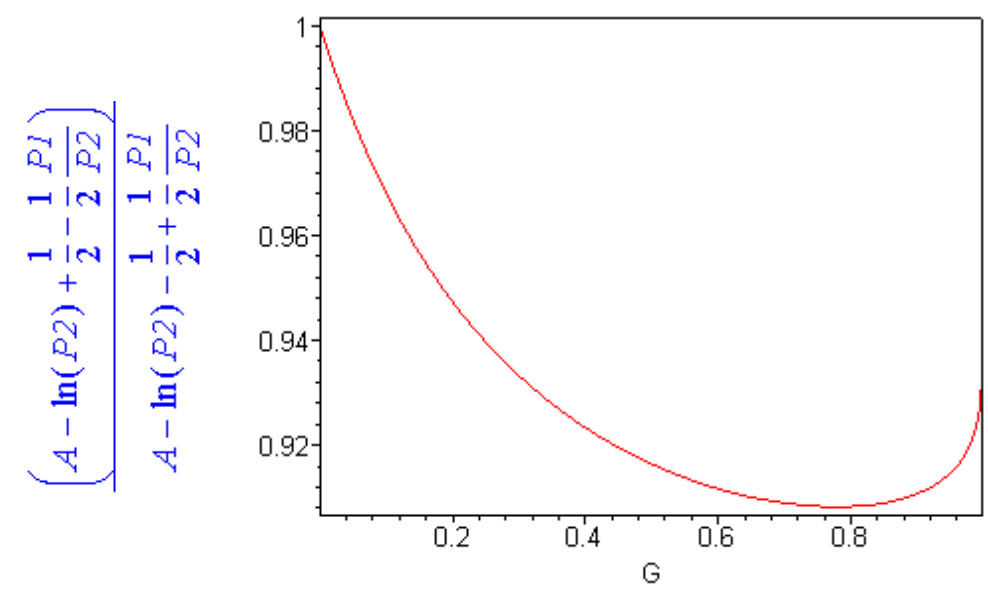

Para determinação do gráfico acima, foi utilizada a seguinte equação que se aproxima ao comportamento da relação $\mathbf{P 2 / P 1}$ em função do grau de metaestabilidade, $G$ :

$>\mathrm{P} 2 / \mathrm{P} 1:=(1+2 * \mathrm{G}) /(1+5 * \mathrm{G}) ; \mathrm{fvL} ; \mathrm{fvL}:=\mathrm{fvL}$

$$
\frac{P 2}{P 1}:=\frac{1+2 G}{1+5 G}
$$

Simplificando a Equação $\mathbf{I}^{\prime}$, admitindo que o termo que multiplica $v 1$ é igual a 1 , tem-se a seguinte expressão:

EQUAÇÃO ( I ):

$>$ v2 (P2) : $=\mathrm{Cp} * \mathrm{~B} *(\ln (\mathrm{Pv})-\ln (\mathrm{P} 2)) /(\mathrm{A}-\ln (\mathrm{Pv})) /(\mathrm{A}-$

$\ln (\mathrm{P} 2)) / \mathrm{P} 2 /(\mathrm{A}-\ln (\mathrm{P} 2)-1 / 2+1 / 2 * \mathrm{P} 1 / \mathrm{P} 2)+\mathrm{v} 1$;

$\mathrm{v} 2(P 2):=\frac{C p B(\ln (P v)-\ln (P 2))}{(A-\ln (P v))(A-\ln (P 2)) P 2\left(A-\ln (P 2)-\frac{1}{2}+\frac{\frac{1}{2} P 1}{P 2}\right)}+v 1$

\section{Introduzindo a Condição de Chapman-Jouguet}

Pela condição de Chapman-Jouguet, $\mathrm{d}(\mathrm{J} * \mathrm{~J})=0$, condição de máxima vazão com velocidade sônica, sabendo que, a Eq. de Rayleigh é:

$>\mathrm{J}(\mathrm{P} 2, \mathrm{v} 2):=\operatorname{sqrt}(-(\mathrm{P} 2-\mathrm{P} 1) /(\mathrm{v} 2-\mathrm{v} 1))$;

$$
\mathrm{J}(P 2, v 2):=\sqrt{-\frac{P 2-P 1}{v 2-v 1}}
$$

$>d\left(J^{\wedge} 2\right):=2 * d J=0$;

$$
\mathrm{d}\left(J^{2}\right):=2 d J=0
$$

$>\mathrm{dJ}=\mathrm{d}(\mathrm{J}, \mathrm{P} 2) * \mathrm{DP} 2+\mathrm{d}(\mathrm{J}, \mathrm{v} 2) * \mathrm{Dv} 2$

$d J=\mathrm{d}(J, P 2) D P 2+\mathrm{d}(J, v 2) D v 2$

$>\mathrm{dJ}:=\operatorname{diff}(\operatorname{sqrt}(-(\mathrm{P} 2-\mathrm{P} 1) /(\mathrm{v} 2-\mathrm{v} 1)), \mathrm{P} 2) * \mathrm{DP} 2+\operatorname{diff}(\operatorname{sqrt}(-$ $(\mathrm{P} 2-\mathrm{P} 1) /(\mathrm{v} 2-\mathrm{v} 1)), \mathrm{v} 2) * \mathrm{Dv} 2=0$; 


$$
d J:=-\frac{1}{2} \frac{D P 2}{\sqrt{-\frac{P 2-P 1}{v 2-v 1}(v 2-v 1)}}+\frac{\frac{1}{2}(P 2-P 1) D v 2}{\sqrt{-\frac{P 2-P 1}{v 2-v 1}(v 2-v 1)^{2}}}=0
$$

Simplificando a equação acima, tem-se:

\section{EQUAÇÃO ( II ):}

$>\mathrm{Dv} 2 / \mathrm{DP} 2=(\mathrm{v} 2-\mathrm{v} 1) /(\mathrm{P} 1-\mathrm{P} 2)$;

$$
\frac{D v 2}{D P 2}=\frac{v 2-v 1}{P 1-P 2}
$$

Com as EQUAÇÕES I e II é possível determinar P2. Para isto a derivada de Dv2/DP2 é:

$>$ Dv2:=diff (v2 (P2), P2) ;

$$
\begin{gathered}
D v 2:=-\frac{C p B}{P 2^{2}(A-\ln (P v))(A-\ln (P 2))\left(A-\ln (P 2)-\frac{1}{2}+\frac{\frac{1}{2} P 1}{P 2}\right)} \\
+\frac{C p B(\ln (P v)-\ln (P 2))}{-\frac{(A-\ln (P v))(A-\ln (P 2))^{2} P 2^{2}\left(A-\ln (P 2)-\frac{1}{2}+\frac{\frac{1}{2} P 1}{P 2}\right)}{C p B(\ln (P v)-\ln (P 2))}} \\
-\frac{(A-\ln (P v))(A-\ln (P 2)) P 2^{2}\left(A-\ln (P 2)-\frac{1}{2}+\frac{\frac{1}{2} P 1}{P 2}\right)}{(A-\ln (P v))(A-\ln (P 2)) P 2\left(A-\ln (P 2)-\frac{1}{2}+\frac{\frac{1}{2} P 1}{P 2}\right)^{2}}
\end{gathered}
$$


Substituindo a derivada de $v 2$ na Eq. II e, combinando a Eq. I em II, obtem-se: $>\mathrm{Dv} 2=(\mathrm{v} 2(\mathrm{P} 2)-\mathrm{v} 1) /(\mathrm{P} 2-\mathrm{P} 1)$;

\section{Cp B}

$$
\begin{gathered}
P 2^{2}(A-\ln (P v))(A-\ln (P 2))\left(A-\ln (P 2)-\frac{1}{2}+\frac{\frac{1}{2} P 1}{P 2}\right) \\
+\frac{C p B(\ln (P v)-\ln (P 2))}{(A-\ln (P v))(A-\ln (P 2))^{2} P 2^{2}\left(A-\ln (P 2)-\frac{1}{2}+\frac{\frac{1}{2} P 1}{P 2}\right)} \\
-\frac{C p B(\ln (P v)-\ln (P 2))}{(A-\ln (P v))(A-\ln (P 2)) P 2^{2}\left(A-\ln (P 2)-\frac{1}{2}+\frac{\frac{1}{2} P 1}{P 2}\right)} \\
\frac{(A-\ln (P v))(A-\ln (P 2)) P 2\left(A-\ln (P 2)-\frac{1}{2}+\frac{1}{P 2}\right)^{2}}{C p B(\ln (P v)-\ln (P 2))\left(-\frac{1}{P 2}-\frac{1}{2} \frac{P 2}{P 2}\right)} \\
(A-\ln (P v))(A-\ln (P 2)) P 2\left(A-\ln (P 2)-\frac{1}{2}+\frac{\frac{1}{2} P 1}{P 2}\right)(P 2-P 1)
\end{gathered} .
$$

Combinando os termos da equação acima, tem-se:

$$
\begin{aligned}
& (-1 / \mathrm{P} 2+((\ln (\mathrm{Pv})-\ln (\mathrm{P} 2)) /(\mathrm{A}-\ln (\mathrm{P} 2)) / \mathrm{P} 2)-(\ln (\mathrm{Pv})- \\
& \ln (\mathrm{P} 2)) / \mathrm{P} 2-(\ln (\mathrm{Pv})-\ln (\mathrm{P} 2)) /(\mathrm{A}-\ln (\mathrm{P} 2)- \\
& 1 / 2+1 / 2 * \mathrm{P} 1 / \mathrm{P} 2) *(-1 / \mathrm{P} 2-1 / 2 * \mathrm{P} 1 / \mathrm{P} 2 \wedge 2))=(\ln (\mathrm{Pv})- \\
& \ln (\mathrm{P} 2)) /(\mathrm{P} 2-\mathrm{P} 1) \text {; } \\
& -\frac{1}{P 2}+\frac{\ln (P v)-\ln (P 2)}{(A-\ln (P 2)) P 2}-\frac{\ln (P v)-\ln (P 2)}{P 2}-\frac{(\ln (P v)-\ln (P 2))\left(-\frac{1}{P 2}-\frac{1}{2} \frac{P 1}{P 2^{2}}\right)}{A-\ln (P 2)-\frac{1}{2}+\frac{\frac{1}{2} P 1}{P 2}}= \\
& \frac{\ln (P v)-\ln (P 2)}{P 2-P 1} \\
& >\text { eq1 }:=-1 /(\ln (\mathrm{Pv})-\ln (\mathrm{P} 2))+1 /(\mathrm{A}-\ln (\mathrm{P} 2))-1-1 /(\mathrm{A}-\ln (\mathrm{P} 2)- \\
& 1 / 2+1 / 2 * \mathrm{P} 1 / \mathrm{P} 2) *(-1-1 / 2 * \mathrm{P} 1 / \mathrm{P} 2)=\mathrm{P} 2 /(\mathrm{P} 2-\mathrm{P} 1) \text {; } \\
& \text { eq1 }:=-\frac{1}{\ln (P v)-\ln (P 2)}+\frac{1}{A-\ln (P 2)}-1-\frac{-1-\frac{1}{2} \frac{P 1}{P 2}}{A-\ln (P 2)-\frac{1}{2}+\frac{\frac{1}{2} P 1}{P 2}}=\frac{P 2}{P 2-P 1}
\end{aligned}
$$


Aqui é substituído $\mathbf{P 2} / \mathbf{P 1}=\boldsymbol{P r}$;

$$
\begin{aligned}
& >\text { eq1 }:=-1 /(\ln (\mathrm{Pv})-\ln (\mathrm{P} 2))+1 /(\mathrm{A}-\ln (\mathrm{P} 2))-1-1 /(\mathrm{A}-\ln (\mathrm{P} 2)- \\
& 1 / 2+1 / 2 / \operatorname{Pr}) *(-1-1 / 2 / \operatorname{Pr})=-\operatorname{Pr} /(1-\operatorname{Pr}) \text {; } \\
& \text { eq } 1:=-\frac{1}{\ln (P v)-\ln (P 2)}+\frac{1}{A-\ln (P 2)}-1-\frac{-1-\frac{1}{2} \frac{1}{P r}}{A-\ln (P 2)-\frac{1}{2}+\frac{\frac{2}{P r}}{P r}}=-\frac{P r}{1-P r} \\
& \text { > eq1 : }=(1-\mathrm{Pr}) /(\ln (\mathrm{Pv})-\ln (\mathrm{P} 2))-(1-\mathrm{Pr}) /(\mathrm{A}-\ln (\mathrm{P} 2))+(1- \\
& \mathrm{Pr})+(1-\mathrm{Pr}) /(\mathrm{A}-\ln (\mathrm{P} 2)-1 / 2+1 / 2 / \mathrm{Pr}) *(-1-1 / 2 * 1 / \mathrm{Pr})-\operatorname{Pr}=0 \text {; } \\
& \text { eq1 }:=\frac{1-P r}{\ln (P v)-\ln (P 2)}-\frac{1-P r}{A-\ln (P 2)}+1-2 \operatorname{Pr}+\frac{(1-\operatorname{Pr})\left(-1-\frac{1}{2} \frac{1}{\operatorname{Pr}}\right)}{A-\ln (P 2)-\frac{1}{2}+\frac{\frac{1}{2}}{P r}}=0
\end{aligned}
$$

A pressão à montante da onda, P1, pode ser escrita como: $P 1=(1-G) * P v$, onde $\boldsymbol{G}$ é o grau de metaestabilidade. Como $\mathrm{P} 2=\mathrm{Pr} * \mathrm{P} 1$, logo:

$$
\begin{aligned}
& >\ln (\mathrm{P} 2):=\ln (1-\mathrm{G})+\ln (\mathrm{Pv})+\ln (\mathrm{Pr}) \text {; } \\
& \ln (P 2):=\ln (1-G)+\ln (P v)+\ln (P r) \\
& \text { > eq1 ; } \\
& \frac{1-P r}{-\ln (1-G)-\ln (P r)}-\frac{1-P r}{A-\ln (1-G)-\ln (P v)-\ln (P r)}+1-2 \operatorname{Pr} \\
& +\frac{(1-P r)\left(-1-\frac{1}{2} \frac{1}{P r}\right)}{1}=0 \\
& A-\ln (1-G)-\ln (P v)-\ln (P r)-\frac{1}{2}+\frac{\overline{2}}{P r}
\end{aligned}
$$

Eis a equação que mostra que a razão das pressões da onda é função do grau de metaestabilidade e da pressão de vapor:

\section{EQUAÇÃO IIIa:}

$$
\begin{aligned}
\text { eq } 1:= & \frac{1-\operatorname{Pr}}{-\ln (1-G)-\ln (\operatorname{Pr})}-\frac{1-\operatorname{Pr}}{A-\ln (1-G)-\ln (P v)-\ln (P r)}+1-2 \operatorname{Pr} \\
+ & \frac{(1-\operatorname{Pr})\left(-1-\frac{1}{2} \frac{1}{P r}\right)}{A-\ln (1-G)-\ln (P v)-\ln (P r)-\frac{1}{2}+\frac{\frac{1}{2}}{P r}}=0
\end{aligned}
$$

- Cabe lembrar que pode ser substituída a expressão " $A-\ln (P v)$ ” por “ $B / T 0$ ", pois: $\mathrm{T} 0:=\mathrm{B} /(\mathrm{A}-\ln (\mathrm{Pv}))$.

Exemplo 1: Iso-octano à $131^{\circ} \mathrm{C}(P v=220 \mathrm{kPa})$ e pressão inicial igual a pressão de 
saturação $(P v)$. Para isto é necessário obter as constantes A e B.

Pelo livro do Vargaftik, iso-octano a $20^{\circ} \mathrm{C}$ as propriedades são:

$\mathrm{T}=20^{\circ} \mathrm{C}$

$\mathrm{T}=293,15 \mathrm{~K}$

$\mathrm{Pv}=5,15 \mathrm{kPa}$

$\mathrm{vL}=0,001444 \mathrm{~m} 3 / \mathrm{kg}$

$\mathrm{vV}=4,4444 \mathrm{~m} 3 / \mathrm{kg}$

$\mathrm{hLV}=309,4 \mathrm{~kJ} / \mathrm{kg}$

Sabendo que $\mathrm{B}=(\mathrm{hLV} / \mathrm{vLV})^{*}(\mathrm{~T} / \mathrm{Pv})$ e $\mathrm{A}=\mathrm{Ln}(\mathrm{Pv})+\mathrm{B} / \mathrm{T}$ :

$B=3963,7$;

$A=22,07$.

$>\ln (\mathrm{Pv}):=\operatorname{evalf}(\ln (220000)) ; \mathrm{A}:=22.07$;

$\ln (P v):=12.30138283$

$A:=22.07$

$>$ eq $2:=$ eq1

$$
\begin{aligned}
\text { eq2 }:= & \frac{1-\operatorname{Pr}}{-\ln (1-G)-\ln (P r)}-\frac{1-\operatorname{Pr}}{9.76861717-\ln (1-G)-\ln (P r)}+1-2 \operatorname{Pr} \\
+ & \frac{(1-P r)\left(-1-\frac{1}{2} \frac{1}{P r}\right)}{9.268617170-\ln (1-G)-\ln (\operatorname{Pr})+\frac{\frac{1}{2}}{P r}}=0
\end{aligned}
$$

$>$ with (plots):

implicitplot (eq2, $\mathrm{G}=0.0001 .0 .9999, \operatorname{Pr}=0.48 \ldots 0.9999$,

title="iso-octano $\backslash \mathrm{n} T 0=131^{\circ} \mathrm{C}$ (Psat $\left.=220 \mathrm{kPa}\right)$ e P0=Psat",

labels=['Grau de metaestabilidade, $\mathrm{G}^{-}$,"P2 /P1"],

$\operatorname{grid}=[200,100]$, axes=boxed, resolution $=200$, view $=[0 . .1$, $0.48 \ldots 1])$;

Warning, the name changecoords has been redefined

iso-octano

$\mathrm{TO}=131^{\circ} \mathrm{C}(\mathrm{Psat}=220 \mathrm{kPa})$ e $\mathrm{PO}=\mathrm{Psat}$

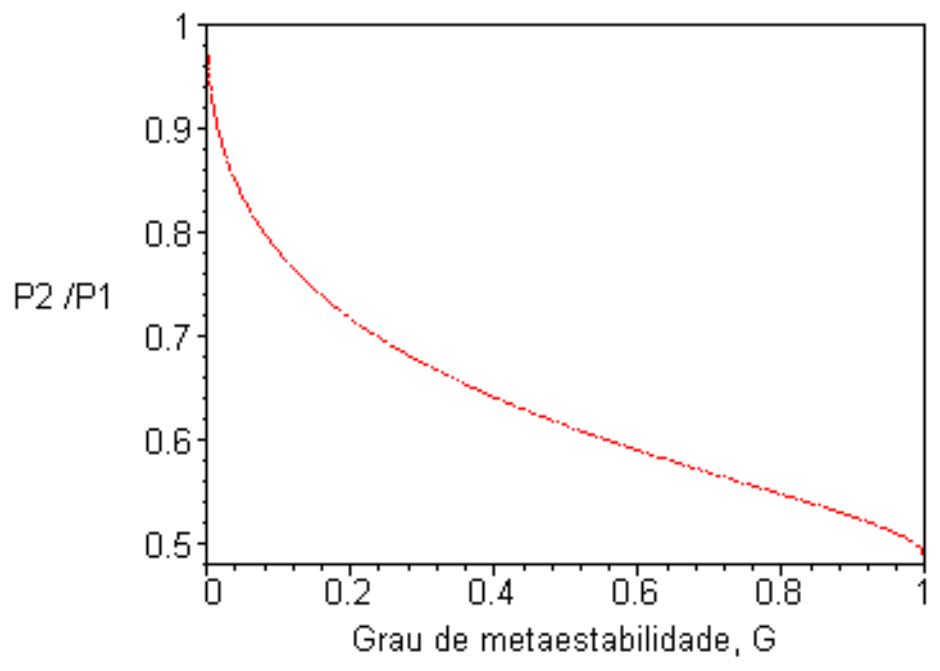




$$
\begin{aligned}
& \text { > G: }=0.000001 \text {; fsolve (eq2,Pr,0..1); unassign('G', 'Pr'); } \\
& \mathrm{G}:=1 / 2 \text {; fsolve (eq2, } \mathrm{Pr}, 0 . .1) \text {; unassign('G', 'Pr') ; } \\
& \mathrm{G}:=.9999999 \text {; fsolve (eq2,Pr,0..1); unassign('G', 'Pr'); } \\
& G:=.110^{-5} \Rightarrow \quad \text { Pr }=.9991043152 \\
& G:=\frac{1}{2} \Rightarrow>\quad \operatorname{Pr}=.6146788395 \\
& G:=.9999999 \quad \Rightarrow \quad \operatorname{Pr}=.4864074550
\end{aligned}
$$

restart;

\section{Expressão para pressão inicial maior que a pressão de saturação}

Caso a pressão de injeção assume um valor acima da pressão de saturação, deve-se resolver a onda de evaporação acrescentando ao valor da entalpia inicial do líquido a expressão "(v1*(P0-Psat))", ou seja, "(h1 Cp*T0 + v1*(P0-Psat))", portanto, a equação final pode ser escrita como:

$$
\begin{aligned}
& >\text { eq3 : }=(1-\mathrm{Pr}) /(\mathrm{Phi}-\ln (1-\mathrm{G})-\ln (\mathrm{Pr}))-(1-\mathrm{Pr}) /(\mathrm{A}-\ln (1-\mathrm{G})- \\
& \ln (\mathrm{Pv})-\ln (\mathrm{Pr}))+1-2 * \mathrm{Pr}+(1-\mathrm{Pr}) /(\mathrm{A}-\ln (1-\mathrm{G})-\ln (\mathrm{Pv})-\ln (\mathrm{Pr})- \\
& \begin{array}{c}
1 / 2+1 / 2 / \mathrm{Pr}) *(-1-1 / 2 * 1 / \mathrm{Pr})=0 ; \\
\text { eq3 }:=\frac{1-\operatorname{Pr}}{\Phi-\ln (1-G)-\ln (\operatorname{Pr})}-\frac{1-\operatorname{Pr}}{A-\ln (1-G)-\ln (P v)-\ln (\operatorname{Pr})}+1-2 \operatorname{Pr} \\
+\frac{(1-\operatorname{Pr})\left(-1-\frac{1}{2} \frac{1}{\operatorname{Pr}}\right)}{A-\ln (1-G)-\ln (P v)-\ln (\operatorname{Pr})-\frac{1}{2}+\frac{\frac{1}{2}}{P r}}
\end{array}
\end{aligned}
$$

Como T0:=B/( $\mathrm{A}-\ln (\mathrm{Pv}))$, a equação acima pode ser escrita da seguinte forma: $>(1-P r) /(P h i-\ln (1-G)-\ln (P r))-(1-P r) /(B / T 0-\ln (1-G)-$ $\ln (\mathrm{Pr}))+1-2$ * $\mathrm{Pr}+(1-\mathrm{Pr}) /(\mathrm{B} / \mathrm{T} 0-\ln (1-\mathrm{G})-\ln (\mathrm{Pr})-1 / 2+1 / 2 / \mathrm{Pr})$ * $(-$ $1-1 / 2 * 1 / \operatorname{Pr})=0$;

\section{EQUAÇÃO III:}

$\frac{1-P r}{\Phi-\ln (1-G)-\ln (P r)}-\frac{1-P r}{\frac{B}{T 0}-\ln (1-G)-\ln (P r)}+1-2 \operatorname{Pr}$
$+\frac{(1-P r)\left(-1-\frac{1}{2} \frac{1}{P r}\right)}{\frac{B}{T 0}-\ln (1-G)-\ln (P r)-\frac{1}{2}+\frac{\frac{1}{2}}{P r}}=0$

onde,

$>\mathrm{Phi}:=\mathrm{v} 1$ * $(\mathrm{P} 0-\mathrm{Pv}) *(\mathrm{~A}-\ln (\mathrm{Pv})) *(\mathrm{~A}-\ln (\mathrm{Pv})-\ln (1-\mathrm{G})-$ 
$\ln (\mathrm{Pr})) / \mathrm{Cp} / \mathrm{B}$;

$\Phi:=\frac{v 1(P 0-P v)(A-\ln (P v))(A-\ln (1-G)-\ln (P v)-\ln (P r))}{C p B}$

Exemplo 2: Iso-octano com temperatura inicial de $56^{\circ} \mathrm{C}(\mathrm{Pv}=25 \mathrm{kPa})$ e pressão de $750 \mathrm{kPa}$ :

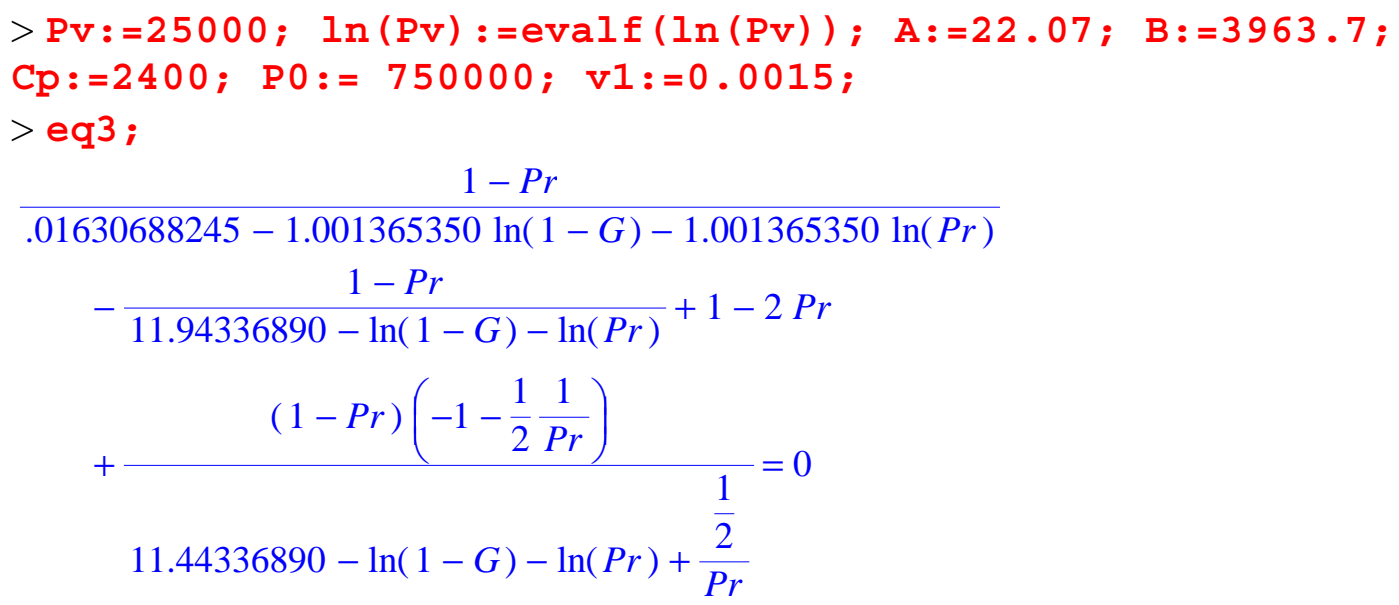

Phi; $01630688245-.001365350312 \ln (1-G)-.001365350312 \ln (\operatorname{Pr})$

$>$ with (plots) :

implicitplot (eq3, G=0.0001..0.9999, $\mathrm{Pr}=0.48 \ldots 0.9999$, title="iso-octano $\backslash \mathrm{n} T 0=56^{\circ} \mathrm{C}(\mathrm{Psat}=25 \mathrm{kPa})$ e $\mathrm{P} 0=750 \mathrm{kPa} "$, labels=["Grau de metaestabilidade, G" ,'P2 /P1'], grid $=[100,100]$, axes=boxed, resolution $=200$, view $=[0 \ldots 1$, $0.4 \ldots 1]$ );

Warning, the name changecoords has been redefined

iso-octano

$\mathrm{TO}=56^{\circ} \mathrm{C}(\mathrm{Psat}=25 \mathrm{kPa})$ e $\mathrm{PO}=750 \mathrm{kPa}$

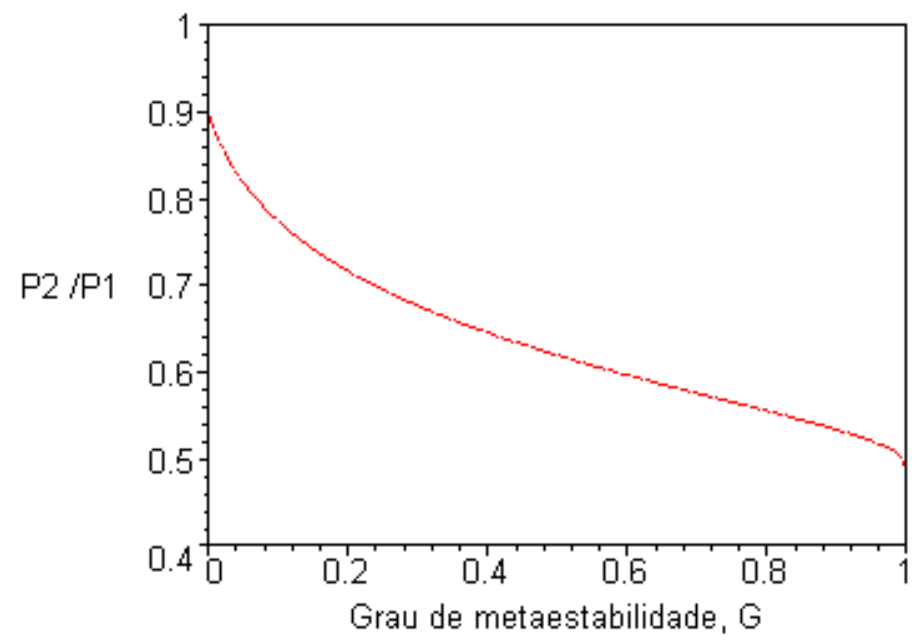


$>G:=0$; fsolve (eq3,Pr,0..1); unassign('G' , 'Pr') ; $\mathrm{Pr}=.8999163913$ $G:=\frac{1}{2}$; fsolve (eq3,Pr, 0..1) ; unassign ('G', 'Pr') ; $\operatorname{Pr}=.6197466868$ $G:=.9999999$; fsolve (eq3,Pr, 0..1); unassign('G', 'Pr') ; $\mathrm{Pr}=$ .4886120289

restart;

\section{Comparação entre a solução numérica e pela solução da Equação} III:

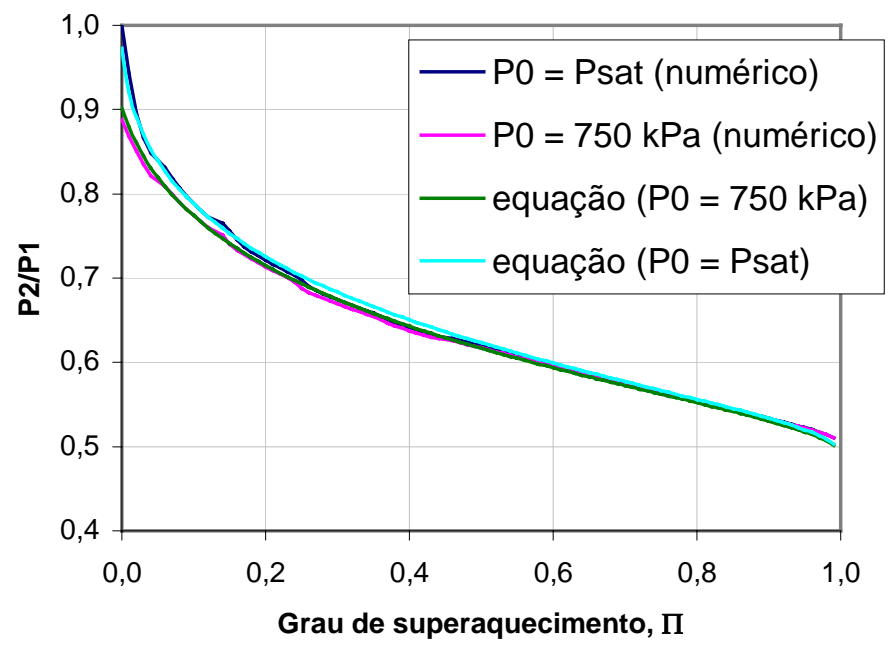

A máxima diferença entre os dois métodos (numérico e analítico) foi de $2 \%$.

\section{Simplificação da Equação III:}

\section{A equação III ainda pode ser simplificada:}

$$
\begin{aligned}
& >\text { eq1 : = }(1-P r) /(-\ln (1-G)-\ln (P r))-(1-P r) /(A-\ln (1-G)- \\
& \ln (\mathrm{Pv})-\ln (\mathrm{Pr}))+1-2 * \mathrm{Pr}+(1-\mathrm{Pr}) /(\mathrm{A}-\ln (1-\mathrm{G})-\ln (\mathrm{Pv})-\ln (\mathrm{Pr})- \\
& 1 / 2+1 / 2 / \mathrm{Pr}) *(-1-1 / 2 * 1 / \mathrm{Pr})=0 \text {; } \\
& \text { eq1 }:=\frac{1-\operatorname{Pr}}{-\ln (1-G)-\ln (P r)}-\frac{\searrow}{A-\ln (1-G)-\ln (P v)-\ln (P r)}+1-2 \operatorname{Pr} \\
& +\frac{\searrow(1-P r)\left(-1-\frac{1}{2} \frac{1}{P r}\right)}{1}=0 \\
& A-\ln (1-G)-\ln (P v)-\ln (P r)-\frac{1}{2}+\frac{\overline{2}}{P r}
\end{aligned}
$$

A Eq. III (acima) possui dois termos cujos denominadores têm valores aproximados e estão indicados pelas setas. Por isto, estes denominadores serão 
substituídos por um denominador médio, como segue:

$>1 / 2 *\{A-\ln (1-G)-\ln (P v)-\ln (P r)\}+1 / 2 *\{A-\ln (1-G)-\ln (P v)-$ $\ln (\operatorname{Pr})-1 / 2+1 / 2 / \mathrm{Pr}\}=\mathrm{A}-\ln (\mathrm{Pv})-\ln (1-\mathrm{G})-\ln (\mathrm{Pr})-1 / 4+1 / 4 / \mathrm{Pr}$;

$\frac{1}{2}\{A-\ln (1-G)-\ln (P v)-\ln (P r)\}+\frac{1}{2}\left\{A-\ln (1-G)-\ln (P v)-\ln (P r)-\frac{1}{2}+\frac{\frac{1}{2}}{\operatorname{Pr}}\right\}$

Denominador para os dois termos:

$$
\Rightarrow \quad=A-\ln (P v)-\ln (1-G)-\ln (P r)-\frac{1}{4}+\frac{\frac{1}{4}}{\operatorname{Pr}}
$$

Desta forma, a Equação III pode ser reescrita como:

$>$ eq4 : $=(1-\mathrm{Pr}) /(\mathrm{Phi}-\ln (1-\mathrm{G})-\ln (\mathrm{Pr}))+((1-\mathrm{Pr}) *(-1-1-$

$1 / 2 * 1 / \mathrm{Pr})) /(\mathrm{A}-\ln (\mathrm{Pv})-\ln (1-\mathrm{G})-\ln (\mathrm{Pr})-1 / 4+1 / 4 / \mathrm{Pr})+1-2 * \operatorname{Pr}=$ 0 ;

\section{EQUAÇÃO IV:}

eq4 : $=1-2 \frac{P_{2}}{P_{1}}+\frac{1-\frac{P_{2}}{P_{1}}}{\Phi-\ln (1-G)-\ln \left(\frac{P_{2}}{P_{1}}\right)}+\frac{\left(1-\frac{P_{2}}{P_{1}}\right)\left(-2-\frac{1}{2} \frac{P_{1}}{P_{2}}\right)}{\frac{B}{T_{0}}-\ln (1-G)-\ln \left(\frac{P_{2}}{P_{1}}\right)-\frac{1}{4}+\frac{1}{4} \frac{P_{1}}{P_{2}}}=0$

$>\mathrm{Phi}:=\mathrm{v} 1$ * $(\mathrm{P} 0-\mathrm{Pv})$ * $(\mathrm{A}-\ln (\mathrm{Pv}))$ *(A- $\ln (\mathrm{Pv})-\ln (1-\mathrm{G})-$ $\ln (\mathrm{Pr})) / \mathrm{Cp} / \mathrm{B}$;

$\Phi=\frac{v_{1}\left(P_{0}-P_{\text {sat }}\right)\left(\frac{B}{T_{0}}-\ln (1-G)-\ln \left(\frac{P_{2}}{P_{1}}\right)\right)}{C p_{L} \cdot T_{0}}$

\section{Exemplo 3:}

$>\mathrm{Pv}:=25000 ; \ln (\mathrm{Pv}):=\operatorname{evalf}(\ln (\mathrm{Pv})) ; \mathrm{A}:=22.07 ; \mathrm{B}:=3963.7$;

$\mathrm{Cp}:=2400 ; \mathrm{P} 0:=750000 ; \mathrm{v} 1:=0.0015$;

$P v:=25000 ; \ln (25000):=10.12663110 ; A:=22.07 ; B:=3963.7$

$$
\text { Cp := } 2400 ; P 0:=750000 ; v 1:=.0015
$$

$>$ eq4 ; 


$$
\begin{gathered}
\frac{1-\operatorname{Pr}}{.01630688245-1.001365350 \ln (1-G)-1.001365350 \ln (\operatorname{Pr})} \\
+\frac{(1-\operatorname{Pr})\left(-2-\frac{1}{2} \frac{1}{\operatorname{Pr}}\right)}{11.69336890-\ln (1-G)-\ln (\operatorname{Pr})+\frac{\frac{1}{4}}{\operatorname{Pr}}}+1-2 \operatorname{Pr}=0
\end{gathered}
$$

Phi ;

$$
.01630688245-.001365350312 \ln (1-G)-.001365350312 \ln (\operatorname{Pr})
$$

$>$ with (plots):

implicitplot (eq4, G=0.0001..0.9999, $\mathrm{Pr}=0.48 \ldots 0.9999$, title $=$ iso-octano $\backslash \mathrm{n} \mathrm{T} 0=56^{\circ} \mathrm{C}(\mathrm{Psat}=25 \mathrm{kPa})$ e $\mathrm{P} 0=750 \mathrm{kPa}$, labels=["Grau de metaestabilidade, G" ,'P2 /P1'], grid $=[100,100]$, axes=boxed, resolution $=200$, view $=[0 \ldots 1$, $0.4 \ldots 1])$;

iso-octano

$\mathrm{TO}=56^{\circ} \mathrm{C}(\mathrm{Psat}=25 \mathrm{kPa})$ e $\mathrm{P} 0=750 \mathrm{kPa}$

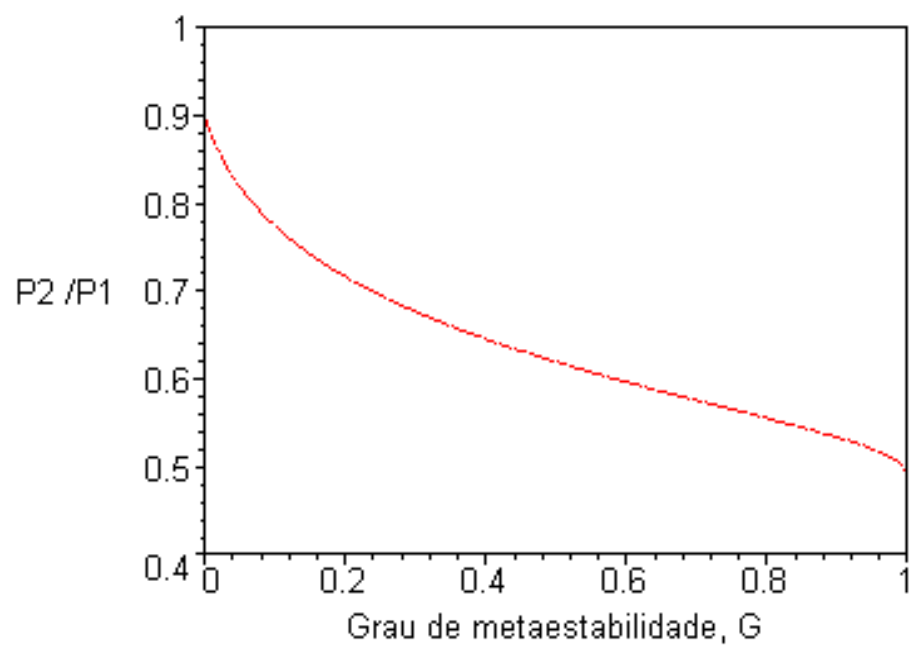

$>\mathrm{G}:=0$; fsolve (eq4,Pr,0.1..1); unassign('G', 'Pr');

$\mathrm{G}:=1 / 2$; fsolve (eq4,Pr,0.1..1); unassign('G', 'Pr') ;

$\mathrm{G}:=.9999999$; fsolve (eq4,Pr,0.1..1); unassign('G', 'Pr'); $G:=0$

$$
\begin{gathered}
\operatorname{Pr}=.8999121871(0,89991639) \\
G:=\frac{1}{2} \\
\operatorname{Pr}=.6196285133(0,61974668) \\
G:=.9999999 \\
\operatorname{Pr}=.4885297157(0,48861203)
\end{gathered}
$$

Os resultados deste exemplo (em azul), que foram calculados através da Eq. IV (esta vem da simplificação da Eq. III), são bastante semelhantes aos resultados do Exemplo 2 (resolvidos pela Eq. III), que estão entre parênteses. 


\section{Apêndice IV}

Aplicativo Computacional para

Aquisições de Imagens e

Apresentação de Algumas Tentativas

de Métodos Ópticos para

Visualização do Jato 


\begin{abstract}
APÊNDICE IV
Este apêndice tem o objetivo de apresentar alguns recursos da câmara CCD e da placa de aquisição de imagens explorados pelo aplicativo computacional de aquisição de imagens desenvolvido neste trabalho. Em seguida são mostradas algumas tentativas de métodos ópticos para aquisição de imagens que não tiveram sucesso, mas que ainda podem ser explorados. No final, são mostrados alguns trechos do manual da câmara CVM50 que indicam os recursos aqui mencionados.
\end{abstract}

\title{
IV.1. O Aplicativo COMPUTACIONAL PARA AqUISIÇÃo DE IMAGENS
}

\section{IV.1.1. Características da Placa de Aquisição de Imagens - DT3152 da marca Data Translation}

A placa de aquisição de imagens possui os seguintes recursos:

- Digitaliza imagem preto e branco com profundidade de 8 bits e resolução de 640x480;

- aceita sinal digital para adquirir a imagem (“trigger”);

- $\quad$ possui 8 sinais digitais de saída disponíveis (DA0, DA1, DA2, DA3, DA4, DA5, DA6 e DA7);

- $\quad$ possui 4 canais de entrada de sinal de vídeo;

- $\quad$ envia sinais de controle para a câmera de CCD do tipo: sinal de freqüência de controle do vertical (VD, ou "vertical frequency", sinal que controla a mudança de campos) e sinal de freqüência de controle (HD, ou "horizontal frequency”, sinal que controla a mudança da linha, na varredura do campo).

Como são utilizados estes recursos: 
- esta placa dispara o início do processo de aquisição de dados, enviando um sinal digital para a placa de aquisição de dados (pelo DA0);

- em seguida, esta placa controla o tempo de exposição da primeira câmara CCD através dos sinais HD e VD;

- para adquirir uma imagem, a placa recebe um sinal digital da placa de aquisição de dados (CAD1236 da Lynx) através do recurso “trigger”. Geralmente, após adquirir as imagens obtidas pelo "Schlieren” (total de quatro imagens), ela recebe um último sinal de disparo para obter a imagem da $2^{\mathrm{a}}$. câmara do sistema de “iluminação por detrás”. Até este momento, ainda não ocorreu a injeção;

- $\quad$ em seguida, a placa de aquisição de imagens, envia um sinal digital (DA1) para disparar o injetor;

- $\quad$ enquanto ocorre a injeção, ela faz aquisição do número de imagens do jato predeterminadas pelo usuário, sendo a aquisição também obtida pelo recurso de “trigger”. Além disso, ela também faz a aquisição da imagem da $2^{\mathrm{a}}$. câmara CCD;

- a injeção é interrompida através da ausência de tensão do sinal de saída (DA1) no controle do cilindro pneumático;

- e o monitoramento do ensaio se encerra após $1 s$ do fechamento da injeção, praticamente.

\section{IV.1.2. Características da Câmara CCD - CV-M50 da Coastar}

A câmara CCD possui os seguintes recursos:

- funciona de modo entrelaçado;

- a imagem é preta e branca;

- aceita monitoramento do sinal vertical para regular o tempo de exposição do sensor CCD. 
Como já foi visto a placa de aquisição de imagem pode controlar o tempo de exposição da câmara CCD através dos sinais de controle vertical e horizontal. Para isto, é necessário configurar a câmara CCD no recurso "Long Time Exposure” (ver manual da câmara CCD, CV-M50). Este recurso viabilizou o sincronismo entre o tempo de exposição da câmara CCD e o disparo da lâmpada do tipo “flash”. No final deste apêndice, é mostrada uma parte do manual da câmara CCD com a descrição da configuração desta função.

\section{IV.1.3. Características da Placa de Aquisição de Dados (CAD 1236 da Lynx) para Monitoramento da Aquisição de Imagens}

Para este monitoramento de aquisição de imagens a placa CAD 1236 dispõe de dois sinais de saída, do tipo digital, com recurso de freqüência no modo retangular de onda.

Um sinal ("trigger”) é enviado para a placa de aquisição de imagens que faz o disparo da aquisição da imagem. O outro sinal é responsável para acionar a lâmpada de “flash”. Como já foi visto no Capítulo 3, este sinal é combinado com o sinal que monitora o tempo de abertura da câmara CCD para que o Flash dispare quando a câmara CCD estiver apta para obter a imagem. Caso contrário, o disparo pode ocorrer quando o sensor CCD não estiver habilitado e, conseqüentemente, não haverá imagem.

\section{IV.1.4. A Interface do Programa de Aquisição de Imagens}

O programa tem uma interface que possibilita visualizar o campo de expansão do jato na câmara de baixa pressão para ajustar o alinhamento das duas câmaras CCDs. Também o usuário ajusta o número de imagens que quer obter durante a injeção sabendo que cada imagem é adquirida em um intervalo de 0,5 s (ver Fig. IV.1), portanto, se a 
opção é de 6 imagens do jato, o ensaio deve ter no mínimo uma duração de 3 s. A opção de ajuste do tempo de exposição do CCD para adquirir a imagem já está predeterminada no aplicativo computacional e pode ser vista na Fig. IV.2.

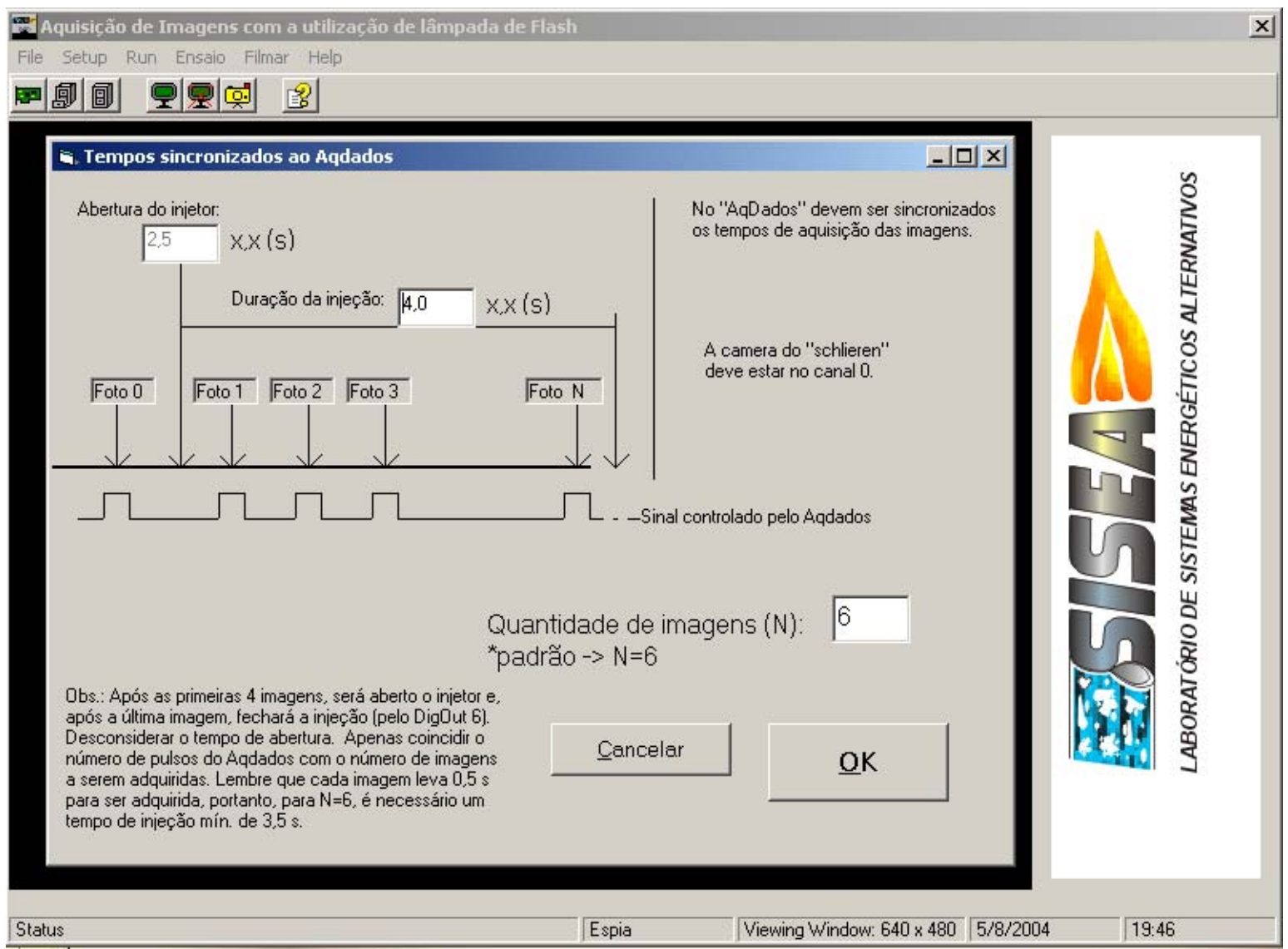

Figura IV.1 - Interface do aplicativo que configura o tempo de injeção e a quantidade de imagens obtidas no jato. 


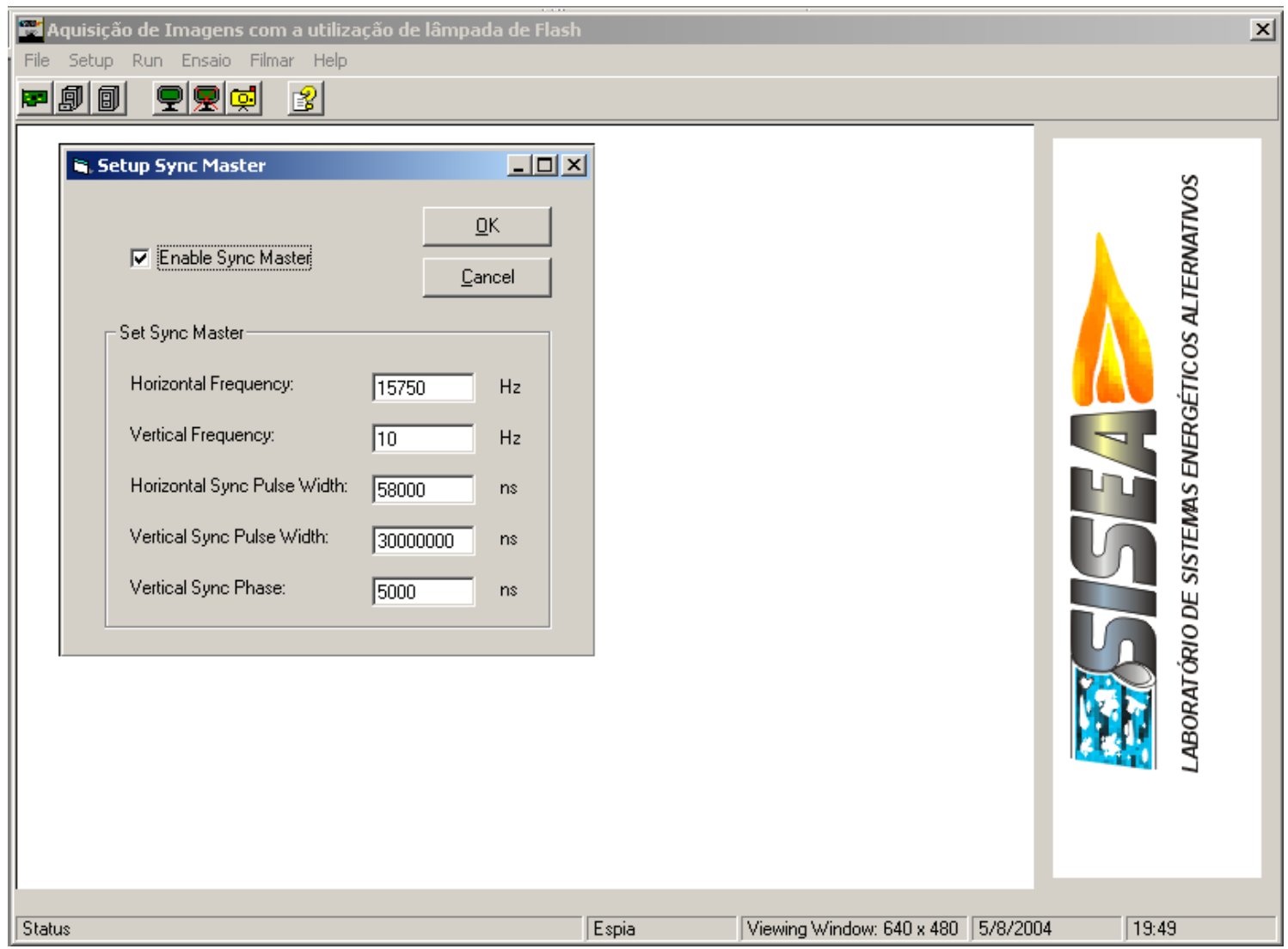

Figura IV.2 - Interface do aplicativo onde estão configuradas as freqüências de varredura do campo (Vertical Frequency) e das linhas (Horizontal Frequency) para monitorar o tempo de exposição da câmara CCD.

Na Fig. 3.20 do Capítulo 3, é mostrada a interface do programa com o botão de acionamento do ensaio, onde está escrito “Inicia” com a quantidade de imagens que devem ser obtidas. Nele existe todo o código para realização da seqüência de eventos que o aplicativo realiza durante a injeção, como foi visto na Seção IV.1.1.

O código computacional deste aplicativo é apresentado a seguir: 
O aplicativo “AqJatos” foi desenvolvido através da biblioteca de funções “DtActive Open Layers”, da Data Translation, cuja linguagem computacional está em "Visual Basic".

\author{
VERSION 5.00 \\ Begin VB.Form frmEnsaio \\ Dim N_image As Long \\ Dim i As Integer \\ Dim tempo As Integer \\ Dim conta As Integer \\ Dim pausa As Integer \\ Public cam2 As Integer \\ Dim aux As Integer
}

Private Sub cmdPassthru_Click()

On Error GoTo ErrHandler

'Configura os tempos de exposição da câmara CCD

frmMain.DTAOLFG1.SyncMasterEnabled = False

frmMain.DTAOLFG1.VerticalFrequency = 10

frmMain.DTAOLFG1.VerticalPulseWidth $=30000000$

frmMain.DTAOLFG1. HorizontalPulseWidth $=58000$

frmMain.DTAOLFG1.SyncMasterEnabled = True

frmMain.DTAOLFG1.VideolnputSource $=$ Chan0

Call frmMain.DTAOLFG1.StartPassthru

Exit Sub

ErrHandler:

MsgBox (Err.Description)

End Sub

Private Sub Form_Load()

On Error GoTo ErrHandler

'Inicia filmagem da camera CCD

$\mathrm{N}$ _image $=$ (frmTempos. Nfotos)

cmdInicia.Caption = "Inicia(Quantidade:" + CStr(frmTempos.Nfotos) + " imagens)"

Lbl_duracao.Caption = CStr(frmTempos.T_duracao $)+$ " s"

tempo $=0$

conta $=0$ 
Exit Sub

ErrHandler:

MsgBox (Err.Description)

End Sub

Private Sub cmdCancela_Click()

On Error GoTo ErrHandler

'Unload Ensaio form

Unload frmEnsaio

'Para visualizacao da filmagem da camera

Call frmMain.DTAOLFG1.StopPassthru

frmMain.DTAOLFG1.SyncMasterEnabled = False

frmMain.DTAOLFG1.DigIOPattern = 0

frmMain.DTAOLFG1.VideolnputSource $=$ Chan0

Exit Sub

ErrHandler:

MsgBox (Err.Description)

End Sub

Private Sub cmdInicia_Click()

On Error GoTo ErrHandler

'Opção de utilização da 2a . câmara CCD

If Optcamera2. Value $=$ True Then

cam2 = 1

camera2 $=$ True

Else

cam2 $=0$

camera2 $=$ False

End If

'Configura os tempos de exposição da câmara CCD

Call frmMain.DTAOLFG1.StopPassthru

frmEnsaio. MousePointer = 11 'ampulheta

frmMain.DTAOLFG1.VideolnputSource = Chan0

frmMain.DTAOLFG1.SyncMasterEnabled = False

frmMain.DTAOLFG1.VerticalFrequency $=10$ 
frmMain.DTAOLFG1.VerticalPulseWidth $=30000000$

frmMain.DTAOLFG1. HorizontalPulseWidth $=58000$

frmMain.DTAOLFG1.SyncMasterEnabled = False

'ativar os parametros do trigger da placa de imagem

frmMain.DTAOLFG1.TriggerType = ExternalTrigger

frmMain.DTAOLFG1.TriggerTransition = OnLowToHigh

'frmMain.DTAOLFG1.MultTriggerType = ExternalTrigger

'frmMain.DTAOLFG1.MultTriggerTransition = OnLowToHigh

'frmMain.DTAOLFG1.MultTriggerMode = TriggerForEach

'Destroi da memoria antigas imagens para salvar novas, caso exista.

For $\mathrm{i}=1$ To (frmMain.DTAOLFG1.FrameCount)

If frmMain.DTAOLFG1.FrameCount $>0$ Then

Call frmMain.DTAOLFG1.DestroyFrame(IdQuadro(i)) End If

Next i

aux $=\mathrm{N}$ image $+4+$ cam2 + cam2

For $\mathrm{i}=1$ To aux 'este laço reserva a memoria para as imagens

'Allocate a frame buffer.

IdQuadro(i) = frmMain.DTAOLFG1.AllocateFrame(FrameLeft, FrameTop,

FrameWidth, FrameHeight, FrameHorizontalScale, FrameVerticalScale,

Next i

FrameType, Defaultımage)

pausa $=0$

Espera.Enabled = True 'habilita contador para aquisição das primeiras imagens

Exit Sub

ErrHandler:

MsgBox (Err.Description)

End Sub

Private Sub Espera_Timer()

pausa $=$ pausa +1

If $($ cam2 = 1) Then

frmMain.DTAOLFG1.SyncMasterEnabled = False

End If

If (pausa = 6) Then

frmMain.DTAOLFG1.SyncMasterEnabled = True

'ativar a porta DigOut7 da placa para um sinal de TTL elevado

' 1 = 00000001 (em binário) e o valor 1 corresponde ao sinal elevado de

TTL

frmMain.DTAOLFG1.DigIOPattern = 1 'dispara Aqdados

Espera. Enabled $=$ False 


\section{contador. Enabled = True 'habilita contador para aquisição das primeiras imagens}

End If

End Sub

Private Sub contador_Timer()

'adquirir as quatro primeiras imagens

If (conta > 0) And (conta < 5) Then 'este laço realiza a aquisição frmMain.DTAOLFG1.DiglOPattern = 1

'Hide picture box if it's currently visible.

frmMain. Picture1. Visible $=$ False

'Acquire an image into the frame buffer. wait

Call frmMain.DTAOLFG1.AcquireFrames(1, IdQuadro(conta), False)

'Display acquired image.

Call frmMain.DTAOLFG1.DrawAcquiredFrame(, IdQuadro(conta))

\section{End If}

conta $=$ conta +1

If $($ conta = 5) And (cam2 = 1) Then

frmMain.DTAOLFG1.VideolnputSource = Chan2

End If

If $($ conta = 6) And (cam2 = 1) Then

'adquirir a imagem da camera secundaria

'Hide picture box if it's currently visible.

frmMain. Picture1.Visible = False

'Acquire an image into the frame buffer. wait

Call frmMain.DTAOLFG1.AcquireFrames(1, IdQuadro(5), False)

'Display acquired image.

Call frmMain.DTAOLFG1.DrawAcquiredFrame(, IdQuadro(5))

frmMain.DTAOLFG1.VideolnputSource = Chan0

End If

If $($ conta $=9)$ Then

'ativam-se as portas DigOut7 e 6 da placa para um sinal de TTL elevado ' $3=00000011$ (em binario) e o valor 1 corresponde ao sinal elevado de

TTL

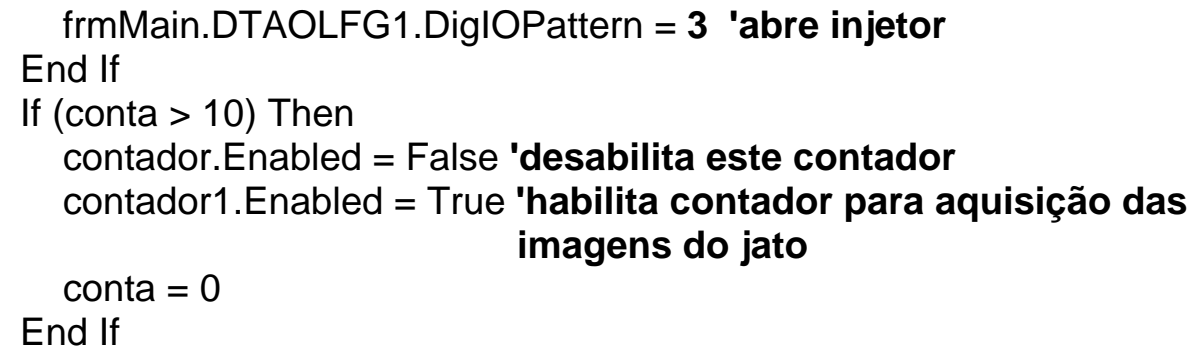

End Sub 


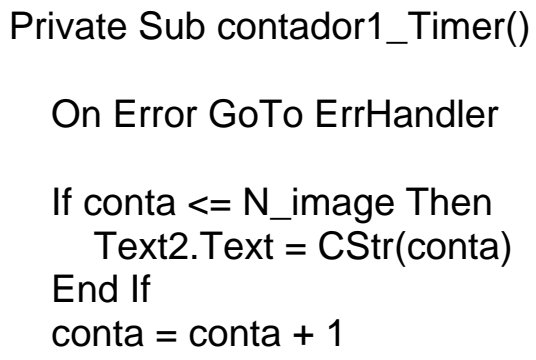

\section{'adquirir as imagens do jato}

If conta $<=\mathrm{N}$ image Then

frmMain.DT̄AOLFG1.VideolnputSource = Chan0

'Hide picture box if it's currently visible.

frmMain.Picture1. Visible $=$ False

'Acquire an image into the frame buffer. wait

Call frmMain.DTAOLFG1.AcquireFrames(1, IdQuadro(conta + 4 + cam2), False)

'Display acquired image.

cam2))

Call frmMain.DTAOLFG1.DrawAcquiredFrame(, IdQuadro(conta + 4 +

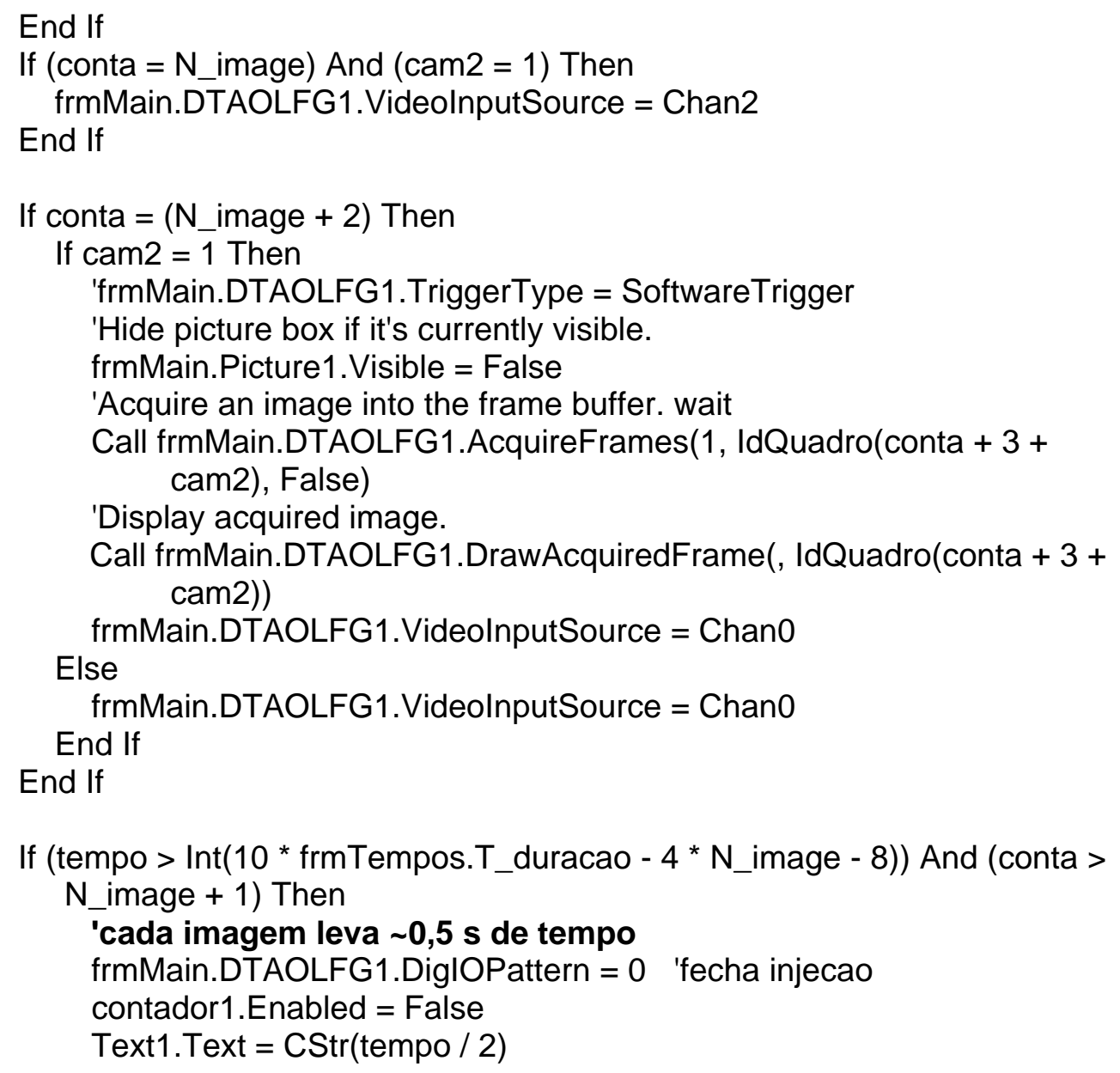
cam2)) 
'Unload Ensaio form.

Unload frmEnsaio

'sai a ampulheta e volta ao normal

frmEnsaio. MousePointer $=0$

'desabilita trigger

frmMain.DTAOLFG1. TriggerType = SoftwareTrigger

'Make the "Salvar" form visible.

frmSalvar.Show vbModal

End If

tempo $=$ tempo +1 'tempo estah em quatro decimos de segundo 0,100s

Exit Sub

ErrHandler:

MsgBox (Err.Description)

End Sub

Private Sub Form_Unload(Cancel As Integer)

On Error GoTo ErrHandler

Call frmMain.DTAOLFG1.StopPassthru

'sinal "0" para todas as saidas

frmMain.DTAOLFG1.DiglOPattern = 0

'desabilita triger externo

frmMain.DTAOLFG1.TriggerType = SoftwareTrigger

frmMain.DTAOLFG1.VideolnputSource = Chan0

Exit Sub

ErrHandler:

MsgBox (Err.Description)

End Sub 


\section{IV.2. Tentativas DE MÉtodos ÓPticos PARA VISUALIZAÇÃO DOS JATOS}

\section{IV.2.1. Iluminação por "Lâmina de laser" ou "laser sheet”}

Testes foram realizados para obtenção de imagens com iluminação lateral por lâmina ("laser sheet”). Esta técnica visa observar a estrutura interna do núcleo líquido e o desvio da trajetória da gotícula após a onda de evaporação.

Pode-se observar nesta técnica através da imagem obtida que a parte líquida do jato fica iluminada, diferente do "Schlieren" que possui esta porção com a tonalidade quase que totalmente escura. Isto ocorre porque a iluminação do "Schlieren" fica por detrás com relação ao observador e nesta técnica, a iluminação é lateral, de preferência a $90^{\circ}$, em relação ao observador. Sendo uma lâmina de "laser", a imagem observada decorre da reflexão da luz nas gotículas. Também, a imagem observada se refere a uma secção transversal do jato apenas, sem integrar informações das outras secções, dando oportunidade de se extrair conclusões sobre o comportamento do fluido na região do núcleo líquido.

A Fig. IV.3 mostra a disposição da fonte de "laser" com potência de 5 mW que ilumina o jato. A Fig. IV.4 ilustra a área que a lâmina de "laser" abrange quando alinhada a saída do bocal. E na Fig. IV.5 é apresentada a imagem obtida do jato. Neste teste, pode-se concluir que a quantidade de luz ainda é insuficiente para obter uma boa imagem com um menor tempo de exposição. 


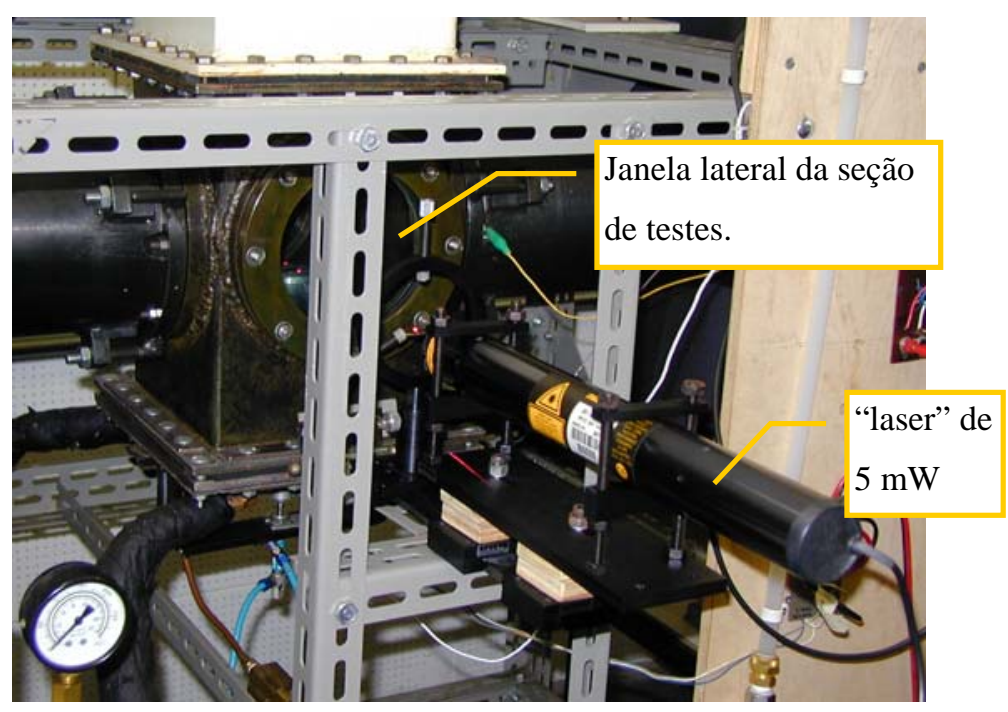

Figura IV.3 - Esquema da disposição da iluminação com a lâmina lateral de "laser”.

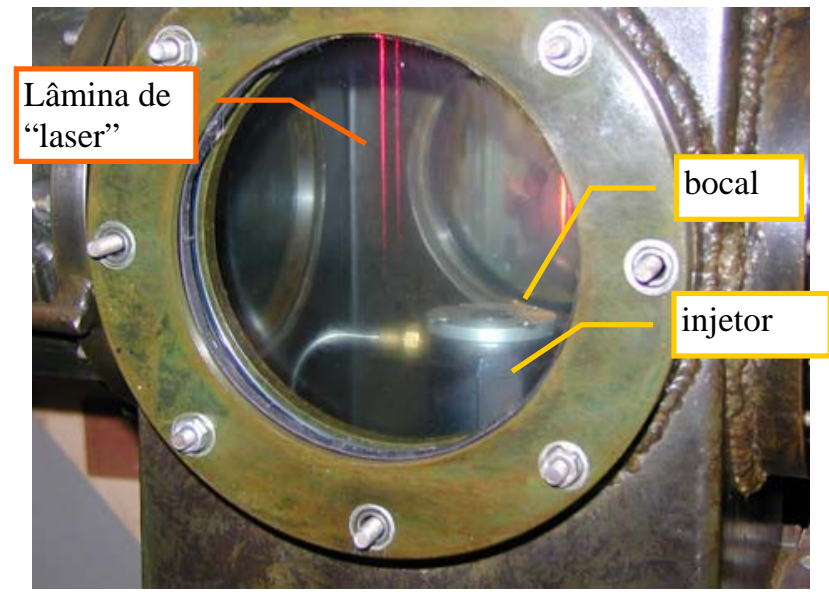

Figura IV.4 - Fotografia da lamina de "laser” que ilumina o jato. A fonte de "laser” está atrás do injetor. 


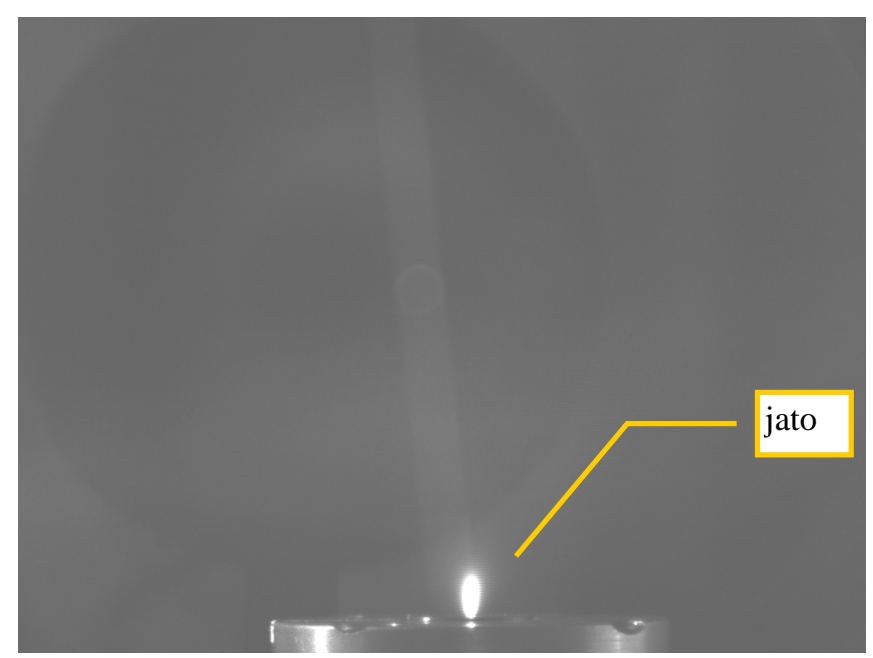

Figura IV.5 - Imagem de um jato obtido com a lâmina de "laser”. No caso, o tempo de exposição foi de 1/60s.

\section{IV.2.2. Imagem Termográfica}

A câmara CCD CV-M50 possui uma faixa sensível à radiação infravermelha. Foi utilizada uma ponta de solda (instrumento para soldar componentes eletrônicos) aquecida como teste preliminar para obtenção deste tipo de imagem termográfica, que está mostrada na Fig. IV.6. Na figura, a radiação de sua temperatura está correlacionada com a iluminação da ponta de solda obtida na imagem. Infelizmente, para um ensaio com temperatura de injeção de $160{ }^{\circ} \mathrm{C}$, não foi possível obter uma imagem termográfica do jato. 


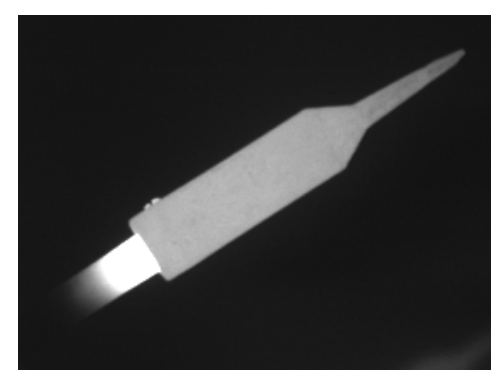

Figura IV.6 - Imagem termográfica de uma ponta de solda aquecida.

A seguir, são extraídos trechos do manual da câmara CCD com as características, procedimento de configuração do “Long Time Exposure” (utilizado no sincronismo da câmara com o “flash”) e faixa de comprimentos de ondas sensíveis ao sensor CCD. 


\section{General}

The CV-M50 is a monochrome 1/2" CCD camera designed for automated imaging applications featuring high performance and unique functions within a uniform and compact housing.

The high-speed shutter function and asynchronous random trigger function allow the camera to capture high quality images of fast moving objects. It is suitable for industrial applications such as on-line inspection and measurements.

In addition to conventional random trigger modes, the newly added pulse width control shutter mode makes it possible control the accumulation time by the trigger pulse width.

\section{Standard Composition}

The standard camera composition consists of the camera main body, tripod mount plate and operation manual.

\section{Main Features}

- $1 / 2$ " interline transfer CCD sensor with 768 (h) $\times 494$ (v) pixels for EIA and 752 (h) $\times 582$ (v) pixels for CCIR.

- High horizontal resolution. 570 TV lines for EIA. 560 TV lines for CCIR.

- Excellent S/N. Better than 56dB.

- High sensitivity. Minimum $0.05 \mathrm{~lx}$ illumination on CCD sensor.

- Improved smear performance and higher dynamic range.

- Random trigger modes with edge pre-select shutter, start/stop shutter and pulse width control shutter.

- Random trigger shutter up to $1 / 10,000 \mathrm{sec}$.

- Long-time exposure mode from a single field to several seconds.

- WEN -, EEN - and pixel clock output to support further advanced image capturing.

- Internal or external HD/VD synchronization.

- Easy shutter and functions mode setting from rear panel.

- Lens mount for C-mount lens.

- The camera features a robust package, lightweight and compact size. 


\subsubsection{Long Time Exposure Mode}

The Long time exposure will work in 3 modes:

1. Interlaced with field accumulation.

2. Interlaced with frame accumulation.

3. Non-interlaced with field accumulation.

The exposure time is the interval between 2 ext. VD pulses sent to the camera VD input. Each ext. VD pulse will reset and restart the internal VD in the camera as for ext. HD/VD input. So the camera is synchronized to the external HD/VD supply after each VD input.

An exposure starts after input of an external VD pulse, and ends after the next input of ext. VD, which again starts a new exposure.

The long time exposure is a continuous process where each external VD will synchronize the camera, stop an exposure, start a new exposure and read out the previous accumulated signal as interlaced or non-interlaced fields.

The exposure control can be done by feeding every $\mathrm{N}^{\text {th }} \mathrm{VD}$ pulse from the external $\mathrm{HD} / \mathrm{VD}$ supply to the camera. $\mathrm{N}$ is the wanted exposure time in number of fields. This is typically done in the frame grabber PC.

The range for long time exposure is from $1 \mathrm{~V}$ (a single field) to $\infty$. However the dark current signal will increase by longer time, so $>2$ seconds are not recommended at normal ambient temperature.

To use this mode:

Set: $\quad$ SW1-1, 2 and 3 to OFF

SW1-4 to OFF for normal shutter.

SW1-5 to ON for frame accumulation or OFF for field accumulation.

SW1-6 to OFF for 2:1 interlaced or ON for non-interlaced.

Jumper JP6 on PK8057 to CLOSE

Input: Ext.VD pulses with the exposure interval to pin 7 on 12 pin multi connector.

Ext. HD to pin 6 on 12 pin multi connector.

75 Ohm termination is done with SW 2-1 and SW2-2 on PK8057 board.

The timing for the external VD interval has to be as follow. ( $V$ is the time for a single field)

Interlaced with field accumulation. $1 \mathrm{~V}$ or more

Interlaced with frame accumulation. $2 \mathrm{~V}$ or integral number of $2 \mathrm{~V}$

Non-interlaced with field accumulation. $2 \mathrm{~V}$ or more

Note: The external HD/VD sync. generator, which supply the ext. VD an HD signals should follow the scanning standard for the camera setting.

$\begin{array}{lll} & \text { EIA } & \text { CCIR } \\ \text { Interlaced and field accumulation. } & 1 \mathrm{~V}=262.5 \mathrm{H} & 1 \mathrm{~V}=312.5 \mathrm{H} \\ \text { Interlaced and frame accumulation. } & 2 \mathrm{~V}=525.0 \mathrm{H} & 2 \mathrm{~V}=625.0 \mathrm{H} \\ \text { Non-interlaced and field accumulation. } & 2 \mathrm{~V}=524.0 \mathrm{H} & 2 \mathrm{~V}=624.0 \mathrm{H}\end{array}$

Refer to Timing Chart and Cautions on next page.

Detailed switch and jumper setting is described in "7. Mode Setting".

For connections see 5. "Pin Assignment". 


\section{CV-M50}

\section{Cautions in the Long Time Exposure Mode.}

1. Theoretical exposure time is as follows. EIA: $1 / 30$ sec. to $\infty$. CCIR: $1 / 25 \mathrm{sec}$. to $\infty$.

2. It is recommended not to use exposure $>2 \mathrm{sec}$. since visible dark-current noise may occur.

3. Ext. HD signal ( $4.0 \mathrm{Vp}-\mathrm{p} \pm 2.0 \mathrm{~V}$ at $75 \mathrm{Ohm}$ terminated) has to be input continuously The falling edge of Int. HD signal and Ext. VD signal are phase-synchronized.

4. Timing of ext. VD signal in each accumulation mode has to be set, as described before.

a) 2:1 Interlaced mode (Field accumulation mode)

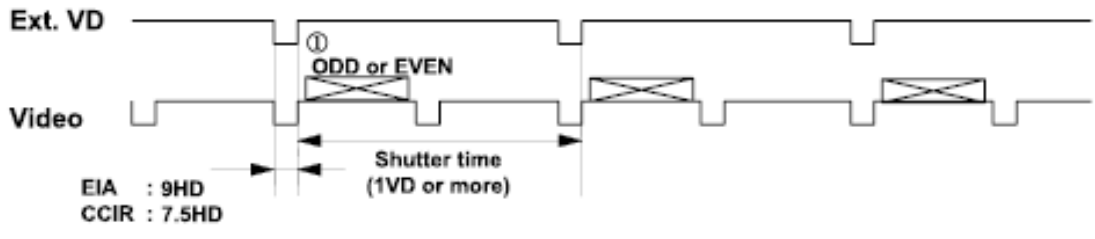

b) 2:1 Interlaced mode (Frame accumulation mode)

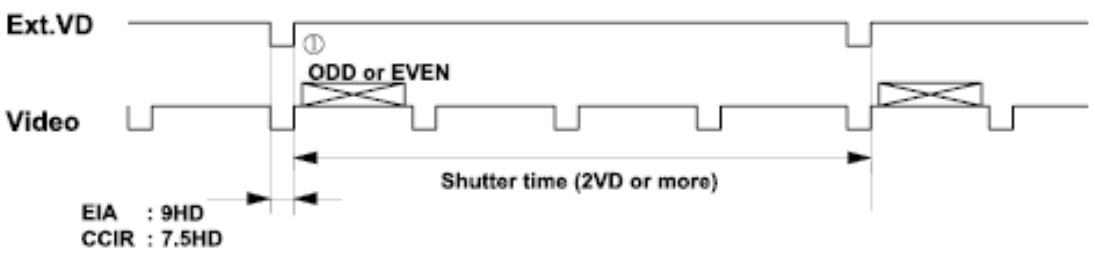

c) Non interlaced mode (Field accumulation mode)

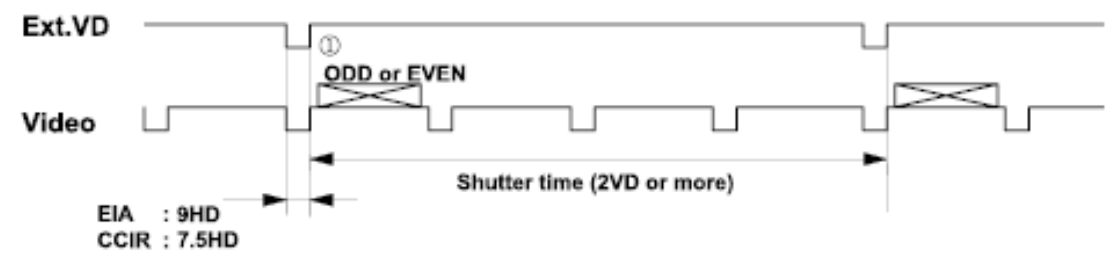




\section{CV-M50}

\section{Specifications}

\begin{tabular}{|c|c|}
\hline Sanning system & $\begin{array}{l}\text { ElA } 525 \text { lines } \\
30 \mathrm{frames} / \mathrm{sec} \text {. }\end{array}$ \\
\hline CD sensor & Mbnochrome $1 / 2$ " HyperHAD IT COD \\
\hline Sensing are a & $6.6 \mathrm{~mm}(\mathrm{H}) \times 4.8 \mathrm{~mm}$ (v) \\
\hline Efedmep trels & 758 (h) $\times 494$ (v) \\
\hline Elemerts in vdeo autput & $758(h) \times 485(v)$ \\
\hline Cell sze & $8.4(\mathrm{~h}) \times 9.8(\mathrm{v}) \mathrm{\mu m}$ \\
\hline Besciuticn (forizontat) & 570 TV lines \\
\hline Besolution (wertical) & 575 TV Ines \\
\hline Sersitivityon sensar & $0.051 \mathrm{x}$ \\
\hline S/Nratio & $>56 \mathrm{~dB}$ (AGC off, Ga irma 1) \\
\hline Video cutput & CompositeVS sigra I1.0Vpp, 750rm \\
\hline Gamina & $0.45-1.0$ \\
\hline Gan & Mantal - Automatic. 0 to $+15 \mathrm{~dB}$ by potertioneter or $A C \mathcal{C}$ \\
\hline Sarning & $2: 1$ interlace-non-interlace \\
\hline Acumulation & Field-frame \\
\hline Synchronization & Int. X-tal. Ext HD/VDorrandon trigger \\
\hline HDsync. Iput/ouput & $4 \mathrm{~V}, 750 \mathrm{hm}^{*}$ \\
\hline VDsync input/autput & $4 \mathrm{~V}, 750 \mathrm{hm}^{\circ}$ \\
\hline Trigger input & $4 \mathrm{~V}, \sqrt{50 \mathrm{hm}^{7}}$ \\
\hline Trigger input duation & sHD interval \\
\hline WENoutput (arite enchle) & $4 \mathrm{~V}, 750 \mathrm{rm}$ \\
\hline EENoutput (exposure enable) & $4 \mathrm{~V}, 750 \mathrm{rm}$ \\
\hline Pxelclock output (cptiona) & $4 \sqrt{ }, 750$ roll sine \\
\hline Noriral shutter & Or, $1 / 100,1 / 250,1 / 500,1 / 1000,1 / 2000,1 / 4500,1 / 10,000$ sec. \\
\hline Edge pre-selectstutter & $1 / 60, \sqrt{100}, \sqrt{2} 50,1 / 500,1 / 000,1 / 2000,1 / 4500, V 10,000 \mathrm{sec}$ \\
\hline Pulse width con rolled stutter & $>1 \mathrm{H}(64 \mathrm{usec})$ to $<60$ msec. \\
\hline Start/stop trigger shutter & $1 / 77 \mathrm{sec}$ to $1 / 10,000 \mathrm{sec}$ \\
\hline Long time exposure & 1 field $\mathbf{b} \approx$. Duration between ext. VD puses \\
\hline Qperating temperature & $-5^{\circ} \mathrm{C}$ to $+45^{\circ} \mathrm{C}$ \\
\hline Hurmitity & $20-80 \%$ mon-ondensm \\
\hline Storagetenp./humidity & $-25^{\circ} \mathrm{C}$ to $60^{\circ} \mathrm{C} / 20-90 \%$ \\
\hline Power & $12 V D C \pm 10 \% .25 W$ \\
\hline Lens maunt & C-mount \\
\hline Dmensians & $40 \times 50 \times 80 \mathrm{~mm}(\mathrm{H} \times \mathbf{m} \times \mathrm{D})$ \\
\hline Mass & $230 \mathrm{~g}$ \\
\hline
\end{tabular}

- HD sync, WD sync/7niggor) input or output by intornd jumpars

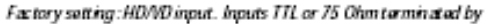
intond jempors. Factary seroing. 75 Chm torminat.

Note: Above specifications are subject to change without notice.

\subsection{Spectral Sensitivity}

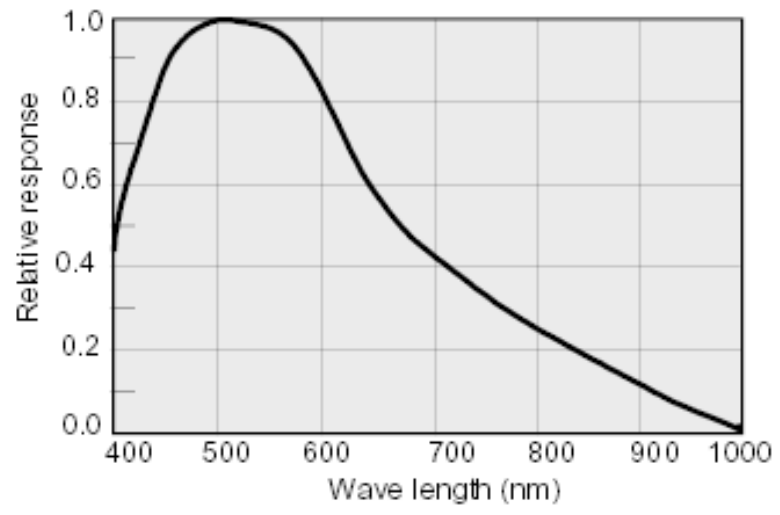




\section{Apêndice V}

\section{Alguns Esquemas e Fotografias da Bancada Experimental}




\section{APENDICE V}

Neste apêndice estão apresentadas três fotografias e dois esquemas da instalação do laboratório.

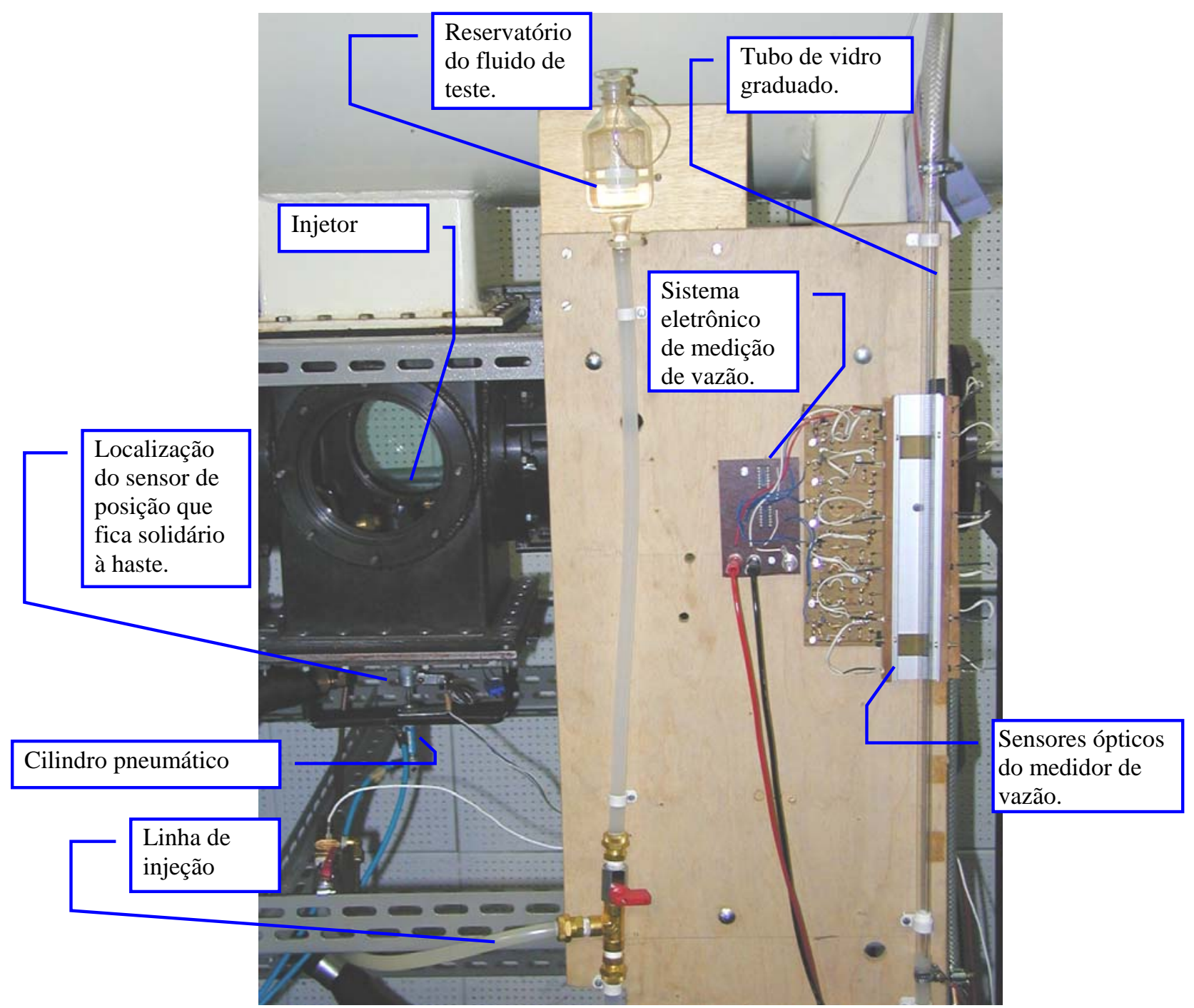

Figura V.1 - Alguns componentes do sistema de injeção. 


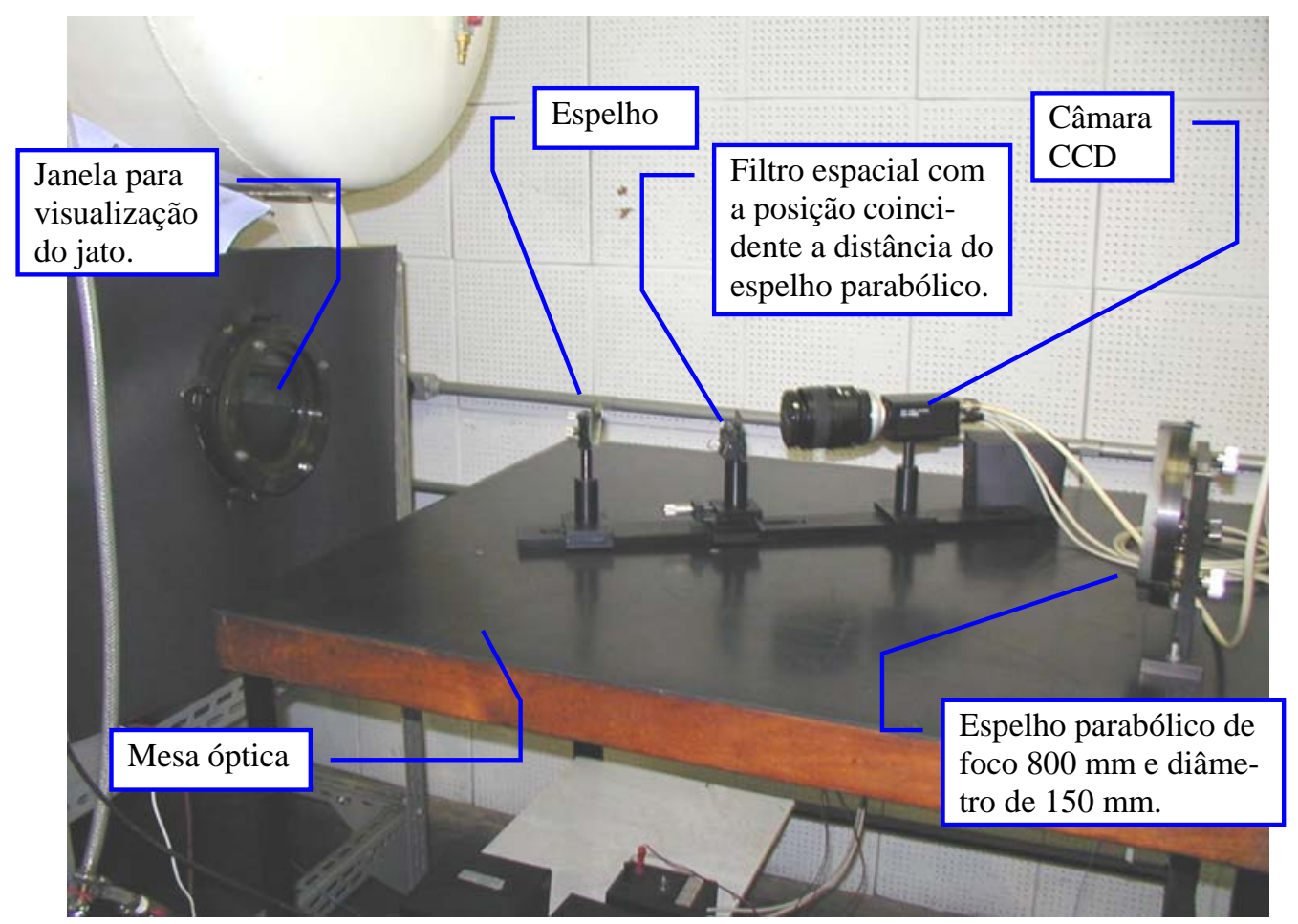

Figura V.2 - Mesa óptica com a camara CCD.

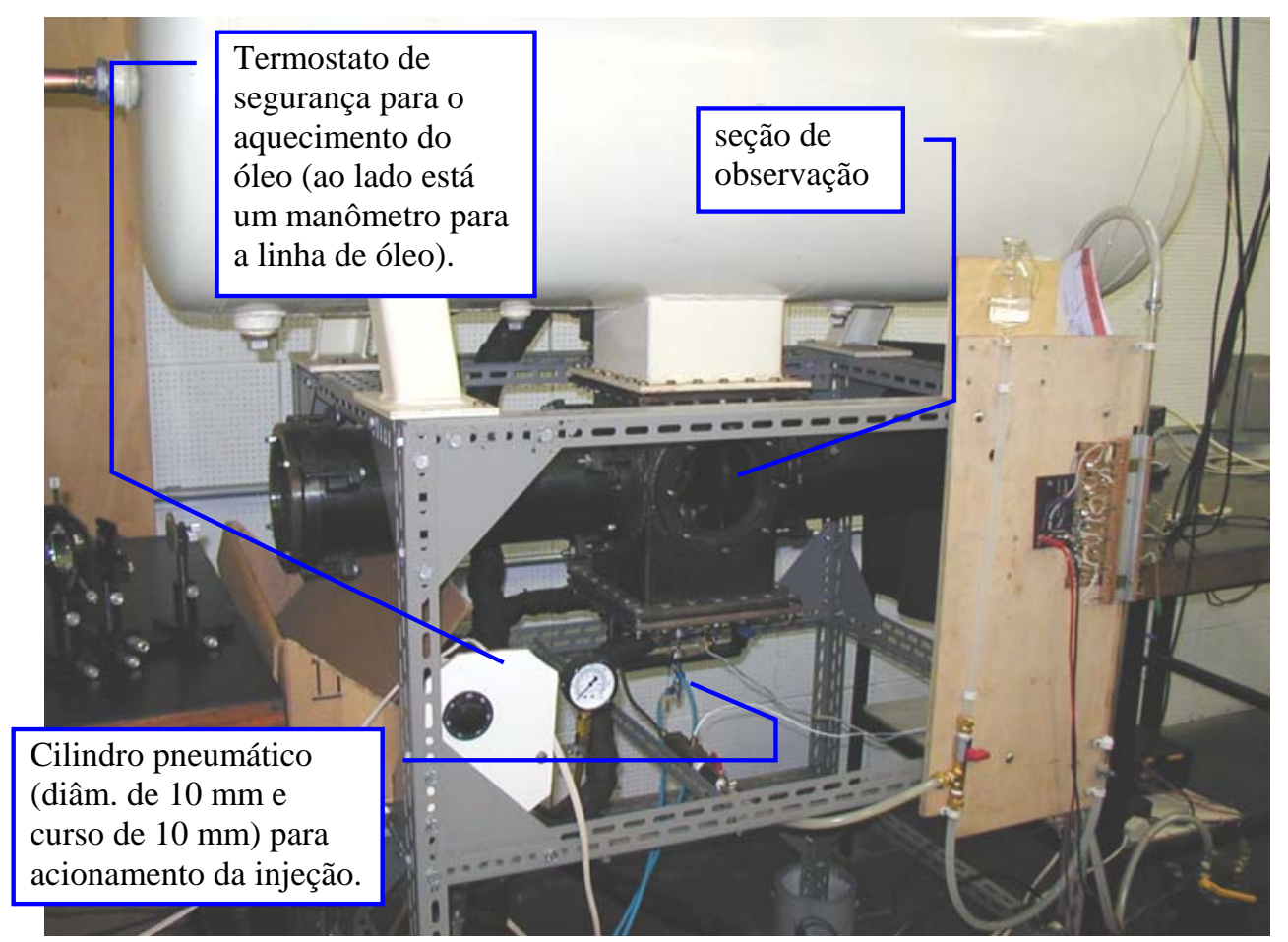

Figura V.3 - Mesa óptica com a camara CCD. 


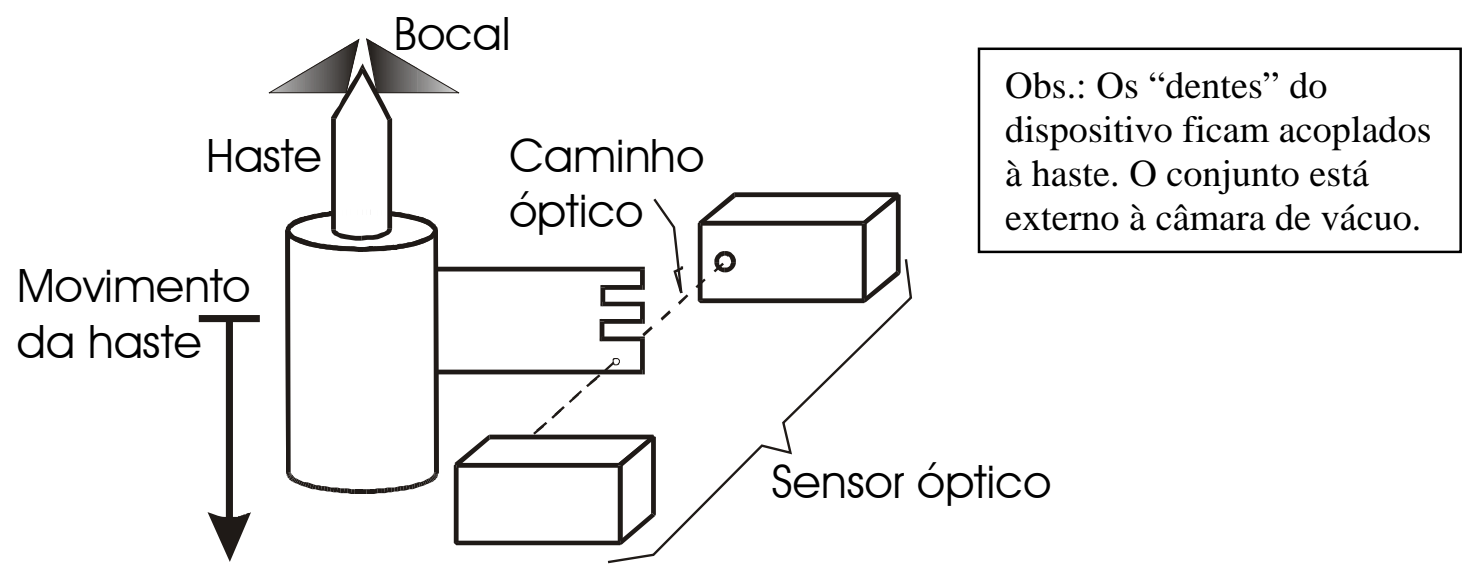

Figura V.4 - Esquema do sensor de posição.

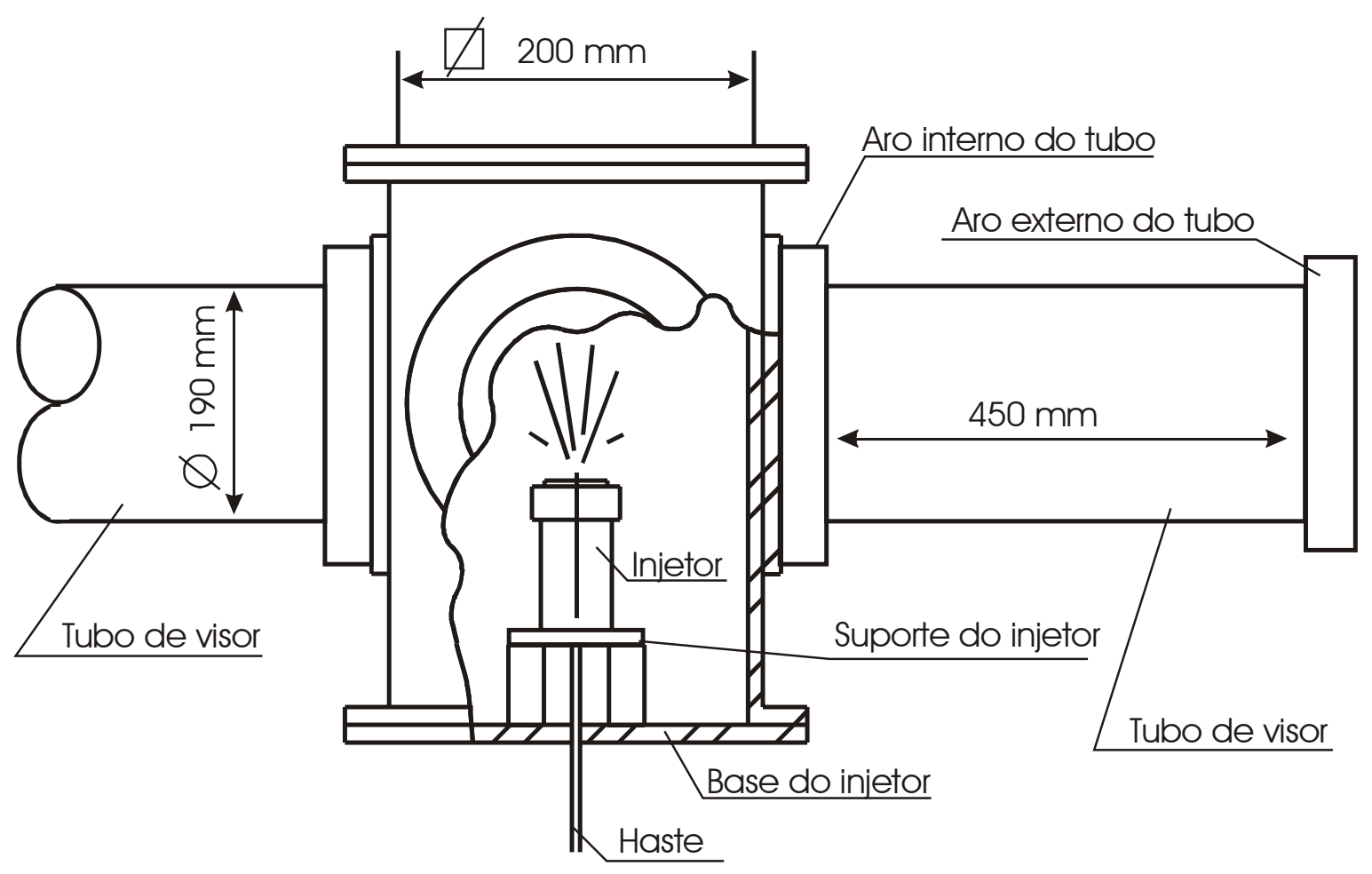

Figura V.5 - Esquema da seção de observação com algumas dimensões. 